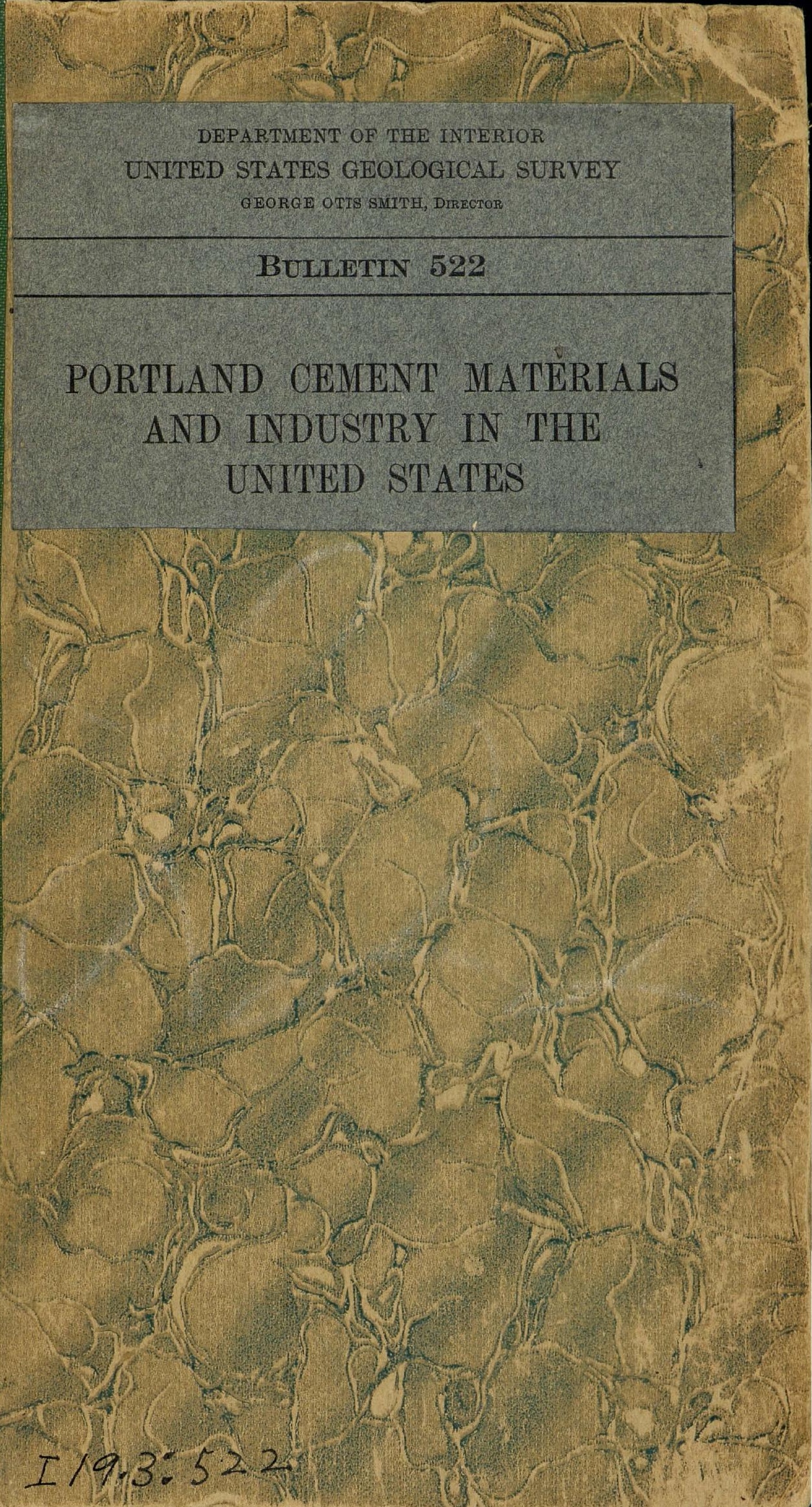


TEXAS TECH UNIVERSITY

3 1295013465322 
DEPARTMENT OF THE INTERIOR

UNITED STATES GEOLOGICAL SURVEY

GEORGE OTIS SMITH, DIRECTOR

BULLETIN 522

\title{
PORTLAND CEMENT MATERIALS AND INDUSTRY IN THE UNITED STATES
}

BY

\author{
EDWIN C. ECKEL
}

WITH CONTRIBUTIONS BY

ERNEST F. BURCHARD AND OTHERS

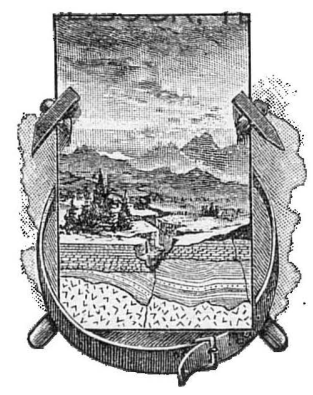

WASH I NGTON .

GOVERNMENT PRINTING OFFICE 1913 



\section{CONTENTS.}

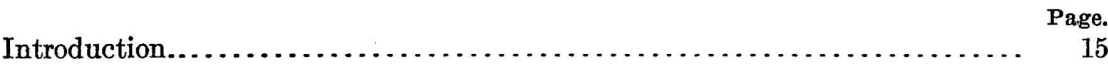

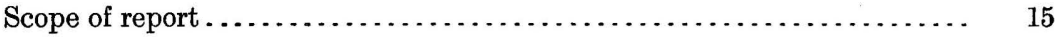

Acknowledgments....................................... 15

Part I.-The Portland cement industry in general ................ 16

Classification of cements..................................... 16

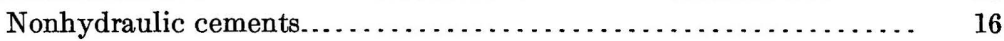

Hydraulic cements. . . . . . . . . . . . . . . . . . . . . . . . . . . 16

Hydraulic limes.......................................... 16

Natural cements..................................... 16

Portland cement................................... 17

Puzzolan cement .................................. 18

Predecessors of Portland cement............................. 18

Ancient puzzolan cements.............................. 18

Natural cements..................................... 19

European natural cements. . . . . . . . . . . . . . . . . . 19

American natural cements. . . . . . . . . . . . . . . . . . . . . 20

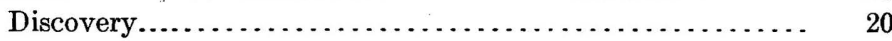

Growth of the natural-cement industry .............. 21

Portland cement.............................................. 24

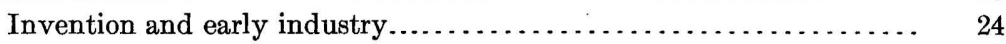

Aspdin's patent..................................... 24

Specification . . . . . . . . . . . .

Technical value................................ 24

Contemporary notices............................. 25

Growth of Portland cement industry in Europe............. 26

The Portland cement industry in America.................... 27

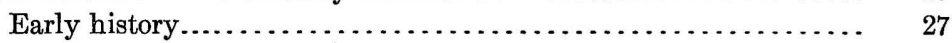

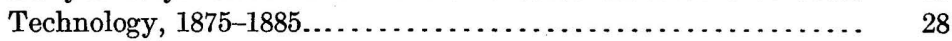

American modifications......................... $\quad 28$

The rotary kiln and its effect on the industry......... 29

Improveme ts in grinding . . . . . . . . . . . . . . . 30

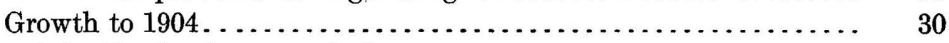

Statistics of the Portland cement industry ..................... 31

American production of Portland cement, 1870-1911............ 31

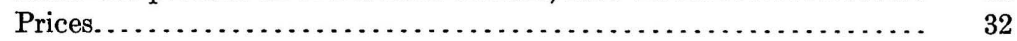

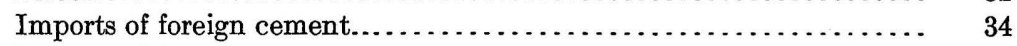

Exports of American cement............................ $\quad 35$

Geographic concentration of the cement industry .............. 36

Production by States.............................. 36

Production by commercial districts..................... 37

Production of the Lehigh district, $1890-1910 \ldots \ldots \ldots \ldots \ldots \ldots . \quad 38$ 
PortLAND GEMENT INDUSTRY

Introduction............................................ 40

Definition of Portland cement. . . . . . . . . . . . . . . . . . . 40

Stages in manufacture............................... 40

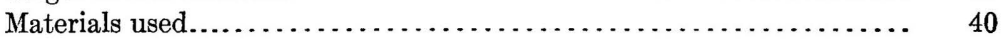

Cement materials proper.................................. 41

Approximate composition of the cement mixture.............. 41

Raw materials actually used $. . \ldots \ldots \ldots \ldots \ldots \ldots \ldots \ldots \ldots \ldots \ldots ., 41$

Production according to raw materials used.................... 42

Limestones........................................ 43

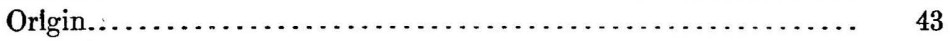

Varieties........................................ 43

Chemical composition.............................. 44

Impurities..................................... 44

Magnesia..................................... 44

Silica alone.................................... 45

Silica with alumina and iron........................ 46

Iron alone....................................... 46

Physical characters.................................. $\quad 46$

Effect of heat...................................... 47

Limestones used in cement manufacture................. $\quad 47$

Argillaceous limestones (cement rock) $\ldots \ldots \ldots \ldots \ldots \ldots \ldots . \quad 47$

Pure hard limestones............................. 49

Soft limestones (chalk) ........................... $\quad 50$

Fresh-water marls................................. 51

Shell deposits................................. 53

Alkali waste................................... 54

Blast-furnace slag.............................. $\quad 55$

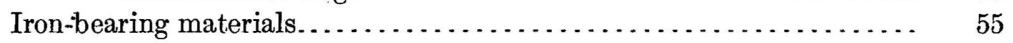

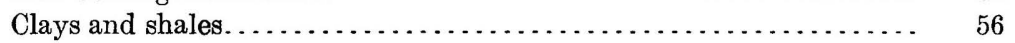

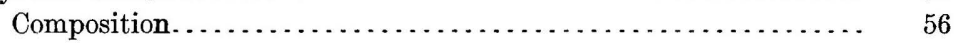

Varieties........................................... 56

Excavation of raw materials............................... 57

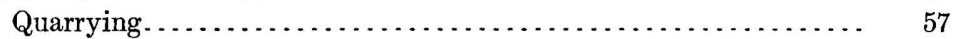

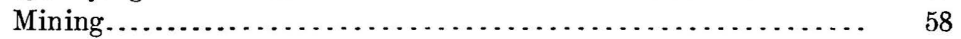

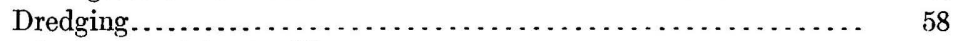

Cost of raw materials at mill . . . . . . . . . . . . . . . . . . . . $\quad 59$

Fuels used in Portland cement manufacture................... 60

The uses of fuel..................................... 60

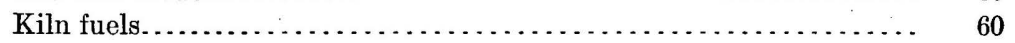

Relative importance.................................... 60

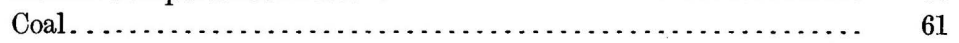

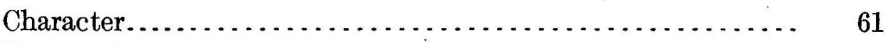

Preparation.......................................... 61

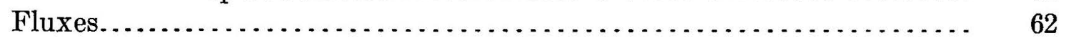

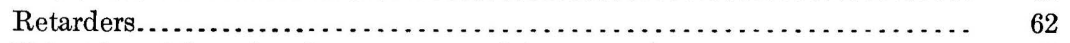

Valuation of deposits of cement materials......................... 63

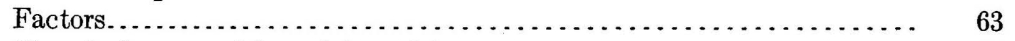

Chemical composition of material......................... 65

Physical character of material............................ 66

Amount of material available $\ldots, \ldots, \ldots, \ldots, \ldots, \ldots, \ldots, \ldots, \ldots, \ldots, \quad 66$ 
Part II.-Raw materials of the Portuand cement industry-Continued.

Valuation of deposits of cement materials-Continued.

Location of plant.

Page.

With respect to transportation routes................. 66

With respect to fuel supplies. . . . . . . . . . . . . . . . 66

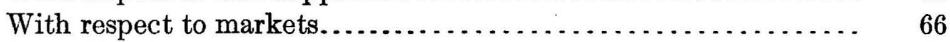

Part III.-Portland cement Resources of the United States ........ 67

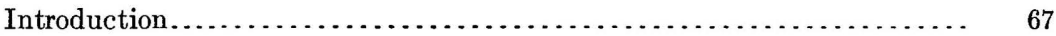

Alabama. . . . . . . . . . .

Portland cement materials, by Eugene A. Smith............... 68

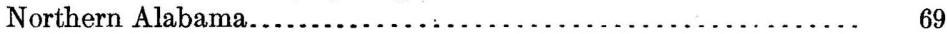

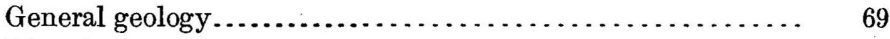

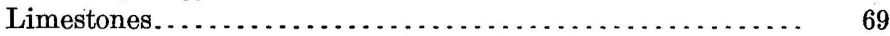

Chickamauga limestone. .................... 69

Mississippian ("Lower Carboniferous") limestones. . . . . 71

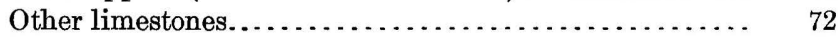

Clays and shales.............................. 72

Ordovician ("Lower Silurian") and Cambrian shales. . . 72

Mississippian ("Lower Carboniferous") shales. ........ 73

Pennsylvanian ("Coal Measures") shales............. 73

Cretaceous clays. ........................... 73

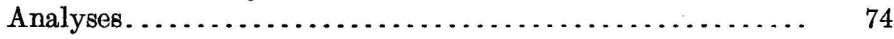

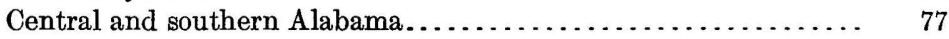

Raw materials............................... 77

Limestones................................ 77

Selma chalk ("Rotten limestone").............. 77

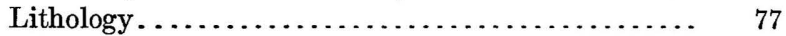

Distribution............................. 79

St. Stephens limestone..................... 82

Lithology . ............................ 82

Distribution.......................... 83

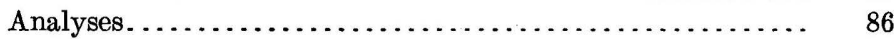

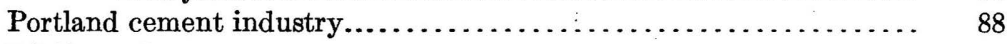

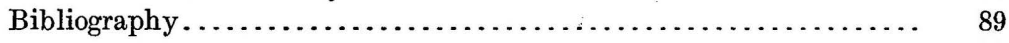

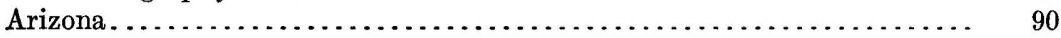

Portland cement materials............................ 90

Portland cement industry.............................. 91

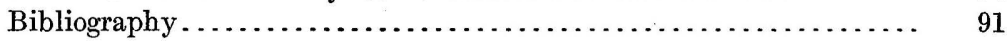

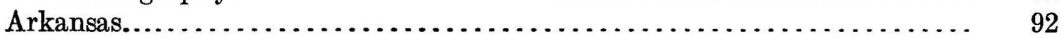

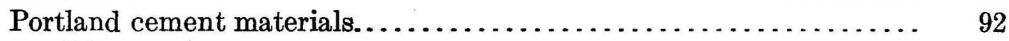

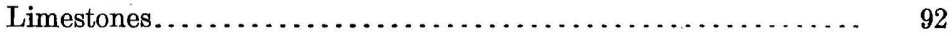

Izard limestone. . . . . . . . . . . . . . . . . . . . . . . . 92

Polk Bayou and St. Clair limestones................. 94

St. Joe limestone member of Boone formation. . . . . . . . . . . 96

Limestones of the Boone formation................. 97

Limestone underlying the chert.............. 97

Limestone overlying the chert. ............... 97

Limestones in the chert bed.................... 98

Pitkin ("Archimedes") limestone. . . . . . . . . . . . . . . . . 100

Cretaceous chalk beds. . . . . . . . . . . . . ........... 101

Distribution and character.................... 101

Annona ("Whitecliffs") chalk.................. 102

Rocky Comfort area...................... 102

Whitecliffs area.......................... 103

Saline Landing area..................... 104 
P'art III.-Portland cement resources of the United States-Contd.

Arkansas-Continued.

Portland cement materials-Continued.

Limestones-Continued.

Cretaceous chalk beds-Continued.

"Saratoga" chalk member of Marlbrook marl ... 106

Distribution and character.................. 106

Washington area.......................... 107

Okolona area............................. 109

Deciper area......................... 110

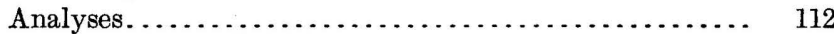

Tertiary and Carboniferous clays and shales............... 113

Portland cement industry.............................. 115

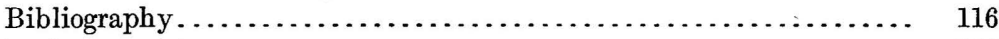

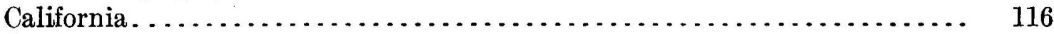

Portland cement materials............................ 116

General features.................................. 116

San Diego County................................. 116

Orange County ...................................... 117

Los Angeles County . . . . . . . . . . . . . . . . . . . . . . . . 117

Kern County ....................................... 117

San Benito County . . . . . . . . . . . . . . . . . . . . . . 118

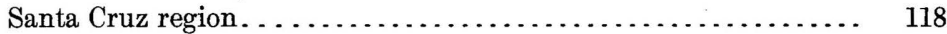

Solano and Contra Costa counties . . . . . . . . . . . . . . . . 118

Sonoma County.................................. $\quad 119$

Shasta County .................................... $\quad 119$

Portland cement industry ............................. 120

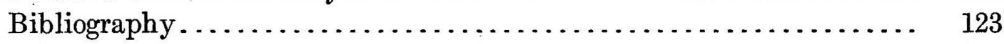

Colorado. ................................................ 124

Portland cement materials................................ 124

Distribution........................................ 124

Limestones east of the Front Range...................... 124

Limestones west of the Front Range...................... $\quad 127$

Portland cement industry................................. $\quad 128$

Bibliography........................................ 128

Connecticut. ............................................. 128

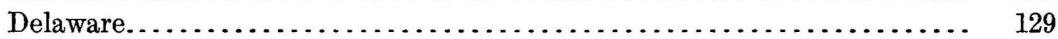

Florida. . . . . . . . . . . . . . . . . . . . . . . . . . . . . . . . 129

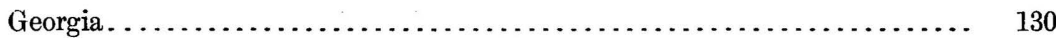

Portland cement materials................................ 130

Distribution..................................... 130

Metamorphic limestones or marbles................... 131

Chickamauga limestone........................... 131

Bangor limestone...................................... 132

Cretaceous and Tertiary limestones.................... 133

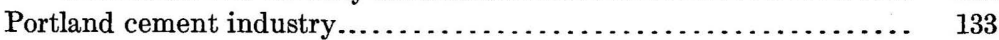

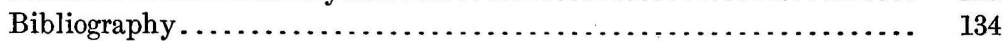

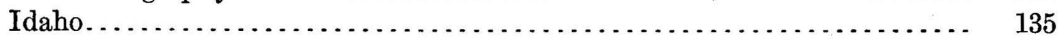

General distribution of Portland cement materials................. 135

Lime Point............................................ ${ }_{136}$

Illinois................................................... 140

Portland cement materials................................. 140

Ordovician ("Trenton") limestone.................... 140

Mississippian limestones............................... $\quad 142$ 
Part III.-Portland cement Resources of the United States-Contd.

Illinois-Continued.

Portland cement materials-Continued.

Page.

Pennsylvanian ("Coal Measures") limestones................. 143

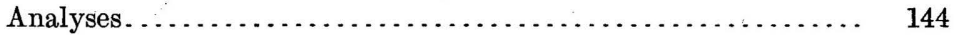

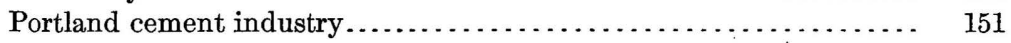

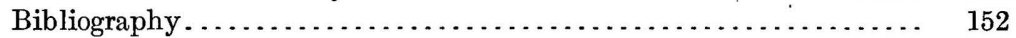

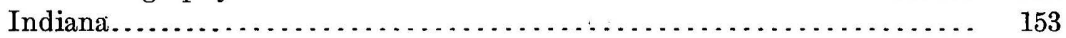

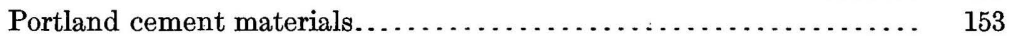

Cincinnatian shales and limestones..................... 153

Mississippian ("Lower Carboniferous") limestones and shales.... 153

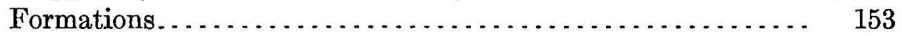

Chester group......................................... 154

Mitchell limestone.................................. 154

Spergen limestone................................. 154

Harrodsburg limestone.......................... 154

"Knobstone" group............................... 154

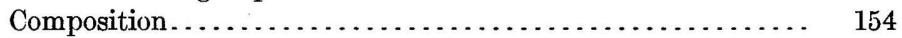

Limestones of the Pennsylvanian series ("Coal Measures")...... 155

Fresh-water marls of Quaternary age.................. 155

Portland cement industry............................... 157

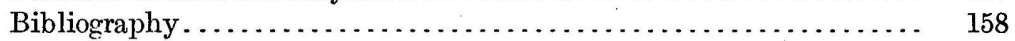

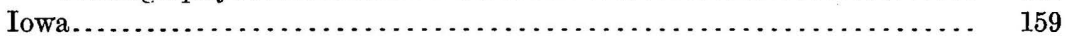

Portland cement materials.................................. 159

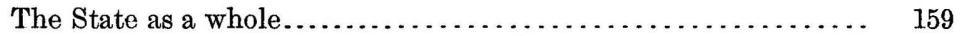

Character and distribution of materials............. 159

Calcareous marls.............................. 159

Chalk deposits.................................... 160

Limestones................................... 161

Ordovician limestones........................ 161

Devonian limestones.......................... 162

Subdivisions............................. 162

Wapsipinicon limestone................... 163

Cedar Valley limestone..................... 163

Lime Creek shale. . . . . . . . . . . . . . . . . . 165

Carboniferous limestones........................ 166

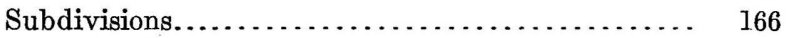

Kinderhook group........................ 166

Osage group............................. 167

"St. Louis limestone"

Des Moines group...................... 170

Missouri group........................... 171

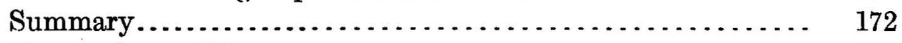

Economic conditions. ........................... 173

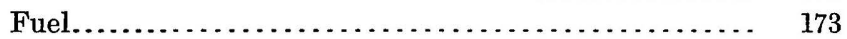

Transportation..................................... 174

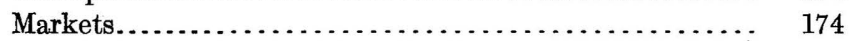

District near Dubuque, by E. F. Burchard............... 174

Character of materials............................. 175

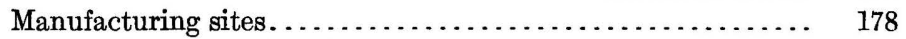

Maps and other publications....................... 179

Portland cement industry.............................. 179 
Par III.-Portland cement resources of the United States-Contd. Page.

Kansas................................................. 180

Portland cement materials............................. 180

Subdivisions.................................. 180

Mississippian ("Lower Carboniferous") limestones........... 180

Pennsylvanian ("Coal Measures") limestones and shales....... 181

Permian limestones................................ 184

Cretaceous limestones.............................. 184

Portland cement industry, by E. F. Burchard............... 185

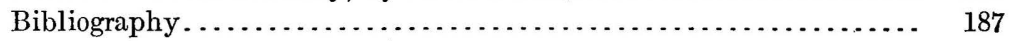

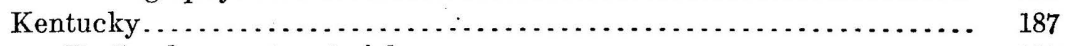

Portland cement materials............................ 187

Subdivisions.................................... 187

Limestones of Trenton and Stones River age................ 188

Cincinnatian (Upper Ordovician) limestones................ 189

Mississippian ("Lower Carboniferous") limestones............ 189

Pennsylvanian ("Coal Measures") limestones................. 191

Portland cement industry ................................ 191

Louisiana. . . . . . . . . . . . . . . . . . . . . . . . . . . . . . . . 191

Maine.............................................. 192

Portland cement materials.............................. 192

General features.................................. 192

Limestones of the Rockland-Rockport region. . . . . . . . . . 193

Limestones from other localities...................... 195

Maryland .................................................. 196

Portland cement materials............................... 196

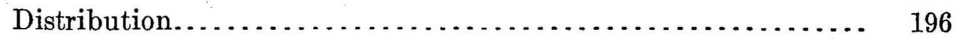

Greenbrier limestone and adjacent shales.................. 196

Helderberg limestone and adjacent shales................ 199

Limestones of the Cayuga group......................... 202

Limestones of the Shenandoah group..................... 203

Metamorphic limestones of the Piedmont area................ 205

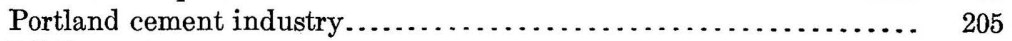

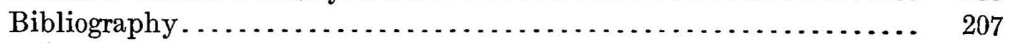

Massachusetts......................................... 207

Michigan.................................................. 208

Portland cement materials.............................. 208

Limestones...................................... 208

Dundee limestone............................ 208

Traverse formation............................. 210

Grand Rapids group............................ 211

Marl deposits.................................. 212

Shales and clays....................................... 216

Traverse formation................................. 216

Antrim shale................................. 217

Coldwater shale................................ 217

Saginaw formation............................. $\quad 219$

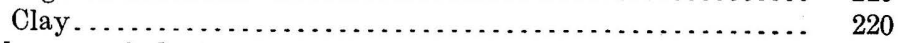

Portland cement industry................................ 223

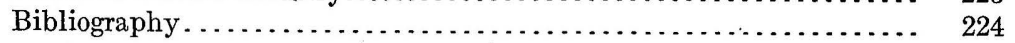

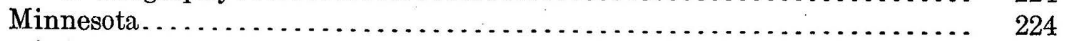

Mississippi. ........................................... 224

Portland cement materials.............................. 224

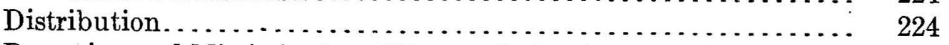

Devonian and Mississippian ("Lower Carboniferous") limestones. $\quad 225$ 
Part III.-Portland cement Resources of the United States-Contd. Mississippi-Continued.

Portland cement materials-Continued.

Page.

Cretaceous limestone (Selma chalk or "Rotten limestone")...... 226

General features................................ ${ }_{226}$

Local occurrences................................ $\quad 228$

Kemper County............................... 228

Noxubee and Lowndes counties................... $\quad 229$

Oktibbeha County................................. . 232

Chickasaw and Monroe counties................... 233

Lee County .................................. 234

Prentiss County................................ 235

Alcorn County............................. 236

Tertiary limestone (Vicksburg limestone) .................. $\quad 237$

Distribution................................ 237

Local occurrences of Vicksburg limestone, by A. F. Crider... 237

General features............................. 237

Vicksburg.................................... 237

Byram..................................... 240

Plain ......................................... 241

Brandon....................................... 241

Bay Spring..................................... 242

Red Hill................................... $\quad 243$

Clays............................................... 244

Residual clays of the Selma chalk.................... 244

Porters Creek clay................................ 244

Bibliography.......................................... 245

Missouri.................................................... 246

General features..................................... 246

Portland cement materials.............................. 246

Distribution................................... $\quad 246$

Kimmswick and Plattin limestones..................... 247

Late Ordovician shale............................... 248

Devonian formations.................................. 248

Mississippian ("Lower Carboniferous") limestones and shales.... 248

Pennsylvanian ("Coal Measures") limestones and shales........ 250

Loess and surface clays............................... 251

Portland cement industry.................................. 252

Montana.................................................... 253

Portland cement materials, by W. H. Weed.................... 253

Portland cement industry, by E. F. Burchard.................. 256

Nebraska........................................... 256

Portland cement materials............................. 256

Carboniferous formations............................. 256

Niobrara formation and Benton group................... 257

Pierre shale....................................... 258

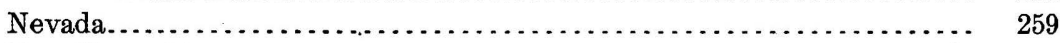

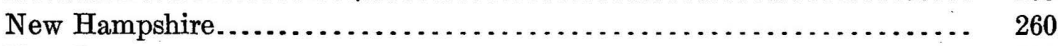

New Jersey.......................................... 260

Portland cement materials.................................. 260

Limestones of Warren and Sussex counties................. 260

Lithology ................................... $\quad 260$

Hardyston quartzite................................... 261 
Part IiI.-Portland cement resources of the United States-Contd.

New Jersey-Continued.

Portland cément materials-Continued.

Limestones of Warren and Sussex counties-Continued.

Magnesian Kittatinny limestone.

Page.

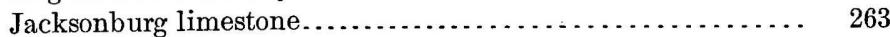

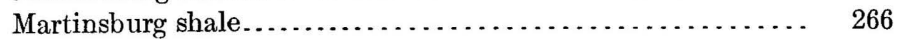

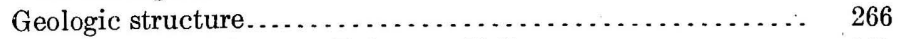

Silurian limestones of upper Delaware Valley ............... 267

White crystalline limestones of the Highlands... . . . . . . . . 268

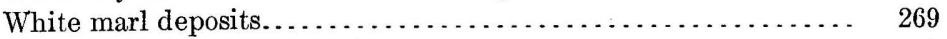

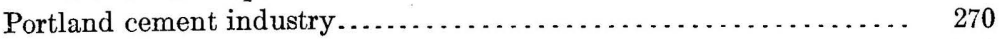

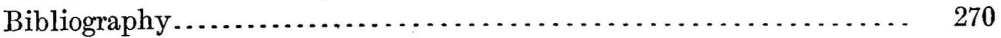

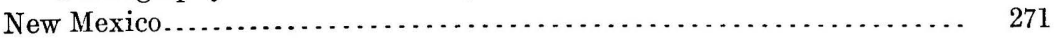

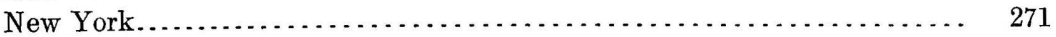

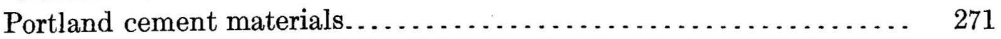

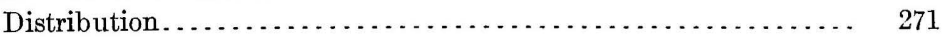

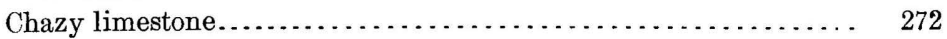

Mohawkian limestones................................. 273

Northern New York.......................... 273

Southeastern New York (Poughkeepsie district).......... 275

Limestones of Clinton age. . . . . . . . . . . . . . . . . . 276

Helderberg group and Onondaga limestone.............. 278

Distribution. . . . . . . . . . . . . . . . . . . . . . . 278

Western New York............................ 279

Central New York. . . . . . . . . . . . . . . . . . . . . . . 280

Hudson River valley ........................... . . 280

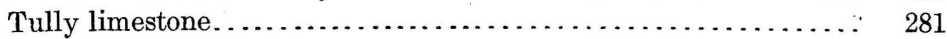

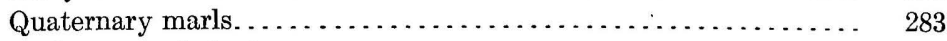

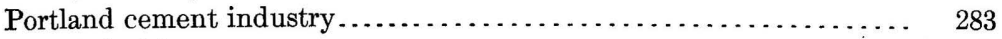

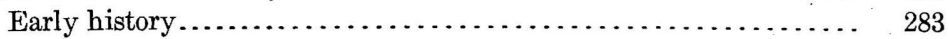

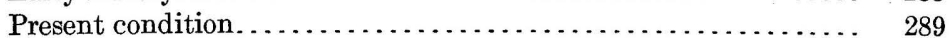

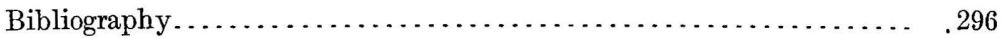

North Carolina. . . . . ...................................... 297

Portland cement materials. . . . . . . . . . . . . . . . . . . . . 297

Crystalline limestones. . . . . . . . . . . . . . . . . . . . . . . 297

Soft limestones (shell marls) . . . . . . . . . . . . . . . . . . 297

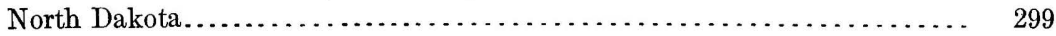

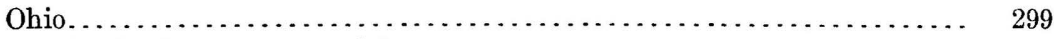

Portland cement materials. . . . . . . . . . . . . . . . . . . . . . . 299

"Trenton" limestone................................ 299

Cincinnatian shales and limestones................... 300

"Clinton" limestone............................... 301

"Corniferous" limestone............................. 301

Maxville ("Lower Carboniferous") limestone... . . . . . . . . . . . 301

Pennsylvanian ("Coal Measures") limestones............... 302

Quaternary marls.............................. 302

Portland cement industry ............................. 302

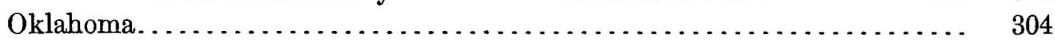

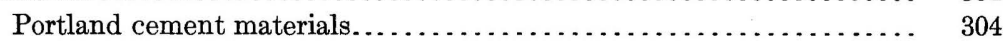

Cambrian, Ordovician, Silurian, and Devonian limestones...... 304

Arbuckle limestone... . . . . . . . . . . . . . . . . . . . . . . . . 304

Viola limestone... . . . . . . . . . . . . . . . . . . . . . . . . . . . 304 
Part III.-Portland cement Resources of the United States-Contd.

Oklahoma-Continued.

Portland cement materials-Continued.

Cambrian, Ordovician, Silurian, and Devonian limestonesContinued.

Sylvan shale.

Page.

305

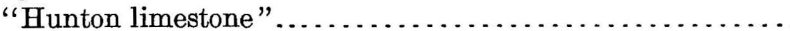

Carboniferous limestones. . . . . . . . . . . . . . . . . . . . .

Cretaceous limestones. . . . . . . . . . . . . . . . . . . . . .

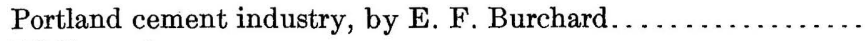

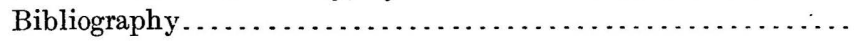

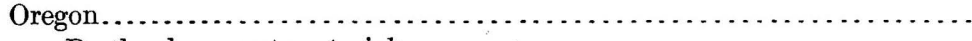

Portland cement materials............................ $30^{7}$

Southwestern Oregon. .............................. 307

Northeastern Oregon. . . . . . . . . . . . . . . . . . . . . . . . 309

Portland cement industry, by E. F. Burchard. . . . . . . . . . . . 310

Pennsylvania....................................... 310

Portland cement materials.............................. 310

State at large. . . . . . . . . . . . . . . . . . . . . . . . . 310

Ordovician limestones.......................... 310

Lewistown limestone (Helderberg and Cayuga)............ 311

Carboniferous limestones. . . . . . . . . . . . . . . . . . . . . 312

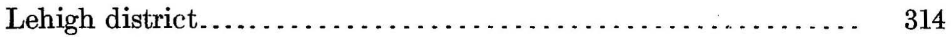

Location and area............................ 314

Geology..................................... 314

Magnesian limestone......................... 314

Ordovician limestones...................... 315

Martinsburg shale.......................... 316

Portland cement industry .............................. 317

General features................................... 317

I ehigh district.................................... 318

Manufacturing methods......................... 318

Materials used................................ 318

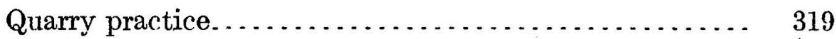

Mill practice............................ 320

Character and composition of the product............ 321

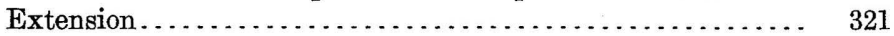

Western and southern Pennsylvania................. 322

Rhode Island . . . . . . . . . . . . . . . . . . . . . . . . . . . . . . 323

South Carolina. . . . . . . . . . . . . . . . . . . . . . . . . . . . . . . . 324

South Dakota. . . . . . . . . . . . . . . . . . . . . . . . . . .

Portland cement materials. . . . . . . . . . . . . . . . . . . . . 325

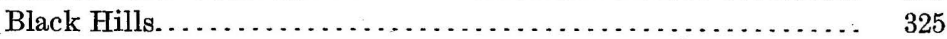

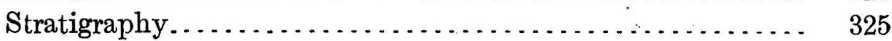

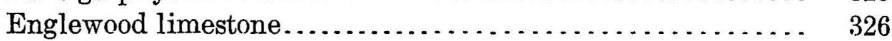

Pahasapa limestone. ......................... 326

Minnekahta limestone......................... 327

Southeastern South Dakota. . . . . . . . . . . . . . . . . . . . . 328

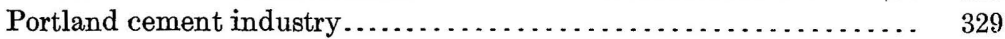

Tennessee, by E. O. Ulrich. . . . . . . . . . . . . . . . . . . . . . . . . 329

Portland cement materials. . . . . . . . . . . . . . . . . . . . . 329

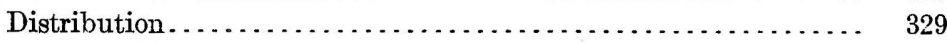

Cambrian limestones................................ 330 
Part III.-Portland cement resources of the United States-Contd.

Tennessee, by E. O. Ulrich-Continued.

Portland cement materials-Continued. Page.

Ordovician limestones. . . . . . . . . ................. 330

East Tennessee. . . . . . . . . . . . . . . . . . . . . . . . . . 330

East side of valley . . . ........................ 330

West side of valley.......................... 331

Western and middle Tennessee . . . . . . . . . . . . . . . . 332

Stones River group.......................... 332

Limestones of Trenton age.................... 332

Leipers formation . . . . . . . . . . . . . . . . . 333

Silurian and Devonian limestones................... 333

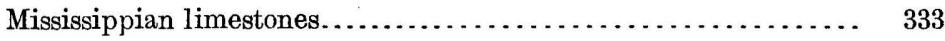

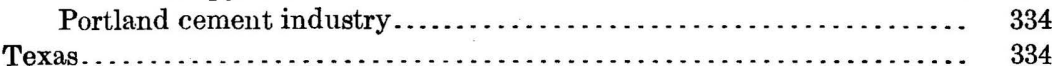

Portland cement materials.............................. 335

State at large, by J. A. Taff. . . . . . . . . . . . . . . . 335

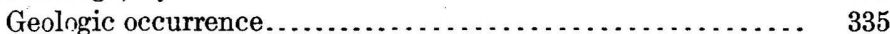

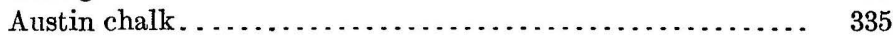

Fredericksburg group. ........................ 336

Vicinity of Austin, by E. F. Burchard ................. 337

Physical character of cement materials............... 337

Chemical composition. .......................... 339

Economic relations. . . . . . . . . . . . . . . . . . . . . . 344

Near El Paso, by G. B. Richardson..................... 344

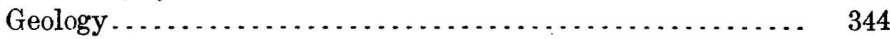

Clays. . . . . . . . . . . . . . . . . . . . . . . . . . . . 345

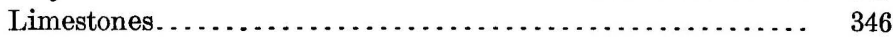

Portland cement industry ............................ 347

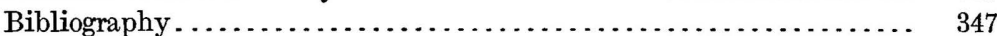

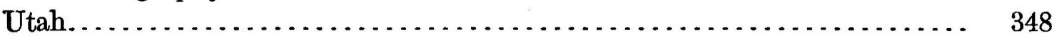

Portland cement materials. ........................... 348

Portland cement industry ............................. 349

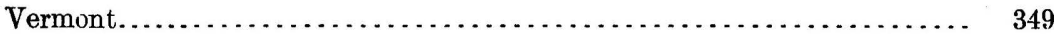

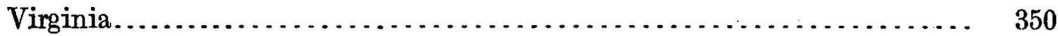

Portland cement materials. . . . . . . . . . . . . . . . . . . 350

Distribution. ....................................... 350

Tertiary shell beds or "marls"......................... 351

Greenbrier and Newman limestones (Mississippian age)....... 352

Lewistown limestone................................ 355

Ordovician limestones (Trenton and Stones River age)....... 356

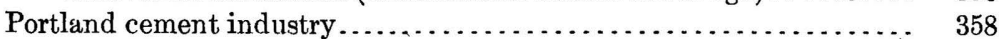

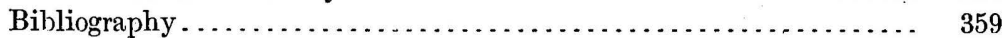

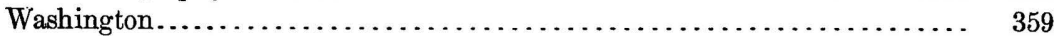

Portland cement materials............................ 359

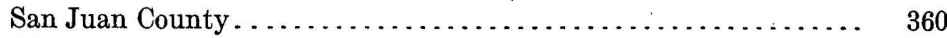

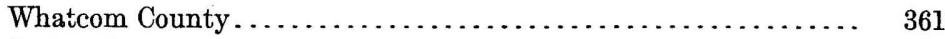

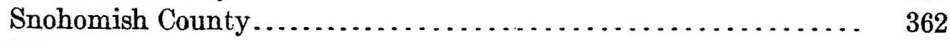

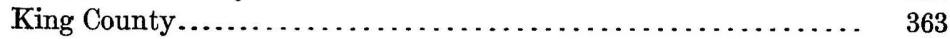

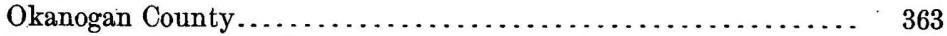

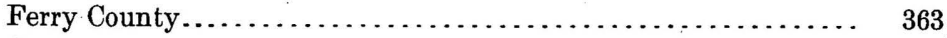

Stevens County.................................... 364

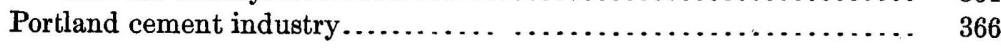


Part III.-Portland cement Resources of the United States-Contd. Page.

West Virginia........................................ 367

Portland cement materials............................ 367

Distribution.................................... 367

Pennsylvanian limestones......................... 368

Greenbrier limestone............................... 368

Lewistown limestone. . . ........................ $\quad 369$

Ordovician limestones (Trenton and Stones River age)....... $\quad 370$

Portland cement industry ............................. 371

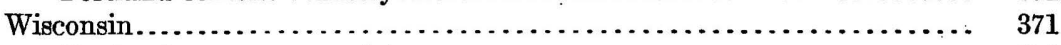

Portland cement materiais.............................. 371

Ordovician and Silurian limestones..................... 371

Quaternary shell marls............................... 373

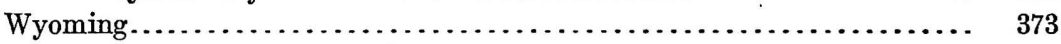

Bibiolography, by E. F. Burchard............................. 375

Publications of the United States Geological Survey.................. 375

Publications by miscellaneous Government bureaus................. 377

Publications by State geological surveys...................... 378

Nonofficial publications....................................... 380

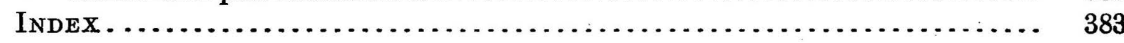




\section{ILLUSTRATIONS.}

Plate I. Map showing distribution of Portland cement plants in the United

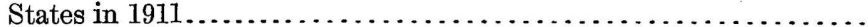

II. Geolcgic map of Mississippi, Alabama, and parts of Georgia and Florida ..........................................

III. Map of the chalk region of southwestern Arkansas, showing Upper Cretaceous chalk and chalky clays......................... 100

IV. Map of California showing distribution of limestone.............. 116

V. Geologic map of Illinois. . . . . . . . . . . . . . . . . . . . . . . . . . 140

VI. Geologic map of Iowa............................... 160

VII. Map of Kansas showing principal limestones................. 180

VIII. Map of Kentucky and Tennessee showing limestone formations..... 188

IX. Geologic map of the Lower Peninsula of Michigan............. 208

X. Map of the Lower Peninsula of Michigan showing marl deposits and Portland cement plants .............................. 210

XI. Geologic map of Missouri............................. 246

XII. Map of New York showing distribution of cement materials. ...... 272

XIII. Map of Hudson River cement district, New York................. 274

XIV. Map of cement-rock areas near Poughkeepsie, N. Y.............. 276

XV. Geologic map of Ohio and Indiana.................... 300

XVI. Map of Oklahoma showing principal limestone areas........... 304

XVII. Map of the Lehigh district, Pennsylvania-New Jersey, showing distribution of cement rock................................ $\quad 310$

XVIII. Map of part of eastern Texas showing distribution of limestone suitable for Portland cement............................. 336

XIX. Map of Virginia, West Virginia, Maryland, and part of Pennsylvania, showing distribution of limestones..........................

Figure 1. Production of Portland and natural cements in the United States,

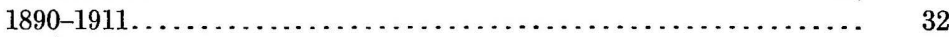

2. Range of cement prices in the United States, $1880-1911 . . . \ldots \ldots . .34$ 


\title{
PORTLAND CEMENT MATERIALS AND INDUSTRY OF THE UNITED STATES.
}

\author{
By Edwin C. Eckel, with contributions by Ernest F. Burchard \\ and others.
}

\section{INTRODUCTION.}

This report has been prepared in order to give information desired by two classes of persons-owners of lands on which marl, limestone, or clay deposits are found, and cement manufacturers or those who desire to become such. For the benefit of those of the first class, who wish to know whether a given material is suitable for Portland cement manufacture, the writer has attempted, in Parts I and II of the report (pp. 16-66), to describe the chemical and physical properties which a Portland cement material must have, and above all to show that the value of cement material depends almost entirely upon its location with respect to fuel supply, transportation routes, and markets. For cement manufacturers, present and prospective, who want to know at what localities in a given State or group of States cement materials will probably be found and who desire information in advance of actual testing as to the physical and chemical character of the materials, Part III (pp. 67 et seq.), dealing with the cement resources of the separate States, has been prepared.

The report is intended to be a discussion of the Portland cement materials of the United States, not a manual of cement manufacture nor a guide to cement testing or utilization. A brief sketch of the general status of the Portland cement industry is, however, presented in Part $\mathrm{I}$, in order to make the subject clear to the great number of people who are interested, in one way or another, in the condition and growth of this important branch of manufacture.

It is with pleasure that the writer acknowledges indebtedness to the managers and chemists-of the numerous Portland cement plants throughout the United States. Most of these plants, with their quarries or mines, have been personally examined by the writer, and at every one of them all possible facilities have been afforded for making a thorough examination. For obvious business reasons some of the information obtained in this manner can be stated only in a general way, but permission to publish most of it has been freely given. The chapters which have been contributed mainly by other geologists are credited directly to them in both text and table of contents. Special acknowledgment is due to Mr. E. F. Burchard, who has revised statistics and bibliographies, in addition to preparing the sections directly credited to him. 


\section{PART I. THE PORTLAND CEMENT INDUSTRY IN GENERAL.}

\section{CLASSIFICATION OF CEMENTS.}

The relations of the various cementing materials ${ }^{1}$ used in modern structural work may be concisely expressed as follows:

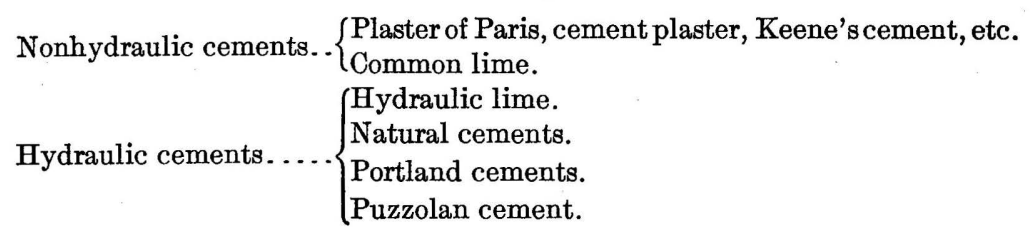

\section{NONHYDRAULIC CEMENTS.}

Nonhydraulic cements do not have the property of "setting" or hardening under water. They are made by burning, at a comparatively low temperature, either gypsum or pure limestone. The products obtained by burning gypsum are marketed as "plaster of Paris," "cement plaster," "Keene's cement," and so forth, according to the process of manufacture. The product of burning limestone is common lime. The plasters and limes will not be further discussed in the present bulletin.

\section{HYDRAULIC CEMENTS.}

Hydraulic cements are those which set when used under water. This property, which is due to the formation during manufacture of compounds of lime with silica, alumina, and iron oxide is possessed in very different degree by different cements.

\section{HYDRAULIC LIMES.}

Hydraulic limes are produced by burning, at comparatively low temperatures, a natural siliceous limestone which carries so much lime carbonate in proportion to its silica and alumina that the burned product will contain considerable free lime in addition to the silicates and aluminates that have been formed. In consequence of the free lime the burned mass will slake, but in consequence of the silicates and aluminates it will slake slowly and will have hydraulic properties. Hydraulic limes are thus intermediate between cements and true limes. They do not fall within the scope of this bulletin.

\section{NATURAL CEMENTS.}

Natural cements are produced by burning a naturally impure limestone, containing from 15 to 40 per cent of silica, alumina, and iron

1 Eckel, E. C., Cements, limes, and plasters: Their materials, manufacture, and properties, 1905: 
oxide, at a comparatively low temperature, about that of ordinary lime burning. The operation can be carried on in a kiln closely resembling an ordinary limekiln. During the burning the carbon dioxide of the limestone is almost entirely driven off, and the lime combines with the silica, alumina, and iron oxide; forming a mass containing silicates, aluminates, and ferrites of lime. If the original limestone contained much magnesium carbonate the burned rock will contain a corresponding amount of magnesia.

The burned mass will not slake if water be added. It is necessary, therefore, to grind it rather fine. After grinding, if the resulting powder (natural cement) be mixed with water it will harden rapidly. This hardening or setting will also take place either in air or under water. Natura] cements therefore differ from ordinary limes in two noticeable ways:

(1) The burned mass does not slake on the addition of water.

(2) The powder has hydraulic properties - that is, if properly prepared, it will set under water.

\section{PORTLAND CEMENT.}

Portland cement is produced by burning a finely ground artificial mixture containing essentially lime, silica, alumina, and iron oxide in certain definite proportions. Usually this combination is made by mixing limestone or marl with clay or shale in such proportion that the mixture will contain about three parts of lime carbonate to one part of clayey materials. The mixture is burned at a high temperature, approaching $3,000^{\circ} \mathrm{F}$., in kilns of special design and lining. During the burning, the lime combines with the silica, alumina, and iron oxide, forming a semifused mass called "clinker," which consists of silicates, aluminates, and ferrites of lime in certain fairly definite proportions. This clinker must be finely ground and the resulting powder (Portland cement) will set under water.

Portland cements differ from natural cements in the following important particulars:

(1) Natural cements are not made from carefully prepared and finely ground artificial mixtures but from natural rock.

(2) Natural cements are burned at a lower temperature than Portland cement, the mass in the kiln never being heated high enough to even approach the fusing or clinkering point.

(3) Natural cements, after burning and grinding, are, as a rule, yellow to brown in color and light in weight, having a specific gravity of 2.7 to 3.1 , whereas Portland cement is commonly blue to gray in color and heavier, its specific gravity ranging from 3 to 3.2 .

(4) Natural cements set more rapidly than Portland cement but do not attain so high tensile strength.

$48834^{\circ}-$ Bull. $522-13-2$ 
(5) Portland cement is a definite product, its percentages of lime silica, alumina, and iron oxide arying only between narrow limits, whereas brands of natural cements differ greatly in composition.

PUZZOLAN CEMENT.

Puzzolan cements are made by mixing powdered slaked lime with either a volcanic ash or a blast-furnace slag. The product is simply a mechanical mixture of two ingredients, as the mixture is not burned at any stage of the process. After mixing, the mixture is finely ground. The resulting powder (puzzolan cement) will set under water.

Puzzolan cements are usually light bluish, and are of lower specific gravity and less tensile strength than Portland cement. They are better adapted to use under water than in air.

\section{PREDECESSORS OF PORTLAND CEMENT.}

Although the Portland cement industry has now attained great importance, it is less than a century old and its period of rapid growth did not really begin until within the last quarter century. The industry is therefore very young compared with the manufacture of iron, for example. During earlier periods of the world's history, however, other cements were used in much the same fashion that Portland cement is used to-day, and before taking up Portland cement itself it may be of interest to sketch briefly the history of early cement making and the character of the materials used.

\section{ANCIENT PUZZOLAN CEMENTS.}

There does not seem to be the slightest evidence that hydraulic cements approaching the Portland type were ever used by Egyptians, Greeks, or Romans in their structural works. The earliest cementing materials of which there is any record were ordinary limes and plasters much like those used to-day. The Romans were acquainted with pozzuolana, a volcanic ash that is found abundantly in the vicinity of Naples, which when powdered and mixed with black lime possesses distinct hydraulic properties and gives results approximating those of the modern hydraulic cements. Cements of this type were used in many of the early engineering works of Rome. Puzzolan cements are still made, but the best-known representative of the group is not made from volcanic ash but from blast-furnace slag.

During the Middle Ages, with the general retrogression in technical knowledge, the use of even these primitive puzzolan cements seems to have been discontinued. The material employed for holding masonry together in large structural work was plain lime mortar, though by using an abundance of time and by taking great care in 
preparing the lime, the mortar, and the stone, structures of very remarkable strength and durability were finally developed. At a few places in Europe impure limestones were burned to a lime which necessarily must have possessed some hydraulic properties. But these sporadic instances of the occurrence and use of what may be considered a low-grade natural cement should not be allowed to obscure the fact that the great masonry structures of the Middle Ages were built with practically common lime.

\section{NATURAI CEMENTS.}

\section{EUROPEAN NATURAL CEMENTS}

The almost exclusive use of lime mortar for structural work persisted until very near the close of the eighteenth century, when a new series of cementing materials, of distinctly more modern type, was developed by careful experiment almost simultaneously in France and in England. These were the natural cements, and cementing materials of this type have remained in use down to the present day.

In 1756, or thereabout, Smeaton, an English engineer, began a series of experiments on lime mortars, in order to devise a lime suitable for marine construction, particularly for use in building the Eddystone lighthouse. No record of these experiments was published until 1791, so that they had no immediate influence on engineering practice. Smeaton soon found that the property of hardening under water, known to be possessed by some limes, was' not due to the purity of these particular limes, as had been long supposed. In fact, the truth was quite the reverse, for the very impure clayey limestones, when burned, would harden under water, and the pure limes would not. Though the experiments of Smeaton were apparently not carried to the point of making a true cement, his conclusions regarding the effect of clay in limestone opened the way for further investigation and research.

The next step marked a great advance in practice. This was the invention in 1796 in England and almost simultaneously in France of a cement like our present-day natural or Rosendale cements. Parker, who took out an English patent in 1796, later termed his new product "Roman" cement, which was clearly a misnomer, for he had invented a product never known to the Romans. The Parker patent contemplated the use, as a raw material, of certain concretions of clay and limy matter which were common in some of the English coastal formations. These concretions were to be burned "with a heat stronger" than that used for burning lime." When so burned, the product would not slake naturally when water was applied to it, as would an ordinary lime. When powdered, however, and mixed into a paste with water, it would harden not only in air but also under water. 
Parker's cement soon came into general use in England, and similar products were manufactured in France and in other portions of the Continent.

\section{AMERICAN NATURAL CEMENTS.}

DISCOVERY.

When the construction of the Erie Canal was undertaken, the use of ordinary lime as mortar was contemplated. As a large amount of lime would be used for this purpose, many limestone beds throughout the State were examined and tested. Good limes were found to be available at many points along the course of the canal, and the engineers had apparently no expectation of finding a better material. During the progress of work on the middle section of the canal, however, it was found that the lime burned from a certain stone refused to slake. The quarry from which this stone came had been opened on the land of T. Clarke, in the town of Sullivan, Madison County, in a bed of limestone which to all appearances was satisfactory enough.

The failure on the part of the contractor to deliver the lime brought the matter to the attention of Benjamin Wright, engineer in charge of the middle division, and Canvass White, one of his two associates. Fortunately, White had visited England in order to secure as much information as possible concerning the materials and methods then employed in great public works and had devoted much time to a study of the limes and cements used as mortar materials. Parker's "Roman cement" had then passed the experimental stage, and in both England and France natural cement was gradually but steadily supplanting lime as an engineering material. The cost of Parker's cement, however, was an obstacle to its extensive use.

Because of this preliminary acquaintance with the subject, White was peculiarly well fitted to cope with the difficulty in Madison County. He visited the Clarke quarry, examined and tested both the quarry stone and the burned product, and decided that the obstinate lime was really a high-grade natural cement, which required only grinding to make it fit for use. Tests on a larger scale soon proved that his conclusion was correct, and the first American natural cement was put to extensive use in the locks and walls of the middle section of the canal during the years 1818-19.

Fortunately, a contemporary professional estimate exists as to the value of this material. Wright, in a letter dated in 1820 , summarizes the facts regarding White's cement, stating that it "is found to be a superior water cement and is used very successfully in the stonework of the Erie Canal and believed to be equal to any of the kind found in any other country. It is pulverized (as it will not slake) and then used by mixing two parts lime and one part sand. It hardens best under water, and it is believed its properties are partially lost if permitted to dry suddenly or if not used soon after mixing." 
Ninety years of testing have hardly given a more satisfactory summary of the properties of natural cements than is contained in Wright's last sentence.

Another contemporary account (1821) states that "the price of this lime, pulverized and burnt and delivered at Utica, is 20 cents the bushel."

White took out a patent on this cement, and for several years a controversy raged as to its tenability. The matter was settled in 1825, so far as the State of New York was concerned, by the action of the legislature, which bought the patent rights for New York from White for $\$ 10,000$ and immediately threw them open to the free use of citizens of the State.

It is pleasant to know that the discovery and prompt utilization of this new material by White and Wright were rewarded with equal promptness by their professional advancement on the canal work.

The chemical character of this first American natural cement is established by an analysis, made in 1822 by Seybert, of a sample of the limestone used in its preparation. The analysis gave the following results:

Analysis of the first American natural cement.

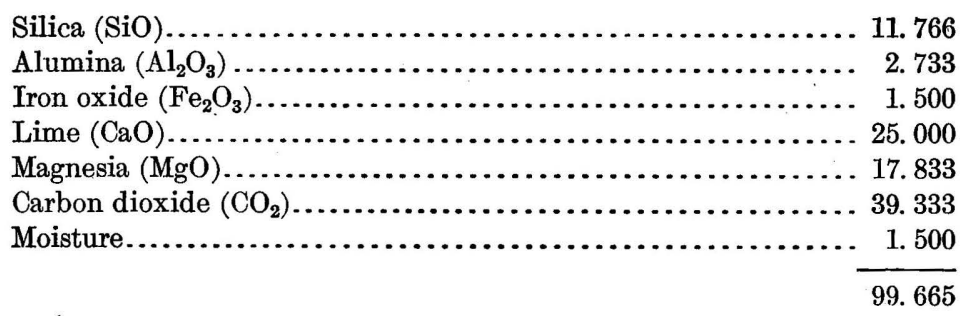

If this analysis be accepted as representative of the rock used, the resulting cement would have a cementation index of 0.74 and at the present day would be regarded as a hydraulic lime rather than as a natural cement.

\section{GROWTH OF THE NATURAL CEMENT INDUSTRY.}

The use of the Madison County cement on the canal stimulated search for other deposits of cement rock. In Wright's letter he states that this rock "is found in great abundance in the counties of Madison, Onondaga, and Cayuga." He thus outlined what has since been the natural cement district of central New York. Latèr in the same letter Wright remarks: "I do not know that it is found in the counties west of Cayuga, but presume from the geological character of that country it may be found in all the country west to Niagara, and probably farther west." Within a few years this proved to be a fact, cement rock being discovered in Erie County, in the extreme western part of the State. 
The first natural cement manufactured in Erie County was made in 1824 at Williamsville. In 1839 Jonathan Delano erected cement works at Falkirk, near Akron, making about 2,000 barrels of cement the first year. He furnished the cement for the feeder dam at Tona. wanda Creek and for the Genesee Valley Canal. In 1843 the business passed to the hands of James Montgomery, who increased the output to 10,000 barrels a year. The business afterward came into the possession of Enos Newman, a partner of Montgomery, and has been in his family ever since.

In $1854 \mathrm{H}$. Cummings \& Son established a natural cement plant at Akron, which was operated for several years. This plant was succeeded by another, managed by sons of the founder. The Akron plant was sold to the Akron Cement Co. in 1871, and the Cummings brothers erected another plant about 2 miles west of Akron.

The first natural cement made within the present limits of Buffalo was manufactured in 1850 by Warren Granger. His plant was near Scajaquada Creek, just below the Main Street Bridge, in what is now Forest Lawn Cemetery. In 1874 Lewis J. Bennett commenced the manufacture of natural cement at Buffalo Plains, near Main Street. This establishment, which has been carried on continuously under the control of the Bennett family, is now incorporated as the Buffalo Cement Co.

Third among the districts in point of age came the Rosendale region of eastern New York, which, however, soon became first as a producer and has ever since maintained a high standard in both the quality and quantity of its output.

The discovery of cement rock and the commencement of manufacture of natural cement in the Rosendale district took place apparently about 1825 , though there is considerable uncertainty as to the exact date. The industry, however, did not develop so rapidly as might be supposed, for in $1843 \mathrm{~W}$. W. Mather ${ }^{1}$ referred to the immediate past as follows:

When making the reconnaissance [in 1837], soon after the commencement of the geological survey, the business had but commenced, and there was no cement manufactured on the Rondout except at Lawrenceville, and there but few kilns were in operation. It was not then known to the inhabitants that the cement rock was abundant except at and near these quarries until some of them were then informed of its inexhaustible quantities. Even now few are aware of the great extent of the rock and still fewer understand how to trace out the situation of favorably located new quarries.

During the six years that had elapsed since 1837, however, the industry seems to have grown rapidly, for in his final report (1843) Mather states ${ }^{2}$ that 16 firms, working 60 kilns, were then operating in the Rosendale district. He estimated the product at 500,000 to

1 Geology of the first geological district: Nat. Hist. New York, div. 4, pt. 1, 1843, p. 330.

2 Idem, p. 329. 
600,000 barrels per year, and notes that about 700 men were employed in the quarries, in the mills, and in handling the cement.

Soon after the industry had become established in New York it was taken up in several other States. R. W. Lesley has pointed out the direct relation of the early natural cement industry to the canal construction, which was then so prevalent. ${ }^{1}$

The first large publir works built in this country were the canals, and the most necessary thing to build a canal was mortar that would hold the stones together at the locks or walls under water. Consequently, wherever canals were to be built there was a search for cement rocks, and all the earliest works in this country were established on the lines of the canals. Thus, on the Chesapeake \& Ohio Canal were the Cumberland and Round Top Works; on the Lehigh Canal, the works at Siegfrieds and Coplay, Pa.; on the Richmond \& Alleghany Canal, the works at Balcony Falls, Va.; on the Delaware \& Hudson Canal, the large group of works at Rosendaleand Kingston; and on the Falls of the Ohio Canal, the large aggregation of works about Louisville. From this fact grew the early package used in shipping cement in this country, the barrel, which was the package best adapted to water transportation; and it took many years to overcome the prejudice against any other form of package and to substitute the paper or duck bag for the barrel.

The following table shows the dates of establishment of the natural cement industry in various localities in the United States between 1818 and 1901:

Dates of establishment of the natural-cement industry in different States.

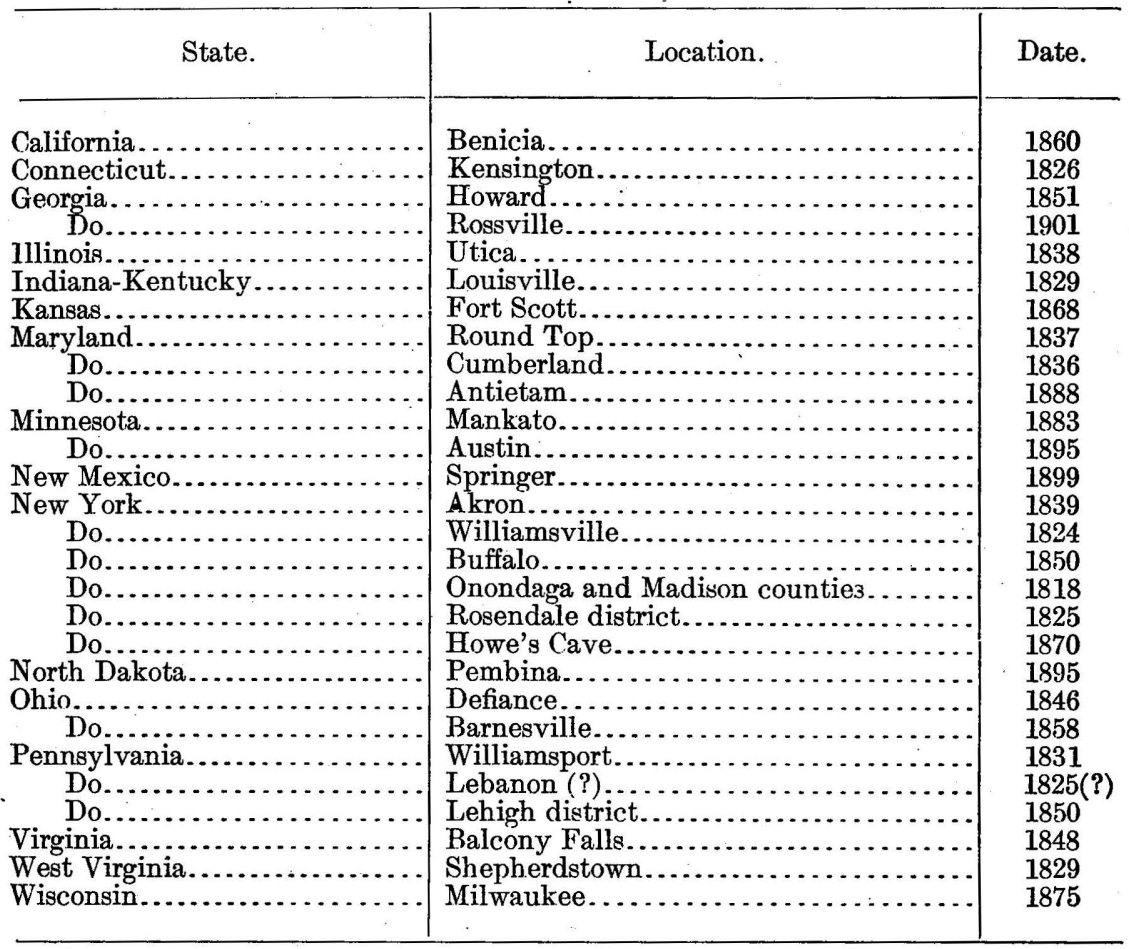


The natural cement industry grew rapidly in the United States, reaching a maximum production of not quite $10,000,000$ barrels in 1899. After that date, however, it began to suffer heavily from the competition of domestic Portland cement, and in the last decade its output has shown an almost continuous rapid annual decrease, until now it has become relatively unimportant. This matter will be noted further in discussing the statistical growth of the American Portland cement industry (pp. 31-32).

\section{PORTLAND CEMENT.}

\section{INVENTION AND EARLY HISTORY.}

\section{ASPDIN'S PATENT.}

\section{SPECIFICATION.}

In 1824 Mr. Joseph Aspdin, of Leeds, England, received a British patent for a cementing product which he named Portland cement. The name was due to a rather fanciful resemblance between the set cement and a well-known English building stone-the oolitic limestone of Portland.

Aspdin's specification, which is numbered 5022 and dated October 21,1824 , is as follows: ${ }^{1}$

My method of making a cement or artificial stone for stuccoing buildings, waterworks, cisterns, or any other purpose to which it may be applicable (and which I call Portland cement) is as follows: I take a specific quantity of limestone, such as that generally used for making or repairing roads, after it is reduced to a puddle or powder; but if I can not procure a sufficient quantity of the above from the roads, I obtain the limestone itself and I cause the puddle or powder or the limestone, as the case may be, to be calcined. I then take a specific quantity of argillaceous earth or clay and mix them with water to a state approaching impalpability, either by manual labor or machinery. After this proceeding I put the above mixture into a slip pan for evaporation, either by the heat of the sun or by submitting it to the action of fire or steam conveyed in flues or pipes under or near the pan, until the water is entirely evaporated. Then I break the said mixture into suitable lumps and calcine them in a furnace similar to a limekiln till the carbonic acid is entirely expelled. The mixture so calcined is to be ground, beat, or rolled to a fine powder and is then in a fit state for making cement or artificial stone. This powder is to be mixed with a sufficient quantity of water to bring it into the consistency of mortar, and thus applied to the purposes wanted.

\section{TECHNICAL VALUE OF ASPDIN'S INVENTION.}

As Aspdin's patent is often criticized for its vagueness, it is of interest to examine it more closely and get some idea of its real technologic importance. It seems clear that the specification of his patent covered the general method of Portland cement manufacture most suitable for the raw materials available to him, though it certainly omits to mention certain important factors or limitations in that process. To put his invention into simpler form, it may be said that Aspdin 
specified that a pure limestone was to be burned to lime. This lime was to be mixed with a definite quantity of clay, and the mixture was then to be pulverized in a wet state. The wet mixture was to be dried and crushed and then calcined in a vertical kiln; and finally the burned product was to be powdered.

It is unquestionable that this was really a very clear and definite description of the manufacture of Portland cement by a wet-mixing and grinding method. When this method was applied to hard limestone, burning in two stages was almost a necessary consequence. Aspdin's process, substantially as described, was in high favor until 1875 or thereabout, then fell into disuse, but now seems to be again becoming of interest to cement manufacturers.

The only serious omissions in the Aspdin specification are that the relative amounts of lime and clay to be used are not even approximately stated and that no mention is made of the necessity of burning the mixture at a temperature considerably above that of an ordinary limekiln. But that these omissions were due not to lack of knowledge, but to carelessness or secretiveness in framing the specification, is shown by the fact that Aspdin was actively engaged in Portland cement manufacture within a year of the issuance of his patent, and that the Aspdin family long continued prominent in the English Portland cement industry.

\section{CONTEMPORARY NOTICES OF ASPDIN'S INVENTION.}

In view of the great industrial importance attained by the Portland cement industry developed under the Aspdin patent of 1824, the writer thought it of interest to examine the files of several technical journals of that period in the hope that some contemporary mention of the invention might be found. This search was successful, and two of these contemporary notices are here reproduced.

- Aspdin's patent was applied for, it will be recollected, in 1824, the specification being dated October 21. In its issue of February 5, 1825, the London Mechanic's Register mentions the granting of the patent in the following terms, under the simple caption "Artificial stone":

Mr. Joseph Apsden, ${ }^{1}$ of Leeds, has taken outa patent for a new mode of producing an artificial stone or cement for the covering of buildings. He calls it Portland cement, from its resemblance to Portland stone; its component parts are as follows: A given quantity of limestone, of the kind usually employed for mending roads, is to be pulverized by beating or grinding, or it may be taken from the road in a pulverized state, or in the state of puddle; this, when dried, is to be calcined in a furnace in the usual. way. A similar quantity of argillaceous earth or clay is then to be mixed in water with the calcined limestone, and the whole perfectly incorporated by manual labor or by machinery into a plastic state. This mixture is then to be placed in a shallow vessel for the purpose of evaporation, and then to be submitted to the action of the air,

\footnotetext{
1 It should be noted that in these early references Aspdin's name is mispelled Apsdin or Apsden.
} 
the sun, or the heat of fire, or steam conducted by pipes or flues under the pans or evaporating vessels. This composition, when in a dry state, is to be broken into lumps of suitable sizes, and is then to be calcined again in a furnace similar to a limekiln till the carbonic acid has been entirely dispelled. The mixture so prepared is then to be pulverized by grinding or beating, and when reduced to a fine powder is in a fit state for use, and with the addition of so much water as will be sufficient to bring it into the consistency of mortar will, when applied to its purpose, make a compact and durable stone equal to the Portland stone itself.

The above notice, it will be seen, is merely a bare outline of the matter set forth in the patent specifications, with nothing added in the way of editorial comments. Another notice, of slightly earlier date, is more interesting. It appears in the Register of the Arts and Sciences (London) of January 22, 1825, under the heading "Apsdin's patent Portland cement, or artificial stone." This notice is as follows:

This is a patent lately granted to Mr. Apsdin, a mason, of Leeds, for an earthy preparation, which he calls Portland cement. Its composition, that of equal parts of limestone and aluminous earth, has been long known to the chemical world as forming a hard stony cement; a fact that ought to have been communicated to $\mathrm{Mr}$. Apsdin by the person who assisted him in his specification, which would have saved him the useless expenditure of about $£ 120$. As it is, his exclusive privilege of manufacture can only extend to the peculiar process set forth in his specification, and we sincerely hope he may make a good profit by the undertaking.

The patentee directs that common limestone is to be pulverized and then calcined in a furnace. A like quantity of clay is then to be mixed with the calcined limestone in water and made into a plastic paste. This composition is then to be dried, to be broken into lumps, and calcined again, until the carbonic acid has been driven off, when it is to be taken out of the furnace and reduced to powder. It is employed as a cement, or artificial stone, by mixing with the powder a sufficient quantity of water to make it into a paste, when it quickly solidifies into a hard substance.

The following account of a similar composition is extracted from a French work:

"M. Bruy finds that an excellent artificial puzzolana may be made by calcining, at a red heat, three parts of clay with one part of slaked lime, by measure. M.de St. Leger, who makes the article for sale, considers these proportions as the best."

\section{GROWTH OF THE PORTLAND CEMENT INDUSTRY IN EUROPE.}

Though Aspdin, as already noted, was almost immediately engaged in the commercial manufacture of his new cement, the Portland cement industry of England for some years grew very slowly. The same was true on the Continent, where the manufacture of Portland cement was soon taken up. The natural cements had gained a firm foothold, and at the necessary difference in price it was difficult to displace the earlier type. At first, too, both types were used entirely as cementing materials proper, to hold together bricks or stone; the use of cement in mass, in the form of concrete, came much later. This naturally restricted the growth of both the Portland and the natural cement industries.

About 1850, however, a distinct increase in the use and production of Portland cement, both in England and on the Continent, became 
noticeable. From this time on Portland cement rapidly displaced the older natural cements in all European markets and gradually became an important article of import into the United States.

\section{THE PORTLAND CEMENT INDUSTRY IN AMERICA.}

\section{EARLY HISTORY OF AMERICAN PORTLAND CEMENT.}

In spite of the rather rapid development of the Portland cement industry abroad, particularly in England and Germany, after 1850 or thereabout, it was not until the end of the third quarter of the nineteenth century that its manufacture was actively taken up in the United States. Then, like many other industries, it took life almost simultaneously in several parts of the country, experiments in the manufacture of Portland cement being carried on almost or quite independently at a number of small plants in New York, in the Lehigh district, in western Pennsylvania, in Michigan, and in Maine.

Apparently the first attempt at Portland cement manufacture in the United States was made in 1872, when an experimental plant was constructed at Kalamazoo, Mich., the material used being a mixture of marl and clay. This project seems to have been commercially unsuccessful; little can be learned concerning its history and it certainly exercised no influence on the slightly later developments in New York and Pennsylvania.

In 1875 a true Portland cement was being made commercially at a small plant in western Pennsylvania, the raw materials used being limestone and clay. This plant, which was located at Wampum, Pa., was the basis of the Crescent Portland Cement Co., which is still in existence. At about the same date, several small experimental plants were erected in the Hudson River district in New York. These did not result in any immediate development of the industry in that State, and their history can be disregarded here, particularly as it is described in detail on pages 284-285 of this bulletin.

In the meantime, and in a manner almost entirely disconnected from the above experiments, the foundation for the great Portland cement industry of the Lehigh district was being laid, the start being made under rather unpromising conditions. Natural cement had long been manufactured in the Lehigh region, and in the early seventies D. O. Saylor and his associates began selecting from the natural cement rock quarries the stone which would on burning yield a Portland cement. The result, though always variable and often (perhaps usually) unsatisfactory, was that a certain small tonnage of good Portland cement began to be produced annually in this district, really as a sort of by-product of the natural cement industry. The present Coplay Cement Manufacturing Co. is the direct outgrowth 
of this first successful attempt to manufacture Portland cement on a commercial scale in the Lehigh district.

The Portland cement industry had now gained at least a foothold in the United States, and within the next 10 or 15 years small plants were established in several localities. To understand properly the importance of the next development, it is necessary to consider briefly the technologic status of the industry during its early American growth, for the next factor to appear, though one which seemed at first to be of technologic interest solely, finally eompletely revolutionized the Portland cement industry of the world and placed the American industry far in advance of its European congener.

TECHNOLOGY OF PORTLAND OEMENT, 1875-1885.

AMERICAN MODIFICATIONS.

When the manufacture of Portland cement was first taken up in the United States the natural tendency was to follow closely along European lines, both as to raw materials and processes. At that date nearly all if not all European plants used soft natural raw materials, which were mixed and ground in a wet condition and burned in stationary vertical kilns, the resulting clinker being then ground by millstones. In all of these respects European practice was faithfully followed by some of the early American plants, among them the plants at Kalamazoo (Mich.), South Bend (Ind.), and Wayland (N. Y.).

This process, however, was not particularly well adapted even to conditions in England and Germany, and in the United States was almost prohibitive. It involved reducing the raw materials to powder or to a wet slurry; mixing them to a paste with water; forming the mixture, after partial drying, into bricks or balls; charging these bricks, often by hand, into the vertical kiln in which they were burned; unloading the kiln, also by hand, and finally grinding the clinker in a peculiarly ineffective and expensive way.

When both of the raw materials to be used were naturally wet and naturally soft, as when marl and clay were used, the earlier stages of the wet process were of course considerably simplified and relatively inexpensive. But with the hard, dry raw materials used in the Lehigh district the wet process was as expensive as it was absurd. This fact was recognized early, and for a number of years after the first successful experiments little or no increase in the American output of Portland cement could be noted, the margin of profit as against foreign cements cheaply laid down in the coast cities being too small to encourage the American manufacturer to take up large-scale production.'

It was early recognized by those who had commenced the experimental manufacture of Portland cement in the United States that the. 
relatively dear labor and cheap fuel of America, as contrasted with the cheap labor and dear fuel of Europe, would necessitate great changes in the technology of the industry if it were ever to be established on a firm commercial footing. The most interesting features of the early American experimental work, indeed, were the frank acceptance of these conditions and the careful search for alternative methods.

In the general effort to cut down the excessive labor cost of the product, two distinct though interrelated points of attack were obvious. In order to fit the industry satisfactorily into American labor and fuel conditions, both the burning and the grinding processes must be cheapened by mechanical improvements. Both of these points received prompt attention, and both the necessary improvements were effected when the old stationary kilns and millstones were displaced, respectively, by the rotary kiln and by modern grinding machinery.

\section{THE ROTARY KILN AND ITS EFFECT ON THE INDUSTRY.}

Of the two changes, the substitution of the rotary for the stationary kiln demands the greater attention, not only because it is the more distinctively American but also because of its important effects on the industry. Though the rotary was foreshadowed at an earlier date, the Ransome patents (Great Britain, 1885; United States, 1886) are usually considered to be the basis of its later developments, the kilns now in use being the direct successors of those of the Ransome type.

For present purposes it is sufficient to describe the rotary kiln as a steel cylinder lined with fire brick and set at a slight inclination to the horizontal. The raw mixture is fed in at the upper end and travels slowly downward by gravity as the kiln is revolved. The fuel is blown in at the lower end, and the burned clinker also falls out at this lower end. It had been expected that the fuel to be used in the Ransome kiln would be producer gas, but as a matter of fact when the rotary was first successfully used in the cement industry-at South Rondout, N. Y., in 1889-petroleum was used as fuel, and for some years its use continued to be the current American practice.

At the South Rondout plant it was found possible to charge the mixed and ground raw materials direct to the kiln without wetting, so that another step had been made in the industry. In 1891, at Montezuma, N. Y., naturally wet raw materials (marl and clay) were charged into the kiln without preliminary drying. The two main types of present American practice were thus in existence-the dry process, used with limestone or cement rock, and the wet process, used with marl. Of the two, the dry process has proved far the more economical and at present is almost universally used. 
The next step in the development of American cement manufacturing methods began about 1895, when powdered coal was first substituted for petroleum as fuel. Its use very soon became standard practice throughout the United States, except at the few localities where petroleum or natural gas abounded.

The most recent development in the rotary kiln has been purely a matter of dimension. In 1903 American rotaries had become practically standardized in size and capacity. Almost every kiln in the country used on dry materials was 60 feet in length, and a kiln of this size had a rated capacity of 200 barrels of cement a day. In the Lehigh district the 60-foot kilns usually yielded a little more than their nominal capacity, and elsewhere a little less. Beginning with the proved success of longer kilns at the Edison plant, however, a rapid lengthening commenced about 1905 and as yet has not steadied down to anything like standardization. The kilns now installed usually range between 100 and 150 feet in length and yield from 400 to 800 barrels a day. A few kilns 250 feet in length are in operation.

\section{IMPROVEMENTS IN GRINDING.}

Parallel with the changes in type and capacity came the great changes in crushing and grinding machinery which have produced the enormous tonnages of raw and finished material. The cracker crushers and millstones of the early industry have given place to larger and more efficient reducers. At present the gyratory crusher is almost exclusively used for the first stage of reduction. For finer grinding Griffin and Huntingdon mills were at first used; later ball and tube mills came into favor; but at present there seems to be some reaction toward earlier types.

\section{GROWTH OF THE AMERICAN INDUSTRY TO 1904.}

In 1905 the United States Geological Survey published, as its Bulletin 243, a report on the cement materials and industry of the United States, prepared by the present writer. The introduction to Bulletin 243, written in 1904, contained the following statements, which will bear repetition here because the industry has advanced so rapidly that the summary of its growth to 1904 already has a certain historic interest.

The marvelous growth of the American Portland cement industry during the last decade has created a widespread interest in the raw materials and in the methods of manufacture of Portland cement-the most important of the cementing materials. This interest is not confined to those who have a direct financial stake in the industry, as the product is so widely used and its uses are so rapidly increasing that some knowledge of its manufacture and properties is of advantage to everyone connected, directly or indirectly, with engineering or building operations. In its importance to our present civilization cement is surpassed among mineral products only by iron, coal, and oil; in rate of increase in annual production during the last decade even 
these three products can not be compared with it. In 1890 the total production of Portland cement in the United States was 335,500 barrels, valued at $\$ 439,050$; in 1903 it exceeded $22,000,000$ barrels, while the value was over $\$ 27,000,000$.

During the 16 years which witnessed the development of the American Portland cement industry two of the greatest gold discoveries in the world's history were made-in Colorado and Alaska. The annual gold production of Alaska and of the Cripple Creek district in Colorado have $* * *$ impressed themselves on every citizen of the United States, while the Portland cement industry has attained its growth in comparative obscurity. Yet on comparison it will be seen that the gold production of Cripple Creek is only slightly greater than the output of Portland cement, while the production of Alaska sinks into comparative insignificance. * * * Moreover the greater part of this increase has been within the last decade. The production of Portland cement has risen from a little less than $\$ 2,500,000$ in 1896 to over $\$ 27,000,000$ in 1903.

Since the above paragraphs were written the American Portland cement industry has continued its remarkable rate of growth, reaching in 1911 an output of over 78,500,000 barrels, valued at more than $\$ 66,000,000$.

\section{STATISTICS OF THE PORTLAND CEMENT INDUSTRY.1}

\section{AMERICAN PRODUCTION OF PORTLAND CEMENT, 1870-1911.}

The following statistics cover the annual production of Portland cement in this country from the inception of the industry, in the early seventies, to the present day:

Production of Portland cement in the United States, 18\%0-1911, in barrels.

\begin{tabular}{|c|c|c|c|c|c|}
\hline Year. . & Quantity. & Value. & Year. & Quantity. & Value. \\
\hline $\begin{array}{l}1870-1879 \ldots \ldots \ldots \\
1880 \ldots \ldots \ldots \\
1881 \ldots \ldots \ldots \\
1882 \ldots \ldots \ldots \ldots\end{array}$ & $\begin{array}{l}82,000 \\
42,000 \\
60,000 \\
85,000\end{array}$ & $\begin{array}{r}\$ 246,000 \\
126,000 \\
150,000 \\
191,250\end{array}$ & $\begin{array}{l}1897 \ldots \ldots \ldots \\
1898 \ldots \ldots \ldots \\
1899 \ldots \ldots \ldots \ldots\end{array}$ & $\begin{array}{l}2,677,775 \\
3,692,284 \\
5,652,266 \\
8,482,020\end{array}$ & $\begin{array}{l}4,315,891 \\
5,970,773 \\
8,074,371 \\
9,280,525\end{array}$ \\
\hline $\begin{array}{l}1883 \ldots \ldots \ldots \\
1884 \ldots \ldots \\
1885 \ldots \ldots \ldots\end{array}$ & $\begin{array}{r}90,000 \\
100,000 \\
150,000 \\
150,000\end{array}$ & $\begin{array}{l}193,500 \\
210,000 \\
292,500 \\
292,500\end{array}$ & $\begin{array}{l}1901 \ldots \ldots \ldots \ldots \\
1902 \ldots \ldots \ldots \ldots \ldots \\
1903 \ldots \ldots \ldots \ldots \\
1904 \ldots \ldots \ldots \ldots\end{array}$ & $\begin{array}{l}12,711,225 \\
17,230,644 \\
22,342,973 \\
26,505,881\end{array}$ & $\begin{array}{l}12,532,360 \\
20,864,078 \\
27,713,319 \\
23,355,119\end{array}$ \\
\hline $\begin{array}{l}1887 \ldots \ldots \ldots \ldots \\
1888 \ldots \ldots \ldots \\
1889 \ldots \ldots \ldots \ldots \\
1890 a \ldots \ldots \ldots \\
1891 \ldots \ldots \ldots \ldots \ldots\end{array}$ & $\begin{array}{l}250,000 \\
250,000 \\
300,000 \\
335,500 \\
454,813\end{array}$ & $\begin{array}{l}487,500 \\
487,500 \\
500,000 \\
704,050 \\
967,429\end{array}$ & $\begin{array}{l}1905 \ldots \ldots \ldots \ldots \ldots \ldots \ldots \\
1906 \ldots \ldots \ldots \ldots \ldots \ldots \ldots \\
1907 \ldots \ldots \ldots \ldots \ldots \ldots \ldots \ldots\end{array}$ & $\begin{array}{l}35,246,812 \\
46,463,424 \\
48,785,390 \\
51,072,912\end{array}$ & $\begin{array}{l}33,245,867 \\
52,466,186 \\
53,992,551 \\
43,547,679\end{array}$ \\
\hline \multirow{2}{*}{ 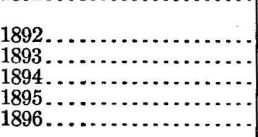 } & \multirow{2}{*}{$\begin{array}{r}547,440 \\
590,652 \\
798,757 \\
990,324 \\
1,543,023\end{array}$} & \multirow{2}{*}{$\begin{array}{r}1,153,600 \\
1,158,138 \\
1,383,473 \\
1,586,830 \\
\$ 2,424,011\end{array}$} & \multirow[t]{2}{*}{$\mid \begin{array}{l}1909 \ldots \ldots \ldots \ldots \ldots \ldots \\
1910 \ldots \ldots \ldots \ldots \ldots\end{array}$} & $\begin{array}{l}64,991,431 \\
76,549,951 \\
78,528,637 \\
\end{array}$ & $\begin{array}{l}52,858,354 \\
68,205,800 \\
66,248,817 \\
\end{array}$ \\
\hline & & & & $507,752,834$ & $495,225,971$ \\
\hline
\end{tabular}

$a$ The figures for 1890 and prior years were estimates made at the close of each year but are believed to be substantially correct. Since 1890 the official figures are based on complete returns from all producers.

This table shows fair but not in any way remarkable growth until 1895. In the latter year, however, a very striking development commenced, coincident with the development of coal burning in the

\footnotetext{
1 For further statistics the reader is referred to Mineral Resources U. S. for 1911, pt. 2, U..S. Geol. Survey, 1912 , pp. 487-493.
} 
Barrels

$80,000,000$

$75,000,000$

$70,000,000$

$65,000,000$

$60,000,000$

$65,000,000$

$60,000,000$

$45,000,000$

$40,000,000$

$30,000,000$

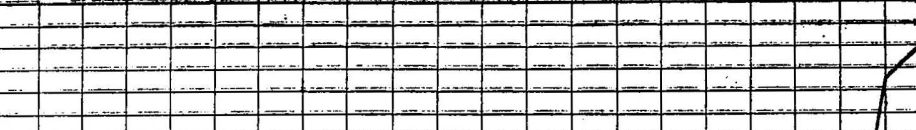

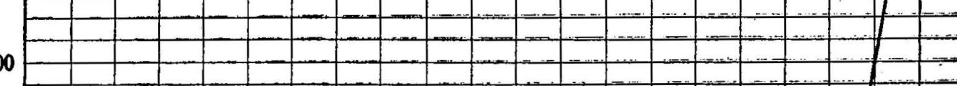

00

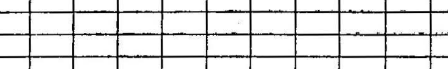

-

\begin{tabular}{llllllll}
\hline & & & & & & &
\end{tabular}

$+$

$+$

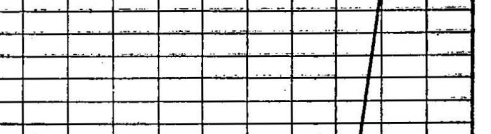

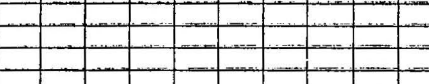

$-$

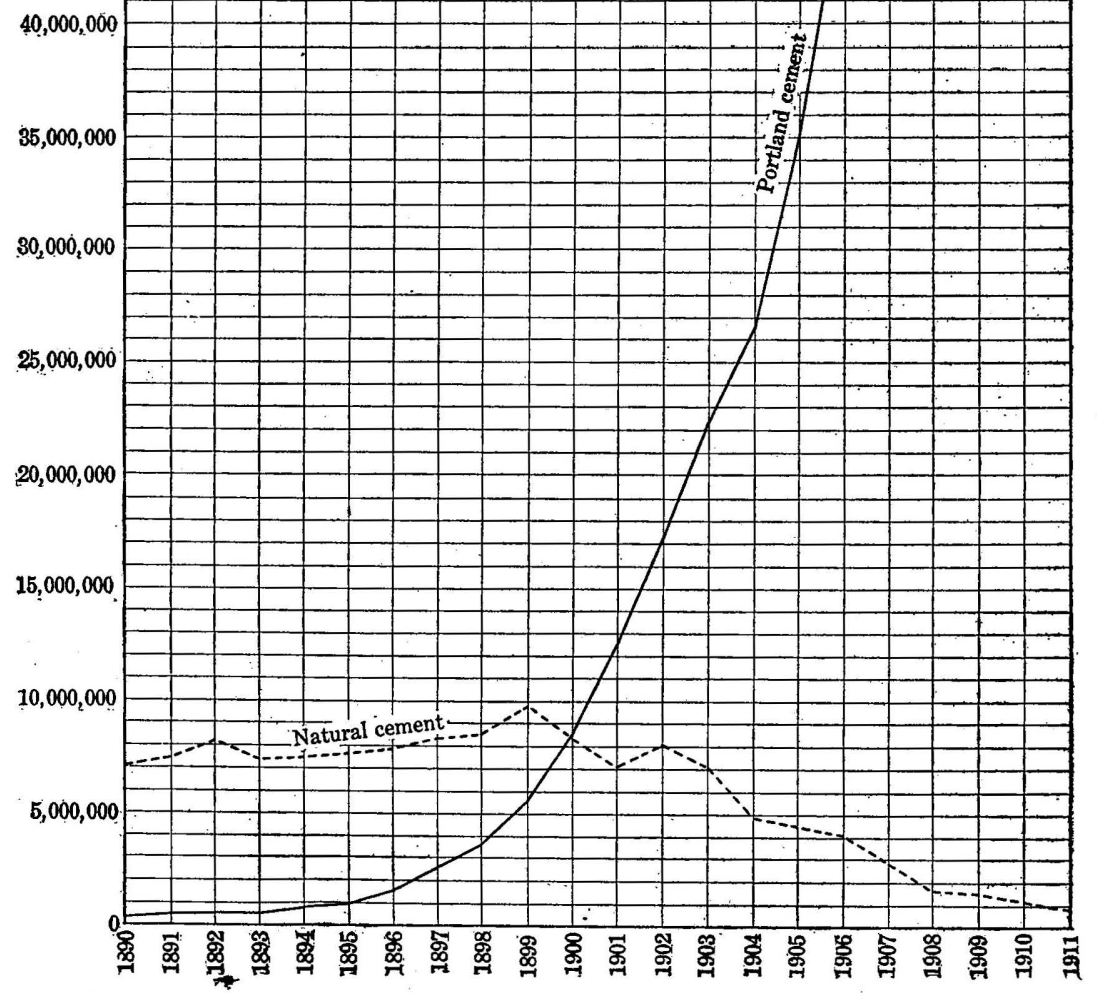

FIGURE 1.-Production of Portland and natural cements in the United States, 1890-1911. 
rotary kiln, and continued until 1907, when it was checked by the financial crisis. The check was only temporary, however, and within a year the old rate of advance had been resumed.

The phenomenal grow th of the American Portland cement industry is brought out still more strikingly in figure 1, where the later portion of the advance is shown graphically for the years 1890 to 1911, inclusive. For convenience in comparison, the gradual decline of the American natural cement industry has been plotted on the same diagram.

The rate of growth of Portland cement has been irregular, but has been high on the average, and has in no year been actually reversed. The production of natural cement, on the other hand, reached its maximum in 1899 , with an output of $9 ; 868,179$ barrels, since when it has shown a rapid and almost continuous decrease each year, until now it is relatively unimportant.

The recent growth of the American Portland cement industry has, as a matter of fact, been so rapid that its present relative standing among our great industries is realized by few, even of those directly interested. Its importance, both commercially. and financially, is perhaps best brought out by comparison with the American iron industry, whose standing is everywhere fully understood.

Several years ago, when the author first published comparative data on the cement and iron industries, it was necessary to plot the cement output in barrels and the pig-iron output in long tons in order to bring them together on the same diagram. Since then, however, the growth of the Portland cement manufacture has been so rapid that this expedient is no longer necessary; it is now possible to make comparisons by tables that give similar units of quantity. The following table gives the output of pig iron and Portland cement in long tons during every fifth year from 1880 to 1910, inclusive.

Comparative growth of cement and iron industries.

\begin{tabular}{|c|c|c|c|}
\hline . & $\begin{array}{l}\text { Pig iron, } \\
\text { long tons. }\end{array}$ & $\begin{array}{l}\text { Portland } \\
\text { cement, } \\
\text { long tons. }\end{array}$ & $\begin{array}{l}\text { Percentage } \\
\text { of cement } \\
\text { to pig iron. }\end{array}$ \\
\hline $\begin{array}{r}1880 \\
1885 \\
1890 \\
1895 \\
1900 \\
1905 \\
1910 \\
19\end{array}$ & $\begin{array}{r}7,749,233 \\
7,415,469 \\
9,202,703 \\
9,446,308 \\
13,789,242 \\
22,992,380 \\
26,674,123\end{array}$ & $\begin{array}{r}7,000 \\
25,000 \\
56,000 \\
165,000 \\
1,414,000 \\
5,874,469 \\
12,986,152\end{array}$ & $\begin{array}{r}0.1 \\
.3 \\
.6 \\
1.7 \\
10.3 \\
24.3 \\
48.7\end{array}$ \\
\hline
\end{tabular}

PRICES.

Perhaps the most striking feature connected with the Portland cement industry in this country has been the decline in cement prices 48834 $4^{\circ}-$ Bull. $522-13-3$ 
during the last 30 years. This decline has, as a matter of fact, been as steady and as marked as the growth in annual output.

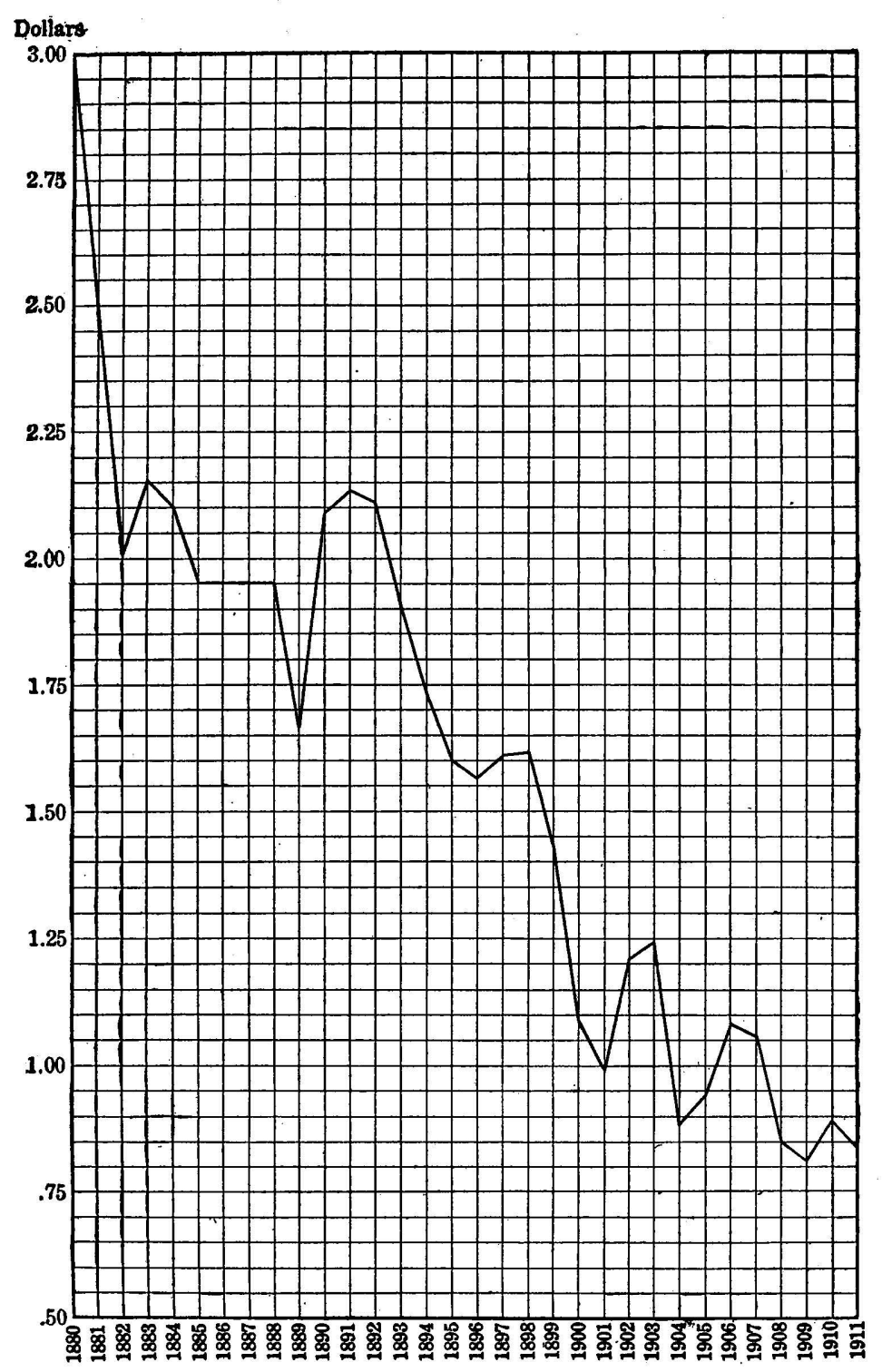

Figure 2-Range of cement prices in the United States, 1880-1911.

The following table gives the average price per barrel of Portland cement in bulk at the point of manufacture, derived from the official figures published annually by the Geological Survey. The price excludes the cost of the package, but includes packing-house labor: 
Average prices per barrel of Portland cement, 1870-1911.

\begin{tabular}{|c|c|c|c|c|c|}
\hline $1870-1880$ & $\$ 3.00$ & 1893 & $\$ 1.91$ & $1903 .$. & $\$ 1.2$ \\
\hline $1881 \ldots$ & 2.50 & 1894 & 1. 73 & 1904. & .88 \\
\hline $1882 .$. & 2. 01 & 1895. & 1. 60 & 1905. & .94 \\
\hline $1883 .$. & 2.15 & 1896. & 1.57 & $1906 .$. & 1.13 \\
\hline $1884 \ldots . .$. & 2. 10 & 1897. & 1.61 & $1907 \ldots$ & 1.11 \\
\hline 1885-1888.. & 1.95 & 1898. & 1.62 & $1908 \ldots$ & .85 \\
\hline 1889. & 1.67 & 1899. & 1.43 & $1909 .$. & .81 \\
\hline 189( & 2.09 & 1900. & 1.09 & $1910 \ldots \ldots \ldots \ldots \ldots$ & .89 \\
\hline 189 & 2.13 & 1901. & .99 & $1911 \ldots \ldots \ldots \ldots \ldots$ & 84 \\
\hline 92. & 2.11 & 1902. & 1.21 & & \\
\hline
\end{tabular}

In the diagram on page 34 (fig. 2) the fall in cement prices from 1880 to 1911 is shown graphically.

\section{IMPORTS OF FOREIGN CEMENT.}

In the early history of the American Portland cement industry the domestic price of cement was regulated largely by the price of the imported product. During recent years, however, domestic prices have been so low that foreign cements can not be profitably brought in except at a few places on the Pacific coast. The import trade has therefore ceased to be of serious interest to the American producer.

The following table shows the foreign cement imported into the United States during the years 1878 to 1911 , inclusive. Owing to the manner in which import statistics are grouped under existing tariff schedules, the quantities given include not only Portland cement, but all other hydraulic cements. Portland cement, however, probably makes up at least 95 per cent of the total in each year.

Imports of foreign cement, 1878-1911, in barrels.

\begin{tabular}{|c|c|c|c|c|}
\hline 1878. & 92,000 & 1890. & $1,940,186$ & $\ldots 11,963,023$ \\
\hline 1879. & 106,000 & 1891. & $2,988,313$ & ${ }^{1} 2,251,969$ \\
\hline $1880 \ldots \ldots \ldots \ldots$ & 187,000 & 1892 . & $2,440,654$ & ' 968,409 \\
\hline $1881 \ldots$ & 221,000 & 1893. & $2,674,149$ & ${ }^{1} 896,845$ \\
\hline $1882 \ldots \ldots \ldots \ldots$ & 370,406 & 1894. & $2,638,107$ & ${ }^{1} 2,273,493$ \\
\hline $1883 . \ldots \ldots \ldots \ldots$ & 456,418 & 1895. & $2,997,395$ & ${ }^{1} 2,033,438$ \\
\hline $1884 \ldots \ldots \ldots \ldots$ & 585,768 & 1896. & $2,989,597$ & 1842,121 \\
\hline $1885 \ldots \ldots \ldots \ldots$ & 554,396 & 1897. & $2,090,924$ & ${ }^{1} 443,888$ \\
\hline ......... & $91.5,255$ & 1898. & $1,152,861$ & 306,863 \\
\hline $1887 \ldots \ldots \ldots \ldots$ & 514,095 & 1899. & $12,108,388$ & 164,670 \\
\hline$\ldots \ldots$ & 335,504 & 1900. & $2,386,683$ & \\
\hline ........ & 740,356 & $1901 \ldots \ldots \ldots$ & ${ }^{1} 939,330$ & \\
\hline
\end{tabular}

\section{EXPORTS OF, AMERICAN CEMENT.}

The United States exports very little cement, the quantity annually shipped ranging usually between 1 and 3 per cent of the domestic production. The following table gives the quantity and value of all classes of hydraulic cement exported during the years 1900-1911, inclusive. These totals represent Portland cement almost exclusively. 
Exports of hydraulic cement, 1900-1911, in barrels.

\begin{tabular}{|c|c|c|c|c|c|}
\hline Year. & Quantity. & Value. & Year. & Quantity. & Value. \\
\hline 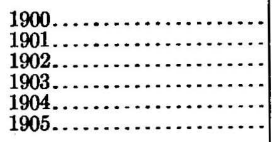 & $\begin{array}{l}100,400 \\
373,934 \\
340,821 \\
285,463 \\
774,940 \\
897,686\end{array}$ & $\begin{array}{r}\$ 225,306 \\
679,296 \\
526,471 \\
433,984 \\
1,104,086 \\
1,387,906\end{array}$ & $\begin{array}{l}1906 \ldots \\
1907 \ldots \\
1908 \ldots \\
1909 \ldots \\
1910 \ldots \\
1911 \ldots\end{array}$ & $\begin{array}{r}583,299 \\
900,550 \\
846,528 \\
1,056,922 \\
2,475,957 \\
3,135,409\end{array}$ & $\begin{array}{r}\$ 944,886 \\
1,450,841 \\
1,249,229 \\
1,417,534 \\
3,477,981 \\
4,632,215\end{array}$ \\
\hline
\end{tabular}

Probably much more serious attention will be given to the export trade in future, particularly by the eastern mills, for its development seems to be the simplest method of disposing of the surplus which now periodically weighs on the eastern cement market. Of course an export trade in a commodity like cement-relatively bulky and low in value-does not promise any large direct profit to the individual producer, but indirectly the creation and maintenance of such a trade will benefit the industry at large. Ow.ing to the scanty fuel supplies of most parts of South and Central America and the West Indies the development of local cement industries seems unlikely in those promising markets.

\section{GEOGRAPHIC CONCENTRATION OF THE CEMENT INDUSTRY.}

PORTLAND CEMENT PRODUCTION, BY STATES.

In 1906 and 1907 the leading cement-producing States ranked in the same order, as follows: Pennsylvania, New Jersey,. Indiana, Michigan, Kansas, New York, Illinois, Missouri. In 1908, however, some very notable changes in rank occurred, owing to the decreases shown by the Eastern States and Michigan, and the heavy increases reported from some of the Middle Western States. The order of production in 1908 was therefore as follows: Pennsylvania, Indiana, Kansas, Illinois, New Jersey, Michigan, Missouri, New York.

In 1909 Pennsylvania still led in production, followed in order by nearly the same States as in 1908, but Missouri ran ahead of Michigan. In 1910 and 1911 Michigan occupied eighth place, owing to the rapid rise of California as a producer, this State having passed Kansas and taken third place.

In the following table the Portland cement production is given by States, or by groups of States where there are less than three producers in a single State. By the term "producer" is meant a Portland cement manufacturing company, whether the company operates one or more plants. In the table the term "producing plant". is applied to a mill or group of mills located at one place and operated by one company, but each establishment at a different place is counted as a plant. 
Production of Portland cement in the United States in 1910 and 1911, by States.

\begin{tabular}{|c|c|c|c|c|c|c|c|}
\hline \multicolumn{4}{|c|}{1910} & \multicolumn{4}{|c|}{1911} \\
\hline State. & $\begin{array}{l}\text { Produc- } \\
\text { ing } \\
\text { plants. }\end{array}$ & $\begin{array}{l}\text { Quantity } \\
\text { (barrels). }\end{array}$ & Value. & State. & $\begin{array}{c}\text { Produc- } \\
\text { ing } \\
\text { plants. }\end{array}$ & $\begin{array}{l}\text { Quantity } \\
\text { (barrels). }\end{array}$ & Value. \\
\hline Pennsylva: & 25 & $26,675,978$ & $\$ 19,551,268$ & Pennsylvan & 25 & $26,864,679$ & $\$ 19,258,253$ \\
\hline ina... & 5 & $7,219,199$ & $6,487,508$ & Indiana. & 5 & $7,407,830$ & $5,937,241$ \\
\hline Kansas & 11 & $5,655,808$ & $5,359,408$ & $\begin{array}{l}\text { California.......... } \\
\text { Kansas. }\end{array}$ & $\begin{array}{r}8 \\
12\end{array}$ & $\begin{array}{l}6,317,701 \\
4,871,903\end{array}$ & $\begin{array}{l}8,737,150 \\
3,725,108\end{array}$ \\
\hline $\begin{array}{l}\text { California....................... } \\
\text { Washington }\end{array}$ & $\begin{array}{l}7 \\
2\end{array}$ & $6,385,588$ & $8,843,210$ & Illinois............ & $\begin{array}{r}5 \\
3 \\
3\end{array}$ & $\begin{array}{l}4,582,341 \\
4,411,890\end{array}$ & $\begin{array}{l}3,583,301 \\
3,259,528\end{array}$ \\
\hline Illinois. & 5 & $4,459,450$ & $4,119,012$ & Michigan........... & 11 & $3,686,716$ & $\begin{array}{l}3,344,312 \\
3,024,676\end{array}$ \\
\hline Missouri. & 4 & $4,455,589$ & $3,858,088$ & New York. & 7 & $3,314,217$ & $2,669,194$ \\
\hline New Jerse & 3 & $4,184,698$ & $3,067,265$ & Iowa... & 3 & $1,952,590$ & $1,881,253$ \\
\hline Mic & 12 & $3,687,719$ & $3,378,940$ & Ohio... & 5 & $1,451,852$ & $1,228,680$ \\
\hline New & 8 & $3,296,350$ & $2,906,551$ & $\begin{array}{l}\text { Washington...... } \\
\text { Utah............... }\end{array}$ & $\begin{array}{l}3 \\
3\end{array}$ & $\begin{array}{r}960,573 \\
662,849\end{array}$ & $\begin{array}{r}1,496,807 \\
827,523\end{array}$ \\
\hline $\begin{array}{l}\text { Texas.......... } \\
\text { Oklahoma.... }\end{array}$ & $\begin{array}{l}4 \\
2\end{array}$ & $2,287,445$ & $2,664,846$ & Texas. & 4 & $2,438,493$ & $2,541,449$ \\
\hline $\begin{array}{l}\text { Iowa.......... } \\
\text { Kentucky } \\
\text { West Virginia }\end{array}$ & $\begin{array}{l}2 \\
1 \\
1\end{array}$ & $2,010,37.9$ & $1,986,694$ & $\begin{array}{l}\text { Tennessee......... } \\
\text { West Virginia.... }\end{array}$ & $\begin{array}{l}2 \\
1\end{array}$ & $1.981,341$ & $1,590,438$ \\
\hline & 5 & 1597670 & & Kentucky......... & 1 & & \\
\hline ill & $\boldsymbol{b}$ & $1,527,670$ & $1,279,717$ & Virgi & $\therefore$ & & \\
\hline $\begin{array}{l}\text { Alabama.. } \\
\text { Georgia... }\end{array}$ & 2 & 50 & 105 & Marylan & $\overline{2}$ & $1,487,753$ & $1,084,315$ \\
\hline Tenn & 1 & & & Colorado. & 2 & $1,162,081$ & $1,272,317$ \\
\hline $\begin{array}{l}\text { Maryland............ } \\
\text { Virginia............. }\end{array}$ & $\begin{array}{l}1 \\
2\end{array}$ & $1,206,158$ & 830,218 & Alabam & 2 & 858,969 & 782,272 \\
\hline $\begin{array}{l}\text { Arizon } \\
\text { Colora }\end{array}$ & 1 & & & & & & \\
\hline Montana... & $\begin{array}{l}2 \\
1\end{array}$ & $1,204,761$ & $1,543,620$ & Tot & 115 & $78,528,637$ & $66,248,817$ \\
\hline Utah....... & 3 & 811,800 & $1,005,960$ & & & & \\
\hline Total.. & 111 & $76,549,951$ & $68,205,800$ & & & & \\
\hline
\end{tabular}

PRODUCTION BY COMMERCIAL DISTRICTS.

In the present grouping the United States has been divided into 11 subdivisions based on the grouping of plants in direct relation to the trade territory covered by each group. This grouping is also logical when the raw materials are considered. For instance, the plants in northeastern Indiana and northern Kentucky, all of which are near Ohio River, and all of which use hard limestone, are grouped together, and those in Michigan and northeastern Indiana, most of which use marl, are grouped together. Plants near Chicago, whether in Illinois or Indiana, are logically grouped together because of their nearly equal freight rates. The Southeastern States, in which plants use mostly Appalachian limestone, are grouped together, and central Texas has been transferred to the group of Great Plains States, to which it more logically belongs. Plants between Missouri River and Mississippi River in Missouri and Iowa are grouped together, and the plants in the Rocky Mountain States and western Texas are considered in a group intermediate between the Great Plains and the Pacific coast. The following table summarizes 
the statistics for 1910 and 1911 for each district with regard to the number of active plants, the total production in 1910 and 1911, the percentage of gain and loss in 1911, and the average price per barrel.

Production of Portland cement in 1910 and 1911, by commercial districts.

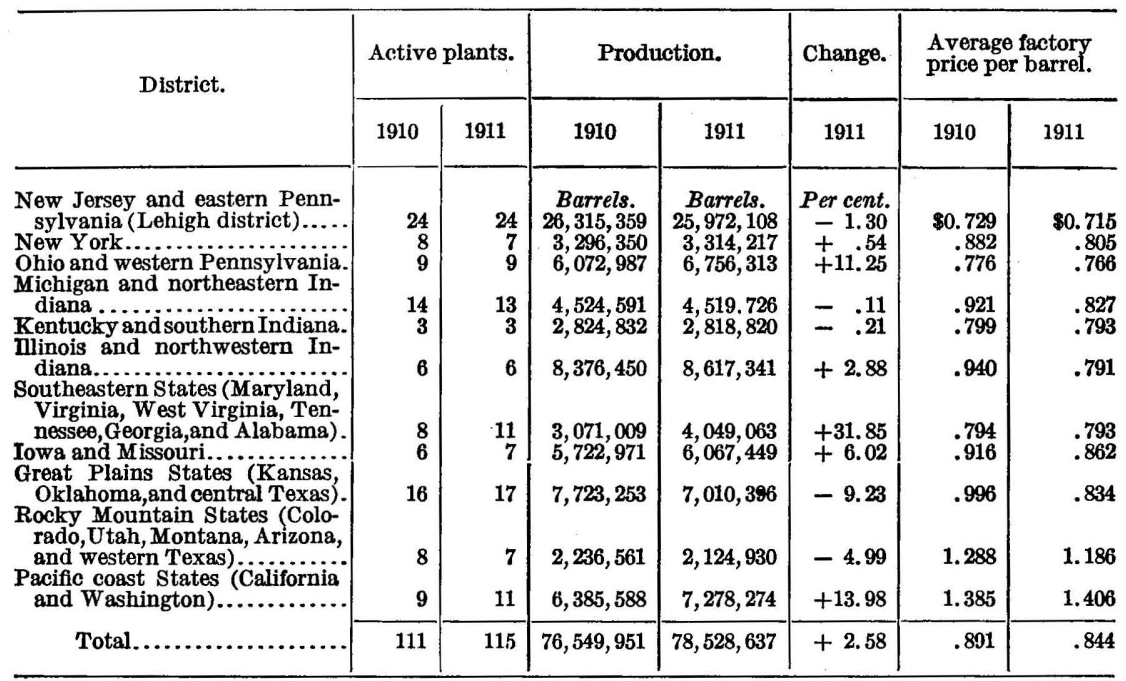

This table brings out some interesting facts concerning the 1911 output in the several districts. According to the returns received there were decreases in production in 1911 as compared with 1910 in the Lehigh, Michigan-northeastern Indiana, Kentucky-southern Indiana, Great Plains, and Rocky Mountain districts. The increases recorded in production were in the New York, Ohio-western Pennsylvania, Illinois-northwestern Indiana, Southeastern States, IowaMissouri, and Pacific coast districts. The greatest decrease in production was in the Great Plains district, which amounted to 9.23 per cent of the 1910 production. The greatest increase in production, 31.85 per cent, was recorded in the Southeastern States, and the Pacific coast showed a gain of nearly 14 per cent. These two large increases were due in large part to the starting of three new mills in the Southeastern and two new mills in the Pacific coast States.

PRODUCTION OF THE LEHIGH DISTRICT, 1890-1910.

The Portland cement industry still exhibits, though to a less degree, the same tendency toward geographic centralization that gave Pittsburgh its preeminence as an iron producer. The Portland cement plants are concentrated in the so-called Lehigh district of Pennsylvania and its New Jersey continuation. The Lehigh district is the place where the Portland cement manufacture was first undertaken on a large scale, and it owes its continued preeminence to its posses- 
sion of good raw materials, good labor, good and fairly cheap fuel, and excellent transportation facilities to large eastern markets. At present, however, each year witnesses a marked narrowing of the profitable market area for Lehigh cement. The growth of the district is being limited by that of competing localities, just as the growth of the Pittsburgh steel district is being limited by that of Gary, Buffalo, Birmingham, and the Atlantic plants. During ordinary years, the existing cement plants in western Pennsylvania now limit the western Pennsylvania and Ohio shipments, and the plants in West Virginia, Virginia, and New York are more and more restricting shipments to the South and the East.

The Lehigh district possesses great manufacturing advantages, and its annual output has by no means necessarily reached its maximum, but the decrease in the margin of profit and the narrowing of the market area are so obvious that strong companies can no longer look to their Lehigh district plants as being sufficient for the future.

The following table shows the production of the Lehigh district for each year since 1890, the total production, and the percentage of the Lehigh district output to the total production:

Portland cement production in the Lehigh district and in the United States, 1890-1911, in barrels.

\begin{tabular}{|c|c|c|c|c|c|c|c|}
\hline Year. & $\begin{array}{c}\text { Lehigh dis- } \\
\text { trict } \\
\text { output. }\end{array}$ & $\begin{array}{c}\text { Total } \\
\text { output of } \\
\text { the United } \\
\text { States. } \\
\end{array}$ & $\begin{array}{l}\text { Percent- } \\
\text { age of to- } \\
\text { tal manu- } \\
\text { factured } \\
\text { in Lehigh } \\
\text { district. }\end{array}$ & Year. & $\begin{array}{c}\text { Lehigh dis- } \\
\text { trict } \\
\text { output. }\end{array}$ & $\begin{array}{c}\text { Total } \\
\text { output of } \\
\text { the United } \\
\text { States. }\end{array}$ & $\begin{array}{l}\text { Percent- } \\
\text { age of to- } \\
\text { tal manu- } \\
\text { factured } \\
\text { in Lehigh } \\
\text { district. }\end{array}$ \\
\hline $\begin{array}{l}1890 \ldots \ldots \ldots \\
1891 \ldots \ldots \ldots \\
1892 \ldots \ldots \ldots\end{array}$ & $\begin{array}{l}201,000 \\
248,500 \\
280,840\end{array}$ & $\begin{array}{l}335,500 \\
454,813 \\
547,440\end{array}$ & $\begin{array}{l}60.0 \\
54.7 \\
51.3\end{array}$ & $\begin{array}{l}1902 \ldots \ldots \ldots \ldots \\
1903 . \ldots \ldots \ldots \ldots\end{array}$ & $\begin{array}{l}10,829,922 \\
12,324,922 \\
14,211,039\end{array}$ & $\begin{array}{l}17,230,644 \\
22,342,973 \\
26,505,881\end{array}$ & $\begin{array}{l}62.8 \\
55.2 \\
53.7\end{array}$ \\
\hline $\begin{array}{l}1893 \ldots \ldots . \\
1894 \ldots \ldots \\
1895 \ldots \ldots\end{array}$ & $\begin{array}{l}265,317 \\
485,329 \\
634,276\end{array}$ & $\begin{array}{l}590,652 \\
798,757 \\
990,324\end{array}$ & $\begin{array}{l}44.9 \\
60.8 \\
64.0\end{array}$ & $\begin{array}{l}1905 \ldots \ldots \ldots \\
1906 \ldots \ldots\end{array}$ & \begin{tabular}{|l|}
$17,368,687$ \\
$22,784,613$ \\
$24,417,686$
\end{tabular} & \begin{tabular}{|l}
$35,246,812$ \\
$46,463,424$ \\
$48,785,390$
\end{tabular} & $\begin{array}{l}49.3 \\
49.0 \\
50.0\end{array}$ \\
\hline $\begin{array}{l}1896 \ldots \ldots . \\
1897 \ldots \ldots \\
1898 \ldots \ldots\end{array}$ & $\begin{array}{l}1,048,154 \\
2,002,059 \\
2,674,304\end{array}$ & $\begin{array}{l}1,543,023 \\
2,677,775 \\
3,692,284\end{array}$ & $\begin{array}{l}68.1 \\
74.8 \\
72.4\end{array}$ & $\begin{array}{l}1908 \ldots . \\
1909 \ldots \\
1910 \ldots\end{array}$ & $\begin{array}{l}20,200,387 \\
24,246,706 \\
26,315,359\end{array}$ & $\begin{array}{l}51,072,612 \\
64,991,431 \\
76,549,951\end{array}$ & $\begin{array}{l}39.6 \\
37.3 \\
34.4\end{array}$ \\
\hline $\begin{array}{l}1899 \ldots \ldots . . \\
1900 \ldots \ldots . . \\
1901 . \ldots . .\end{array}$ & $\begin{array}{l}4,110,132 \\
6,153,629 \\
8,595,340\end{array}$ & $\begin{array}{r}5,652,266 \\
8,482,020 \\
12,711,225\end{array}$ & $\begin{array}{l}72.7 \\
72.6 \\
67.7\end{array}$ & 1911. & $25,972,108$ & $78,528,637$ & 33.1 \\
\hline
\end{tabular}




\section{PART II. RAW MATERIALS OF THE PORTLAND CEMENT INDUSTRY.}

\section{INTRODUCTION.}

\section{DEFINITION OF PORTLAND CEMENT.}

Portland cement is an artificial chemical product of fairly definite composition, containing approximately 60 to 65 per cent lime, 20 to 25 per cent silica, and 5 to 12 per cent iron oxide and alumina. Each of the four constituents named may vary within certain limits, but these possible variations are so interrelated that it is possible to express the general composition of present-day Portland cements very closely by a formula, even though it be an empirical one.

\section{STAGES IN MANUFACTURE.}

The essential feature in the manufacture of Portland cement is the formation of a fairly definite chemical compound under the action of intense heat. That this may be properly accomplished and that the compound so formed may be put in shape for utilization, three general stages in manufacture are necessary, whatever the details of the processes employed may be: First, raw materials of proper chemical and physical composition must be intimately mixed in proper proportions, drving and fine grinding being necessary to secure the very essential intimacy of the mixing; second, the raw mix thus prepared must be burned at a very high temperature until it unites chemically and physically as a clinkered mass; third, the clinker so formed must be ground very finely. The end result of these processes is the Portland cement of commerce.

\section{MATERIALS USED.}

The raw materials used in the manufacture of Portland cement may, for convenience, be grouped as (1) cement materials proper, including limestone, marl, shells, cement rock, clay, shale, and so forth, which may be combined to form the actual cement mixture; (2) fuels, including the coal, oil, or gas used to burn the cement, as well as the fuel usually required to furnish power for the plant; (3) fluxes and retarders, including gypsum, lime chloride, alkalies, fluorite, and the like, which may be added to the cement or the cement mixture at different stages to accomplish certain purposes.

These several classes of raw materials will be discussed in the order named, greatest attention being paid to the cement materials proper. It should be observed, however, that this very concentration of attention on the cement materials proper has led to serious errors in the location of cement plants. It can hardly be stated too strongly that no degree of excellence in the limestone or shale can make up 
for a poor or expensive fuel supply or for a small market. On the other hand, given cheap fuel and a good market, the manufacturer may be justified in building a plant to use very poor limestones.

\section{CEMENT MATERIATS PROPER.}

\section{APPROXIMATE COMPOSITION OF THE CEMENT MIXTURE.}

In order to determine what raw materials can be used to advantage in the Portland cement mixture it is first necessary to decide in a general way the composition of the mixture.

The ordinary Portland cement mixture, when made from normal and natural raw materials, contains about 75 per cent of lime carbonate $\left(\mathrm{CaCO}_{3}\right)$ and 20 per cent of silica $\left(\mathrm{SiO}_{2}\right)$, alumina $\left(\mathrm{Al}_{2} \mathrm{O}_{3}\right)$, and iron oxide $\left(\mathrm{Fe}_{2} \mathrm{O}_{3}\right)$ together, the remaining 5 per cent including magnesium carbonate, alkalies, sulphur, and other unavoidable but unnecessary constituents. When blast-furnace slag is used in the mixture, the bulk composition will be suitably modified.

The essential elements entering into a Portland cement mixturesilica, alumina, iron, and lime-are all extremely abundant, being in fact the four commonest elements of the earth's crust. They are also very widely distributed, occurring naturally in different forms as important constituents of many different kinds of rocks. It can therefore readily be seen that, so far as ease in finding raw materials of proper chemical composition alone is concerned, a satisfactory Portland cement mixture could be prepared by combining, in an almost infinite number of ways and proportions, many possible kinds of raw materials. Obviously, too, the artificiality of the mixture might show all possible gradations, varying from one extreme, where a natural rock of absolutely correct theoretical composition was alone used, to the other extreme, where two or more raw materials widely different in composition would have to be mixed in almost equal amounts.

\section{RAW MATERIALS ACTUALIY USED.}

The almost infinite number of raw materials that are theoretically available for cement making are, however, reduced to a very few under existing commercial conditions. The necessity of making the mixture as cheaply as possible prevents the use of a large number of materials that would be available if chemical composition were the only thing to be considered. Some materials that are otherwise suitable are too scarce; some are too difficult to pulverize. In consequence, a comparatively few combinations of raw materials are actually used.

In certain localities there are deposits of argillaceous (clayey) limestone or "cement rock" in which the lime, silica, alumina, and iron oxide exist in so nearly the proper proportions that only a relatively small amount (say 10 per cent) of other material is required to make a mixture of correct composition. In most cement plants, 
however, all or nearly all the necessary lime is furnished by one raw material, and the silica, alumina, and iron oxide are largely or entirely supplied by another. At most plants, too, the raw material which furnishes the lime is natural-a limestone, chalk, or marl-but at a few it is an artificial product, such as the chemically precipitated lime carbonate which results as waste from alkali manufacture. The silica, alumina, and iron oxide of the mixture are as a rule derived from clays, shales, or slates; but at a few plants blast-furnace slag is used as the silico-aluminous ingredient.

The chief combinations of raw materials now used in the United States in the manufacture of Portland cement may be grouped under four heads: (1) Argillaceous limestone (cement rock) and pure limestone; (2) pure hard limestone and clay or shale; (3) marl and clay; (4) slag and limestone.

\section{PRODUCTION ACCORDING TO RAW MATERIALS USED.}

In the following table the production of Portland cement in the United States is classified according to the kinds of raw materials from which it is manufactured. .

Type 1 comprises cement produced from a mixture of argillaceous limestone ("cement rock") and pure limestone. This is the combination of materials used in all the cement plants of the Lehigh district of Pennsylvania and New Jersey and at a few western plants.

Type 2 comprises cement made from a mixture of comparatively pure limestone with clay or shale. This mixture is employed at the majority of plants in various parts of the United States.

Type 3 comprises cement manufactured from a mixture of marl and clay. This type of mixture is used in certain plants in Michigan, Ohio, Indiana, New York, and Utah.

Type 4 comprises cement manufactured from a mixture of limestone and blast-furnace slag.

Production, in barrels, and percentage of total output of Portland cement in the United States according to type of material used, 1898-1911.

\begin{tabular}{|c|c|c|c|c|c|c|c|c|}
\hline \multirow{2}{*}{ Year. } & \multicolumn{2}{|c|}{$\begin{array}{l}\text { Type 1. Cement rock } \\
\text { and pure limestone. }\end{array}$} & \multicolumn{2}{|c|}{$\begin{array}{l}\text { Type } 2 . \text { Limestone } \\
\text { and clay or shale. }\end{array}$} & \multicolumn{2}{|c|}{$\begin{array}{l}\text { Type 3. Marl and } \\
\text { clay. }\end{array}$} & \multicolumn{2}{|c|}{$\begin{array}{l}\text { Type 4. Blast-fur- } \\
\text { nace slag and lime- } \\
\text { stone. }\end{array}$} \\
\hline & Quantity. & $\begin{array}{c}\text { Per- } \\
\text { centage. }\end{array}$ & Quantity. & $\begin{array}{c}\text { Per- } \\
\text { centage. }\end{array}$ & Quantity. & $\begin{array}{c}\text { Per- } \\
\text { centage. }\end{array}$ & Quantity. & $\begin{array}{c}\text { Per- } \\
\text { centage. }\end{array}$ \\
\hline 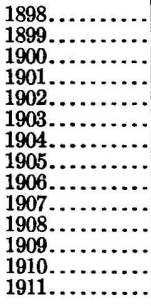 & $\begin{array}{r}2,764,694 \\
4,010,132 \\
5,960,739 \\
8,503,500 \\
10,953,178 \\
12,493,694 \\
15,173,391 \\
18,454,902 \\
23,896,951 \\
25,859,095 \\
20,678,693 \\
24,274,047 \\
26,520,911 \\
26,812,129\end{array}$ & $\begin{array}{l}74.9 \\
70.9 \\
70.3 \\
66.9 \\
63.6 \\
55.9 \\
57.2 \\
52.4 \\
51.4 \\
53.0 \\
40.6 \\
37.3 \\
34.6 \\
34.1\end{array}$ & $\begin{array}{r}365,408 \\
546,200 \\
1,034,041 \\
2,042,209 \\
3,738,303 \\
6,333,403 \\
7,526,323 \\
11,172,389 \\
16,532,212 \\
17,190,697 \\
23,047,707 \\
32,219,365 \\
39,720,320 \\
40,665,332\end{array}$ & $\begin{array}{r}9.9 \\
9.7 \\
12.2 \\
16.1 \\
21.7 \\
28.3 \\
28.4 \\
31.7 \\
35.6 \\
35.2 \\
45.0 \\
49.6 \\
51.9 \\
51.8\end{array}$ & $\begin{array}{r}562,092 \\
1,095,934 \\
1,454,797 \\
2,001,200 \\
2,220,453 \\
3,052,946 \\
3,332,873 \\
3,884,178 \\
3,958,201 \\
3,606,598 \\
2,811,212 \\
2,711,219 \\
3,307,220 \\
3,314,176\end{array}$ & $\begin{array}{r}15.2 \\
19.4 \\
17.1 \\
1.7 \\
12.9 \\
13.7 \\
12.6 \\
11.0 \\
8.5 \\
7.4 \\
5.5 \\
4.2 \\
4.3 \\
4.2\end{array}$ & $\begin{array}{r}32,443 \\
164,316 \\
318,710 \\
462,930 \\
473,294 \\
1,735,343 \\
2,076,000 \\
2,129,000 \\
4,535,300 \\
5,786,800 \\
7,001,500 \\
7,737,000\end{array}$ & $\begin{array}{l}\cdots . . \\
\because 0.4 \\
1.3 \\
1.8 \\
2.1 \\
1.8 \\
4.9 \\
4.5 \\
4.4 \\
8.9 \\
8.9 \\
9.2 \\
9.9\end{array}$ \\
\hline
\end{tabular}


The preceding table shows a decrease in the relative production from cement rock (type 1) and marl (type 3), and a corresponding increase in the production from limestone (type 2) and slag (type 4). The falling off in the relative output from marl was not unexpected, and this relative decrease may continue. The decrease in the percentage produced from cement rock is due simply to the lessening comparative importance of the Lehigh district (see pp. 38-39), but it may be reversed in the near future, for two districts containing cement rock of the Lehigh type, though widely separated geographically from the Lehigh district itself, may become important producers within the next few years.

\section{IIMESTONES.}

Limestone is the most important ingredient, in one form or another, in a Portland cement mixture. Limestones of certain types are also employed in the manufacture of hydraulic limes, natural cements, and slag cements. It has therefore seemed desirable to discuss the origin, composition, varieties, and chemical and physical characters of limestone in general.

\section{ORIGIN OF LIMESTONES.}

Limestones have been formed largely by the accumulation on the sea bottom of the calcareous remains of such organisms as the foraminifera, corals, and mollusks. Many of the thick and extensive limestone deposits of the United States were probably marine deposits formed in this way. Some of these limestones still show the fossils of which they were formed, but others have lost all trace of organic origin through the fine grinding to which the shells and corals were subjected before their deposition. It is probable also that a large part of the calcium carbonate of these limestones was a purely chemical deposit from solution, cementing the shell fragments together.

Other limestones, far less extensive though important in the present connection, owe their origin to the indirect action of organisms. The marls, so important to-day as Portland cement materials, fall in this class. (See pp. 51-52.) Deposits of this class are small.

Deposition from solution by purely chemical"means has undoubtedly given rise to numerous limestone deposits. When this deposition took place in caverns or in the open air it gave rise to onyx deposits and to the "travertine marls" of certain localities in Ohio and elsewhere. When it took place in isolated portions of the sea through evaporation of the sea water it gave rise to the limestone beds which so frequently accompany deposits of salt and gypsum.

\section{VARIETIES OF LIMESTONE.}

A number of terms, based upon differences of origin, texture, and composition, are in general use for the different varieties of limestone. 
The term "marble," properly used, denotes a limestone which, through the action of heat and pressure, has become more or less distinctly crystalline, but the word is often used to denote any limestone that will take a good polish. The term "marl," as at present used in cement manufacture, is applied to a loosely cemented mass of lime carbonate formed in lake basins (p. 51). Calcareous tufa and travertine are more or less compact limestones, deposited by spring or stream waters along their courses. Oolitic limestones, so-called because of their resemblance to a mass of fish roe, are made up of small rounded grains of lime carbonate having a concentrically laminated structure. Chalk is a fine-grained limestone composed of finely comminuted shells, particularly those of the Foraminifera. The presence of much silica gives rise to a siliceous or cherty limestone. If the silica present is in combination with alumina the resulting limestone will be clayey or argillaceous.

\section{CHEMICAL COMPOSITION OF LIMESTONE.}

IMPURITIES.

A theoretically pure limestone is merely a massive form of the mineral calcite. Such an ideal limestone would therefore consist entirely of calcium carbonate or carbonate of lime $\left(\mathrm{CaCO}_{3}\right)$ or 56 per cent calcium oxide $(\mathrm{CaO})$ plus 44 per cent carbon dioxide or carbonic acid $\left(\mathrm{CO}_{2}\right)$. As might be expected, limestones as quarried differ more or less widely from this theoretical composition; (1) they may contain magnesia in place of part of the lime; or (2) they may contain silica, iron, alumina, alkalies, or other impurities.

Magnesia is often described as an "impurity" in limestones, but the word hardly expresses the facts. The magnesium carbonate present, whatever its amount, simply serves to replace an equivalent amount of calcium carbonate, and the resulting rock, whether little or much magnesia is present, is still a pure carbonate rock. Silica, alumina, iron, sulphur, and alkalies, however, are actual impurities, and not merely chemical replacements of part of the calcium carbonate. It seems advisable to discriminate between these two classes, even though a given sample of limestone may fall under both.

\section{MAGNESIA.}

The theoretically pure limestones, are, as above noted, composed entirely of calcium carbonate and thus they correspond to the chemical formula $\mathrm{CaCO}_{3}$. Even aside from the presence of such impurities as iron, alumina, and silica, it may be said that lime is rarely the only base in a limestone. During or after the formation of the limestone a certain percentage of magnesia is generally introduced in place of part of the lime, producing a more or less magnesian limestone. In such magnesian limestones part of the calcium carbonate is replaced 
by magnesium carbonate $\left(\mathrm{MgCO}_{3}\right)$, the general formula for magnesian limestone being therefore $x \mathrm{CaCO}_{3}, y \mathrm{MgCO}_{3}$. In this formula $x$ may vary from 100 per cent to zero, while $y$ will vary inversely from zero to 100 per cent. If the two carbonates are united in equal molecular proportions, the resultant rock is called dolomite. It has the formula $\mathrm{CaCO}_{3}, \mathrm{MgCO}_{3}$ and is composed of 54.35 per cent calcium carbonate and 45.65 per cent magnesium carbonate. If the calcium carbonate has been entirely replaced by magnesium carbonate, the resulting pure carbonate of magnesia is called magnesite, having the formula $\mathrm{MgCO}_{3}$ and being composed of 47.6 per cent magnesia ( $\mathrm{MgO}$ ) and 52.4 per cent carbon dioxide $\left(\mathrm{CO}_{2}\right)$.

Rocks of the limestone series may therefore vary in composition from pure calcite limestone at one end of the series to pure magnesite at the other. The term limestone has, however, been restricted in general use to rocks which have a composition between that of calcite and that of dolomite. All the more uncommon phases, carrying more than 45.65 per cent magnesium carbonate, are usually described simply as impure magnesites.

The presence of much magnesia in finished Portland cement is considered undesirable, 4 per cent being the maximum permissible under most American specifications. Therefore the limestone to be used in Portland cement manufacture should not carry more than 3 or 4 per cent of magnesium carbonate.

\section{SILICA ALONE.}

The silica in limestone may be combined with alumina as a clayey impurity or may not be combined with it. Its effect on the value of the limestone for cement making is very different in the two cases. If silica alone is present in a limestone, alumina and iron oxide being entirely or practically absent, it may occur in any one of three forms, each of which has a different effect on the cement produced.

1. In perhaps its commonest form, silica may be present as nodules, masses, or beds of flint or chert. Silica in this form will enter into combination with the lime of a cement mixture, but not readily nor completely unless fluxes are added. The presence of chert and flint, however, adds heavily to the expense of both the crushing and the fine grinding. Generally even a small proportion of silica in this form scattered through a mass of limestone will be sufficient to rule the rock out of consideration as a possible Portland cement material. However, it is entirely a matter of relative cost, and if circumstances justify or require the use of cherty limestones no insuperable technologic obstacles stand in the way of their use.

2. A few rare beds (for example, the hydraulic limestones of Teil, France) contain a large amount of silica and almost no alumina and iron, yet the silica and lime combine readily, though not perfectly, 
on burning. It is probable that the silica is very finely divided and is really in colloidal form, occurring as the result of chemical precipitation or organic action. Very few highly siliceous limestones, however, will make a sound cement on burning unless alumina, iron oxide, or some equivalent fluxes are present.

3 . In the crystalline limestones (marbles), and less commonly in limestones which are but slightly recrystallized, silica may occur as a constituent of one of the silicate minerals. As these will usually contain alumina or iron oxide, in addition to the silica, they may be more properly discussed under the next heading.

SILICA WITH ALUMINA AND IRON.

Silica, alumina, and generally iron oxide combined in the form of clay, are very common impurities in limestones. When present in this combined form they unite readily with the lime under the action of heat. An argillaceous limestone, therefore, if otherwise satisfactory, forms an excellent basis for a Portland-cement mixture, and all such limestones are of peculiar interest in the present connection. The best known are the cement rocks of the Lehigh district of Pennsylvania and New Jersey.

Silica, accompanied by alumina and iron, is present in some crystalline limestones as a more or less complex silicate. If this silicate is uniformly distributed throughout the mass of the limestone the rock may be very suitable for cement. In many such silicates, however, magnesia is present in objectionable quantity. The best limestones of this type known to the writer are those described by L. J. Pepperberg from Montana. ${ }^{1}$ (See p. 254.)

IRON ALONE.

The iron present in a limestone is generally in the form of the oxide $\left(\mathrm{Fe}_{2} \mathrm{O}_{3}\right)$ or the sulphide $\left(\mathrm{FeS}_{2}\right)$, or, more rarely, as a carbonate or in a complex silicate. In any of these forms it is a very useful fluxing agent, aiding greatly in the combination of the silica and lime in the kiln. When present as the sulphide, however, it is to be avoided, for the sulphur may, under certain conditions of burning, be injurious to the resulting cement, but in modern rotary practice, injury rarely happens.

\section{PHYSICAL CHARACTERS OF LIMESTONES.}

Owing partly to differences in origin, limestones of different kinds show great variations in physical characters, texture, hardness, color, weight, porosity, and compactness, ranging from the loosely consolidated marls and shell beds, through the chalks, to the hard, compact normal limestones and the still more compact crystalline limestones or marbles. In absorptive properties and in density, both

1 Cement material near Havre, Mont.: Bull. U. S. Geol. Survey 330, 1909, pp. 327-336. 
of which are of importance in cement making, the differences are very great. The chalky limestones may show a specific gravity as low as 1.85, corresponding to a weight of 110 pounds to the cubic foot, whereas the compact limestones, commonly used for building purposes, range between 2.3 and 2.9 , corresponding approximately to weights of 140 to 185 pounds to the cubic foot.

From the point of view of the Portland cement manufacturer these variations in physical properties are of economic interest chiefly in their bearing on two points - the percentage of water carried by the limestone as quarried and the ease with which the rock may be crushed and pulverized. To some extent the two properties counterbalance each other; the softer the limestone the more absorbent is it likely to be.

\section{EFFECT OF HEAT ON LIMESTONE.}

If a practically pure nonmagnesian limestone is heated its carbon dioxide is driven off, leaving quicklime (calcium oxide, $\mathrm{CaO}$ ). If a practically pure magnesian limestone is similarly treated, the product is a mixture of calcium oxide and magnesium oxide $(\mathrm{MgO})$. The rapidity and perfection of this decomposition can be increased by passing steam or air through the burning mass. In practice this is accomplished either by the direct injection of air or steam or more simply by thoroughly wetting the limestone before putting it into the kiln.

If, however, the limestone contains an appreciable amount of silica, alumina, and iron, the effects of heat will not be so simple. At temperatures of $800^{\circ} \mathrm{C}$. and upward these clayey impurities will combine with the lime oxide, giving silicates, aluminates, and related salts of lime, and will produce a natural cement. An artificial mixture of a certain uniform composition, burned at a higher temperature, will give a Portland cement.

\section{LIMESTONES USED IN CEMENT MANUFACTURE.}

As stated on page 42, various types of limestone may be used in the manufacture of Portland cement.

ARGILLACEOUS LIMESTONES (CEMENT ROCK).

An argillaceous limestone containing approximately 75 per cent of lime carbonate and 20 per cent of clayey materials (silica, alumina, and iron oxide) would, of course, be the ideal material for use in the manufacture of Portland cement, as such a rock would contain within itself in the proper proportions all the necessary ingredients. It would require the addition of no other material, but when burnt alone would give a good cement. This ideal cement material is never found, but certain argillaceous limestones approach it very closely in composition. 
The most important deposit of these argillaceous limestones or "cement rocks" is that extensively utilized in Portland cement manufacture in the Lehigh district, which comprises parts of Berks, Lehigh, and Northampton counties, Pa., and of Warren County, N. J. Within this relatively small area are situated 21 Portland cement mills, which produce a little over one-third of the entire American output. As deposits of the cement rock used by these plants extend far beyond the present Lehigh district, a marked extension of the district will probably take place as the need for larger supplies of raw material becomes more apparent.

The "cement rock" of the Lehigh district, a highly argillaceous limestone of Ordovician age, is about 300 feet thick. The rock is very dark gray and commonly has a slaty fracture. In composition it ranges from about 60 per cent lime carbonate with 30 per cent clayey material up to 80 per cent lime carbonate with 15 per cent of silica, alumina, and iron. The lower beds of the formation everywhere contain more lime carbonate than the higher ones. The content of magnesium carbonate is high, as Portland-cement material goes, ranging from 3 to 6 . per cent.

Near and in some places immediately beneath this cement rock are beds of purer limestone, containing from 85 to 96 per cent lime carbonate. The usual practice in the Pennsylvania and New Jersey plants has been, therefore, to mix a relatively small amount of this purer limestone with the low-lime "cement rock" in such proportions as to give a proper cement mixture.

The economic and technologic advantages of such a combination are very evident. Both the pure limestone and the cement rock, particularly the latter, can be quarried very easily and cheaply. As quarried they carry but little water, so that the expense of drying them is slight. The fact that about four-fifths of the cement mixture will be made up of a natural cement rock permits coarser grinding of the raw mixture than would be permissible in plants using pure limestone or marl with clay. When natural cement rock is used as part of the mixture less fuel is probably necessary to clinker the mixture than when pure limestone is mixed with clay.

Such mixtures of argillaceous limestone or "cement rock" with a small amount of pure limestone evidently possess important advantages over mixtures of pure hard limestone or marl with clay. They are, on the other hand, less advantageous as cement materials than the chalky limestones. (See pp. 50-51.)

The analyses in the table below are fairly representative of the materials employed in the Lehigh district. The first four are of "cement rock," the last two of the purer limestone. 
Analyses of Lehigh district cement materials.

\begin{tabular}{|c|c|c|c|c|c|c|}
\hline \multirow[b]{2}{*}{ Silica $\left(\mathrm{SiO}_{2}\right)$. } & \multicolumn{4}{|c|}{ Cement rock. } & \multicolumn{2}{|c|}{ Limestone. } \\
\hline & 10.02 & 9.52 & 14.52 & 16.10 & 3.02 & 1.98 \\
\hline Alumina $\left(\mathrm{Al}_{2} \mathrm{O}_{3}\right)$ & 6.26 & 4.72 & 6.52 & 2.20 & 1.90 & .70 \\
\hline 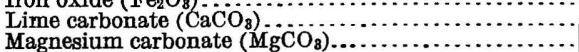 & $\begin{array}{r}78.65 \\
4.71\end{array}$ & $\begin{array}{r}80.71 \\
4.92\end{array}$ & $\begin{array}{r}73.52 \\
4.69\end{array}$ & $\begin{array}{r}76.23 \\
3.54\end{array}$ & $\begin{array}{r}92.05 \\
3.04\end{array}$ & $\begin{array}{r}95.19 \\
2.03\end{array}$ \\
\hline
\end{tabular}

Certain Portland cement plants, particularly in the western part of the United States, use combinations of materials closely similar to those in the Lehigh district. Analyses are given in the following table:

Analyses of "cement rock" and limestone from the western United States.

\begin{tabular}{|c|c|c|c|c|c|c|}
\hline & \multicolumn{2}{|c|}{ Utah. } & \multicolumn{2}{|c|}{ California. } & \multicolumn{2}{|c|}{ Colorado. } \\
\hline & $\begin{array}{c}\text { Cement } \\
\text { rock. }\end{array}$ & $\begin{array}{l}\text { Lime- } \\
\text { stone. }\end{array}$ & $\begin{array}{c}\text { Cement } \\
\text { rock. }\end{array}$ & $\begin{array}{l}\text { Lime- } \\
\text { stone. }\end{array}$ & $\begin{array}{l}\text { Cement } \\
\text { rock. }\end{array}$ & $\begin{array}{l}\text { Lime- } \\
\text { stone. }\end{array}$ \\
\hline 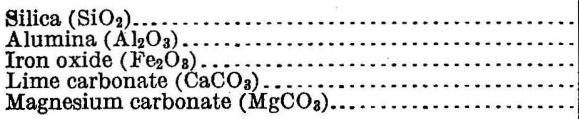 & $\begin{array}{c}21.2 \\
8.0 \\
62.08 \\
3.8\end{array}$ & \begin{tabular}{r}
6.8 \\
3.0 \\
\hdashline 89.8 \\
$\quad .76$
\end{tabular} & $\begin{array}{r}20.06 \\
10.07 \\
3.39 \\
63.40 \\
1.54\end{array}$ & $\begin{array}{r}7.12 \\
2.36 \\
1.16 \\
87.70 \\
.84\end{array}$ & $\begin{array}{r}14.20 \\
5.21 \\
1.73 \\
75.10 \\
1.10\end{array}$ & 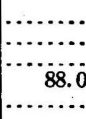 \\
\hline
\end{tabular}

In addition to these cement rocks many of the chalky limestones (see pp. 50-51) are sufficiently argillaceous to be classed as such. Because of their softness, however, all the chalky limestones will be described together.

PURE HARD LIMESTONES.

Soon after the American Portland cement industry had become fairly well established in the Lehigh district attempts were made in New York State to manufacture Portland cement from a mixture of pure limestone and clay. These attempts were not commercially successful, and although their failure was not.due to any defects in the limestone used, a certain prejudice arose against the use of the hard limestones. In recent years, however, this has disappeared, and a very large proportion of the American output is now made from mixtures of limestone with clay or shale. The use of the hard limestone is doubtless due in great part to recent improvements in grinding machinery, for most of the purer limestones are much harder than argillaceous limestones like the Lehigh district "cement rock," and it was very difficult to pulverize them finely and cheaply with the crushing appliances in use when the Portland cement industry was first started in America.

$48834^{\circ}-$ Bull. $522-13-4$ 
Analyses of representative pure hard limestones and of the clays or shales with which they are mixed are given in the following table:

Analyses of pure hard limestones and clayey materials.

\begin{tabular}{|c|c|c|c|c|c|c|c|c|}
\hline \multirow[b]{2}{*}{ 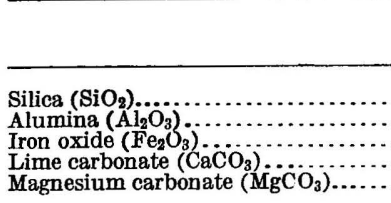 } & \multicolumn{4}{|c|}{ Limestones. } & \multicolumn{4}{|c|}{ Clays and shales. } \\
\hline & $\begin{array}{r}1.72 \\
1.63 \\
6.59 \\
90.58\end{array}$ & $\begin{array}{r}0.86 \\
.63 \\
1.03 \\
97.06\end{array}$ & $\begin{array}{r}0.56 \\
1.23 \\
.29 \\
97.23 \\
.75\end{array}$ & $\begin{array}{r}0.40 \\
.44 \\
97.99 \\
.42\end{array}$ & $\begin{array}{r}63.56 \\
27.32 \\
3.60 \\
2.60\end{array}$ & $\begin{array}{r}55.80 \\
30.20 \\
2.54\end{array}$ & $\begin{array}{r}56.30 \\
29.86 \\
\cdots \cdots \\
\cdots \cdots \\
\cdots \cdots . . \\
\end{array}$ & $\left\{\begin{array}{r}60.00 \\
23.26 \\
4.32 \\
1.70 \\
1.50\end{array}\right.$ \\
\hline
\end{tabular}

The first limestone analysis represents a type used in several plants in the Middle West. It is a relatively impure limestone, its principal impurity being iron oxide. It contains 8.22 per cent of iron oxide and alumina, as compared with 1.72 per cent of silica, and therefore great care is required in selecting a suitable high-silica clay to mix with it.

SOFT LIMESTONES (CHAL'K).

Chalk, properly speaking, is a pure carbonate of lime, composed of the remains of the shells of minute organisms, those of Foraminifera being especially prominent. The chalks and soft limestones agree not only in having usually originated in this way but also in being rather soft and therefore readily and cheaply crushed and pulverized. As Portland cement materials they are therefore almost ideal. One defect of these soft, chalky limestones, however, which to a small extent counterbalances their obvious advantages is the fact that most of them absorb water very readily. A chalky limestone whicb in a dry season will not carry more than 2 per cent of moisture as quarried may, in consequence of prolonged wet weather, show as high as 15 or 20 per cent of water. This difficulty can, of course, be avoided if care is taken in quarrying to avoid unnecessary exposure to water and, if necessary, to provide facilities for storing a supply of the raw materials during wet seasons.

The chalks and chalky limestones are confined almost entirely to certain Southern and Western States. They are all of approximately the same geologic ages-Cretaceous or Tertiary-and are mostly confined to one division of the Cretaceous. The principal chalk or soft limestone deposits available for use in Portland cement manufacture occur in three widely separated areas, in (a) Alabama and Mississippi, (b) Texas and Arkansas, and (c) Iowa, Nebraska, North and South Dakota.

In composition these chalks, or "rotten limestones," vary from a rather pure calcium carbonate, low in both magnesia and clayey materials, to an impure clayey limestone requiring little additional clay to make it fit for use in Portland cement manufacture. The 
analyses in the table below show the range of composition of the chalky limestones.

Analyses of chalky limestones.

\begin{tabular}{|c|c|c|c|c|c|c|}
\hline . & $\begin{array}{l}\text { Demopo- } \\
\text { lis, Ala. }\end{array}$ & $\begin{array}{l}\text { San Anto- } \\
\text { nio, Tex. }\end{array}$ & $\begin{array}{l}\text { Dallas; } \\
\text { Tex. }\end{array}$ & $\begin{array}{l}\text { White } \\
\text { Cliffs, } \\
\text { Ark. }\end{array}$ & $\begin{array}{l}\text { Yankton, } \\
\text { S. Dak. }\end{array}$ & $\begin{array}{l}\text { Milton, } \\
\text { N. Dak. }\end{array}$ \\
\hline 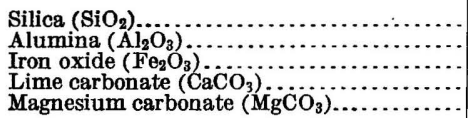 & $\begin{array}{r}12.13 \\
4.17 \\
3.28 \\
75.07 \\
.92\end{array}$ & $\begin{array}{r}5.77 \\
2.12 \\
90.15 \\
.15\end{array}$ & $\begin{array}{r}23.55 \\
1.50 \\
70.21 \\
.58\end{array}$ & $\begin{array}{r}7.97 \\
1.09 \\
88.64 \\
.73\end{array}$ & $\begin{array}{r}8.20 \\
7.07 \\
83.59 \\
\text { Undet. }\end{array}$ & $\begin{array}{r}9.15 \\
4.80 \\
2.30 \\
63.75 \\
1.25\end{array}$ \\
\hline
\end{tabular}

FRESH-WATER MARLS.

Marls, in the sense in which the term is used in the Portland cement industry, are incoherent limestones which have been deposited in the basins of existing or extinct lakes. So far as chemical composition is concerned, marls are practically pure limestones, being composed almost entirely of calcium carbonate. Physically, however, they are granular, incoherent deposits, differing greatly from the compact rocks commonly called limestones. Their curious physical character is due to the conditions under which they were deposited.

The above definition of marl is that commonly used in the cement industry, but in geologic and agricultural reports, particularly in those issued before the Portland cement industry became prominent in this country, the term has been used for several very different substances. The following three uses of the term have been particularly common, and must be guarded against when such reports are being examined for descriptions of deposits of cement materials:

(1) In early days the terms "marls" and "marlytes" were applied to calcareous shales and often to shales which were not particularly calcareous. This use of the term will be found in many of the earlier geologic reports issued by New York, Ohio, and other interior States.

(2) In New Jersey and in the States farther south that border on the Atlantic and Gulf of Mexico the term "marl" is commonly applied to deposits of soft, chalky, or unconsolidated limestone, much of which contains considerable clayey and phosphatic matter. These limestones are of marine origin and are not related to the fresh-water marl deposits here discussed.

(3) In the States mentioned in the last paragraph, but particularly in New Jersey and Virginia, large deposits of the so-called "greensand marls" occur. This material is in no way related to the true marls, which are essentially lime carbonates, but is almost entirely an iron silicate, with very small percentages of clayey, calcareous, and phosphátic matter.

The exact cause of the deposition of marls has been the subject of much investigation and discussion, particularly since they have 
become of economic importance. The most important papers concerning this question are as follows:

Blatchley, W. S., and Ashley, G. H., The lakes of northern Indiana and their associated marl deposits: Twenty-fifth Ann. Rept. Indiana Dept. Geol. and Nat. Res., 1900, pp. 31-321.

DAvrs, C. A., A contribution to the natural history of marl: Jour. Geology, vol. 8, 1900, pp. $485-497$.

- Second contribution to the natural history of marl: Jour. Geology, vol. 9, 1901, pp. 491-506.

A contribution to the natural history of marl: Rept. Michigan Geol. Survey, vol. 8 , pt. 3, 1900, pp. 65-102.

LANe, A. C., Notes on the origin of Michigan bog limes: Rept. Michigan Geol. Survey, vol. 8, pt. 3, 1900, pp. 199-223.

Disregarding points in controversy, which are of no practical importance, it may be said that marls are deposited in lakes from spring or stream waters carrying lime carbonate in solution. The actual deposition is due in part to purely physical and chemical causes, and in part to the direct or indirect action of animal or vegetable life. The result in any case is that a calcareous deposit consisting of lime carbonate, mostly in a finely granular form, interspersed with shells and shell fragments, forms along the sides and over the bottom of the lake.

The geographic distribution of marl deposits is intimately related to the geologic history of the region in which they occur. Marl beds are the result of the filling of lake basins. Lakes are not common in the United States, except in areas which have been glaciated, for they are in general due to the damming of streams by glacial material. Workable marl deposits, therefore, are confined almost exclusively to those portions of the United States and Canada lying north of the southern limit of the glaciers.

Important beds occur in the New England States, in central and western New York, in Michigan, and in northern Ohio, Indiana, and Illinois. Marl occurs also in Wisconsin and Minnesota but has not yet been exploited in these States for cement manufacture.

Most marls are very pure lime carbonates and require the addition of considerable clay to fit them for use in making Portland cement. They are readily excavated, but necessarily carry a large proportion of water. On this account the mixture is commonly made in the wet way, which necessitates driving off a large amount of water in the kilns. Analyses of typical marls and clays are given in the following table:

Analyses of marls and clays used in cement plants.

\begin{tabular}{|c|c|c|c|c|c|c|}
\hline & \multicolumn{3}{|c|}{ Marl. } & \multicolumn{3}{|c|}{ Clay. } \\
\hline 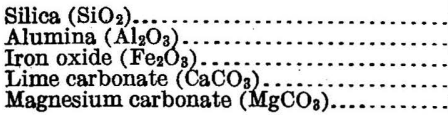 & $\begin{array}{r}0.25 \\
.10 \\
94.39 \\
.38\end{array}$ & $\begin{array}{r}3.0 \\
\cdots . . . \\
93.0 \\
1.5\end{array}$ & $\begin{array}{c}1.60 \\
1.55 \\
88.9 \\
.94\end{array}$ & $\begin{array}{r}40.48 \\
20.95 \\
25.80 \\
.99\end{array}$ & $\begin{array}{r}52.0 \\
17.0 \\
5.0 \\
20.0\end{array}$ & $\begin{array}{r}63.75 \\
16.40 \\
6.35 \\
4.0 \\
2.1\end{array}$ \\
\hline
\end{tabular}


SHELL DEPOSITS.

Some marl deposits consist largely of the shells of fresh-water mollusks. The shell deposits here described, however, are of different type, being marine in origin. They make up distinct and often large beds in several Tertiary formations along the Atlantic coast and are now used as cement materials at Norfolk, Va. Recent shells, made available by the oyster industry, are also used in making lime.

At numerous horizons in the Eocene and Miocene of the Atlantic and Gulf coast Tertiary, beds composed largely or entirely of shells are found. In places the shells are simply packed closely together, with no appreciable amount of foreign matter present. At other points contemporary or later mixture with clay or other impurity has occurred.

The most striking of these accumulations of fossil shells are in Virginia, North Carolina, and South Carolina, though similar deposits occur in the other South Atlantic and Gulf States.

As oyster shells are now burned into lime at Baltimore, Norfolk, and New Orleans, and as attempts may soon be made to utilize them as Portland cement material, their average composition is of technologic interest. A search of existing literature on the subject, made a few years ago, disclosed very few papers bearing on the composition of commercial shell, as procurable in cargoes. Some analyses of shell had been reported, but most of these analyses were made for scientific purposes, and the chemist selected the purest and cleanest shell obtainable.

During recent work on the marl deposits of eastern North Carolina by the author, occasion was taken to sample some cargoes of oyster shells unloaded at Newbern, N. C. The samples were averaged and analyzed by A. J. Phillips at the St. Louis laboratory of the Survey, with the following resuits:

Analysis of oyster shells (Atlantic coast).

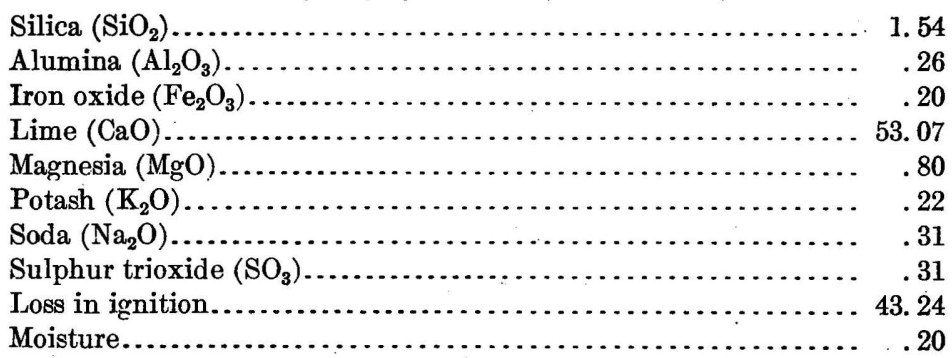

A recent report on Mississippi cement materials contains another analysis of commercial shell, which is reprinted here for comparison. This analysis represents the average of a lot of shell from Biloxi, Miss: 
Analysis of oyster shells (Gulf coast).

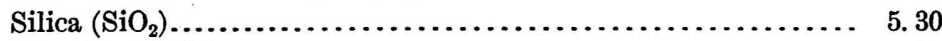

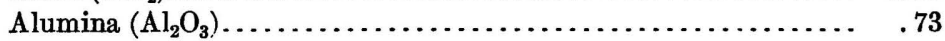

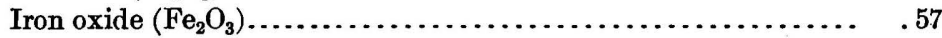

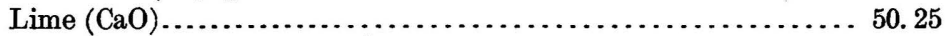

Magnesia (MgO) ..................................... $\quad .45$

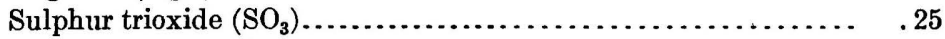

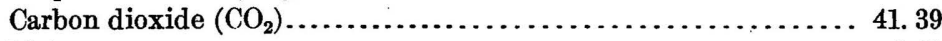

Moisture..............................................

This Mississippi sample is rather more impure than that from North Carolina, the principal difference being in its relatively higher percentage of silica.

These analyses indicate that commercial shell, as obtainable in quantity along the Atlantic and Gulf coasts, is about equivalent in composition to the purest limestones ordinarily quarried. There is no question whatever as to the value of such a product for use in lime burning, and there is a fair possibility that it may become useful as a cement material. There are, of course, no chemical difficulties connected with its use for the latter purpose. The questions which would arise would relate to the cost of pulverizing such materials, on which no data exist; and on the possibility of obtaining a suffciently large and steady supply of shell at a coast point where fuel is cheap and good clays are convenient.

The following papers contain data or references to the subject of shell composition:

Brown, L. P., and Korner, J. S. H., Analysis of oyster shells and oyster-shell lime: Am. Chem. Jour., vol. 11, 1889, pp. 36-37.

Crider, A. F., Cement and Portland cement materials of Mississippi: Bull. Mississippi Geol. Survey No. 1, 1907, p. 25.

Eckel, E. C., The composition of recent shells: Cement Age, vol. 6, 1908, pp. 244, 421. How, Dr., On the comparative composition of some recent shells, a Silurian fossil shell, and a Carboniferous shell limestone: Am. Jour. Sci., 2d ser., vol. 41, 1866, pp. 379-384.

ALKALI WASTE.

A very large amount of waste results from the manufacture of caustic soda. This waste material is chiefly a precipitated form of calcium carbonate and if sufficiently free from impurities furnishes a cheap source of lime for use in Portland cement manufacture.

The availability of alkali waste for cement making depends largely on the process used at the alkali plant. Leblanc-process waste, for example, carries a very large proportion of sulphides, which prevent its use as a Portland cement material. The ammonia process, on the other hand, generally yields very pure lime, mostly carbonate, though partly lime hydrate. As pyrite is not employed in the ammonia process, the waste is usually low enough in sulphur to be used as cement material. The waste may carry a small or a very large proportion of magnesia, the percentage varying according to the character of the limestone used in the alkali plant. If a limestone 
low in magnesium carbonate has been used the resulting waste is a very satisfactory Portland cement material.

The following analyses fairly represent the waste at alkali plants using the ammonia process:

Analyses of alkali waste.

\begin{tabular}{|c|c|c|c|c|}
\hline . & 1 & 2 & 3 & 4 \\
\hline 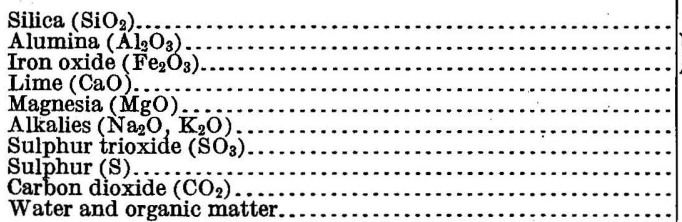 & $\begin{array}{r}0.60 \\
3.04 \\
53.33 \\
.48 \\
.20 \\
\text { n. d. } \\
\text { n. d. } \\
42.43 \\
\text { n. d. }\end{array}$ & $\begin{array}{r}1.75 \\
0.61 \\
50.60 \\
5.35 \\
.64 \\
\text { n. d. } \\
.10 \\
41.70\end{array}$ & $\begin{array}{r}1.98 \\
1.41 \\
1.38 \\
48.29 \\
1.51 \\
1.64 \\
1.26 \\
\text { n. d. } \\
39.60 \\
3.80\end{array}$ & $\begin{array}{r}0.98 \\
1.62 \\
50.40 \\
4.97 \\
.50 \\
\text { n. d. } \\
.06 \\
\text { n. d. } \\
\text { n. d. }\end{array}$ \\
\hline
\end{tabular}

Of the analyses quoted, those in the first and third columns represent materials used in Portland cement manufacture in England and the United States. The second and fourth columns represent wastes too high in magnesia to be advisable for such use.

BLAST-FURNACE SLAG.

True Portland cements, which must be sharply distinguished from the slag (or puzzolan) cements (see p. 18), can be made by burning a finely powdered mixture of blast-furnace slag and limestone and pulverizing the resulting clinker.

The slags from iron furnaces consist essentially of lime $(\mathrm{CaO})$, silica $\left(\mathrm{SiO}_{2}\right)$, and alumina $\left(\mathrm{Al}_{2} \mathrm{O}_{3}\right)$, though small percentages of iron oxide $(\mathrm{FeO})$, magnesia $(\mathrm{MgO})$, and sulphur (S) are commonly present. Slag may therefore be regarded as a very impure limestone or a very calcareous clay, from which the carbon dioxide has been driven off.

In the United States several plants belonging to the United States Steel Corporation manufacture true Portland cement from slag.

The slag used at a German Portland cement plant has the following range in composition:

Analysis of slag used in Portland cement manufacture.

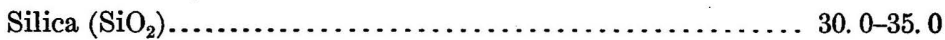

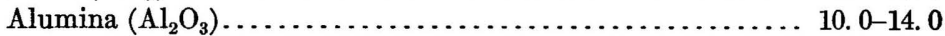

Iron oxide $(\mathrm{FeO}) \ldots \ldots \ldots \ldots \ldots \ldots \ldots \ldots \ldots \ldots \ldots \ldots \ldots \ldots \ldots \ldots, .2-1.2$

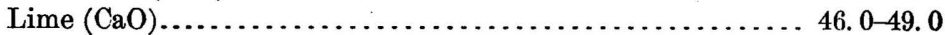

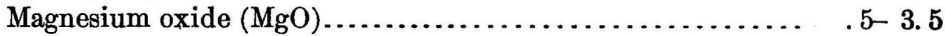

Sulphur trioxide $\left(\mathrm{SO}_{3}\right) \ldots \ldots \ldots \ldots \ldots \ldots \ldots \ldots \ldots \ldots \ldots \ldots, .2-\quad .6$

\section{IRON-BEARING MATERIALS.}

During recent years considerable attention has been paid to the development of Portland cements carrying relatively high iron and low alumina. Cements of this type are said to be better than highalumina cements for use in salt or alkaline waters and to be equally 
good for other uses. If these advantages can be proved, there is of course considerable room for the development of this type.

In making high-iron and low-alumina cements the shale or clay used in the ordinary cement mixture is replaced either by iron ore (Michaelis process) or by greensand (Spencer-Eckel process). Either gives a product low in alumina and relatively high in iron. The relative advantages of the two methods of procedure can not well be discussed in this place. It is of technologic and commercial interest to note, however, that when greensand is used a valuable potash by-product is recoverable during the process.

\section{CLAYS AND SHALES.}

\section{COMPOSITION.}

For use as Portland cement materials clays or shales should be free from gravel and sand, as the silica present as pebbles or grit is practically inert in the kiln unless ground more finely than is economically practicable. In composition they should carry not less than 55 per cent of silica, and preferably from 60 to 70 per cent. The alumina and iron oxide together should be not more than half as great as the silica, and the composition will usually be better if they are only about one-third. Nodules of lime carbonate, gypsum, or pyrite, if present in any quantity, are undesirable, though the lime carbonate is not absolutely injurious. Magnesia and the alkalies should be low, preferably not above 3 per cent.

\section{VARIETIES.}

Clays are ultimately derived from the decay of older rocks, the finer particles being carried off by streams and deposited along channels, in lakes, or along parts of the seacoast or sea bottom. In chemical composition the clays are made up essentially of silica and alumina, though nearly all contain more or less iron oxide and many contain lime, magnesia, alkali, and sulphur, but usually in small percentages.

Shales are clays which have become hardened by pressure. The so-called "fire clays" of the "Coal Measures" are shales, as are many of the other "clays" of commerce.

Slates, so far as origin is concerned, are merely a form of shale in which a fine, even, and parallel cleavage has been developed by pressure. In composition, therefore, they vary exactly as do the shales, and so far as composition is concerned they deserve no greater attention as a Portland cement material than any other shale. Commercial considerations in the slate industry, however, give slate considerable local importance. In preparing either roofing slate or mill stock for market there is enormous waste, so much material being lost in splitting, sawing, and dressing that only 10 to 25 per cent of the rock quarried reaches the market, the remaining 75 to 90 per cent going 
to the dump heap. This waste is not only of no value but is a continual source of trouble and expense to the slate quarryman, and any method of disposing of it cheaply, even if it did not yield a direct profit, would interest him.

Much of this slate waste is of proper composition for use, in combination with limestone, in a Portland cement mixture, as is indicated by the table below, which -was prepared by the writer some time ago for another purpose, but which is of interest here. It is based on many analyses of American roofing slates obtained from a number of widely separated slate-producing districts, and its results can be accepted as fairly representative.

Composition of American roofing slates.

\begin{tabular}{|c|c|c|c|}
\hline & Maximum. & Average. & Minimum. \\
\hline 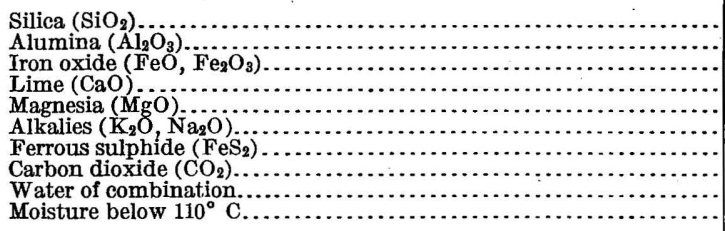 & 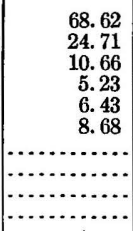 & $\begin{array}{r}60.64 \\
18.05 \\
6.87 \\
1.54 \\
2.60 \\
4.74 \\
.38 \\
1.47 \\
3.51 \\
.62\end{array}$ & 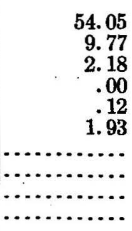 \\
\hline
\end{tabular}

The table shows the possibilities of slate waste in the Portland cement industry and also its limitations. As a troublesome waste product, the refuse slate could be obtained at the cost of handling by a cement plant near a slate quarry. The waste slate would be serviceable enough, so far as chemical composition is concerned, and could be used in place of clay or shale in the cement mixture. To the cement manufacturer it would be worth as much as an equivalent amount of clay or shale, but no more.

\section{EXCAVATION OF RAW MATERIALS.}

The natural raw materials used in Portland cement manufacture are obtained by quarrying, mining, or dredging, the method employed depending on the physical character of the material and the topographic and geologic conditions.

\section{QUARRYING.}

The term "quarrying," as here used, includes all methods of obtaining raw materials from open excavations-quarries, cuts, or pits-whether the material be limestone, shale, or clay. Quarrying is the most natural and common method of excavating the raw materials for cement manufacture. If marl, which is usually worked by dredging, be excluded from consideration, probably 95 per cent of the raw materials used at American Portland cement plants is obtained by 
quarrying. If marls be included the percentages excavated by the different methods would probably be about as follows: Quarrying, 92 per cent; dredging, 6 per cent; mining, 2 per cent.

In most limestone quarries the material is blasted out and loaded by hand on cars or carts. In a few limestone and in more shale quarries a steam shovel does the loading. In certain clay and shale pits the steam shovel does all the work, both excavating and loading the raw materials.

At most quarries the rock is shipped to the mill as quarried, without any treatment except sledging to convenient size for loading. At a few, however, crushing plants are installed, from which the rock is sent as crushed stone to the mill. At some quarries driers are used, the stone being dried before it is shipped to the mill. Except for saving mill space, this practice seems to have little to commend it.

\section{MINING.}

The term "mining," as distinguished from "quarrying," denotes methods of obtaining any kind of raw material by underground workings, through shafts and tunnels. Mining is, of course, rarely employed in excavating substances having a value to the ton so low as the raw materials for Portland cement. In some places, however, a thin bed of limestone or shale is overlain by so great a thickness of other strata that mining is cheaper than stripping and quarrying.

-Mining is considerably more expensive than quarrying, but it has a few advantages that partly counterbalance the greater cost per ton of raw material. A mine can be worked steadily and economically in all kinds of weather, whereas an open cut, or quarry, is commonly more or less unworkable for about three months of the year. Material won by mining is, moreover, always dry and clean.

\section{DREDGING.}

The term "dredging". as here used includes all methods of excavating soft, wet raw materials. In the United States the only raw material for Portland cement manufacture extensively worked by dredging is marl. In a few places the clay used is obtained from deposits overlain by more or less water; but this is rare except where the marl and clay are interbedded or associated.

A marl deposit, in addition to containing much diffused water, is usually covered by water to a considerable depth. Many such deposits require the partial draining of the basin to enable tracks to be laid near enough to be of service.

In dredging marl the excavator is in many places mounted on a barge, which floats in water in a channel made by previous excavation. At a few deposits which either were originally covered by very little water or which have been drained, the shovel is mounted on a car that runs on tracks laid along the edge of the deposit. 
A deposit worked by dredging lies in a basin or depression at a lower elevation than the mill, thus necessitating uphill transportation, which may be effected in two ways, the choice depending largely on the manufacturing process used. At most plants using dome or chamber kilns, or at plants where the marl is to be dried before it is sent to the kiln, the excavated material is loaded by the shovel on cars and hauled to the mill by horse or steam power. At normal marl plants using a very wet mixture it is probably more economical to dump the marl from the excavator into tanks, add sufficient water to make it flow readily, and pump the fluid mixture to the mill in pipes.

\section{COST OF RAW MATERIALS AT MILL.}

The most natural way, perhaps, to express the cost of the raw materials delivered at the mill would be to state it as being so many cents a ton or cubic yard, and this is the method followed by quarrymen or miners in general. To the cement manufacturer, however, such an estimate is not so suitable as one based on the cost per ton or barrel of finished cement.

It may be considered that hard and comparatively dry limestones or shales lose $33 \frac{1}{3}$ per cent in weight on burning, or that 600 pounds of dry raw material will make about 400 pounds of clinker. Allowing something for other losses in manufacture, it is convenient and sufficiently accurate to estimate that 600 pounds of dry raw material will give one barrel of finished cement. The raw material must be increased if it carries any appreciable amount of water. Many clays contain 15 per cent or more of water; and soft chalky limestones, if quarried during wet weather, may carry over 20 per cent. A Portland cement mixture composed of a pure chalky limestone and a clay might, therefore, average 10 to 20 per cent of water; consequently about 700 pounds of such a mixture would be required to make one barrel of finished cement.

With marls the loss on drying and burning is much greater. Russell states ${ }^{1}$ that according to determinations made by $\mathrm{E}$. D. Campbell, 1 cubic foot of marl, as it usually occurs in the natural deposits, contains about $47 \frac{1}{2}$ pounds of lime carbonate and 48 pounds of water. In making cement from a mixture of marl and clay, therefore, it would be necessary to figure on excavating and transporting over 1,000 pounds of raw material for every barrel of finished cement.

Thus the cost of raw materials at the mill, per barrel of cement, will vary not only with the cost of excavation but with the kind of materials in use. In dealing with hard dry materials extracted from open quarries near the mills the cost of raw materials may range from 8 to 15 cents a barrel of cement. The lower figure is probably about 
the lowest attainable under good management and favorable natural conditions; the higher figure is probably a maximum for fairly careful management of a difficult quarry under eastern labor conditions. If it is necessary to mine the materials the cost will be somewhat increased. Cement rock has been mined at a cost equivalent to 10 cents a barrel of cement, but only under particularly favorable conditions. The cost of mining and transportation may reach 20 cents a barrel.

With regard to wet marls and clays, it is difficult to give even an approximate estimate. It seems probable, however, when the dead weight handled is allowed for, that these soft materials delivered at the mill will cost about half as much per barrel of finished cement as the hard dry limestones and shales.

\section{FUELS USED IN PORTLAND CEMENT MANUFACTURE.}

\section{THE USES OF FUEL.}

In the Portland cement industry, as at present conducted, fuel is put to two distinct uses, and for each use the tonnage required is heavy when compared to the output of cement. The fuel supply of a cement plant is therefore but little, if at all, inferior in importance to the supply of limestone and shale.

The fuel is used for burning the materials and for power. By far the greater number of American plants need fuel for both purposes, though a few plants, mostly in the West, derive their power from hydroelectric installations.

The fuel used in power plants needs no further discussion here. With regard to kiln fuels the case is different, and certain features of their selection and use may be profitably considered.

\section{KILN FUELS.}

\section{RELATIVE IMPORTANCE.}

The fuels that may be used in the rotary kiln of modern Portland cement practice are powdered coal, petroleum, and gas. The present relative importance of these three types of kiln fuel is brought out in the following table, which is based on statistics collected by the United States Geological Survey in 1911:

Fuels used in Portland cement plants in 1911.

\begin{tabular}{|c|c|c|c|c|}
\hline Fuel used. & $\begin{array}{l}\text { Number } \\
\text { of } \\
\text { plants. }\end{array}$ & $\begin{array}{l}\text { Number } \\
\text { of kilns. }\end{array}$ & $\begin{array}{c}\text { Output in } \\
1911 .\end{array}$ & $\begin{array}{c}\text { Per- } \\
\text { centage } \\
\text { of total } \\
\text { output. }\end{array}$ \\
\hline 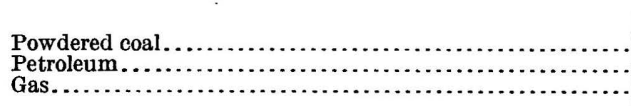 & $\begin{array}{r}87 \\
19 \\
9\end{array}$ & $\begin{array}{r}714 \\
143 \\
59\end{array}$ & $\begin{array}{c}\text { Barrels. } \\
64,125,198 \\
10,960,563 \\
3,442,876\end{array}$ & $\begin{array}{r}81.7 \\
13.9 \\
.4 .4\end{array}$ \\
\hline Total... & 115 & 916 & $78,528,637$ & 100.0 \\
\hline
\end{tabular}


In further explanation of the above figures, it may be said that petroleum is used in the kilns of all the cement plants operating in California and in part of those in Kansas, Missouri, Washington, and Texas. Natural gas was used in 1911 by about half the plants operating in Kansas and by one plant in Oklahoma. In 1907 a small output of cement was burned with producer gas, and although none at all was burned with it in 1911, it is possible that this fuel will become slightly more important in future. At present the uso of producer gas in the kiln is justified only where good coal is dear and poor coal or lignite is cheap; or, more exceptionally, where the product would be injured by coal ash, as where a white Portland cement is manufactured.

\section{COAL.}

CHARACTER.

The coal used as fuel in the rotary kiln is bituminous coal, preferably high in volatile matter and low in fixed carbon, ash, and sulphur.'

The following analyses, published by Russell, are fairly representative of West Virginia and Pennsylvania coals used as kiln fuel at different Portland cement plants:

Analyses of cement-kiln coals.

\begin{tabular}{|c|c|c|c|c|}
\hline & 1 & 2 & 3 & 4 \\
\hline 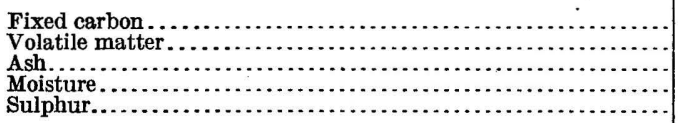 & $\begin{array}{r}56.15 \\
35.41 \\
6.36 \\
2.08 \\
1.30\end{array}$ & $\begin{array}{r}56.33 \\
35.26 \\
7.06 \\
1.35 \\
1.34\end{array}$ & $\begin{array}{r}55.82 \\
39.37 \\
3.81 \\
1.00 \\
.42\end{array}$ & $\begin{array}{r}51.69 \\
39.52 \\
6.13 \\
1.40 \\
1.46\end{array}$ \\
\hline
\end{tabular}

The kiln coal as bought from the mines is commonly slack, but is occasionally "run of mine." Run-of-mine coal must be crushed, often through rolls, before proceeding further, but slack can go directly to the drier in preparation for its fine reduction.

PREPARATION OF COAL FOR KILN.

Coal as bought may carry as high as 15 per cent of water in winter or in wet seasons. Usually it will run from 3 to 8 per cent. To obtain good results from the crushing machinery this water must be driven off. For coal drying, as for the drying of raw materials, the rotary drier seems best adapted to American conditions. It should be said, however, that in drying coal it is usually considered inadvisable to allow the products of combustion to pass through the cylinder in which the coal is being dried. This restriction serves to decrease slightly the possible economy of the drier, but an evaporation of 6 to 8 pounds of water per pound of fuel coal can still be counted on with any good drier. The fuel cost of drying coal containing 8 per cent. of moisture, allowing $\$ 2$ per ton for the coal used as fuel, will therefore be about 3 to 4 cents per ton of dried product. 
Though apparently brittle enough when in large lumps, coal is difficult to puiverize finely. For cement-kiln use the fineness of reduction is extremely variable. The finer the coal the better the results obtained from it in the kiln, and the poorer the quality of the coal the finer it must be pulverized. The fineness attained in practice may therefore vary from 85 to 95 per cent or even more through a 100-mesh sieve. At one plant a very poor but cheap coal, pulverized to pass 98 per cent through a 100-mesh sieve, gives very good results in the kiln.

Coal is usually pulverized by two operations, being first crushed to 20 to 30 mesh in a Williams mill or ball mill and finally reduced in a tube mill. At many plants, however, the entire reduction takes place in one stage, Griffin, Raymond, or Huntington mills being used.

The total cost of crushing (if necessary), drying, and pulverizing coal, and of conveying and feeding the product to the kiln, together with fair allowances for replacements and repairs and for interest on the plant, will probably range from about 20 to 30 cents per ton of dried coal, equivalent to 1 to 2 cents per barrel of cement. This may seem a heavy addition to the cost of cement manufacture, but it must be borne in mind that complete drying and fine pulverizing enable the manufacturer to use much poorer and therefore cheaper grades of kiln coal than he otherwise could.

\section{FLUXES.}

At different times and at different American plants fluxing materials of one sort or another have been added to the raw mixture in order to promote combination of the silica and lime in the kiln. Among the materials used for this purpose are iron oxide, fluorspar, cryolite, and several alkaline compounds.

Under normal conditions and when the plant has ordinarily good raw materials at its disposal it may be taken for granted that the use of fluxing materials causes more trouble than it is worth. The burning temperature can be appreciably lowered by this means, it is true, but rarely in a regular and steady way.

However, when the plant is compelled to run on poor raw materials-a cherty limestone, a high-silica and low-alumina clay, or the like - then the use of some fluxing material may be not only justifiable but absolutely necessary.

\section{RETARDERS.}

The Portland cement produced in the modern rotary-kiln process is invariably so quick-setting naturally as to require the addition of some retarder in order to make it satisfactory for general structural use. The retarder almost universally used at present is sulphate of lime. This substance, when added to cement in quantities up to 
$2 \frac{1}{2}$ or 3 per cent, retards the rate of set of the cement almost proportionately to the amount used and up to the limit mentioned appears to exert no appreciable injurious influence on the strength of the cement. When more than 3 per cent is added to the cement, however, the retarding influence of the lime sulphate becomes much less marked, and a decided weakening of the cement is noticeable. Most cement specifications, therefore, contain limitations on the amount of sulphur trioxide to be contained by the cement, and this amounts to a restriction on the amount of lime sulphate that can be added.

Sulphate of lime may be added in either of two forms-as crude gypsum or as burned plaster. Crude gypsum is a natural hydrous sulphate of lime, containing approximately 80 per cent of lime sulphate and 20 per cent of water. If this gypsum be calcined at a relatively low temperature, most of its combined water will be driven off. The resulting burned plaster carries about 93 per cent of lime sulphate and only 7 per cent of combined water.

In Portland cement manufacture either gypsum or burned plaster may theoretically be used to retard the set of the cement, but gypsum is almost universally employed in the United States. This is merely a question of cost. It is true that to secure the same amount of retardation it is necessary to add a little more gypsum than burned plaster, but gypsum is much cheaper than burned plaster. It is of course obvious that if cheap supplies of sulphuric acid were available, the acid could be added in solution as a spray on the cement clinker. Lesley experimented with the process some years ago, and apparently the only obstacle to its introduction was the high cost of acid. At some localities, however, sulphuric acid would seem to-day to be available in competition with gypsum.

The addition of the gypsum to the clinker is usually made before it has passed into the ball mill, pulverizer, or whatever mill is in use for preliminary grinding. Adding it at this point insures much more thorough mixing and pulverizing than if the mixture were made later in the process. At some of the few plants which use plaster instead of gypsum the finely ground plaster is not added until the clinker has received its final grinding and is ready for storage or packing.

\section{VALUATION OF DEPOSITS OF CEMENT MATERIALS.}

FACTORS.

Very erroneous ideas appear to be current concerning the value of deposits of cement materials. It should be clearly understood that in most parts of the United States excellent cement materials are common, and that the commercial value of undeveloped deposits of such materials is necessarily slight. In most of the Eastern, Southern, 
and Middle Western States there is no difficulty whatever in securing lands containing limestones suitable for cement manufacture at prices ranging from $\$ 5$ to $\$ 50$ per acre, and only exceptional circumstances would allow any cement deposit to be valued at more than the latter price. As indicated below, the value of the deposit depends less upon the character of the materials than upon other factors, prominent among which are the general scarcity of limestone and the demand for good limestone in each particular area.

As an illustration of the effect of these factors in influencing the value of a limestone deposit, the Bangor limestone of Alabama may be considered. In northern Alabama as well as in adjoining portions of Tennessee and Georgia the Bangor limestone of the Mississippian series (lower Carboniferous) shows great thickness and purity; at many places it is 300 to 600 feet thick, and it is mostly very low in magnesia and otherwise entirely acceptable as a cement material. Generally, too, excellent cement shales (of Clinton age) occur near the limestone, and in many places workable coal beds are found in its vicinity.

Yet with all these conditions in its favor it is probably safe to say that in northern Alabama thousands of acres underlain by this Bangor limestone could be purchased at $\$ 10$ to $\$ 20$ an acre, and even at the lower price named such a purchase would prove an exceedingly bad investment for a cement manufacturer. Two of the prime requisites for a high limestone valuation are here lackingthere is no market and therefore no particular reason to build a cement plant in this particular area, and even if a cement market should some time develop there, the available acreage of limestone is so great that no element of monopoly value can be figured into its valuation.

The effect of these two elements-demand and scarcity-can be brought out well by supposing a 100-acre tract of this northern Alabama limestone land to be transplanted to some spot where nonmagnesian limestone is in demand and where it is scarce. Buffalo, Chicago, and New York City are three striking instances of important points where suitable local limestones are obtainable either with difficulty or not at all. The 100-acre tract of Bangor limestone moved to Buffalo would be cheap to-day at $\$ 10,000$ an acre; if within striking distance of the New York market its value might easily be many times that.

These extreme instances of low and high valuation have been cited merely to impress the fact that ordinarily a deposit of cement material is valued not according to the properties of the material itself, but according to the demand for such material in the immediate vicinity and the local scarcity of similar deposits. 
The determination of the possible value for Portland cement manufacture of a deposit of raw material is a complex problem, depending on a number of distinct factors, the more important of which are (1) chemical composition; (2) physical character, (3) amount available, (4) location with respect to transportation routes, (5) location with respect to fuel supplies, (6) location with respect to markets. Ignorance of the respective importance of these factors frequently leads to an overestimate of the value of a deposit of raw material.

\section{CHEMICAL COMPOSITION OF MATERIAL.}

The raw material must be of correct chemical composition for use as a cement material. This implies that the material, if a limestone, must contain as small a percentage as possible of magnesium carbonate. Under present conditions 3 to 4 per cent is the maximum permissible. Free silica, in the form of chert, flint, or sand must be absent or present only in small quantity, say, 1 per cent or less. If the limestone is a clayey limestone or "cement rock," the proportion between the silica and its alumina and iron should fall within the limits

$$
\frac{\mathrm{SiO}_{2}}{\mathrm{Al}_{2} \mathrm{O}_{3}+\mathrm{Fe}_{2} \mathrm{O}_{3}}>2: \frac{\mathrm{SiO}_{2}}{\mathrm{Al}_{2} \mathrm{O}_{3}+\mathrm{Fe}_{2} \mathrm{O}_{3}}<3.5 \text {. }
$$

A clay or shale should satisfy the above equation, and should be free from sand, gravel, etc.

The nearer a limestone approaches in composition the mixture used in Portland cement manufacture the greater its value for that purpose, for it will require the addition of less extraneous material to make the mixture absolutely correct in composition. The following are analyses of Portland cement mixtures ready for burning, as used at various large cement plants in the United States:

Analyses of Portland cement mixtures.

\begin{tabular}{|c|c|c|c|c|}
\hline . & 1 & 2 & 3 & 4 \\
\hline 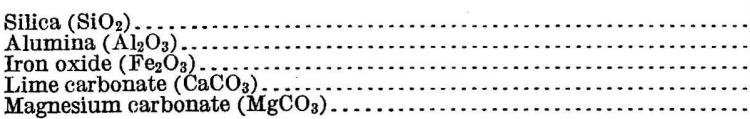 & $\begin{array}{r}12.85 \\
4.92 \\
1.21 \\
76.36 \\
2.13\end{array}$ & $\begin{array}{r}12.92 \\
4.83 \\
1.77 \\
75.53 \\
4.34\end{array}$ & $\begin{array}{r}13.52 \\
6.56 \\
75.13 \\
4.32\end{array}$ & $\begin{array}{r}14.94 \\
2.66 \\
1.10 \\
75.59 \\
4.64\end{array}$ \\
\hline
\end{tabular}

The usual mixtures carry from 75 to 77 per cent of lime carbonate. If this be borne in mind, it is obvious that there is a great advantage in using, as one of the raw materials, a limestone of about. this degree of purity. If rock of this composition occurs in sufficient quantity, it would require but little admixture of other materials to keep the cement correct in composition.

$48834^{\circ}-$ Bull. $522-13-5$ 


\section{PHYSICAL CHARACTER OF MATERIAL.}

Economy in excavating and crushing requires that the raw materials should be as soft and as dry as possible. On this account cherty limestones, very wet chalky limestones, and wet sticky clays are disadvantageous raw materials.

\section{AMOUNT OF MATERIAL AVAILABLE.}

Each barrel of cement made will require the use of approximately 450 pounds of limestone and 150 pounds of clay or shale. A plant making 1,000 barrels per day will therefore use, in the course of an ordinary year, about 66,000 tons of limestone and 22,000 tons of clay or shale. Assuming average density for these materials, a 1,000barrel plant will use up almost 1,000,000 cubic feet of limestone a year, together with 250,000 cubic feet of shale.

As the investment in plant is heavy, it would be folly to locate a cement plant, under ordinary circumstances, with less than 20 years' supply of raw materials in sight. A thousand-barrel plant, therefore, should have 20,000,000 cubic feet of limestone and 5,000,000 cubic feet of clay or shale on its properties.

\section{LOCATION OF PLANT.}

\section{LOCATION WITH RESPECT TO TRANSPORTATION ROUTES.}

Portland cement is bulky for its value, and the cement business is therefore much aflected by transportation rates. To locate a plant on only one railroad, unless the railroad officials are financially connected with the cement plant, is simply to invite disaster. At least two transportation routes should be available, and it is best of all if one of these be a good water route.

\section{LOCATION WITH RESPECT TO FUEL SUPPLIES.}

Every barrel (380 pounds) of Portland cement marketed implies that at least 200 to 300 pounds of coal have been used in the power plant and the kilns. In other words, each kiln in the plant will, with its corresponding crushing machinery, use up from 6,000 to 9,000 tons of coal a year. The item of fuel cost is therefore highly important for in the average plant about 30 to 40 per cent of the total cost of the cement will be chargeable to coal.

\section{LOCATION WITH RESPECT TO MARKETS.}

In order to achieve an established position in the trade, a new coment plant should preferably have a local market area, within which it may sell practically on a noncompetitive basis, and easy access to a larger though competitive market area. 


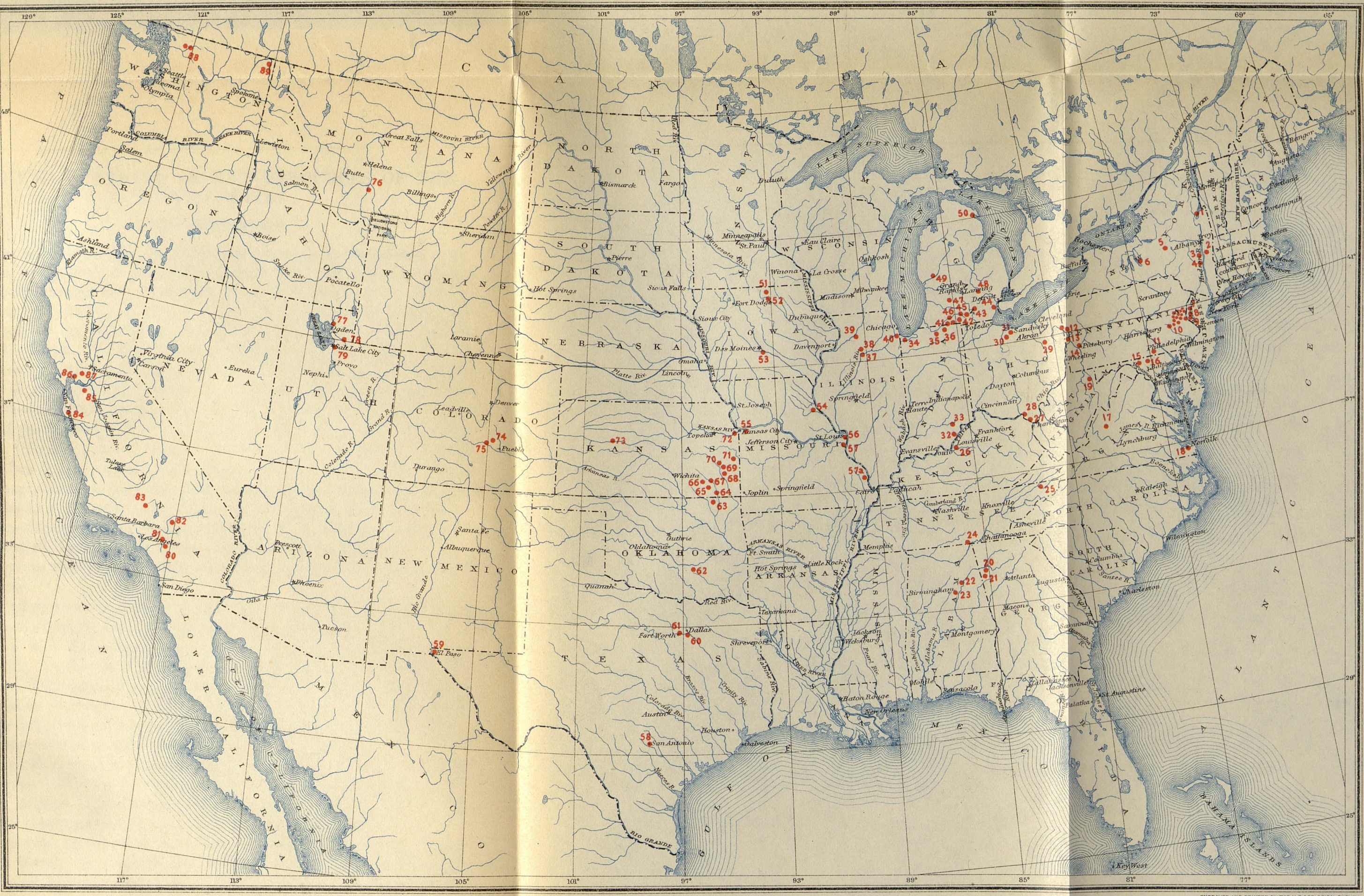

MAP SHOWING DISTRIBUTION OF PORTLAND CEMENT PLANTS IN THE UNITED STATES, 1911 



\section{PART III. PORTLAND CEMENT RESOURCES OF THE UNITED STATES.}

\section{INTRODUCTION.}

In the following pages the States are taken up in alphabetic order, and the well-known available Portland cement materials of each are described, whether these materials are now utilized or not. If Portland cement plants are now in operation in any given State, brief summaries of the raw materials they use, the processes they follow, and other details of technical or historical interest connected with their work are usually given. Most of these descriptions were originally based ${ }^{1}$ on the results of the writer's field work done during 1903 and 1904 for the United States Geological Survey, in the course of which most of the cement plants then operating in the United States were visited. In the present bulletin the descriptive matter relative to plants has been brought up to date as fully as seems advisable, it being borne in mind that the chief concern of this bulletin is with raw materials and not with manufacturing methods or trade conditions. In this.revision essential contributions by E. F. Burchard have been incorporated, in addition to the sections directly credited to him. As shown in Plate I, Portland cement plants are now in operation in 24 States.

The following table gives the main facts regarding the occurrence of the more important cement materials in the various States.

In this table four symbols are used to denote degrees of abundance or rarity. A indicates the occurrence of large and widely distributed deposits; $\mathrm{B}$ indicates the occurrence either of a few large deposits or of a number of small ones; $\mathrm{C}$ indicates the occurrence of a few small deposits only; 0 indicates that the material is either absolutely wanting or is so scarce as not to be of commercial importance.

In regard to the fuel supplies noted in the table, a word of caution is necessary. The term "coal" is here limited to such coals as can be used in cement manufacture with reasonable economy. Peat, lignite, and many western "coals" are therefore omitted.

The cement resources of the various States can not be described in uniform detail. In some States the limestones have been accurately mapped throughout their extent and numerous analyses are available. In such States more detailed discussion of the cement resources is possible than in those in which geologic mapping is less advanced. For some of the States the descriptions are unsatisfactory, but it would have been impossible adequately to repair these defects of omission in any reasonable length of time. 
Occurrence of the more important cement materials, by States.

\begin{tabular}{|c|c|c|c|c|c|c|c|c|c|c|c|c|c|}
\hline \multirow[b]{2}{*}{ State. } & \multicolumn{3}{|c|}{ Raw materials. } & \multicolumn{3}{|c|}{ Fuels. } & \multirow[b]{2}{*}{ State. } & \multicolumn{3}{|c|}{ Raw materials. } & \multicolumn{3}{|c|}{ Fuels. } \\
\hline & 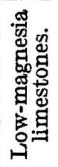 & 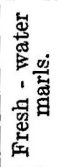 & 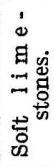 & ठृँ & تี่ & $\underset{\mathfrak{j}}{\dot{b}}$ & & 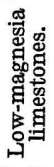 & 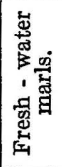 & 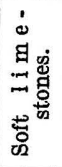 & ర్లే & ळ̈ं & 密 \\
\hline Alabama. & A & 0 & A & A & 0 & $\mathbf{C}$ & Nंebraska. & B & 0 & B & 0 & 0 & 0 \\
\hline Arizona. . & $\mathbf{B}$ & 0 & 0 & $\mathrm{C}$ & 0 & 0 & Nevada.... & $\mathbf{B}$ & 0 & 0 & 0 & 0 & 0 \\
\hline Arkansas. & $\mathrm{A}$ & 0 & B & $\mathrm{B}$ & 0 & $\mathbf{C}$ & New Hampshire. & B & 0 & 0 & 0 & 0 & 0 \\
\hline alifornia. & $\mathbf{B}$ & 0 & $\vec{B}$ & 0 & $\mathbf{A}$ & B & New Jersey ....... & $\mathbf{A}$ & $\mathbf{C}$ & 0 & $\mathbf{0}$ & 0 & 0 \\
\hline Colorado. & A & 0 & $\mathrm{~A}$ & $\ddot{A}$ & $\mathrm{~B}$ & 0 & New Mexico........ & $\mathbf{B}$ & 0 & 0 & $\ddot{\mathbf{B}}$ & 0 & 0 \\
\hline Connecticut. & $\mathbf{C}$ & 0 & 0 & 0 & 0 & 0 & New York. & A & $\mathbf{A}$ & 0 & 0 & $\mathbf{C}$ & $\mathbf{B}$ \\
\hline Delaware.... & $\mathbf{C}$ & 0 & 0 & 0 & 0 & 0 & North Carolina... . & C. & 0 & $\hat{\mathbf{A}}$ & $\mathbf{C}$ & 0 & 0 \\
\hline Florida... & $\mathbf{A}$ & 0 & A & 0 & 0 & 0 & North Dakota..... & 0 & 0 & $\mathbf{C}$ & 0 & 0 & 0 \\
\hline Georgia. & A & 0 & $\mathrm{~B}$ & $\mathbf{B}$ & 0 & 0 & 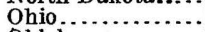 & A & A & 0 & $\mathbf{A}$ & A & $\mathbf{A}$ \\
\hline Idaho... & $\mathbf{B}$ & 0 & 0 & $\mathrm{C}$ & 0 & 0 & Oklahoma. & $\mathrm{A}$ & 0 & B & A & $\mathrm{A}$ & A \\
\hline Illinois. . & $\vec{A}$ & A & 0 & A & $\mathrm{A}$ & A & Oregon. . & C & 0 & 0 & $\mathrm{C}$ & 0 & 0 \\
\hline Indiar & A & $\mathrm{A}$ & 0 & A & A & A & Pennsylvania .... & $\mathbf{A}$ & 0 & 0 & $\ddot{\mathbf{A}}$ & A & A \\
\hline Iowa. - & A & 0 & 0 & $\mathrm{~A}$ & 0 & 0 & Rhode Island . . . . . & C & 0 & 0 & 0 & 0 & 0 \\
\hline Kansas. & A & 0 & $\mathbf{C}$ & $\mathrm{B}$ & $\hat{\Lambda}$ & A & South Carolina.... & $\mathbf{C}$ & 0 & B & 0 & 0 & 0 \\
\hline Kentucky. . & $\mathrm{A}$ & 0 & 0 & $\mathrm{~A}$ & $\mathrm{~B}$ & B & South Dakota.... & 0 & 0 & B & 0 & 0 & 0 \\
\hline Louisiana.... & 0 & 0 & $\mathrm{C}$ & 0 & $\mathbf{\Lambda}$ & A & Tennessee......... & A & 0 & 0 & $\mathbf{A}$ & $\mathbf{C}$ & C \\
\hline Mair & $\mathrm{B}$ & 0 & 0 & 0 & 0 & 0 & Texas............. & A & 0 & A & $\mathrm{C}$ & 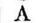 & A \\
\hline Maryland. & A & 0 & 0 & $\mathrm{~A}$ & 0 & 0 & Utah . . . . . & $\mathrm{A}$ & $\mathbf{B} a$ & 0 & $\mathbf{A}$ & $\mathrm{C}$ & 0 \\
\hline Massachusetts.... & C & $\mathrm{C}$ & 0 & 0 & 0 & 0 & Vermont... & B & 0 & 0 & 0 & 0 & 0 \\
\hline Michigan..... & A & A & 0 & $\mathrm{~A}$ & 0 & 0 & Virginia........... & $\mathrm{A}$ & 0 & A & $\mathbf{B}$ & 0 & 0 \\
\hline Minnesota. & $\mathrm{C}$ & $\mathrm{C}$ & 0 & 0 & 0 & 0 & Washington....... & B & 0 & 0 & B & 0 & 0 \\
\hline Mississippi.. & $\mathbf{C}$ & 0 & $\AA$ & 0 & 0 & 0 & West Virginia.... & $\mathrm{A}$ & 0 & 0 & $\mathbf{A}$ & $\mathrm{A}$ & $\mathbf{A}$ \\
\hline Missouri... & $\mathbf{A}$ & 0 & 0 & A & 0 & 0 & Wisconsin ....... & C & $\mathbf{C}$ & 0 & 0 & 0 & 0 \\
\hline Montana... & A & 0 & $\mathbf{B}$ & $\mathbf{C}$ & 0 & 0 & Wyoming......... & $\bar{A}$ & 0 & $\overrightarrow{\mathbf{B}}$ & $\mathbf{A}$ & B & $\mathbf{C}$ \\
\hline
\end{tabular}

a Marl resulting from evaporation of water of Great Salt Lake.

It will be noted that the descriptions of the cement resources of certain States have been prepared by other geologists, in which case they are signed. by the individual authors. Full credit has been given in notes for contributions of less extent and for quotations from reports already published. Brief bibliographies are attached under each State, where the publications seemed important enough to justify. Many references are made, in footnotes, to reports of State surveys or of the United States Geological Survey. Such reports, if not out of print, may usually be obtained, either free or at a nominal price, on application to the officials at the heads of the respective surveys.

Maps showing the distribution of cement materials have been inserted wherever the data justified their presentation.

\section{PORTLAND CEMENT RESOURCES OF ALABAMA.}

\section{PORTLAND CEMENT MATERIALS.}

\section{By Eugene A. Smith.}

Several extensive series of limestones capable of furnishing excellent raw material for the manufacture of Portland cement occur in Alabama, and shales and clays to complete the mixture are found in every county in the State. Owing to the marked geologic distinction between northern Alabama and central and southern Alabama, the two portions of the State will be discussed separately. 


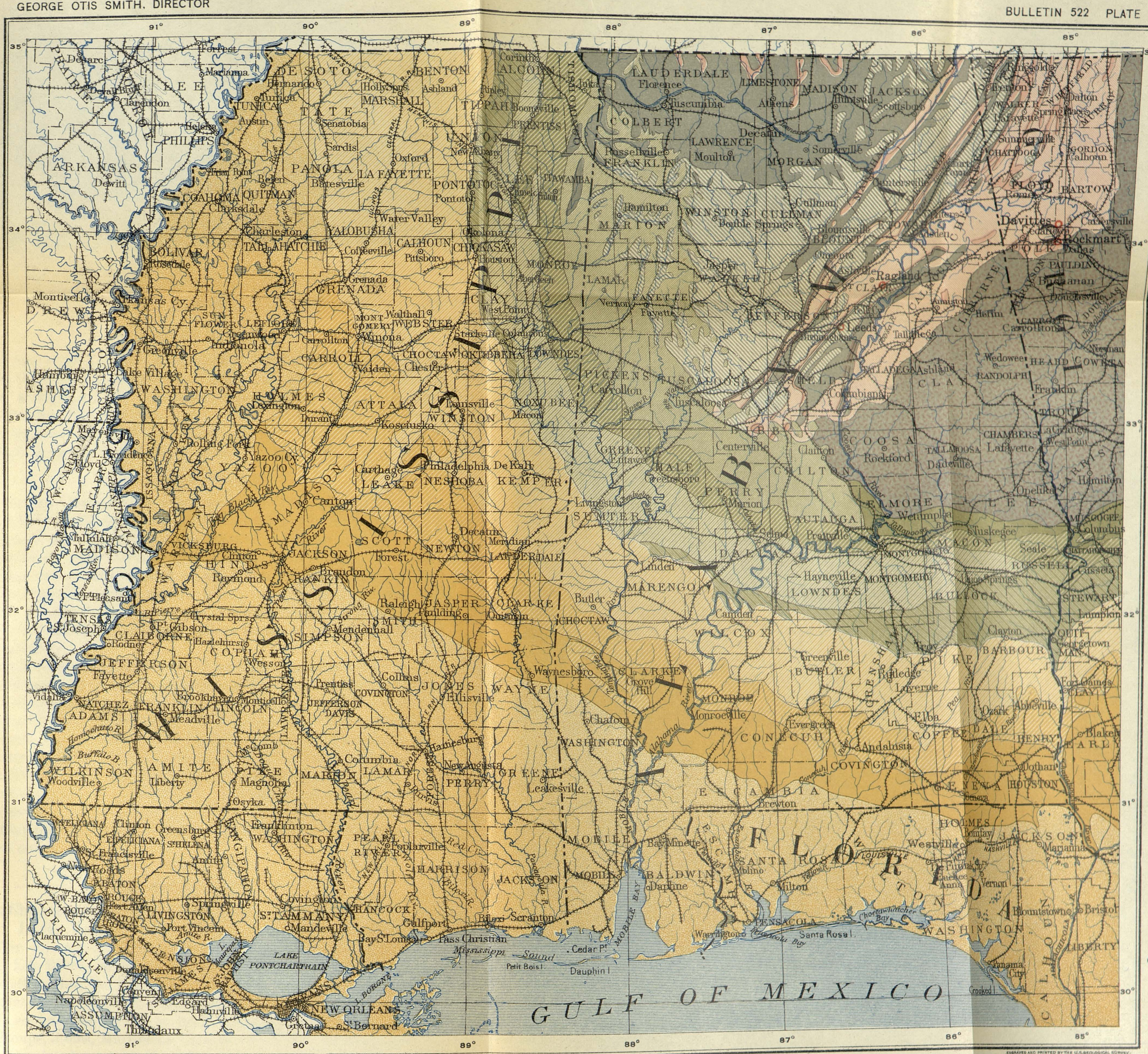

GEOLOGIC MAP OF MISSISSIPPI, ALABAMA, AND PARTS OF GEORGIA AND FLORIDA

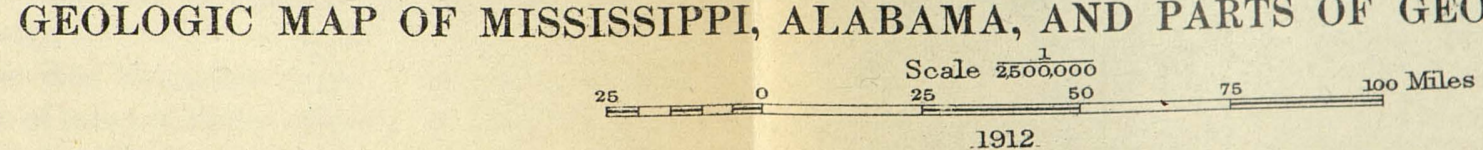

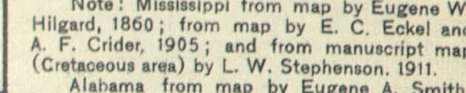

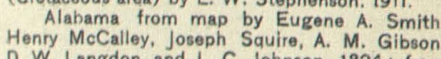

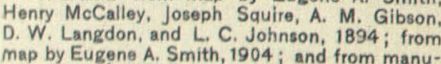

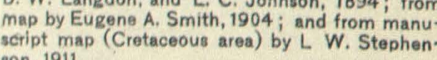

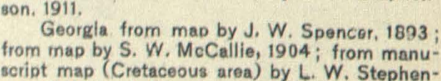

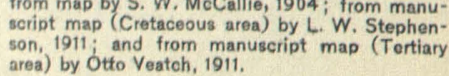

Chiefly shales, limestones, and
dolomites

IGNEOUS AND METAMORPHIC ROCKS

Chiefly schists, slates, and gneisses

Portland cement plan 



\section{Northern Alabama.}

The raw materials for the manufacture of Portland cement occurring in the Paleozoic formations of northern Alabama are limestones, shales, and clays. The limestones belong mainly to the Mississippian ("Lower Carboniferous") series and to the Chickamauga limestone, the shales to the Pennsylvanian series ("Coal Measures"), and the clays to the Cambrian, Mississippian, and Pennsylvanian.

\section{GENERAL GEOLOGY.}

In northern Alabama the combined effects of geologic structure and erosion have produced certain definite topographic types with which the geologic outcrops are closely connected. (See Pl. II.)

- Structurally northern Alabama is made up of a series of parallel synclines and anticlines, most of which trend a little north of east. The anticlines are sharp narrow folds; the synclines are flat wide basins. Erosion has cut away the synclines, and the streams of the region now run along anticlinal valleys bordered by flat-topped synclinal plateaus.

The plateaus throughout most of northern Alabama are capped by conglomerates, shales, and sandstones of the "Coal Measures." The Mississippian limestones commonly crop out along the sides and at the immediate base of the plateaus. The Ordovician ("Lower Silurian") beds occur as long narrow outcrops in the valleys. The middle portions of most of the valleys are occupied by Cambrian shales and the Knox dolomite. The Chickamauga limestone would normally outcrop as two parallel bands in each valley-between the middle of the valley and the foothills of the plateaus-but faulting has been so common that in most valleys only one band is present, the other being faulted out.

\section{LIMESTONES.}

\section{Chickamadga LIMESTONE.}

The Chickamauga limestone outcrops in Alabama in three principal areas. In the Tennessee River valley some of the smaller streams that flow into the river from the north, like Flint River, Limestone Creek, Elk River, Bluewater Creek, and Shoal Creek, have eroded their valleys into the limestone. These areas are crossed at only a few points by the railroads leading out from Huntsville and Florence, and no commercial use has as yet been made of the rock.

In Roups, Jones, Murphrees, Cahaba, Big Wills, and Coosa valleys erosion has in places sunk the valley floors into Cambrian strata, and in consequence the Chickamauga limestone occupies a narrow belt on each side, near the base of the Red Mountain ridges. But as a fault occurs on one or the other side of most of these valleys, the Red Mountain ridges and the accompanying Chickamauga limestone are more fully represented on the unfaulted side-the east side in all except 
Murphrees Valley. The Chickamauga forms practically a continuous belt along the undisturbed side and in places outcrops in extensive areas on the faulted side also, as for instance at Vance, on the Alabama Great Southern Railroad, where the rock is quarried for flux for the furnace of the Central Iron Co. at Tuscaloosa. Analysis 1 (p. 75) shows its composition. Other analyses from lower ledges in the quarry show only 1.22 per cent of silica, but more magnesia.

Where erosion has not gone so deep as to reach the Cambrian, the Chickamauga extends entirely across the trough, as in the lower part of Brown Valley from Brooksville to beyond Guntersville. Above Guntersville the Chickamauga is seen mainly on the east side of the valley. The river touches these outcrops at many points, and at Guntersville the railroad connecting that city with Attalla affords additional means of transportation. No developments have yet been made in this area.

In the valley separating the Warrior from the Cahaba coal field, known as Roups Valley in the south and as Jones Valley in the north, the Chickamauga limestone occupies a narrow, continuous belt, mostly near the base of the eastern Red Mountain ridge, though in places it is high up on the ridge and even at its summit, as at Gate City, where the quarries of the Sloss Iron Co. are located. Many analyses of the rock from this quarry have been made. (See Nos. $2,3,4,5,6$, p. 75.)

In Murphrees Valley the continuous belt of Chickamauga limestone, as above explained, is on the west side, and the faulted remnants are on the east side. No quarries have been opened. The Louisville \& Nashville Railroad goes up the valley as far as Oneonta.

In Cahaba Valley, which separates the Cahaba coal field from the Coosa coal field, the Chickamauga is well exposed on the east side for the entire length of the valley from Gadsden down. It expands into wide areas near the south end, where it has been quarried for lime burning at Pelham, Siluria, Longview, Calera, and other places on the line of the Louisville \& Nashyille Railroad. (See analyses 7, 8 , and 9, p. 75.) The Central of Georgia and the Southern railways cross this belt about midway of its length at Leeds, in Jefferson County, and the Louisville \& Nashville Railroad crosses it at its northern end, where a quarry at Rock Springs, on the flank of Colvin Mountain, supplies rock for lime burning. (See analysis 10, p. 75.) At Pratts Ferry, on Cahaba River, a few miles above Centerville, in Bibb County, the Chickamauga limestone makes high bluffs along the river for several miles and is most conveniently placed for easy quarrying. Marble works established here in former days should be again put in operation, since the marble is of fine quality and is beautifully variegated. No analyses are available, but there is no doubt that much of the rock is sufficiently low in magnesia for cement making. Cahaba River and a short spur from the Mobile \& Ohio Railroad afford transportation. 
In Big Wills Valley, which separates Sand and Lookout mountains, the Chickamauga limestone occupies perhaps 25 square miles, but it is crossed only by the railroad connecting Gadsden with Guntersville. No analyses are available.

In the Coosa Valley region the Chickamauga outcrops are found mostly on the western border, near the base of Lookout Mountain, as in Broomtown Valley and in other valleys extending south toward Gadsden. Although these belts have been utilized in the past for the old Gaylesville, Cornwall, and Round Mountain furnaces, and possibly for some furnaces now in blast, no analyses are available. Farther south, along the western border of the Coosa Valley, running parallel with the Coosa coal field in Calhoun, St. Clair, and Shelby counties, there are numerous long, narrow outcrops of Chickamauga limestone. The Calcis quarry of the Tennessee Coal, Iron \& Railroad Co., on the Central of Georgia Railway, near Sterrett, is on one of these outcrops and furnishes limestone with a very low and uniform percentage of silica and magnesia. Analyses 11, 12, 13, 14, 15, and 16 (p. 75) exhibit the quality of the rock as received at the Ensley Steel Works, but care is taken at the quarry to select ledges low in silica and magnesia, and the analyses therefore represent only the selected ledges and not the run of the quarry. Near Talladega Springs, Marble Valley, and Shelby are other occurrences of the rock, and a quarry a few miles east of Shelby furnace has for many years supplied that furnace with its flux. (See analyses 17, 18, 19, and 20, p. 75.)

\section{MISSISSIPPIAN ("LOWER CARBONIFEROUS") LIMESTONES.}

Limestones suitable for cement manufacture occur in the Bangor limestone of the Mississippian ("Lower Carboniferous") series. Perhaps the most accessible occurrences of this rock are in the Tennessee Valley, west of Tuscumbia and south of the river and railroad, where the former quarries of Fossick \& Co. were located. The outcrop extends eastward along the base of Little Mountain as far as Whitesburg, above which place to Guntersville the river flows through a valley floored with Mississippian limestone. The Southern Railway passes over outcrops of this rock in most of the mountain coves east of Huntsville, and from Scottsboro to the Tennessee line the country rock is almost entirely of this formation. The Louisville \& Nashville Railroad south of Decatur nearly to Wilhite is mostly in the same formation. These two lines together with Tennessee River would provide ample transportation for the rock or for the finished product. For an analysis of the rock from the Fossick quarries see page 75.

In Brown Valley, south of Brooksville, the Bangor limestone is the prevailing rock, and at Bangor and Blount Springs, on the Louisville \& Nashville Railroad, extensive quarries have been worked for many years for flux for the furnaces of the Birmingham district. (See analyses Nos. 2, 3, 4, 5, 6, 7, 8, and 9, p. 75.) 
From Brooksville to the Tennessee line a great thickness of this limestone is exposed along the western escarpment and below the top of Sand Mountain, which is capped by sandstones of the "Coal Measures." The river runs near the foot of the mountain and would afford transportation.

In similar manner the Bangor limestone outcrops along the western flank of Lookout Mountain in Little Wills Valley, from near Attalla to the Georgia line. South of Attalla it forms the lower part of the escarpments of Blount and Chandler mountains. The Alabama Great Southern Railroad passes very near the outcrop from the Georgia line down to Springville, Ala. South of Springville large outcrops occur in Shades Valley, and at Trussville are quarries which have supplied the Birmingham furnaces. (See analyses 10 to 17 , inclusive, p.75.)

In Murphrees Valley the main outcrop of this rock is on the western side, where quarries at Compton have for many years been worked to supply the Birmingham furnaces. (See analyses 18, 19, and 20, p. 75.) Rock from these quarries varies somewhat, but by proper selection suitable material can easily be obtained.

In the valleys lying east of Shades Valley and in parts of Shades Valley itself the formation becomes prevailingly shales and sandstones, limestones being few and inferior.

CRYSTALLINE AND OTHER LIMESTONES.

The Cambrian limestones contain generally a large proportion of magnesia and for this reason are not suited for Portland cement manufacture, though admirably adapted for furnace stone.

Along the eastern border of the Coosa Valley, near its contact with the metamorphic rock, there is a belt of limestone which in places is metamorphosed to a white crystalline marble of great purity, which has been quarried at several places for ornamental stone. (See analyses 1 to 7 ,.inclusive, p. 75.) The Louisville \& Nashville Railroad from Calera to Talladega passes close to this belt.

CLAYS AND SHALES.

The most important clays in the Paleozoic region occur in Pennsylvanian ("Coal Measures"), Mississippian, Ordovician, and Cambrian formations. But as a later formation-the Tuscaloosa of the Cretaceous-borders the Paleozoic on the west and south, and as it contains great variety as well as abundance of clays, it will be described here, although it is not Paleozoic.

ORDOVICIAN ("LOWER SILURIAN") AND CAMBRIAN SHALES.

Associated with the cherty limestones and brown iron ores of the Ordovician and Cambrian formations are beds of fine white clay, much of it china clay. A white clay in the brown ore bank at Rock Run, in Cherokee County (see analysis 7, p. 76), is about 30 feet in thickness. Other clays seem adapted to cement making. (See analyses 8, 9, 10, 11, and 12, p. 76.) No great number of the clays have been analyzed, 
but they are known to be widely distributed in Calhoun, Talladega, Jefferson, Tuscaloosa, and other counties in connection with the brown-ore deposits.

\section{MISSISSIPPIAN ("LOWER CARBONIFEROUS") SHALES.}

Associated with the cherty limestones of the lowermost division of the Carboniferous in some of the anticlinal valleys are beds of clay of excellent quality, much of it china clay.

Probably the best exposures of these clays are in Little Wills Valley, between Fort Payne and the Georgia border, and on the line of the Alabama Great Southern Railroad, where for many years quarries have supplied tile works and potteries. The clays lie near the base of the formation, close above the black shale of the Devonian, and average about 40 feet in thickness, though in places they reach 200 feet. The clay beds are 12 to 18 inches thick and contain seams of chert 2 to 8 inches thick. The upper half of the clay is more gritty than the lower half, much of which contains material suitable for making the finer grades of porcelain. (See analyses 3-6, p. 76.)

\section{PENNSYLVANIAN ("COAL MEASURES") SHALES.}

Many beds of shale in the Pennsylvanian have been utilized for making vitrified brick and fire brick, and some of them may be used for making cement. A great body of these shales occurs in connection with the coal seams of the Horse Creek or Mary Lee coal group, in Jefferson and Walker counties. They are conveniently situated with reference to limestone and coal and alsoo to transportation lines, and are therefore well worth the attention of those who contemplate building cement plants.

On the property of W. H. Graves, near North Birmingham, overlying the coal seam mined by him, are two beds of shale-one yellowish, the other gray. (See analyses 1 and 2, p. 76.)

Similar shales are used also at Coaldale, in Jefferson County, and at Pearce's mill, in Marion. Physical tests but no analyses have been made.

Most of the coal seams mined in Alabama rest upon clay beds which have not yet been specially examined as to their fitness for cement making, but which, in view of the proximity of the coal mines to the limestones, might be worth investigation.

\section{CRETACEOUS CLAYS.}

The most important clays of Alabama are found in the lowermost division of the Upper Cretaceous, in the Tuscaloosa formation, which is, in part at least, equivalent to the Raritan formation of New Jersey. The prevailing strata of the Tuscaloosa are yellowish and grayish sands, but subordinated to them are great lenses of massive clay, varying in quality from clay that burns almost pure white to dark purple and mottled clays that contain much iron. 
The Tuscaloosa occupies a belt extending from the northwest corner of the State around the edges of the Paleozoic formations to the Georgia line at Columbus. This belt is widest at the western boundary of the State, where it is 30 to 40 miles wide. Its width at Wetumka and thence eastward to the Georgia line is only a few miles. The widest and most important part of this belt, in Elmore, Bibb, Tuscaloosa, Pickens, Fayette, Marion, Lamar, Franklin, and Colbert counties, is traversed by the Mobile \& Ohio, the Alabama Great Southern, the Louisville \& Nashville, the Southern, and the Kansas City, Memphis \& Birmingham railroads, as well as by Warrior and Tombigbee rivers.

These clays have been described in some detail and certain analyses which appear to indicate the fitness of the clays for cement making are here republished. ${ }^{1}$ (See analyses, p. 76.)

In Elmore County, in the vicinity of Coosada, along the banks of Coosa River, about Robinson Springs, Edgewood, and Chalk Bluff, are many deposits of these clays, some of which have been used in potteries for many years. (See analyses 13, 14, and 15, p. 76.)

In Bibb County clay for fire brick has been quarried very extensively at Bibbville and near Woodstock (see analyses 16 and 17, p. 76) and carried to Bessemer by the Alabama Great Southern Railroad. The beds are very thick and extensive. The Mobile \& Ohio Railroad crosses other extensive deposits in the southern part of the county.

The most important of the clay beds in Tuscaloosa County are traversed by the Mobile \& Ohio and the Alabama Great Southern Railroads. Many large beds are exposed along the Mobile \& Ohio road in Pickens County, but very few have been investigated. (See analysis 22, p. 76.) In Lamar and Fayette counties the same conditions prevail as in Pickens and Tuscaloosa. (See analyses 23, 24, 25,26, p. 76 .)

Marion is one of the leading counties of the State for fine clays, but it is touched by railroads only along its southern border and its extreme northeastern corner. Although at present not available because inaccessible, the clays from Bexar, from the great clay deposit which gives the name to Chalk Bluff and which underlies about two townships, and from about 16 miles southwest of Hamilton, the county seat, are worthy of consideration. (See analyses 27, 28, and 29 , p. 76.)

Colbert County has numerous fine clays. (See analyses 31 and 32, p. 76.)

\section{ANALYSES.}

The following tables give analyses of limestones and clays from northern Alabama:

1 Bull. Geol. Survey Alabama No. 6, 1900. 
Analyses of Chickamauga limestone from Alabama.

\begin{tabular}{|c|c|c|c|c|c|c|c|c|c|c|}
\hline & 1 & 2 & 3 & 4 & 5 & 6 & 7 & 8 & 9 & 10 \\
\hline $\begin{array}{l}\text { Silica }\left(\mathrm{SiO}_{2}\right) \ldots \ldots \\
\text { Iron oxide and alumina }\left(\mathrm{Fe}_{2} \mathrm{O}_{3}\right. \\
\left.\text { and } \mathrm{Al}_{2} \mathrm{O}_{3}\right) \ldots \ldots \ldots \\
\text { Lime carbonate }\left(\mathrm{CaCO} \mathrm{C}_{3}\right) \\
\text { Magnesium carbonate }(\mathrm{MgCO} \\
\text { Sulphur }(\mathrm{S}) \ldots \ldots \ldots \ldots\end{array}$ & $\begin{array}{r}4.48 \\
1.22 \\
88.85 \\
3.52 \\
\text {. }\end{array}$ & $\begin{array}{r}5.70 \\
1.87 \\
91.16 \\
\hdashline \cdots \\
\hdashline . \cdots\end{array}$ & $\begin{array}{r}2.43 \\
3.30 \\
89.88 \\
\end{array}$ & $\begin{array}{r}3.65 \\
.91 \\
92.38 \\
\ldots . .\end{array}$ & $\begin{array}{r}3.29 \\
1.49 \\
92.61 \\
\ldots .\end{array}$ & $\begin{array}{r}3.82 \\
1.96 \\
90.44 \\
\cdots\end{array}$ & $\begin{array}{r}0.39 \\
.13 \\
99.11 \\
.75 \\
\hdashline .7 .\end{array}$ & $\begin{array}{r}0.15 \\
\operatorname{Tr} . \\
99.16 \\
.75 \\
2 . .\end{array}$ & $\begin{array}{r}0.78 \\
\\
97.35 \\
1.27 \\
\hdashline .2 .\end{array}$ & $\begin{array}{r}1.00 \\
.30 \\
97.00 \\
\mathrm{Tr} . \\
\mathrm{Tr} .\end{array}$ \\
\hline & 11 & 12 & 13 & 14 & 15 & 16 & 17 & 18 & 19 & 20 \\
\hline $\begin{array}{l}\text { Silica }\left(\mathrm{SiO}_{2}\right) \ldots \ldots \ldots \\
\text { Iron oxide and alumina }\left(\mathrm{Fe}_{2} \mathrm{O}_{3}\right. \\
\left.\text { and } \mathrm{Al}_{2} \mathrm{O}_{3}\right) \ldots \ldots \ldots \\
\text { Lime carbonate }\left(\mathrm{CaCO}{ }_{3}\right) \ldots \ldots \\
\text { Magnesium carbonate }(\mathrm{MgCO} \\
\text { Sulphur }(\mathrm{S}) \ldots \ldots \ldots \ldots \ldots\end{array}$ & $\begin{array}{r}0.43 \\
.42 \\
98.49 \\
.16\end{array}$ & $\begin{array}{r}0.58 \\
\\
.25 \\
95.78 \\
2.89\end{array}$ & $\begin{array}{r}0.38 \\
.47 \\
98.35 \\
.30\end{array}$ & $\begin{array}{r}0.34 \\
.46 \\
96.53 \\
2.17\end{array}$ & $\begin{array}{r}0.39 \\
\\
.37 \\
94.27 \\
4.47\end{array}$ & $\begin{array}{r}0.98 \\
\\
.52 \\
96.92 \\
1.08 \\
\ldots . . .\end{array}$ & $\begin{array}{r}2.50 \\
1.40 \\
96.70 \\
\cdots \ldots . .\end{array}$ & $\begin{array}{r}2.09 \\
1.01 \\
93.77 \\
2.48 \\
. .2 .\end{array}$ & $\begin{array}{r}1.08 \\
\\
.63 \\
98.91 \\
.58 \\
\ldots . .\end{array}$ & $\begin{array}{r}2.25 \\
.68 \\
95.40 \\
.94 \\
. . .\end{array}$ \\
\hline
\end{tabular}

1. Average of several carloads of flux rock from quarry at Vance, Tuscaloosa County, of Central Iron Co. at Tuscaloosa. H. Buel, analyst.

2. Gate City quarry, Jefferson County. Average sample from the crusher. Henry McCalley, analyst.

3-6. Gate City quarry. J. W. Miller, analyst.

7, 8. Longview quarries, Shelby County. Used in burning lime. Rept. Geol. Survey Alabama for 1875,1876, pp. 113-114.

9. Jones quarry, near Longview. Idem, p. 116 .
10. Rock Spring quarry, Etowah County. Used in burning lime and for flux. W. B. Phillips, analyst.

11-16. Rock from Calcis quarry, St. Clair County. J. R. Harris, analyst.

17-20. Shelby quarry, Shelby County. Used for flux in Shelby furnaces. Rept. Geol. Survey Alabama for 1875,1876 , pp. $117-118$.

Analyses of Mississippian limestones from Alabama.

\begin{tabular}{|c|c|c|c|c|c|c|c|c|c|c|}
\hline & 1 & 2 & 3 & 4 & 5 & 6 & 7 & 8 & 9 & 10 \\
\hline 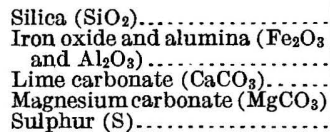 & $\begin{array}{r}0.50 \\
1.45 \\
96.58 \\
2.58\end{array}$ & $\begin{array}{r}1.73 \\
.78 \\
96.54\end{array}$ & $\begin{array}{r}0.77 \\
.35 \\
97.60\end{array}$ & $\begin{array}{r}1.14 \\
.34 \\
98.53 \\
\cdots \\
. . .\end{array}$ & $\begin{array}{r}1.02 \\
1.38 \\
95.25 \\
1.73\end{array}$ & \begin{tabular}{|r|}
1.40 \\
1.17 \\
94.67 \\
2.26
\end{tabular} & $\begin{array}{r}0.68 \\
1.02 \\
96.54 \\
1.26\end{array}$ & $\begin{array}{r}0.81 \\
.89 \\
97.45 \\
.35\end{array}$ & $\begin{array}{r}0.82 \\
.60 \\
97.37 \\
.75 \\
.029\end{array}$ & $\begin{array}{r}2.16 \\
2.31 \\
89.15 \\
4.20\end{array}$ \\
\hline & 11 & 12 & 13 & 14 & 15 & 16 & 17 & 18 & 19 & 20 \\
\hline $\begin{array}{l}\text { Silica }\left(\mathrm{SiO}_{2}\right) \\
\text { Iron oxide and alumina }\left(\mathrm{Fe}_{2} \mathrm{O}_{3}\right. \\
\left.\text { and } \mathrm{Al}_{2} \mathrm{O}_{3}\right) \\
\text { Lime carbonate }\left(\mathrm{CaCO} \mathrm{CO}_{3}\right) \ldots \\
\text { Magnesium carbonate }(\mathrm{MgCO} \\
\text { Sulphur }(\mathrm{S}) \ldots \ldots \ldots\end{array}$ & $\begin{array}{r}3.12 \\
2.32 \\
85.87 \\
4.20\end{array}$ & $\begin{array}{c}0.85 \\
.65 \\
96.64 \\
1.36 \\
.024\end{array}$ & $\begin{array}{r}1.08 \\
.61 \\
96.91 \\
.90 \\
.019\end{array}$ & $\begin{array}{r}0.73 \\
.65 \\
97.60 \\
.52 \\
.018\end{array}$ & $\begin{array}{r}0.64 \\
.62 \\
97.48 \\
.76\end{array}$ & $\begin{array}{r}1.12 \\
.90 \\
96.38 \\
1.10\end{array}$ & $\begin{array}{r}0.42 \\
\\
.37 \\
97.32 \\
1.39 \\
.020\end{array}$ & $\begin{array}{r}2.05 \\
.76 \\
89.64 \\
8.15\end{array}$ & $\begin{array}{r}4.45 \\
3.30 \\
86.35 \\
\cdots\end{array}$ & $\begin{array}{r}2.80 \\
.70 \\
94.59\end{array}$ \\
\hline
\end{tabular}

1. Average sample from Fossick quarry, near Rockwood, Franklin County. Government Arsenal, Watertown, Mass., analyst.

2. Average sample from Blount Springs quarry-a compact limestone. Henry McCalley, analyst.

3. Average sample from Blount Springs quarry - a granular oolitic limestone. Henry McCalley, analyst.

4. Average sample upper 75 feet, Blount Springs quarry. J. L. Beeson, analyst.

5-9. Average sample Blount Springs quarry. J. R. Harris, analyst.

10, 11. From Worthington quarry, near Trussville, Jefferson County. C. A. Meissner, analyst.

12-17. From Vanns, near Trussville. J. R. Harris, analyst.

18. Average of about 150 feet thickness of rock used for flux, Compton quarry, Blount County. J. L. Beeson, analyst.

19, 20. Stockhouse sample, Compton quarry. W. B. Phillips, analyst.

Analyses of crystalline marbles.

\begin{tabular}{|c|c|c|c|c|c|c|c|}
\hline & 1 & 2 & 3 & 4 & 5 & 6 & 7 \\
\hline $\begin{array}{l}\text { Silica }\left(\mathrm{SiO}_{2}\right) \ldots \ldots \\
\text { Iron oxide and alumina }\left(\mathrm{Fe}_{2} \mathrm{O}_{3} \text { and } \mathrm{Al}_{2} \mathrm{O}_{3}\right) \ldots \\
\text { Lime carbonate }\left(\mathrm{CaCO}_{3}\right) \\
\text { Magnesium carbonate }\left(\mathrm{MgCO}_{3}\right)_{\ldots}\end{array}$ & $\begin{array}{r}\text { Tr. } \\
99.47 \\
.38\end{array}$ & $\begin{array}{r}2.70 \\
.40 \\
90.80 \\
\text { Tr. }\end{array}$ & $\begin{array}{r}2.95 \\
1.15 \\
95.25 \\
.62\end{array}$ & $\begin{array}{r}4.65 \\
.75 \\
94.40 \\
.41\end{array}$ & $\begin{array}{r}2.80 \\
.48 \\
95.60 \\
.66\end{array}$ & $\begin{array}{r}1.35 \\
.30 \\
97.60 \\
\mathrm{Tr} .\end{array}$ & $\begin{array}{r}0.28 \\
.28 \\
99.19 \\
.14\end{array}$ \\
\hline
\end{tabular}

1. Herd's upper quarry, Talladega County. Tuomey, Michael, Second Bien. Rept. Geology of Ala bama, 1858, p. 119 .

2. Herd's quarry, sec. 16, T. 21, R. 4 E., Talladega County. W. B. Phillips, analyst.

3. Taylor's mill, Talladega County, white marble. W. C. Stubbs, analyst.

4. Taylor's mill, Talladega County, blue marble. W. C. Stubbs, analyst.

5. Taylor's mill, Talladega County. A. F. Brainerd, analyst.

6. Nix quarry, sec. 36, 'T. 20, R. 4 E., Talladega County, white marble. W. B. Phillips, analyst.

7. Gannt's quarry, sec. 2, T. 22, R. 3 E., Talladega County, white marble. A. F. Brainerd, analyst. 
Analyses of Paleozoic and lowermost Upper Cretaceous clays.

\begin{tabular}{|c|c|c|c|c|c|c|c|c|c|c|c|}
\hline & 1 & 2 & 3 & 4 & 5 & 6 & 7 & 8 & 9 & 10 & 11 \\
\hline 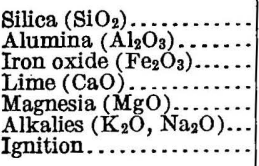 & $\begin{array}{r}61.55 \\
20.25 \\
7.23 \\
\text { Tr. } \\
.99 \\
1.25 \\
6.19\end{array}$ & $\begin{array}{r}57.80 \\
25.00 \\
4.00 \\
2.10 \\
.80 \\
1.80 \\
7.50\end{array}$ & $\begin{array}{r}79.80 \\
11.75 \\
1.75 \\
.75 \\
\text { Tr. } \\
1.50 \\
4.11\end{array}$ & $\begin{array}{r}82.0 \\
12.1 \\
\mathrm{~T} \\
\mathrm{~T} \\
.3 \\
.6 \\
4.3\end{array}$ & \begin{tabular}{l|r} 
& 66.25 \\
17 & 22.90 \\
r. & 1.60 \\
r. & Tr. \\
33 & Tr. \\
30 & .75 \\
33 & 9.05
\end{tabular} & \begin{tabular}{|r}
82.11 \\
11.41 \\
1.40 \\
$\mathrm{Tr}$. \\
.66 \\
1.80 \\
4.00
\end{tabular} & $\begin{array}{r}60.50 \\
26.55 \\
.30 \\
.90 \\
.65 \\
2.70 \\
7.90\end{array}$ & $\begin{array}{r}72.20 \\
22.04 \\
.16 \\
.50 \\
.40 \\
.60 \\
5.80\end{array}$ & $\begin{array}{r}57.00 \\
17.80 \\
5.60 \\
2.10 \\
1.20 \\
6.00 \\
9.45\end{array}$ & $\begin{array}{r}67.95 \\
20.15 \\
1.00 \\
1.00 \\
\text { Tr. } \\
1.87 \\
8.00\end{array}$ & $\begin{array}{r}61.50 \\
26.20 \\
2.10 \\
.50 \\
.43 \\
.70 \\
7.29\end{array}$ \\
\hline \multirow[t]{2}{*}{ Total. } & 98.66 & 99.00 & 99.16 & 99.4 & \begin{tabular}{l|l}
17 & 100.55
\end{tabular} & 101.38 & 99.50 & 101.70 & 99.15 & 99.97 & 98.72 \\
\hline & 12 & 13 & 14 & 15 & 16 & 17 & 18 & 19 & 20 & 21 & 22 \\
\hline $\begin{array}{l}\text { Silica }\left(\mathrm{SiO}_{2}\right) \\
\text { Alumina }\left(\mathrm{Al}_{2} \mathrm{O}_{3}\right) \ldots \\
\text { Iron oxide }\left(\mathrm{Fe}_{2} \mathrm{O}_{3}\right) \ldots \\
\text { Lime }(\mathrm{CaO}) \\
\text { Magnesia }(\mathrm{MgO}) \ldots \\
\text { Alkalies }\left(\mathrm{K}_{2} \mathrm{O}, \ldots \ldots\right. \\
\left.\text { Ignition } \mathrm{Na}_{2} \mathrm{O}\right) \\
\end{array}$ & $\begin{array}{r}84.21 \\
9.75 \\
.69 \\
.70 \\
.14 \\
4.10 \\
4.10\end{array}$ & $\begin{array}{r}66.61 \\
21.04 \\
2.88 \\
.40 \\
.58 \\
.70 \\
7.00\end{array}$ & $\begin{array}{r}62.60 \\
26.98 \\
.72 \\
.40 \\
.36 \\
.65 \\
9.30\end{array}$ & $\begin{array}{r}60.3 \\
20.2 \\
6.1 \\
.0 \\
.7 \\
1.8 \\
10.2\end{array}$ & \begin{tabular}{r|r}
88 & 65.82 \\
1 & 24.58 \\
6 & 1.25 \\
9 & $\cdots . .$. \\
2 & Tr. \\
30 & .60 \\
1 & 8.16
\end{tabular} & \begin{tabular}{r|r}
74.25 \\
17.25 \\
1.19 \\
.40 \\
$\mathrm{Tr}$. \\
.52 \\
6.30
\end{tabular} & $\begin{array}{r}61.25 \\
25.60 \\
2.10 \\
.25 \\
.82 \\
1.35 \\
8.10\end{array}$ & $\begin{array}{r}65.35 \\
21.30 \\
2.72 \\
.60 \\
.86 \\
\text { Tr. } \\
8.79\end{array}$ & $\begin{array}{r}60.03 \\
24.66 \\
3.69 \\
.13 \\
.38 \\
\operatorname{Tr} \\
11.34\end{array}$ & $\begin{array}{r}58.13 \\
24.68 \\
3.85 \\
.15 \\
.32 \\
1.78 \\
11.78\end{array}$ & $\begin{array}{r}68.23 \\
20.35 \\
3.20 \\
.34 \\
\text { Tr. } \\
.74 \\
7.16\end{array}$ \\
\hline \multirow[t]{2}{*}{ Total. . } & 99.59 & $\begin{array}{ll}99.21 & 1\end{array}$ & 101.01 & 99.5 & \begin{tabular}{l|l}
77 & 100.41
\end{tabular} & 99.39 & 99.47 & 99.62 & 100.23 & 100.51 & 100.02 \\
\hline & 23 & 24 & 25 & & 26 & 27 & 28 & 29 & 30 & 31 & 32 \\
\hline 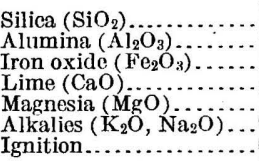 & $\begin{array}{r}\text { 60. } 90 \\
\text { 18. } 98 \\
\text { 7. } 68 \\
\text { Tr. } \\
\text { Tr. } \\
\text { Tr. } \\
\text { 13. } 63\end{array}$ & $\begin{array}{r}63.27 \\
19.68 \\
3.52 \\
1.30 \\
\text { Tr. } \\
1.20 \\
9.80\end{array}$ & $\begin{array}{r}67.1 \\
19.3 \\
2.8 \\
\mathrm{~T} \\
.7 \\
.0 \\
7.7\end{array}$ & $\begin{array}{l}10 \\
37 \\
88 \\
7 r . \\
73 \\
67 \\
79\end{array}$ & $\begin{array}{r}65.58 \\
19.23 \\
4.48 \\
\text { Tr. } \\
\text { Tr. } \\
6.90\end{array}$ & $\begin{array}{r}68.10 \\
21.89 \\
2.01 \\
.80 \\
.28 \\
.40 \\
5.75\end{array}$ & $\begin{array}{c}65.49 \\
24.84 \\
\mathrm{Tr} . \\
1.26 \\
\mathrm{Tr} . \\
\mathrm{Tr} . \\
7.80\end{array}$ & $\begin{array}{r}70.00 \\
21.31 \\
2.88 \\
.20 \\
\text { Tr. } \\
\text { Tr. } \\
6.85\end{array}$ & $\begin{array}{r}67.50 \\
19.84 \\
6.15 \\
.12 \\
.10 \\
7.65 \\
7.6\end{array}$ & $\begin{array}{r}66.45 \\
18.53 \\
2.40 \\
1.50 \\
1.25 \\
\operatorname{Tr} . \\
9.46\end{array}$ & $\begin{array}{r}64.90 \\
25.25 \\
\text { Tr. } \\
\text { Tr. } \\
8.90\end{array}$ \\
\hline Total. . & 100.92 & 98.77 & 98.5 & 54 & 96.19 & 99.23 & 99.39 & 101.24 & 101.36 & 99.59 & 99.05 \\
\hline
\end{tabular}

Pennsylvanian ("Coal Measures"):

1. Dark-yellow shale from "Coal Measures," W. H. Graves, near Birmingham, Jefferson County. 2. Light-gray shale from same locality.

Mississippian:

3-5. Fire clay, near Valley Head, Dekalb County.

6. China clay, Eureka mines, Dekalb County.

Ordovician and Cambrian:

7. China clay, Rock Run, Cherokee County (Dykes ore bank).

8. Fire clay, Rock Run, Cherokee County.

9. Pottery clay, Rock Rum, Cherokee County.

10. China clay, J. R. Hughes, Gadsden, Etowah County.

11. Stoneware clay, Blount County.

12. Stevens fire clay, Oxanna, Calhoun County; probably too much free sand

Lowermost Upper Cretaceous (Tuscaloosa formation):

13. Stoneware clay, Coosada, Elmore County.

14. Pottery clay, MeLean's, near Edgewood, Elmore County.

15. Stoneware clay, Chalk Bluff, Elmore County.

16. Fire clay, Woodstock, Bibb County.

17. Fire clay, Bibbville, Bibb County.

18. Fire clay, Hulls Station, Alabama Great Southern Railroad, Tuscaloosa County.

19. Pottery clay, H. H. Cribbs, Alabama Great Southern Railroad, Tuscaloosa County.

20. Pottery clay, J. C. Bean, Mobile \& Ohio Railroad, Tuscaloosa County.

21. Fire clay, J. C. Bean, Mobile \& Ohio Railroad, Tuscaloosa County.

22. Stoneware clay, Roberts's mill, Pickens County.

23. Pottery clay, Cribl's place, Lamar County.

24. Stoneware clay, H. Wiggins, Fayette County.

25-26. Pottery clay, W. Doty, Fayette County.

27. Blue clay, railroad cut near Glen Allen, Marion County.

28. China clay, Briggs Frederick, Marion County.

29. Pottery clay, 10 miles sonthwest of Hamilton, Marion County.

30. Pottery clay, Thomas Rollins, Franklin County.

31. Pottery clay, J. W. Williams, Pegram, Colbert County.

32. China clay, Pegram, Colbert County. 


\section{Central and Southern Alabama.}

RAW MATERIALS.

The raw materials in central and southern Alabama suitable for making Portland cement are argillaceous limestones, pure limestones, and clays.

The limestones valuable as cement materials occur mainly in the Selma chalk or "Rotten limestone" of the Upper Cretaceous and in the St. Stephens limestone of the Tertiary. The clays available are the residual clays from the decomposition of these two limestone formations, the stratified clays of the "Grand Gulf formation," and the alluvial clays in the river and creek bottoms. Later investigation may show that some of the other stratified clays of the Cretaceous and Tertiary formations, especially the clays of the lowermost Upper Cretaceous (Tuscaloosa formation), are suitable for cement making.

The Upper Cretaceous in Alabama has four divisions-the Tuscaloosa formation, the Eutaw formation, the Selma chalk, and the Ripley formation, named in ascending order. The Tuscaloosa is of fresh-water origin and is made up in the main of sands and clays in many alternations. In places the clays occur in deposits of sufficient size and purity to make them commercially valuable. The Eutaw is of marine origin and is composed of more or less calcareous sands and clays, but nowhere shows beds of limestone properly so called. The Selma chalk is of marine origin and is composed, in part at least, of the microscopic shells of Foraminifera. The Ripley, like the Selma, is a marine formation and is generally predominantly calcareous but contains some sandy and clayey beds. The Selma chalk alone offers limestone in such quantity and of such composition as to be fit for Portland cement material.

\section{LIMESTONES.}

SELMA CHALK ("ROTTEN IIMESTONE").

LITHOLOGY.

The Selma chalk is calcareous throughout its entire thickness of about 1,000 feet. The rock, however, varies in composition between somewhat wide limits; for this reason three divisions may readily be distinguished. The upper division is highly argillaceous, holding 25 per cent or more of clayey matter; portions of it are composed of calcareous clays or marls rather than limestone, containing great numbers of fossils, mainly oysters. Along Tombigbee River these beds make the bluffs from Paces Landing down nearly to Moscow, and on the Alabama they form the banks of the river from Elm Bluff down to Old Lexington Landing. The strata exhibited in these 
bluffs consist of dark-colored fossiliferous calcareous clays, alternating with lighter-colored and somewhat more indurated ledges of purer, less argillaceous rock. At Elm Bluff the upper half of the bluff, which is about 125 feet high, is of this character.

The lower half of the bluff at Elm Bluff is composed of rock more uniform in composition and freer from clay than the upper part, containing generally less than 25 per cent of clayey material. It forms the top of the middle division of the Selma chalk. In this middle division the fossils are rarer than in either of the others, oysters and anomias being the most common. This variety of the rock forms the bluffs along Alabama River from Elm Bluff up to Kings Landing. It is seen in its most typical exposure at White Bluff, where it is at least 200 feet in thickness, rising almost perpendicularly on the right bank of the river. On Tombigbee River it extends from near Bartons Bluff past Demopolis up to Arcola and Hatchs Bluff. Its lowermost beds, a compact limestone of great purity, form the upper parts of Bartons and Hatchs bluffs. On Little Tombigbee River the same rock makes the celebrated bluffs at Bluffport and at Jones Bluff (Epes) and appears along the stream for several miles beyond.

The width of outcrop shows that the middle division of the Selma chalk must be about 300 feet thick. It underlies the most fertile and typical prairie lands of the South. At intervals throughout this region the limestone rock appears at the surface in what are known as "bald prairies," so named from the fact that they are bare of trees. The disintegration and leaching out of the limestone leaves a residue of yellowish clay, several feet thick in low places, which is used at the Demopolis plant in the manufacture of cement. In most localities where suitable limestone is found the clay is present in sufficient quantity to supply the needs of the cement manufacturer.

At the base of this middle division a bed consisting of several ledges of compact, hard, pure limestone, which weathers into curious shapes, has received the names horse-bone rock and bored rock. This bed appears at the top of Hatchs Bluff, at Arcola Bluff, between Demopolis and Epes, at Jordans Ferry, and at other places. Its outcrop makes a ridge easily followed and characterized by the presence on the surface of loose fragments of the limestone.

The lowest division of the Selma chalk, like the uppermost, is composed of clayey limestone or in many places of a calcareous clay. The color is dark gray to bluish, and most exposures show striping, due to alternating bands of lighter-colored purer limestone. Along Alabama River the strata of this division are seen in the bluffs from Kings Landing up to Selma and beyond. On Warrior River they are seen in the bluffs at Arcola, Hatchs, Millwood, and Erie, in the last-named locality occupying the upper part only of the bluff. On 
the Tombigbee they form most of the bluffs at Gainesville, Roes, and Kirkpatricks.

Above Roes, at Jordans, occurs the junction with the middle and lower divisions. About 10 or 15 feet below the hard ledges of pure limestone forming the base of the middle division the dark-colored argillaceous rock tends to flake off and weather into caves, some of them several feet deep and 20 feet or more long. These holes extend in some places for great distances along the bluffs, as on Alabama River just above Kings Landing, on the Tombigbee below Roes Bluff, and at Jordans Ferry.

The outcrop of the argillaceous rocks of the third division gives rise to black prairie soils, in which beds of fossil shells, mainly oysters, are common.

It has been suggested that the argillaceous rocks of the first and third divisions could be mixed with the purer limestone of the middle division in such proportions as to constitute a good cement material and to do away with the need of adding other clay to the limestone. It would be easy to select localities near the junction of the two divisions where both varieties of the rock could be quarried, if not in the same pits at least in pits closely adjacent. Localities of this sort would be found along the borders north and south of the belt of outcrop of the white rock at Demopolis.

Distribution OF THE SELMA CHALK.

As suitable material for cement manufacture can be had in practically unlimited quantity all along the outcrop of the purer limestone of the middle division, the location of cement plants will be determined rather by the facilities for transportation, the cheapness of fuel, and the cost and abundance of labor. Examinations of the rock were consequently confined to localities which appear to be most favorably situated in these respects, and especially to localities on navigable streams or north-south railroad lines, or both. In making collections for analysis material from the middle division was generally chosen, as most of the limestone of the formation which contains 75 per cent or more of carbonate of lime is to be found in this division. At the same time specimens of the more argillaceous material, especially of the lower division of the formation, were collected in order to ascertain the practicability of providing a cement mixture by using proper proportions of the purer and more argillaceous materials.

On Tombigbee River at Gainesville the limestone, 30 to 40 feet thick, appears on the river bluff beneath a heavy covering of sands and pebbles. -A short distance from the river, however, the rock outcrops at the surface and may be quarried without difficulty. (See analyses $1,2,3$, and 4, p. 86.) Other specimens are from the Roberts place, 3 miles east of Gainesville; one was taken from the top of 
a 30-foot bluff and others from the surface 1 mile and 5 miles from the river. (See analyses 5 and 6, p. 86.)

At Jones Bluff, on the Tombigbee, near Epes station, on the Alabama Great Southern Railroad, white limestone of remarkably uniform composition shows along the river bank for about a mile, with an average height of perhaps 60 feet. Here the bare rock forms the surface, so that no overburden need be removed in quarrying. The railroad crosses the river at this locality, which thus has the advantage of both rail and water transportation. From the lower end of this exposure down to Bluffport the white rock is seen at many places; for example, below Lees Island, at Martins Ferry, Braggs, and elsewhere. It generally has a capping of 15 to 20 feet of red loam and other loose materials. (See analyses 7, 8, and 9, p. 86.)

At Bluffport the white rock in places forms a bluff 100 feet or more high along the right bank of the river for a mile or more. (See analysis 10, p. 86.) As at Epes, the rock extends up to the surface, so that quarrying would be attended with little or no difficulty. Below the Bluffport bluffs the easterly course of the river brings it into the territory of the lower strata of the formation, and the white rock does not appear again below Jordans Ferry, except in thin patches at the tops of some of the bluffs. (See analyses 11, 12, 13, and 14, p. 86.) Specimens from Roes Bluff represent the prevailing dark-colored argillaceous rock and the lighter-colored ledges.

At Demopolis the white rock extends along the left bank from 1 mile above the landing to about 2 miles below, with an average height of perhaps 40 or 50 feet. The rock is remarkably uniform in appearance and probably in composition. (See analysis 29, p. 87.) At McDowells the main bluff is on the right bank and the rock is of great purity. (See analysis 16, p. 86.) The exposures continue down to Paces Landing, 9 miles below Demopolis, beyond which the bluffs are much darker in color and striped with lighter bands, characteristic of the upper part of the formation. Thence down nearly to Moscow the upper beds are exposed.

Above Demopolis at Arcola and Hatchs Bluff the bluish clayey limestones of the lower division of the Selma chalk are seen in force, with the lowermost ledges of the middle division--the horse-bone rock-capping them. (See analyses 19 and 20, p. 86.)

From Demopolis eastward the line of the Southern Railway is on the outcrop of this white rock, as far as Massillon, where it passes into the territory of the lower division. Two miles from Demopolis on this road is the 6-kiln cement-manufacturing plant of the Alabama Portland Cement Co. This plant has not been operated since 1908. The quarry is across the railroad track from the kilns, a few hundred feet distant. The clay formerly used is residual from the decomposition of the limestone and is obtained from the river bank a 
few yards away. (See analyses $15,18,40$, pp. 86-87.) A specimen taken from Knoxwood station, between the cement works and Demopolis station, shows similar eomposition (analysis 17, p. 86).

At Van Dorn station the white rock outcrops widely, and just east of the station there is a deep cut through it. (See analyses 21, 22, $41,42,43,44,45,46$, pp. $86-87$.)

About Uniontown the bare rock is exposed at numerous points, and the place offers very great advantages for the location of cement plants. (See analyses $23,24,25,26$, pp. 86-87.)

Residual clay overlies the limestone at the Pitts home place (analysis 1, p. 87). South of Massillon, near the crossing of the Southern and the Louisville \& Nashville railroads, near Martins station, the white rock shows in numerous exposures, making a country somewhat similar to that about Uniontown. At many points the rock has no overburden and is admirably adapted to cheap quarrying. On the banks of Bogue Chitto Creek, near Martins station, on the Milhous place, the rock is exposed in a bluff, beneath a bed of plastic clay, and below a considerable thickness of red loam and sands of the Lafayette formation. (See analysis 27, p. 87.)

The same rocks make the great bluff of White Bluff, on Alabama River. Specimens were selected from about halfway down the bluff, and from 20 feet lower. Generally red loam and sands of the Lafayette cap the limestone, but near the upper end of the bluff the white rock extends to the summit, eapped only by plastic clay. (See analysis 28, p. 87.)

At Elm Bluff the upper and middle divisions of the formation are in contact. At Kings Bluff the middle and lower parts of the formation are in contact. At the other bluffs of the river between Kings Landing and Selma rock of the lower division is exhibited. (See analyses 30,31 , and 47, p. 87 .)

To summarize: From Demopolis eastward along the line of the Southern Railway, by Van Dorn, Gallion, Uniontown, Massillon, and thence by Martins and Milhous stations to White Bluff, the white rock appears at the surface in clean exposures at almost innumerable points, either immediately on or very near to the railroad. So far as the quality, quantity, and accessibility of the limestone are concerned, manufactories of cement might be located almost anywhere in this territory. From Demopolis westward the same conditions prevail up the river to Epes, and thence to Gainesville, beyond which point the white rock is to the west of the river at greater or less distance. East of Alabama River the outcrop of the cement rock is crossed by the Louisville \& Nashville Railroad (Repton branch), between Berlin and Pleasant Hill stations. (See analysis 31, p. 87.) On the Montgomery and Selma road, at the crossing of Pintlala Creek near Manack station, the limestone is exposed in the creek $48834^{\circ}-$ Bull. $522-13-6$ 
banks and in the open fields, in many places with little or no overburden. (See analyses 32 and 33, p. 87.) On the main branch of the Louisville \& Nashville Railroad the white rock shows between the city and McGhees switch. Examinations have not been carried beyond Montgomery, but it is known that the white prairie rock is crossed by the Central of Georgia Railway between Matthews and Fitzpatrick stations, and there seems to be no doubt that along this stretch of the road suitable rock will be found convenient to the line.

\section{ST. STEPHENS LIMESTONE.}

LITHOLOGY.

The St. Stephens or "White" limestone of the Alabama Tertiary, which includes Oligocene and the uppermost of the Eocene strata, is, in general, equivalent to the Vicksburg and Jackson limestones of the Mississippi geologists.

In Alabama the St. Stephens limestone exhibits three rather well defined phases, which, in descending order, are (1) the upper division, observed only in Clarke County, (2) the middle division, regarded as equivalent to the Vicksburg limestone of Mississippi geologists, and (3) the lower division, regarded as equivalent to the Jackson group of Mississippi geologists. Of these only the middle division is of immediate interest, for the first is, as far as known, restricted to one locality (Salt Mountain), and the third is exposed in few places along Alabama rivers and railroads.

The following section of St. Stephens Bluff, Tombigbee River, will give an idea of the strata of this division:

Section of St. Stephens Bluff.

Feet.

$1-5$

2. Highly fossiliferous limestone holding mainly oysters and full of holes,

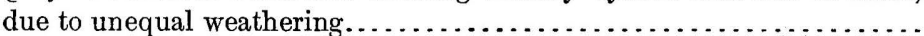

3. "Orbitoides limestone" (chimney rock), a soft, nearly uniform, porous limestone, making smooth perpendicular face of the bluff except where bands of harder limestone of very nearly similar composition alternate with the softer rock. Both varieties hold great numbers of the circular shells of Orbitoides mantelli. The harder ledges are nearly pure carbonate of lime, take a good polish, and are often burned for lime......

4. Immediately below 3 , for 5 or 6 feet, the strata were not visible, being hidden by the rock falling from above, but the space seems to be occupied by a bluish clay. Then follows a soft rock of somewhat the same consistency as No. 3 above, but containing a good deal of greensand. The fossils are mostly oysters and Plagiostoma dumosa. This bed is in places rather indurated superficially and forms projecting ledges.......

5. Bluish clayey marl with much greensand, containing the same fossils as No. 4. It washes or caves out from under No. 4, which overhangs it....

6. Massive joint clay, yellow on exposed surface, blue when freshly broken; no fossils observed. Extends below the water level to unknown depth; exposed
$10-12$

10-15

$4-5$ 
The rock of this division that seems best suited for cement material is the soft "chimney rock" or "Orbitoides limestone" of bed No. 3 above. This is usually quarried for chimneys and other constructions by sawing it out and dressing it down with a plane into blocks of suitable size, which are then laid like brick.

Numerous analyses show that this rock is purer than most of the Selma chalk of the Cretaceous. In cement making it will, in consequence, require the intermixture of a larger proportion of clay, and the question of obtaining suitable clay in sufficient quantity in close proximity becomes of some importance. The residual clay left after decomposition and leaching of the limestone seems to be fairly well adapted to the purpose. Besides this residual clay there are available some river and creek clay's near the limestone, and also the clays of the "Grand Gulf" formation, which in this section very generally overlie the limestone. Near Manistee Junction, on the Repton branch of the Louisville \& Nashville Railroad, the lastnamed clays are present in sufficient quantity to be of value if the composition is suitable. (See analyses 2 and 3, p. 87.)

DISTRIBUTION OF ST. STEPHENS LIMESTONE.

The bluff at St. Stephens, a section of which has been given, is typical of the formation. Here the whole of the soft "Orbitoides limestone" or "chimney rock" might be used, as the composition is uniform throughout. The overlying harder limestone has almost the same composition, but it is less easily crushed and worked (analysis 34, p. 87). It may be quarried from the surface down, as it is covered only by a thin layer of residual clay (analysis 2, p. 87). Clay occurs near St. Stephens at the water level (No. 6 of the St. Stephens section). (See analysis 4, p. 87.)

From Hobson's quarry, just above the Lower Salt Works Landing, dowǹ to Oven Bluff, a distance of 2 miles, the "Orbitoides limestone" or "chimney rock" occurs at the base of bluffs of Tertiary age. At the quarry the hard limestone, which is being taken out for riprap work, lies, as at St. Stephens, just above the soft chimney rock. Along the stretch of river above described this chimney rock lies just above the river bottom in a bed 15 or 20 feet thick and is easily accessible. (See analyses 37,38 , and 39, p. 87.) As regards clay, three varieties have been examined, a residual clay from over the limestone, a swamp-bottom clay from the low grounds of Leatherwood Creek, and a clay from the "Grand Gulf formation," which here overlies the St. Stephens limestone.

The first shoal in the river above Mobile is a few miles above Oven Bluff, and from the latter place down there is a 9-foot channel at all seasons, which will give to Oven Bluff a certain advantage in regard to transportation. The shoal mentioned is removable, so that 
St. Stephens may be classed with Oven Bluff as regards transportation by water, except that the former is some miles farther from the Gulf.

At Glendon station, a few miles east of Jackson, an exposure of the chimney rock close to the track is about 20 feet thick and is covered by red residual clay similar to that at St. Stephens and Oven Bluff. The same chimney rock may be seen along the road between the station and Jackson, and no doubt it occurs from Glendon up to Suggsville station within convenient reach of the railroad. Near Suggsville station the same rock occurs within a short distance of the railroad along the road leading from the station to the town.

Between Suggsville and Gosport the country rock is the St. Stephens limestone. There is no railroad between these places.

At Perdue Hill the St. Stephens limestone outcrops near the base of the hills which descend to the terrace on which the town of Claiborne stands. The bluff at Claiborne Landing shows near the summit the calcareous clays or clayey limestone which lies at the base of the St. Stephens, and which is generally thought to be the equivalent of the Jackson group of the Mississippi geologists. It is possible that this rock, where it occurs in sufficient quantity, may be suitable for cement making, since its composition is not very different from much of the Selma chalk. No investigations have yet been made concerning it, for the reason that there are comparatively few points where it appears in adequate thickness and in favorable localities as regards transportation.

At Marshalls Landing, just above the mouth of Randons Creek, at the top of the bluff, beneath the usual covering of residual clay, is the first exposure of the chimney rock along Alabama River. Below the orbitoidal or chimney rock at Marshalls there are 20 feet or more of a porous limestone. In the same bluff there are beds of calcareous clay, which might possibly be used in mixing with the limestone. "(See analysis 5, p. 87.) At the landing these would be difficult to quarry because of overlying strata, but they could certainly be found without cover along the bluffs above Marshalls.

From Marshalls down to Gainestown Landing the river bluffs show beds of the limestone at numerous points. At Gainestown the topmost bed of the St. Stephens, the hard crystalline limestone, occurs not far above the water level in the river. This stone has been cut and polished and proves to be a first-rate marble, taking a good polish and showing agreeable variations in color. The soft chimney rock underlies the hard limestone here as at other points.

At Choctaw Bluff, some miles below Gainestown, the last exposure of the Tertiary limestones on the river is an argillaceous limestone with numerous fossils; it seems hardly. likely to be of use in cement making. 
A few miles east of Marshalls Landing; at Manistee Mills, the terminus of a sawmill road, a quarry of the chimney rock is conveniently situated as to transportation, since it is on the railroad. Across the county to the Repton branch of the Louisville \& Nashville Railroad the St. Stephens limestone may, of course, be found at thousands of places; but only those that lie on a railroad line are here discussed.

Below Monroe station, near Drewry, on the Repton Branch, the Louisville \& Nashville Railroad crosses the outcrop of the chimney rock. A few miles below Drewry, at Manistee Junction, the "Grand Gulf clays" are finely exposed in railroad cuts both north and south of the station. (See analysis 47, p. 87.) Clays which may be suitable for admixture with the limestone are obtained from these cuts. (See analysis 3, p. 87.)

The chimney rock may be found at many points below Evergreen, in the vicinity of Sparta and Castleberry stations. Many bluffs of this rock occur on the banks of Murder Creek in this vicinity, and several quarries from which the stone has been obtained for building purposes are within short distances of the railroad line. At the foot of Taliaferros Heights the limestone forms high bluffs on the creek; at Ellis Williams Spring there are bluffs with the soft rock at the base and the hard horse-bone rock at the top; and on the creek bank a few hundred yards away is one of the quarries mentioned above. In fact, the localities where the rock may be found within convenient distance of the railroad and in a position favorable to cheap quarrying are numerous in all this region. (See analyses 35 and 36, p. 87.) No clays were seen except the usual residual clays from the decomposition of the limestone and a clay occurring close to Evergreen in the pits of Wild Bros. These Evergreen occurrences have attracted attention because of their location on the line of a great railroad system within short distance of tidewater. Farther east the limestone formation extends across Alabama and into Georgia and Florida and is crossed in two places by the Central of Georgia Railway.

To summarize: Though the St. Stephens limestone outcrops across the State from the Mississippi line to Chattahoochee River in many broad belts, attention has been concentrated on those localities which lie upon navigable streams or upon railroad lines terminating in Gulf ports. As compared with the middle division of the Selma chalk, the limestone is more uniform in composition, higher in lime, softer, and more easily quarried and crushed, and in geographical position many miles nearer the Gulf. Its thickness, on the other hand, is much less, although sufficient to supply an indefinite number of cement plants with raw material. 


\section{ANALYSES.}

The following tables give analyses of Cretaceous and Tertiary limestones and clays of central and southern Alabama:

\section{Analyses of Cretaceous and Tertiary limestones.}

\begin{tabular}{|c|c|c|c|c|c|c|c|c|c|c|c|c|}
\hline & 1 & 2 & 3 & 4 & 5 & 6 & 7 & 8 & 9 & 10 & 11 & 12 \\
\hline $\begin{array}{l}\text { Insoluble matter... } \\
\text { Iron oxide and a }\end{array}$ & 29.50 & 23.00 & 18.42 & 27.25 & 19.10 & 21.98 & \begin{tabular}{l|l|} 
& 9.44
\end{tabular} & 16.69 & 16.41 & 11.68 & 26.26 & 31.16 \\
\hline $\begin{array}{r}\left(\mathrm{Fe}_{2} \mathrm{O}_{3} \text { and } \mathrm{Al}_{2} \mathrm{O}_{3}\right) \ldots \ldots \\
\text { Lime carbonate }(\mathrm{CaCO}) \ldots\end{array}$ & $\begin{array}{r}5.00 \\
56.71\end{array}$ & $\begin{array}{r}3.14 \\
67.67\end{array}$ & $\begin{array}{l}10.79 \\
65.21\end{array}$ & $\begin{array}{l}15.96 \\
54.00\end{array}$ & $\begin{array}{r}3.70 \\
75.57\end{array}$ & $\begin{array}{r}4.10 \\
69.75\end{array}$ & $\left|\begin{array}{r}1.76 \\
86.28\end{array}\right|$ & $\begin{array}{r}2.22 \\
80.48\end{array}$ & $\begin{array}{r}3.14 \\
77.43\end{array}$ & $\begin{array}{r}1.82 \\
85.10\end{array}$ & $\begin{array}{r}3.06 \\
67.28\end{array}$ & $\begin{array}{r}5.44 \\
55.84\end{array}$ \\
\hline$\underset{\left(\mathrm{MgCO}_{3}\right)}{\mathrm{Magnesium}}$ carbonate & 1.69 & 2.26 & 1.57 & 1.11 & 1.24 & 1.50 & 1.02 & .53 & 1.30 & 1.25 & 1.87 & 2.12 \\
\hline $\begin{array}{l}\text { Sulphuric trioxide }\left(\mathrm{SO}_{3}\right) \ldots \\
\text { Total sulphur. }\end{array}$ & 1.32 & 1.97 & .30 & $\begin{array}{r}.44 \\
1.23\end{array}$ & .69 & 1.02 & & & & & & \\
\hline Water and organic matter. & 5.78 & 1.96 & $\cdots \cdots$ & ...... & 1.70 & 1.65 & 1.30 & .... & 1.99 & $\cdots$ & 1.53 & 5.44 \\
\hline \multirow[t]{2}{*}{ Total } & & & 97.12 & 99.99 & & & 100.00 & 99.92 & 100.27 & 99.85 & 100.00 & 100.00 \\
\hline & 13 & 14 & 15 & 16 & 17 & 18 & 19 & 20 & 21 & 22 & 23 & 24 \\
\hline Insoluble matt & 31.74 & 14.92 & 13.32 & 6.06 & 15.18 & 12.50 & 41.18 & 3.02 & 14.36 & 15.63 & 16. 18 & 19.20 \\
\hline $\begin{array}{l}\text { Iron oxide and alumina } \\
\left(\mathrm{Fe}_{2} \mathrm{O}_{3} \text { and } \mathrm{Al}_{2} \mathrm{O}_{3}\right) \ldots \ldots \ldots\end{array}$ & 4.42 & 3.46 & 8.74 & 1.62 & 2.22 & 2.76 & 4.16 & 1.10 & 2.80 & 2.02 & 3.08 & 3.58 \\
\hline Lime carbonate $\left(\mathrm{CaCO}_{3}\right) \ldots$ & 65.82 & 78.52 & 73.94 & 90.40 & 78.57 & 80.71 & 44.78 & 93.52 & 80.47 & 78.77 & 75.35 & 72.21 \\
\hline Magnesium car b on a te & & & & 15 & 28 & & 60 & 30 & 301 & 0 & 25 & \\
\hline Sulph & 2.10 & 1.02 & .27 & 1.10 & $\begin{array}{r}1.38 \\
.91\end{array}$ & $\begin{array}{l}1.02 \\
1.62\end{array}$ & 2.08 & 1.38 & 1.30 & 1.04 & 1.35 & 1.98 \\
\hline $\begin{array}{l}\text { Total sulphur.......... } \\
\text { Water and organic ma }\end{array}$ & & & 64 & & & & & & & & & \\
\hline Water and organic matter.. & 5.92 & 2.08 & & .77 & 1.74 & 1.36 & 7.20 & .98 & 1.07 & 2.54 & 4.04 & 3.03 \\
\hline Total. & 100.00 & 100.00 & 98.31 & 100.00 & 100.00 & 100.00 & 100.00 & $|100.00|$ & $100.00 \mid$ & 100.00 & 100.00 & 100.00 \\
\hline
\end{tabular}

1. Gainesville Bluff, Tombigbee River, 5 feet from top of bluff. R. S. Hodges, analyst.

2. Gainesville Bluff, Tombigbee River, lower part of bluff. R. S. Hodges, analyst.

3. Gainesville. F. P. Dewey, analyst.

4. Gainesville. A. W. Dow, analyst.

5. Roberts's place, near Gainesville, top of bluff. R. S. Hodges, analyst.

6. Roberts's place, near Gainesville, 5 feet above water. R. S. Hodges, analyst.

7. Jones Bluff, at Epes. R. S. Hodges, analyst.

8. Jones Bluff, at Epes. Dr. Mallett, analyst.

9. Hillmans Bluff, below Epes. R.S. Hodges, analyst.

10. Bluffport Ferry, Tombigbee River. R. S. Hodges, analyst.

11. Jordans Ferry, Tombigbee River. R. S. Hodges, analyst.

12. Belmont Bluff, Tombigbee River. R. S. Hodges, analyst.

13. Roes Bluff, Tombigbee River, main part of bluff. R. S. Hodges, analyst.

14. Roes Bluff, Tombigbee River, light-colored ledges. R. S. Hodges, analyst.

15. Demopolis, F. P. Dewey. U.S. Mint, analyst.

16. MeDowells Bluff, below Demopolis. R. S. Hodges, analyst.

17. Knoxwood, near Demopolis. R. S. Hodges, analyst.

18. Material used in Demopolis Cement Works. R. S. Hodges, analyst.

19. Hatchs Bluff, Warrior River above Demopolis; main part of bluff. R. S. Hodges, analyst.

20. Hatchs Bluff; Warrior River, above Demopolis; ledges at top of bluff. R. S. Hodges, analyst.

21. At Van Dorn station, from roadside. R. S. Hodges, analyst.

22. At Van Dorn station, railroad cut east of station. R. S. Hodges, analyst.

23. Uniontown, P. H. Pitts, Home place. R. S. Hodges, analyst.

24. Uniontown, P. H. Pitts, Houston place. R. S. Hodges, analyst. 
Analyses of Cretaceous and Tertiary limestones-Continued.

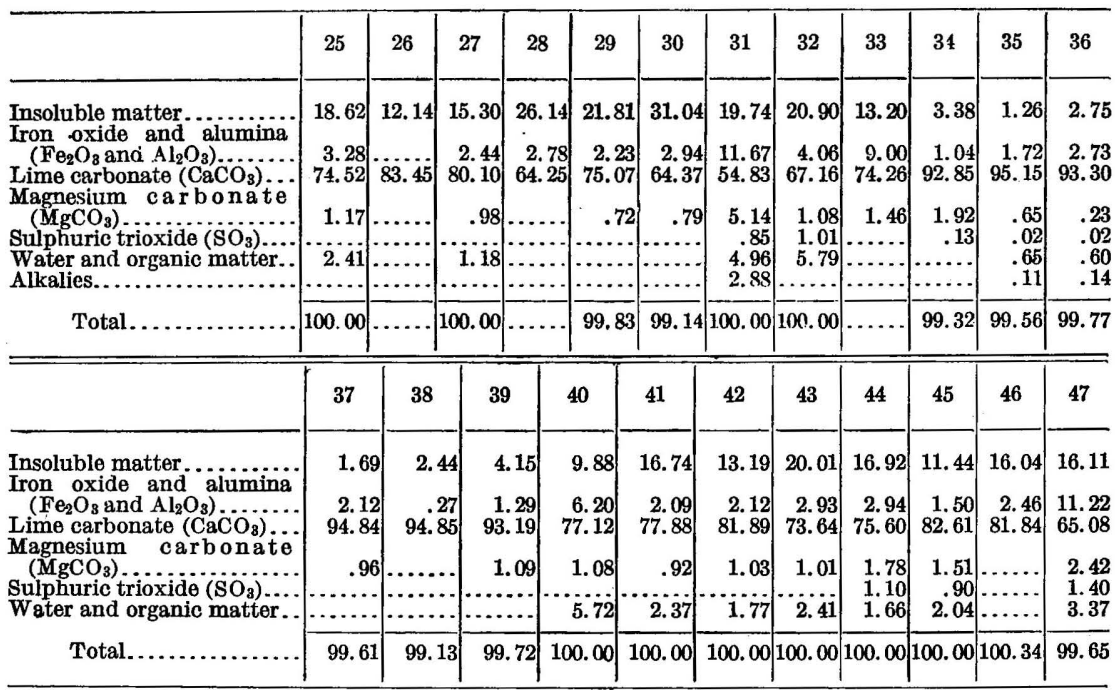

25. Uniontown, P. H. Pitts, Rural Hill place. R. S. Hodges, analyst.

26. Uniontown, 1 mile south, on McKinley road. R. S. Hodges, analyst.

27. Railroad cut, Martins station, Southern Railway, Dallas County. R. S. Hodges, analyst.

28. White Bluff, Alabama River; lower part of bluff. R. S. Hodges, analyst.

29. Demopolis, Tombigbee River. Dr. Mallett, analyst.

30. Limestone from Cahaba, Alabama River. Dr. Mallett, analyst.

31. Limestone from Benton, Alabama River. W. B. Phillips, analyst.

32. Limestone from Manack station, Lowndes County. R. S. Hodges, analyst.

33. Limestone from Manack station. B. B. Ross, analyst.

34. Orbitoidal member of St. Stephens limestone, St. Stephens, Tombigbee River. R. S. Hodges, analyst.

35-36. Orbitoidal member of St. Stephens limestone, near Evergreen. Dr. W. B. Phillips, analyst.

37. Orbitoidal member of St. Stephens limestone, Col. Darrington's, near Oven Bluff, Clarke County. Dr. Mallett, analyst.

38-39. Orbitoidal member of St. Stephens limestone, Clarke County, near river. Dr. Mallett, analyst. 40. Rock used in Alabama Portland Cement Works, Demopolis. Analysis sent in by T. G. Cairns, general manager.

41. Limestone from property of J. B. Kornegay, at Van Dorn, sample No. 1. R. S. Hodges, analyst.

42. Limestone from property of J. B. Kornegay, at Van Dorn, sample No. 2. R. S. Hodges, analyst.

43. Limestone from property of J. B. Kornegay, at Van Dorn; sample No. 3. R. S. Hodges, analyst.

44. Limestone from property of $\dot{J}$. $T$. Collins, at Van Dorn, sample No. 1 ; dark color. $R$. S. Hodges, analyst.

45. Limestone from property of J. T. Collins, at Van Dorn, sample No. 2; light color. R. S. Hodges, analyst.

46. Average of three samples of limestone from near Van Dorn; L. H. Conard, Demopolis. R. S. Hodges, analyst.

47. Limestone from bluff at steamboat landing, Selma. T. W. Miller, analyst.

Analyses of Cretaceous and Tertiary clays.

\begin{tabular}{|c|c|c|c|c|c|}
\hline . & 1 & 2 & 3 & 4 & 5 \\
\hline 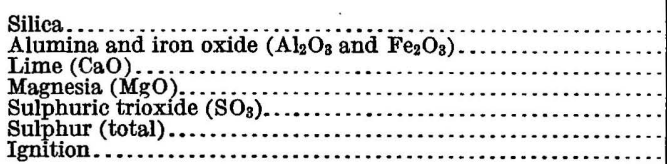 & $\begin{array}{r}69.57 \\
19.04 \\
.37 \\
\cdots \\
\cdots \\
9.68\end{array}$ & $\begin{array}{r}59.71 \\
24.79 \\
.48 \\
+\ldots . \\
14.96\end{array}$ & $\begin{array}{r}66.60 \\
25.86 \\
.34 \\
.34 \\
.89 \\
5.11\end{array}$ & \begin{tabular}{|r|}
49.23 \\
24.42 \\
$\cdots$ \\
$\cdots$ \\
$\cdots$ \\
$\cdots$
\end{tabular} & $\begin{array}{r}51.30 \\
33.22 \\
1.37 \\
.96 \\
.41 \\
\ldots . . .92\end{array}$ \\
\hline 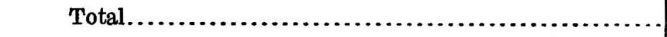 & 98.66 & 99.94 & 99.14 & $\ldots$ & 97.68 \\
\hline
\end{tabular}

1. Residual clay over limestone at P. H. Pitts's home place, Uniontown. R. S. Hodges, analyst.

2. Residual clay over St. Stephens limestone, St. Stephens Bluff. R. S. Hodges, analyst.

3. "Grand Gulf clay," Manistee Junction, Monroe County. T. W. Miller, analyst; average of bed.

4. Clay at water's edge, St. Stephens Bluff. R. S. Hodges, analyst.

5. Residual clay overlying orbitoidal member of the St. Stephens limestone, Marshalls Landing. R. S. Hodges, analyst. 


\section{PORTLAND CEMENT INDUSTRY.}

The Alabama chalks and limestones possess many economic advantages over most other limestones that occur near the Atlantic and Gulf coasts. These advantages may be briefly stated as follows:

1. The deposits of the Selma chalk of the Cretaceous are in general of almost the proper composition for making Portland cement. They require the addition of little or no clay, and in consequence the cost of grinding and mixing is materially less than that of preparing an ordinary limestone-clay mixture. As against this advantage, the chalks have a very low silica-alumina ratio, and many of them are difficult to dry properly. The St. Stephens limestone of the Tertiary is not so near the ideal composition as the Selma chalk but is nevertheless a very satisfactory cement-making material if used in combination with the overlying "Grand Gulf clays."

2. Coal of good quality occurs within a reasonable distance of all the Alabama cement-rock deposits. (See Pl. II.) As the weight of coal used for power and kilns is 50 to 60 per cent of that of the cement produced, a supply of cheap fuel is important to the success of a cement plant.

3. Labor is abundant and cheap in the Coastal Plain cement district of central and southern Alabama and is reasonably so in northern Alabama.

4. In addition to supplying the market for cement in such cities as Atlanta, Birmingham, Mobile, and New Orleans, cement plants on the navigable rivers of Alabama can place their product at any point on the Gulf or southern Atlantic seaboard at very low prices, for the cost of transportation by water is low compared with the railroad freight rates which most other plants will be compelled to pay.

In view of these advantages it seems reasonable to expect that in the near future Alabama will take high rank among the States as a producer of Portland cement. In 1911 two plants were in operation, one old plant was idle, one under construction, and others were in various stages of promotion. The two operating plants are at Leeds and at Ragland.

The oldest plant, now inactive, is owned by the Alabama Portland Cement Co. and is located at Spocari, near Demopolis, Marengo County, on the line of the Southern Railway. The raw materials used were the soft chalky limestone of the Cretaceous and a residual clay, both occurring in the immediate vicinity of the plant. Analyses 1 and 2 of the following table show the composition of the limestone used at the plant and analyses 3 and 4 that from near-by localities. The limestone actually quarried runs a little too high in lime carbonate to make a good Portland cement by itself and a small amount of clay is added to get the proper mixture. No analyses of this clay are at present available. 
Analyses of limestone near Demopolis, Ala.

\begin{tabular}{|c|c|c|c|c|}
\hline . & 1 & 2 & 3 & 4 \\
\hline 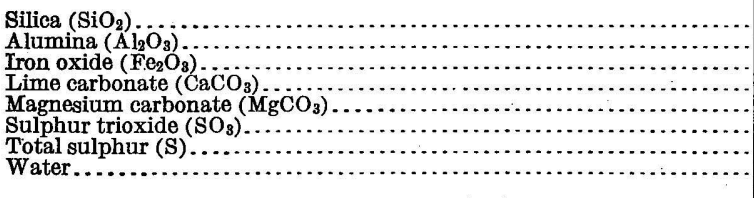 & $\begin{array}{r}12.50 \\
2.76 \\
80.71 \\
1.05 \\
1.62 \\
\text { n. d. } \\
1.36\end{array}$ & $\begin{array}{r}9.88 \\
6.20 \\
77.12 \\
1.08 \\
\text { n. d. } \\
\text { n. d. } \\
\text { 5. } 72\end{array}$ & $\left\{\begin{array}{r}12.13 \\
4.17 \\
3.28 \\
75.07 \\
.92 \\
\text { n.d. } \\
\text { n.d. } \\
\text { n.d. }\end{array}\right.$ & $\begin{array}{r}13.32 \\
8.74 \\
73.94 \\
1.40 \\
.27 \\
.64 \\
\text { n. d. }\end{array}$ \\
\hline
\end{tabular}

1. Quarry Alabama Portland Cement Co. R. S. Hodges, analyst.

2. Quarry Alabama Portland Cement Co. S. Doc. No. 19, 58th Cong., 1st sess., 1903, p. 22.

3. Demopolis. Proc. Alabama Industrial and Scientific Soc., vol. 5, 1895, pp. 44-51.

4. Demopotis. F. P. Dewey, analyst.

The following analyses are of the "Red Diamond" brand of Portland cement, manufactured at this plant:

Analyses of Portland cement made near Demopolis, Ala.

\begin{tabular}{|c|c|c|c|c|c|}
\hline . & 1 & 2 & 3 & 4 & 5 \\
\hline Silica $\left(\mathrm{SiO}_{2}\right)$ & 20.54 & 20.25 & 19.99 & 19.91 & 19.56 \\
\hline Alumina $\left(\mathrm{Al}_{2} \mathrm{O}_{3}\right) \ldots$ & $\begin{array}{l}8.55 \\
3.84\end{array}$ & 13.44 & 13.74 & 13.63 & 12.16 \\
\hline Lime $(\mathrm{CaO})$ & $\begin{array}{r}5.84 \\
63.85\end{array}$ & 63.60 & 61.36 & 63.82 & 62.27 \\
\hline Magnesia (MgO). & .66 & 1.03 & .61 & .83 & .64 \\
\hline Sulphur trioxide ( $\mathrm{SO}_{3}$ & n. d. & .41 & n. d. & 1.16 & \\
\hline Total sulphur (S)..... & n. d. & .99 & n. d. & n. d. & n. d. \\
\hline Water, otc.... & 1.34 & n. d. & n. d. & n. d. & n. d. \\
\hline
\end{tabular}

1. Clinker. F. W. Clarke, analyst.

2. Cement. A. W. Dow, analyst.

3. Cement. S. Doc. No. 19, 58th Cong., 1st sess., 1903, p. 23.

4. Cement. R. S. Hodges, analyst.

5. Cement. Cement Directory, 2d ed., 1903, p. 254.

The second Portland cement plant to go into operation in Alabama was that of the Standard Portland Cement Co. at Leeds. The raw materials used are pure limestone of Trenton age (Chickamauga limestone) and shales of the Clinton ("Rockwood") formation. A plant of the Atlantic \& Gulf Portland Cement Co., near Ragland, using Chickamauga limestone and Carboniferous shale, has gone into operation recently.

Among prospective plants in various stages of promotion or construction may be mentioned a plant at St. Stephens, near Mobile, to use St. Stephens limestone and overlying clay; a plant near Blount Springs, to use Bangor limestone and probably shales of the Clinton formation; and a plant near Ensley, to use blast furnace slag and limestone of Chickamauga or Bangor age.

\section{BIBLIOGRAPHY.}

Smith, E. A., Alabama's resources for the manufacture of Portland cement: Proc. Alabama Indus. and Sci. Soc., vol. 5, 1895, pp. 44-51; Tradesman, Dec. 15, 1895. - Cement resources of Alabama: Bull. U. S. Geol. Survey No. 225, 1904, pp. 424-447.

- and Eckes, E. C., The cement resources of Alabama: S. Doc. No. 19, 53d Cong., 1st sess., 1903, 23 pp.

Survey No. 8, 1904, 93 pp.

- and Ries, HeINRICH, Preliminary report on the clays of Alabama: Bull. Alabama Geol. Survey No. 6, 1900, 220 pp. 


\section{PORTLAND CEMENT RESOURCES OF ARIZONA.}

\section{PORTLAND CEMENT MATERIALS.}

Very little detailed information is available concerning either the areal distribution or the chemical composition of the limestones of Arizona. Reports on mining districts contain scattered notes on distribution, but give few analyses. Some data are available in regard to several specific cement properties in the State.

In 1905, though no commercial Portland cement industry had previously been established in Arizona, a plant was started and operated there by the United States Reclamation Service. This interesting experiment in Federal ownership of an industrial enterprise was due to the necessity for procuring large supplies of cement, at a reasonable price, for one of the largest of the projected irrigation dams (the Roosevelt dam), which was to be constructed in the Salt River valley. At that date cement for this dam could have been obtained only from plants on the Pacific coast, at Salt Lake City, or in Colorado; and freight rates would have made the cost prohibitive.

The results of analysis of a number of raw materials occurring near the dam site are given in the following table. Nos. 1 and 2 represent the range of the limestone and Nos. 6 and 7 the clays used at the cement plant.

Analyses of limestones and shales from Tonto dam site, Arizona.

\begin{tabular}{|c|c|c|c|c|c|c|c|c|}
\hline & 1 & 2 & 3 & 4 & 5 & 6 & 7 & 8 \\
\hline 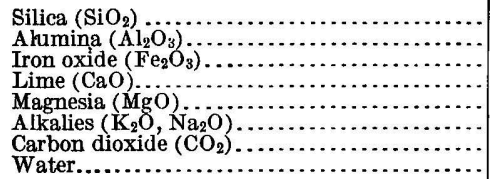 & $\left\{\begin{array}{r}3.30 \\
.20 \\
53.65 \\
.60 \\
\text { n. d. } \\
\text { n. d. } \\
\cdots \cdots . . .\end{array}\right.$ & $\begin{array}{r}0.51 \\
.20 \\
55.56 \\
.10 \\
\text { n. d. } \\
43.77 \\
\cdots \cdots\end{array}$ & $\begin{array}{r}50.60 \\
15.80 \\
9.30 \\
4.07 \\
\text { n. d. } \\
\text { n. d. } \\
2.80\end{array}$ & $\begin{array}{r}55.70 \\
20.50 \\
6.61 \\
\cdots . . . \\
\text { n. d. } \\
\text { n. d. } \\
11.25\end{array}$ & $\begin{array}{r}51.00 \\
16.70 \\
3.39 \\
4.58 \\
\text { n. d. } \\
\text { n. d. } \\
20.10\end{array}$ & $\begin{array}{r}51.90 \\
23.70 \\
6.10 \\
.97 \\
\text { n. d. } \\
\text { n. d. } \\
13.40\end{array}$ & $\mid \begin{array}{r}50.51 \\
14.63 \\
5.03 \\
6.77 \\
3.00 \\
5.24 \\
13.30\end{array}$ & $\left\{\begin{array}{r}67.90 \\
18.00 \\
\text { n. d. } \\
\text { n. d. } \\
\ldots . . .\end{array}\right.$ \\
\hline
\end{tabular}

1. Limestone near dam site. E. Duryee, analyst. Water-Supply Paper U. S. Geol. Survey No. 73, 1902 , p. 48.

2. Limestone near dam site. U. S. Geol. Survey laboratory, analyst. Tdem, p. 49.

3. Shale near dam site. E. Duryee, analyst. Idem, p. 48 .

4. Clay 1 mile from dam site. E. Duryee, analyst. Idem.

5. Clay from Sallie May Canyon. E. Duryee, analyst. Idem.

6. Clay 3 miles north of dam site. E. Duryee, analyst. Idem.

7. Clay 3 miles north of dam site. U. S. Geol. Survey laboratory, analyst. Idem, p. 49.

8. Shale from canyon below dam site. E. Duryee, analyst. Idem, p. 48.

Samples of limestone from places along or near Gila River, near projected dams for irrigation purposes, were analyzed by E. Duryee with a view to determining their value as Portland cement materials. These analyses are given in the following table: 
Analyses of limestone near Gila River, Ariz.

[E. Duryee, analyst.]

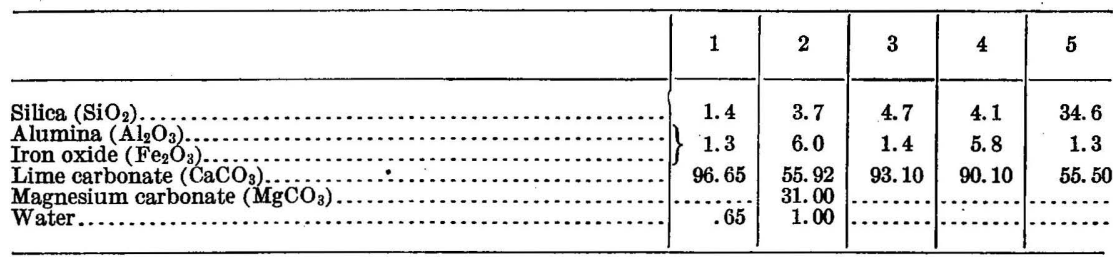

1. San Carlos, gray. 2. San Carlos, pink. 3. Riverside, blue. 4. Queen Creek, blue. 5. Queen Creek, gray.

None of these latter samples have been utilized to the present date.

The following analyses ${ }^{1}$ of limestone from the Bisbee district of southeastern Arizona were made by W. F. Hillebrand on samples collected by F. L. Ransome:

Analyses of limestones from Bisbee district, Arizona.

\begin{tabular}{|c|c|c|c|c|c|}
\hline & 1 & 2 & 3 & 4 & 5 \\
\hline 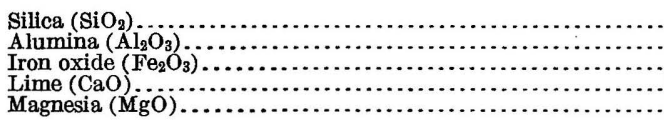 & $\begin{array}{r}11.80 \\
2.15 \\
1.08 \\
45.86 \\
.48\end{array}$ & \begin{tabular}{r|}
12.53 \\
1.04 \\
1.26 \\
27.28 \\
17.41
\end{tabular} & $\begin{array}{r}8.52 \\
.64 \\
50.07 \\
.55\end{array}$ & $\begin{array}{r}0.06 \\
.12 \\
55.80 \\
.13\end{array}$ & $\begin{array}{r}2.52 \\
.24 \\
53.68 \\
.46\end{array}$ \\
\hline
\end{tabular}

1. Abrigo limestone, Cambrian.

2. Abrigo limestone, Cambrian.

3. Martin limestone, Devonian.

4. Escabrosa limestone, Mississippian.

5. Naco limestone, Pennsylvanian.

PORTLAND CEMENT INDUSTRY IN ARIŹONA.

The Government plant at the Roosevelt (Salt River) dam was sold to private parties after the completion of the dam. It will be removed to a point near Phoenix and operated as a commercial plant.

Though cement has at present no large market in Arizona, considerable local demand for it exists for use in railroad construction and in the mining camps. A small plant, therefore, may find a local market for its product.

\section{BIBLIOGRAPHY.}

Davis, A. P., and Duryee, E., Tests of cement materials from Salt River, Arizona:

Water-Supply Paper U. S. Geol. Survey No. 73, 1902, pp. 48-51.

Duryee, E., Tests of cement materials from Gila River, Arizona: Water-Supply

Paper U. S. Geol. Survey No. 33, 1900, pp. 82-90.

—- Cement investigations in Arizona: Bull. U. S. Geol. Survey No. 213, 1903, pp. 372-380.

Ransome, F. L., Geology of the Globe copper district, Arizona: Prof. Paper U. S.

Geol. Survey No. 12, 1903, 168 pp.

Geology and ore deposits of the Bisbee quadrangle, Arizona: Prof. Paper

U. S. Geol. Survey No. 21, 1904, 168 pp. 


\section{PORTLAND CEMENT RESOURCES OF ARKANSAS.}

\section{PORTLAND CEMENT MATERIALS.}

Arkansas is divided geologically into two very distinct parts, only one of which is provided with materials adapted for use in Portland cement manufacture. The portion of the State lying southeast of a line drawn through Pocahontas, Powhatan, Jacksonport, Searcy, Little Rock, Benton, Arkadelphia, Prescott, and Texarkana is covered by clays and gravels and contains absolutely no limestones fit for use in cement manufacture. In the region northwest of that line, however, a number of limestones are available for making cement.

\section{LIMESTONES.}

Of the limestone formations in Arkansas seven seem to be worth considering as possible sources of cement materials. These limestones, which will be described below, ${ }^{1}$ are the following:

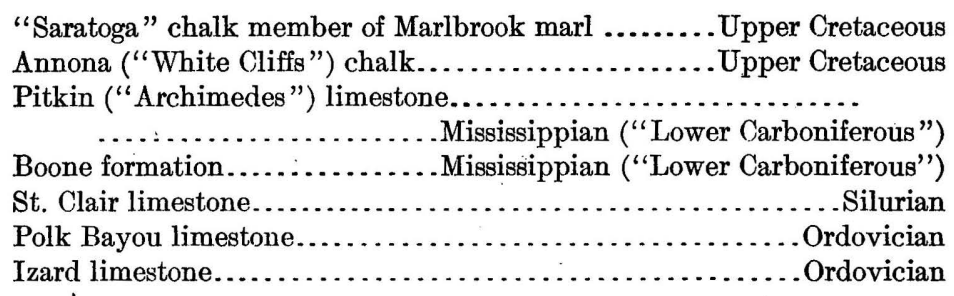

IZARD LIMESTONE.

The Izard limestone occurs in Independence, Izard, Stone, Searcy, Marion, and Newton counties. It is found in quantity on all the main branches of Lafferty Creek and at some points reaches a thickness of 200 feet. In places it occurs in almost perpendicular bluffs, but more commonly it is seen in steep, terraced slopes. The finest exposures are along the tributary flowing west from Cushman, known as Blowing Cave Creek; in the ravine in the north part of sec. 13, T. 14 N., R. 8 W., and on the lower part of West Lafferty Creek for 4 miles above its junction with East Lafferty. In secs. 3 and 10, T. 14 N., R. 8 W., the exposures are especially noteworthy both for quantity and quality.

At Penters Bluff on White River and in the adjoining region the limestone is admirably situated for quarrying. Penters Bluff is almost perpendicular and is more than 400 feet high, 285 feet of the base being Izard limestone. In the rear of the lower end of the bluff a ravine from a fourth to half a mile in length penetrates the hill at a small angle from the course of the river, leaving a high narrow wall,

\footnotetext{
1 Abstracted from discussions of the Silurian and Carboniferous limestones by T. C. Hopkins (Marbles and other limestones: Ann. Rept. Arkansas Geol. Survey for 1890, vol. 4, 1893), and of the Cretaceous chalks by J. A. Taff (Chalk of southwestern Arkansas: Twenty-second Ann. Rept. U. S. Geol. Survey, pt. 3, 1902, pp. 687-742). E. O. Ulrich has kindly furnished many data concerning the Paleozoic limestones.
} 
which has an abrupt face riverward and is so close to the river bank that there is scarcely room for the road along its base. The rear of this wall is a steep, terraced slope facing the ravine. The slope of the south end of the wall is rather steep for 60 to 70 feet from its base; farther up it is gentler. The rocks have a low dip to the southeast. The south end of the bluff for about a quarter of a mile consists entirely of the Izard limestone.

West of Penters Bluff, on the north side of White River, the limestone is covered in a few places by the chert débris but crops out almost continuously along the hills next to the river and on the lower course of all its tributaries at least as far as Mount Olive.

The largest and most conspicuous outcrop of Izard limestone west of Penters Bluff is on Wilson Creek in the northwestern part of the Batesville quadrangle. At the base of the hill on each side of the creek are from 100 to 200 feet of Izard limestone. The bottom of the bed is not exposed. At some places the limestone outcrops in solid continuous layers; at others the surface is covered with more or less regular rectangular blocks, the result of weathering. The position of the stone for quarrying is all that could be desired.

In the eastern part of Stone County the Izard limestone is extensively developed on the south side of White River. Along the river from a point opposite Penters Bluff to the lower end of Round Bottom this limestone forms the base of the hills and is from 100 to 200 feet thick. Up the river from Round Bottom the base of the hills is composed of saccharoidal sandstone, the Izard limestone lying near the top. Toward the north the Izard limestone gradually approaches the tops of the hills until it thins out and disappears entirely in the northern part of the county, being replaced by the underlying rocks. It appears in large exposures along Cagen and Dry creeks, Rocky Bayou, Hell Creek, and South Sylamore Creek and in smaller quantities on North Sylamore and Livingstone creeks.

In Searcy County the Izard limestone is not nearly so thick as it is farther east, for it gradually thins to the west. It occurs in considerable quantities along Big Spring, Bald Knob, Little Rock, Rock, Brush, and Bear creeks, on the south side of Buffalo River, and on the north side of Mill and Jimisons creeks.

In the eastern part of Newton County a small quantity of Izard limestone occurs along Buffalo River, the most western outcrop noted being in sec. 26, T. 16 N., R. 21 W., about a mile below Jasper.

The Izard limestone is seen at its maximum thickness on White River at Penters Bluff, Izard County, where 285 feet are exposed, and the bed extends below the level of the river, so that the total thickness can not be ascertained. From this point it gradually thins eastward to R. 4 W. in Independence County and westward to R. 18 W. near the western border of Searcy County. It thus has an east-west extent 
of more than 80 miles. Its width north and south varies from 3 to 10 miles, depending on the topography. At Rocky Bayou its thickness is 160 feet; at Roasting Ear Creek, 150 feet; at St. Joe, 150 feet; on Jimisons Creek, southwest from St. Joe, 50 feet; at Penters Bluff, the lowest exposure on White River, 285 feet; and in sec. 26, T. $15 \mathrm{~N}$., R. 10 W., opposite the lower end of Round Bottom, 130 feet. It extends much farther up the river and ends somewhere between the mouth of Livingstone Creek and Rappied Branch. On the east end of the river bluff, above the mouth of Hidden Creek, it is 250 feet thick.

The Izard limestone is a smooth, fine-grained, compact, homogeneous, nonfossiliferous, even-bedded limestone, breaking with a conchoidal fracture. It is mostly of a dark-blue color, varying locally to buff, light and dark gray, and almost black.

Partial analyses of Izard limestone.

\begin{tabular}{|c|c|c|}
\hline & $\begin{array}{c}\text { From Polk } \\
\text { Bayou. }\end{array}$ & $\begin{array}{l}\text { Lithograph- } \\
\text { ic quarry, } \\
\text { Lafferty } \\
\text { Creek. }\end{array}$ \\
\hline $\begin{array}{l}\text { Insoluble in hydrochloric acid. } \\
\text { Carbonate of lime (CaCO} \\
\text { Carbonate of magnesia }\left(\mathrm{MgCO}_{3}\right)\end{array}$ & $\begin{array}{r}1.44 \\
97.97\end{array}$ & $\begin{array}{r}0.34 \\
98.67 \\
2.14\end{array}$ \\
\hline 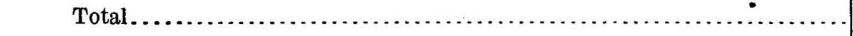 & 99.41 & 101.15 \\
\hline
\end{tabular}

POLK BAYOU AND ST. CLAIR LIMESTONES.

On the north side of White River the Polk Bayou and St. Clair limestones outcrop over a somewhat irregular belt 80 miles or more in length and from 2 to 10 miles in width, running across the central part of north Arkansas in a nearly east-west direction, and extending from Hickory Valley in R. 5 W. to Mount Hersey in R. 19 W., with isolated outcrops as far west as Jasper, in R. 21 W. In Independence County; at the eastern end of the area, the outcrop is all on the north side of White River. It crosses White River at Penters Bluff, from which place it is found only on the south side of the river. Its northwestern boundary in the main is the fault near St. Joe.

In the western part of the area the outcrop is comparatively thin, the maximum thickness being exposed at Penters Bluff. The western and northwestern limits are fairly well defined. On the south the rocks dip beneath the overlying Mississippian beds of the Boston Mountains.

On the south side of White River, as on the north side, the marble outcrops along the narrow, winding watercourses. On both sides of the river the rocks have a gentle south dip, so that as the northern limit of the outcrop is approached the limestones occur higher and higher up the hillsides until they are finally displaced by the under- 
lying Ordovician rocks. On the south side of the river the limestones gradually descend to the beds of the streams, where they dip away gently toward the south, disappearing beneath the overlying Mississippian rocks. Except where concealed by the chert débris, the limestone outcrop on the south side of the river is continuous as far west at least as R. $12 \mathrm{~W}$.

The eastern limit of the limestone outcrop on the south side of White River is in the NW. $\frac{1}{4}$ sec. 5, T. 14 N., R. 8 W., just above Penters Bluff. Opposite the bluff the limestone is concealed by chert débris. Upstream from the outcrop in sec. 5 the hills become steeper and are so close to the river that from Penters Bluff to the mouth of Sylamore Creek they form a river bluff, which is broken by numerous small creeks and ravines and by two short strips of alluvium-Jones Bottom, in R. 9 W., and Round Bottom, in R. 10 W. This bluff is not so high nor so prominent as Penters Bluff, but it consists of the same rocks-Izard limestone at the base, overlain by Polk Bayou limestone, which is capped with chert.

The St. Clair and Polk Bayou limestones, considered together, form one of the thickest and most important series of limestones in the State. They are underlain by the blue Izard limestone and overlain by the Devonian Chattanooga shale or its basal sandstone member (Sylamore), in places an inconspicuous bed only a few inches in thickness. In the absence of both the Sylamore sandstone member and the rest of the Chattanooga shale the St. Clair and Polk Bayou limestones are overlain by the St. Joe limestone, which forms the basal member of the Boone formation.

The maximum thickness of these formations, which is 155 feet or more, is at Penters Bluff, on White River. The limestones thin out gradually toward the east, west, and north; on Polk Bayou they are probably not more than $\mathbf{1 0 0}$ feet thick, and on Dota Creek, still farther east near the Paleozoic border, they do not occur at all. Above the mouth of Hidden Creek, on White River, they are 50 feet thick; but a few miles farther up the river, below the mouth of Twin Creek, only a trace of them remain. On the south side of White River, on Little Rocky Bayou, the thickness is from 25 to 40 feet; on South Sylamore it is from 25 to 50 feet, and at St. Joe it is from 20 to 30 feet.

In general, both the Polk Bayou and the St. Clair limestones are highly crystalline, being composed of small crystals of nearly uniform size. They are tenacious, easily cut, break with difficulty, and have a slightly conchoidal fracture. In weathering the crystals are separated, and the material then resembles coarse sand.

These formations commonly outcrop in heavy layers from 2 to 4 feet or more in thickness; but in some places the rock is massive, the entire exposure being in one solid bed. 
Except where deeply stained with manganese and iron the St. Clair limestone is a remarkably pure carbonate of lime.

Analyses of St. Clair and Polk Bayou limestones.

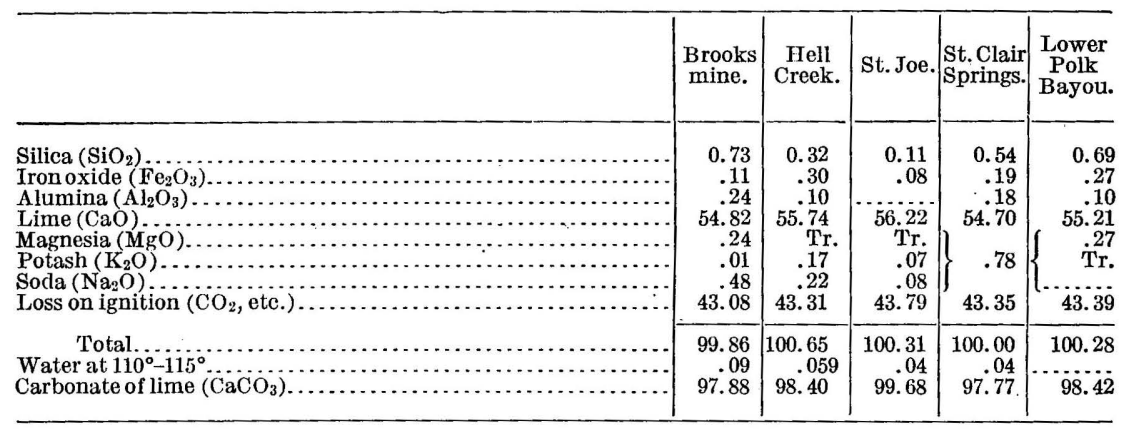

ST. JOE LIMESTONE MEMBER OF BOONE FORMATION.

St. Joe marble is the name given by the Arkansas geologists to the conspicuous bed of red limestone which is widely distributed over nearly all the counties of Arkansas north of the Boston Mountains. It is so named from the village of St. Joe, in Searcy County, Ark., where there is a typical exposure and where it was first studied by the Arkansas Geological Survey. In the publications of the United States Geological Survey this bed is termed the St. Joe limestone member of the Boone formation.

The St. Joe limestone is situated at the base of the Boone formation, of which it forms a part. It is underlain by the Chattanooga shale, where that formation occurs, or by Silurian or Ordovician rocks. In the eastern part of the marble area of the State it overlies the St. Clair limestone, from which it is separated in most places by a thin bed of Devonian shale or sandstone; west and north of the borders of the St. Clair limestone it overiies the Ordovician saccharoidal St. Peter sandstone or the Yellville limestone, with either of which, in the local absence of the Devonian Chattanooga shale, it may be in direct contact.

The thickness of the St. Joe limestone member throughout the greater part of the area in which it occurs is from 25 to 40 feet. But as in many places no definite line of demarcation exists between the marble and the overlying chert, the upper limit of the marble is somewhat questionable. In some places in the eastern part of the area the chert rests directly on the Ordovician rocks, showing the entire absence of the St. Joe, and in other places, as in the vicinity of Marble City, the chert is at one place 100 feet and at another 250 feet above the bottom of the marble. In such places, however, the upper part of the bed is of gray limestone similar to that interbedded with the 
chert elsewhere, but no sharp line can be drawn between the red marble at the base and the gray limestone overlying it, for the two gradually merge into each other.

The chemical analyses given in the accompanying table show the St. Joe limestone to be a comparatively pure carbonate of lime.

Analyses of limestone from St. Joe limestone member of Boone formation.

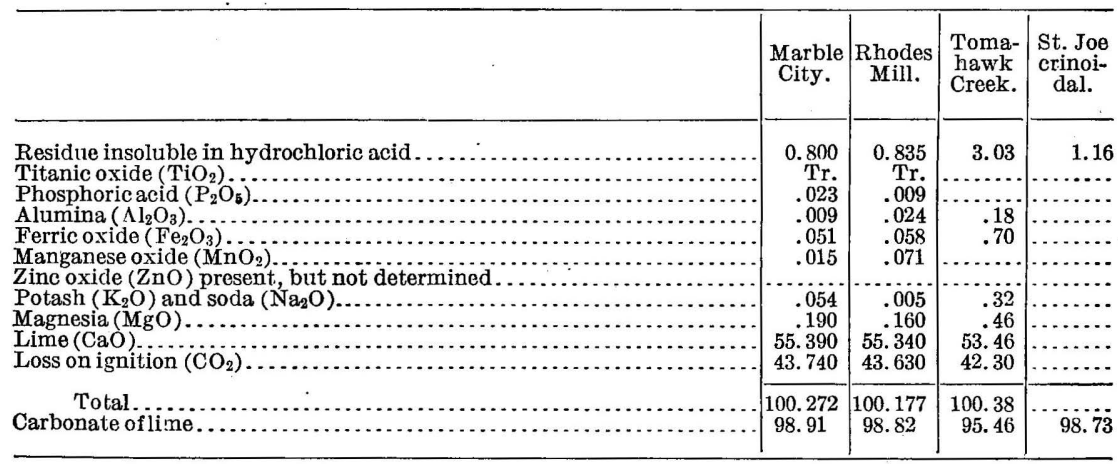

LIMESTONES OF THE BOONE FORMATION.

The Boone formation contains large quantities of limestone, some of the most valuable beds in the State occurring in it. In different parts of the region it differs widely both in quantity and quality. In some places it is made up almost entirely of limestone, and in others it consists almost entirely of chert. For convenience it is considered under three heads: (1) The limestone underlying the chert; (2) the limestone overlying the chert; and (3) the limestone in the chert bed.

LIMESTONE UNDERLYING THE CHERT.

The bed underlying the chert has been designated the St. Joe limestone member and has already been described in detail.

LIMESTONE OVERLYING THE CHERT.

The limestone overlying the chert is classed as part of the chert bed, but in many places it is apparently separate. In most places it is dark gray on a fresh fracture but changes on exposure to light gray, on account of the loss of bituminous matter. In some places the rock is almost entirely free from organic matter. It is coarsely crystalline, slightly fossiliferous, homogeneous in texture, very tenacious and has a conchoidal fracture. It gives out a fetid odor on a fresh surface. In few places does it present sharp edges on weathered exposures but outcrops in rounded bowlders or prominences through the soil. In places the limestone contains numerous small angular fragments of chert.

$48834^{\circ}-$ Bull, 522-13-7 
The limestone overlying the chert bed was not observed in the eastern part of northwestern Arkansas, where, however, limestone does occur in many places near the top of the chert bed but either contains intercalated chert or is overlain by thin layers of chert and is distinct lithologically from the bed overlying the chert in the western part of the area. ${ }^{1}$. It occurs in the western part of the State, in Carroll, Madison, Benton, and Washington counties, where it outcrops around the numerous outliers of the Boston Mountains. Comparatively small quantities of it are exposed on Grindstone and Pond mountains, near Eureka Springs, but on Swain Mountain, T. 19 N., R. $26 \mathrm{~W}$., it forms a prominent ledge around the east end of the mountain between the chert and the overlying Batesville sandstone, outcropping in rounded ledges along the Eureka Springs-Huntsville road, where it is very dark, almost black, on a fresh surface. It is exposed in large quantities in Stanley Branch around the borders of the Batesville sandstone areas, in heavy ledges around the base of Keefer Mountain south of Hindsville, about Goshen, in T. 17 N., R. $28 \mathrm{~W}$., on the tributaries of Richland Creek, and on Poor, Ellis, Humphrey, Blansett, and other mountains on the west side of White River.

LIMESTONES IN THE CHERT BED.

Though most variable in quantity and quality, the limestones in the chert form some of the largest and most valuable beds in North Arkansas. Instead of a persistent, clearly defined bed of limestone running through the chert, there is rather a bed of chert, with large quantities of limestone variously mixed through it. In some places the limestone occurs in irregular layers, varying from an inch to a foot or more in thickness, intercalated with like irregular layers of chert; in other places it occurs in lenticular masses; again, the chert occurs in lenticular or nodular masses in the limestone; in still others the chert and limestone are so intimately diffused that it is not possible to draw any sharp line between them. In many localities, however, the limestone forms a bed from 20 to 100 feet or more in thickness, almost or entirely free from chert, and it is in such places that the stone acquires economic value. The variability of the Boone formation is largely due to local causes favoring or retarding replacement of limestone by chert.

Nearly all the limestone in the chert is more or less crystalline, but it is much more so in some places than in others. In a general way it is more crystalline in the central part of the area than it is either to the east or west and more crystalline to the east than to the west.

There are many local changes in color, texture, and structure of the limestone in the chert, and there are some distinctly marked varieties of it.

1 E. O. Ulrich states that part of this limestone-the black variety-is a bed in the basal part of the Fayetteville shale. 
The oolitic limestone, which is one of the most valuable varieties, is known to occur at three localities-northeast of Batesville; near War Eagle Creek, about 4 miles north of Huntsville; and on Brush Creek, in T. 17 N., R. 28 W. The rock at Batesville ${ }^{1}$ occurs in layers from 3 to 5 feet thick and can be quarried in as large pieces as can be handled. In color and appearance it somewhat resembles the oolitic stone of Indiana, but it is harder and more crystalline than most of the latter and is harder to work. At the two other localities it is lighter colored, softer, and more easily wrought.

Another variety, found in the western part of Independence County, is a hard, compact, close-grained, finely crystalline, slightly fossiliferous, dark-colored stone, the dark color being due to bituminous matter, which in some places occurs only in such small quantities as to give the stone a light-gray color. In some places the limestone develops a shaly structure, but in most places it occurs in firm, solid, and resonant layers from 2 inches to 3 feet thick.

A variety widely distributed over the central part of the area is highly fossiliferous, coarsely crystalline, and varies from light to dark gray in color. The fossils are mostly crinoid stems, though the rock contains numerous bryozoans and brachiopods. In some places it contains considerable amorphous matter, but at many others it is almost completely crystalline.

The limestones in the chert vary greatly in composition, ranging by close gradations from chert to almost pure calcium carbonate. However, nearly all the large beds are comparatively pure carbonate of lime. Some nodules or lenticular masses of chert occur in the heavy beds of limestone, but nowhere was any considerable quantity of silica found diffused through them. The whole series, in fact, might be divided into (1) chert almost free from lime, (2) calcareous chert or siliceous limestone, and (3) comparatively pure limestone.

Analyses of limestones from chert bed in Boone formation.

\begin{tabular}{|c|c|c|c|}
\hline . & 1 & 2 & 3 \\
\hline 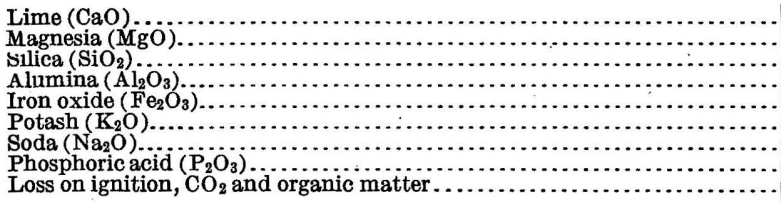 & $\begin{array}{r}55.17 \\
\operatorname{Tr} . \\
1.61 \\
.00 \\
.14 \\
.14 \\
.09 \\
.10 \\
43.13\end{array}$ & $\begin{array}{r}55.42 \\
.39 \\
.68 \\
.00 \\
.32 \\
.19 \\
.19 \\
.17 \\
43.56\end{array}$ & $\begin{array}{r}56.14 \\
\text { Tr. } \\
.30 \\
.00 \\
.06 \\
.12 \\
.08 \\
\text { Tr. } \\
43.77\end{array}$ \\
\hline 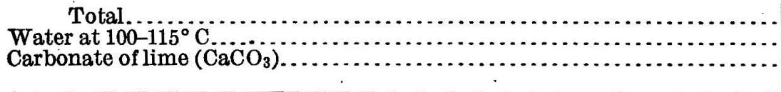 & $\begin{array}{l}100.38 \\
.057 \\
98.29\end{array}$ & $\begin{array}{r}100.92 \\
.09 \\
98.59\end{array}$ & $\begin{array}{r}100.47 \\
.49 \\
100.23\end{array}$ \\
\hline
\end{tabular}

1. Allen's quarry; Polk Bayou, sec. 4, T. 13 N., R. 6 W.

2. Near Victor post office, sec. 10, T. 13 N., R. 7 W.

3. Mill Creek, sec. 13, T. 16 N., R. 18 W.

1 According to E. O. Ulrich this rock overlies the Boone and belongs to the Moorefield shale. 
Partial analyses of limestone from the chert bed in Boone formation.

\begin{tabular}{|c|c|c|c|c|c|c|c|}
\hline & 1 & 2 & 3 & 4 & 5 & 6 & 7 \\
\hline 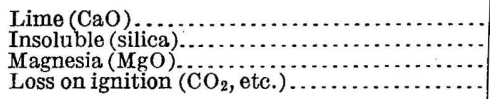 & $\begin{array}{r}54.92 \\
1.47 \\
.\end{array}$ & $\begin{array}{r}53.66 \\
4.38 \\
2\end{array}$ & $\begin{array}{r}55.06 \\
\cdots .03 \\
\ldots\end{array}$ & $\begin{array}{r}54.89 \\
.21\end{array}$ & $\begin{array}{r}55.09 \\
.50 \\
43.61\end{array}$ & $\begin{array}{r}56.15 \\
.19 \\
43.58\end{array}$ & $\begin{array}{r}55.12 \\
.28 \\
.45 \\
. . .\end{array}$ \\
\hline $\begin{array}{l}\text { Total } \\
\text { Water at } 110-115^{\circ} \mathrm{C}\left(\mathrm{CaCO}_{3}\right) \\
\text { Calcium carbonate } \\
\text { Magnesium carbonate }\left(\mathrm{MgCO}_{3}\right) \ldots\end{array}$ & $\begin{array}{r}56.39 \\
.10 \\
98.07\end{array}$ & $\begin{array}{r}58.04 \\
.31 \\
95.82\end{array}$ & \begin{tabular}{c}
55.09 \\
\hdashline 98.32
\end{tabular} & $\begin{array}{r}55.10 \\
\hdashline 98.02\end{array}$ & $\begin{array}{r}99.20 \\
.03 \\
98.37\end{array}$ & $\begin{array}{r}99.92 \\
100.25 \\
-2 .\end{array}$ & $\begin{array}{r}55.85 \\
98.43 \\
.95\end{array}$ \\
\hline
\end{tabular}

1. Loster's spring.

2. Jones quarry.

3. Pond Mountain, sec. 23 , T. 20 N., R. 26 W.

4. Limekiln at Rogers.

5. Brush Creek, Madison County, sec. 25, T. 17 N., R. 28 W.

6. Sec. 15 , T. 17 N., R. 26 W.

7. Denieville, Independence County.

PITKIN ("ARCHIMEDES") LIMESTONE.

The Pitkin ("Archimedes") limestone is impure, generally loose textured, very fossiliferous, and varies from bluish-gray to brown. In most places it is distinguished by a spiral-shaped bryozoan of the genus Archimedes, from which its former name was derived. The compactness of the stone appears to vary with the size of the fossils. Where these are large the texture is open, or even loosely aggregated; where they are small they are closely compacted and the rock is firm and durable. In some places the formation grades into sandstone, the change being so gradual that no line of demarcation is visible; in other places it is very argillaceous; and as a rule it contains iron and bituminous matter. At some localities it has a loose, shaly structure, and in others it occurs in strata 10 feet or more thick.

The Pitkin limestone varies in thickness from a few inches to 80 feet or more. It measures 25 to 40 feet in Washington County, 80 feet on Pinnacle Mountain, Newton County, and is apparently more than this on the face of the Boston Mountains, south of Buffalo River, where no measurement was made. C. E. Siebenthal reports a thickness of 200 feet in the Boston Mountains, south of Mountain View.

This Pitkin limestone is widely distributed over northern Arkansas, occurring in nearly all rock exposures at the proper horizon, but as it is in some places less durable than the overlying rocks, it is frequently concealed by talus. Elsewhere it is more durable than the overlying rocks and forms a prominent escarpment along the face of the mountains. It outcrops along the north face of the Boston Mountains and in many of the northern outliers from Independence County west into Oklahoma. It outcrops also on the south side of the Boston Mountains in several places in Crawford, Franklin, Johnson, and Newton counties. In Limestone Valley, Franklin County, it has a thickness of 100 feet or more.

It is prominently developed in the group of mountain peaks in the southern part of Boone County and the northern part of Newton 


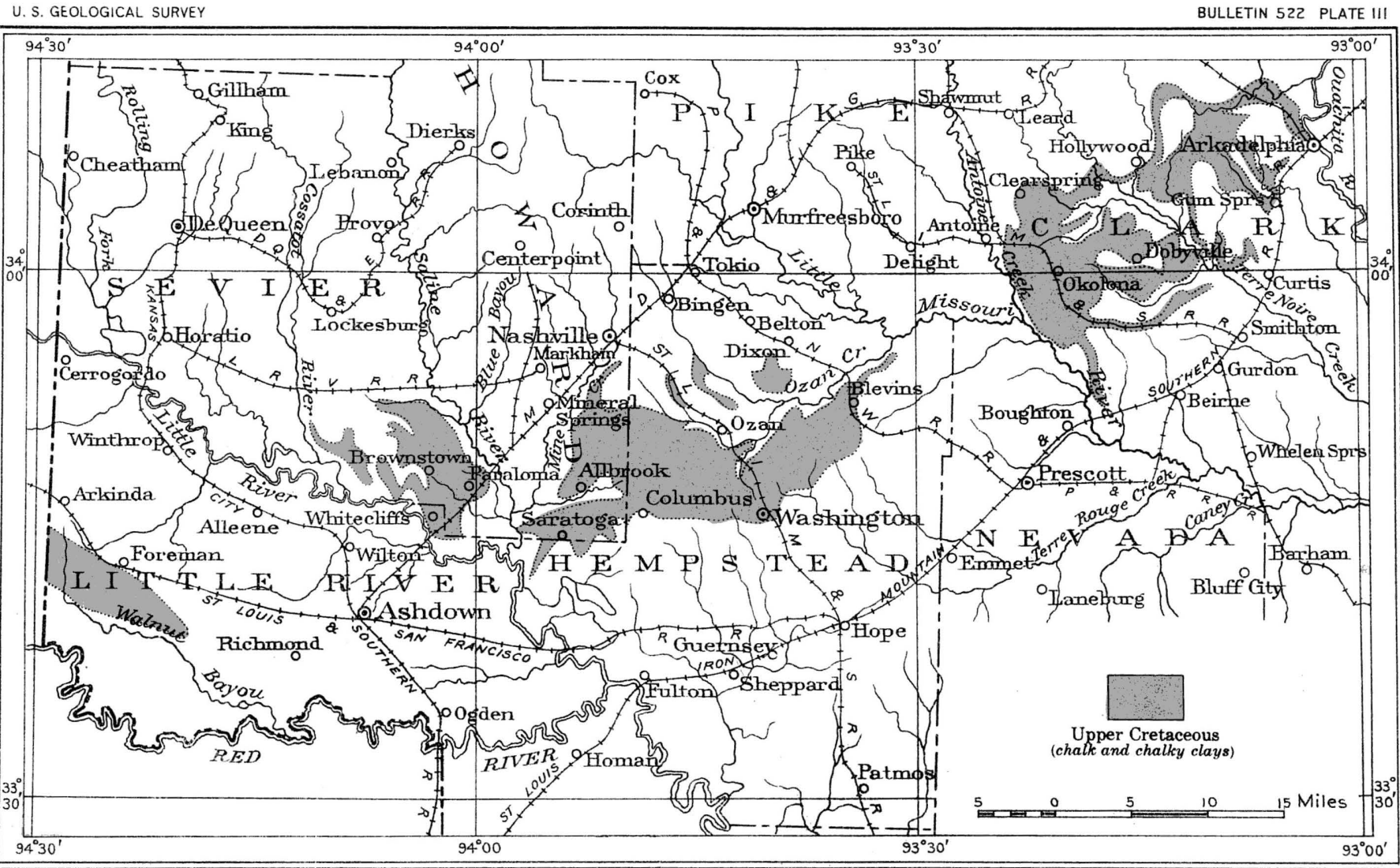

MAP OF THE CHALK REGION OF SOUTHWESTERN ARKANSAS

By Joseph A. Taff 

County. At Fodder Stack it forms the cap rock, about 100 square feet. On Pinnacle Mountain it occurs in a prominent ledge 80 feet thick, 400 feet below the top of the mountain. On Pilot Mountain, at the north end of Boat Mountain, it is 30 feet thick and lies 200 feet below the top of the mountain. It is concealed by talus in many places on both Pilot and Boat mountains.

Large exposures of the. Pitkin limestone exist on both sides of Buffalo River, in Newton County, on the mountain between Big and Little Buffalo creeks, and at many places along the north face of the Boston Mountains in Searcy, Stone, and Independence counties. The rock is conspicuous on the mountain south of Jamestown, Independence County, as well as at many places on Salado Creek, in the same county, and it skirts the highlands southwest of the Oil Trough bottom.

\section{CRETACEOUS CHALK BEDS.}

DISTRIBUTION AND CHARACTER.

The Cretaceous rocks of Arkansas occur only in the southwestern part of the State, reaching as far northeast as Arkadelphia. (See Pl. III.) On the north they are bordered by Paleozoic sandstones and shales, and on the south and east they pass out of sight beneath sands, gravels, and clays of later age.

The only part of the series considered here is the chalk formation of the Upper Cretaceous. This is geologically continuous with the Austin chalk of Texas (see pp. 335-336), but is covered in many places by sands, gravels, and river bottoms, so that it occurs as a series of isolated outcrops. It outcrops near Rocky Comfort, in Little River County, and near White Cliffs, Saline Landing, Washington, and Okolona, and on Big and Little Deciper creeks.

The chalk of all these areas is of Upper Cretaceous age, but it varies considerably in stratigraphic position. The chalk beds at Rocky Comfort, White Cliffs, and Saline Landing become more sandy and clayey and less chalky as they are traced northeastward from the last-named area, and in a short distance become worthless as cement materials. In the same region a series of limy clays, situated geologically about 200 feet above this first chalk series, becomes more chalky as it is traced northeastward. This second chalk bed is worth considering as a cement material in its outcrops near Washington and Okolona and on Big and Little Deciper creeks.

The first or lower series of chalk beds is the Annona ("White Cliffs") chalk and the second or higher series is the "Saratoga" chalk member of the Marlbrook marl, each being named from a locality at which it is well exposed.

1 The description of the Cretaceuus chalks is in large part taken from a very detailed report by J. A. Taff on The chalk of southwestern Arkansas, with notes on its adaptability to the manufacture of hydraulic caments: Twenty-second Ann. Rept. U. S. Geol. Survey, pt. 3, 1902, pp. 689-742. So far as possible this matter is stated in Mr. Taff's own words. 


$$
\text { ANNONA ("White CLIFFs") CHALK. }
$$

Rocky Comfort area.-The chalk which outcrops in the vicinity of Rocky Comfort is remarkably uniform in physical appearance. It is massive, white, sufficiently friable to soil the fingers, and may be broken in thin pieces by hand but can be pulverized only by a hammer. On exposure the chalk breaks into conchoidal fragments, which weather to lumps and finally become chalky dust. In the hillsides south of Rocky Comfort the bedding is scarcely perceptible. In physical appearance this chalk is like that near White Cliffs and is of practically the same composition as that from White Cliffs quarry.

The lower beds are exposed by the road in the SE. $\frac{1}{4}$ SE. $\frac{1}{4}$ sec. 21 , T. 12 S., R. 32 W., and also near the middle of sec. 21, with chalky marl cropping below. These basal beds are more clayey and siliceous than those higher in the formation south of Rocky Comfort.

From the center of sec. 21 to the "line road" in the SW. $\frac{1}{4}$ sec. 29 the chalk is concealed beneath residual black soil. At the line road the chalk is well exposed in ditches and on high ground along the road almost through the SE. $\frac{1}{4}$ SW. $\frac{1}{4}$ sec. 29. The lower beds of the formation are also exposed in the hill and bluff facing the river bottom in the NE. $\frac{1}{4}$ NE. $\frac{1}{4}$ sec. 31 .

From the base the chalk grades downward through bluish clayey chalk into still less chalky clay. This transition clay chalk is exposed at the contact in the SW. $\frac{1}{4}$ sec. 29 and in deep ditches on the hill slopes below the Hopson graveyard, in the NE. $\frac{1}{4}$ NE. $\frac{1}{4}$ sec. 30 . Though analysis (No. 2, p. 112) of the transition clayey chalk from the latter locality shows that the marl contains 25 per cent of silica, sand is not visible.

From sec. 30 northward to the Holman place, near the center of sec. 18, the clayey chalk is generally concealed by its residual soil. Grayish-blue, sandy, chalky marl, partly indurated at the surface, outcrops at the Holman House and in gullies 500 feet farther west. This chalky marl is perceptibly more sandy than that higher in the section immediately below the true chalk.

The crumbling edges of the chalk deposits outcrop in the low bluff of Walnut Bayou bottom from the NE. $\frac{1}{4}$ NE. $\frac{1}{4}$ sec. 30 southward to the extreme south end of the chalk area, in the SE. $\frac{1}{4}$ SW. $\frac{1}{4}$ sec. 32 .

Excellent exposures of the chalk occur in and near the road in the SW. $\frac{1}{4}$ SW. $\frac{1}{4}$ sec. 32 . (See analysis 3, p. 112.) The chief difference between this and the other samples of the purer chalk analyzed is that it contains much more clay. The only perceptible physical difference, however, is that it is a little harder.

A rather large exposure of white chalk, of beds near the top of the formation, appears on Col. Henry Hawkins's place, in the NW. $\frac{1}{4}$ 
sec. 33. About one-fourth mile southeast of the house, in the SE. $\frac{1}{4}$ NW. $\frac{1}{4}$ sec. 33 , the top of the true chalk and the base of the succeeding chalky marl are exposed. A thin mantle of gravel conceals part of both the chalk and the marl. The upper layers of the chalk are also exposed south of the branch, in the SE. $\frac{1}{4}$ sec. 28 .

There are smaller exposures of chalk in this region, but it is believed that those above described are typical.

White Cliffs area.--The chalk exposed in the White Cliffs area occupies parts of secs. $25,26,35$, and 36 , T. 11 S., R. 29 W., and secs. 30 and 31 , T. 11 S., R. 28 W., covering an area of about 600 acres.

A large part of the chalk of the area is covered by a thin mantle of gravel and sand. In places this gravel may be several feet thick, but it is believed that it will nowhere interfere seriously with the removal of the chalk. The chalk is also concealed in places, especially near the border of the area, by its own residual soil, containing scattered pebbles or a very thin layer of gravel.

The most noteworthy exposure of chalk in southwestern Arkansas occurs in the cliffs overlooking Little River from the east side, in the northeast corner of sec. 35, T. 11 S., R. 29 W., immediately above the ferry.

From the brink of the cliff down to the water level is 115 feet, and about 15 feet of chalk is exposed at a higher level by the road which leads from the cement works. The following is a detailed section, beginning at the top of the chalk and marl in the cliff:

\section{Section at White Cliffs Landing.}

1. Massive creamy-white chalk, in beds from a foot to about 10 feet thick, separated by thin partings of very slightly laminated chalk. The variation in the character of the chalk from bed to bed is not perceptible on physical examination, and the stratification planes are not clearly defined except upon partial weathering of the rock. (See analyses 7,8 , and 9, p. 112)...

2. Massive dull bluish-white siliceous chalk. Slightly harder than the pure chalk of 1 , practically without indication of bedding, and because of its hardness projects in a steep bench overhanging the less chalky beds below. Contains nearly twice as much silica as 1. (See analysis 6.) Occurs in the bench beneath the quarry and passes to the level of the river bottom near the clay pit south of the works. Outcrops also near the middle of the bluffs north of the cliffs, spreading out at the surface in the cultivated fields a mile southeast of the village of White Cliffs.......................

3. Massive, vety siliceous dull-blue argillaceous chalk marl. Contains more than twice as much sand and nearly three times as much clay as 2 . Very friable; weathers in recesses beneath the siliceous chalk...............

4. Bluish sandy, chalky marl, containing great numbers of the fossil shell Gryphæa vesicularis. Except for the abundant fossils this rock would be classed with No. 3, though it is probably slightly more sandy.............

5. Bluish sandy, chalky marl, gradually increasing in sandiness from the top downward to the level of the river............................... 
The lower 30 to 35 feet of the white chalk of 1 is freshly exposed in the quarry. The top of the bluish-white chalk of 2 forms the bench beneath the quarry and occurs at the base of the bluff southeast of the landing. The sandy chalk members 3,4 , and 5 rise gradually northward from the lower part of the cliff and are found in the highland between Whitecliffs and Brownstown.

One-half mile west of Dr. Coats's house, in the NW. $\frac{1}{4}$ sec. 23, T. $11 \mathrm{~S} .$, R. $29 \mathrm{~W}$., bed 4 is exposed at the top of the bluff. Below it the following section is well shown in deep gullies down to the level of the valley:

\section{Section of marl below the Annona chalk.}

1. Sandy, chalky marl. Dull bluish when not weathered, becoming grayish or whitish yellow after long exposure. Contains numerous specimens of the large oyster Exogyra ponderosa, besides Ostrea larva and many other fossils common to the Upper Cretaceous marls. The upper half of this member is bed 5 , at the base of the cliff at White Cliffs Landing..................

2. Blue clay marl. Contains some large oysters as above; has less lime and

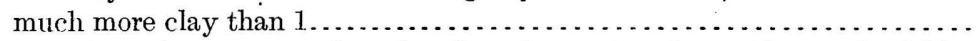

3. Dark-blue gritty greensand marl. Contains scattered smooth round pebbles of black and white quartz an inch and less in diameter.................

4. Blue clay marl down to the level of the bottom land, exposed.............

Feet.

This section is about 2 miles north-northeast of the chalk cliff in the NW. $\frac{1}{4}$ sec. 35 . The sandy marl bed, here about 100 feet above the river, is at water level at the cliff. This marl bed with the associated marls and chalks above, which are conformable with it, dips toward the southeast at the rate of about 50 feet to the mile. The base of the chalk at the north side of the chalk area is fully 50 feet above the river bottom. At the south side, a mile distant, it is at the level of the bottom. There may be local variations in the dip of the beds, but the general dip is estimated to be nearly 50 feet to the mile toward the southeast.

Saline Landing area.-The chalk of the Saline Landing area extends with practically continuous exposure from the chalk bluff at Saline Landing, in the S. $\frac{1}{2}$ sec. 35 , T. 11 S., R. 28 W., to sec. 14, T. $11 \mathrm{~S} .$, R. 27 W., and is about 7 miles in length and one-third mile in width. (See Pl. III.)

The base of the chalk is not exposed in this area, though the lower sandy member outcrops in secs. 21 and 22, toward the source of Plum Creek, in the border of the creek bottom, within less than a mile of the exposure of fossiliferous blue marl outcropping on the north side of Plum Creek in secs. 15 and 16. The structure of the rocks shows that this marl belongs not more than 50 feet below the base of the chalk.

The chalk at the top, as exposed in many places in the south side of the area, grades up into blue clay marl through 20 to 30 feet of 'marly chalk and chalky marl. This gradation is especially well shown 
in the chalky barren hill slopes near the Columbus Mineral Springs road, in the south side of sec. 14, T. 11 S., R. 27 W.

The thickness of the chalk in the southwestern part of the area is not known, as its lower portion is concealed. Near the northeast corner of sec. 22 , T. 11 S., R. 27 W., the full thickness of the purer chalk above the lower sandy member will not exceed 25 feet. Near the east side of sec. 14, T. 11 S., R. 27 W., the entire chalk bed passes beneath the bottom of Plum Creek.

The divide between the sources of Plum and South Ozan creeks is flat, and the chalk deposits are entirely concealed beneath the soil. The crop of the chalk, as indicated by the structure of the rocks, would extend northeastward through secs. 7, 8, 5, 4, and 3, in T. $11 \mathrm{~S}$., R. 26 W., and into Ozan Creek bottom. (See Pl. III.)

The chalk bluff at Saline Landing rises 20 feet above low water and is about 300 feet long. When visited by Taff the river was at flood, and less than 10 feet of the bluff was exposed, showing a white, massive rock, without distinct bedding planes, with the upper 5 feet weathered to a chalky earth. Specimens of the chalk were collected from the water level, which would be near the center of the bluff at the usual low stage of the river. Analysis shows that this chalk is nearly the same as the lower sandy member of the Annona chalk, and suggests that it is in the lower part of the chalk formation of the Whitecliffs area. (Compare analyses 6 and 10, p. 112.)

The chalk has been quarried for building stone near the top of the formation in the northwest corner of the NE. $\frac{1}{4} \mathrm{SW} . \frac{1}{4}$ sec. 30 , T. $11 \mathrm{~S}$., R. 27 W. Analysis 11 (p. 112) is of fresh chalk from this quarry and shows it to be of nearly the same composition as that near the top of the chalk at White Cliffs.

From the top of the chalk in this vicinity there is a gradual change upward through about 10 feet of marly chalk and then through nearly 30 feet of chalk marl into an overlying blue-clay marl, which is continuous for 175 feet to the base of the "Saratoga" chalk member of the Marlbrook marl. The middle portion of this chalk is exposed in the large mound, surrounded by the bottom land of Plum Creek, in the center of the SE. $\frac{1}{4}$ SW. $\frac{1}{4}$ sec. 21 , T. 11 S., R. 27 W., on J. E. Johnson's place. Here also the chalk has been quarried, giving fresh exposures of the rock. Analysis of fresh chalk taken from this quarry is nearly the same as that from the quarry of the White Cliffs Cement Works. (See analysis 12, p. 112.) The lower sandy member is freshly exposed in the head of the large drainage ditch near the middle of the west side of the SW. $\frac{1}{4}$ NW. $\frac{1}{4}$ sec. 22 , T. 11 S., R. $27 \mathrm{~W}$. (Compare analyses 6 and 14.) The upper and purer chalk member is well exposed in the ditches and chalk barrens on the lower ridge across the SW. $\frac{1}{4}$ NE. $\frac{1}{4}$ sec. 22 , T. 11 S., R. 27 W. 
The easternmost exposure of the chalk south of Plum Creek is in the SE. $\frac{1}{4}$ sec. 14 , T. 11 S., R. 27 W., where the chalk barrens in the slopes of the hill show the upper edge of the chalk and the succeeding chalk and clay marl for 50 feet above the creek bottom.

\section{"SARATOGA" CHALK MEMBER OF MARLBROOK MARL.}

Distribution and character.--The "Saratoga" chalk lies nearly 200 feet above the Annona chalk, above clayey beds belonging to the Marlbrook marl. It is also overlain by marl beds belonging to the Marlbrook, of which it thus forms the intermediate member. It has a maximum thickness of about 50 feet where complete sections have been found. The nature of the deposit varies only slightly from top to bottom and shows but little change along its outcrop from the vicinity of Saratoga near West Saline River, in Hempstead County, to Little Deciper Creek near Arkadelphia, in Clark County. The "Saratoga" chalk member is not known in this region west of West Saline River, because of erosion and of concealment by late Tertiary gravel and sand in the highlands and by Pleistocene alluvium and silt in the lowland and river bottoms.

\section{General section of the "Saratoga" chalk.}

1. Chalky rock continuing upward from 2. Becomes more sandy through imperceptible grades to limy greensand at the top of the member. Analyses from the chalk near the central part of this division show it to contain from 40 to 50 per cent of silica............................... 20-30

2. Generally even-textured chalky marl, which contains less sand than the higher beds. Analysis shows it to contain about 31 per cent of siliceous matter. The sand is perceptibly finer and the rock is more chalky in appearance than in other parts of the member.................... 10-15

3. Sandy clayey chalk, containing great numbers of the fossil oyster Gryphæa vesicularis. These fossils are found in the marls some distance both above and below this member, but in no other bed of rock in this region have they been found in such abundance. In natural exposures the chalk weathers from about them so that they generally almost cover the surface of the ground or are scattered in the soil. This shell bed at the base of the member is very characteristic and easily recognizable. It outcrops at the north border of the "Saratoga" chalk member and throughout its extent..

Feet.

The "Saratoga" member is massive, dull bluish, sandy, and chalky. Exposures do not usually show distinct bedded structure, though a slight variation in weathered surfaces may indicate the dip of the rock. As the rock weathers it changes in color from dull blue to grayish and creamy white. Its hardness and general physical appearance are almost identically the same as those of the lower sandy member of the Annona chalk. It breaks in rudely conchoidal flakes and crumbles at the tap of the hammer. Small pieces of the 
fresh rock may be broken by the hand and crumbled to dust between the fingers, but not without some difficulty.

Washington area.-The rock section is well exposed in the Washington area, as illustrated in the section below:

\section{Section north of Saratoga.}

1. Surficial deposit of fine yellow sand, extending from the level of Saratoga down to the "Saratoga" chalk member, about......................... Feet.

. "Saratoga" chalk member of Marlbrook marl exposed in brink of hill north and east of Saratoga and in knob one-half mile north of Saratoga, lower

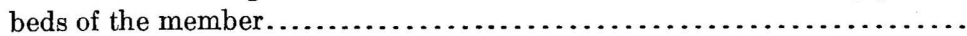

3. Limy blue-clay marl (Marlbrook marl)

Exposed around the base of the hill at Saratoga; in the cultivated lands $1 \frac{1}{2}$ miles north of the town it becomes gradually more chalky downward from the top to its contact with the chalk marl below.

4. Bluish friabie chalk marl (Marlbrook marl) $20-30$ Gradation bed from the blue marl above to the purer chalk below.

5. White Annona chalk in the Saline Landing area.

Thick deposits of sand cap the hill at Saratoga, concealing all the chalk rock except the lower beds in the slopes east and northeast of the town.

The lower part of the "Saratoga" chalk member outcrops in a considerable area on Mr. Jones's place in the NE. $\frac{1}{4}$ sec. 35 , SW. $\frac{1}{4}$ sec. 25 , and SW. $\frac{1}{4}$ sec. 36, T. 11 S., R. 27 W. The chalky oystershell bed at the base of the member is well exposed north, south, and west of the house, which is in the NE. $\frac{1}{4}$ NE. $\frac{1}{4}$ sec. 35 .

Samples of the chalk taken from the top of the oyster-shell bed near the base of the member are not physically different from the same bed examined at other localities in the area. The fresh rock is grayish white and sandy.

The shell bed at the base of the member is exposed at the edge of the highland near the Columbus-Albrook road, a mile northwest of Columbus. The same bed is exposed also at the crest of the highland a mile north of the town. The chalk marl highest in the member occurs in the cultivated fields between the outcrop of the shell bed and the town.

From near Columbus eastward to the end of the member in the Washington area the whole of the "Saratoga" crops out or is covered only lightly by soil. Throughout this extent the basal shell bed is almost continuously exposed, except in the very bottoms of the valleys, and may be easily distinguished through the open fields by the abundant shells weathering upon its surface.

Between Columbus and the railroad north of Washington the outcrop of the chalky marl is not more than 30 feet thick, and usually 10 to 20 feet of the lower part was all that was exposed. 
The overlying greensand marl is more friable than the "Saratoga" chalk, and its soil descends and conceals the contact between the two as well as the upper part of the latter. A section of the "Saratoga" chalk with better exposures than are usually found occurs along the railroad north of Washington.

The north cut on the railroad is in a blue clay-marl 30 to 50 feet below the base of the "Saratoga." It is 10 feet deep and about 300 feet long. The marl in this cut, which was originally blue, is weathered to a creamy yellow to a depth of about 8 feet. It is transected by many joints, which pass nearly vertically across the bedding and continue down below the base of the cut. Along these joints, even below the zone of general weathering, the blue color of the marl is changed to yellow to a depth of several inches. The fresh marl is friable when dry and plastic when wet. It has a very fine texture and contains scarcely perceptible grit, yet analysis shows it to contain 43 per cent of silica and 6.5 per cent of clay. (See analysis 15, p. 113.) Nearly $40^{\circ}$ per cent of this silica is in the form of impalpable sand.

The shell bed, the base of the "Saratoga," is exposed in the field southwest of this railroad cut. The middle cut is one-third mile south of the north cut and is in the lower part of the "Saratoga" chalk above the oyster-shell bed. This cut is 300 feet long and but a few feet deep, exposing an estimated thickness of 15 feet of rock. The structure of the rock indicates a low inclination toward the south, but is not sufficiently clear to determine the degree of dip. Ditches above the south end of the cut expose about 25 feet of chalk marl above that at the railroad, making the whole section of rock exposed at this place nearly 40 feet. Very little change in the nature of the rock could be noted. The fresh chalk rock near the center of the middle cut, from the lower and more chalky part of the member, contains less than one-half the amount of silica found in the blue marl 40 feet below, though in physical appearance it is more sandy. (See analysis 16, p. 113.)

One-half mile south of the middle cut and a few hundred feet north of the south cut the top of the "Saratoga" is exposed in a ditch at the railroad. The sandy marl in this exposure is but little above the chalky marl at the top of the exposure opposite the middle cut. It is massive, dull blue, and very sandy, approaching a sandstone in composition.

The south cut, which is about 2 miles north of the town of Washington, is in the lower part of the greensand marl which overlies the "Saratoga." This cut is about 30 feet deep and about 300 feet long. From the surface downward about 20 feet the greensand is weathered from dark blue or greenish blue to shades of dull brownish yellow. Unaltered marl was collected from near the base of the cut (analysis 
17 , p. 113). It is very sandy, containing 75.77 per cent of silica and 5.72 per cent of lime. Similar greensand marl, estimated to be more than 100 feet thick, occurs between this cut and Washington.

From the railroad eastward to the end of the member in this area, in sec. 29 , T. 10 S., R. 24 W., the "Saratoga" chalk crops in an irregular belt one-half to three-fourths mile wide, making an intermediate upland, marked by projecting ridges and spurs, between the high timbered greensand country on the south and the flat black land of the clay marls bordering Ozan Creek bottom on the north.

Ckolona area.-Okolona area is in the southwestern part of Clark County, south and east of Okolona, between the bottom lands of Antoine and Terre Noire creeks.

The "Saratoga" chalk at the crest of the ridge south of Okolona is 50 to 150 feet above the lowland to the west and south. The crest of this ridge slopes southward with the dip of the rock, which is nearly 50 feet per mile.

East of Okolona the chalky marl forms a triangular area of rolling upland about 3 square miles in extent.

The stream which rises in the southwest part of the town and flows southeastward past the railroad station separates the area south of the town from that east of it. It is probable that these two areas are connected by narrow bands of outcropping marl which extend down the sides of the valley about 2 miles southeast of the village.

The "Saratoga" chalk is exposed near the crest of the escarpment north of the Okolona-Dobyville road, from the east side of sec. 30, T. 8 S., R. 21 W., to the edge of the Terre Noire bottom, $1 \frac{1}{2}$ miles east of Dobyville.

The marl near the middle of the "Saratoga" member is well exposed toward the top of the ridge at the forks of the road, $1 \frac{1}{2}$. miles south of Okolona. In physical appearance this rock is the same as that at the middle of the member in the vicinity of Washington. It is massive and dull blue on fresh exposure and weathers to shades of drab or light yellow. It contains nearly 43 per cent of silica and 49 per cent of calcium carbonate. (See analysis 19, p. 113.)

Two and one-half miles south of Okolona and one-fourth mile west of the road, on the Mat Hardin place, deep gullies expose the lower 20 feet of the "Saratoga" member as well as the blue marl below. The Gryphra vesicularis zone is well marked, but the fossils are a little less abundant than in the Washington area, 20 miles farther west. In the lower 10 feet of the member the chalk-marl is finer in texture and more chalky than in the higher beds. The silica is nearly 10 per cent less than in the marl near the middle of the member. (See analysis 21, p. 113.)

Numerous other exposures of the lower part of the member occur in the gullies and slopes of the hill on the west side of the ridge, where 
the land was once cultivated. The top of the "Saratoga" member passes beneath the bottom land of Little Missouri River, about 3 miles south of Okolona.

Five miles south of Okolona the greensand marl above the "Saratoga" chalk member forms the bluffs from the level of the Little Missouri bottom up to the top of the ridge.

About 20 feet of the middle portion of the member is exposed in the Okolona-Garden road a mile east of Okolona.

In the high rolling country east of Okolona the "Saratoga" member is generally concealed beneath its own soil or beneath sand of Neocene age.

The lower beds of the chalk outcrop in the Okolona-Dobyville road, 2 miles west of Dobyville, and at several other places in the top of the escarpment between Okolona and Dobyville.

One-fourth of a mile north of Joseph Doby's house, at Dobyville, the full section of the "Saratoga" member is exposed in an old field.

The following section shows the character of the "Saratoga" member at Dobyville:

Section at Dobyville.

1. Gravel, reddish and yellow stratified clays. ........................

2. Blue marl ................................................. 15

3. Dull-bluish chalky marl. Slightly indurated at the top. Contains numerous casts of bivalve shells and gastropods. Calcareous sandstone at the top becoming more chalky downward until the lower part of the chalky marl is found to be the same as that occurring south of Okolona and in the Wash-

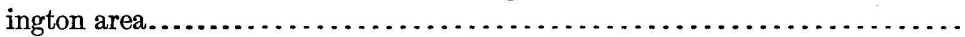

4. Even-textured chalk-marl with Gryphæa vesicularis shells at the base. Contains more chalk than the beds above and has finer texture. In places, also, very fine particles of greensand were noted disseminated through the

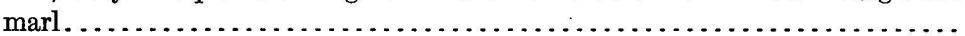

5. Fine-textured blue clay marl; the upper part of the 150 to 200 feet of blue marl (lower part of Marlbrook marl), which lies between the Annona chalk and the "Saratoga" chalk member.

From the vicinity of Okolona eastward, the outcrop of the "Saratoga" member descends gradually from the brink of the escarpment to the level of the river bottom, nearly 2 miles east of Dobyville.

Deciper area.-The next known occurrence of the "Saratoga" chalk member east of Okolona is on Big Deciper and Little Deciper creeks, 3 to 5 miles west of Arkadelphia.

The occurrence of the "Saratoga" chalk on the Deciper creeks is confined to outcrops in the middle and lower slopes of the valley near the Arkadelphia-Dobyville and Arkadelphia-Hollywood roads. (See Pl. III.)

Near the center of sec. 28 , T. 7 S., R. 20 W., on the Bozeman place, one-third mile northeast of the house, about 30 feet of the "Saratoga" member is exposed, as follows; 
Section of the "Saratoga" chalk at the Bozeman place.

1. Sandy soil to the top of the ridge.

Feet.

2. Chalky marl, more sandy than 3 . The sandy element in this marl increases

in quantity upward ...................................... 10 15

3. Even-textured blue chalk marl. Contains a sprinkling of fine greensand.

The same in all respects as the lower 15 feet of the member at Dobyville and Okolona. Contains about 30 per cent of sand and 61 per cent of chalk.

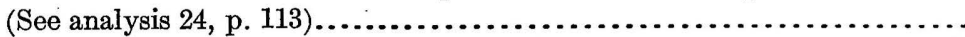

4. Gryphæa vesicularis zone, shell marl. Limits not sharply marked. Through 1 to 2 feet of the marl at the base the shells are abundant, and in it is a thin layer of shells indurated by calcareous matrix.................. 1-2

5. The blue marl from the Gryphra vesicularis zone downward; exposed.......

At one place one-fifth mile northeast and at another 500 feet east of the Bozeman house the chalky marls occur higher in the member and are still more sandy than that of No. 2 in the section. These outcrops are in the heads of narrow gulches which descend to the Deciper Valley. At the locality 500 feet east of the house the marl is very sandy, partly indurated, and contains numerous casts of fossils similar to those found near the top of the member at Dobyville. The exposures are just below the springs which flow from the base of the stratified yellow sands and blue clays. They show about 10 feet of marl overlain by about 10 feet of interstratified sand and clay, followed by an overwashed yellow sandy soil to the top of the hill, 40 feet above.

One-fourth mile southeast of Mount Bethel Church, near the northeast corner of sec. 33 , T. 7 S., R. 20 W., beds similar to those east of the Bozeman house are exposed. A spring issues from the contact between the chalk-marl and the overlying sand and blue clay. The top of the marl is 70 feet below the crest of the hill.

The chalky sand of the upper part of the "Saratoga" member is exposed on the Arkadelphia-Okolona road, on the west bank of Big Deciper Creek, near the middle of sec. 34, T. 7 S., R. 20 W., as well as in the bluff of the creek near by. The top of the sandy marl, which stands here 20 feet above the creek; contains casts of fossils as at the Bozeman place, and is overlain also by the same kind of interstratified sand and clay.

Twenty feet of the even-textured lower and more chalky division of the "Saratoga" member is exposed in the road cut on the Arkadelphia-Okolona road, 100 yards west of Little Deciper Creek.

Sand and clay conceal the higher beds of the member. The Gryphra vesicularis zone, with underlying blue marl, outcrops a few feet above the creek bottom.

One-half mile above the road, on the Wright place, the lower 30 feet of the "Saratoga" member is exposed in the gullies at the west side of the creek bottom. The lower 10 to 15 feet of the marl is identically 
the same as that found at the road and on the Bozeman place west of Big Deciper Creek. (See analysis 26, p. 113.) The basal division of the member, containing the same indurated shell bed, outcrops about 10 feet above the creek bottom; below it is the blue marl. Yellow sandy clays overlie the chalky marl here, as in the exposures noted on Big Deciper Creek.

At the east side of the creek bottom, on the Arkadelphia-Okolona road, and northward through the Haskins place, the lower part of the "Saratoga" member is exposed in gullies in an abandoned field.

ANALYSES.

The following table gives analyses by chemists of the Ünited States Geological Survey of chalk and chalk marl from the Cretaceous beds of southwestern Arkansas;

Analyses of chalk and chalk marl from southwestern Arkansas.

\begin{tabular}{|c|c|c|c|c|c|c|c|c|c|c|c|c|c|}
\hline & 1 & 2 & 3 & 4 & 5 & 6 & 7 & 8 & 9 & $10^{\circ}$ & 11 & 12 & 13 \\
\hline $\begin{array}{l}\text { Silica }\left(\mathrm{SiO}_{2}\right) \text { and in- } \\
\text { soluble } a .\end{array}$ & 6.15 & 25.13 & 8.53 & 7.32 & 27.28 & 12.67 & 6.83 & 7.86 & 7.97 & 14. 68 & 4.91 & 7.35 & 34.76 \\
\hline $\begin{array}{l}\text { Ferric oxide and alu- } \\
\text { mina }\left(\mathrm{Fe}_{2} \mathrm{O}_{3} \text { and }\right.\end{array}$ & & 20.10 & 0.00 & 1.02 & 21.20 & 12.04 & 0.00 & 1.00 & 7.97 & 14.68 & 4.91 & 7.35 & 34.76 \\
\hline $\left.\mathrm{Al}_{2} \mathrm{O}_{3}\right) \ldots \ldots$. & 5.79 & 3.90 & 1.22 & 1.26 & 5.00 & 1.93 & .95 & 1.30 & 1.09 & 2.15 & .93 & 1.06 & 5. \\
\hline Lime (CaO) & 46.81 & 35.81 & 48.50 & 49.94 & 34.81 & 45.56 & 50.41 & $\begin{array}{l}49.55 \\
-28\end{array}$ & $\begin{array}{l}49.64 \\
5\end{array}$ & 45.0 .3 & 51.78 & 49.66 & 29.10 \\
\hline $\begin{array}{l}\text { Magn } \\
\text { Equa }\end{array}$ & & & & & & & & & & & & & \\
\hline $\begin{array}{l}\text { honat } \\
\text { Equal t }\end{array}$ & 83.60 & 64.32 & 86.60 & 89.17 & 62.15 & 81.35 & 90.01 & 88.48 & 88.64 & $79.4 n$ & 92.46 & 88.67 & 51.95 \\
\hline carbonate $\left(\mathrm{MgCO}_{3}\right)$ & .69 & 1.28 & .78 & .67 & 1.28 & .90 & .46 & .58 & .73 & .92 & .63 & .71 & 1.49 \\
\hline
\end{tabular}

$a$ "Insoluble" refers to insoluble in $\mathrm{HCl}$. The other columns refer to the soluble portions only.

Rocky Comfort area:

1. SW. $\frac{1}{4}$ SW $\frac{1}{4}$ sec. 32, T. 12 S., R. 32 W., 2 miles southwest of Rocky Comfort. White chalk near the middle of the Annona chalk.

2. NE. I NE. 1 sec. 30, T. 12 S., R. 32 W., 2 miles west of Rocky Comfort. The chalky marl immediately below the white chalk.

3. Rocky Comfort, Little River County, Ark., near nartheast corner of NE. $\frac{1}{1}$ sec. $2 \delta$, T. 12 S., R. 32 W., from lower middle part of the Annona chalk.

4. Same locality as 3 , from the lower part of the Annona chalk.

White Clitl's area:

5. NE. 1 NE. 1 sec. 35 , T. 11 s., R. 29 W., top of the lower sandy marl bed beneath the white chalk.

6. Chalk bluff, White Cliffs Landing, near the middle of the bluff in the lower part of the white chalk.

7. Chalk bluff, White Cliffs Landing, 15 feet above the base of the purer white chalk.

8. Chalk bluff', White Cliffs Landing, White chalk 10 feet below the top of the cliff.

9. Cement works, White Cliffs Landing. Average of the lower 35 feet of the purer white chalk in the quarry at the cement works.

Saline Landing area:

10. Saline Landing, Howard County, Ark., sec. 35, T. 11 S., R. 28 W., from the middle of the chalk blutf.

11. Northwest comer of NE. $\frac{1}{4}$ SW. $\frac{1}{4}$ sec. 30 , T. 11 S., R. 27 W. White chalk from very near the top of the Annona chalk.

12. Near the center of the SE. I SW. i sec. 21 , T. 11 S., R. 27 W., from near the midale of the white chalk.

13. Near the base of the knob 1 mile N. $15^{\circ}$ E. from Saratoga, Ark. Chalky blue marl 100 feet above the top of the white chalk. 
Analyses of chalk and chalk marl from southwestern Arkansas-Continued.

\begin{tabular}{|c|c|c|c|c|c|c|c|c|c|c|c|c|c|}
\hline & 14 & 15 & 16 & 17 & 18 & 19 & 20 & 21 & 22 & 23 & 24 & 25 & 26 \\
\hline $\begin{array}{l}\text { Silica }\left(\mathrm{SiO}_{2}\right) \text { and in- } \\
\text { soluble } a_{\ldots} \ldots \ldots \ldots \ldots\end{array}$ & 12.65 & 43.09 & 21.90 & \begin{tabular}{|l|}
75.77 \\
\end{tabular} & 30.68 & 43.72 & 35.16 & 31.05 & 31.01 & 36.17 & 32.26 & 30.84 & 30.29 \\
\hline $\begin{array}{l}\text { Ferric oxide and ain- } \\
\text { mina }\left(\mathrm{Fe}_{2} \mathrm{O}_{3} \text { and }\right.\end{array}$ & 1.66 & 6.55 & 2.35 & 5.46 & 4.91 & 2.76 & 2.85 & 3.46 & 2.93 & 5.37 & 7.05 & 3.73 & 3. \\
\hline Lime (CaO & 45.85 & 22.77 & 40.57 & 5.72 & 32.60 & 27.95 & 32.75 & 32.18 & 34.63 & 29.16 & 17.24 & 34.31 & 34.7 \\
\hline Magnesia (M & .49 & .92 & .59 & .91 & .48 & .42 & .43 & .69 & .50 & .48 & .63 & .60 & .55 \\
\hline $\begin{array}{l}\text { Equal to lime car- } \\
\text { bonate }\left(\mathrm{CaCO}_{3}\right) \ldots\end{array}$ & 81.87 & 40.65 & 72.41 & 10.21 & 58.22 & 49.90 & 58.48 & 57.41 & 61.83 & 52.06 & 30.78 & 61.26 & 62.08 \\
\hline $\begin{array}{l}\text { Equal to magnesium } \\
\text { carbonate }\left(\mathrm{MgCO}_{3}\right)\end{array}$ & 1.02 & 1.93 & 1.23 & 1.91 & 1.00 & .88 & .90 & 1.44 & 1.05 & 1.00 & 1.32 & 1.26 & 1.15 \\
\hline
\end{tabular}

$a$ "Insoluble" rofers to insoluble in HCl. The other columns refer to the soluble portions only.

Saline Landing area-Continued.

14. Near the center of the east side of the SW. $\frac{1}{4} \mathrm{NW} . \frac{1}{4}$ sec. $22, \mathrm{~T} .11 \mathrm{~S} .$, R. 27 W., from the lower part of the white chalk.

Washington area:

15. North cut on the railroad, about 3 miles north of Washington, Ark. Chalky blue marl 40 feet below the base of the "Saratoga" chalk member of Marlbrook marl.

16. Middle cut on the railroad, about $2 \frac{1}{2}$ miles north of Washington, Ark., from the center of the cut in the lower part of the "Saratoga" chalk member of Marlbrook marl.

17. South cut on the railroad, about 2 miles north of Washington, Ark., from the greensand marl in the center of the cut.

18. SE. 1 sec. 25, T. 10 S., R. 25 W., head of Morisett ditch, from bluish chalky marl, about 150 feet below the "Saratoga" chalk member of Marlbrook marl. Okolona area:

19. Forks of road, $1 \frac{1}{2}$ miles south of Okolona, Ark., from middle of "Saratoga" chalk member of Marlbrook marl.

20. SE. $\frac{1}{4}$ sec. 4, T. 9 S., R. 22 W., about $\frac{1}{2}$ mile southwest of Okolona, from sandy marl bed at base of the Annona chalk.

21. 21 miles south of Okolona, on the Mat. Hardin place, from the lower 15 feet of the "Saratoga" chalk member of Marlbrook marl.

22. Same locality as 21 . "Saratoga" chalk member 16 feet above the base.

23. SE. $\frac{1}{1}$ sec. 4 , T. 9 S., R. 22 W., about $1 \frac{1}{2}$ miles south of Okolona, yellowish chalky marl about midway between the Annona chalk and "Saratoga" chalk member of Marlbrook marl. Deciper area

24. J. L. Bozeman's place, $\frac{1}{3}$ mile northeast of the house, in the NW. $\frac{1}{3}$ sec. $28, T .7$ S., R. 20 W., from the bluish chalky marl 4 feet below the base of the "Saratoga" chalk member.

25. Same locality as 24, from "Saratoga" chalk member 10 feet above the hase.

26. Little Deciper Creek at Okolona-Arkadelphia road, from "Saratoga" chalk member about 10 feet above the base.

\section{TERTIARY AND CARBONIFEROUS CLAYS AND SHALES.}

The information below on clays is from a publication on cement materials of southwest Arkansas, by Dr. Branner. (See p. 116.)

None of the surface clays found in the immediate vicinity of the chalk deposits can be depended upon. They are, as a rule, too sandy, and are not of uniform composition. Reference is here made especially to the sandy clays overlapping the chalk beds to the north and east of Rocky Comfort, to the clays of the bottom lands south and west of Whitecliffs, and to those south, north, and west of the chalk exposures at Saline Landing. Fortunately the Tertiary rocks which overlap the Cretaceous to the south and east contain an abundance of excellent clays, some of which are utilized for the manufacture of pottery at Benton and Malvern (Perla switch). Many other deposits occur on and near the railway about Arkadelphia, Malvern, between Malvern and Benton, between Benton and Bryant, at Olsens switch, and at Mabelvale. At Little Rock extensive beds of both clays and clay shales exist, and beds of shale may be found along the line of the Little Rock and Fort Smith road to Fort Smith and beyond.

$48834^{\circ}-$ Bull. $522-13-8$ 
All the Tertiary clays at Benton, Bryant, Olsens switch, Mabelvale, and Little Rock lie nearly horizontal, dipping gently toward the southeast. In many places they can be had by stripping off a few feet of post-Tertiary gravel and soil; but in other places the covering is too thick, and the clays can be obtained only by a system of drifts.

On account of the geographic relations to the chalk beds, only clays convenient to railway transportation along the St. Louis, Iron Mountain \& Southern Railway southwest of Little Rock need be here discussed. Should a factory be located.west of Little Rock, the Carboniferous clay shales would have to be used. Of these there is no lack between Little Rock and Fort Smith.

At Little Rock two general classes of clays are available for cement manufacture: (1) The Tertiary clays that occur in horizontal beds in the southern and southwestern part of the city; and (2) the Carboniferous clay shales exposed in the railway cuts along the south bank of Arkansas River, in the cuts west of the town, and in others west of Argenta. Other clays about Little Rock and Argenta, such as the chocolate-colored clays along the margins of the river bottoms and the pinkish clays forming the high river terraces and used for making bricks on the north side of the river, are not available for cement manufacture, partly because they are too sandy but also because they are not homogeneous. The pink clay of Argenta contains more than 83 per cent of silica.

The Carboniferous clay shales are well exposed in the railway cut near the upper bridge, and where the electric power house stands. Similar shales may be found here and there over a large part of Pulaski County, within the Carboniferous area.

The following analyses of representative samples show the composition of the clays. Where the percentage of sand is given the analyses represent washed clay.

Analyses of shales and clays from Arkansas.

Carboniferous shales.

\begin{tabular}{|c|c|c|c|c|c|c|c|c|}
\hline & 1 & 2 & 3 & 4 & 5 & 6 & 7 & 8 \\
\hline 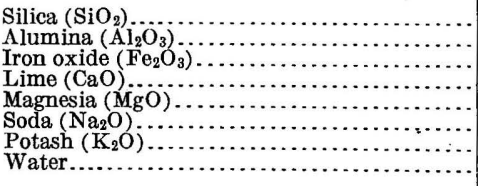 & \begin{tabular}{r|}
53.30 \\
23.29 \\
9.52 \\
.36 \\
1.49 \\
2.76 \\
1.36 \\
5.16
\end{tabular} & $\begin{array}{r}62.36 \\
25.52 \\
2.16 \\
.51 \\
.29 \\
.66 \\
1.90 \\
5.32\end{array}$ & $\begin{array}{r}58.43 \\
22.50 \\
8.36 \\
.32 \\
1.14 \\
1.03 \\
2.18 \\
6.87\end{array}$ & $\begin{array}{r}65.12 \\
19.05 \\
7.66 \\
.34 \\
.31 \\
.85 \\
1.23 \\
6.12\end{array}$ & \begin{tabular}{r|}
57.12 \\
24.32 \\
8.21 \\
.72 \\
1.74 \\
.53 \\
2.07 \\
7.58
\end{tabular} & $\begin{array}{r}55.36 \\
26.96 \\
5.12 \\
.30 \\
1.16 \\
1.03 \\
2.69 \\
7.90\end{array}$ & $\begin{array}{r}51.30 \\
24.69 \\
10.57 \\
.32 \\
.63 \\
.72 \\
2.18 \\
9.11\end{array}$ & $\begin{array}{r}69.34 \\
22.56 \\
1.41 \\
\text { Tr. } \\
\text { Tr. } \\
2.31 \\
.04 \\
5.12\end{array}$ \\
\hline 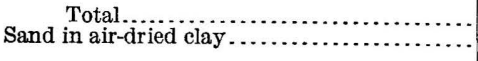 & 100.48 & $\begin{array}{c}98.72 \\
\ldots\end{array}$ & & 21.88 & . & 100.52 & & \\
\hline
\end{tabular}

1. Clay shale from railroad cut at south end of upper bridge, Little Rock.

2. Decayed shale from Iron Mountain railroad cut at crossing of Mount Ida road, Little Rock.

3. Clay shale from Nigger Hill, Fort Smith

4. From Harding \& Boucher's quarry, Fort Smith.

5. Clay shale from Round Mountain, White County, sec. 6 , T. 5 N., R. 10 W.

6. From Clarksville, east of college.

8. From NW. sec. 23 T. 1 . 
Analyses of shales and clays from Arkansas-Contınued.

Tertiary clays.

\begin{tabular}{|c|c|c|c|c|c|c|c|c|c|c|}
\hline . & 1 & 2 & 3 & & 4 & 5 & 6 & 7 & 8 & 9 \\
\hline \multirow[t]{2}{*}{ 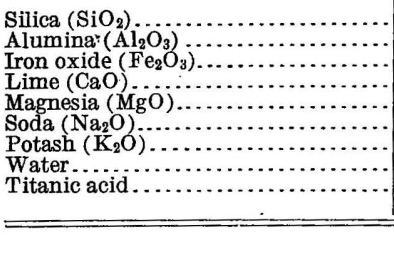 } & $\begin{array}{r}63.07 \\
23.92 \\
1.94 \\
.23 \\
\text { Tr. } \\
1.08 \\
1.15 \\
7.07\end{array}$ & $\begin{array}{r}72.44 \\
18.97 \\
1.59 \\
.18 \\
\text { Tr. } \\
.91 \\
1.35 \\
5.39\end{array}$ & $\begin{array}{r}69.95 \\
22.34 \\
1.44 \\
\text { Tr. } \\
.08 \\
1.18 \\
1.28 \\
5.98\end{array}$ & \multicolumn{2}{|c|}{\begin{tabular}{r}
71.09 \\
19.86 \\
1.81 \\
.11 \\
\hdashline .81 \\
1.45 \\
5.67
\end{tabular}} & $\begin{array}{r}65.27 \\
18.75 \\
7.34 \\
.81 \\
1.26 \\
.81 \\
1.10 \\
6.88\end{array}$ & $\begin{array}{r}64.38 \\
17.29 \\
8.25 \\
1.11 \\
.80 \\
.42 \\
1.41 \\
6.95\end{array}$ & \begin{tabular}{r|r}
63.19 \\
18.76 \\
7.05 \\
.78 \\
1.68 \\
1.50 \\
.21 \\
7.57
\end{tabular} & $\begin{array}{r}64.49 \\
23.86 \\
2.11 \\
.31 \\
\mathrm{Tr} . \\
1.82 \\
.11 \\
8.11\end{array}$ & $\begin{array}{r}67.90 \\
22.07 \\
1.33 \\
.05 \\
.59 \\
.38 \\
1.15 \\
6.86\end{array}$ \\
\hline & 10 & 11 & 12 & & & 13 & 14 & 15 & 16 & 17 \\
\hline 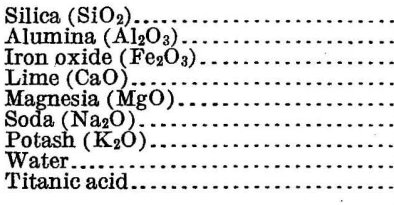 & $\begin{array}{r}48.34 \\
34.58 \\
1.65 \\
.81 \\
\text { Tr. } \\
1.26 \\
.44 \\
12.94 \\
1.56\end{array}$ & $\begin{array}{r}62.34 \\
20.63 \\
3.34 \\
.17 \\
.67 \\
.33 \\
.73 \\
9.34 \\
1.49\end{array}$ & \begin{tabular}{l|r}
4 & 68. \\
3 & 17. \\
4 & 3. \\
7 &. \\
7 & 1. \\
3 &. \\
3 & 1. \\
4 & 6. \\
9 &
\end{tabular} & $\begin{array}{l}03 \\
19 \\
00 \\
81 \\
00 \\
54 \\
00 \\
31\end{array}$ & & $\begin{array}{c}3.29 \\
8.19 \\
6.45 \\
.31 \\
2.44 \\
\text { Tr. } \\
.56 \\
\ldots . .\end{array}$ & $\begin{array}{r}76.33 \\
16.04 \\
1.24\end{array}$ & $\begin{array}{r}75.99 \\
16.12 \\
1.35 \\
a 1.45\end{array}$ & $\begin{array}{r}73.24 \\
19.61 \\
1.04 \\
\\
\text { a. } 78\end{array}$ & $\left\{\begin{array}{r}45.28 \\
37.39 \\
1.71 \\
1.83 \\
.29 \\
\hdashline . .2 \\
13.49\end{array}\right.$ \\
\hline
\end{tabular}

$a$ By difference.

1. Benton, Hick's bed, sec. 12 , T. 2 S., R. 15 W.

2. Benton, Rodenbaugh, sec. 12 , T. 2 S., R. 15 W.

3. Benton, Herrick \& Davis's bank.

4. Benton, Henderson's pit, upper bed.

5. Mabelvale, A. W. Norris's well.

5. Mabelvale, A. W. Norris's well.
6. Olsen's switch, "fuller's clay."

7. "Fuller's earth," Alexander, SW. $\frac{1}{1}$ SE. $\frac{1}{4}$ sec. 8, T. 1 S., R. 13 W.

8. Benton, Woolsey's clay.

9. Ridgwood, SW. $\frac{1}{4}$ NE. $\frac{1}{4}$ sec. 25, T. 1 N.; R. 12 W.

10. Benton, Howe's pottery.

11. Clay from sec. 4 , T. 8 S., R. 15 W.

12. Clay from sec. 5, T. 8 S., R. $15 \mathrm{~W}$

13. Clay from S. $\frac{1}{2}$ sec. 13 , T. 2 S., R. 13 W

14. John Foley's, NE. $\frac{1}{4}$ SE. $\frac{1}{4}$ sec. 18, T. 13 S., R. 24 W.

15. Climax pottery, W. $\frac{1}{2}$ SE. $\frac{1}{4}$ sec. $5, T$ T. 15 S., R. 28 W.

16. Atchison's, NE. $\frac{1}{4}$ NE. $\frac{1}{1}$ sec. 24 , T. 4 S., R. 17 W.

17. Kaolin, sec. 36, T. 1 N., R. 12 W. Tarpley's.

\section{PORTLAND CEMENT INDUSTRY IN ARKANSAS.}

In 1895 a Portland cement plant was erected at Whitecliffs Landing, on Little River, in southwestern Arkansas. This plant was designed to use the Cretaceous chalk, which occurs in abundance at that locality (pp. 103-104), mixed with clay dredged from the river-bottom land. From such data as are now available it seems probable that the use of a better clay would have helped the plant over some of its earlier difficulties.

In the original plant four Johnson kilns were erected, and of course a wet process was followed. Between technical difficulties and litigation the company had a rather checkered existence. Periods of idleness have alternated with reorganizations, and for several years the plant has been inactive. 
BIBLIOGRAPHY.

Adams, G. I., Purdue, A. H., Ulrich, E. O., and Burchard, E. F., The lead and zinc deposits of northern Arkansas: Prof. Paper U. S. Geol..Survey No. 24, 1904. (Describes limestones of northenn Arkansas.)

Adams, G. I., and Ulrich, E. O., Fayetteville, folio (No. 119), Geol. Atlas U. S., U. S. Geol. Survey, 1905.

Branner, J. C., On the manufacture of Portland cement: Ann. Rept. Arkansas Geol. Survey, 1888, vol. 2, pp. 291-302.

- The cement materials of southwest Arkansas: Trans. Am. Inst. Min. Eng., vol. 27, 1898, pp. 42-63.

- Clays of Arkansas: Bull. U. S. Geol. Survey No. 351, 1908.

Hopkins, T. C., Marbles and other limestones (of Arkansas): Ann. Rept. Arkansas Geol. Survey for 1890, vol. 4, 1893, 443 pp.

TAFF, J. A., Chalk of southwestern Arkansas: Twenty-second Ann. Rept. U. S. Geol. Survey, pt. 3, 1902, pp. 687-742.

\section{PORTLAND CEMEN'T RESOURCES OF CATIFORNIA.}

\section{PORTLAND CEMENT MATERIALS.}

GENERAL FEATURES.

Few extensive beds of limestone are found in California, but numerous comparatively small areas occur, and many of these furnish rock suitable for use as a Portland cement material.

Detailed mapping of California geology has been so fragmentary that few generalizations can be drawn regarding the distribution of limestones low in magnesia and otherwise suitable for use as Portland cement materials. The areas in which limestones are known to occur are indicated on Plate IV, but it is practically certain that not all of the areas shown will yield material fit for Portland cement; on the other hand deposits of good material probably exist which do not appear on the map.

In the following paragraphs data are presented concerning some of the better-known areas of limestone. These are not necessarily the more important, but are simply those concerning which information is available as to the composition of the rock. When not otherwise credited most of the data in this section have been summarized. from reports of the State mineralogist of California. J. S. Diller, of the United States Geological Survey, has furnished all of the data for the Redding district and has located the deposits on the map.

As a matter of convenience descriptions of the limestones are arranged under county headings.

\section{SAN DIEGO COUNTY.}

Fine-grained chalklike limestone occurs near the Pacific coast at Jamul, San Diego County, where it was used about 20 years ago in a small Portland cement plant. This enterprise never attained any 


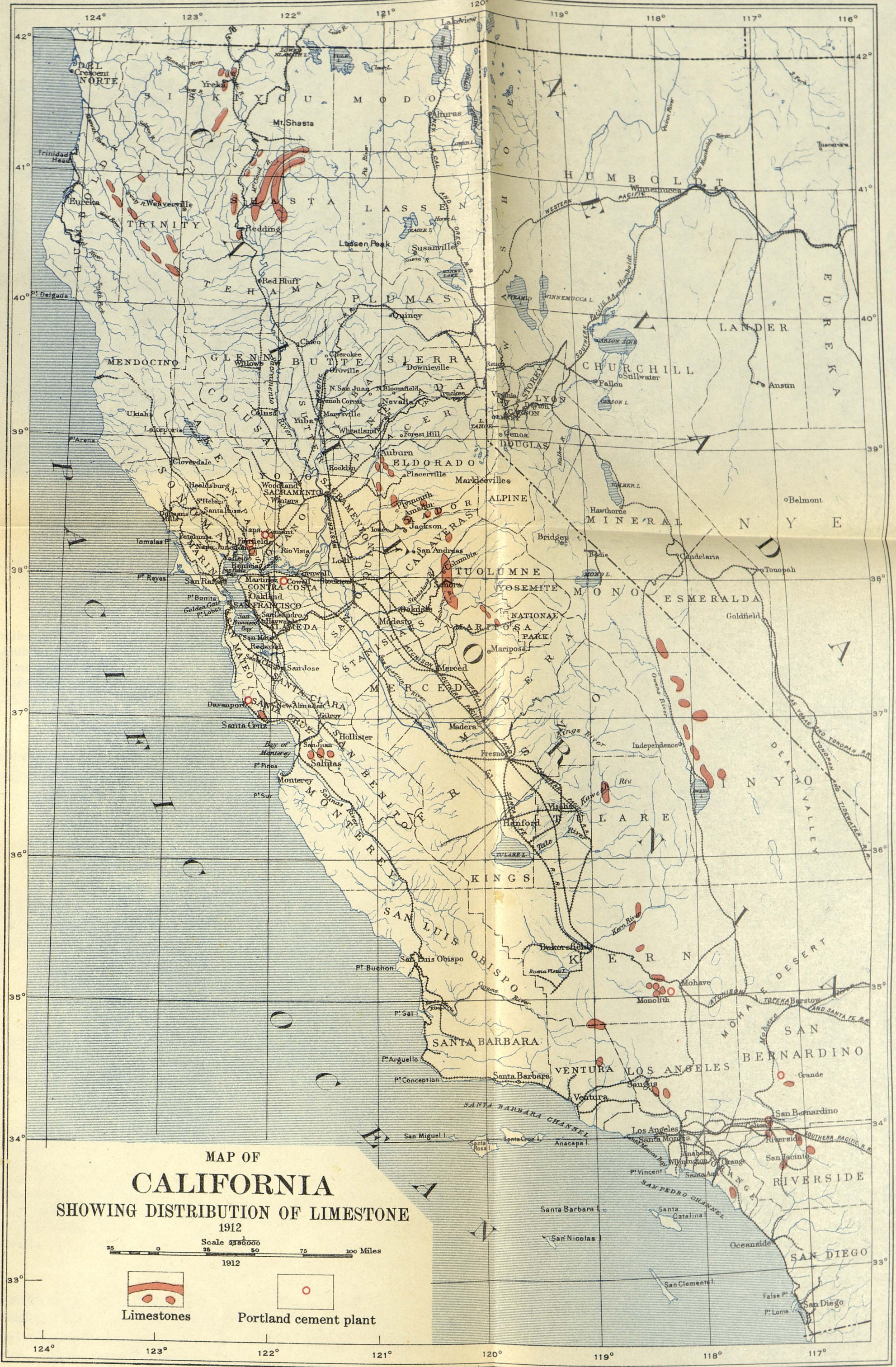



great importance, and for a number of years has been out of existence. The composition of the limestone used was as follows:

$$
\text { Analysis of limestone from San Diego County, Cal. }{ }^{1}
$$

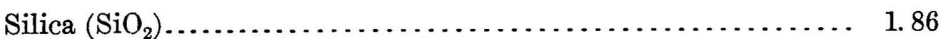

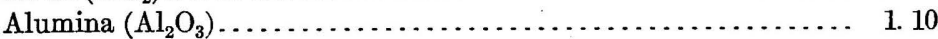

Lime carbonate $\left(\mathrm{CaCO}_{3}\right) \ldots \ldots \ldots \ldots \ldots \ldots \ldots \ldots \ldots \ldots \ldots \ldots \ldots \ldots, 94.28$

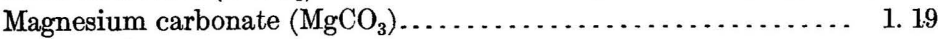

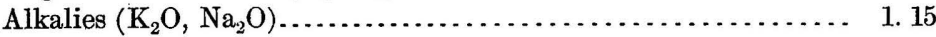

\section{ORANGE COUNTY.}

In Orange County a shell limestone is exposed at San Fernando and on the mesa at different places, both toward Orange, where there is a large exposure at the Los Alisos ranch, and toward San Juan.

Analyses of shell limestone. from Orange County, Cal. ${ }^{a}$

\begin{tabular}{|c|c|c|}
\hline$\cdot$ & 1 & 2 \\
\hline 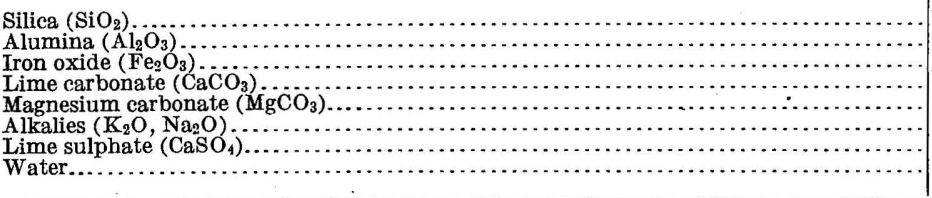 & $\begin{array}{r}14.25 \\
81.36 \\
.76 \\
1.32 \\
.42 \\
1.25\end{array}$ & $\begin{array}{r}27.08 \\
\\
65.26 \\
1.22 \\
2.02 \\
1.02 \\
1.20\end{array}$ \\
\hline
\end{tabular}

$a$ Eighth Ann. Rept. California State Mineralogist, 1888, p. 880.

LOS ANGELES COUNTY.

On the flat land at the edge of the foothills near Mission San Fer nando, Los Angeles County, a shell limestone of the following composition occurs in extensive deposits:

Analysis of limestone from Los Angeles County, Cal.

Silica $\left(\mathrm{SiO}_{2}\right)$

Alumina $\left(\mathrm{Al}_{2} \mathrm{O}_{3}\right)$

Iron oxide $\left(\mathrm{Fe}_{2} \mathrm{O}_{3}\right) \ldots \ldots \ldots \ldots \ldots \ldots \ldots \ldots \ldots \ldots \ldots \ldots \ldots \ldots \ldots \ldots \ldots \ldots \ldots \ldots \ldots \ldots \ldots \ldots \ldots \ldots \ldots \ldots \ldots \ldots \ldots \ldots$
Lime carbonate $\left(\mathrm{CaCO}_{3}\right) \ldots \ldots \ldots \ldots \ldots \ldots \ldots$

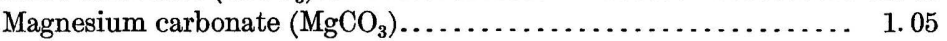

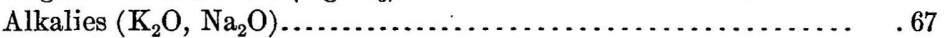

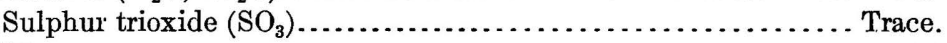

Water............................................... 1.76

KERN COUNTY.

Extensive deposits of limestone occur in Kern County at Tehachapi and vicinity. These have been largely used for burning into lime and for many years have furnished the bulk of the building lime supply of California. More recently attention has been directed to the possi-

1 Ninth Ann. Rept. California State Mineralogist, 1890, p. 309. 
bility of utilizing these deposits as Portland cement materials, and several cement projects have been based on them. The limestone is highly crystalline and satisfactory enough in chemical composition.

\section{SAN BENITO COUNTY.}

The following partial analyses are of very pure limestones occurring west of Hollister in San Benito County. ${ }^{1}$ No other information is available concerning them. Recently, however, a Portland cement plant has been projected at Crittenden in San Benito County.

Analyses of limestone from San Benito County, Cal.

\begin{tabular}{|c|c|c|c|}
\hline & 1 & 2 & 3 \\
\hline 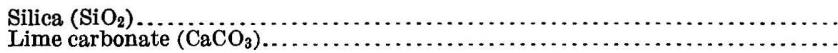 & $\begin{array}{r}2.10 \\
96.00\end{array}$ & $\begin{array}{r}0.7 \\
99.2\end{array}$ & $\begin{array}{r}0.5 \\
99.0\end{array}$ \\
\hline
\end{tabular}

SANTA CRUZ COUNTY.

Extensive deposits of limestone occur near the coast in the vicinity of Santa Cruz. These deposits are accompanied by shale and clay of good composition for cement uses, as can be seen from the following analyses: ${ }^{2}$

Analyses of cement materials from Santa Cruz County, Cal.

\begin{tabular}{|c|c|c|c|c|c|}
\hline \multirow[b]{2}{*}{ 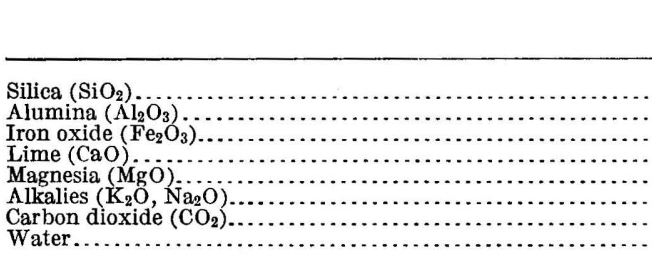 } & \multicolumn{2}{|c|}{ Limestone. } & \multicolumn{3}{|c|}{ Clay. } \\
\hline & $\begin{array}{r}2.40 \\
.51 \\
.56 \\
51.31 \\
1.25 \\
1.45 \\
40.32 \\
1.21\end{array}$ & $\begin{array}{r}4.71 \\
1.20 \\
.60 \\
50.02 \\
.75 \\
1.80 \\
39.25 \\
1.40\end{array}$ & $\begin{array}{r}63.73 \\
22.12 \\
9.01 \\
2.83 \\
\text { Tr. } \\
.21 \\
\text { n. d. } \\
1.12\end{array}$ & $\begin{array}{r}60.03 \\
21.76 \\
11.49 \\
3.37 \\
.25 \\
1.36 \\
\text { n. d. } \\
1.45\end{array}$ & $\begin{array}{r}62.22 \\
20.02 \\
8.25 \\
1.96 \\
\text { Tr. } \\
.81 \\
\text { n. d. } \\
6.52\end{array}$ \\
\hline
\end{tabular}

Other analyses, together with further details concerning the limestones and clays at Davenport, in this county, are given on pages 122-123.

\section{SOLANO AND CONTRA COSTA COUNTIES.}

Very extensive beds of travertine are exposed from Vallejo to Goodyears, Solano County, and from Mount Diablo to Pinole, Contra Costa County. They are now utilized as Portland cement materials at Cowell, Contra Costa County, and at Suisun, Solano County.

The following analyses ${ }^{3}$ of travertines have been obtained from published reports. Other analyses will be found on page 121.

1 Mineral Resources U. S. for 1889-90, U. S. Geol. Survey, 1892, p. 383.

2 Eighth Ann. Rept. California State Mineralogist, 1888, p. 881.

3 Idem, p. 882. 
Analyses of travertine from Solano and Contra Costa counties, Cal.

\begin{tabular}{|c|c|c|c|c|c|}
\hline & 1 & 2 & 3 & 4 & 5 \\
\hline 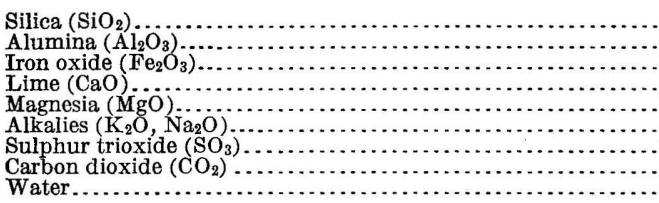 & \begin{tabular}{r|}
9.05 \\
7.56 \\
5.20 \\
33.35 \\
1.25 \\
2.05 \\
1.03 \\
28.56 \\
2.05
\end{tabular} & $\begin{array}{r}42.61 \\
15.05 \\
4.10 \\
17.98 \\
2.60 \\
.26 \\
.84 \\
14.12 \\
.96\end{array}$ & $\begin{array}{r}12.89 \\
2.95 \\
40.32 \\
2.26 \\
.37 \\
40.11 \\
.67\end{array}$ & $\begin{array}{r}6.12 \\
50.85 \\
.24 \\
.83 \\
\text { n. d. } \\
41.96 \\
\text { n. d. }\end{array}$ & $\begin{array}{r}0.26 \\
.20 \\
34.80 \\
.30 \\
.14 \\
\text { n. d. } \\
43.38 \\
.50\end{array}$ \\
\hline
\end{tabular}

1, 2, 3. Contra Costa County, between Mount Diablo and Pinole.

4. Benicia, Solano County.

5. Port Costa, Contra Costa County.

SONOMA COUNTY.

Limestone is quarried in Sonoma County 6 miles northeast of Geyserville, on Little Sulphur Creek. The rock is described ${ }^{1}$ as a "hard, compact, drab-colored limestone, with pure white schist of microcrystalline limestone throughout the mass." An analysis follows:

Analysis of limestone from Sonoma County, Cal.

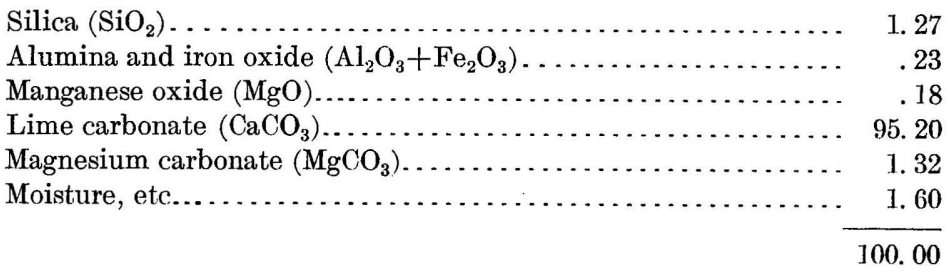

From its analysis this limestone would be satisfactory enough as a cement material, but from the remainder of the description quoted from above the entire deposit can not be very large.

\section{SHASTA COUNTY.}

The limestones occurring in the Redding district of Shasta County are described as follows by J. S. Diller ${ }^{2}$ :

More limestone occurs in the copper region of Shasta County, Cal., than in an equal area of any other part of the State. A thick limestone of Triassic age occurs along the stage road east of Furnaceville, and subordinate masses crop out around the upper slope of Bear Mountain, a few miles northwest of Sherman, but the principal mass of this belt forms Brock Mountain, on Squaw Creek, and may be traced for many miles to the north. This limestone is full of fossils and is especially noted for the large lizard-like animals it contains. It is generally pure and at Brock Mountain is used for flux in the Bully Hill smelter.

A belt of more prominent limestone ridges and peaks extends from near Lilienthals north by Gray Rock, the Fishery, and Hirz Mountain, along the McCloud for many miles. The limestone where best developed is over 1,000 feet thick, and until recently

${ }^{1}$ Bull California State Min. Bur. No. 38, 1906, pp. 93-94.

2 Bull. U. S. Geol. Survey No. 213, 1903, p. 365. 
has been used for flux at Bully Hill. It is cut by numerous irregular dikes of igneous rock, which locally interfere with quarrying. If the projected branch railroad up Pit River is ever built, it would pass near this great limestone. [This branch railroad, the Sacramento Valley \& Eastern, now extends up Pit River to Bully Hill.-E. F. B.]

A third belt of limestone occurs near Kennett, within a few miles of the railroad, and furnishes not only flux for the Mountain Copper Co. at the Keswick smelter, but also lime, which is burned at Kennett and shipped to many points on the Southern Pacific Railroad. This limestone is of Devonian age and consequently much older than the others. Although the limestone is not nearly as large as the others and isolated on ridge crests by igneous rocks, it is more valuable because more accessible. Smaller masses occur near Horsetown and at several points on the plain northeast of Buckeye, where lime has been burned, but since the Kennett locality has been opened they are of little importance.

Below are given partial analyses of three of the limestones above described by Mr. Diller:

Analyses of limestones from Redding district, Cal.

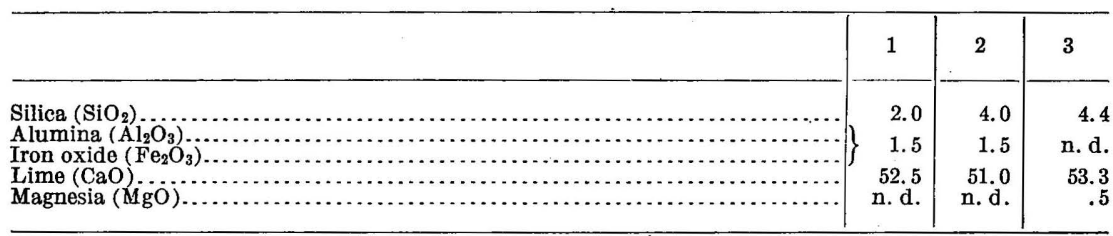

1. Near U. S. Fishery at Baird. Bull. U. S. Geol. Survey No. 225, 1904, p. 176.

2. Brock Mountain, 6 miles northeast of Delamar. Idem.

3. Kennett. Eighth Ann. Rept. California State Mineralogist, 1888, p. 572.

PORTLAND CEMENT INDUSTRY IN CALIFORNIA.

Until 1903 only one Portland cement plant had succeeded in establishing itself in California. This was the California Portland Cement Co., at Colton, San Bernardino County. In consequence of this slight development of a local industry, California was until quite recently supplied largely with foreign Portland cement, always high priced and frequently of poor quality. During 1903, however, two additional plants went into operation near San Francisco; and within the last 5 years 5 other Portland cement plants have been completed, and the prospects seem good for further expansion during the next period of business activity. At present California ranks third among the States as a cement producer, the annual output of the State being considerably in excess of $7,000,000$ barrels, or more than 1 barrel per capita of tributary population. Pacific coast plants now produce more cement per capita than the average of the United States, and though this fact does not prove that the maximum expansion on the coast has yet been reached, it does indicate a possible maximum of further expansion for the domestic trade.

The fuel question is also of pressing interest. Owing to the lack of good native coals and the abundant supply of petroleum, oil is burned at all the plants. So long as this is produced freely enough to be sold at reasonable prices, it will be possible to use it economi- 
cally in cement burning. A decrease in the supply from the oil fields, however, would be a serious matter to capital invested in the California cement industry.

At present eight Portland cement companies are operating in California, as follows: The Pacific Portland Cement Co., at Cement, near Suisun; the California Portland Cement Co., at Colton; the Cowell Portland Cement Co., at Cowell; the Santa Cruz Portland Cement Co., at Davenport; the Standard Portland Cement Co., at Napa Junction; the Riverside Portland Cement Co., at Riverside; the Golden State Portland Cement Co., at Oro Grande; and the mill of the Los Angeles aqueduct at Monolith.

The plant of the Pacific Portland Cement Co., at Cement, about 6 miles east of Suisun, Solano County, uses travertine and clay. The travertine, a very pure lime carbonate deposited from surface waters carrying it in solution, is extensively exposed in the immediate vicinity of the cement plant. Bakersfield oil is used for fuel, and the plant is run by electric power from Marysville. Analyses of the raw materials and of the finished cement, which is marketed as "Golden Gate" brand, follow:

Analyses of travertine, clay, and cement, Suisun, Cal.

\begin{tabular}{|c|c|c|c|c|}
\hline \multirow[t]{2}{*}{-} & \multicolumn{2}{|c|}{ Travertine. } & \multirow{2}{*}{ Clay. } & \multirow{2}{*}{ Cement. } \\
\hline & 1 & 2 & & \\
\hline 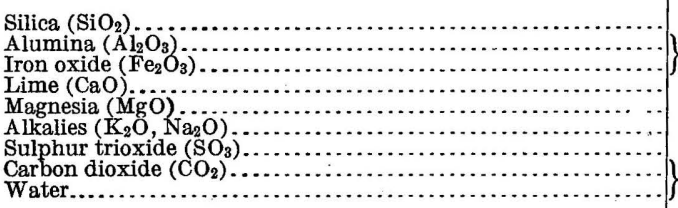 & $\begin{array}{l}1.25 \\
1.00 \\
53.65 \\
.55 \\
\text { n. d. } \\
\text { n. d. } \\
43.40\end{array}$ & $\begin{array}{r}1.21 \\
.70 \\
.50 \\
53.62 \\
.44 \\
\text { n. } .8 \\
.11 \\
42.98\end{array}$ & $\begin{array}{r}58.25 \\
18.56 \\
7.35 \\
3.10 \\
1.28 \\
2.35 \\
.45 \\
8.55\end{array}$ & $\begin{array}{r}22.25 \\
7.65 \\
3.35 \\
62.85 \\
.78 \\
.69 \\
1.34 \\
1.00\end{array}$ \\
\hline
\end{tabular}

The Standard Portland Cement Co. plant is at Napa Junction, Napa County. The raw material, which is obtained from a comparatively small area of limestone in the neighborhood, consists of two grades of rock-one a relatively pure limestone carrying from 85 to 90 per cent of lime carbonate, the other a much more clayey limestone carrying from 60 to 65 per cent of lime carbonate. So far as chemical composition is concerned, the materials used are closely similar to those used in the Lehigh district of Pennsylvania and in Warren County, N. J.; but the California limestones are much softer than those of the Lehigh district. The quarry contains beds of still more clayey composition, and deposits of adobe clay overlie the rock in places. Analyses of the two grades of limestone used at this plant are presented in the following table: 
Analyses of raw materials used for cement at Napa Junction, Cal.

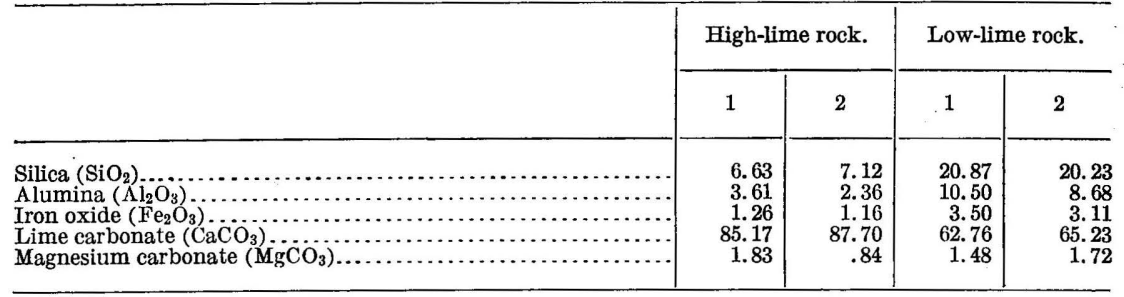

The plant of the California Portland Cement Co. at Colton, San Bernardino County, uses clay and a pure and very highly crystalline limestone or marble obtained from a ridge in rear of the plant. The limestone ranges from 90 to 98 per cent or more in lime carbonate.

The Cowell Portland Cement Co. plant at Cowell, at the foot of Mount Diablo near Concord, Contra Costa County, uses travertine from a deposit covering several hundred acres and shaly clay associated with the travertine. A more recent adobe clay also occurs near the plant. The following analyses by Dr. Percy Hobbs show the composition of these materials:

Analyses of travertine, Cowell, Cal.

\begin{tabular}{|c|c|c|c|c|c|}
\hline & 1 & 2 & 3 & 4 & 5 \\
\hline 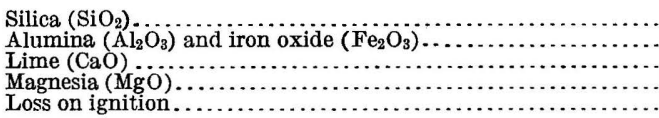 & $\begin{array}{r}1.80 \\
.54 \\
54.24 \\
.70 \\
43.52\end{array}$ & $\begin{array}{r}10.80 \\
6.88 \\
44.28 \\
.78 \\
38.08\end{array}$ & $\begin{array}{r}4.56 \\
1.34 \\
52.16 \\
.54 \\
41.86\end{array}$ & $\begin{array}{r}4.36 \\
1.12 \\
52.48 \\
.66 \\
41.95\end{array}$ & $\begin{array}{r}1.64 \\
.54 \\
54.74 \\
.70 \\
43.08\end{array}$ \\
\hline
\end{tabular}

1. Float average from hill north of large quarry.

$2,3,4$. From face of large quarry.

5. Average from dump and face of upper quarry.

Analyses of shales and clays, Cowell, Cal.

\begin{tabular}{|c|c|c|c|c|c|c|}
\hline \multirow[t]{2}{*}{ - } & \multicolumn{5}{|c|}{ Shale clay underlying travertine. } & \multirow{2}{*}{$\begin{array}{c}\begin{array}{c}\text { Adobe } \\
\text { clay. }\end{array} \\
6\end{array}$} \\
\hline & 1 & 2 & 3 & 4 & 5 & \\
\hline 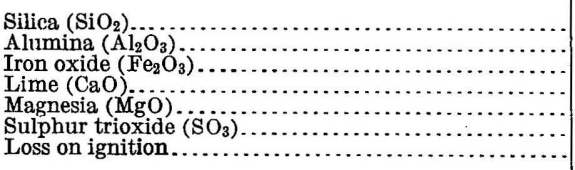 & $\begin{array}{r}53.20 \\
23.97 \\
6.03 \\
1.84 \\
1.65 \\
12.66 \\
12.80\end{array}$ & $\begin{array}{r}61.68 \\
19.39 \\
5.29 \\
.72 \\
1.69 \\
.41 \\
11.36\end{array}$ & $\begin{array}{r}55.64 \\
22.88 \\
5.08 \\
2.68 \\
1.49 \\
1.78 \\
11.80\end{array}$ & $\begin{array}{r}53.16 \\
19.40 \\
5.32 \\
3.72 \\
1.94 \\
1.93 \\
12.30\end{array}$ & $\begin{array}{r}58.36 \\
24.72 \\
5.12 \\
1.24 \\
1.36 \\
1.98 \\
11.36\end{array}$ & $\begin{array}{r}53.56 \\
20.94 \\
4.54 \\
2.14 \\
1.81 \\
\text { n. d. } \\
15.18\end{array}$ \\
\hline
\end{tabular}

The mill of the Santa Cruz Portland Cement Co. at Davenport, a few miles north of Santa Cruz, uses shale and a very pure and highly crystalline limestone. The shale is really diatomaceous, which accounts for the high silica percentage and for the fact that with such a high silica percentage it is still possible to use it as a cement mate- 
rial. The following tables contain analyses by L. T. Bachman of the limestone and shale, as well as of clinker and cement made at the plant several years ago:

Analyses of limestone, Davenport, Cal.

\begin{tabular}{|c|c|c|}
\hline & 1 & 2 \\
\hline 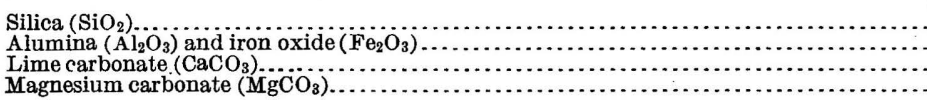 & $\begin{array}{r}1.30 \\
.60 \\
98.13 \\
.28\end{array}$ & $\begin{array}{r}1.12 \\
.46 \\
98.85 \\
.30\end{array}$ \\
\hline
\end{tabular}

Analyses of shale and cement, Davenport, Cal.

\begin{tabular}{|c|c|c|c|c|c|c|c|}
\hline \multirow{2}{*}{. } & \multicolumn{3}{|c|}{ Diatomaceous shale. $a$} & \multirow{2}{*}{ Clinker. } & \multicolumn{3}{|c|}{ Cement. } \\
\hline & 1 & 2 & 3 & & 5 & 6 & 7 \\
\hline 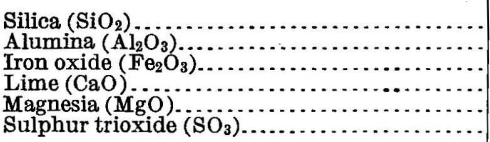 & $\begin{array}{r}79.76 \\
10.84 \\
2.76 \\
\text { Tr. } \\
1.07 \\
.62\end{array}$ & $\begin{array}{r}74.38 \\
11.77 \\
3.35 \\
\text { Tr. } \\
.87 \\
.44\end{array}$ & $\begin{array}{r}77.52 \\
8.74 \\
3.40 \\
\text { Tr. } \\
1.16 \\
\text { n. d. }\end{array}$ & $\begin{array}{r}23.90 \\
8.54 \\
64.42 \\
1.32 \\
\text { n. d. }\end{array}$ & $\begin{array}{r}25.84 \\
4.42 \\
62.90 \\
1.25 \\
.70\end{array}$ & $\begin{array}{r}25.30 \\
5.54 \\
63.30 \\
1.00 \\
.59\end{array}$ & $\begin{array}{r}26.04 \\
5.72 \\
62.56 \\
1.45 \\
.42\end{array}$ \\
\hline
\end{tabular}

$a$ Dried above $100^{\circ} \mathrm{C}$.

The Riverside Portland Cement Co. operates a plant at Riverside, using a mixture of limestone and clay. Since 1910 the city of Los Angeles has owned and operated a Portland cement plant in connection with the building of the Los Angeles aqueduct. ${ }^{1}$ It is located at Monolith, on the main line of the Southern Pacific Railway, about midway of the length of the aqueduct. Three deposits of limestone are owned by the city within 3 to 6 miles of the mill; one of them, covering a tract of 120 acres, 6 miles from the mill, has been opened by a quarry on a hillside about 800 feet above the valley. The stone is delivered to a storage bin at the base of the hill by an aerial tramway 4,700 feet long, and is carried to the cement mill by a 3 -foot gage railroad. Clay is dredged from a broad depression partly filled by a small lake and is delivered to the mill by an aerial tramway 5,800 feet long. Oil is used for kiln fuel.

The Golden State Portland Cement Co. operates a plant at Oro Grande, using a mixture of limestone, clay, and shale. This plant reported its first commercial output in 1911.

\section{BIBIIOGRAPHY.}

DiLler, J. S., Limestone of the Redding district, California: Bull. U. S. Geol. Survey No. 213, 1903, p. 365.

Grimsley, G. P., The Portland cement industry in California: Eng. \& Min. Jour., July 20, 1901. 
Irelan, Wrlliam, California natural and artificial cement: Eighth Ann. Rept. California State Mineralogist, 1888, pp. 865-884.

California cement: Ninth Ann. Rept. California State Mineralogist, 1890, pp. 309-311.

Structural and industrial materials of California: Bull. No.38, California State Mining Bureau, 1906.

JACKson, A. W., Building stones of California: Seventh Ann. Rept. California State Mineralogist, 1887, pp. 206-217.

Johnston, W. D., Clays of California: Ninth Ann. Rept. California State Mineralogist, 1890, pp. 287-308.

Lrppincotr, J. B., Manufacture of Portland cement in southern California: WaterSupply Paper U. S. Geol. Survey No. 60, 1902, pp. 135-137.

\section{PORTLAND CEMENT RESOURCES OF COLORADO.}

\section{PORTIAND CEMENT MATERIALS.}

\section{DISTRIBUTION.}

The limestones of Colorado available for use as cement materials may conveniently be divided on a geographical basis into two groups. The first of these groups includes the limestones, mostly of Cretaceous age, which occur in the plains region of the eastern half of the State and in a narrow belt immediately east of the Front Range. The second group includes the limestones, mostly Carboniferous, which lie west of the Front Range. The two groups differ not only in geologic age but, owing to their geographic position, in their commercial possibilities. At present it seems probable that the Cretaceous limestones are of greater industrial importance for cement manufacturing than the Carboniferous rock.

\section{LIMESTONES EAST OF THE FRONT RANGE.}

The one hundred and fifth meridian through most of its extent in Colorado coincides closely with the dividing line between the Cretaceous rocks of eastern Colorado and the older formations of the central and western parts of the State. East of the Front Range the rocks are mostly of Cretaceous or younger age. They consist chiefly of shales and sandstones but include two limestone formations-the Niobrara and the Greenhorn-of great importance for cement making.

The Niobrara, which is by far the more important in both thickness and areal extent, outcrops as a narrow but fairly continuous belt just east of the Front Range, passing through Fort Collins, just west of Denver, down to Colorado Springs. At Colorado Springs this narrow belt joins a much more extensive area of Niobrara limestone which occupies much of Pueblo, Otero, Huerfano, Las Animas, Bent, Prowers, Kiowa, and Cheyenne counties. The distribution of the limestone in this area is described by Darton. ${ }^{1}$

IDarton, N. H., Geology and underground water resources of the central Great Plains: Prof. Paper U. S. Geol. Survey No. 32, 1905, p. 107. 
No good analyses of Niobrara limestone from southeastern Colorado are available, but from experience gained during attempts to manufacture cement in Colorado from this limestone, it is probably safe to say that the Niobrara limestone is for the most part low enough in magnesia to be satisfactory. Through much of its extent its chief defect is lack of lime rather than excess of magnesia.

Concerning the Niobrara limestone in the narrow belt lying just east of the Front Range, a recent paper by G. C. Martin ${ }^{1}$ supplies very complete data. The following quotations cover the sections of greatest interest to cement manufacturers:

The Niobrara limestone is one of the formations which outcrops in the foothills and is the highest and easternmost one that contributes essentially to the typical foothills topography. It consequently outcrops as a long, narrow belt parallel to the mountains and to the other ridges of the foothills. The position of this belt is in general from 2 to 3 miles east of the mountains, approaching nearer to them or extending farther out toward the plains, according as the dip is steep or gentle. The basal member of the Niobrara usually consists of thick and massive limestone and makes a very distinct ridge, but where this member is thinner or less massive the ridge disappears. The dip is in general noticeably steeper in the basal bed, which lies nearest the mountains, and flattens perceptibly toward the east. The width of this belt is between one-eighth and one-half mile, varying with the amount of dip, as the thickness of the formation remains fairly constant.

The Niobrara is essentially a limestone formation, although calcareous shales make up a considerable part of it. The thickness is about 400 feet. The basal member is a massive white to gray limestone, whose thickness ranges from 10 to 20 feet. This bed, which rests with apparent conformity on the top member of the Benton (Carlile shale), is apparently persistent, having been seen through practically the entire length of the region studied. It is succeeded by shaly limestones and calcareous shales, the former predominating and the calcareous nature of all the beds being persistent. These beds vary somewhat in character along the strike, fairly massive limestones being developed at several places. These more massive limestone beds are apparently present at several horizons but predominate toward the middle of the formation.

The Niobrara limestone has already been described as occurring in a narrow northsouth belt along a line of low ridges just east of the main foothills. It dips eastward under the plains at angles of $24^{\circ}$ to $70^{\circ}$ along the western edge. Most of these dips are so steep that within short distances they carry the limestone too deep to be quarried cheaply; consequently it is only where the limestone rises into a ridge of considerable height that there is any large amount of material that can be easily quarried. The most desirable localities for quarries are where the ridge is high but falls off steeply into a transverse valley, thus affording sites where quarries can be opened with their facesabove the general drainage level and with a considerable bulk of rock near at hand. Such points exist where the limestone belt crosses the valleys of St. Vrain Creek, Little Thompson Creek, Thompson River, and Cache la Poudre River. At each of these points, except on Little Thompson Creek, a railroad follows the line of the stream and crosses the limestone belt, the topographic conditions favorable for a good quarry site being thus combined with easy transportation facilities. There are numerous localities on either side of these railroads where quarries could be opened.

The analyses in the following tables were made at the U. S. Geological Survey laboratory at St. Louis, Mo., especially for Martin's

${ }_{1}$ The Niobrara limestone of northern Colorado as a possíbJe cement material: Bull. U. S. Geol. Survey No. 380, 1909, pp. 314-326. 
report, on samples collected by him. The analyses in the first table cover samples of the massive basal member of the Niobrara; those in the second table are of samples from the upper and more clayey portion of the formation:

Analyses of basal bed of Niobrara limestone.

\begin{tabular}{|c|c|c|c|c|c|c|}
\hline & 166 & 169 & 163 & 162 & 160 & 156 \\
\hline 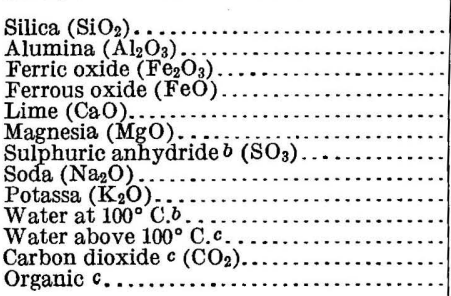 & $\begin{array}{r}a 5.97 \\
a 1.74 \\
a .18 \\
a .64 \\
a 49.82 \\
a .75 \\
\text { Trace. } \\
a .16 \\
a .34 \\
.17 \\
.07 \\
39.84 \\
.43\end{array}$ & $\begin{array}{r}a 7.14 \\
a 1.63 \\
a .14 \\
a .48 \\
a \quad 49.11 \\
a 1.04 \\
\text { Trace. } \\
a .17 \\
a .45 \\
.33 \\
.19 \\
39.00 \\
.52\end{array}$ & $\begin{array}{r}\text { b } 5.33 \\
\text { b } 1.54 \\
b .23 \\
b .48 \\
\text { b } 50.69 \\
\text { b. } .56 \\
\text { b. } .05 \\
b .21 \\
.12 \\
.51 \\
39.90 \\
.44\end{array}$ & $\begin{array}{r}a 5.35 \\
a 1.45 \\
a .45 \\
a .56 \\
a .29 \\
a .57 \\
.09 \\
a .03 \\
a .13 \\
.08 \\
.24 \\
40.07 \\
.27\end{array}$ & $\begin{array}{r}a 5.10 \\
a 1.80 \\
a .03 \\
a .56 \\
a 50.27 \\
a 1.01 \\
.12 \\
a .07 \\
a .26 \\
.17 \\
.49 \\
40.11 \\
.16\end{array}$ & $\begin{array}{r}a 4.79 \\
a .99 \\
a .14 \\
a .48 \\
a .50 .54 \\
a .56 \\
.10 \\
a .14 \\
a .37 \\
.17 \\
.29 \\
40.38 \\
1.09\end{array}$ \\
\hline & 100.11 & 100.20 & 100.06 & 100.58 & 100.16 & 100.04 \\
\hline
\end{tabular}

$a$ Determined by A. J. Phillips. $\quad b$ Determined by G. R. Brobst. $\quad c$ Determined by P. H. Bates.

166. One-eighth mile north by one-third mile west of southeast corner sec. 20, T. 7 N., R. 69 W., Larimer County.

169. Two-fifths mile south by two-fifths mile west of northeast corner sec. 13, T. 4 N., R. 70 W., Larimer County.

163. Two-fifths mile east of southwest corner sec. 35 , T. 4 N., R. 70 W., Larimer County.

162. One-third mile west by 100 feet south of northeast corner sec. 21 , T. 3 N., R. 70 W., Boulder County. 160. One-fifth mile south by one-fifth mile east of northwest corner sec. 28 , T. 3 N., R. $70 \mathrm{~W}$ Borlder County.

156 . One-half mile west by one-fourth mile south of northeast corner sec. 5 , T. 2 N., R. 70 W., Boulder County.

Analyses of shaly members of Niobrara limestone.

\begin{tabular}{|c|c|c|c|c|c|c|c|c|}
\hline & 165 & 167 & 168 & 164 & 161 & 159 & 157 & 158 \\
\hline 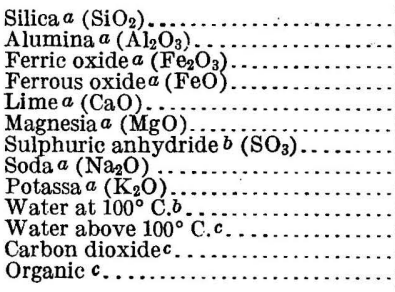 & $\begin{array}{r}17.40 \\
6.17 \\
.54 \\
.56 \\
39.38 \\
.67 \\
.52 \\
.18 \\
.62 \\
.86 \\
1.98 \\
30.75 \\
.36\end{array}$ & $\begin{array}{r}11.10 \\
3.51 \\
.18 \\
.81 \\
43.86 \\
.99 \\
.07 \\
.11 \\
.61 \\
.60 \\
2.01 \\
34.58 \\
1.64\end{array}$ & $\begin{array}{r}11.13 \\
4.58 \\
.40 \\
.56 \\
43.60 \\
1.05 \\
\text { Trace. } \\
.20 \\
.78 \\
.57 \\
1.21 \\
34.38 \\
1.72\end{array}$ & $\begin{array}{r}18.59 \\
6.03 \\
.31 \\
.89 \\
38.55 \\
.70 \\
.10 \\
.24 \\
.98 \\
.67 \\
2.13 \\
29.14 \\
1.78\end{array}$ & $\begin{array}{r}9.60 \\
2.41 \\
.18 \\
.81 \\
45.87 \\
.81 \\
.32 \\
.19 \\
.69 \\
.41 \\
1.43 \\
36.00 \\
1.48\end{array}$ & $\begin{array}{r}25.54 \\
8.72 \\
.54 \\
.80 \\
33.70 \\
.56 \\
.14 \\
.12 \\
.47 \\
.66 \\
2.38 \\
25.43 \\
1.19\end{array}$ & $\begin{array}{r}15.34 \\
5.34 \\
.54 \\
1.13 \\
40.81 \\
.80 \\
.12 \\
.29 \\
.93 \\
.48 \\
1.61 \\
32.15 \\
.67\end{array}$ & $\begin{array}{r}60.31 \\
16.61 \\
2.33 \\
1.70 \\
2.91 \\
2.46 \\
.12 \\
.99 \\
2.95 \\
1.15 \\
4.52 \\
2.81 \\
1.34\end{array}$ \\
\hline 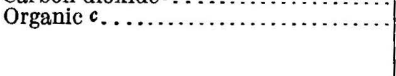 & 99.99 & 100.07 & 100.18 & 100.11 & 100.20 & 100.25 & 100.21 & 100.20 \\
\hline
\end{tabular}

$a$ Determined by A. J. Phillips. $b$ Determined by G. R. Brobst. $\quad c$ Determined by P. H. Bates.

165. Shaly limestone, one-third mile south by one-fourth mile west of northeast corner sec. 29, T. 8 N., R. 69 W., Larimer County.

167. Shaly limestone, one-tenth mile north by one-fourth mile west of southeast corner sec. 20, T. 7 N.,

R. 69 W., Larimer County.

168. One-third mile east of southwest corner sec. 9, T. 5 N., R. 69 W., Larimer County.

164. Shaly limestone, one-third mile west of southeast corner sec. 35, T. 4 N., R. 70 W., Larimer County, 161. Shaly limestone, one-third mile south by one-fourth mile west of northeast corner sec. $28, T$. 3 N.,

R. 70 W., Boulder County.

159. Shaly limestone, one-half mile west by-one-fourth mile north of southeast corner sec. 28, T. 3 N., R. 70 W., Boulder County. 157. Shaly limestone, one-third mile west by one-fourth mile south of northest corner sec. 5, T. 2 N.,
R. 70 W., Boulder County.

158. Clay shale, one-fourth mile west by one-fourth mile south of northeast corner sec. 5 , T. 2 N., R. 70 W, Boulder County. 


\section{LIMESTONES WEST OF THE FRONT RANGE.}

In central and western Colorado limestones of Mississippian age cover large areas and are probably the most promising cement materials of this portion of the State, though other limestones of both later and earlier age occur in the region. Their geographic position, however, makes improbable any important use of them for cement in the near future.

The following table contains analyses of a number of limestones from central and western Colorado sufficiently low in magnesia to be of interest:

Analyses of limestones from Colorado west of the Front Range.

\begin{tabular}{|c|c|c|c|c|c|c|c|c|c|}
\hline & 1 & 2 & 3 & 4 & 5 & 6 & 7 & 8 & 9 \\
\hline \multirow[t]{2}{*}{ 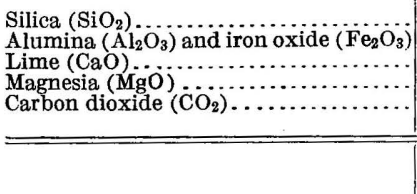 } & $\begin{array}{r}21.45 \\
1.20 \\
40.64 \\
.73 \\
32.73\end{array}$ & $\begin{array}{r}6.47 \\
.77 \\
46.65 \\
2.64 \\
39.55\end{array}$ & $\begin{array}{r}3.71 \\
.55 \\
47.40 \\
4.49 \\
42.15\end{array}$ & $\begin{array}{r}2.27 \\
.14 \\
53.79 \\
.46 \\
42.76\end{array}$ & $\begin{array}{r}0.22 \\
\mathrm{Tr} . \\
55.17 \\
.21 \\
43.58\end{array}$ & $\begin{array}{r}0.23 \\
.09 \\
55.49 \\
.24 \\
43.87\end{array}$ & \begin{tabular}{r}
0.06 \\
\hdashline 5.81 \\
43.85
\end{tabular} & $\begin{array}{r}0.22 \\
.20 \\
55.45 \\
.24 \\
43.84\end{array}$ & $\begin{array}{r}0.11 \\
.10 \\
55.68 \\
\text { Tr. } \\
43.75\end{array}$ \\
\hline & 10 & 11 & 12 & 13 & 14 & 15 & 16 & 17 & 18 \\
\hline \multirow[t]{2}{*}{ 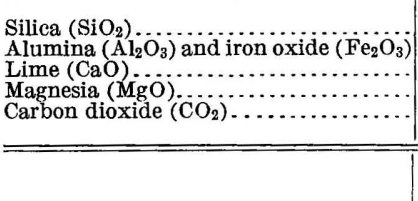 } & $\begin{array}{r}6.54 \\
.92 \\
50.58 \\
.36 \\
40.18\end{array}$ & $\begin{array}{r}1.44 \\
.13 \\
54.98 \\
\text { Tr. } \\
\text { n. d. }\end{array}$ & $\begin{array}{r}5.32 \\
.91 \\
48.73 \\
2.95 \\
41.71\end{array}$ & $\begin{array}{r}0.51 \\
55.10 \\
.17 \\
43.82\end{array}$ & $\begin{array}{r}2.37 \\
.19 \\
53.64 \\
.73 \\
42.93\end{array}$ & $\begin{array}{r}0.33 \\
\text { Tr. } \\
55.81 \\
.16 \\
44.03\end{array}$ & $\begin{array}{r}4.13 \\
4.13 \\
53.00 \\
.59 \\
42.28\end{array}$ & $\begin{array}{r}0.75 \\
1.00 \\
53.40 \\
.45 \\
42.46\end{array}$ & $\begin{array}{l}\text { n. d. } \\
\text { n.d. } \\
53.20 \\
\text { n. d. } \\
\text { n.d. }\end{array}$ \\
\hline & 19 & 20 & 21 & 22 & 23 & 24 & 25 & 26 & 27 \\
\hline 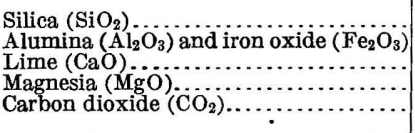 & $\begin{array}{r}31.12 \\
.55 \\
37.28 \\
.54 \\
29.88\end{array}$ & $\begin{array}{r}2.04 \\
.15 \\
54.62 \\
.25 \\
43.28\end{array}$ & $\begin{array}{r}0.82 \\
.07 \\
55.47 \\
.22 \\
43.86\end{array}$ & $\begin{array}{r}0.36 \\
.17 \\
55.58 \\
.37 \\
44.17\end{array}$ & $\begin{array}{r}4.42 \\
.10 \\
52.97 \\
42.40\end{array}$ & $\begin{array}{r}0.62 \\
.25 \\
55.24 \\
.24 \\
43.81\end{array}$ & $\begin{array}{r}7.91 \\
.32 \\
50.83 \\
.70 \\
40.90\end{array}$ & $\begin{array}{r}1.75 \\
.32 \\
53.60 \\
1.23 \\
43.65\end{array}$ & $\begin{array}{r}2.69 \\
.21 \\
54.23 \\
.21 \\
42.97\end{array}$ \\
\hline
\end{tabular}

1-9. Glenwood Springs, Garfield County. George Steiger, analyst. Bull. U. S. Geol. Survey No. 168, 1900 , p. 273 .

10. North Park, Grand County. B. E. Brewster, analyst. U. S. Geol. Expl. 40th Par., vol. 2, 1877, p. 115 .

11. Gunnison County. Ann. Rept. Colorado State School Mines for 1887, p. 21.

12. Morrison, Jefferson County. L. G. Eakins, analyst. Bull. U. S. Geol. Survey No. 168, 1900, p. 270

13. Mount Silverheels, Park County. W. F. Hillebrand, analyst. Idem, p. 272.

14. Fairplay, Park County. W. F. Hillebrand, analyst. -Ibid.

15. Aspen, Pitkin County. L. G. Eakins, analyst. Idem, p. 273.

16. Aspen Mount, Pitkin County. Reese \& Richards, analysts. Rept. Colorado State School Mines, 1836, p. 67

17. Aspen Mount, Pitkin County. F. Bardwell, analyst. Idem.

18. Aspen Mount, Pitkin County. F. Buckley, analyst. Idem, p. 68

19. Aspen district, Pitkin County. George Steiger, analyst. Buli. U. S. Geol. Survey No. 168, 1900 p. 272.

20. Jacque Mount, Tenmile district, Summit County. W. F. Hillebrand, analyst. Idem, p. 274.

21. Near Sabbath Rest tunnel, Tenmile district, Summit County. W. F. Hillebrand, analyst. Idem.

22. Searls Gulch, Tenmile district, Summit County. W. F. Hillebrand, analyst. Idem.

23. North of Sugarloaf, Tenmile district, Summit County. W. F. Hillebrand, analyst. Idem

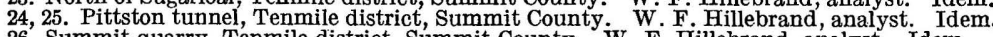

26. Summit quarry, Tenmile district, Summit County. W. F. Hillebrand, analyst. Idem.

27. Fletcher shaft, Copper Mountain, Tenmile district, Summit County. W. F. Hillebrand, analyst. Idem. 


\section{PORTLAND CEMENT INDUSTRY IN COLORADO.}

Only two Portland cement plants are at present in operation in Colorado, but several other attempts have been made to manufacture cement in the State. The materials used at the present plants, as well as at all the previous plants, are limestones of various grades of purity from the Niobrara formation.

The plant of the Colorado Portland Cement Co., at Portland, about 5 miles east of Florence, Fremont County, south of Arkansas River, and the plant of the United States Portland Cement Co., at Concrete, both use an argillaceous limestone averaging about 71 per cent of lime carbonate and a purer limestone carrying about 88 per cent of lime carbonate. The argillaceous limestone occurs in several beds, aggregating about 60 feet in thickness; the purer limestone is taken from a 40-foot bed lying about 50 feet below the other. Coal is used as fuel at these plants. The Newcastle Portland Cement Co. is reported to have built a small demonstrating plant at Newcastle, in western Colorado, but no output has yet been reported.

\section{BIBLIOGRAPHY.}

Darton, N. H., Preliminary report on the geology and underground water resources of the Central Great Plains: Prof. Paper U. S. Geol. Survey No. 32, 1905.

- Geology and underground waters of the Arkansas Valley in eastern Colorado: Prof. Paper U. S. Geol. Survey No. 52, 1906.

Emmons, S. F., and others, Geology of the Denver Basin in Colorado: Mon. U. S. Geol. Survey, vol. 27, 1896.

Lakes, Arthur, Building and monumental stones of Colorado: Mines and Minerals, vol. 22, 1901, pp. 29-30.

- Sedimentary building stones of Colorado: Mines and Minerals, vol. 22, 1901, pp. 62-64.

Martin, G. C., The Niobrara limestone of northern Colorado as a possible cement material: Bull. U. S. Geol. Survey No. 380, pp. 314-326, 1909.

Ries, Heinrich, The clays and clay-working industry of Colorado: Trans. Am. Inst. Min. Eng., vol. 27, 1898, pp. 336-340.

\section{PORTIAND CEMENT RESOURCES OF CONNECTICUT.}

Many outcrops of limestone occur in Connecticut, but few of them are large enough to justify the erection of a cement plant. Furthermore, most Connecticut limestones carry entirely too much magnesium carbonate to be available for use as Portland cement material, particularly the thick and extensive limestone beds that are so extensively quarried and utilized for lime burning in the vicinity of Danbury, Canaan, and elsewhere in western Connecticut. Numerous analyses of these limestones show that few of them carry less than 20 per cent of magnesium carbonate, and that many carry as much as 40 per cent. On the other hand few of the nonmagnesian limestones, which occur chiefly in central and eastern Connecticut, are over a few feet thick or have more than a very narrow outcrop. 
Of the analyses given below 2 and 3 are fairly typical of most of the limestones of western Connecticut. They are in general reasonably pure, so far as clayey matter is concerned, most of them carrying very low percentages of silica, alumina, iron oxide, and the like, but almost all of them are high in magnesia, many approaching dolomite in composition. A few beds show very low magnesia percentages. (See analysis 1.) Such would of course be serviceable as Portland cement materials, but unfortunately they are not extensive, and they can not be told at sight from the high-magnesia rocks in the same quarry. They therefore can not be separated during quarrying. For this reason the writer believes that such local occurrences of low-magnesia rocks give no promise of a future Portland cement industry in Connecticut.

Analyses of limestones from Connecticut.

\begin{tabular}{|c|c|c|c|}
\hline & 1 & 2 & 3 \\
\hline 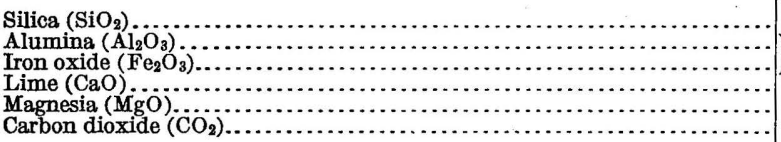 & $\begin{array}{r}5.83 \\
3.90 \\
50.40 \\
.10 \\
39.72\end{array}$ & $\begin{array}{r}0.08 \\
.25 \\
30.46 \\
21.48 \\
47.58\end{array}$ & $\begin{array}{r}0.48 \\
.20 \\
31.31 \\
21.03 \\
46.98\end{array}$ \\
\hline
\end{tabular}

1. Quarry of Danbury Lime Co, Danbury, Fairfield County. Mineral Resources U. S. for 1889-1890, 1892, p. 386.

2. Quarry of Canaan Lime Co., Canaan, Litchfield County. Twentieth Ann. Rept. U. S. Geol. Sur-

vey, pt. 6 (continued), 1899, p. 370.
3. Quarry of Canfield Bros., East Canaan, Litchfield County. Idem.

\section{PORTLAND CEMENT RESOURCES OF DELAWARE.}

Except for a relatively small area of pre-Cambrian and metamorphic rocks in extreme northern Delaware, the entire State is composed of fairly recent geologic formations-Cretaceous and later. A few isolated outcrops of crystalline limestones have been found in the metamorphic area, but their magnesia content is variable, and they do not occur in sufficient quantity to be worthy of consideration by the cement manufacturer.

\section{PORTLAND CEMENT RESOURCES OF FLORIDA.}

Though Florida is largely underlain by beds of limestone of Tertiary and recent age, great areas of these are covered by later deposits of sand and gravels. Partly because of this, and still more because of the lack of local fuel deposits and cement markets, no attempt has ever been made to manufacture Portland cement in the State. Should commercial conditions ever render a local cement industry possible there will probably be little difficulty in locating suitable deposits of limestone, for the Vicksburg group, the St. Stephens limestone of which is so promising a source of cement material $48834^{\circ}-$ Bull. $522-13-9$ 
in Alabama (see pp. 82-85), covers a large area in northern Florida, and other limestones of equal value outcrop elsewhere in the State. (See Pl. II, p. 68.)

The analyses in the following table give some idea of the composition of various Florida limestones:

Analyses of limestones from Florida.

\begin{tabular}{|c|c|c|c|c|c|c|c|c|c|}
\hline & 1 & 2 & 3 & 4 & 5 & 6 & 7 & 8 & 9 \\
\hline 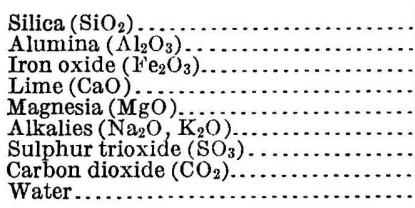 & $\begin{array}{r}39.01 \\
1.20 \\
.53 \\
30.99 \\
.42 \\
.71 \\
.33 \\
24.25 \\
3.07\end{array}$ & $\begin{array}{r}12.31 \\
12.19 \\
.66 \\
26.28 \\
16.72 \\
.50 \\
\text { n. d. } \\
38.12 \\
2.99\end{array}$ & $\begin{array}{r}0.17 \\
.20 \\
.08 \\
54.03 \\
.29 \\
\text { n. d. } \\
\text { n. d. } \\
42.52 \\
\text { n. d. }\end{array}$ & $\begin{array}{r}0.25 \\
.17 \\
.07 \\
54.01 \\
.77 \\
\text { n. d. } \\
\text { n.d. } \\
42.84 \\
\text { n.d. }\end{array}$ & $\begin{array}{r}0.12 \\
.08 \\
54.38 \\
.86 \\
\text { n. d. } \\
\text { n. d. } \\
43.36 \\
\text { n. d. }\end{array}$ & $\begin{array}{l}0.19 \\
.16 \\
55.12 \\
.30 \\
\text { n. d. } \\
\text { n. d. } \\
43.28 \\
\text { n. d. }\end{array}$ & $\begin{array}{r}0.07 \\
.16 \\
54.02 \\
1.06 \\
\text { n.d. } \\
\text { n. d. } \\
43.20 \\
\text { n. d. }\end{array}$ & $\begin{array}{r}2.94 \\
.23 \\
51.51 \\
.71 \\
\text { n.d. } \\
\text { n.d. } \\
41.59 \\
2.64\end{array}$ & $\begin{array}{r}8.50 \\
.73 \\
47.29 \\
1.51 \\
\text { n. d. } \\
\text { n. d. } \\
39.00 \\
3.37\end{array}$ \\
\hline
\end{tabular}

1. Limestone of A palachicola group, Wakulla County. Tenth Census, vol. 6, 1884, p. 193.

2. River Junction, Escambia County. George Steiger, analyst. Bull. U. S. Geol. Survey No. 168, 1900, p. 257 .

3. Artesian well, Key West, 25 feet down. 、 George Steiger, analyst. Idem.

4. Artesian well, Key West, 100 feet down. George Steiger, analyst. Idem.

5. Artesian well, Key West, 150 feet down. George Steiger, analyst. Idem.

6. Artesian well, Key West, 1,400 feet down. George Steiger, analyst. Idem.

7. Artesian well, Key West,2,000 feet down. George Steiger, analyst. Idem.

8. Shell rock, near Fort Worth. F. W. Clarke, analyst. Idem.

9. Shell rock, near Seville. F. W. Clarke, analyst. Idem.

Of the nine analyses quoted in the foregoing table, eight represent limestones safely within the permissible limit of magnesia. The exception is analysis 2 , which is here reproduced because attempts have been made to utilize the rock in the manufacture of a lightcolored natural cement, a use to which it is well enough adapted. Its curiously low content of iron oxide and its equally abnormal high percentage of alumina should be noted.

Quite recently consideration has been given to the possibility of utilizing the extensive peat deposits of Florida to supplement the otherwise unsatisfactory fuel supplies of the State. It is improbable, however, that a commercial cement industry can be started on this basis.

\section{PORTLAND CEMENT RESOURCES OF GEORGIA.}

\section{PORTLAND CEMENT MATERIALS.}

\section{DISTRIBUTION.}

Georgia is fairly well supplied with limestones, many of which are suitable for use in Portland cement manufacture. Four series are worth considering here. (See Pl. II, p. 68.) Named from oldest to youngest these four are:

1. Metamorphic limestones (marbles) of uncertain age.

2. Chickamauga limestone of Ordovician ("Lower Silurian") age.

3. Bangor limestone of Mississippian ("Lower Carboniferous") age.

4. Cretaceous and Tertiary limestones (so-called "marls"). 


\section{METAMORPHIC LIMESTONES OR MARBLES. ${ }^{1}$}

Highly crystalline limestones, suitable for use as marble, occur in parts of northern Georgia, notably in the counties of Fannin, Gilmer, Pickens, and Cherokee. The principal outcrops closely parallel the line of the Louisville \& Nashville Railroad from near Canton northward to the Georgia-North Carolina line. Throughout the entire belt the marble has been quarried more or less extensively.

As shown by McCallie, the marble is of two distinct types, so far as chemical composition is concerned. One of these types, represented by the analyses below ${ }^{1}$ rarely carries over 1 per cent of magnesia and is therefore available as a Portland cement material. The other type carries 15 to 22 per cent of magnesia and is therefore not worth considering in the present connection.

\section{Analyses of metamorphic limestones from Georgia.}

[W. H. Emerson, analyst.]

\begin{tabular}{|c|c|c|c|c|c|}
\hline . & 1 & 2 & 3 & 4 & 5 \\
\hline Silica $\left(\mathrm{SiO}_{2}\right)$ & 0.35 & 1.62 & 2.12 & 1.43 & 0.76 \\
\hline $\begin{array}{l}\text { Alumina }\left(\mathrm{Al}_{2} \mathrm{O}_{3}\right) \\
\text { Iron oxide }\left(\mathrm{Fe}_{2} \mathrm{O}_{3}\right)\end{array}$ & .15 & .32 & .10 & 3.28 & .42 \\
\hline Lime $(\mathrm{CaO})$ & 55.00 & 54.41 & 54.06 & 52.77 & 54.67 \\
\hline $\begin{array}{l}\text { Magnesia }(\mathrm{MgO}) \\
\text { Carbon dioxide }\left(\mathrm{CO}_{2}\right) \ldots \ldots \ldots \ldots \ldots \ldots \ldots \ldots \ldots \\
.\end{array}$ & $\begin{array}{r}1.12 \\
44.16\end{array}$ & $\begin{array}{r}.75 \\
43.13\end{array}$ & $\begin{array}{r}.90 \\
42.86\end{array}$ & 41.82 & $\begin{array}{r}1.01 \\
43.49\end{array}$ \\
\hline
\end{tabular}

1. Marble from Creole quarry of Georgia Marble Co., near Tate, Pickens County.

2. Marble from E towah quarry of Georgia Marble Co., near Tate, Pickens County.

3. Coarse white marble, Georgia Marble Co.'s quarry, near Tate, Pickens County.

4. Haskins property, 1 mile southeast of Red Clay, Whitfield County.

5. Ellinger property, 1 mile east of Varnells station, Whitfield County.

\section{CHICKAMAUGA · LIMESTONE.}

The Chickamauga limestone occurs only in northwest Georgia, where it appears as a series of long narrow bands commonly trending N. $30^{\circ}$ E. (See Pl. II.) A few of the more important areas will be briefly described, beginning in the extreme northeastern portion of the State, particular attention being paid to outcrops on or near railroads.

A belt of Chickamauga limestone entering Georgia a few miles southwest of Chattanooga is followed by the Alabama Great Southern Railroad from near Chattanooga to a few miles below Trenton; another belt is crossed by the same railroad about 3 miles south of Rising Fawn; a third belt is followed closely by the Southern Railway from Rossville to Cedar Grove; and a fourth is followed by the same road from Bronco to Menlo. The railroad from Chattanooga to Summerville runs for 5 miles east of Chickamauga across one of these limestone belts. An extensive belt of the limestone borders the western faces of Taylors Ridge and White Oak Mountains, but

1 The composition, character, and distribution of these valuable building stones are described by S. W. McCallie in Preliminary report on the marbles of Georgia: Bull. Georgia Geol. Survey No. 1, 1907. To this bulletin reference should be made for details concerning the crystalline limestones of Georgia. 
is crossed by railroads near Ringgold and Lavender only. Other belts are crossed at Dalton and between Dalton and Tunnelhill.

The Chickamauga limestone is very extensively exposed in the northern half of Polk County, being crossed by railroads at or near the stations of Esomhill, Cedartown, Fish Creek, Rockmart, Davittes, and Taylorsville. As later noted, one Portland cement plant in operation at Rockmart is already utilizing this limestone.

Throughout Georgia the Chickamauga limestone is commonly rather pure, carrying 90 to 95 per cent of lime carbonate and less than 2 per cent of magnesium carbonate. Analyses 1, 2, and 4 of the following table ${ }^{1}$ fairly represent its composition. Analysis 3 represents a highly magnesian type of rock that is tortunately uncommon; its reference to the Chickamauga may be erroneous.

Analyses of Chickamauga limestone from Georgia.

\begin{tabular}{|c|c|c|c|c|}
\hline . & 1 & 2 & 3 & 4 \\
\hline Silica $\left(\mathrm{SiO}_{2}\right)_{\text {. }}$ & 2.82 & . & 8.16 & 2.30 \\
\hline $\begin{array}{l}\text { Alumina }\left(\mathrm{Al}_{2} \mathrm{O}_{3}\right) \\
\text { Iron oxide }\left(\mathrm{Fe}_{2} \mathrm{O}_{3}\right) \ldots \ldots \ldots \ldots \ldots \ldots \ldots \ldots \ldots \ldots \ldots \ldots \ldots\end{array}$ & 1.80 & 2.23 & 9.50 & .40 \\
\hline $\begin{array}{l}\text { Lime carbonate }\left(\mathrm{CaCO} \mathrm{O}_{3}\right) \\
\text { Magnesium carbonate }\left(\mathrm{MgCO}_{3}\right)\end{array}$ & $\begin{array}{r}91.40 \\
3.75\end{array}$ & $\begin{array}{r}94.37 \\
2.10\end{array}$ & $\begin{array}{l}55.47 \\
25.33\end{array}$ & $\begin{array}{r}95.20 \\
2.17\end{array}$ \\
\hline
\end{tabular}

1. South of Trenton, Polk County. J. M. McCandless, analyst.

2. Codartown, Pölk County. W. J. Land, analyst.

4. Devitte lime quarry, 5 miles northeast of Rockmart, Polk County. Chemist, Cherokee Iron Co., analyst.

\section{BANGOR LIMESTONE.}

The Bangor limestone in Georgia occurs only in Dade, Walker, and northwestern Chattooga counties. It appears as a series of belts one-half mile to almost 2 miles wide, which closely follow the trend of Sand, Lookout, and Pigeon mountains and generally running up high on the flanks as well as occupying parts of the valleys at their feet.

The Bangor limestone in its Georgia areas varies between 700 and 900 feet in thickness. The greater part of this is a rather heavybedded blue limestone, commonly quite pure and low in magnesia. Toward the top the limestone becomes more clayey and interbedded shales more and more numerous.

Analyses of Bangor limestone from Georgia.

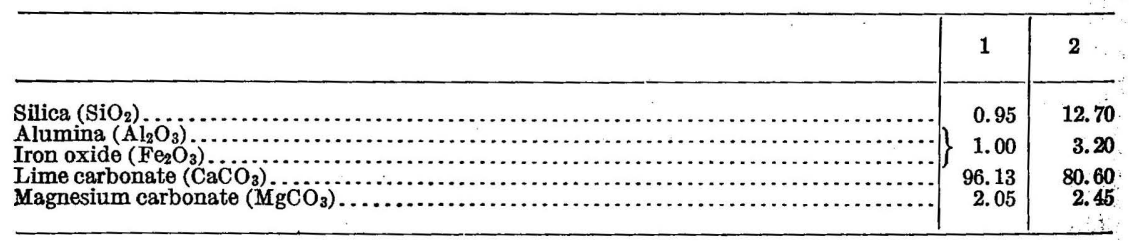

1. Rising Fawn, Date County. J. M. McCandless, analyst. Paleozoic group of Georgia, 1893, p. 271. 2. Side of Sand Mountain, Polk County. J. M. MeCandless, analyst. Idem, p. 271.

1 Spencer, J. W., Geology of the Paleozoic group of Georgia, Georgia Geol. Survey, 1893. 
CRETACEOUS AND TERTIARY LMMESTONES.

The portion of Georgia lying south and southeast of a line drawn through Knoxville to Columbus is occupied by clays, gravels, and soft limestones of Tertiary and Cretaceous age. The limits of these formations have never been accurately mapped, so that the distribution of the soft limestone beds can be stated only in a general way. Several areas of the soft limestones (commonly called "marls" in geological and agricultural reports) are known to occur. One of these areas is the continuation of the Tertiary rocks of Alabama described as the St. Stephens limestone. (See pp. 82-85.) In Georgia this limestone occupies most of the counties of Decatur, Miller, Baker, Mitchell, Dougherty, and Lee. The only analysis of it from a Georgia locality is No. 6 of the table below. Other limestone beds occur in the Cretaceous and Tertiary region, but little is known concerning their distribution.

Such analyses as are available are presented in the following table. They all show considerable silica, alumina, and iron oxide but are remarkably low in magnesia.

Analyses of Cretaceous and Tertiary limestones from Georgia.

\begin{tabular}{|c|c|c|c|c|c|c|}
\hline . & 1 & 2 & 3 & 4 & 5 & 6 \\
\hline 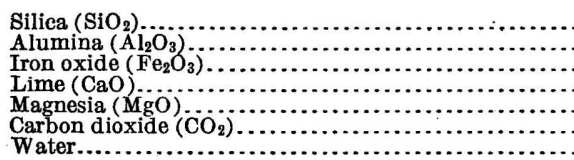 & $\begin{array}{r}8.90 \\
.55 \\
3.22 \\
50.14 \\
.05 \\
37.05 \\
1.23\end{array}$ & $\begin{array}{r}6.30 \\
.41 \\
1.65 \\
49.87 \\
.12 \\
39.21 \\
1.63\end{array}$ & $\begin{array}{r}9.63 \\
.62 \\
4.31 \\
46.76 \\
36.52 \\
1.31\end{array}$ & $\begin{array}{r}13.86 \\
1.11 \\
2.08 \\
45.65 \\
.08 \\
34.87 \\
1.19\end{array}$ & $\begin{array}{r}13.86 \\
1.76 \\
3.02 \\
43.67 \\
.04 \\
34.12 \\
1.45\end{array}$ & $\begin{array}{r}14.44 \\
1.33 \\
2.65 \\
42.88 \\
.15 \\
31.96 \\
1.63\end{array}$ \\
\hline
\end{tabular}

1. Reddick's quarry, Screven County. Tenth Census, vol. 6, 1884, p. 312.

2. Washington County. Idem.

3. Shell Bluff, Burke County. Idem.

4. Houston County. Idem.

5. Near Montezuma, Macon County. Idem.

6. Near Albany, Dougherty County. Idem.

\section{PORTLAND CEMENT INDUSTRY IN GEORGIA.}

In spite of the fact that Georgia is fairly well supplied with suitable cement materials and possesses small supplies of coal, there are only two Portland-cement plants in operation in the State and it is hardly probable that it will ever become the seat of any really large cement industry. The eastern and southern portions of the State can be supplied with cement more cheaply from Pennsylvania, Virginia, and Alabama than from plants in northwest Georgia; and the only large city-Atlanta-in northwest Georgia itself can be reached almost as well from Alabama as from any probable Georgia cement location

The two plants now in operation are that of the Southern States Portland Cement Co., about one-half mile east of the village of Rockmart, and that of the Piedmont Portland Cement \& Lime Co., at Portland. The Portland cement manufactured at these plants is 
made from a mixture of pure limestone and shale, both of which occur in the immediate vicinity.

Hard blue slates, which have been extensively quarried for roofing slate and other purposes, outcrop on the hills south of Rockmart. These slates are of Ordovician age and have been described by C. W. Hayes as the Rockmart slate. East of the town the Chickamauga limestone, which is the surface rock over an extensive area, contains beds of pure nonmagnesian limestone, which for a number of years have been quarried and burned into lime.

The Southern States Portland Cement Co. purchased the property of the old Georgia Slate Co., about one-half mile southwest of Rockmart, and carried on extensive operations with the diamond drill in testing the slate formation. The intention at that time was to quarry the slate, sell for roofing slate and mill stock the portions best suited for those uses, and utilize the scrap and waste in the manufacture of cement. At a later date in the history of the plant, however, shales of normal type were substituted for slate in the cement mixture. The quarries from which the limestone is obtained are one-half mile east of town, near the cement plant.

Analyses of slate, shale, and limestone from the particular quarries which have been worked by the Southern States Portland Cement Co. are not available. Spencer, however, quotes analyses of slate and limestone from the vicinity, and these will serve fairly well to indicate the character of the material.

Analyses of slate and limestone from Rockmart, Ga.

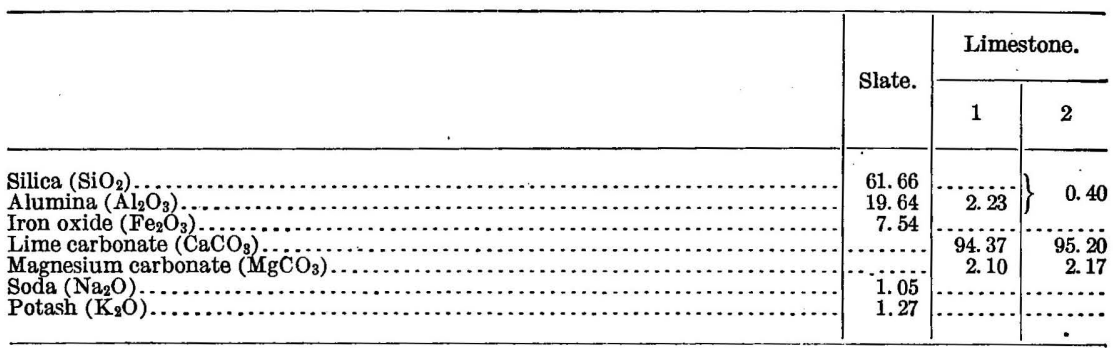

The Piedmont Portland Cement \& Lime Co. is reported to be building a plant at Aragon.

\section{BIBLIOGRAPHY.}

LADD, G. E., Clays of Georgia: Bull. Georgia Geol. Survey No. 6, 1898, 204 pp.

McCallie, S. W., Marbles of Georgia: Bull. Georgia Geol. Survey No. 1, 2d ed., 1907, $126 \mathrm{pp}$.

Maynard, T. Poole, Limestones and cement materials of north Georgia: Bull.

Georgia Geol. Survey No. 27, 1912, 293 pp.

Spencer, J. W., Geology of the Paleozoic group of Georgia, Atlanta, 1893, $406 \mathrm{pp}$.

Hayes, C. W., Ringgold folio (No. 2), Geol. Atlas U. S., U. S. Geol. Survey, 1894.

- Stevenson folio (No. 19), Geol. Atlas U. S., U. S. Geol. Survey, 1895.

- Rome folio (No. 78), Geol. Atlas U. S., U. S. Geol. Survey, 1902. 


\section{PORTLAND CEMENT RESOURCES OF IDAHO.}

GENERAL DISTRIBUTION.

Such geologic work as has been done in the State of Idaho has been so largely in connection with the examination of isolated mining districts or for other special purposes that very little general information is available concerning the Portland - cement resources of the State.

Small isolated areas of crystalline limestone or marble occur in the western portion. Marble is reported from the valleys of Snake and Clearwater rivers, also from places in Kootenai and Cassia counties. Near Hailey, Boise, and Weiser limestone is quarried and burned into lime, and some fluxing rock is quarried in the State for use in smelters.

The following notes were published by Russell, on limestones of Idaho: ${ }^{1}$

Limestone occurs in great quantities on the borders of Snake River, from 1 to 3 miles above the mouth of Grande Ronde River, and also about 8 miles farther upstream. The value of this stone for marble has not been tested, but it certainly merits careful study. An analysis of an average sample of the rock is given in the first eolumn of the subjoined table of analyses of limestone, which shows it to be of exceptional purity.

Limestone outcrops beneath the Columbia River lava on the right bank of Mission Creek, about a half mile above where it emerges from the deeper portion of its canyon in the Craig Mountain uplift, and also in a gulch about 1 mile to the west. Along Mission Creek, for a distance of approximately 300 feet, the limestone is admirably exposed in the precipitous canyon wall to a height of 500 feet. It is in general a hard, grayish-blue rock, containing a few obscure fossils. The strike of the beds is N. $50^{\circ} \mathrm{E}$. (magnetic), and the dip is eastward at an angle of from 80 to $85^{\circ}$. Formerly it was burned in kilns, which still remain, and it is said to have yielded a good lime. The value of the stone as marble can scarcely be judged from the weathered outcrops, but its dark color would probably make the demand for it small, even if on quarrying it is found sufficiently massive to be taken out in blocks of the desired size. An analysis of a typical sample of this rock is presented in the subjoined table, which shows that, like the similar limestone in Snake River canyon, it is of exceptional purity and will make an excellent lime, and it is all that could be desired in the production of Portland cement or for use in the manufacture of beet sugar, etc.

On the left bank of Mission Creek, opposite the outcrop just described, a landslide has brought down basalt from above and concealed the limestone which normally should appear there. Visitors to this locality will no doubt be interested in observing the manner in which the landslide has caused the stream to be turned aside from a formerly more direct course and made to cut into its right bank, thus removing some of the débris that once concealed a portion of the limestone and making it more available for quarrying. The surface of the fallen mass forms an irregular terrace at an elevation of about 500 feet above the stream. The surface of this terrace presents a good illustration, on a small scale, of landslide topography.

Limestone occurs also at Orofino and at three or four localities on Orofino Creek within the first mile above its mouth, as well as on the southern side of Clearwater River about a half mile below Orofino. At each of these localities the well-defined beds are associated with schist; they strike about north-south and stand nearly

1 Russell, I. C., Geology and water resources of Nez Perce County, Idaho, pt. 2: Water-Supply Paper U. S. Geol. Survey No. 54, 1901, pp. 120-121. 
vertical. The limestone has been metamorphosed and is now mostly a coarsely crystalline marble, varying in color from white to gray. It is susceptible of a high polish and should find a ready market for building and monumental purposes, provided it can be had in blocks of the desired size. It is favorably situated for quarrying, being close to the Northern Pacific Railroad. The surface is considerably shattered but is not deeply weathered. Whether it is sufficiently massive at a moderate depth below the surface to be of value can only be determined by trial. A sample of the nearly white, coarse-grained marble from Orofino has been analyzed, with the results shown in the third column of the following table:

Analyses of limestones from Nez Perce County, Idaho.

[W. F. Hillebrand and George Steiger, analysts.]

\begin{tabular}{|c|c|c|c|}
\hline Constituent. & $\begin{array}{c}\text { Snake } \\
\text { River } \\
\text { canyon. }\end{array}$ & $\begin{array}{l}\text { Mission } \\
\text { Creek. }\end{array}$ & Orofino. \\
\hline 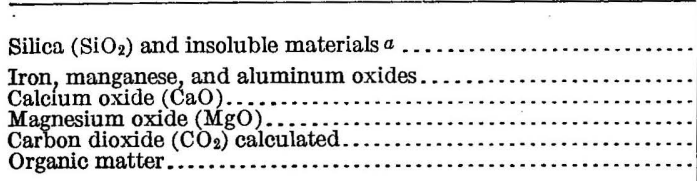 & $\begin{array}{r}0.39 \\
.10 \\
55.34 \\
.10 \\
43.59 \\
.\end{array}$ & 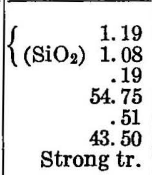 & $\begin{array}{r}0.64 \\
\left(\mathrm{SiO}_{2}\right) 0.37 \\
.12 \\
51.96 \\
3.05 \\
44.08 \\
\mathrm{Tr} .\end{array}$ \\
\hline & ........... & 100.14 & 99.85 \\
\hline 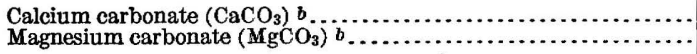 & $\begin{array}{r}98.83 \\
.21\end{array}$ & $\begin{array}{r}97.69 \\
1.07\end{array}$ & $\begin{array}{r}92.71 \\
6.38\end{array}$ \\
\hline
\end{tabular}

$a$ The insoluble portions in analyses Nos. 2 and 3 contained a trace of titanium oxide $\left(\mathrm{TiO}_{2}\right)$.

$b$ The amounts of carbonates calculated are a trifle too high if the silica found was originally in combination with some of the dissolved lime and magnesia.

The analysis of limestone from Snake River is by Steiger; the others are by Hillebrand.

The limestones from Snake River canyon and Mission Creek are exceptionally pure and are suitable for use in the manufacture of Portland cement, in the beetsugar industry, etc. The limestone at Orofino evidently would make a good lime if properly calcined, but it is not desirable for the other purposes mentioned, on account of the magnesium present. ${ }^{1}$ There are, however, several beds of limestone near Orofino, a careful study of each of which would very likely reveal the presence of material as rich in calcium carbonate and as free from impurities as the limestone from Mission Creek and Snake River canyon.

\section{LIME POINT.}

The following description of an occurrence of cement materials in Idaho on Snake River, near the mouth of Grande Ronde River, about 30 miles south of Lewiston, Idaho, is abstracted from an unpublished report by Hoyt S. Gale, of the Geological Survey, who examined the locality in March, 1912. The area has been described in earlier published reports of the Geological Survey as deserving careful consideration for the possible value of its rocks as Portland cement material. ${ }^{2}$

The sedimentary rocks from which it is proposed to obtain cement material outcrop along the lower canyon walls bordering Snake

\footnotetext{
1 The 3.05 per cent of magnesium, considered by Russell to be undesirable, appears in the light of later cement manufacturing not to be excessive.-E. C. E.

2 Russell, I. C., Geology and water resources of Nez Perce County, Idaho, pt. 2: Water-Supply Paper No. 54,1901 , pp. 121-122, 133-136.
} 
River, especially near Lime Point and just above the mouth of Grande Ronde River. They have the lithologic appearance of Paleozoic rocks and are probably, in part at least, of Mississippian age, this being suggested by the lithology of the beds and by a few layers containing crinoid and coral fragments. The limestone outcrops extend north or northeast, probably for several miles, and are assumed to be continuous in outcrop toward the south. Associated with the more conspicuous limestones are large thicknesses of shale. As the latter give way more readily to erosion, their outcrops are now found along the gulches tributary to Snake River, between ridges capped by the more resistant limestones.

The sedimentary outcrops near Lime Point are limited on the west by basaltic igneous rocks belonging in greater part to the Columbia River basalt of the lava plains, whose extensive occurrence throughout this general region makes the appearance of the sedimentary rocks rather exceptional.

The Columbia River basalt is very fully described by Russell. ${ }^{1}$ It forms the surface over nearly the whole of Washington and Oregon east of the crest of the Cascade Mountains, extends into Idaho to the older formations of the Cour d'Alene and Bitterroot mountains, and also reaches southern Idaho. It is known to attain a thickness of more than 4,000 feet.

The canyon of Snake River between the mouth of Grande Ronde River and Lewiston consists chiefly of the deeply eroded channel, cut to a depth of a thousand feet and more, in the nearly horizontal flows of this basaltic lava. These canyon walls expose alternating layers of dark compact and vesicular lava, intercalated with fragmental layors of similar volcanic material. Many fine examples of columnar jointing are shown in the more compact beds. Along this portion of Snake River a dip to the north is recognizable as the cliffs formed by the more massive layers in the flows pass beneath water level in the direction in which the stream is flowing. As a whole, however, the lava flows lie approximately horizontal.

The abrupt termination of the sedimentary outcrops including the limestone against the igneous rocks to the west is considered to have resulted from an extensive fault, by which the lava flow series, together with the underlying sedimentary strata on the east, were elevated with relation to the general level of the lava plains. This interpretation of the structure was not conclusively proved in the short time devoted to the present examination and does not agree with that given by Russell, who explains the sediments as the remnants of the older topography buried in the lava flows and later revealed by erosion of the river channels. He says: "Upstream from the mouth of

1 Bull. U. S. Geol. Survey No. 108; Water-Supply Paper U. S. Geol. Survey Nos. 4, 53, and 54.

2 Water-Supply Paper No. 53, p. 27. 
Grande Ronde River the horizontal lava sheets in the canyon wall abut against cliffs of schist which form the precipitous border of a buried mountain." In this statement it is assumed he refers to the relation of the Columbia River basalt to all of the sedimentary rocks, including the limestone. A view to the north from the summit above Lime Point shows erosion of a zone of weaker beds along the contact of the lava and the sediments, and in at least one case a distinct drag is indicated in the abrupt uptilt of the otherwise nearly horizontal flow beds.

At the mouth of Grande Ronde River another intrusive rock, provisionally termed a diabase porphyry, of later age than at least a part of the Columbia River basalt, truncates the edges of the basalt flows along the line of the major fault referred to above. This diabase forms a series of rounded knobs, and from a distance the areas it covers may be distinguished chiefly by the absence of horizontally bedded layers which mark the basaltic lava. A small dike supposed to be related to this intrusive occurs just abore and a few feet south of the tunnel portal near the lower end of Lime Point.

The composition of the cement rock is indicated by seven samples collected by Hoyt S. Gale, analyzed in the laboratory of the Bureau of Standards by A. B. Lort (test number, 11359; laboratory numbers, 3742 to 3748 , inclusive). ${ }^{1}$

Analyses of samples of supposed cement material from Lime Point, 30 miles south of Lewiston, Idaho.

\begin{tabular}{|c|c|c|c|c|c|c|c|}
\hline & 1 & 2 & 3 & 4 & 5 & 6 & 7 \\
\hline 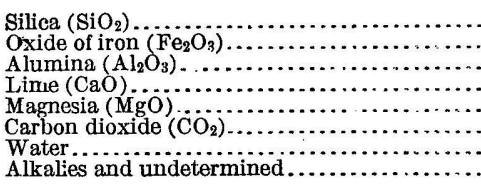 & $\begin{array}{r}6796 \\
2.30 \\
1592 \\
1.80 \\
.80 \\
4.05 \\
7.17\end{array}$ & 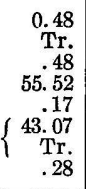 & $\begin{array}{r}0.34 \\
\text { Tr. } \\
.18 \\
55.72 \\
.43 \\
43.20 \\
\text { Tr. } \\
.13\end{array}$ & $\begin{array}{r}57.30 \\
3.55 \\
12.51 \\
11.66 \\
3.02 \\
11.74 \\
.22\end{array}$ & $\begin{array}{r}71.86 \\
1.75 \\
13.97 \\
.38 \\
.24 \\
2.89 \\
8.91\end{array}$ & $\left\{\begin{array}{r}37.94 \\
4.10 \\
9.22 \\
23.28 \\
3.74 \\
18.21 \\
2.63 \\
.88\end{array}\right.$ & $\begin{array}{r}66.70 \\
21.15 \\
11.57 \\
1.80 \\
1.00 \\
10.78 \\
6.00\end{array}$ \\
\hline & 100.00 & $\overline{100.00}$ & 100.00 & 100.00 & 100.00 & 100.00 & 100.00 \\
\hline
\end{tabular}

1. White pulverent deposit found in considerable quantities along several of the gulches on or adjacent to the cement property

2. Average of 121 samples of limestone chipped at approximately uniform intervals throughout the 160 feet length of the tunnel on the cement property.

3. Average of about 30 samples representing a limestone outcrop at least 50 feet in thickness taken in a way similar to No. 2 northeast of the located claims.

4 . Average of 45 samples of shale from the face of a cut bank near locality of sample 3 .

5. Sample of band of metamorphosed calcareous shale, included by intrusive basalt, prospected on the located claims near the crest of the ridge.

6 . Average from a prospect pit in thin-bedded shale on the cement claims.

7. Sample representing an outcrop of metamorphosed shale, included within the intrusive diabase, on the gulch just above the cement company's cabins.

The following comment on these samples is also quoted from the report on these analyses:

An analysis of these samples shows that both the limestone and the shales can be combined so as to produce after burning Portland. cement, though the ratio of the

1 The report of these analyses states: "Precautions were not taken to obtain a high degree of accuracy in these analyses, as it was believed that a limit of error of \pm 0.30 would not interfere with the proper interpretation of these results." 
silica to the oxide of aluminum is such as to cause the oxide of aluminum to be low in the finished product. The lime in general tends to be high, which would require very fine grinding and thorough mixing to insure a sound cement.

That these raw materials can be combined so as to produce Portland cement does not establish their economic value, as the physical character of the rock as influencing cost of grinding and burning has a very potent effect on cost of production.

Sample No. 1 is apparently of local occurrence and can not be expected to furnish sufficiently large quantities of material to be of much importance for cement manufacture. Sample No. 2 probably represents a large body of massive limestone readily available. It is very similar to that represented by sample No. 3, obtained from the extension of this formation a mile or more north, both of these being exceptionally pure limestones. Samples Nos. 4 and 6 are shales from surface exposures and may be altered by the leaching of surface waters, but they are perhaps the best samples to be had under present conditions. Samples Nos. 5 and 7 are metamorphosed bands of the shale beds adjacent to the intrusive igneous rock. Consequently they are of very uncertain extent and uncertain composition for any considerable distance, the relation of the igneous rock to any particular part of the shale being chiefly accidental. Thus samples Nos. 2, 3,4 , and 6 are probably the best as representing normal rocks of the area.

A product fairly well within the specifications for a normal Portiand cement (Bureau of Standards government specification for Portland cement, circular No. 33, 1912, p. 18) may be obtained by combining Nos. 2 and 6 in the proportion of 3 to 2 . By recalculation of the two analyses combined in these proportions, eliminating only the volatile, the following composition is obtained:

Analysis of mixture of rock of samples Nos. 2 and 6 in the proportion of 3 to 2 .

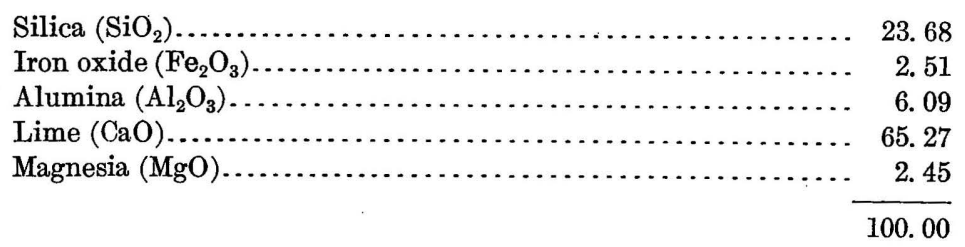

The only factor that falls without the limits of the specifications is the lime, which is a little too high. The ratio of silica to iron and alumina together as contained in the original rock is as 2.8 is to 1 , a satisfactory proportion.

The samples are to a considerable extent random in selection and do not necessarily represent the bulk of the sedimentary beds in the vicinity. Nevertheless they leave little doubt that the limestone and the larger masses of calcareous shales may be considered as almost unlimited. The limestone outcrop is only a part of the massive bedded strata which undoubtedly are very extensively 
distributed throughout this part of the State, though generally buried by the great lava flows, probably to inaccessible depths. However, the one outcrop at and near Lime Point on Snake River is essentially continuous for perhaps several miles and can supply an enormous amount of material.

While the deposits at Lime Point may possess an advantage for use as cement material by reason of their situation at the river's margin, they are not necessarily more valuable chemically than their extensions to the north or the south and possibly elsewhere in the region. At present, however, transportation facilities are not very favorable. There has been no way of reaching the property by wagon road since the abandonment of the river ferry at the mouth of Captain John Creek. Water transportation down Snake River from near the mouth of Grande Ronde River would probably be feasible for all but about four months of the usual low water in summer time. At least three railroad surveys follow Snake River in this vicinity; their stakes may be found on both sides of the river. The most recent survey is on the Washington side; it was recorded in October, 1911, in the railroad division of the General Land Office.

\section{PORTLAND CEMENT RESOURCES OF ILLINOIS.}

\section{PORTLAND CEMENT MATERIALS.}

Low-magnesia limestones suitable for use in Portland cement manufacture occur in Illinois in the Ordovician, the Mississippian, and the Pennsylvanian ("Coal Measures"). Only the Ordovician and Pennsylvanian limestones have yet been utilized in Illinois as Portland cement materials, though the Mississippian limestones, when their location, thickness, and composition are considered, would seem to be the most promising of the three.

\section{ORDOVICIAN ("TRENTON") LIMESTONES.}

Though the Ordovician limestones cover a very large part of northern Illinois, they seem, in that part of the State, to be almost everywhere high in magnesia and therefore unavailable as Portland cement material. In western and southwestern Illinois, however, along Mississippi River, a number of isolated areas of Ordovician limestone occur, the rock from which, from the analyses available, seems sufficiently low in magnesia.

The geologic map (Pl. V) shows the location of four separate areas of Ordovician limestone in the district considered. The first area lies on the east bank of Mississippi River at and below Thebes for a mile or two. The second area, larger than this, extends along the east bank of Mississippi River from Harrisonville to Smiths Landing, in the northern part of Monroe County. A third area is 


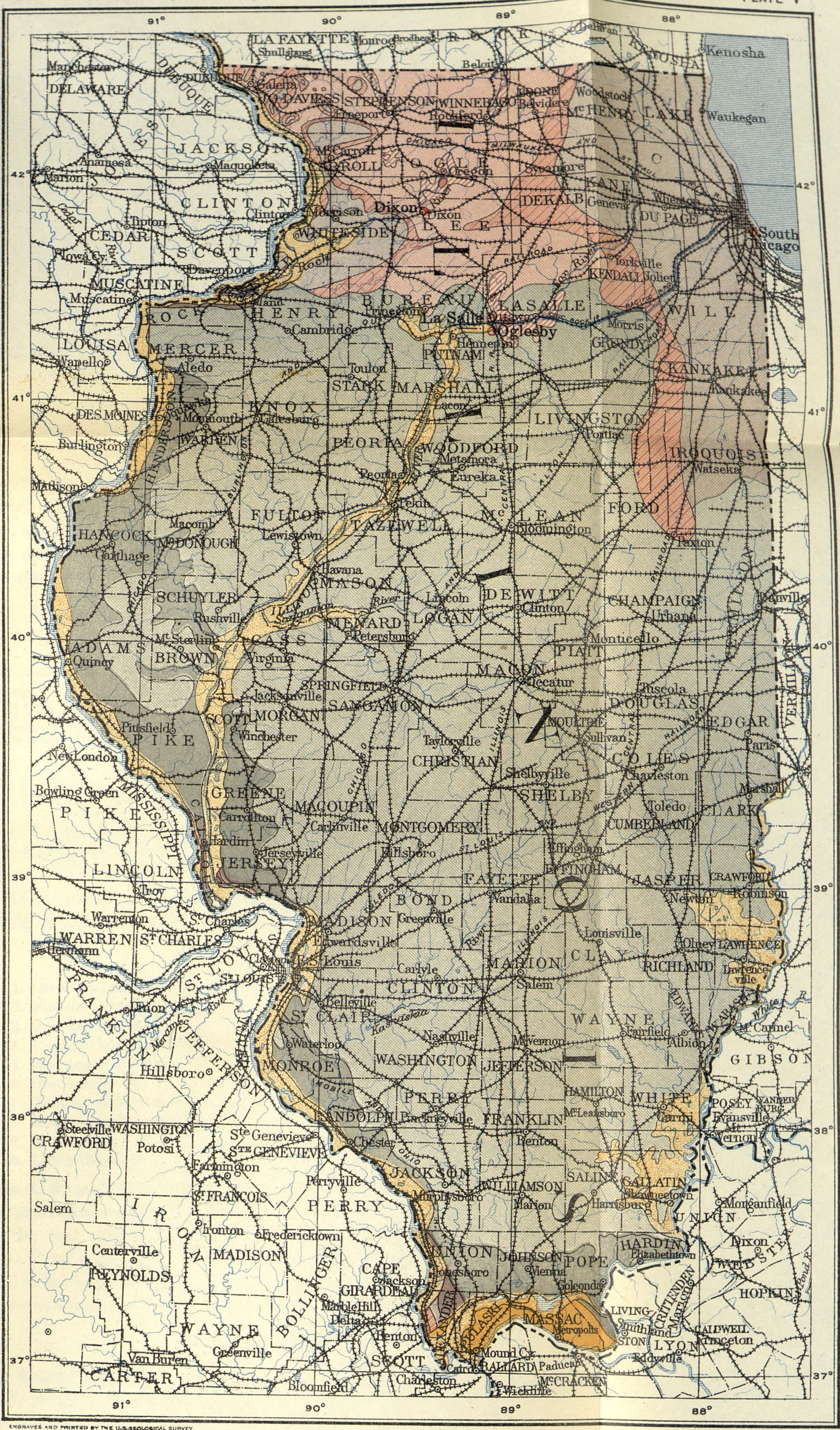

GEOLOGIC MAP OF ILLINOIS
Scale $\frac{1}{2500,000}$
250

Weller's map published by Geologica Survey of llinois in 1907

\section{LEGEND}

Alluvium, sands, and gravels
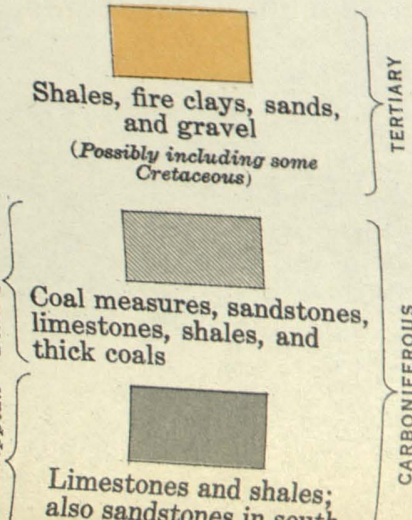

andstones in south

ern part of State south-

Limestones in northern and central, black shale

and limestone in southern part of State

Dolomite, massive, in part cherty

Shales, blue, argillaceous. Thin bands of limestone and dolomite in norther part of State. Shales,

sandstones, and lime-

stones in southern part of State
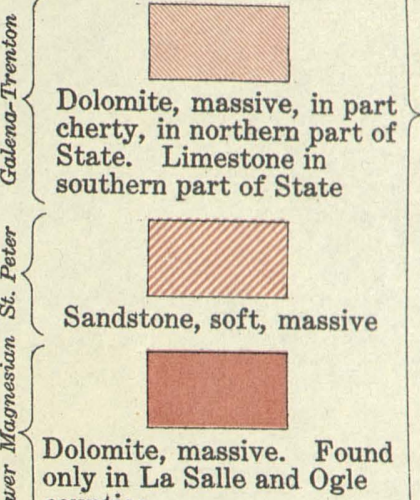
only in La Salle and Ogle counties

Portland cement plant 

exposed along both banks of Illinois River, near Hartford, in Jersey County. The fourth area lies along the east bank of Mississippi River, south of Harding, in Calhoun County.

The only available analyses of Ordovician limestone from any of these areas show a very pure nonmagnesian limestone.

Analyses of Ordovician limestone from Thebes, Alexander County, Ill.

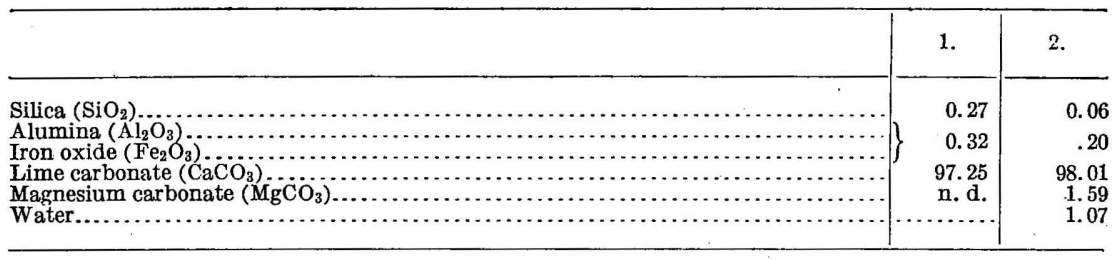

1. Bull. Illinois State Geol. Survey No. 4, 1907, p. 180. F. W. Pate, analyst.

2. Geol. Survey Illinois, vol. 1, 1866, p. 148. H. Pratten, analyst.

Similar occurrences of nonmagnesian Ordovician limestones across the river in Missouri are discussed on page 247, where further analyses are given.

In the cut on the Illinois Central Railroad north of the zincsmelting works at Lasalle the following section is shown: ${ }^{1}$

Section near Lasalle, Ill.

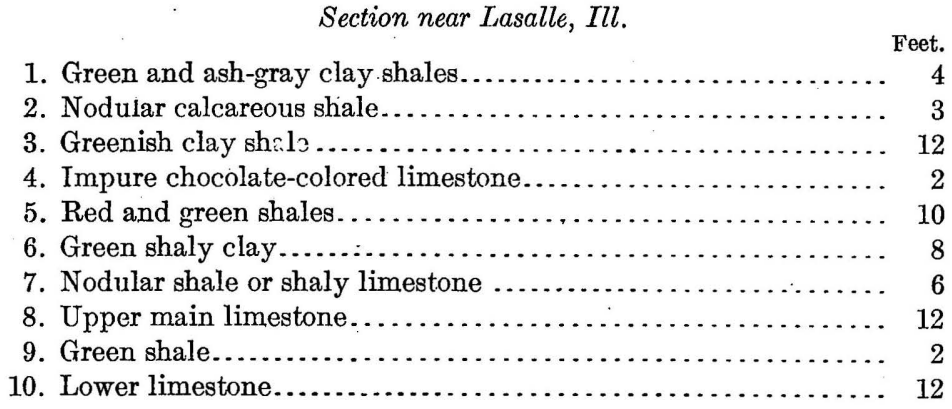

Beds 8,9 , and 10 of this section, taken together, represent bed 5 of the preceding section. The shale parting (No. 9) which here separates the two limestone beds increases in thickness farther south, until at Peru it measures 6 to 8 feet. This limestone series occurs at about the horizon of coal bed No. 9 of the Illinois reports and is probably the same as the limestones exposed near Carlinville.

\section{MISSISSIPPIAN LIMESTONES.}

The Mississippian limestones occur only in one belt, which extends through western and southern Illinois. The northern end of this belt is near New Boston, in Mercer County. From this point the limestones extend southward along Mississippi River, in a belt averaging perhaps 20 miles in width, through Henderson, Hancock, Adams, and 
Pike counties. A narrow branch of this belt extends up Illinois River as far as Beardstown, and narrower bands border several of the larger tributaries of the Illinois. The main belt continues southward parallel to and usually bordering Mississippi River and covers the greater part of Scott, Greene, and Jersey counties. Near Alton the limestone belt contracts until it is only a few miles in width, but widens out again a few miles south of Alton and covers extensive areas in Madison, St. Clair, Monroe, Randolph, and Jackson counties. Near the southern boundary of Jackson County the belt leaves the Mississippi and turns eastward through Union, Johnson, Pope, and Hardin counties.

The following notes by Stuart Weller and E. F. Burchard on promising Portland cement materials from near Golconda, Pope County, are quoted from the latest Illinois Geological Survey bulletin:1

W 319.* Location: Sec. 19, T. 13 S., R. 7 E. Geological formation, "Chester." Sample from quarry on hillside north of Golconda to right of road going up hill. At this point about 15 feet of limestone has been quarried and crushed for road making. Above the limestone and also below it are shaly beds.

W 320. Location: SW. $\frac{1}{4}$ SE. $\frac{1}{4}$ sec. 22 , T. 11 S., R. 7 E. Rainey place, 14 miles north of Golconda. Geological formation, Ste. Genevieve. Sample from prospect pit for spar.

Section on Rainey farm.

Feet.

2. Shale........................................... 10

1. Limestone with shale partings (W 320) $\ldots \ldots \ldots \ldots \ldots \ldots \ldots \ldots \ldots$

W 321.* Location: Sec. 26, T. 13 S., R. 6 E. Geological formation, "Chester." Sample from outcrop on property of Edward B. Clark, Limestone Hill, west of Golconda and one-fourth mile northwest of the Illinois Central Railroad. (See Pl. XVIII.) The outcrop of 100 feet or more of limestone and shale is so covered with talus that the proportions of limestone and shale cannot be seen. The sample was taken from one of the outcropping beds of limestone.

Bu 20.* Location: Sec. 26, T. 13 S., R. 6 E. Geological formation, "Chester." Sample is composite of all outcropping limestone beds in the same section from which sample W $321^{*}$ was taken. The sample represents an aggregate of 50 feet or more of limestone. The overburden is light. The analyses of samples of shale from the same locality, as given in a later chapter, indicate that the materials are well adapted for cement manufacture.

Bu $21,{ }^{*} 22,{ }^{*} 23 .{ }^{*}$ Examination was made by Mr. Burchard, of the U. S. Geological Survey, of shales and limestone on the Edward B. Clark property known as Limestone Hill. This lies west of Golconda in sec. 26, T. 13 S., R. 6 E., and offers excellent opportunity for cement manufacture (Bu $\left.20^{*}\right)$.

$\mathrm{Bu} 21^{*}$ is from a 5 - or 6 -foot roadside exposure of a bed of shale which is probably 25 feet thick. $\mathrm{Bu} 22^{*}$ is from a $5 \frac{1}{2}$-foot prospect hole in the creek bank and occurs in the same horizon as $\mathrm{Bu} 21$. $^{*} \mathrm{Bu} 23^{*}$ is from a $6 \frac{1}{2}$-foot exposure in a prospect pit.

The overburden on the shale represented by $\mathrm{Bu} 21^{*}$ and $22^{*}$ ranges up to 40 feet. The shale from which $\mathrm{Bu} 23^{*}$ was taken underlies the limestone represented by $\mathrm{Bu} 20$,* and if used in connection with the shale interbedded with the limestone would probably furnish enough material for $\approx$ cement mixture.

1 Bleininger, A. V., Lines, E. F., and Layman, F.E., Portland cement resources of Illinois: Bull. Mlinois Geol. Survey, No. 17, 1912; pp. 91 and 111. 
As in other States, the Mississippian limestones of Illinois are in general rather well adapted for use as Portland cement materials. In places they contain beds too high in magnesium carbonate, but their commonest type contains say 90 to 95 per cent of lime carbonate, 1 to 4 per cent of magnesium carbonate, and 1 to 6 per cent of silica, alumina, and iron oxide. The analyses below are fairly representative.

Analyses of Mississippian limestone from Illinois.

\begin{tabular}{|c|c|c|c|c|c|c|c|c|c|c|c|c|c|}
\hline . & 1 & 2 & 3 & 4 & 5 & 6 & 7 & 8 & 9 & 10 & 11 & 12 & 13 \\
\hline $\begin{array}{l}\text { Silica }\left(\mathrm{SiO}_{2}\right) \ldots \ldots \\
\text { Alumina and iron oxide }\left(\mathrm{Al}_{2} \mathrm{O}_{3}\right. \\
\left.\text { and } \mathrm{Fe}_{2} \mathrm{O}_{3}\right) \ldots \ldots \\
\left.\text { Lime carbonate }(\mathrm{CaCO})_{3}\right) \\
\text { Magnesium carbonate }\left(\mathrm{MgCO}_{3}\right)\end{array}$ & $\begin{array}{r}0.47 \\
2.18 \\
95.62 \\
.82\end{array}$ & $\begin{array}{r}0.05 \\
.20 \\
94.68 \\
4.31\end{array}$ & $\begin{array}{r}0.37 \\
.27 \\
92.77 \\
6.75\end{array}$ & $\mid \begin{array}{r}12.50 \\
2.10 \\
82.48 \\
\text { n.d. }\end{array}$ & \begin{tabular}{r|r}
2.72 & \\
1.06 & \\
90.86 & 9 \\
3.18 &
\end{tabular} & $\begin{array}{r}0.23 \\
.91 \\
96.20 \\
\text { n.d. }\end{array}$ & $\left|\begin{array}{r}6.00 \\
1.32 \\
90.31 \\
1.40\end{array}\right|$ & $\begin{array}{r}5.33 \\
.83 \\
92.36 \\
\text { n. d. }\end{array}$ & $\begin{array}{r}6.38 \\
.49 \\
91.05 \\
\text { n. d. }\end{array}$ & $\begin{array}{r}1.90 \\
.67 \\
95.57 \\
.89\end{array}$ & $\begin{array}{r}4.92 \\
1.40 \\
89.40 \\
3.07\end{array}$ & $\mid \begin{array}{r}2.47 \\
1.11 \\
93.81 \\
1.15\end{array}$ & $\begin{array}{r}1.99 \\
.36 \\
91.40 \\
4.40\end{array}$ \\
\hline
\end{tabular}

1. Marblehead, Adams County. N. G. Bartlett, analyst. Twentieth Ann. Rept. U. S. Geol. Survey, pt. 6 (continued), 1899 , p. 377.

2. Quincy, Adams County. H. Pratten, analyst. Geol. Survey Illinois, vol. 1, 1866, p. 108.

3. Quincy, Adams County. C. G. Hopkins, analyst. Twentieth Ann. Rept. U. S. Geol. Survey, pt. 6 (cont'd), 1899, p. 377.

4. Nauvoo, Hancock County. H. Pratten, analyst. Geol. Survey Illinois, vol. 1, 1866, p. 99.

5. Rosiclare, Hardin County. H. Pratten, analyst. Idem, p. 374.

6. Rosiclare, Hardin County. A. W. Gregory, analyst. Buil. Illinois Geol. Survey No. 4, 1907, p. 183.

7, 8. Belknap, Johnson County. F. W. Pate, analyst. Idem, p. 179.

9. Ullin, Pulaski County. F. W. Pate, analyst. Idem, p. 181.

10, 11, 12. Menard, Randolph County. F. W. Pate, analyst. Idem, pp. 181-182.

13. Anna, Union County. F. W. Pate, analyst. Idem, p. 179.

\section{PENNSYLVANIAN ("COAL MEASURES") LIMESTONES.}

The Pennsylvanian ("Coal Measures") rocks of Illinois cover most of the State south of a line through Paxton, Wilmington, Lasalle, Princeton, and Rock Island. This thick series consists largely of shales and sandstones, but it includes also some relatively thin beds of limestone, from which three of the five Portland cement plants now operating in Illinois draw their raw material.

Most of the limestones are thin but fairly persistent. One bed or series of beds well exposed near Lasalle and Oglesby shows a total thickness of 20 to 25 feet of limestone.

In the following geologic section, given in descending order, at Lasalle, Lasalle County, bed No. 5 is the limestone used by the three Portland cement plants at and near Lasalle.

Section at Lasalle, Ill. ${ }^{1}$

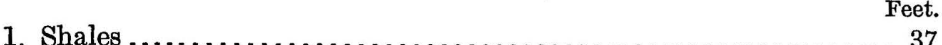

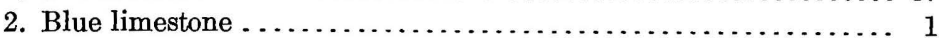

3. Bituminous shale and coal ............................ 2

4. Shales .......................................... 32

5. Limestone ....................................... 20

6. Bituminous shale and coal ......................... 36

7. Fire clay (absent in places).

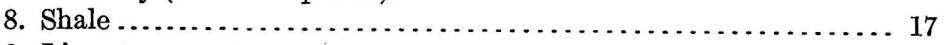

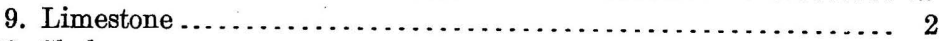

10. Shale. 
The Pennsylvanian limestones, though generally high in clayey impurities, are commonly low in magnesium carbonate. The analyses given in the following table are of the more argillaceous limestones. For analyses of purer rocks, used at three Portland cement plant's in the State, see pages 151-152.

Analyses of Pennsylvanian limestone from Illinois.

\begin{tabular}{|c|c|c|c|c|c|c|c|}
\hline & 1 & 2 & 3 & 4 & $E$ & 6 & 7 \\
\hline Silica $\left(\mathrm{SiO}_{2}\right)$ & 7.54 & 17.11 & 18.54 & 13.89 & 19.49 & 10.27 & 3.91 \\
\hline $\begin{array}{l}\text { Alumina } \\
\text { Iron oxide }\left(\mathrm{Al}_{2} \mathrm{O}_{3}\right) \\
\left.\mathrm{Fe}_{2} \mathrm{O}_{3}\right)\end{array}$ & 3.43 & 1.97 & 3.91 & 2.61 & 3.71 & 15.32 & 1.56 \\
\hline $\begin{array}{l}\text { Lime (CaO) } \\
\text { Magnesia }(\mathrm{MgO}){ }_{\ldots}\end{array}$ & $\begin{array}{r}45.57 \\
4.36\end{array}$ & $\begin{array}{r}44.44 \\
1.12\end{array}$ & $\begin{array}{r}42.03 \\
1.54\end{array}$ & $\begin{array}{r}45.91 \\
1.00\end{array}$ & $\begin{array}{r}41.75 \\
1.21\end{array}$ & $\begin{array}{r}38.49 \\
2.41\end{array}$ & $\begin{array}{r}52.38 \\
.26\end{array}$ \\
\hline
\end{tabular}

1-5. Lasalle County.

6. Sugar Creek, Sangamon County. H. Pratten, analyst. Geol. Survey Illinois, vol. 1, 1866, p. 60.

7. Charleston, Coles County. F. W. Pate, analyst. Bul J.tulinois State Geol. Survey No. 4, 1907, p. 182.

\section{ANALYSES.}

In the following tables are given a number of analyses of limestones, shales, and clays without reference to age, many of which are considered suitable for the manufacture of Portland cement. The shales are used in large quantities for the manufacture of clay products. These analyses of limestones were made by the Illinois Geological Survey ${ }^{1}$ and are published here through the courtesy of that bureau. 
Analyses of Illinois limestones.

[Samples marked (*) are considered suitable for Portland-cement manufacture.]

\begin{tabular}{|c|c|c|c|c|c|c|c|c|c|c|c|}
\hline County. & Sample number. & $\begin{array}{c}\text { Loss on } \\
\text { ignition. }\end{array}$ & $\begin{array}{c}\text { Silica } \\
\left(\mathrm{SiO}_{2}\right) .\end{array}$ & $\begin{array}{c}\text { Iron oxide } \\
\left(\mathrm{Fe}_{2} \mathrm{O}_{3}\right) \\
\text { aluming } \\
\left(\mathrm{Al}_{2} \mathrm{O}_{3}\right)\end{array}$ & $\begin{array}{l}\text { Lime } \\
(\mathrm{CaO}) .\end{array}$ & $\begin{array}{c}\text { Magnesia } \\
\text { (MgO). }\end{array}$ & $\begin{array}{c}\text { Water } \\
\text { at } 105^{\circ} \mathrm{C} .\end{array}$ & $\begin{array}{l}\text { Silica } \\
\left(\mathrm{SiO}_{2}\right) \text {. }\end{array}$ & $\begin{array}{l}\text { Iron oxide } \\
\left(\mathrm{Fe}_{2} \mathrm{O}_{3}\right) \\
\text { alumina } \\
\left(\mathrm{Al}_{2} \mathrm{O}_{3}\right)\end{array}$ & $\begin{array}{c}\text { Lime } \\
\text { carbonate } \\
\left(\mathrm{CaCO}_{3}\right)\end{array}$ & $\begin{array}{l}\text { Mrgnesium } \\
\text { carbonate } \\
\left(\mathrm{MgCO}_{3}\right)\end{array}$ \\
\hline $\begin{array}{l}\text { Adams........ } \\
\text { Adams........ } \\
\text { Adams........ }\end{array}$ & $\mid \begin{array}{ccc}\mathrm{C} & 15 & \ldots \ldots \ldots \ldots \\
\mathrm{C} & 16 * \ldots \ldots \ldots \ldots \\
\mathrm{C} & 17 * \ldots \ldots \ldots \ldots\end{array}$ & $\begin{array}{l}35.10 \\
39.90 \\
37.24\end{array}$ & $\begin{array}{r}19.78 \\
9.66 \\
12.26\end{array}$ & $\begin{array}{l}1.94 \\
1.54 \\
3.92\end{array}$ & $\begin{array}{l}43.42 \\
48.38 \\
44.46\end{array}$ & $\begin{array}{r}0.84 \\
.68 \\
.94\end{array}$ & $\begin{array}{r}0.30 \\
.26 \\
.23\end{array}$ & $\begin{array}{r}19.78 \\
9.66 \\
12.26\end{array}$ & $\begin{array}{l}1.94 \\
1.54 \\
3.92\end{array}$ & $\begin{array}{l}77.47 \\
86.32 \\
79.33\end{array}$ & $\begin{array}{l}1.76 \\
1.42 \\
1.96\end{array}$ \\
\hline Alexander. & D $42 *$. & $\ldots \ldots$. & .27 & .32 & 66.25 & .48 & .... & .27 & .32 & 99.77 & 1.18 \\
\hline $\begin{array}{l}\text { Brown } \\
\text { Brown } \\
\text { Brown } \\
\text { Brown } \\
\text { Brown } \\
\text { Brown } \\
\text { Brown } \\
\text { Brown } \\
\text { Brown } \\
\text { Brown } \\
\text { Brown } \\
\text { Brown } \\
\text { Brown } \\
\text { Brown } \\
\text { Brown }\end{array}$ & 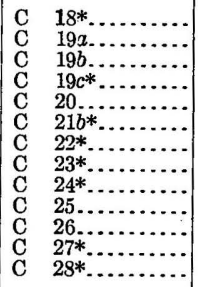 & $\begin{array}{l}42.70 \\
30.84 \\
14.76 \\
40.10 \\
35.98 \\
36.40 \\
37.26 \\
39.62 \\
40.74 \\
42.20 \\
40.04 \\
40.82 \\
41.02\end{array}$ & $\begin{array}{r}2.96 \\
26.46 \\
56.64 \\
7.26 \\
16.90 \\
15.40 \\
13.54 \\
8.78 \\
6.44 \\
5.80 \\
8.36 \\
6.62 \\
5.86\end{array}$ & \begin{tabular}{r|}
1.46 \\
10.36 \\
10.80 \\
2.40 \\
3.06 \\
3.10 \\
3.10 \\
2.40 \\
1.90 \\
3.98 \\
3.92 \\
2.64 \\
2.42
\end{tabular} & $\begin{array}{l}52.90 \\
24.30 \\
16.74 \\
50.10 \\
43.88 \\
45.32 \\
46.16 \\
48.66 \\
50.54 \\
39.00 \\
44.22 \\
49.00 \\
49.82\end{array}$ & $\begin{array}{r}.64 \\
8.88 \\
.68 \\
.38 \\
.54 \\
.50 \\
.56 \\
.60 \\
.60 \\
9.60 \\
3.74 \\
1.44 \\
1.20\end{array}$ & \begin{tabular}{l|}
.16 \\
.22 \\
.39 \\
.15 \\
.31 \\
.40 \\
.07 \\
.18 \\
.16 \\
.33 \\
.26 \\
.20 \\
.23
\end{tabular} & $\begin{array}{r}2.96 \\
26.46 \\
56.64 \\
7.26 \\
16.90 \\
15.40 \\
13.54 \\
8.78 \\
6.44 \\
5.80 \\
8.36 \\
6.62 \\
5.86\end{array}$ & $\begin{array}{r}1.46 \\
10.36 \\
10.80 \\
2.40 \\
3.06 \\
3.10 \\
3.10 \\
2.40 \\
1.90 \\
3.98 \\
3.92 \\
2.64 \\
2.42\end{array}$ & $\begin{array}{l}94.39 \\
43.36 \\
29.87 \\
89.39 \\
78.30 \\
80.86 \\
82.36 \\
86.82 \\
90.18 \\
69.59 \\
78.90 \\
87.43 \\
88.89\end{array}$ & $\begin{array}{r}1.34 \\
18.56 \\
1.42 \\
.79 \\
1.13 \\
1.05 \\
1.17 \\
1.25 \\
1.25 \\
20.07 \\
7.81 \\
3.01 \\
2.51\end{array}$ \\
\hline 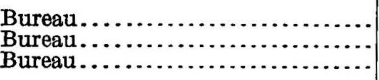 & 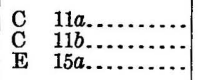 & $\begin{array}{l}29.56 \\
32.78 \\
32.38\end{array}$ & $\begin{array}{l}26.18 \\
22.76 \\
23.30\end{array}$ & $\begin{array}{r}11.00 \\
11.10 \\
8.64\end{array}$ & $\begin{array}{l}28.82 \\
31.20 \\
33.86\end{array}$ & $\begin{array}{l}5.34 \\
2.82 \\
2.96\end{array}$ & $\begin{array}{l}.22 \\
.41 \\
.46\end{array}$ & $\begin{array}{l}26.18 \\
22.76 \\
23.30\end{array}$ & $\begin{array}{r}11.00 \\
11.10 \\
8.64\end{array}$ & $\begin{array}{l}51.42 \\
55.67 \\
60.42\end{array}$ & $\begin{array}{r}11.16 \\
5.89 \\
6.19\end{array}$ \\
\hline $\begin{array}{l}\text { Clark } \\
\text { Clark } \\
\text { Clark } \\
\text { Clark } \\
\text { Clark } \ldots \ldots \ldots\end{array}$ & 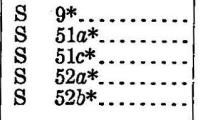 & $\begin{array}{l}41.92 \\
43.18 \\
43.16 \\
43.16 \\
40.78\end{array}$ & $\begin{array}{l}4.04 \\
1.74 \\
2.12 \\
1.46 \\
6.26\end{array}$ & $\begin{array}{l}2.94 \\
2.26 \\
1.56 \\
1.62 \\
5.50\end{array}$ & $\begin{array}{l}51.26 \\
52.94 \\
53.24 \\
53.86 \\
46.02\end{array}$ & $\begin{array}{r}.66 \\
.53 \\
.69 \\
.55 \\
1.96\end{array}$ & $\begin{array}{l}.17 \\
.14 \\
.08 \\
.03 \\
.22\end{array}$ & $\begin{array}{l}4.04 \\
1.74 \\
2.12 \\
1.46 \\
6.26\end{array}$ & $\begin{array}{l}2.94 \\
2.26 \\
1.56 \\
1.62 \\
5.50\end{array}$ & $\begin{array}{l}91.46 \\
94.46 \\
95.00 \\
96.10 \\
82.11\end{array}$ & $\begin{array}{l}1.38 \\
1.11 \\
1.44 \\
1.15 \\
4.10\end{array}$ \\
\hline Coles..... & s $\quad 3 * \ldots$ & $\cdots$ & 3.91 & 1.56 & 62.20 & 1.00 & $\cdots$ & 3.91 & 1.56 & 93.67 & 2.46 \\
\hline 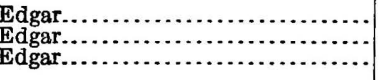 & $\begin{array}{lr}\text { Bu } & 2 * \\
\mathrm{~S} & 50 a^{*} \\
\mathrm{~S} & 50 c^{*}\end{array}$ & $\begin{array}{l}42.00 \\
43.18 \\
38.98\end{array}$ & $\begin{array}{l}2.66 \\
1.52 \\
8.02\end{array}$ & $\begin{array}{l}2.34 \\
1.74 \\
5.52\end{array}$ & $\begin{array}{l}51.90 \\
53.78 \\
46.30\end{array}$ & $\begin{array}{r}1.42 \\
.58 \\
1.35\end{array}$ & $\begin{array}{l}.22 \\
.04 \\
.25\end{array}$ & $\begin{array}{l}2.66 \\
1.52 \\
8.02\end{array}$ & $\begin{array}{l}2.34 \\
1.74 \\
5.52\end{array}$ & $\begin{array}{l}92.62 \\
95.96 \\
82.61\end{array}$ & $\begin{array}{l}2.97 \\
1.21 \\
2.82\end{array}$ \\
\hline 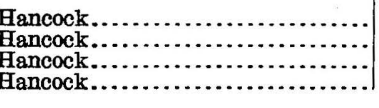 & $\begin{array}{ll}\mathrm{C} & 38 \\
\mathrm{C} & 40 * \ldots \ldots \ldots \ldots \\
\mathrm{C} & 41 * \ldots \ldots \ldots \ldots \\
\mathrm{C} & 42 \ldots \ldots \ldots \ldots\end{array}$ & $\begin{array}{l}33.40 \\
42.48 \\
38.94 \\
\mathbf{3 5 . 9 8}\end{array}$ & $\begin{array}{r}23.24 \\
2.62 \\
10.20 \\
16.24\end{array}$ & $\begin{array}{l}3.34 \\
1.48 \\
2.36 \\
3.80\end{array}$ & $\begin{array}{l}38.76 \\
53.62 \\
48.24 \\
41.84\end{array}$ & $\begin{array}{r}2.00 \\
.38 \\
.58 \\
2.50\end{array}$ & $\begin{array}{l}.28 \\
: .13 \\
.24 \\
.28\end{array}$ & $\begin{array}{r}23.24 \\
2.62 \\
10.20 \\
16.24\end{array}$ & $\begin{array}{l}3.34 \\
1.48 \\
2.36 \\
3.80\end{array}$ & $\begin{array}{l}69.16 \\
95.67 \\
86.08 \\
74.66\end{array}$ & $\begin{array}{r}4.18 \\
.79 \\
1.21 \\
5.23\end{array}$ \\
\hline
\end{tabular}


Analyses of Illinois limestones-Continued.

\begin{tabular}{|c|c|c|c|c|c|c|c|c|c|c|c|}
\hline County. & Sample number. & $\begin{array}{l}\text { Loss on } \\
\text { ignition. }\end{array}$ & $\begin{array}{c}\text { Silica } \\
\left(\mathrm{SiO}_{2}\right) .\end{array}$ & $\begin{array}{c}\text { Iron oxide } \\
\left(\mathrm{Fe}_{2} \mathrm{O}_{8}\right) \\
\text { alumina } \\
\left(\mathrm{Al}_{2} \mathrm{O}_{3}\right)\end{array}$ & $\begin{array}{l}\text { Lime } \\
(\mathrm{CaO}) .\end{array}$ & $\begin{array}{c}\text { Magnesia } \\
(\mathrm{MgO}) .\end{array}$ & $\begin{array}{c}\text { Water } \\
\text { at } 105^{\circ} \mathrm{C} \text {. }\end{array}$ & $\begin{array}{l}\text { Silica } \\
\left(\mathrm{SiO}_{2}\right) .\end{array}$ & $\begin{array}{c}\text { Iron oxide } \\
\left(\mathrm{Fe}_{2} \mathrm{O}_{3}\right) ; \\
\text { alumina } \\
\left(\mathrm{Al}_{2} \mathrm{O}_{3}\right)\end{array}$ & $\begin{array}{c}\text { Lime } \\
\text { carbonate } \\
\left(\mathrm{CaCO}_{3}\right) .\end{array}$ & $\begin{array}{l}\text { Magnesium } \\
\text { carbonate } \\
\left(\mathrm{MgCO}_{8}\right) \text {. }\end{array}$ \\
\hline $\begin{array}{l}\text { Hardin } \\
\text { Hardin........ }\end{array}$ & $\mid \begin{array}{ll}\mathrm{W} & 322 \ldots \ldots \ldots \ldots \\
\mathrm{W} & 330 * \ldots \ldots \ldots \ldots\end{array}$ & $\begin{array}{l}40.18 \\
39.72\end{array}$ & $\begin{array}{l}9.10 \\
7.78\end{array}$ & $\begin{array}{l}2.14 \\
4.10\end{array}$ & $\begin{array}{l}45.08 \\
48.10\end{array}$ & $\begin{array}{l}3.62 \\
1.06\end{array}$ & $\begin{array}{r}0.18 \\
.33\end{array}$ & $\begin{array}{l}9.10 \\
7.78\end{array}$ & $\begin{array}{l}2.14 \\
4.10\end{array}$ & $\begin{array}{l}80.43 \\
85.82\end{array}$ & $\begin{array}{l}7.56 \\
2.21\end{array}$ \\
\hline Henderson. & C $39 *$ & 43.06 & 2.30 & 1.12 & 54.20 & .34 & .08 & 2.30 & 1.12 & 96.71 & .71 \\
\hline 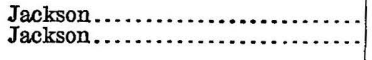 & $\begin{array}{ll}\mathrm{S} & 5 * \\
\mathrm{~S} & 57 a^{*} \ldots \ldots \ldots \ldots\end{array}$ & $\begin{array}{l}42.62 \\
43.92\end{array}$ & $\begin{array}{r}3.08 \\
.86\end{array}$ & $\begin{array}{r}1.12 \\
.72\end{array}$ & $\begin{array}{l}52.24 \\
52.64\end{array}$ & $\begin{array}{l}1.26 \\
2.34\end{array}$ & .14 & $\begin{array}{r}3.08 \\
.86\end{array}$ & $\begin{array}{r}1.12 \\
.72\end{array}$ & $\begin{array}{l}93.21 \\
93.93\end{array}$ & $\begin{array}{l}2.63 \\
4.89\end{array}$ \\
\hline $\begin{array}{l}\text { Johnson........ } \\
\text { Johnson....... } \\
\text { Johnson....... } \\
\text { Johnson...... }\end{array}$ & $\begin{array}{ll}\mathrm{D} & 16^{*} \ldots \ldots \ldots \ldots \ldots \\
\mathrm{D} & 17^{*} \ldots \ldots \ldots \ldots \ldots \\
\mathrm{W} & 304^{*} \ldots \ldots \ldots \ldots \ldots \\
\mathrm{W} & 308^{*} \ldots \ldots \ldots \ldots \ldots \\
\end{array}$ & $\begin{array}{l}\cdots \ldots \ldots \\
43.34 \\
43.20\end{array}$ & $\begin{array}{l}6.00 \\
5.33 \\
2.04 \\
.96\end{array}$ & $\begin{array}{l}1.32 \\
.83 \\
1.22 \\
1.76\end{array}$ & $\begin{array}{l}59.87 \\
61.84 \\
52.72 \\
53.56\end{array}$ & $\begin{array}{r}1.75 \\
.96 \\
1.50 \\
.74\end{array}$ & .12 & $\begin{array}{r}6.00 \\
5.33 \\
2.04 \\
.96\end{array}$ & $\begin{array}{l}1.32 \\
.83 \\
1.22 \\
1.76\end{array}$ & $\begin{array}{l}90.17 \\
93.11 \\
94.07 \\
95.57\end{array}$ & $\begin{array}{l}4.33 \\
2.37 \\
3.14 \\
1.55\end{array}$ \\
\hline 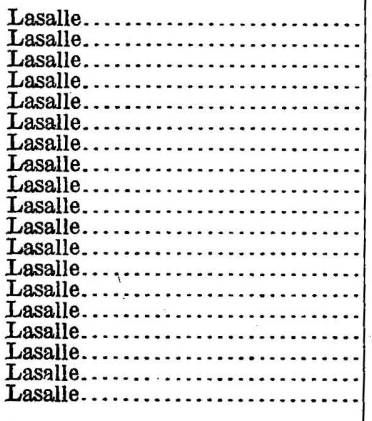 & 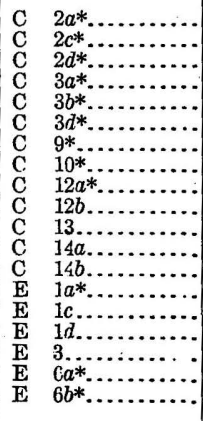 & $\begin{array}{l}42.06 \\
39.26 \\
37.88 \\
42.66 \\
39.48 \\
38.90 \\
40.20 \\
37.38 \\
42.66 \\
35.58 \\
32.14 \\
38.54 \\
38.80 \\
41.06 \\
33.28 \\
34.36 \\
44.92 \\
41.92 \\
39.16\end{array}$ & $\begin{array}{r}2.88 \\
8.78 \\
10.34 \\
1.98 \\
7.94 \\
8.24 \\
6.72 \\
11.10 \\
2.66 \\
15.24 \\
21.18 \\
15.02 \\
14.42 \\
4.92 \\
22.26 \\
17.76 \\
4.58 \\
4.32 \\
9.62\end{array}$ & $\begin{array}{r}2.24 \\
4.76 \\
4.40 \\
1.56 \\
4.80 \\
3.40 \\
5.92 \\
7.84 \\
1.90 \\
7.58 \\
16.36 \\
8.20 \\
11.34 \\
3.08 \\
6.86 \\
9.56 \\
3.72 \\
2.86 \\
5.56\end{array}$ & $\begin{array}{l}51.78 \\
46.08 \\
45.58 \\
53.32 \\
48.02 \\
47.72 \\
47.84 \\
43.46 \\
52.32 \\
41.54 \\
25.02 \\
25.40 \\
26.12 \\
50.52 \\
36.62 \\
36.64 \\
28.36 \\
51.32 \\
46.08\end{array}$ & $\begin{array}{r}.69 \\
1.96 \\
1.38 \\
.75 \\
.68 \\
1.31 \\
.66 \\
1.16 \\
.58 \\
1.14 \\
6.30 \\
12.50 \\
9.82 \\
.89 \\
1.91 \\
2.42 \\
18.30 \\
.59 \\
.74\end{array}$ & $\begin{array}{l}.14 \\
.15 \\
.80 \\
.12 \\
.28 \\
.25 \\
.12 \\
.24 \\
.14 \\
.49 \\
.47 \\
.33 \\
.12 \\
.17 \\
.50 \\
.57 \\
.11 \\
.16 \\
.38\end{array}$ & $\begin{array}{r}2.88 \\
8.78 \\
10.34 \\
1.98 \\
7.94 \\
8.24 \\
6.72 \\
11.10 \\
2.66 \\
15.24 \\
21.18 \\
15.02 \\
14.42 \\
4.92 \\
22.26 \\
17.76 \\
4.58 \\
4.32 \\
9.62\end{array}$ & $\begin{array}{r}2.24 \\
4.76 \\
4.40 \\
1.56 \\
4.80 \\
3.40 \\
5.92 \\
7.84 \\
1.90 \\
7.58 \\
16.36 \\
8.20 \\
11.34 \\
3.08 \\
6.86 \\
9.56 \\
3.72 \\
2.86 \\
5.56\end{array}$ & $\begin{array}{l}92.39 \\
82.22 \\
81.33 \\
95.14 \\
85.68 \\
85.15 \\
85.36 \\
77.55 \\
93.36 \\
74.12 \\
44.64 \\
45.32 \\
46.61 \\
90.14 \\
65.34 \\
65.39 \\
50.60 \\
91.57 \\
82.22\end{array}$ & $\begin{array}{r}1.44 \\
4.10 \\
2.88 \\
1.57 \\
1.42 \\
2.74 \\
1.38 \\
2.42 \\
1.21 \\
2.38 \\
13.17 \\
26.13 \\
20.53 \\
1.86 \\
3.99 \\
5.06 \\
38.25 \\
1.23 \\
1.55\end{array}$ \\
\hline 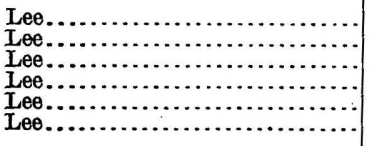 & 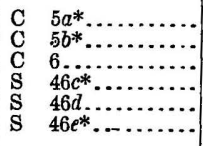 & $\begin{array}{l}40.68 \\
41.70 \\
43.72 \\
40.54 \\
41.94 \\
41.92\end{array}$ & $\begin{array}{l}5.52 \\
3.44 \\
4.50 \\
7.56 \\
5.10 \\
4.78\end{array}$ & $\begin{array}{l}3.66 \\
3.88 \\
4.60 \\
3.54 \\
2.58 \\
4.44\end{array}$ & $\begin{array}{l}49.62 \\
48.92 \\
36.98 \\
48.48 \\
45.84 \\
47.04\end{array}$ & $\begin{array}{r}.68 \\
1.98 \\
11.22 \\
.60 \\
4.58 \\
2.40\end{array}$ & $\begin{array}{l}.20 \\
.16 \\
.11 \\
.09 \\
.25 \\
.14\end{array}$ & $\begin{array}{l}5.52 \\
3.44 \\
4.50 \\
7.56 \\
5.10 \\
4.78\end{array}$ & $\begin{array}{l}3.66 \\
3.88 \\
4.60 \\
3.54 \\
2.58 \\
4.44\end{array}$ & $\begin{array}{l}88.54 \\
87.29 \\
65.98 \\
86.50 \\
81.79 \\
83.93\end{array}$ & $\begin{array}{r}1.42 \\
4.14 \\
23.45 \\
1.25 \\
9.57 \\
5.02\end{array}$ \\
\hline 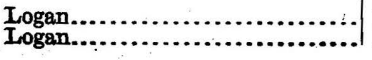 & $\begin{array}{ll}\mathbf{E} & 28 a^{*} \ldots \ldots \ldots \ldots \\
\mathbf{\mathrm { K }} & 28 b \ldots \ldots \ldots \ldots\end{array}$ & $\begin{array}{l}41.86 \\
42.84\end{array}$ & $\begin{array}{l}4.70 \\
2.04\end{array}$ & $\begin{array}{l}2.66 \\
4.92\end{array}$ & $\begin{array}{l}50.60 \\
46.96\end{array}$ & $\begin{array}{r}.82 \\
4.28\end{array}$ & .11 & $\begin{array}{l}4.70 \\
2.04\end{array}$ & $\begin{array}{l}2.66 \\
4.92\end{array}$ & $\begin{array}{l}90.28 \\
83.79\end{array}$ & $\begin{array}{l}1.71 \\
8.95\end{array}$ \\
\hline
\end{tabular}




\begin{tabular}{|c|c|c|c|c|c|c|c|c|c|c|c|}
\hline 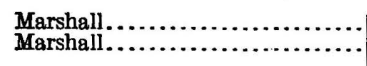 & $\left|\begin{array}{ll}\mathrm{E} & 20 b \ldots \ldots \ldots \ldots\end{array}\right|$ & $\begin{array}{l}27.74 \\
41.38\end{array}$ & $\begin{array}{r}31.74 \\
3.42\end{array}$ & $\begin{array}{l}8.92 \\
2.36\end{array}$ & $\begin{array}{l}31.26 \\
51.76\end{array}$ & $\begin{array}{l}.88 \\
.72\end{array}$ & $\begin{array}{l}.65 \\
.22\end{array}$ & $\begin{array}{r}31.74 \\
3.42\end{array}$ & $\begin{array}{l}8.92 \\
2.36\end{array}$ & $\begin{array}{l}55.78 \\
92.36\end{array}$ & $\begin{array}{l}1.84 \\
1.50\end{array}$ \\
\hline $\begin{array}{l}\text { Montgomery } \ldots \ldots \ldots \ldots \ldots \ldots \ldots \ldots \\
\text { Montgomery } . . . \ldots \ldots \ldots \ldots \ldots \ldots \ldots\end{array}$ & $\begin{array}{l}694^{*} \ldots \ldots \ldots \ldots . . \\
698^{*} \ldots \ldots \ldots \ldots\end{array}$ & $\begin{array}{l}42.98 \\
42.26\end{array}$ & $\begin{array}{l}1.41 \\
2.06\end{array}$ & $\begin{array}{l}2.29 \\
3.45\end{array}$ & $\begin{array}{l}53.15 \\
52.42\end{array}$ & $\begin{array}{r}.85 \\
1.03\end{array}$ & $\begin{array}{l}.13 \\
.16\end{array}$ & $\begin{array}{l}1.41 \\
2.06\end{array}$ & $\begin{array}{l}2.29 \\
3.45\end{array}$ & $\begin{array}{l}94.84 \\
93.53\end{array}$ & $\begin{array}{l}1.78 \\
2.15\end{array}$ \\
\hline 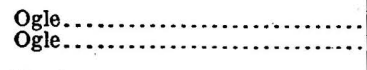 & $\mid \begin{array}{ll}\mathrm{C} & 7 a \ldots \ldots \ldots \ldots \ldots \\
\mathrm{C} & 8 \ldots \ldots \ldots \ldots \ldots\end{array}$ & $\begin{array}{l}43.98 \\
43.90\end{array}$ & $\begin{array}{l}1.38 \\
5.62\end{array}$ & \begin{tabular}{l|}
1.56 \\
4.22
\end{tabular} & $\begin{array}{l}48.40 \\
28.72\end{array}$ & $\begin{array}{r}5.46 \\
16.42\end{array}$ & $\begin{array}{l}.19 \\
.33\end{array}$ & $\begin{array}{l}1.38 \\
5.62\end{array}$ & $\begin{array}{l}1.56 \\
4.22\end{array}$ & $\begin{array}{l}86.36 \\
51.25\end{array}$ & $\begin{array}{l}11.41 \\
34.32\end{array}$ \\
\hline 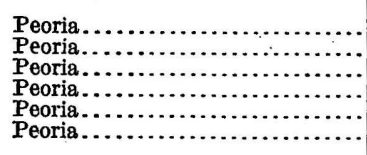 & 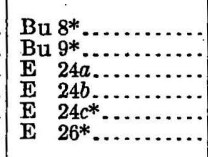 & $\begin{array}{l}37.94 \\
36.70 \\
32.88 \\
33.70 \\
42.70 \\
35.92\end{array}$ & $\begin{array}{r}13.36 \\
14.24 \\
21.96 \\
21.04 \\
2.78 \\
16.46\end{array}$ & $\begin{array}{l}3.24 \\
3.98 \\
5.88 \\
3.70 \\
1.82 \\
3.30\end{array}$ & $\begin{array}{l}46.74 \\
45.30 \\
39.26 \\
41.38 \\
51.52 \\
44.18\end{array}$ & $\begin{array}{r}.42 \\
.46 \\
.48 \\
.56 \\
1.86 \\
.50\end{array}$ & $\begin{array}{l}.14 \\
.23 \\
.48 \\
.25 \\
.12 \\
.26\end{array}$ & \begin{tabular}{r|}
13.36 \\
14.24 \\
21.96 \\
21.04 \\
2.78 \\
16.46
\end{tabular} & $\begin{array}{l}3.24 \\
3.98 \\
5.88 \\
3.70 \\
1.82 \\
3.30\end{array}$ & $\begin{array}{l}83.40 \\
80.83 \\
70.05 \\
73.83 \\
91.93 \\
78.83\end{array}$ & $\begin{array}{r}.88 \\
.96 \\
1.00 \\
1.17 \\
3.89 \\
1.05\end{array}$ \\
\hline 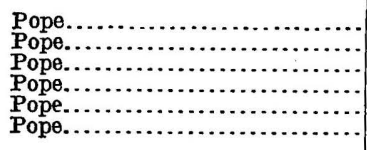 & 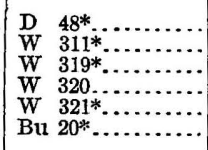 & $\begin{array}{r}40.08 \\
40.46 \\
33.72 \\
40.92 \\
39.85\end{array}$ & $\begin{array}{r}10.45 \\
7.90 \\
7.04 \\
18.06 \\
5.44 \\
7.66\end{array}$ & $\begin{array}{l}1.14 \\
2.74 \\
2.36 \\
8.86 \\
2.90 \\
2.02\end{array}$ & $\begin{array}{l}48.88 \\
49.16 \\
48.44 \\
39.52 \\
50.34 \\
49.74\end{array}$ & $\begin{array}{r}1.28 \\
1.18 \\
1.60 \\
.84 \\
1.00 \\
.93\end{array}$ & $\begin{array}{l}.27 \\
.42 \\
.73 \\
.11 \\
.21\end{array}$ & $\begin{array}{r}10.45 \\
7.90 \\
7.04 \\
18.06 \\
5.44 \\
7.66\end{array}$ & $\begin{array}{l}1.14 \\
2.74 \\
2.36 \\
8.86 \\
2.90 \\
2.02\end{array}$ & $\begin{array}{l}77.32 \\
87.72 \\
86.43 \\
70.52 \\
89.82 \\
88.75\end{array}$ & $\begin{array}{l}2.65 \\
2.47 \\
3.34 \\
1.76 \\
2.09 \\
3.68\end{array}$ \\
\hline Pulaski.............. & D $47 \ldots$ & & 6.39 & .49 & 61.68 & .92 & $\cdots \cdot$ & 6.39 & .40 & 92.90 & 2.27 \\
\hline 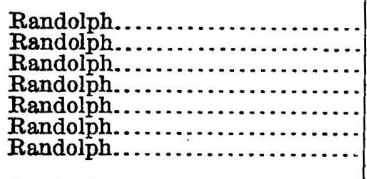 & 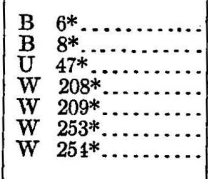 & $\begin{array}{r}43.98 \\
43.08 \\
39.00 \\
41.26 \\
42.72\end{array}$ & $\begin{array}{l}2.48 \\
1.90 \\
1.58 \\
1.85 \\
9.62 \\
4.54 \\
1.50\end{array}$ & $\begin{array}{r}1.11 \\
.67 \\
.56 \\
1.28 \\
1.94 \\
5.12 \\
2.00\end{array}$ & $\begin{array}{l}62.50 \\
63.55 \\
54.84 \\
53.45 \\
48.27 \\
45.82 \\
54.04\end{array}$ & $\begin{array}{r}1.56 \\
1.30 \\
.66 \\
.69 \\
.68 \\
3.64 \\
.52\end{array}$ & \begin{tabular}{r|} 
\\
.28 \\
.22 \\
.16 \\
.69 \\
.1 .3
\end{tabular} & $\begin{array}{l}2.48 \\
1.90 \\
.58 \\
1.85 \\
9.62 \\
4.54 \\
1.50\end{array}$ & $\begin{array}{r}1.11 \\
.67 \\
-.56 \\
-1.28 \\
1.94 \\
5.12 \\
2.00\end{array}$ & $\begin{array}{l}93.95 \\
95.72 \\
97.85 \\
95.37 \\
86.13 \\
81.76 \\
96.42\end{array}$ & $\begin{array}{l}3.86 \\
3.22 \\
1.38 \\
1.44 \\
1.42 \\
7.61 \\
1.09\end{array}$ \\
\hline 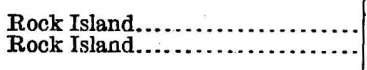 & Bu $15^{*} \ldots \ldots \ldots \ldots$ & $\begin{array}{l}40.00 \\
43.38\end{array}$ & $\begin{array}{l}6.98 \\
1.66\end{array}$ & \begin{tabular}{l|}
4.32 \\
1.16
\end{tabular} & $\begin{array}{l}45.98 \\
54.18\end{array}$ & $\begin{array}{r}2.64 \\
.58\end{array}$ & a............. & $\begin{array}{l}6.98 \\
1.66\end{array}$ & $\begin{array}{l}4.32 \\
1.16\end{array}$ & $\begin{array}{l}82.04 \\
96.67\end{array}$ & $\begin{array}{l}5.52 \\
1.21\end{array}$ \\
\hline 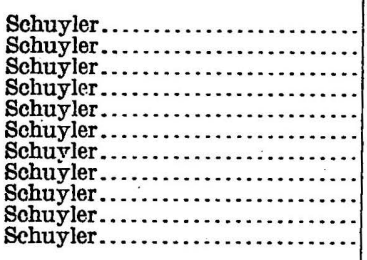 & 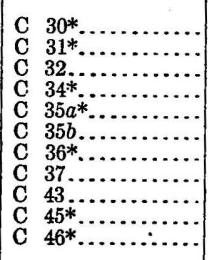 & $\begin{array}{l}41.46 \\
37.76 \\
35.66 \\
42.04 \\
38.84 \\
36.92 \\
38.06 \\
40.66 \\
33.82 \\
42.48 \\
42.22\end{array}$ & $\begin{array}{r}4.14 \\
11.88 \\
15.04 \\
4.14 \\
9.30 \\
15.80 \\
11.30 \\
6.58 \\
18.62 \\
2.66 \\
3.10\end{array}$ & $\begin{array}{l}1.88 \\
3.84 \\
6.44 \\
3.08 \\
4.54 \\
5.88 \\
6.16 \\
2.70 \\
7.24 \\
2.18 \\
2.14\end{array}$ & $\begin{array}{l}51.86 \\
46.46 \\
42.46 \\
49.70 \\
47.98 \\
36.00 \\
43.22 \\
50.60 \\
39.34 \\
53.42 \\
53.12\end{array}$ & $\begin{array}{r}.66 \\
.48 \\
1.34 \\
2.24 \\
.42 \\
6.84 \\
2.72 \\
.42 \\
1.72 \\
.44 \\
.44\end{array}$ & $\begin{array}{l}.22 \\
.24 \\
.18 \\
.14 \\
.49 \\
.30 \\
.25 \\
.24 \\
.26 \\
.14 \\
.24\end{array}$ & $\begin{array}{r}4.14 \\
11.88 \\
15.04 \\
4.14 \\
9.30 \\
15.80 \\
11.30 \\
6.58 \\
18.62 \\
2.66 \\
3.10\end{array}$ & \begin{tabular}{l|}
1.88 \\
3.84 \\
6.44 \\
3.08 \\
4.54 \\
5.88 \\
6.16 \\
2.70 \\
7.24 \\
2.18 \\
2.14
\end{tabular} & $\begin{array}{r}92.53 \\
82.90 \\
75.76 \\
88.68 \\
85.61 \\
64.23 \\
77.11 \\
90.29 \\
70.19 \\
95.32 \\
94.78\end{array}$ & $\begin{array}{r}1.38 \\
1.00 \\
2.80 \\
4.68 \\
.88 \\
14.30 \\
5.68 \\
.88 \\
3.59 \\
.92 \\
.92\end{array}$ \\
\hline 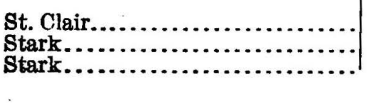 & 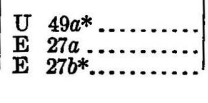 & $\begin{array}{l}41.16 \\
29.66 \\
36.38\end{array}$ & $\begin{array}{r}5.42 \\
27.24 \\
15.40\end{array}$ & $\begin{array}{l}2.24 \\
7.58 \\
2.80\end{array}$ & $\begin{array}{l}50.32 \\
35.28 \\
44.52\end{array}$ & $\begin{array}{r}1.26 \\
.98 \\
.72\end{array}$ & $\begin{array}{l}.34 \\
.78 \\
.29\end{array}$ & $\begin{array}{r}5.42 \\
27.24 \\
15.40\end{array}$ & $\begin{array}{l}2.24 \\
7.58 \\
2.80\end{array}$ & $\begin{array}{l}89.79 \\
62.95 \\
79.44\end{array}$ & $\begin{array}{l}2.63 \\
2.05 \\
1.50\end{array}$ \\
\hline
\end{tabular}


Analyses of Illinois limestones-Continued.

\begin{tabular}{|c|c|c|c|c|c|c|c|c|c|c|c|}
\hline County. & Sample number. & $\begin{array}{l}\text { Loss on } \\
\text { ignition. }\end{array}$ & $\begin{array}{c}\text { Silica } \\
\left(\mathrm{SiO}_{2}\right) .\end{array}$ & $\begin{array}{c}\text { Iron oxide } \\
\left(\mathrm{Fe}_{2} \mathrm{O}_{3}\right) ; \\
\text { alumina } \\
\left(\mathrm{Al}_{2} \mathrm{O}_{3}\right) .\end{array}$ & $\begin{array}{c}\text { Lime } \\
(\mathrm{CaO}) .\end{array}$ & $\begin{array}{l}\text { Magnesia } \\
\text { (MgO). }\end{array}$ & $\begin{array}{c}\text { Water } \\
\text { at } 105^{\circ} \mathrm{C} \text {. }\end{array}$ & $\begin{array}{c}\text { Silica } \\
\left(\mathrm{SiO}_{2}\right) .\end{array}$ & $\begin{array}{c}\text { Iron oxide } \\
\left(\mathrm{Fe}_{2} \mathrm{O}_{3}\right) ; \\
\text { aluma } \\
\left(\mathrm{Al}_{2} \mathrm{O}_{3}\right) .\end{array}$ & $\begin{array}{c}\text { Lime } \\
\text { carbonate } \\
\left(\mathrm{CaCO}_{3}\right) .\end{array}$ & $\begin{array}{l}\text { Magnesium } \\
\text { carbonate } \\
\left(\mathrm{MgCO}_{3}\right) .\end{array}$ \\
\hline $\begin{array}{l}\text { Stephenson.... } \\
\text { Stephenson.... } \\
\text { Stephenson.... } \\
\text { Stephenson ... } \\
\text { Stephenson.... }\end{array}$ & 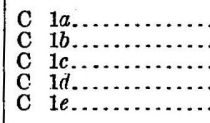 & $\begin{array}{l}40.78 \\
47.00 \\
46.44 \\
45.68 \\
40.02\end{array}$ & $\begin{array}{r}14.02 \\
1.68 \\
2.12 \\
3.22 \\
12.56\end{array}$ & $\begin{array}{l}3.52 \\
1.54 \\
1.70 \\
2.76 \\
7.04\end{array}$ & $\begin{array}{l}26.18 \\
30.82 \\
30.60 \\
29.90 \\
24.98\end{array}$ & $\begin{array}{l}16.22 \\
18.68 \\
19.70 \\
18.46 \\
14.42\end{array}$ & $\begin{array}{l}0.12 \\
.13 \\
.11 \\
.21 \\
.31\end{array}$ & $\begin{array}{r}14.02 \\
1.68 \\
2.12 \\
32.22 \\
12.56\end{array}$ & $\begin{array}{l}3.52 \\
1.54 \\
1.70 \\
2.76 \\
7.04\end{array}$ & $\begin{array}{l}46.71 \\
54.99 \\
54.60 \\
53.35 \\
44.57\end{array}$ & $\begin{array}{l}33.90 \\
39.05 \\
41.18 \\
38.59 \\
30.14\end{array}$ \\
\hline $\begin{array}{l}\text { Union......... } \\
\text { Union........ } \\
\text { Union........ }\end{array}$ & $\begin{array}{lll}\mathrm{D} & 2 \ldots \ldots \ldots \ldots \ldots \\
\mathrm{U} & 66^{*} \ldots \ldots \ldots \ldots \\
\mathrm{W} & 285^{*} \ldots \ldots \ldots \ldots\end{array}$ & $\begin{array}{r}43.28 \\
42.32\end{array}$ & $\begin{array}{l}1.99 \\
1.76 \\
3.30\end{array}$ & $\begin{array}{r}.36 \\
.92 \\
1.48\end{array}$ & $\begin{array}{l}60.79 \\
53.60 \\
51.82\end{array}$ & $\begin{array}{l}3.36 \\
1.02 \\
1.42\end{array}$ & .12 & $\begin{array}{l}1.99 \\
1.76 \\
3.30\end{array}$ & $\begin{array}{r}.36 \\
.92 \\
1.48\end{array}$ & $\begin{array}{l}91.55 \\
95.64 \\
92.46\end{array}$ & $\begin{array}{l}7.82 \\
2.13 \\
2.97\end{array}$ \\
\hline
\end{tabular}


Chemical analyses of Illinois clays.

All the samples marked (*) are satisfactory for cement-making purposes.)

\begin{tabular}{|c|c|c|c|c|c|c|c|c|}
\hline County. & Sample number. & $\begin{array}{c}\text { Silica } \\
\left(\mathrm{SiO}_{2}\right) .\end{array}$ & $\underset{\left(\mathrm{Al}_{2} \mathrm{O}_{3}\right)}{\text { Alumina }}$ & $\begin{array}{c}\text { Ferric } \\
\text { oxide } \\
\left(\mathrm{Fe}_{2} \mathrm{O}_{3}\right)\end{array}$ & $\begin{array}{l}\text { Lime } \\
(\mathrm{CaO}) .\end{array}$ & $\begin{array}{c}\text { Magnesia } \\
(\mathrm{MgO}) \text {. }\end{array}$ & $\begin{array}{l}\text { Loss on } \\
\text { ignition. }\end{array}$ & Remarks. \\
\hline 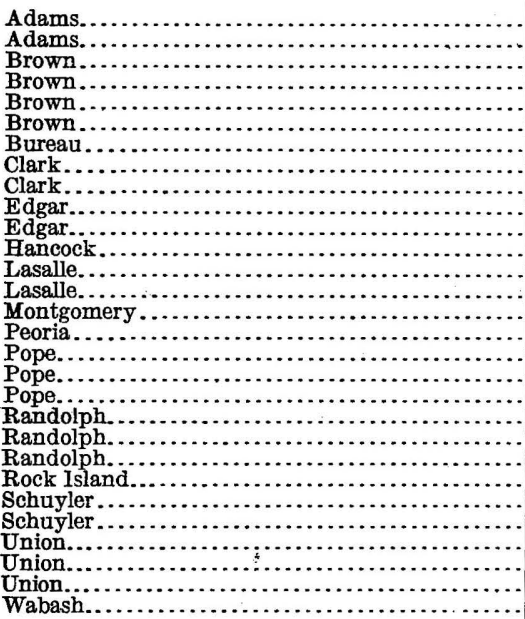 & 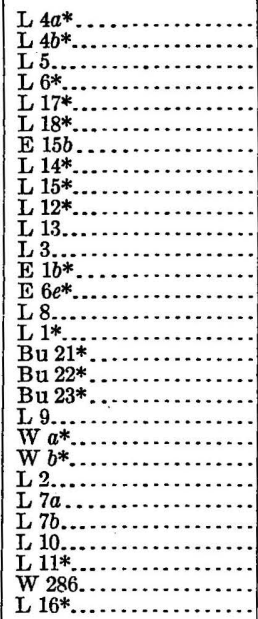 & $\begin{array}{l}49.03 \\
50.81 \\
47.41 \\
61.11 \\
59.92 \\
61.50 \\
49.10 \\
66.32 \\
68.20 \\
58.90 \\
74.24 \\
76.00 \\
49.02 \\
53.48 \\
71.65 \\
57.67 \\
60.75 \\
59.97 \\
59.90 \\
75.93 \\
57.55 \\
63.22 \\
77.31 \\
73.78 \\
73.66 \\
73.10 \\
64.78 \\
71.24 \\
55.95\end{array}$ & $\begin{array}{r}11.91 \\
10.52 \\
14.44 \\
14.76 \\
15.75 \\
18.75 \\
127.34 \\
17.25 \\
14.09 \\
19.09 \\
13.58 \\
9.68 \\
120.14 \\
122.36 \\
12.69 \\
21.60 \\
20.49 \\
21.00 \\
20.27 \\
11.96 \\
23.51 \\
11.98 \\
9.20 \\
16.30 \\
16.37 \\
13.45 \\
18.17 \\
113.74 \\
18.89\end{array}$ & \begin{tabular}{r}
10.75 \\
7.01 \\
7.21 \\
6.31 \\
7.06 \\
5.99 \\
7.74 \\
9.94 \\
8.11 \\
5.73 \\
5.76 \\
\hdashline$\ldots .32$ \\
6.63 \\
7.30 \\
7.15 \\
6.80 \\
3.48 \\
6.05 \\
5.67 \\
5.11 \\
1.76 \\
2.06 \\
5.33 \\
6.74 \\
$\ldots \ldots .0$ \\
8.09
\end{tabular} & $\begin{array}{r}8.41 \\
10.65 \\
9.53 \\
5.55 \\
2.94 \\
.83 \\
7.94 \\
2.01 \\
1.57 \\
1.56 \\
1.58 \\
1.80 \\
13.82 \\
7.64 \\
1.51 \\
1.61 \\
.52 \\
.60 \\
1.14 \\
2.01 \\
2.13 \\
2.30 \\
2.31 \\
.63 \\
.63 \\
2.12 \\
1.43 \\
5.32 \\
2.31\end{array}$ & $\begin{array}{l}5.73 \\
5.74 \\
6.70 \\
3.34 \\
3.28 \\
2.10 \\
2.74 \\
3.38 \\
3.46 \\
3.52 \\
1.86 \\
1.58 \\
2.10 \\
1.78 \\
1.60 \\
3.21 \\
1.73 \\
1.58 \\
1.66 \\
2.04 \\
3.39 \\
3.16 \\
1.86 \\
2.09 \\
2.10 \\
2.18 \\
1.69 \\
1.50 \\
3.06\end{array}$ & $\begin{array}{r}13.02 \\
13.30 \\
13.42 \\
8.00 \\
8.46 \\
8.84 \\
12.88 \\
3.32 \\
2.42 \\
6.18 \\
2.02 \\
3.62 \\
15.46 \\
14.66 \\
5.10 \\
6.80 \\
6.05 \\
5.54 \\
6.70 \\
3.20 \\
5.83 \\
7.50 \\
3.30 \\
4.63 \\
4.85 \\
2.86 \\
5.62 \\
7.66 \\
8.74\end{array}$ & $\begin{array}{l}\text { Too high in silica. } \\
\text { Do. } \\
\text { Do. }\end{array}$ \\
\hline
\end{tabular}

1 Including $\mathrm{Fe}_{2} \mathrm{O}_{3}$. 
Mechanical analyses of Illinois clays.

Clays marked (*) are considered suitable for cement making.

\begin{tabular}{|c|c|c|c|c|c|c|c|c|c|c|c|c|c|c|}
\hline \multirow{2}{*}{ County. } & \multirow{2}{*}{ Sample No. } & \multicolumn{7}{|c|}{ Percentage residue on sieves of mesh- } & \multicolumn{3}{|c|}{ Residue in can- } & \multirow{2}{*}{$\begin{array}{c}\text { Carried } \\
\text { off by } \\
\text { overflow- } \\
\text { average } \\
\text { diameter } \\
0.0069 \mathrm{~mm} \text {. }\end{array}$} & \multirow{2}{*}{$\begin{array}{l}\text { Residue } \\
\text { left after } \\
\text { ignition } \\
\text { and acid } \\
\text { and alkali } \\
\text { treatment } \\
\text { of sample. }\end{array}$} & \multirow[b]{2}{*}{$\begin{array}{l}\text { Surface } \\
\text { factor. }\end{array}$} \\
\hline & & 20 & 40 & 60 & 80 & 100 & 120 & 200 & $\begin{array}{l}\text { First. } a \\
0.0577 .\end{array}$ & $\begin{array}{c}\text { Second. } a \\
0.0354 .\end{array}$ & $\begin{array}{l}\text { Third.a } \\
0.0167 \text {. }\end{array}$ & & & \\
\hline Adams. & L $4 a^{*}$.. & 1.55 & 0.28 & 0.26 & 0.21 & 0.09 & 0.28 & 0.31 & 7.16 & 5.19 & 34.77 & 49.90 & 28.70 & 95.838 \\
\hline Adams. & $\overline{\mathrm{L}} 4 b * .$. & & .08 & .07 & .06 & .04 & .09 & .18 & 9.76 & 23.86 & 44.38 & 21.48 & 23.88 & \\
\hline Brown... & L $5 \ldots \ldots$ & .57 & .11 & .11 & .11 & .04 & .12 & .41 & 11.34 & 6.75 & 44.71 & 35.73 & 18.45 & 82.451 \\
\hline Brown.. & L 6*.. & & .13 & .50 & .52 & .27 & .35 & .37 & 5.66 & 40.22 & 17.30 & 34.68 & 19.80 & 72.980 \\
\hline Brown. & $\overline{\mathrm{L}} 17^{*}$. & .15 & .46 & .48 & .83 & .19 & .98 & 1.69 & 9.84 & 43.95 & 17.81 & 23.65 & 73.31 & 59.064 \\
\hline Brown. & $\overline{\mathrm{L}} 18 *$ & 1. 77 & .76 & .19 & .09 & .51 & .53 & .92 & 18.73 & 28.93 & 17.18 & 31.89 & 73.25 & 67.904 \\
\hline Clark.. & $\mathrm{L} 14 *$. & & ? & .03 & .03 & .05 & 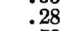 & 3.38 & 6.94 & 52.73 & 15.81 & 20.73 & 49.15 & 55. \\
\hline Clark....... & L $15 * . .$. & 6.60 & .25 & .17 & .13 & .14 & .72 & 2.97 & 29.12 & 32.03 & $\begin{array}{l}12.01 \\
12.10\end{array}$ & 15.77 & 57.05 & 44.203 \\
\hline Edgar.... & $\mathrm{L} 12^{*} \ldots$ & .58 & .18 & .07 & .06 & .03 & .06 & .28 & 10.97 & 32.45 & 20.28 & 35.04 & 7.48 & 73.998 \\
\hline Edgar..... & L $13 .$. & 09 & .02 & .11 & .09 & .11 & 1.27 & 10.40 & 41.42 & 28.80 & 9.00 & 8.79 & 42.43 & 33.452 \\
\hline Hancock... & L 3. & 2.80 & 2.71 & 3.41 & 2.25 & .91 & 2.57 & 4.35 & 17.15 & 15.11 & 29.16 & 19.52 & & 53.000 \\
\hline Montgomery & $\mathrm{L} 8 \ldots$ & 3. 83 & 2.77 & 5.04 & 3.30 & โ. 38 & 3.02 & 3.59 & 15.60 & 32.79 & 14.58 & 33.30 & 75.55 & 68.922 \\
\hline Peoria..... & $\mathrm{L} 1 * \ldots$ & 2. 62 & 1.20 & .17 & .30 & .05 & .03 & .22 & .34 & 5.77 & 19.46 & 69.84 & 10.57 & 114.598 \\
\hline Randolph... & L $9 .$. & & .10 & .13 & .11 & .10 & .35 & 1.38 & 42.70 & 40.69 & 6. 26 & 8.28 & 48.90 & $\begin{array}{r}14.058 \\
34.643\end{array}$ \\
\hline Rock Island. & $\overline{\mathrm{L}} 2 \ldots$ & .19 & .57 & 1. 46 & .91 & .40 & .69 & 1.06 & 19.28 & 15.13 & 41.77 & 17.54 & & \\
\hline Schuyler & $\overline{\mathrm{L}} 7 \alpha$ & & .03 & .07 & .07 & .09 & 0 & 1.73 & 32.54 & 42.93 & 12.01 & 10.29 & 29.45 & 39.880 \\
\hline Schuyler. & $\mathrm{L} 7 b \ldots$ & & & .10 & 12 & & & 1.46 & 40.27 & 32.68 & 13.04 & 11.88 & 36.08 & 41.238 \\
\hline Union.............................. & $\mathrm{L}, 10 \ldots \ldots$ & 1.41 & .43 & .36 & .27 & .14 & .33 & .64 & 20.29 & 46.00 & 13.15 & 16.99 & 77.15 & 48.983 \\
\hline Union................................................ & $\begin{array}{l}\mathrm{L} 11^{*} \ldots \ldots \ldots \\
\mathrm{L} 16^{*} \ldots \ldots \ldots\end{array}$ & 92 & 312 & .08 & .08 & & .21 & $\because 7$ & 24.35 & 42.80 & 14.25 & 17.94 & 40.42 & 50.842 \\
\hline Wabash....... & L 16*..... & .92 & 3.12 & 8.24 & 4.03 & 2.46 & 4.55 & 5. 71 & 11.12 & 22.65 & 15.72 & 21.48 & 50.69 & 49.874 \\
\hline
\end{tabular}

a A verage diameter in millimeters. 
Analyses of Illinois shales.

\begin{tabular}{|c|c|c|c|c|c|c|c|c|c|}
\hline Location. & $\begin{array}{c}\text { Silica } \\
\left(\mathrm{SiO}_{2}\right)\end{array}$ & $\underset{\left(\mathrm{Al}_{2} \mathrm{O}_{3}\right)}{\text { Alumina }}$ & $\begin{array}{c}\text { Ferric } \\
\text { oxide } \\
\left(\mathrm{Fe}_{2} \mathrm{O}_{3}\right)\end{array}$ & $\begin{array}{c}\text { Ferrous } \\
\text { oxide } \\
(\mathrm{FeO}) .\end{array}$ & $\underset{(\mathrm{CaO})}{\operatorname{Lime}}$ & $\begin{array}{c}\text { Magnesia } \\
(\mathrm{MgO})\end{array}$ & $\begin{array}{l}\text { Potash } \\
\left(\mathrm{K}_{\mathbf{2}} \mathrm{O}\right) .\end{array}$ & $\begin{array}{c}\text { Soda } \\
\left(\mathrm{Na}_{2} \mathrm{O}\right)\end{array}$ & $\begin{array}{l}\text { Igni- } \\
\text { tion } \\
\text { loss. }\end{array}$ \\
\hline 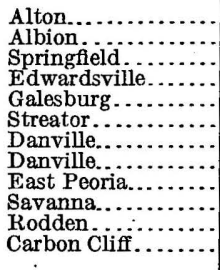 & $\begin{array}{l}63.36 \\
59.34 \\
60.31 \\
63.43 \\
63.62 \\
59.86 \\
64.09 \\
58.52 \\
60.93 \\
47.29 \\
48.41 \\
55.37\end{array}$ & $\begin{array}{l}15.43 \\
15.36 \\
17.74 \\
16.89 \\
16.28 \\
17.43 \\
14.16 \\
15.67 \\
17.93 \\
15.51 \\
18.31 \\
21.40\end{array}$ & $\begin{array}{l}1.80 \\
3.26 \\
5.04 \\
1.52 \\
3.02 \\
1.42 \\
2.65 \\
4.99 \\
8.12 \\
4.80 \\
6.06 \\
6.72\end{array}$ & \begin{tabular}{|r|}
4.02 \\
3.84 \\
1.96 \\
4.24 \\
2.90 \\
5.10 \\
3.16 \\
3.37 \\
Not det. \\
Not det. \\
Not det. \\
Not det.
\end{tabular} & $\begin{array}{l}0.93 \\
0.76 \\
0.41 \\
1.00 \\
0.63 \\
1.05 \\
1.69 \\
1.05 \\
1.33 \\
7.33 \\
5.73 \\
1.76\end{array}$ & $\begin{array}{l}1.58 \\
1.82 \\
1.96 \\
2.11 \\
1.44 \\
2.32 \\
1.64 \\
1.45 \\
0.91 \\
6.19 \\
3.13 \\
0.65\end{array}$ & $\begin{array}{r}3.28 \\
3.82 \\
2.88 \\
2.03 \\
2.60 \\
2.80 \\
2.90 \\
2.94 \\
5 . \\
3 . \\
5.6 \\
2 .\end{array}$ & $\begin{array}{rl} & 0.56 \\
& 0.80 \\
1.07 \\
0.20 \\
1.50 \\
0.18 \\
0.77 \\
\\
01 & 1.48 \\
71 & \\
71 & \\
65 & \\
42 & \end{array}$ & $\begin{array}{r}6.99 \\
7.89 \\
6.71 \\
5.97 \\
5.88 \\
6.35 \\
6.47 \\
7.72 \\
5.73 \\
13.11 \\
12.79 \\
8.75\end{array}$ \\
\hline
\end{tabular}

These analyses represent but a few of the available shales of the State, owing to the fact that a survey of these materials has not yet been made.

\section{PORTLAND CEMENT INDUSTRY IN ILLINOIS.}

Five Portland cement plants are at present operating in Illinois. Three of these plants use limestones and shales from the "Coal Measures," one uses Ordovician limestone and Quaternary clay, and the fifth utilizes a mixture of blast-furnace slag and limestone.

The Chicago Portland Cement Co. plant is at Oglesby, Lasalle County. The following section is exposed in the quarry:

\section{Section at quarry of Chicago Portland Cement Co., Oglesby, Ill.}

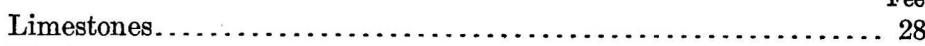

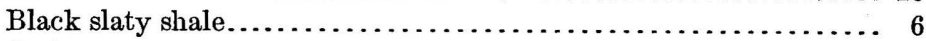

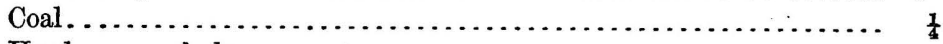

Harder gray shale................................... 9

The raw materials used at the plant are limestone from this quarry and shale from both of the beds noted. Analyses of the raw materials are given in the following table, the shale being from the 6-foot bed of black shale:

Analyses of cement materials from Oglesby, Ill.

\begin{tabular}{|c|c|c|}
\hline : & $\begin{array}{l}\text { Lime- } \\
\text { stone. }\end{array}$ & Shale. \\
\hline 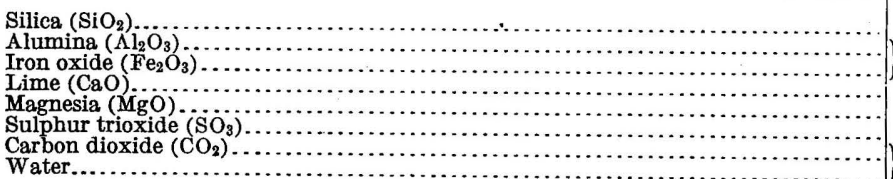 & $\begin{array}{r}6.06 \\
3.92 \\
49.46 \\
.91 \\
.10 \\
39.06\end{array}$ & $\begin{array}{r}53.12 \\
20.60 \\
4.09 \\
4.02 \\
2.24 \\
\text { n. d. } \\
13.70\end{array}$ \\
\hline
\end{tabular}

The plant of the German-American Portland Cement Co. is just east of Lasalle. The quarry shows 8 to 10 feet of limestone, underlain by 3 to $3 \frac{1}{2}$ feet of blue shale, and this in turn is underlain by 11 to 12 feet of limestone. Other shales outcrop beneath the lower lime- 
stone but are not at present used in the cement plant. Analyses of the raw materials, made by W. E. Prüssing, follow:

Analyses of cement materials from Lasalle, Ill.

\begin{tabular}{|c|c|c|c|}
\hline . & \multicolumn{2}{|c|}{ Limestone. } & Shale. \\
\hline Silica $\left(\mathrm{SiO}_{2}\right)$ & 5.43 & 5.06 & 52.74 \\
\hline $\begin{array}{l}\text { Alumina }\left(\mathrm{Al}_{2} \mathrm{O}_{3}\right) \ldots \ldots \ldots \\
\text { Iron oxide }\left(\mathrm{Fe}_{2} \mathrm{O}_{3}\right) \ldots \ldots \ldots\end{array}$ & 1.43 & 2.32 & 21.73 \\
\hline 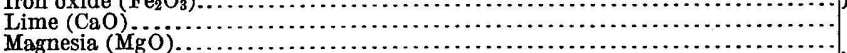 & $\begin{array}{r}52.02 \\
1.11\end{array}$ & $\begin{array}{r}48.29 \\
3.66\end{array}$ & $\begin{array}{r}12.37 \\
2.01\end{array}$ \\
\hline 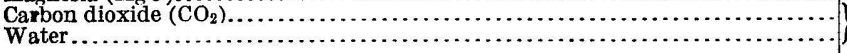 & 40.24 & 41.05 & 11.27 \\
\hline
\end{tabular}

The plant of the Marquette Cement Co. is at Dickinson, about 5 miles south of Lasalle. The limestone used is derived from the two heavy beds in the "Coal Measures." (See sections, pp. 141, 143.) The shales which occur below the limestone, as noted in these sections, are quarried to complete the mixture. Analyses of the raw materials used are as follows:

Analyses of cement materials from Dickinson, Ill.a

\begin{tabular}{|c|c|c|}
\hline & $\begin{array}{l}\text { Lime- } \\
\text { stone. }\end{array}$ & Shale. \\
\hline $\begin{array}{l}\mathrm{Silica}\left(\mathrm{SiO}_{2}\right) \\
\text { Alumina }\left(\mathrm{Al}_{2} \mathrm{O}_{3}\right) \\
\mathrm{Iron} \text { oxide }\left(\mathrm{Fe}_{2} \mathrm{O}_{3}\right) \\
\mathrm{Lime}(\mathrm{CaO}) \\
\text { Magnesia }(\mathrm{Mg} \mathrm{M}) \\
\text { Sulphur }(\mathrm{S}) \\
\text { Carbon dioxide }\left(\mathrm{CO}_{2}\right)\end{array}$ & $\begin{array}{r}8.20 \\
1.30 \\
49.37 \\
.85 \\
\text { n. d. } \\
39.72\end{array}$ & $\begin{array}{r}54.30 \\
19.33 \\
5.57 \\
3.29 \\
2.57 \\
2.36 \\
\text { n. d. }\end{array}$ \\
\hline
\end{tabular}

$a$ Twentieth Ann. Rept. U. S. Geol. Survey, pt. 6 (cont'd), 1899, p. 544. Analyses furnished by the company.

Of the two remaining Portland cement plants in Illinois, that of the Universal Portland Cement Co. at South Chicago uses a mixture of blast furnace slag and crushed limestone from Fairmont, Ill., and that of the Sandusky Portland Cement Co., at Dixon, Lee County, uses a mixture of Quaternary clay and limestone, the latter being Ordovician limestone and of the same age and type as the so-called "glass-rock" of Wisconsin (p. 371).

Coal is the kiln fuel at all the Illinois plants.

\section{BIBLIOGRAPHY.}

In addition to the papers listed below, data on limestones and clays are scattered through the reports issued by both the earlier and the present Illinois Geological Survey.

Bleininger, A. V., Lines, E. F., and Layman, F. E., Portland cement resources of Illinois: Bull. Illinois Geol. Survey No. 17, 1912.

Burchard, E. F., Concrete materials produced in the Chicago district: Bull. U. S. Geol. Survey No. 340, 1907, pp. 383-410. Also Bull. Illinois Geol. Survey, No. 8. 1907, pp. 345-372. 
CADY, G. H., Cement making materials in the vicinity of Lasalle: Bull. Illinois Geol. Survey No. 8, 1907, pp. 127-134.

Conover, A. D., Limestones and sandstones of Mlinois: Reports Tenth Census, vol. 10, 1884, pp. 219-226.

Ries, Heinrich, Clays of Illinois: Prof. Paper U. S. Geol. Survey No. 11, 1903, pp. 94-97.

Rolfs, C. W., and others, Paving brick clays of Illinois: Bull. Illinois Geol. Survey No. 9, 1908, pp. 1-46.

Savage, T. E., Lower Paleozoic stratigraphy of southwestern Illinois: Bull. Illinois Geol. Survey No. 8, 1907, pp. 103-116.

VANHoRN, F. B., Limestones available for fertilizers (in southern Illinois): Bull. Illinois Geol. Survey No. 4, 1907, pp. 177-184.

Weller, S., The geological map of Illinois: Bull. Illinois Geol. Survey No. 6, 1907, 34 pp., map.

\section{PORTLAND CEMENT RESOURCES OF INDIANA.}

\section{PORTLAND CEMENT MATERIALS.}

In Indiana certain limestones that contain only small amounts of magnesia seem worthy of consideration as Portland cement material. These are contained in the Cincinnatian shales and limestones, the Mississippian limestone, the Pennsylvanian limestones ("Coal Measures"; see Pl. XV, p. 300), and the fresh-water marls of Quaternary age. Of these four possible sources of cement material the Mississippian limestone and the Quaternary marl are now used by cement plants in Indiana.

\section{CINCINNATIAN SHALES AND LIMESTONES.}

The Cincinnatian series is found only in southeastern Indiana, occupying part or all of the counties of Union, Wayne, Fayette, Franklin, Dearborn, Ohio, Switzerland, Ripley, and Jefferson. In this area it is made up of bluish thin-bedded limestones interbedded with soft bluish-green calcareous shales. The lower 200 feet consists almost entirely of shale, and the next 200 feet contains more limestones than any other part of the series. Locally, in Clark and Jefferson counties, toward the top of the series, massive sandy limestone beds, brownish in color, occur.

No analyses of the limestones and shales of this series from Indiana localities are available, but a number of analyses of similar materials from adjoining areas in Ohio and Kentucky are given on pages 189,300 .

MISSISSIPPIAN ("LOWER CARBONIFEROUS") LIMESTONES AND SHALES. FORMATIONS.

As shown on the geologic map (PI. XV), the Mississippian rocks in Indiana lie in a belt averaging 20 miles or more in width and extending from Ohio River in a general northwesterly direction to the 
Illinois line. Another area underlies Elkhart, Lagrange, and St. Joseph counties, in the extreme northern part of the State.

The Mississippian rocks as thus mapped include several distinct formations. Beginning at the top these are $(a)$ Chester group (sandstones, shales, and limestones), $(b)$ Mitchell limestone, $(c)$ Spergen limestone (known to the trade as Bedford oolitic limestone), (d) Harrodsburg limestone, and (e) "Knobstone" group (shales and shaly sandstones).

\section{CHESTER GROUP.}

The Chester group, which includes several beds of limestone interbedded with sandstones and shales, is 100 to 150 feet thick and is immediately overlain by the heavy sandstones of the Pottsville formation. In view of the nearness of the thick and valuable Mitchell and Spergen limestones it seems improbable that the limestones of the Chester group will become of importance as cement materials.

\section{MITCHELL LIMESTONE.}

The Mitchell limestone, lying below the Chester group and above the Spergen limestone, consists of thick limestones with some thin beds of shale. It ranges in thickness from 150 to 250 feet.

SPERGEN IIMESTONE.

The Spergen limestone varies in thickness from 30 feet, or even less, to 90 feet, the greater thicknesses lying between Bedford and Salem. The Spergen is the well-known oolitic rock known to the trade as Bedford oolitic stone-a creamy white limestone, soft when freshly quarried, but hardening rapidly on exposure.

HARRODSBURG LIMESTONE.

Underlying the Spergen limestone is the Harrodsburg limestone, which ranges from 30 to 100 feet in thickness and is made up mostly of limestones, with scattered thin beds of shale.

"KNOBSTONE" GROUP.

The lowest division of the Mississippian series, the "Knobstone" group, is about 400 feet in thickness and is made up of shales and shaly sandstones. The "Knobstone" is of interest in the present connection because the shale used at one of the Portland cement plants of the State is derived from it.

compositior.

The composition of the Mississippian limestones of Indiana is shown by the following analyses, most of which are of the Spergen limestone (Bedford oolitic limestone of the trade): 
Analyses of Mississippian limestones from Indiana.

\begin{tabular}{|c|c|c|c|c|c|c|c|c|c|}
\hline & 1 & 2 & 3 & 4 & .5 & 6 & 7 & 8 & 9 \\
\hline $\begin{array}{l}\text { Silica }\left(\mathrm{SiO}_{2}\right) \\
\text { Alumina }\left(\mathrm{Al}_{2} \mathrm{O}_{3}\right) \text { and iron oxide }\left(\mathrm{Fe}_{2} \mathrm{O}_{3}\right) \\
\text { Lime carbonate }\left(\mathrm{CaCO}_{3}\right) \ldots \ldots \ldots \ldots \\
\text { Magnesium carbonate }\left(\mathrm{MgCO}{ }_{3}\right) \ldots \ldots \ldots\end{array}$ & $\begin{array}{r}0.50 \\
.98 \\
96.60 \\
.27\end{array}$ & $\begin{array}{r}0.70 \\
.91 \\
96.79 \\
.23\end{array}$ & $\begin{array}{r}1.74 \\
.29 \\
95.62 \\
.89\end{array}$ & $\begin{array}{r}1.60 \\
.18 \\
95.55 \\
.93\end{array}$ & $\begin{array}{r}0.65 \\
1.00 \\
95.54 \\
.40\end{array}$ & $\begin{array}{r}0.90 \\
3.00 \\
95.00 \\
.22\end{array}$ & $\begin{array}{r}1.13 \\
1.06 \\
96.04 \\
.72\end{array}$ & $\begin{array}{r}0.31 \\
.32 \\
98.09 \\
\cdots\end{array}$ & $\begin{array}{r}0.48 \\
.15 \\
98.91 \\
.63\end{array}$ \\
\hline & 10 & 11 & 12 & 13 & 14 & 15 & 16 & 17 & 18 \\
\hline $\begin{array}{l}\text { Silica }\left(\mathrm{SiO}_{2}\right) \ldots \ldots \\
\text { Alumina }\left(\mathrm{Al}_{2} \mathrm{O}_{3}\right) \text { and iron oxide }\left(\mathrm{Fe}_{2} \mathrm{O}_{3}\right) \\
\text { Lime carbonate }(\mathrm{CaCO}) \\
\text { Magnesium carbonate }\left(\mathrm{Mg} \mathrm{CO}{ }_{3}\right) \ldots \ldots . . .\end{array}$ & $\begin{array}{r}0.84 \\
.13 \\
97.39 \\
.78\end{array}$ & $\begin{array}{r}0.86 \\
.16 \\
98.11 \\
.92\end{array}$ & $\begin{array}{r}0.64 \\
.15 \\
98.27 \\
.84\end{array}$ & $\begin{array}{r}0.76 \\
.15 \\
98.16 \\
.97\end{array}$ & $\begin{array}{r}1.26 \\
.18 \\
97.90 \\
.65\end{array}$ & $\begin{array}{r}1.69 \\
.49 \\
97.26 \\
.77\end{array}$ & $\begin{array}{r}0.63 \\
.39 \\
98.20 \\
.81\end{array}$ & $\begin{array}{r}0.15 \\
.64 \\
93.80 \\
4.01\end{array}$ & $\begin{array}{r}0.50 \\
.71 \\
93.07 \\
4.22\end{array}$ \\
\hline
\end{tabular}

1. Chicago \& Bedford Stone Co., Bedford, Lawrence County. Eighth, Ninth, and Tenth Ann. Repts. Indiana Geol. Survey, 1879, p. 95.

2. Simpson \& Archer quarry, near Spencer. Idem, p. 94.

3, 4, 5. Dunn \& Co., Bloomington. Twenty-first Rept. Indiana Dept. Geology, 1897, p. 320

6. Monroe Marble Co., Stinesville. Report of a geologic reconnaissance of Indiana, $1862, \mathrm{p} .137$.

7. Salem. Idem, 1886 , p. 144 .

8. Stockslager quarry, Harrison County. Idem, 1878, p. 96.

9. Milltown. W. A. Noyes, analyst. Twenty-seventh Rept. Indiana Dept. Geology, 1902, p. 98

10. Acme Bedford Stone Co., Clear Creek, Monroe County. Twentieth Ann. Rept: U. S. Geol. Survey, pt. 6 (continued), 1899, p. 381.

11. Hunter Bros.' quarry, Hunter Valley. W. A. Noyes, analyst. Twenty-first Rept. Indiana Dept. Geology, 1897, p. 320

12. Indiana Stone Co., Bedford, Lawrence County. W. A. Noyes, analyst. Idem.

13. Twin Creek Stone Co., Salem, Washington County. W. A. Noyes, analyst. Idem.

14. Romona Oolitic Stone Co., Romona, Owen County. W. A. Noyes, analyst. Idem.

15-16. Hoosier Stone Co., Bedford, Lawrence County. F. W. Clarke, analyst. Bull. U. S. Geol. Survey No. 42,1887 , p. 140.

17-18. Indiana Steam Stone Works, Big Creek. L. H. Streaker, analyst. Twenty-first Rept. Indiana Dept. Geology, 1897, p. 320 .

LIMESTONES OF THE PENNSYlVANIAN SERIES ("COAL MEASURES").

Limestone beds occur in the "Coal Measures" of Indiana, but details regarding their distribution and composition are lacking. The Pennsylvanian limestones in adjacent portions of Illinois are discussed on page 143 .

FRESH-WATER MARLS OF QUATERNARY AGE.

A very detailed report on "The lakes of northern Indiana and their associated marl deposits" has been made by W. S. Blatchley and G. H. Ashley, ${ }^{1}$ who have described and mapped all the known marl deposits in the State. The following data are abstracted from their report:

Marl deposits of sufficient size to justify the erection of Portland cement plants occur in Indiana in the three northern tiers of counties only. The largest of these deposits, so far as area is concerned, is in Lake Wawasee, which contains about 1,700 acres, and the thickest deposit (45 feet) is reported from Turkey Lake, Lagrange County.

A deposit of marl covering 160 acres and 10 feet thick will supply for 30 years a cement plant producing 500 barrels a day. Thirtythree deposits of this size or greater are described in the report. The

1 Twenty-fifth Ann. Rept. Indiana Dept. Geology, 1901, pp. 31-321. 
names and locations of the lakes containing these workable deposits are as follows:

\section{Lakes containing marl deposits in Indiana.}

1. Hog Lake, Steuben County, 2 miles west of the village of Jamestown, Jamestown Township.

2. Lime Lake, Steuben County, 1 mile northwest of Orland (Mill Grove Township).

3. Clear Lake. Steuben County, in secs. 19 and 20, T. 38 N., R. 15 E. (Clear Lake Township).

4. Shallow and Deep lakes, Steuben County, secs. 6 and 7, T. 37 N., R. 12 E. (Jackson Township).

5. James Lake, Steuben County, 3 miles northwest of Angola.

6. Gage Lake, Steuben County, sec. 35, T. 38 N., R. 12 E.

7. Silver Lake, Steuben County, 4 miles west of Angola.

8. Shipshewana Lake, Lagrange County, three-fourths of a mile west of Shipshewana.

9. Cedar and Grass lakes, Lagrange County, 3 miles northeast of Lima.

10. Fish Lake, Lagrange County, 8 miles southeast of Lagrange.

11. Turkey Lake, Lagrange County, near Stroh.

12. Waldron Lake, Noble County, 2 miles west of Rome City.

13. Eagle Lake, Noble County, sec. 6, T. 34 N., R. 9 E.

14. Deer Lake, Noble County, sec. 25, T. 34 N., R. 8 E. (Sparta Township).

15. Crooked Lake, Whitley County, secs. 3 and 4, T. 32 N., R. 9 E. (Thorn Creek Township).

16. Loon Lake, Whitley County, 9 miles northwest of Columbia City.

17. Simonton Lake, Elkhart County, secs. 13, 14, 15, 16, and 17, T. 38 N., R. 5 E. (Osolo Township).

18. Indiana Lake; Elkhart County, northwest of Bristol.

19. Turkey Lake, Kosciusko County, near Syracuse.

20. Syracuse Lake, Kosciusko County, near Syracuse.

21. Milford Lake, Kosciusko County, 4 miles southeast of Milford.

22. Tippecanoe Lake, Kosciusko County, three-fourths of a mile southeast of Milford.

23. Barbee Lake, Kosciusko County, 3 miles southeast of Oswego.

24. Little Eagle Lake, Kosciusko County, $3 \frac{1}{2}$ miles northeast of Warsaw.

25. Center Lake, Kosciusko County, Warsaw.

26. Winona Lake, Kosciusko County, 1 mile southeast of Warsaw.

27. Manitou Lake, Fulton County, 1 mile southeast of Rochester.

28. Maxinkuckee Lake, Marshall County, secs. 15, 16, 21, 22, 27, 28, and 34, T. 32 N., R. 1 E.

29. Houghton Lake, Marshall County, secs. 7 and 18, T. 32 N., R. 1 E. (Union Township).

30. Chain Lake, St. Joseph County, 5 miles west of South Bend.

31. Du Chemin Lake, Laporte County, 11 miles northeast of Laporte.

32. Fish Lake, Laporte County, Fish Lake station.

33. North Judson Marsh, Starke County, $3 \frac{1}{2}$ miles west of North Judson.

Descriptions are also given of a number of other marl deposits, which, though of sufficient size, have the larger part of their area covered by 10 feet or more of water, and are therefore not workable under present conditions.

The composition of these marls is shown by the following table: ${ }^{1}$ 
Analyses of Quaternary marls from Indiana.

[W. A. Noyes, analyst.]

\begin{tabular}{|c|c|c|c|c|c|c|c|c|c|c|c|c|}
\hline & 1 & 2 & 3 & 4 & 5 & 6 & 7 & 8 & 9 & 10 & 11 & 12 \\
\hline 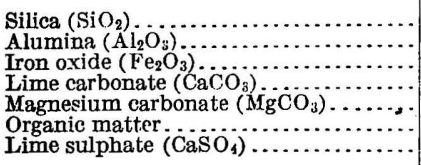 & \begin{tabular}{r|r|}
0.68 & \\
.14 & \\
.28 & \\
90.42 & 8 \\
2.88 & \\
4.13 & \\
$\cdots$ &
\end{tabular} & $\begin{array}{r}1.08 \\
1.16 \\
86.00 \\
9.42 \\
2.32 \\
\cdots\end{array}$ & $\begin{array}{r}0.47 \\
.04 \\
.12 \\
93.29 \\
2.67 \\
1.56 \\
\cdots\end{array}$ & $\mid \begin{array}{r}1.16 \\
.29 \\
92.41 \\
2.38 \\
1.97 \\
0.15\end{array}$ & $\begin{array}{r}4.52 \\
1.34 \\
81.00 \\
6.46 \\
3.68 \\
\cdots\end{array}$ & $\begin{array}{r}5.95 \\
.41 \\
.42 \\
82.07 \\
2.63 \\
6.71 \\
.22\end{array}$ & $\mid \begin{array}{c}7.94 \\
.64 \\
32.89 \\
2.04 \\
3.67 \\
\cdots\end{array}$ & $\begin{array}{r}1.42 \\
.88 \\
88.21 \\
4.78 \\
2.58 \\
\ldots . .\end{array}$ & $\begin{array}{l}1.7 \\
1.2 \\
88.4 \\
2.7 \\
4.2\end{array}$ & \begin{tabular}{l|r}
78 & 2.0 \\
21 & .5 \\
49 & 92.3 \\
71 & 3.5 \\
23 & 2.1 \\
58 & $\cdots$
\end{tabular} & 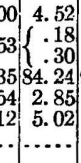 & $\begin{array}{r}2.48 \\
.06 \\
.26 \\
90.67 \\
2.42 \\
2.87 \\
\ldots \ldots\end{array}$ \\
\hline & 13 & 14 & 15 & 16 & 17 & 18 & 19 & 20 & & 21 & 22 & 23 \\
\hline 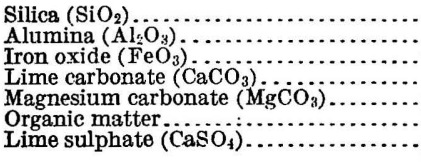 & $\mid \begin{array}{r}2.92 \\
.29 \\
91.02 \\
2.28 \\
2.10 \\
\cdots\end{array}$ & $\begin{array}{r}4.61 \\
.15 \\
.35 \\
84.75 \\
2.81 \\
5.69 \\
\cdots\end{array}$ & $\begin{array}{r}6.39 \\
.19 \\
.30 \\
87.65 \\
2.60 \\
2.88 \\
\cdots . .\end{array}$ & $\begin{array}{r}5.67 \\
.12 \\
.33 \\
85.02 \\
3.85 \\
3.21 \\
0.17\end{array}$ & $\begin{array}{r}6.40 \\
.05 \\
.33 \\
85.3 \\
3.50 \\
3.15 \\
.17\end{array}$ & $\begin{array}{r}15.26 \\
.09 \\
.51 \\
75.07 \\
4.18 \\
3.65 \\
.11\end{array}$ & $\begin{array}{r}2.02 \\
.04 \\
.20 \\
89.22 \\
2.73 \\
4.15\end{array}$ & \begin{tabular}{r|r}
2 & .1 \\
4 &. \\
0 &. \\
2 & 91. \\
3 & 4. \\
5 & 2. \\
- &.
\end{tabular} & $\begin{array}{l}19 \\
05 \\
07 \\
62 \\
02 \\
25 \\
14\end{array}$ & $\begin{array}{r}3.10 \\
.10 \\
.20 \\
87.92 \\
2.64 \\
4.18 \\
.23\end{array}$ & $\begin{array}{r}.82 \\
\ldots .08 \\
91.30 \\
2.90 \\
3.88 \\
.22\end{array}$ & $\begin{array}{r}2.06 \\
.45 \\
.74 \\
89.92 \\
2.46 \\
4.51 \\
\ldots . . .\end{array}$ \\
\hline
\end{tabular}

1. Hog Lake, Steuben County.

2. Lime Lake, Steuben County.

3. Deep Lake, Steuben County.

4. James Lake, Steuben County.

5. Silver Lake, Steuben County.

6. Loon Lake, Whitley County.

7. Mud Lake, Elkhart County.

8. Cooley Lake, Elkhart County.

9. Syracuse Lake, Kosciusko County.

10. Dewart Lake, Kosciusko County.

11. Dewart Lake, Kosciusko County.

12. Tippecanoe Lake, Kosciusko County.

\section{PORTLAND CEMENT INDUSTRY IN INDIANA.}

Indiana now ranks second only to Pennsylvania as a Portland cement producer, the output of the State during 1911 having been about 7,500,000 barrels, produced by five plants. The earliest established plants were those of the Sandusky Portland Cement Co., at Syracuse, the Wabash Portland Cement Co., at Stroh, and the Lehigh Portland Cement Co., at Mitchell. Of these the first two mentioned operated on a mixture of marl and clay, and the one last named used hard limestone and shale.

During the past fow years three other plants have gone into operation in the State. That of the Louisville Cement Co. is at Speeds, near the Ohio River, in the natural-cement district of southern Indiana; that of the United States Cement Co. is at Bedford, and that of the Universal Portland Cement Co. is at Buffington. Of these three newer plants two use a mixture of limestone and shale, and the third operates on a mixture of blast-furnace slag and crushed limestone. The plant at Bedford was not operated in 1911.

Analyses of the raw materials used and of the product turned out at several of the Indiana plants follow. 
Analyses of raw materials and cement from Syracuse, Ind.

\begin{tabular}{|c|c|c|c|c|}
\hline$\cdot$ & 1 & 2 & 3 & 4 \\
\hline 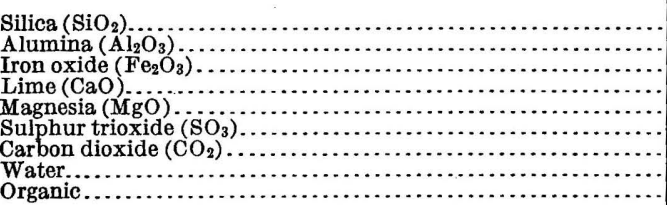 & $\begin{array}{r}1.74 \\
.90 \\
.28 \\
49.84 \\
1.75 \\
1.12 \\
-46.01 \\
\text { n. d. }\end{array}$ & $\begin{array}{r}1.78 \\
1.21 \\
49.55 \\
1.29 \\
(a) \\
40.36 \\
4.23\end{array}$ & $\begin{array}{l}55.27 \\
10.20 \\
3.40 \\
9.12 \\
5.73 \\
\text { n. d. } \\
\text { n.d. } \\
\text { n.d. } \\
\text { n.d. }\end{array}$ & $\begin{array}{r}22.06 \\
4.80 \\
1.66 \\
65.44 \\
3.82 \\
.90 \\
\ldots \ldots . \\
\ldots . .6 \\
\end{array}$ \\
\hline
\end{tabular}

$a \mathrm{CaSO}_{4}, 1.58$ per cent.

1. Marl. Twenty-fifth Ann. Rept. Indiana Dept. Geology, 1901, p. 28.

2. Marl. Nineteenth Ann. Rept. U. S. Geol. Survey, pt. 6 (continued), 1898, p. 493.

3. Clay. Twenty-fifth Ann. Rept. Indiana Dept. Geology, 1901, p. 28.

4. Cement. Idem.

Analyses of raw materials and cement from Stroh, Ind.

\begin{tabular}{|c|c|c|c|c|c|c|}
\hline & 1 & 2 & 3 & 4 & 5 & 6 \\
\hline 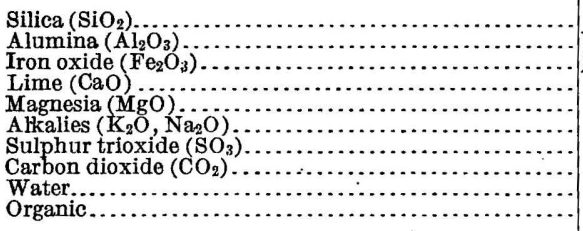 & $\begin{array}{l}0.85 \\
.86 \\
51.04 \\
1.31 \\
\text { n.d. } \\
\text { n.d. } \\
40.10 \\
\text { n.d. } \\
\text { n.d. }\end{array}$ & $\begin{array}{r}0.66 \\
.62 \\
53.17 \\
.47 \\
\text { n. d. } \\
\text { n. d. } \\
42.35 \\
2.53\end{array}$ & $\begin{array}{r}61.70 \\
18.00 \\
8.40 \\
2.91 \\
\text { n. d. } \\
\text { n.d. } \\
13.30\end{array}$ & $\begin{array}{r}57.74 \\
17.76 \\
7.80 \\
3.52 \\
\text { n. d. } \\
\text { n. d. } \\
12.30\end{array}$ & $\begin{array}{r}56.74 \\
19.43 \\
4.83 \\
7.27 \\
\text { 3. } 05 \\
\text { n. d. } \\
\text { n. d. } \\
10.39\end{array}$ & $\begin{array}{r}21.78 \\
7.31 \\
2.65 \\
62.35 \\
2.88 \\
.47 \\
1.78 \\
.23 \\
.55\end{array}$ \\
\hline
\end{tabular}

1. Marl. W. R. Oglesby, analyst. Twenty-fifth Ann. Rept. Indiana Dept. Geology, 1901, p. 112. 2. Marl. Analysis given by Wabash Portland Cement Co., 1904.

3-4. Clay. Idem.

5. Clay. W. R. Oglesby, analyst. Twenty-fifth Ann. Rept. Indiana Dept. Geology, 1901, p..112. 6. Cement. Idem.

Analyses of raw materials for cement from Mitchell, Ind.

\begin{tabular}{|c|c|c|}
\hline & 1 & 2 \\
\hline 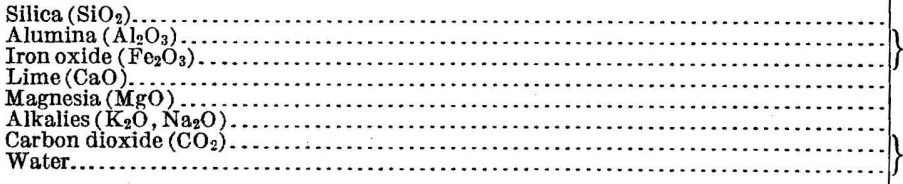 & \begin{tabular}{r|}
0.74 \\
.13 \\
52.49 \\
1.87 \\
n. d. \\
43.68
\end{tabular} & $\left\{\begin{array}{r}59.64 \\
a 19.14 \\
7.59 \\
.26 \\
2.31 \\
4.33 \\
.35 \\
4.36\end{array}\right.$ \\
\hline
\end{tabular}

$a$ With $\mathrm{TiO}_{2}, 1.05$ per cent.

1. Limestone. F. W. Clarke, analyst. Specimen collected by E. C. Eckel.

2. Shale. Twenty-sixth Ann. Rept. Indiana Dept. Geology, p. 276.

\section{BIBLIOGRAPHY.}

The following papers relate to the raw materials or the manufacture of Portland cement in Indiana:

Blatchley, W. S., Preliminary report on the clays and clay industries of the coalbearing counties of Indiana: Twentieth Ann. Rept. Indiana Dept. Geology, 1896, pp. 24-187.

- Clays and clay industries of northwestern Indiana: Twenty-second Ann. Rept. Indiana Dept. Geology, 1898, pp. 105-153.

Portland cement (in Indiana): Twenty-fifth Ann. Rept. Indiana Dept.

Geology, 1901, pp. 1-30. 
Blatchley, W. S., Oolite and oolitic stone for Portland cement manufacture: Twenty-fifth Ann. Rept. Indiana Dept. Geology, 1901, pp. 322-330.

- and Ashuey, G. H., The lakes of northern Indiana and their associated marl deposits: Twenty-fifth Ann. Rept. Indiana Dept. Geology, 1901, pp. 31-321.

Hopkins, T. C., and Siebenthal, C. E., The Bedford white limestone of Indiana: Twenty-first Ann. Rept. Indiana Dept. Geology, 1897, pp. 291-427.

Lathbury, B. B., and Spackman, H. S., The Wabash Portland Cement Company, Stroh, Ind.: The Rotary Kiln, 1902, pp. 128-133.

Siebenthal, C. E., The Bedford oolitic limestone (Indiana): Nineteenth Ann. Rept. U. S. Geol. Survey, pt. 6 (continued), 1898, pp. 292-296.

Udpen, J. A., The Oolitic limestone industry at Bedford and Bloomington, Ind.: Bull. U. S. Geol. Survey No. 430, 1910, pp. 335-345.

\section{PORTLAND CEMENT RESOURCES OF IOWA.} PORTLAND CEMENT MATERIALS.

The State as a whole.

In the preparation of the following statement concerning the Portland cement resources of Iowa the section on the cement resources of the State prepared by H. F. Bain ${ }^{1}$ has been largely drawn upon, most of the matter being quoted entire.

\section{CHARACTER AND DISTRIBUTION OF MATERIALS.}

It has already been shown that materials capable of furnishing the silica and alumina necessary to the manufacture of Portland cement are widespread and that the location of new plants is apt to be determined by the presence of suitable calcareous deposits and favorable industrial conditions. Iowa affords no exception to these general rules. Practically all parts of the State contain shales or clays which might, if necessary, be used as one of the constituents of a cement mixture. The indurated rocks from the Ordovician to the Cretaceous afford shales of wide distribution and excellent character. The surface formations supplement these resources with loess, alluvium, and certain minor bodies of water-laid clay of glacial derivation The calcareous constituent of cements may be derived from marls, chalk, and limestone, all of which occur within the State, though in very unequal importance. Material suitable for use in the manufacture of Portland cement can be found at almost every point in the State. (See Pl. VI.)

\section{CALCAREOUS MARLS.}

North-central Iowa is covered by Wisconsin drift ${ }^{2}$ and is dotted with numerous small shallow lakes resembling in appearance and genesis those of Michigan. From time to time small amounts of marl have been reported from these lakes, but so far no bodies of commercial importance have been located. It is not impossible, however, that such may be found. 


\section{CHALK DEPOSITS.}

The Cretaceous deposits which cover the western third of Iowa include important bodies of chalk. With but two unimportant exceptions, however, the outcrops are confined to the valley of Big Sioux River between Sioux City and Hawarden. These chalk beds received some attention in the course of the early geological surveys of the region and have been restudied in late years by Calvin, ${ }^{1}$ Bain, ${ }^{2}$ and Wilder. ${ }^{3}$

The chalk forms prominent bluffs at intervals and may be well seen near Westfield, Akron, and Hawarden. It was referred to the Niobrara limestone until Wilder discovered fossils characteristic of the Benton in the shale above, thus proving that the chalk is the equivalent of the "Oyster Shell Rim" of the Black Hills or the Greenhorn limestone.

A thickness of 20 to 30 feet is ordinarily seen in individual exposures, but a total thickness of 50 feet is probably present. A generalized section may be given as follows:

Section of Cretaceous chalk beds.

Feet.

1. Chalk.......................................... 4-6

2. Limestone, soft, splitting into thin slabs, and crowded with shells of Inoceramus...................................... 12

3. Chalk............................................ 12

The interbanding of thin-bedded limestone with the chalk, as in the foregoing section, is characteristic. Both materials are soft and grind easily. Almost no magnesia is present, and some of the chalk beds themselves carry enough or more than enough clay to make a good cement mixture. Excellent clays occur everywhere immediately above or below and are now being used at Sioux City and elsewhere in manufacturing a wide variety of clay products.

Analyses of Iowa chalks.

\begin{tabular}{|c|c|c|c|}
\hline$\cdot$ & 1 & 2 & 3 \\
\hline 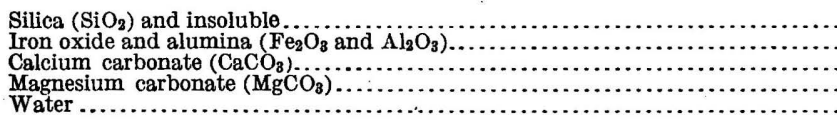 & $\begin{array}{r}22.70 \\
6.68 \\
64.30 \\
5.38\end{array}$ & $\begin{array}{r}83.70 \\
2.48 \\
.08\end{array}$ & $\begin{array}{r}94.39 \\
.70 \\
.06\end{array}$ \\
\hline
\end{tabular}

1. Chalk rock, Hawarden, Iowa. Newberry, analyst.

2. Chalk rock, Westfield, Iowa. Weems, analyst.

3. Chalk rock, Lemars, Iowa. Weems, analyst.

1 Calvin, S., Cretaceous deposits of Woodbury and Plymouth counties, etc.: Iowa Geol. Survey, vol. 1, 1893, pp. 147-161.

2 Bain, H. F., Cretaceous deposits of the Sioux Valley: Iowa Geol. Survey, vol. 3, 1895, pp. 101-114; Geology of Woodbury County: Idem, vol. 5, 1896, pp. 273-275, 295-296; Geology of Plymouth County: Idem, vol. 8, 1898, pp. 354-360.

8 Wilder, F. A., Geology of Lyon and Sioux counties: Iowa Geol. Survey, vol. 10, 1900, pp. 111-115, 151-152. 

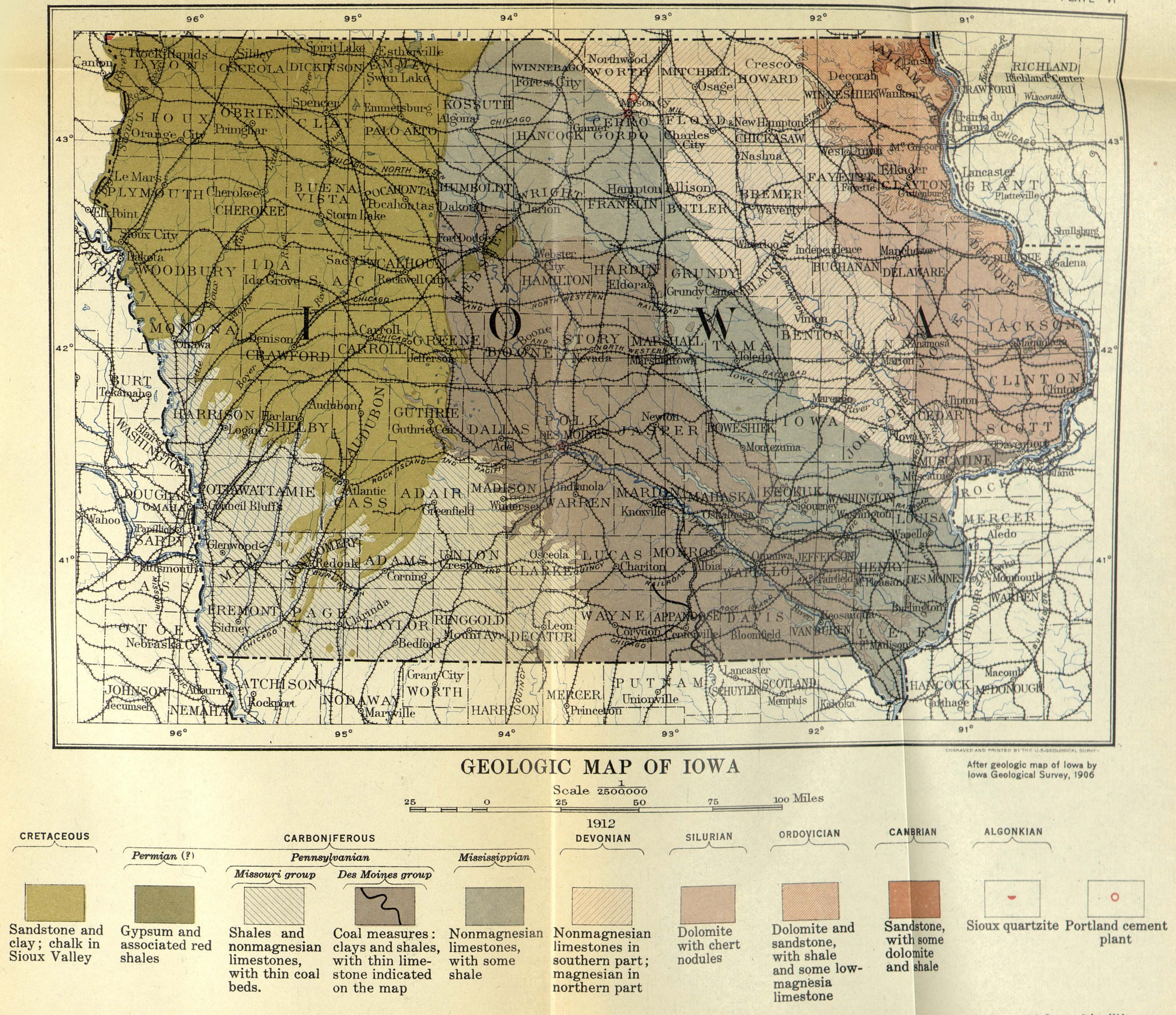

House Doc. 880; 62d Cong., 2d Sess., 2d edition 



\section{LIMESTONES.}

Nonmagnesian limestones áre found in Iowa in the Ordovician, Devonian, and Carboniferous. The limestones of the Cambrian and Silurian are, without important exception, highly magnesian. Those of the Ordovician are predominantly magnesian, though an exception occurs in the case of the beds formerly mapped and discussed under the name "Trenton." In eastern Iowa the dolomites and magnesian limestones have heretofore attracted more attention than the nonmagnesian rocks, and flourishing lime and building stone industries have been founded upon them. Limestone of one class or the other occurs in all of the eastern and most of the southern counties. In the northwest the covering of Cretaceous and Pleistocene deposits limits the outcrops to a few deep stream valleys. (See Pl. VI.) The transportation facilities available at each point may be best learned from the topographic map of the State.

\section{ORDOVICIAN IIMESTONES.}

Below the Devonian but one limestone at all suitable for Portland cement manufacture outcrops in Iowa. In the past it has been called "Trenton" limestone, but it is now known as Platteville limestone, the local name being employed because it is now known that the formation is not the same as the Trenton limestone of New York.

It occupies portions of Dubuque, Clayton, Fayette, Winneshiek, and Allamakee counties. ${ }^{1}$

The strata included in the Platteville limestone are in the main either nonmagnesian or only slightly magnesian. In composition as in geologic position they are almost exactly equivalent to the famous cement rock of the Lehigh Valley, from which one-third of the Portland cement of the United States now comes.

Excellent exposures of the Platteville occur along the Mississippi River and its tributaries in the counties named above. At Specht Ferry, in Dubuque County, the following section was observed:

Galena dolomite:

$$
\text { Specht Ferry section. }
$$

2. Limestone, thin bedded, imperfectly dolomitized, with fossil brachiopod shells only slightly changed; the limestone brown, earthy,

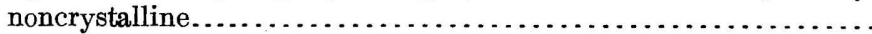

3. Thick, earthy, imperfectly dolomitized beds.......................

4. Thin limestone beds with much shale in the partings; in part a true shale.

5. Limestone, bluish and rather coarse grained; a few fossils...........

6. Limestone similar to above.................................

7. Limestone similar to above............................. 18

\footnotetext{
1 For the geology of Allamakee County see Iowa Geol. Survey, vol. 4, 1895, pp. 35-120; for Dubuque County see Idem, vol. 10, 1900, pp. 379-651; for Fayette County see Idem, vol. 15, 1904, pp. 434-546; for Winneshiek and Clayton counties see Idem, vol. 16, 1905, pp. 37-146, and 213-307.
}

48834음 Bull. 522-13-11 
Decorah shale:

8. Shale, bluish or greenish, containing some thin beds or discontinuous flakes of limestone; the "Green shales" of the Minnesota geologists, now known as Decorah shale................................

Platteville limestone:

9. Limestone, thin bedded, bluish, rather coarse grained, weathering brownish in color.......................................

10. Limestone, in rather heavy layers, which range up to 15 inches in thickness; bluish on fresh fracture, but weathering to buff on ex-

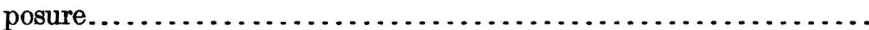

11. Limestone, brittle, fine grained, blue, very fossiliferous, breaking up on weathered surfaces into flexuous layers about 2 inches in thick-

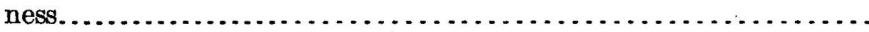

12. Lower buff beds, exposed, about......................... 8

13. Unexposed to level of water in river....................... 45

The Decorah shale (No. 8 of the above section) and the limestones above and below were sampled and analyzed by Lundteigen with the results given below:

Analyses of Platteville limestone, Galena dolomite, and Decorah shale from Specht Ferry section, Iowa.

\begin{tabular}{|c|c|c|c|c|c|c|}
\hline & 1 & 2 & 3 & 4 & 5 & 6 \\
\hline 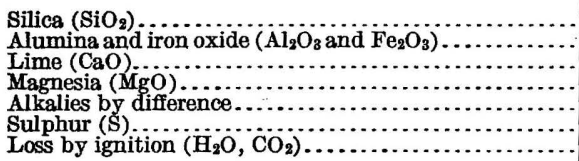 & $\begin{array}{r}7.28 \\
1.97 \\
46.93 \\
2.58 \\
40.39 \\
40.10\end{array}$ & $\begin{array}{r}2.25 \\
1.32 \\
49.66 \\
3.24 \\
42.80\end{array}$ & $\begin{array}{r}46.34 \\
19.90 \\
10.27 \\
2.13 \\
13.01 \\
13.90\end{array}$ & $\begin{array}{r}8.98 \\
2.58 \\
41.32 \\
5.80 \\
.00 \\
40.00\end{array}$ & $\begin{array}{r}5.00 \\
2.07 \\
50.22 \\
.85 \\
.76 \\
.85 \\
40.25\end{array}$ & $\begin{array}{r}54.90 \\
25.50 \\
.41 \\
.30 \\
9.55 \\
.24 \\
9.10\end{array}$ \\
\hline . & 99.25 & 99.27 & 92.55 & 98.68 & 100.00 & 100.00 \\
\hline
\end{tabular}

1. Beds Nos. 5 and 6.

4. Bed No. 10.

2. Bed No. 8 .

5. General sample of limestone.

3. Bed No. 9 .

6. General sample of clay.

Though the magnesia in certain of these beds is higher than is desirable, a large amount of rock, no higher in that constituent than that elsewhere used, is available. It is probable that careful search would locate even better beds at the same horizon farther north.

\section{DEVONIAN LIMESTONES.}

SUBDIVISIONS.

Beds representative of both Upper and Middle Devonian exist in Iowa. The former includes the State quarry limestone of the Iowa State Survey in Johnson County, ${ }^{1}$ the Sweetland Creek shale in Muscatine County, ${ }^{2}$ and the Lime Creek shale. The larger portion of the Iowa Devonian section, however, belongs to the Middle Devonian, which is represented over large areas by the Cedar Valley limestone and the Wapsipinicon limestone. In places these formations have been subdivided and individual members have been mapped. The

1 Calvin, S., Geology of Johnson County: Iowa Geol. Survey, vol. 7, 1897, pp. 33-104.

2 Udden, th A., Geology of Muscatine County: Idem, vol. 9, 1899, pp. 247-388. 
Lime Creek shale and Wapsipinicon limestone each includes some magnesian rock, but in general the Devonian limestones in Iowa are characteristically free from magnesia.

\section{WAPSIPINICON LIMESTONE.}

The Wapsipinicon limestone was first discriminated by .W. H. Norton, who has discussed it in considerable detail and has mapped subdivisions of it in Linn, ${ }^{1}$ Cedar, ${ }^{2}$ and Scott $^{3}$ counties. J. A. Udden has discriminated it in Muscatine County, ${ }^{4}$ and Calvin has mapped certain members belonging to it in Johnson ${ }^{5}$ and Buchanan ${ }^{6}$ counties. In the northern portion of the State there is an overlap, and the Wapsipinicon does not appear at the surface.

The formation includes some shale and some very pure limestones, but magnesia is apt to be abundant in almost any section, and careful sampling will be necessary to determine the availability of the rock at any given point. The Fayette breccia of McGee, which forms the upper member of the Wapsipinicon, includes near Rock Island a very pure limestone, as is shown by the following analysis:

Analysis of limestone from upper part of Wapsipinicon limestone. ${ }^{7}$

Insoluble. 0.42

Iron (as carbonate).

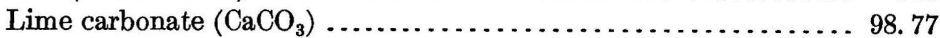

Loss, alkalies, etc.................................. . 45

Samples of the Otis and Kenwood beds of the Iowa State Geological Survey from a railway cut 2 miles north of Cedar Rapids showed so much magnesia as to preclude the use of the rock.

CEDAR VALLEY LIMESTONE.

The most important formation of the Devonian of Iowa, whether measured by areal extent or by thickness, is the Cedar Valley limestone. It extends from Muscatine County on the Mississippi to the Minnesota line in a broad belt trending northwest. It has an estimated maximum thickness of 300 feet and rests to the southeast on the Wapsipinicon limestone. To the northeast it comes by overlap to rest on the Maquoketa shale. ${ }^{8}$ To the southwest it is in turn covered by rocks of the Mississippian series. To the northwest the Lime Creek shale intervenes between it and the Mississippian.

In the southern portion of the area of outcrop the Cedar Valley limestone is characteristically a nonmagnesian limestone, which is

1 Geology of Linn County: Towa Geol. Survey, vol. 4, 1895, pp. 121-195.

2 Geology of Cedar County: Idem, vol. 11, 1901, pp. 279-396.

3 Geology of Scott County: Idem, vol. 9, 1899, pp. 389-520.

${ }^{4}$ Geology of Muscatine County: Idem, vol. 9, 1899, pp. 248-388.

5 Geology of Johnson County: Idem, vol. 7, 1897, pp. 33-116

6 Geology of Buchanan County: Idem, vol. 8, 1898, pp. 201-255.

7 Hall, James, Rept. Geol. Survey Iowa, vol. 1, pt. 1, 1858, p. 372.

8 Calvin, S., Geology of Howard County: Iowa Geol. Survey, vol. 13, 1903, pp. 49-62. 
generally fine grained and breaks with a sharp conchoidal fracture. This phase of the formation is excellently exposed in Johnson County. The following analysis was made by George Steiger, in the laboratory of the United States Geological Survey, from an average sample representing the rock quarried at Iowa City, Johnson County, where a total thickness of about 50 feet is exposed.

\section{Analysis of Cedar Valley limestone at Iowa City.}

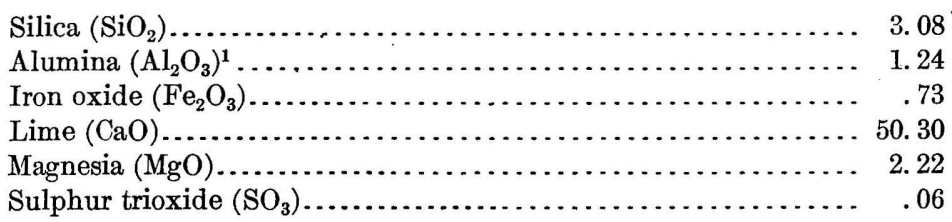

Toward the north the limestone becomes more magnesian until in Howard County it is a massive dolomite which has been mistaken for Niagara dolomite. About midway the rock has been extensively quarried at Independence and Waterloo, where it is a soft easily crushed limestone, apparently nonmagnesian in character. At Waverly it is soft, thin bedded, and exposed to a total thickness of about 50 feet. Analysis of two separate beds, by Lundteigen, gave the following results:

Analyses of Cedar Valley limestone at Waverly.

\begin{tabular}{|c|c|c|}
\hline & 1 & 2 \\
\hline \multirow{6}{*}{$\begin{array}{l}\mathrm{Silica}\left(\mathrm{SiO}_{2}\right) \\
\text { Alumina }\left(\mathrm{Al}_{2} \mathrm{O}_{3}\right. \\
\text { Iron oxide }\left(\mathrm{Fe}_{2} \mathrm{O}_{3}\right) \\
\text { Lime }(\mathrm{CaO}) \\
\text { Magnesia }(\mathrm{MgO}) \\
\text { Sulphur trioxide }\left(\mathrm{SO}_{3}\right) \\
\text { Loss on ignition }\end{array}$} & 46.34 & 2.25 \\
\hline & 19.90 & 1.32 \\
\hline & 10.27 & $\begin{array}{r}49.66 \\
3.24\end{array}$ \\
\hline & $\begin{array}{r}2.00 \\
.01\end{array}$ & $\begin{array}{r}3.24 \\
.00\end{array}$ \\
\hline & 13.90 & 42.80 \\
\hline & 92.42 & 99.27 \\
\hline
\end{tabular}

Still farther north, in Mitchell County, the limestone has attracted attention because certain beds are lithographic. ${ }^{2}$ The following analysis, made by A. B. Hoen, suggests that at least some of the stone is sufficiently free from magnesia to be suitable for cement material.

Analysis of Cedar Valley limestone, Mitchell County.

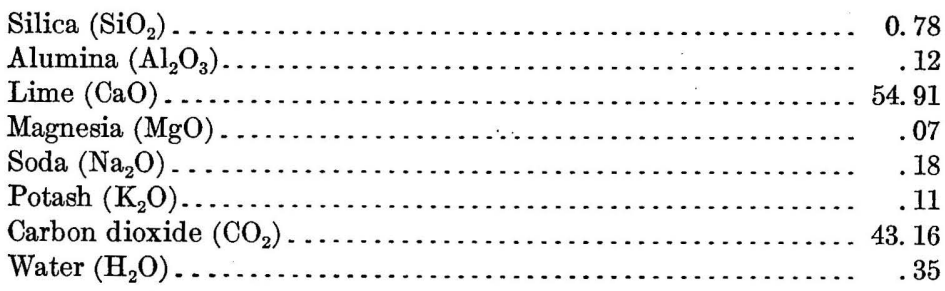

1 With the $\mathrm{Al}_{2} \mathrm{O}_{3}$ is included any $\mathrm{TiO}_{2}$ or $\mathrm{P}_{2} \mathrm{O}_{5}$ present.

2 Iowa Geol. Survey, vol. 13, 1903, pp. 292-352. 
A number of fine exposures show 10 to 15 feet of the nonmagnesian beds. Not all this rock is free from cracks and crystals, but it is all similar in composition to the sample analyzed. At the Gable and other quarries practically no stripping is necessary, and in the vicinity loess clay is abundant.

LIME CREEK SHALE.

The Upper Devonian of Iowa is well displayed in Cerro Gordo County and has been discussed and mapped in Calvin's report on that area under the name Lime Creek shale. ${ }^{1}$ He gives the following general section of the formation:

General section of the Lime Creek shale.

1. Ceet.

1. Calcareous beds, light gray in color................... 20

2. Magnesian shales and argillaceous dolomites . . ............ $\quad 30$

3. Limestone with slender Idiostroma .................... 4

4. Fossiliferous calcareous shales......................... 20

5. Yellow nonfossiliferous shales......................... 10

6. Blue nonfossiliferous shales . ......................... 40

Nos. 4, 5, and 6 of this section make up the Hackberry substage of the Iowa State Survey, and the remaining beds represent the Owen substage of that Survey.

The shales constituting the lower portion of the foregoing section are used at Mason City for the manufacture of clay goods. Their noncalcareous portion is represented in the following analysis, made by G. E. Patrick:

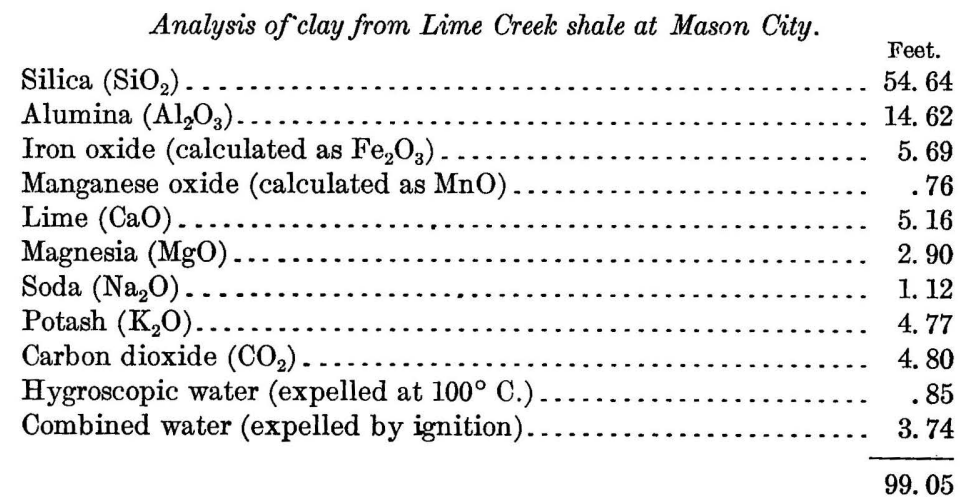

The beds above contain considerable lime. In the vicinity of Mason City, where they outcrop, there are extensive exposures of the nonmagnesian beds of the underlying Cedar Valley, and it should be possible to combine the two to advantage. 


\section{CARBONIFEROUS LIMESTONES.}

SUBDIVISIONS.

Carboniferous rocks underlie a large portion of Iowa. They include limestones, sandstones, shales, and coals. Very few of the limestones are magnesian, and because of this fact, as well as because of their excellent situation with reference to fuel and transportation facilities, it seems not improbable that time will see the development of a considerable cement industry based upon them.

Of the three series into which the Carboniferous has been divided, two-the Mississippian and the Pennsylvanian-are represented in this State. The Mississippian has been divided into the Kinderhook group, Osage group, and "St. Louis limestone," each containing important limestone beds. The Pennsylvanian includes the Des Moines group (lower coal measures) and the Missouri group (upper coal measures). The lower coal measures include most of the coal beds worked in the State but very little limestone. The beds outcrop ${ }^{1}$ in a broad belt between the limestones of the Mississippian series to the east and the calcareous shales and thin limestones of the Missouri group. (See Pl. VI.)

\section{KINDERHOOK GROUP.}

The Kinderhook group forms the lowermost division of the Carboniferous of Iowa. Its principal formation is a soft argillaceous shale, which is exposed to a thickness of 60 feet at Burlington. ${ }^{2}$ Above the shale are about 50 feet of sandstone and limestone belonging also to the Kinderhook group. In general, the beds are not well exposed and in the southern area of outcrop are not likely to be of importance in cement manufacture, except as a source of clay to be mixed with the overlying Burlington limestone. Farther north, in Marshall County, limestone is extensively developed. It is quarried at Le Grande.

The analyses following, by G. E. Patrick, indicate that a considerable portion of the limestone of the Kinderhook group is suitable for cement manufacture.

\footnotetext{
1 Reports upon most of the counties in which the Carboniferous rocks are present will be found in the volumes of the Iowa Geological Survey, as follows:

Appanoose, 5.

Benton, 15.

Blackhawk, 16.

Boone, 5 .

Cerro Gordo, 7.

Dallas, 8.

Davis, 20.

Decatur, 8.

Des Moines, 3.

Franklin, 16.

Fremont and Mills, 13

Grundy, 20.

Guthrie, 7.

Hamilton, 20.

Hancock, 13.

Harrison, 20.
}

2 Weller, Stuart, Iowa Geol. Survey, vol. 10, p. 65 
Analyses of limestone from Kinderhook group at.Legrand, Iowa.

\begin{tabular}{|c|c|c|c|c|}
\hline & 1 & 2 & 3 & 4 \\
\hline 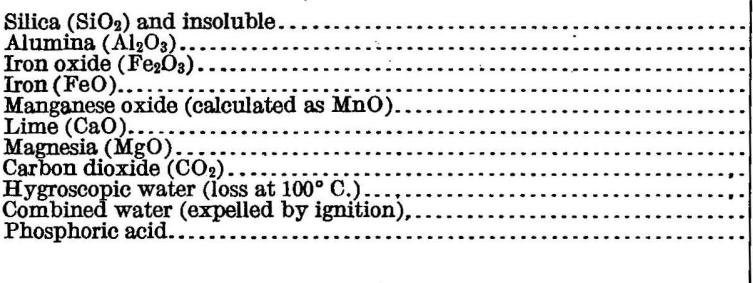 & $\begin{array}{r}0.77 \\
.05 \\
\ldots .09 \\
.09 \\
55.05 \\
.28 \\
43.62 \\
.03 \\
.13 \\
100.02\end{array}$ & $\begin{array}{r}0.96 \\
.07 \\
\ldots . .27 \\
. .08 \\
54.85 \\
.28 \\
43.30 \\
.09 \\
.21 \\
\ldots . . \\
100.11\end{array}$ & $\begin{array}{r}1.24 \\
.18 \\
.15 \\
.09 \\
50.56 \\
3.70 \\
43.79 \\
.06 \\
.15 \\
\mathrm{Tr} \\
99.92\end{array}$ & $\begin{array}{r}1.22 \\
.14 \\
.26 \\
.09 \\
. \mathrm{Tr} . \\
50.42 \\
3.96 \\
43.85 \\
.04 \\
.12 \\
\ldots . . . \\
100.10\end{array}$ \\
\hline
\end{tabular}

Probable combinations.

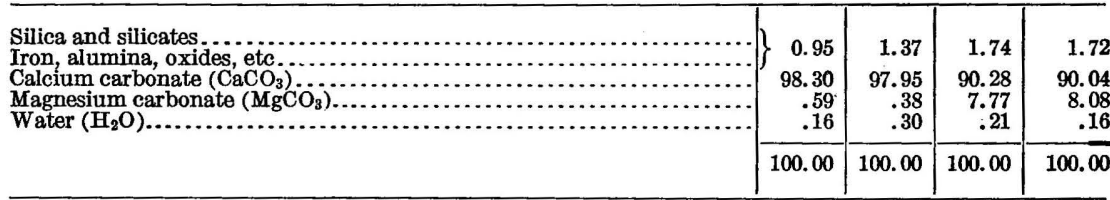

1. Fine-grained oolite.

2. Blue limestone.

3. "Caenstone."

4. Stratified limestone.

Associated with these beds are certain others which are more magnesian, but which happen to be in demand as building stone. Possibly a combination of industries could be based on this association. In Hardin County there is a considerable thickness of the rocks with some associated shale. Still farther north and west the Kinderhook group outcrops but without exposing any great thickness. Though much of the limestone of the Kinderhook group is magnesian, it is believed that in localities where other conditions are favorable the group warrants prospecting and testing.

OSAGE GROUP.

The Osage group includes formations which have been widely known as the Keokuk and Burlington limestones. It consists for the most part of coarse crinoidal limestone, white, nonmagnesian, and with chert in nodules along bedding planes. The limestone, in the upper portion especially, is associated with abundant argillaceous shale, and outcrops in many steep bluffs, at the foot of which the shales of the Kinderhook group are available. The beds are best exposed in Lee and. Des Moines counties but occupy portions of Louisa, Washington, Henry, and other counties in the southeast.

At Burlington, in the south bank of Cascade Hollow, the following section was measured by T. E. Savage:

Cascade Hollow section.

1. Fine-grained, homogeneous soil material; without pebbles, dark colored above, grading down to yellow below

Feet.

2. Clay, reddish-brown, with pebbles and small bowlders of granite and greenstone. 
3. Limestone, much decayed, in layers 1 to 4 inches thick; numerous chert nodules................................................. 5

4. Chert...................................................

5. Limestone, crinoidal, coarse grained; layers 4 to 8 inches thick........... 4

6. Limestone, crinoidal; with chert nodules......................... 1

7. Limestone, coarse, crinoidal; at places massive, at others weathering into layers 3 to 12 inches thick containing numerous fossils .............. 10

An average sample of the limestone of the Osage group was analyzed by George Steiger in the laboratory of the United States Geological Survey with the following results:

Analysis of Burlington limestone.

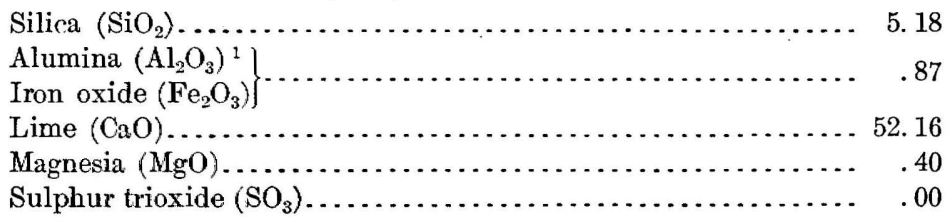

The beds outcropping at this point are thoroughly representative of the limestone of this formation. Greater thicknesses are exposed at other points, and the total thickness has been estimated to be about 250 feet.

\footnotetext{
"ST. LOUIS LIMESTONE."
}

The rocks to which the name "St. Louis limestone" has been applied constitute one of the most widely distributed geologic divisions in Iowa. They rest on the Osage group and lie unconformably below the Des Moines group (lower coal measures). On account of their relation to the coal beds they have been carefully mapped and extensively studied. In central Iowa they include three minor divisions, which have been named by Bain, Pella beds, Verdi beds, and Springvale beds. The latter two are of small outcrop and are in general not of suitable composition for cement manufacture. The beds first named are more important, outcropping widely and being excellently adapted to cement manufacture. They fringe the productive coal measures on the east and occur within the general area of outcrop of the coal beds as scattered inliers resulting from the pronounced unconformity between the Des Moines group and the "St. Louis limestone" hills, which rise like islands above the lowest coal beds.

In most places the Pella beds of Bain show an upper portion consisting of calcareous marl with some thin beds of limestone. This facies is ordinarily 8 to 10 feet thick. Below it are beds of finegrained blue to gray limestone, breaking with clean conchoidal fracture, and commonly thin bedded. The rock is very rarely 
magnesian, and the analysis quoted below is quite representative. The sample was taken by T. E. Savage from the Chilton quarry at Ottumwa, where the following section is exposed:

Section in Chilton quarry at Ottumwa, Towa.

Feet.

1. Soil, fine grained, dark colored, pebbleless.................... 1

2. Clay, reddish brown, with pebbles....................... 3

3. Sandstone, brown, iron stained, mostly incoherent, but in places indurated (Des Moines).......................................... 10

4. Shale, calcareous, weathering into small bits, very fossiliferous ........ 3

5. Limestone, dense, fine grained, gray ....................... $2 \frac{1}{2}$

6. Ijimestone, shaly, soft, weathering readily; similar to No. $4 \ldots \ldots \ldots \ldots \ldots .2$

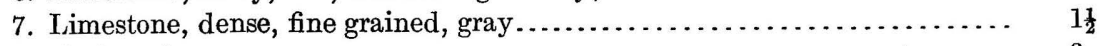

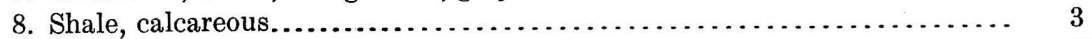

9. Limestone, hard, fine grained, gray, fossiliferous................ $1 \frac{1}{6}$

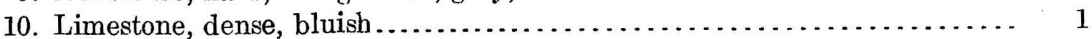

11. Limestone, dense, fine grained, bluish gray, in part massive, in part thin

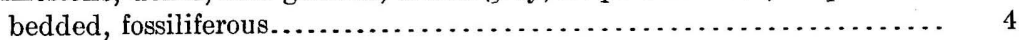

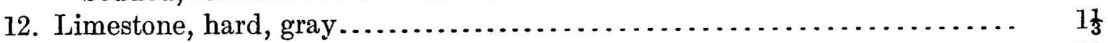

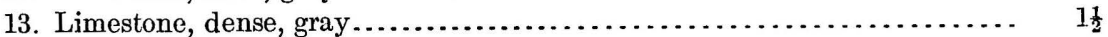

An average sample of the limestone in the Chilton quarry was analyzed in the laboratory of the United States Geological Survey by George Steiger with the following results:

Analysis of "St. Louis limestone" at Ottumwa, Iowa.

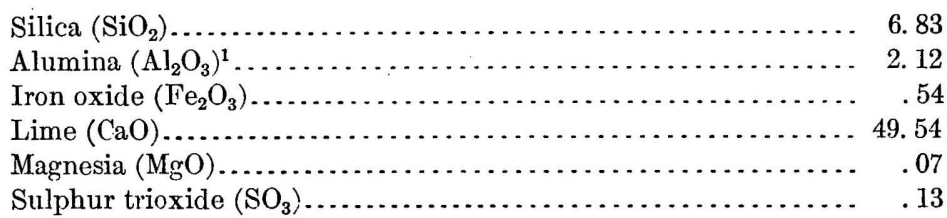

Samples of limestone from Pella, Tracy, Oskaloosa, and Humboldt have also been analyzed, with the following results:

Analyses of Iowa limestones.

\begin{tabular}{|c|c|c|c|c|}
\hline & 1 & 2 & 3 & 4 \\
\hline 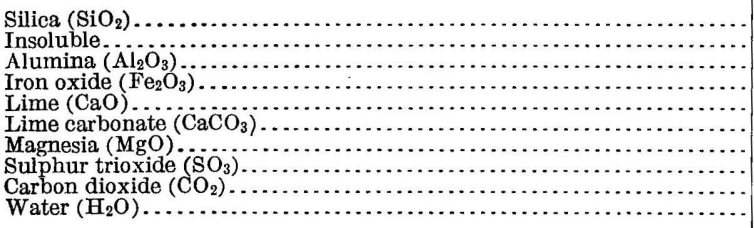 & $\begin{array}{r}4.92 \\
3.39 \\
47.50 \\
\ldots .00 \\
.00 \\
2.09 \\
38.10\end{array}$ & $\begin{array}{r}1.57 \\
.49 \\
.17 \\
\ldots .60 \\
94.60 \\
3.17\end{array}$ & $\begin{array}{r}4.01 \\
.13 \\
.46 \\
\ldots . .30 \\
95.30 \\
.00 \\
\ldots \ldots . .\end{array}$ & $\begin{array}{r}0.91 \\
.48 \\
.73 \\
\ldots \ldots .98 \\
97.98 \\
\cdots \\
\cdots\end{array}$ \\
\hline
\end{tabular}

1. Limestone, Pella. Lundteigen, analyst.

2. Limestone, Tracy. Murray, analyst.

3. Limestone, Oskaloosa. Murray, analyst.

4. Limestone, Humboldt. Murray, analyst. 
Analyses of limestone and interbedded shale from the mouth of Lizard Creek in Webster County were made by Lundteigen with the following results:

Analysis of limestones and shale.

\begin{tabular}{|c|c|c|}
\hline . & $\mathrm{CaCO}_{3}$ & $\mathrm{CaSO}_{4}$ \\
\hline $\begin{array}{l}\text { 1. Upper, limestone, } 2 \text { feet. } \\
\text { 2. Middle, shale, } 2 \text { feet } \\
\text { 3. Bottom, limestone, } 2 \frac{1}{2} \text { feet } \ldots \ldots \ldots \ldots \ldots \\
\end{array}$ & $\begin{array}{l}88.75 \\
53.25 \\
88.75\end{array}$ & $\begin{array}{r}0.28 \\
2.46 \\
.17\end{array}$ \\
\hline
\end{tabular}

A cement made from this material gave the following analysis and on test showed satisfactory color, strength, and setting properties.

Analysis of Fort Dodge cement.

\begin{tabular}{|c|c|}
\hline Silica $\left(\mathrm{SiO}_{2}\right) \ldots \ldots \ldots$. & 25.52 \\
\hline Alumina and iron oxide $\left(\mathrm{Al}_{2} \mathrm{O}_{3}\right.$ and & 8.80 \\
\hline Lime $(\mathrm{CaO}) \ldots$ & 63.48 \\
\hline Magnesia $(\mathrm{MgO})$ & 1. 19 \\
\hline
\end{tabular}

The material from the Pella exposures has been made up into a cement which has good color, is sound on glass, sets very quickly, and has satisfactory strength. The results of these tests, together with the fact that limestone of the same age and character is being extensively used at St. Louis, Mo., makes it certain that the so-called "St. Louis limestone" can be relied on to furnish the calcareous element wherever other conditions are favorable to the establishment of cement plants.

DES MOINES GROUP.

The Des Moines group (lower coal measures) contains very little limestone. Its principal importance in the present connection arises from the coal and clay which make up so large a portion of the group. The clays and shales are extensively used for brickmaking. They are available over wide areas and may prove of service in connection with limestones of the formations above and below.

The following analyses are typical of these clays:

Analyses of brick clay from Des Moines group.

\begin{tabular}{|c|c|c|c|}
\hline 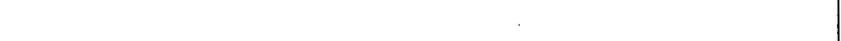 & 1 & 2 & 3 \\
\hline 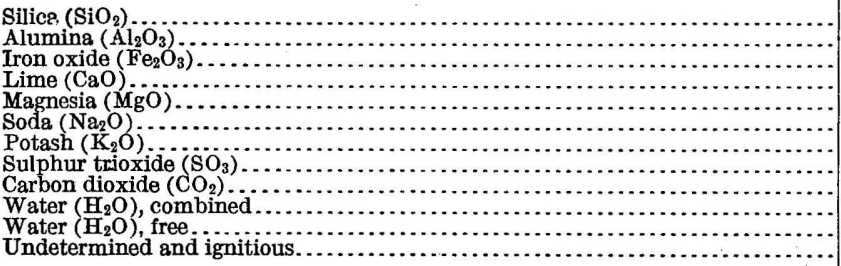 & $\begin{array}{r}53.08 \\
17.71 \\
8.64 \\
4.05 \\
.94 \\
3.70 \\
1.25 \\
\hdashline 2.53 \\
6.77 \\
\hdashline 1.33\end{array}$ & $\begin{array}{r}64.41 \\
20.43 \\
5.88 \\
.34 \\
1.71 \\
1.90\end{array}$ & \begin{tabular}{r}
53.86 \\
26.28 \\
4.32 \\
.12 \\
.43 \\
.43 \\
2.52 \\
1.22 \\
\hdashline 3.02 \\
8.06
\end{tabular} \\
\hline
\end{tabular}

1. Fort Dodge.

2. Des Moines. C. O. Bates, analyst.

3. Ottumwa. J. B. Weems, analyst. 
Near the middle of the Des Moines group are strata which the Iowa geologists have named the Appanoose beds and which have been mapped and discussed in connection with the report on Appanoose County. (See Pl. VI.) They include the Mystic or Centerville coal and certain associated shales and limestones. The latter are known locally, from their relations to the coal, as the "Bottom rock," "Cap rock," "Thirteen-foot limestone," and "Fifty-foot limestone." The limestone bed is thin, usually from 4 to 6 feet in thickness, but near Rathbun and Clarkdale it reaches a thickness of 10 to 15 feet. It is a soft limestone, easily crushed, and because of its close assoriation with clay and a very good coal bed is probably of value. Analyses show that it is practically free from magnesia and runs from 74 to 93 per cent in calcium carbonate. The following analysis, by Lundteigen, is representative:

Analysis of Fifty-foot rock, Rathbun.

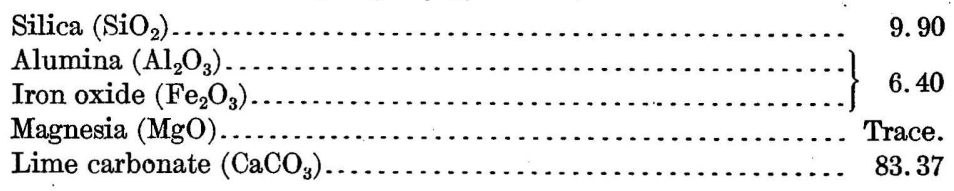

MISSOURI GROUP.

Southwestern Iowa is underlain by rocks of the Missouri group (upper coal measures), which contains very little coal and considerably less sandstone than the Des Moines group (lower coal measures). The beds are mainly shales and limestones. The latter, being almost free from magnesia, in places somewhat earthy, generally free from chert, and easily ground, are well adapted to cement manufacture; indeed, beds stratigraphically equivalent are now in use at Iola, Kans. The most important limestone lies at the base of the group. In Madison County it includes four separate ledges, which vary in thickness from 10 to 25 feet and are separated by shale beds 10 to 20 feet in thickness and in part calcareous. The rocks are quarried at several places, particularly at Earlham, Winterset, and Peru, and the same ledges have been recognized as far south as Decatur County, on the Missouri boundary.

Analyses of individual ledges at Peru, made by Lundteigen, show a lime content ranging from 60.50 to 83 per cent. A cement mixture made from them gave 75.50 per cent $\mathrm{CaCO}_{3}$. At Earlham the following section was measured by T. E. Savage:

Section of Robertson quarry, Eartham.

1. Soil, dark colored, fine grained, pebbleless $\ldots$ Ft. in.

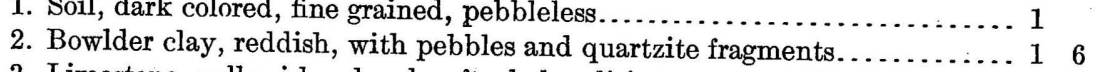

3. Limestone, yellowish-colored, soft, shaly; disintegrates readily ...........

4. Limestone, very hard, light gray, fine grained.................... 7

5. Limestone, softer, with less perfectly comminuted fossil fragments........ 
6. Limestone, hard, white, fine grained; separates in places into three or four uneven layers........................................ 3

7. Shale, soft, calcareous; weathers rapidly into fine bits.............. 4

8. Limestone, dense, gray, fine grained; fossil fragments abundant but indis-

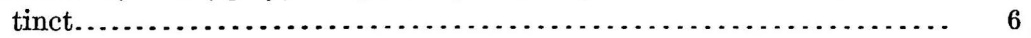

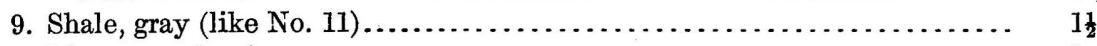

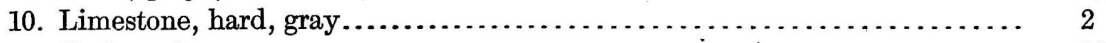

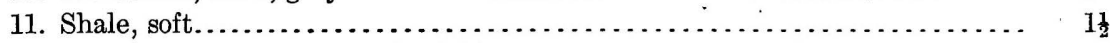

12. Limestone, dense, fine grained, light gray; in places massive, again separating into two layers of about equal thickness.................... 18

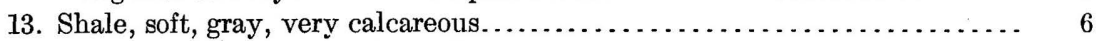

14. Limestone, impure, grayish-yellow ............................ $2 \frac{1}{2}$

15. Shale, soft, gray, calcareous............................... 7

16. Limestone, hard, fine grained, light colored; imperfectly separated into three uneven layers...................................... 13

17. Massive layer, separating in places into two uneven layers with shaly partings between them....................................... 14

18. Iimestone; gray............................................. 13

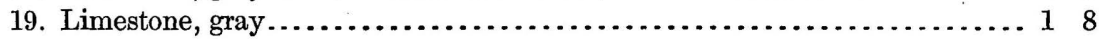

An analysis of an average mixed sample of the limestone of the section, made in the laboratory of the United States Geological Survey by George Steiger, gave the following result:

Analysis of limestone at Earlham.

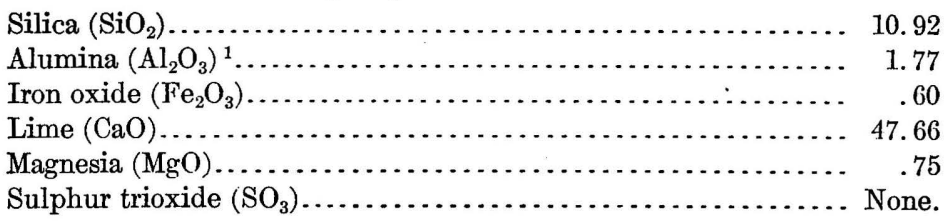

The beds.in the Missouri group above this basal limestone have not been as carefully studied but are apparently similar in composition and character. The next higher limestone, which is well developed at Dekalb, yielded the following on partial analysis by J. B. Weems:

Analysis of limestone from Dekalb.

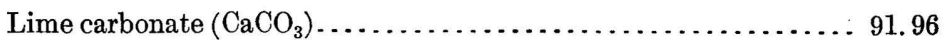

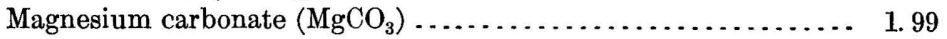

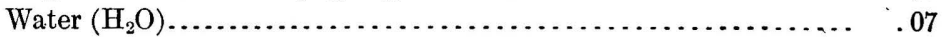

\section{SUMMARY.}

At many points in Iowa materials suitable for making cement are available. The marls are not known to be important and may never prove to be. Chalk found along Sioux River north of Sioux City is a soft, easy-grinding material and is a favorite among cement manufacturers. The advisability of establishing a plant in this district must be determined by consideration of manufacturing costs, 
of market, and of transportation facilities. In regard to the limestones the following general considerations are important.

Much of Iowa is drift covered; within the broad areas underlain by the several limestones there are really comparatively few outcrops, and even where outcrops occur the overburden is in many places so thick as to entail prohibitive stripping costs. The best situations are in the valleys, generally where some important tributary joins the main stream. Fortunately many of the railway lines follow valley routes.

The Platteville limestone (Ordovician), which occurs in the driftless area, generally outcrops in rather steep bluffs, a fact due to the resistant character of the Galena dolomite, which generally overlies it. As compared with the other limestones of the region, the Platteville is the most likely to carry magnesia in excess; but on the other hand it is practically free from chert, is often somewhat earthy in composition, and is intimately associated with shale. As already noted, the similar and approximately equivalent beds in the Lehigh district of Pennsylvania and New Jersey are a very important source of cement material.

The Devonian limestones are in large measure free from both chert and magnesia, though outcrops in the northern part of the State need careful examination to make sure of the absence of the latter. As contrasted with both the Platteville and the Carboniferous limestones, they are in the main harder, a fact that to some extent influences the cost of grinding.

Of the Carboniferous limestones, the limestone of the Kinderhook group is in most places too magnesian and those of the Osage group too full of chert for easy use, though it is probable that some suitable material can be found in each group. The upper beds of the "St. Louis limestone" and the limestones of the Missouri group are entirely suitable as regards composition, freedom from chert, and grinding qualities. Equivalent beds are now in use in Missouri and Kansas. These limestones are, furthermore, excellently situated as regards fuel and clay. The productive coal measures (Des Moines group) outcrop in a broad belt between the limestones of the Kinderhook and Osage groups, and in many sections the upper beds of the "St. Louis limestone" and the shales of the Des Moines group also occur. Where the shales are absent, loess, such as is elsewhere used, is nearly everywhere present.

\section{ECONOMIC CONDITIONS.}

FUEL.

The coal mines of the productive coal measures (Des Moines group) are so situated as to afford cheap fuel to most of the limestone localities. (See Pl. VI.) This is important, since the fuel cost forms 
approximately 30 per cent of the total cost of manufacture. Iowa coal, though not of the highest grade, is still well adapted to cement manufacture. The following analyses, made at the Iowa State College of Agriculture, ${ }^{1}$ indicate the approximate composition of a few of the beds:

Analyses of Iowa coals.

\begin{tabular}{|c|c|c|c|c|c|c|c|c|}
\hline & 1 & 2 & 3 & 4 & 5 & 6 & 7 & 8 \\
\hline 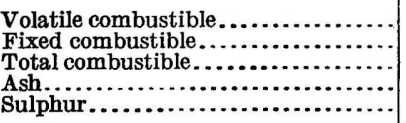 & $\begin{array}{r}42.32 \\
46.31 \\
89.13 \\
10.13 \\
4.10\end{array}$ & $\begin{array}{r}37.79 \\
54.85 \\
92.64 \\
7.36 \\
3.29\end{array}$ & $\begin{array}{r}37.98 \\
47.98 \\
85.96 \\
14.04 \\
5.90\end{array}$ & $\begin{array}{r}45.62 \\
50.29 \\
95.91 \\
4.09 \\
2.74\end{array}$ & $\begin{array}{r}46.06 \\
46.89 \\
92.95 \\
7.05 \\
2.81\end{array}$ & $\begin{array}{r}36.94 \\
54.20 \\
91.14 \\
8.86 \\
2.86\end{array}$ & $\begin{array}{r}35.11 \\
51.91 \\
87.02 \\
12.77 \\
3.02\end{array}$ & $\begin{array}{r}18.23 \\
75.08 \\
93.31 \\
6.69 \\
.60\end{array}$ \\
\hline B.t.u............ & 11,922 & 12,681 & 12,431 & 12,041 & 13,050 & 12,245 & & \\
\hline
\end{tabular}

1. Average of five Monroe County coals.

3. Corey Coal Co., Webster County.

4. Des Moines C. \& M. Co., Polk County.

5. Whitebreast Fuel Co., Pekay, Mahaska County.

6. Carbon Coal Co., Willard, Wapello County.

7. Average of 22 Illinois coals.

8. Pocahontas coal, Virginia.

In the above tables the Pocahontas coal is quoted for comparison. Illinois coals are noted because, in event of the Platteville limestone being used, coal would probably be drawn from Illinois rather than Iowa. Many additional analyses have been published. ${ }^{2}$

TRATSPORTATION.

There are several promising localities along the Mississippi where that river could be directly utilized for transportation and would, in addition, act as a regulator of railway freight rates. The main railway lines of Iowa run either east and west or southeast and northwest, and much of the freight originating in the State, aside from agricultural products, moves to the north and west.

\section{MARKETS.}

Any cement plant established on the Mississippi would find a ready market to the north and west. Iowa itself affords a very considerable market for cement, and an Iowa cement plant would have considerable advantage in reaching important and growing markets.

\section{Portland cement materials in the district near Dubuque.}

By E. F. Burchard.

In the summer of 1905 a detailed geologic survey of the Lancaster quadrangle, lying mainly in Wisconsin and Iowa, was made by E. F. Burchard, J. R. Banister, and A. W. Lewis. During.the survey particular attention was given to certain natural resources of the district,

\footnotetext{
1 Iowa Geol. Survey, vol. 13, 1903, p. 414.

2 Rept. Iowa Geol. Survey, vol. 2, 1894; also, The western interior coal field: Twenty-second Ann. Rept. U. S. Geol. Survey, pt. 3, 1902, pp. 333-366.
} 
among them the beds of limestone and clay, with a view to ascertaining their value for making Portland cement. The Iowa Geological Survey cooperated in the work by making chemical analyses of some of the materials collected.

\section{CHARACTER OF MATERIALS.}

The principal rocks exposed along Mississippi River and near the mouths of its tributaries between Dubuque, Iowa, and Cassville, Wis., together with their ages and essential features, are comprised in the following table:

Rocks exposed north of Dubuque, Iowa.

\begin{tabular}{|c|c|c|c|}
\hline System. & Formation or group. & Character. & Thickness. \\
\hline $\begin{array}{l}\text { Quaternary... } \\
\text { Ordovician... }\end{array}$ & $\left\{\begin{array}{l}\text { Galena dolomite } \ldots \ldots \ldots \ldots \\
\text { Platteville limestone............ } \\
\text { St. Peter sandstone.......... } \\
\text { Prairie du Chien group...... }\end{array}\right.$ & 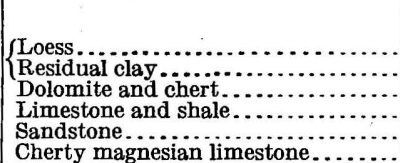 & \begin{tabular}{|r} 
Feet. \\
$1-60$ \\
$1-15$ \\
235 \\
55 \\
70 \\
$1-40$ exposed.
\end{tabular} \\
\hline
\end{tabular}

A few miles back from the river the Maquoketa shale and Niagara limestone are present in the section, above the Galena dolmite, but these rocks have no bearing on the present subject. The beds of particular importance are the limestone and shale of the Platteville, the basal Galena beds, and the residual clay and loess, all of which are exposed in the bluffs of the Mississippi River gorge between Dubuque and Cassville.

A generalized section of the Platteville includes the following divisions:

Generalized section of Platteville limestone.

1. Timest.

1. Limestone, principally in thin beds, and shale............ 10-15

2. Limestone, fine grained, brittle, and thin bedded. . . . . . . 15-25

3. Limestone, magnesian, thick bedded.................... 15-25

4. Shale, bluish, sandy in places........................ 1-5

$41-70$

Nos. 1 and 2 contain the purest limestone, and in places part of No. 3 contains less than 5 per cent of magnesium carbonate. The following table gives the stratigraphic details and the corresponding chemical analyses of the beds at two localities in Iowa. 
[Analyst, L. G. Michael, Iowa College of Agriculture and Mechanic Arts, Ames, Iowa.]

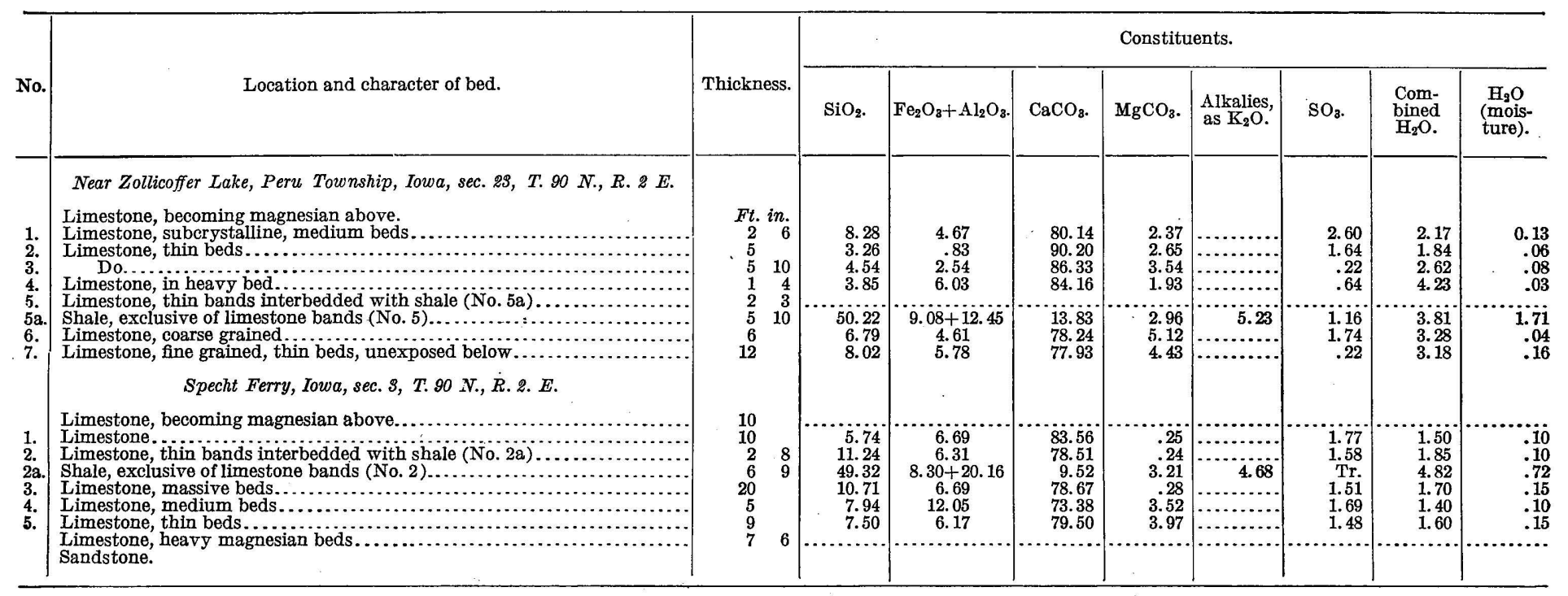


Another section is as follows:

Section of Platteville and Galena limestones near Waupeton, Iowa.

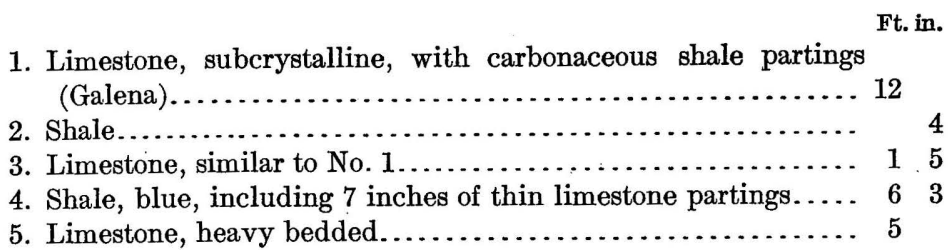

The shale beds, exclusive of the limestone bands, comprising No. 4 , at Waupeton, No. 2 of the section at Potosi station (see p. 372), and Nos. 2 and 3, at McCartney (see p. 373), were analyzed with results given below:

Analyses of shale from upper division of Platteville limestone.

[Analyst, L. G. Michael, Ames, Iowa.]

\begin{tabular}{|c|c|c|c|}
\hline & $\begin{array}{c}\text { Waupeton, } \\
\text { Iowa. }\end{array}$ & $\begin{array}{l}\text { Potosi, } \\
\text { Wis. }\end{array}$ & $\begin{array}{l}\text { McCartney, } \\
\text { Wis. . }\end{array}$ \\
\hline 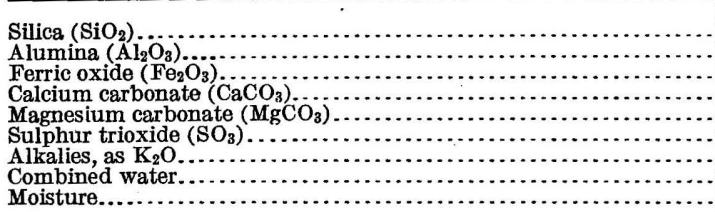 & \begin{tabular}{r|}
50.69 \\
15.63 \\
4.83 \\
11.15 \\
8.43 \\
2.65 \\
1.46 \\
4.64 \\
.49
\end{tabular} & $\begin{array}{r}48.88 \\
14.54 \\
12.00 \\
8.58 \\
3.15 \\
1.26 \\
6.43 \\
4.48 \\
1.30\end{array}$ & $\begin{array}{r}49.10 \\
17.15 \\
8.46 \\
11.04 \\
2.85 \\
1.69 \\
3.62 \\
5.36 \\
.91\end{array}$ \\
\hline
\end{tabular}

For cement manufacture all these shales should preferably carry higher percentages of silica and less iron oxide in order that the ratio $\mathrm{Al}_{2} \mathrm{O}_{3}+\mathrm{Fe}_{2} \mathrm{O}_{3}=\frac{\mathrm{SiO}_{2}}{3}$ should be more nearly approximated. The alumina and iron oxide together should not be greater than $\frac{\mathrm{SiO}_{2}}{2}$, and it is apparent from the above analyses that at Potosi station, as well as at Specht Ferry, their sum is greater than this. It is desirable, therefore, both on account of the chemical composition and the relative thinness of the shale beds, that some other supply of silica and alumina should be at hand. It is possible that such a supply might be obtained from the residual clay and loess at the top of the hills wherever these materials average rich in silica and poor in lime. An idea of the composition of the clay and loess of the region can be had from the accompanying analyses. Though the samples of clay and loess were not taken from the same sections as the limestone and shale, there is an abundance of this unconsolidated material above the Galena dolomite at each locality, and its composition is probably such as to make it important.

$48834^{\circ}-$ Bull. $522-13-12$ 
Analyses of residual clay and loess from the Driftless Area. ${ }^{a}$

[Analyst, R. B. Riggs.]

\begin{tabular}{|c|c|c|c|c|c|c|}
\hline & 1 & 2 & 3 & 4 & 5 & 6 \\
\hline 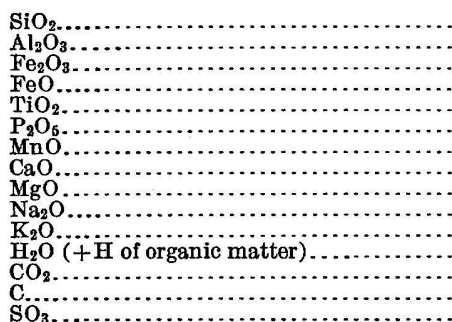 & $\begin{array}{r}71.13 \\
12.50 \\
5.52 \\
.45 \\
.45 \\
.02 \\
.04 \\
.85 \\
.38 \\
2.19 \\
1.61 \\
4.63 \\
.43 \\
.19 \\
. . .\end{array}$ & $\begin{array}{r}49.59 \\
18.64 \\
17.19 \\
.27 \\
.28 \\
.03 \\
.01 \\
.93 \\
.73 \\
.80 \\
.93 \\
10.46 \\
.30 \\
.34 \\
\ldots . .\end{array}$ & $\begin{array}{r}53.09 \\
21.43 \\
8.53 \\
.86 \\
.16 \\
.03 \\
.03 \\
.95 \\
1.43 \\
1.45 \\
.83 \\
10.79 \\
.29 \\
.22\end{array}$ & $\begin{array}{r}49.13 \\
20.08 \\
11.04 \\
.93 \\
.13 \\
.04 \\
.06 \\
1.22 \\
1.92 \\
1.33 \\
1.60 \\
11.72 \\
.39 \\
1.09\end{array}$ & $\begin{array}{r}72.68 \\
12.03 \\
3.53 \\
.96 \\
.72 \\
.23 \\
.06 \\
1.59 \\
1.11 \\
1.68 \\
2.13 \\
2.50 \\
.39 \\
.09 \\
.51\end{array}$ & $\begin{array}{r}64.61 \\
10.64 \\
2.61 \\
.51 \\
.40 \\
.06 \\
.05 \\
5.41 \\
3.69 \\
1.35 \\
2.06 \\
2.05 \\
6.31 \\
.13 \\
.11\end{array}$ \\
\hline
\end{tabular}

$a$ Sixth Ann. Rept. U. S. Geol. Survey, 1885, pp. 250, 282.

1 and 2. Samples of clay from the same vertical section, No. 1 having been taken $4 \frac{1}{2}$ feet from the surface and No. 2 a little more than $8 \frac{1}{2}$ feet from the surface, in contact with the underlying limestone.

3 and 4. Samples of clay that are similarly related, having been taken 3 and $4 \frac{1}{2}$ feet from the surface, the latter clay in contact with the rock.

5. Loess from Dubuque, Iowa.

6. Loess from Galena, Ill.

The materials available show that a cement manufactured in this district would be of the type made from a mixture of ordinary hard limestone and clay or shale. About 52 per cent of the Portland cement now made in the United States is of this type. Magnesium carbonate, the most objectionable of impurities in raw limestone materials, falls in these rocks well within the maximum allowable limits of 5 to 6 per cent. Certain of the limestone beds that are high in silica resemble very closely in composition the "cement rock" of the well-known Lehigh Portland cement district.

The materials in this district would require very little preliminary drying. The limestone is fairly uniform in texture, but it would need very thorough grinding. The shale, clay, and loess are less refractory, and although the clay and loess carry a few chert or quartz pebbles, such objectionable material is not excessive and could be removed by screening.

The Dubuque district is, of course, not ideally situated with regard to fuel, but its distance from the Iowa coal field is not so great as the distance of certain successfully operated cement plants from their fuel base. A possible substitute, at least in part, for coal might be furnished by the great quantities of sawdust and slabs wasted by the several sash and door factories and other lumber mills at Dubuque. This fuel might be utilized in the kilns in the form of producer gas.

\section{MANUFACTURING SITES.}

Along the greater part of the river front between these cities the bluffs rise steeply 60 to 100 feet above the flood plain and then slope more gently to a total height of 150 to 200 feet. On both sides of the river a railroad runs close to the base of the bluff. In 
several lateral ravines and valleys large enough for mill sites the Platteville limestone is favorably situated for quarrying, so that the broken rock may be loaded into a mill by gravity. Five such localities were sectioned and sampled in detail. In the order of their distances from Dubuque they are as follows: (1) Near Zollicoffer Lake, Peru Township, Iowa, in the SW. $\frac{1}{4}$ sec. 23 , T. 90 N., R. 2 E.; (2) at Specht Ferry, Iowa; (3) near Potosi Station, Wis., in the SE. $\frac{1}{4}$ sec. 4, T. 2 N., R. 3 W.; (4) about a mile above Waupeton, Iowa, in the NE. $\frac{1}{4}$ sec. 25, T. 91 N., R. 1 W.; (5) near McCartney, Wis., in sec. 4 , T. 2 N., R. 4 W.

The trade territory for a cement plant would be confined to the region west, north, and northeast of Dubuque and would comprise large parts of Iowa, Minnesota, and Wisconsin. A plant near Dubuque would at present have to meet competition from Mason City, Iowa; Hannibal, Mo.; and Dixon, Ill. Dubuque has the advantages of cheap water transportation and of four direct rail lines to the north and might fairly be able to control the trade along the river up to and including St. Paul and Minneapolis.

\section{MAPS AND OTHER PUBLICATIONS.}

Dubuque, Iowa, is on the south edge of the Lancaster quadrangle, which extends about 35 miles north from latitude $42^{\circ} 30^{\prime}$, and about 9 miles east and 17 miles west from Dubuque. The United States Geological Survey has issued reports on this quadrangle. ${ }^{1}$

Useful maps and discussions of the geology of the Dubuque district have been issued by the State surveys as follows:

Calvin, Samuer, and Bain, H. F., Geology of Dubuque County: Iowa Geol. Survey, vol. 10,1900 , pp. 379-622.

Beyer, S. W., Supplementary report on Portland cement materials in Iowa: Bull. Iowa Geol. Survey No. 3, 1906, 36 pp.

Grant, U. S., Report on the lead and zinc deposits of southwestern Wisconsin, with atlas: Bull. Wisconsin Geol. and Nat. Hist. Survey No. 14, 1906, 100 pp.

\section{PORTLAND CEMENT INDUSTRY IN IOWA.}

Three Portland cement plants were operating in Iowa in 1911. At Mason City the Northwestern States Portland Cement Co. has for several years been utilizing the Cedar Valley limestone of the Middle Devonian and the Lime Creek shales of the Upper Devonian.

The Iowa Portland Cement Co. at Des Moines began manufacturing cement in 1910, utilizing limestone and shale from the Missouri group of the Pennsylvanian. The Lehigh Portland Cement Co. recently completed a plant at Mason City, where materials similar to those of the Northwestern States plant are used. The Iowa plants burn their cement with coal.

\footnotetext{
${ }^{1}$ Grant, U. S., and Burchard, E. F., Lancaster-Mineral Point folio (No. 145), Geol. Atlas U. S., U. S. Geol. Survey, 1907, price 25 cents. The topographic maps are also issued separately and sold for 10 cents each. Burchard, E. F., Portland cement materials near Dubuque, Towa: Bull. U. S. Geol. Survey No. 315,1907 , pp. 225-231.
} 


\section{PORTLAND CEMENT RESOURCES OF KANSAS.}

\section{PORTLAND CEMENT MATERIALS.}

\section{SUBDIVISIONS.}

The limestones available for Portland cement use in Kansas belong to (1) the Mississippian series, (2) the Pennsylvanian series ("Coal Measures"), (3) the Permian series, and (4) the Cretaceous system. Of the four the Pennsylvanian limestones are at present of the greatest importance in the cement industry, and plants using them furnish practically all the Kansas output. The chalky limestones and chalks of the Cretaceous system are also very satisfactory and would become of industrial importance if they were located nearer to markets and to fuel. The limestones of the Permian series are not of much importance at present and offer little hope for the future. Those of the Mississippian series may become of industrial interest later. (See Pl. VII.)

\section{MISSISSIPPIAN ("LOWER CARBONIFEROUS") LIMESTONES.}

Mississippian rocks occur in Kansas in only the extreme southeast corner, where they cover about 30 square miles in Cherokee County. The series is made up of limestones, with interbedded cherts, and a few beds of shale. Most of the limestones are heavily bedded and low in magnesia.

The limestone quarries in the Mississippian rocks are described by Haworth as follows: ${ }^{1}$

In the southeastern part of the State a small amount of quarrying is done in the sub-Carboniferous limestone at and near Galena. This limestone is a highly crystalline one, very compact in character, light blue in color, and occurs in heavy layers, so that large dimension stone could be obtained from it were the quarries operated for that purpose. It is the same rock in every respect, both as to geologic age and general character, that is so extensively quarried at Carthage and other points in Missouri. From the Carthage quarries many thousands of dollars' worth of stone are shipped into Kansas, all of which might be supplied from the Kansas stone if quarries were worked as extensively as might be done. The quarries at Galena are operated to supply local demand, and that only for foundation material in buildings, although considerable dimension stone is shipped from Carthage into Galena for the larger buildings.

Years ago this same stone was quarried at Galena, at Lowell, and elsewhere for the production of lime. It is so abundant in quantity and so easily accessible along the hillsides that it is a great wonder more limekilns are not in operation. The same rock is quarried at different places in Missouri and burnt into lime, producing lime of a good quality, but no better than might be obtained from Kansas quarries.

1 Haworth, Erasmus, Ann. Bull. Mineral Resources of Kansas for 1897-98, pp. 73-74. 


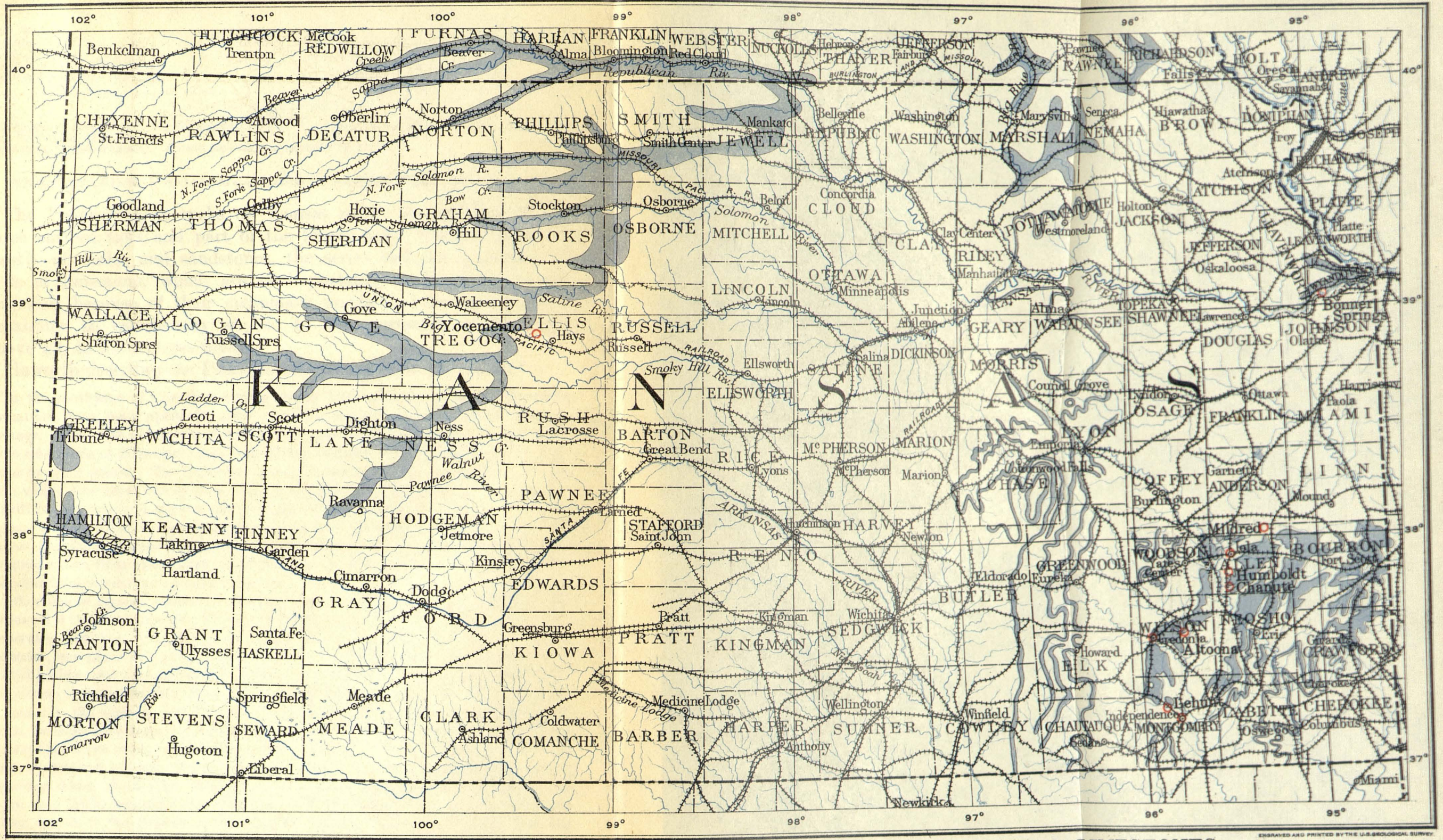

MAP OF KANSAS AND A PART OF NEBRASKA SHOWING PRINCIPAL LIMESTONES

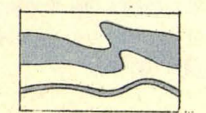

Principal limestones

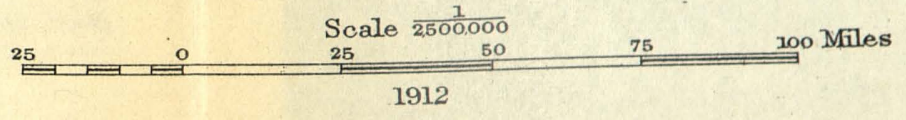

$\circ$

Portland cement plant 

Analyses of Mississippian limestones from Kansas.

\begin{tabular}{|c|c|c|}
\hline & 1 & 2 \\
\hline $\begin{array}{l}\mathrm{Silica}\left(\mathrm{SiO}_{2}\right) \\
\text { Alumina }\left(\mathrm{Al}_{2} \mathrm{O}_{3}\right) \\
\text { Iron oxide }\left(\mathrm{Fe}_{2} \mathrm{O}_{3}\right) \\
\mathrm{Lime} \text { carbonate }\left(\mathrm{Ca} \mathrm{CO}_{3}\right) \\
\text { Magnesium carbonate }\left(\mathrm{MgCO}_{3}\right)\end{array}$ & $\begin{array}{r}0.32 \\
.17 \\
.20 \\
98.66 \\
.73\end{array}$ & $\begin{array}{r}a 8.00 \\
.69 \\
97.32 \\
.80\end{array}$ \\
\hline
\end{tabular}

a Probably erroneous.

1. Quarry on Short Creek, near Spring River, Cherokee County. L. G. Eakins, analyst. Bull. U. S. Geol. Survey No. 78, p. 125.

2. Galena, Cherokee County. Mineral Resources of Kansas, 1897, p. 78.

\section{PENNSYLVANIAN ("COAL MEASURES") LIMESTONES AND SHALES.}

The Pennsylvanian rocks of Kansas cover the counties of the three eastern tiers and part of the fourth tier. Though made up mostly of shales and sandstones, the series includes a number of beds of limestone, which are of importance as Portland cement materials because of their customary purity and because of their proximity to satisfactory shales, to transportation routes, and, above all, to natural-gas fields.

\section{Haworth describes the Pennsylvanian limestones as follows: ${ }^{1}$}

To the northwest of Cherokee County many local quarries in heavy limestone formations have been operated, some of which are still operated in an irregular manner. The most extensive of these is the quarry at Iola, which has produced large quantities of dimension stone and sawed flagstone for local trade and for shipment to other points. The limestone at Iola exists in a layer nearly 40 feet thick, from which dimension blocks of any size or proportion desirable can be obtained.

Still farther to the northwest the next quarries are those along the banks of the Kansas River west of Kansas City, from which large quantities of stone are taken for ballast and for macadamizing streets. Near Kansas City a deposit of fragmentary material exists, from which large quantities have been shipped for making sidewalks, macadamizing streets, and similar purposes.

Other places furnish quantities of stone, the output of which would be greatly increased if the demand were sufficient to justify the extensive operation of quarries. Generally, however, it is principally a local demand, for which no statistics can be gathered, but which in the aggregate amounts to many thousands of dollars.

Still farther west a limestone exists which is remarkable in many of its propreties, permitting it to be successfully quarried for all kinds of dimension stone wherever it comes to the surface. It is known commercially as the Cottonwood Falls limestone, because such large quantities have been shipped from Cottonwood Falls and Strong City to so many points within and without the State. The same rock has been quarried at a dozen or more places to the north of Cottonwood Falls, such as Eskridge, Alma, Manhattan, Beattie, and a number of other places. This limestone is not very thick, averaging from 5 to 8 feet, and generally consists of two individual layers, known in the markets as the "upper" and the "lower." The rock from the two layers differs slightly in quality, the lower one generally producing the best stone. Its most valuable properties are two-almost perfect uniformity of texture throughout, and the absence of vertical fissures. It is white or light cream in color, 
fine and noncrystalline in texture, and well filled with the little rice-grain-like invertebrate fossil, Fusulina cylindrica. The color is so uniform that when the stone is placed in a building the general color effect is very pleasing and satisfactory. The absence of vertical fissures and the uniformity of texture throughout make it possible to obtain dimension blocks of any size desired, which can be worked with perfect uniformity. These qualities make it by all odds the most desirable and therefore the most extensively used stone in the State. Large buildings are erected from it entirely, and many others partly constructed from the same rock. The different quarries, so widely separated, make it possible for a large community to use it without paying excessive freight.

From this Cottonwood Falls limestone the following important buildings are constructed: Snow Hall, and the stone trimmings of the main building, University of Kansas, Lawrence; the Methodist Episcopal Church, Lawrence; the Rock Island depot, Topeka; the Santa Fe depots at Ottawa, Wellington, and elsewhere; and a number of other depot buildings along the lines of the different railways in Kansas.

In addition to the above-mentioned uses, the different railroads in the State use the Cottonwood Falls limestone for bridge building and other construction purposes. This is true to so great an extent that many thousands of dollars' worth of dimension stone are annually supplied the different Kansas lines for use in this State and elsewhere, much of it being shipped outside of the State.

Analyses of Pennsylvanian limestones from Kansas.

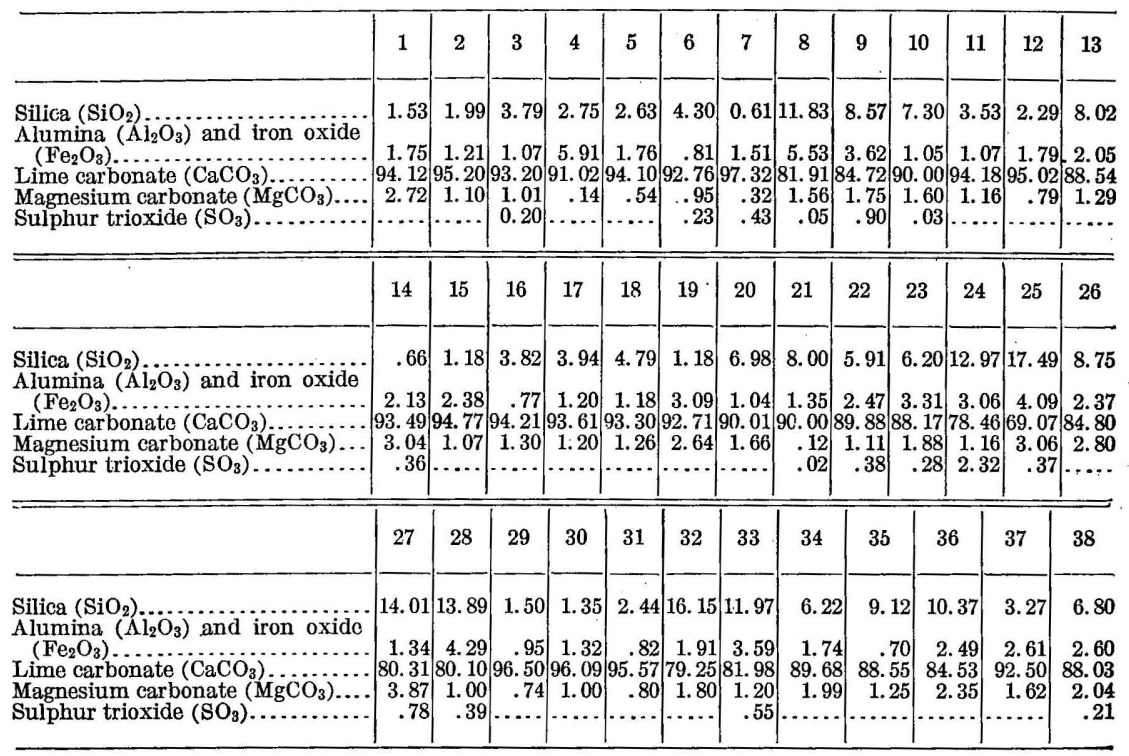
1, 2, 3. Humboldt, Allen County.

6, 7. Garnett, Anderson County.

8. Horton, Brown County.

9. Cottonwood Falls, Chase County.

10. Strong City, Chase County.

11, 12, 13. Lawrence, Douglas County.

14. Moline, Elk County.

15, 16, 17, 18. Lane, Franklin County.

19. Greeley, Franklin County.

20. Winchester, Jefferson County.
21. Ottawa, Johnson County.

$22,23,24$. Lansing, Leavenworth County. 25. Soldiers' Home, Leavenworth County. 26, 27, 28. Beattie, Marshall County. 29, 30, 31. Fontana, Miami County.

32. Independence, Montgomery County. 33. Sabetha, Nemaha County.

34, 35, 36. Alma, Wabaunsee County.

37. McFarland, Wabaunsee County.

38. Yates Center, Woodson County. 
The "Wilson" formation (Pennsylvanian), as described in the Independence folio and other reports on southeastern Kansas, comprises in descending order the following members: Stanton ("Piqua") limestone, Vilas shale, Plattsburg ("Allen") limestone, Lane ("Concreto") shale, Iola limestone, and Chanute shale (in part). The Stanton and Plattsburg ("Allen") limestones are used in Portland cement manufacture.

Sufficient chemical examinations have been made in different localities to show that the "Allen" limestone retains a uniform chemical composition wherever found in the northern part of the Independence quadrangle. It is exposed principally near the middle of the northern edge of the quadrangle, between Neodesha and Fredonia, mainly in the scarps of Verdigris and Fall rivers. Along Fall River it outcrops in a belt about one-half mile in maximum width on either side.

At the west base of Table Mound, on the bank of Elk River, near the plant of the United Kansas Cement Co., the section of the useful rocks exposed consists of 45 feet of pure crystalline Stanton limestone overlying an 80-foot bed of Vilas shale, which in turn rests upon a 5-foot bed of "Allen" limestone underlain by 40 feet or more of Lane ("Concreto") shale. The Stanton probably represents the most important and abundant Portland cement limestone in the Independence quadrangle. It crops out over about 140 square miles, extending from Table Mound westward to Elk and from Elk River northward beyond the limits of the quadrangle. Throughout this area, particularly along its eastern edge, where the Stanton caps the scarp of Fall and Verdigris rivers, it is easily available and in most places can be handled by gravity. Both the Stanton and the Iola limestones are remarkably persistent over wide areas in the State, and they are everywhere likely to be suitable for making Portland cement.

Specimens of Stanton limestone taken at a number of places northwest of the Independence quadrangle have been analyzed with the following results:

Analyses of Stanton ("Piqua") limestone from Kansas. ${ }^{a}$

\begin{tabular}{|c|c|c|c|c|c|c|c|}
\hline Town. & Silica. & $\begin{array}{l}\text { Oxide } \\
\text { of iron and } \\
\text { alumina. }\end{array}$ & $\begin{array}{c}\text { Calcium } \\
\text { carbonate. }\end{array}$ & $\begin{array}{l}\text { Magne- } \\
\text { sium car- } \\
\text { bonate. }\end{array}$ & Sulphates. & Moisture. & Total. \\
\hline 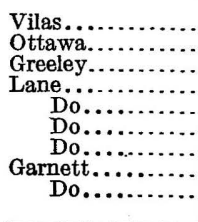 & $\begin{array}{l}2.02 \\
8.00 \\
1.18 \\
1.18 \\
3.82 \\
3.84 \\
4.79 \\
4.30 \\
.61\end{array}$ & $\begin{array}{r}2.65 \\
1.35 \\
3.09 \\
2.38 \\
.77 \\
1.20 \\
1.18 \\
.81 \\
.51\end{array}$ & $\begin{array}{l}96.07 \\
90.00 \\
92.71 \\
94.77 \\
94.21 \\
93.61 \\
93.30 \\
92.76 \\
97.32\end{array}$ & $\begin{array}{r}0.10 \\
.12 \\
2.64 \\
1.07 \\
1.30 \\
1.20 \\
1.26 \\
.95 \\
.32\end{array}$ & 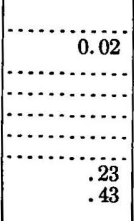 & 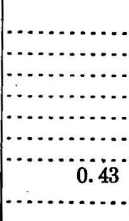 & $\begin{array}{r}100.84 \\
99.49 \\
99.62 \\
99.40 \\
100.10 \\
99.95 \\
100.53 \\
99.48 \\
99.19\end{array}$ \\
\hline
\end{tabular}

a Ann. Bull. Mineral Resources Kansas, 1902. 
As is generally the case, the shales used at Independence and Neodesha are more variable than the limestones. In places they change rapidly in character, principally by a variation in the quantity of sand present. The calcium carbonate also is exceedingly variable, ranging from almost 20 per cent down to a very small quantity. Everywhere, however, the proportions of magnesia and of the alkalies remain fairly constant, and nowhere has an excessive amount of magnesia been found. The following are analyses of shale from different localities in Montgomery and adjacent counties:

Analyses of shale from Montgomery and adjacent counties, Kansas.a

\begin{tabular}{|c|c|c|c|c|c|c|}
\hline Location. & $\begin{array}{c}\text { Silica } \\
\left(\mathrm{SiO}_{2}\right)\end{array}$ & $\begin{array}{c}\text { Alumina and } \\
\text { iron oxide } \\
\left(\mathrm{Al}_{2} \mathrm{O}_{3}, \mathrm{Fe}_{2} \mathrm{O}_{3}\right)\end{array}$ & $\begin{array}{l}\text { Lime } \\
(\mathrm{CaO})\end{array}$ & $\begin{array}{c}\text { Magnesia } \\
\text { (MgO). }\end{array}$ & $\begin{array}{c}\text { Alkalies } \\
\left(\mathrm{Na}_{2} \mathrm{O}, \mathrm{K}_{2} \mathrm{O}\right)\end{array}$ & $\begin{array}{l}\text { Water } \\
\left(\mathrm{H}_{2} \mathrm{O}\right) \text {. }\end{array}$ \\
\hline 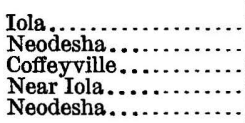 & $\begin{array}{l}55.002 \\
61.80 \\
64.62 \\
57.20 \\
50.80\end{array}$ & $\begin{array}{l}24.367 \\
22.7 \\
21.82 \\
26.80 \\
21.58\end{array}$ & $\begin{array}{l}0.77 \\
8.20 \\
2.50 \\
5.40 \\
8.87\end{array}$ & $\begin{array}{l}3.30 \\
0.216 \\
0.43 \\
3.10 \\
2.19\end{array}$ & $\begin{array}{c}2.106 \\
\text { Trace. } \\
4.15 \\
3.90\end{array}$ & $\begin{array}{l}7.709 \\
7.50 \\
5.01 \\
7.00 \\
5.37\end{array}$ \\
\hline
\end{tabular}

a Ann. Bull. Mineral Resources Kansas, 1902.

\section{PERMIAN LIMESTONES.}

Permian rocks occur west of the Pennsylvanian series and include a few beds of limestone, which are described briefly by Haworth: ${ }^{1}$

A few hundred feet above the Cottonwood Falls limestone are heavy beds of the Permian limestone, which are usually filled with flint nodules. These soft Permian limestones, carrying so much flint, are very serviceable for railroad ballast and are extensively quarried and crushed for this purpose at different places. The quarry near Strong City has probably yielded more ballast of this kind than any other one in the State, but extensive quarries are operated farther west along the Santa $\mathrm{Fe}$ at Florence and near Marion, and along the Rock Island at different points, all of which produce practically the same kind of stone.

Analyses of Permian limestones from Kansas.

\begin{tabular}{|c|c|c|c|c|c|c|}
\hline & 1 & 2 & 3 & 4 & 5 & 6 \\
\hline $\begin{array}{l}\text { Silica }\left(\mathrm{SiO}_{2}\right) \ldots \ldots \\
\text { Alumina }\left(\mathrm{Al}_{2} \mathrm{O}_{3}\right) . .\end{array}$ & 5.04 & 13.60 & 3.34 & $\begin{array}{l}5.27 \\
1.07\end{array}$ & $\begin{array}{l}4.25 \\
05\end{array}$ & 5.51 \\
\hline Iron oxide $\left(\mathrm{Fe}_{2} \mathrm{O}_{3}\right)$ & .96 & 2.55 & 1.69 & 1.03 & .85 & 1.24 \\
\hline $\begin{array}{l}\text { Lime carbonate }\left(\mathrm{CaCO} \mathrm{C}_{3}\right) \\
\text { Magnesium carbonate }\left(\mathrm{MgCO}_{3}\right)_{\ldots} \ldots \ldots \ldots \ldots \ldots \ldots\end{array}$ & $\begin{array}{r}93.32 \\
1.06\end{array}$ & $\begin{array}{r}76.16 \\
7.63\end{array}$ & $\begin{array}{r}93.98 \\
.94\end{array}$ & $\begin{array}{r}89.93 \\
1.18\end{array}$ & $\begin{array}{r}94.06 \\
.62\end{array}$ & $\begin{array}{r}91.50 \\
1.62\end{array}$ \\
\hline
\end{tabular}

1. Eldorado, Butler County. Ann. Bull. Mineral Resources Kansas, 1898, p. 77.

2. Arkansas City, Cowley County. Idem.

3. Cambridge, Cowley County. Idem, p. 78.

4. Silverdale, Cowley County. C. Catlett, analyst. Bull. U. S. Geol. Survey No. 64, p. 46.

5. Winfield, Cowley County. Ann. Bull. Mineral Resources Kansas, 1898, p. 77.
G. Idem.

\section{CRETACEOUS LIMESTONES.}

The chalk and chalky limestones of the Cretaceous are as promising in western Kansas as in Arkansas and Texas but are handicapped by 
their remoteness from fuel and from cement markets. Haworth describes the limestones as follows: ${ }^{1}$

In the central and west central part of the State the Cretaceous limestones have been quarried to a great extent. *** They are generally spoken of locally as magnesian limestone, although such a term is entirely misapplied. A belt of country stretches across the State, by way of Beloit and Russell, throughout which a fine layer of limestone is quarried and broken into pieces suitable for fence posts. Travelers passing from east to west along almost any railroad line in the State can notice large fields and pastures fenced entirely by fastening the wire fencing to these stone posts, which are set in the ground similar to the way common wooden posts are used in ordinary fencing. The Cretaceous limestones also serve many structural purposes in all of the cities and villages within the Cretaceous area. The rock is so soft it can easily be sawed into blocks and worked with chisel and hammer much more rapidly than ordinary limestone. This, added to its property of materially hardening after quarried, greatly increases its value. None of it is what would be called a first-class building material, yet it is capable of being used in many ways and furnishes a convenient and durable structural material for that part of the State, which prevents other stone from being shipped in. Here, as elsewhere, local demands are not so great now as they formerly were, but every year thousands of dollars' worth of the rock are quarried and used for various purposes, principally for supplying fence posts.

Analyses of Cretaceous limestones from Kansas.

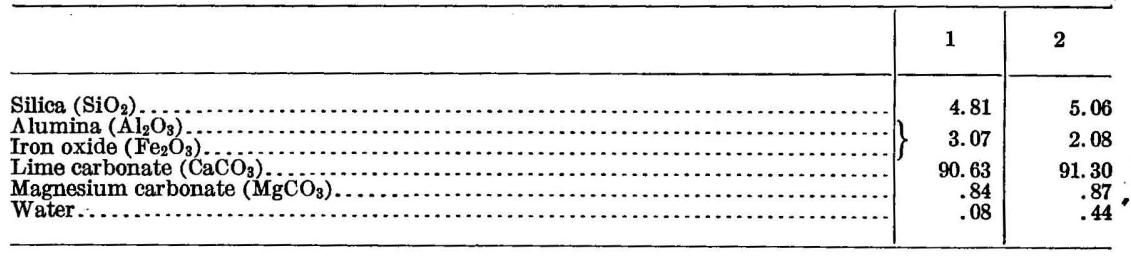

1. Coolidge, Hamilton County. Ann. Bull. Mineral Resources of Kansas, 1898, p. 78.

2. Jetmore, Hodgeman County. Idem.

\section{PORTLAND CEMENT INDUSTRY IN KANSAS.}

By E. F. Burchard.

Kansas ranks fourth among the States as a producer of Portland cement, being exceeded in importance by Pennsylvania, Indiana, and California. In 1911 its production amounted to 4,871,903 barrels, valued at $\$ 3,725,108$. This production came from 12 plants, all of which use a mixture of Carboniferous limestone and shale. By far the greater part of this production comes from southeastern Kansas, the remainder coming from plants in the vicinity of Kansas City and from one plant at Yocemento in west-central Kansas.

The materials used at all these plants are very satisfactory, but their strongest recommendation is their convenient location with respect to each other and to fuel supplies. The chief factor in the rapid growth of the Kansas cement industry was the very cheap and abundant supply of natural gas available for fuel, so that both burning and power cost ran much lower than in Eastern cement plants.

1 Am. Bull. Mineral Resources Kansas for 1897-98, pp. 75-76. 
This fuel supply has probably now passed its maximum, and its cost will figure more largely in the expenses of Kansas cement plants in the future.

Cement making in Kansas is principally centered around Iola, where the Iola Portland Cement Co. and the United Kansas Portland Cement Co. were the first to begin to manufacture Portland cement in the State. The material used is the Iola limestone (see p. 183) mixed with a contiguous Pennsylvanian shale.

The composition of the raw materials used at the plants of the Iola and United Kansas Portland Cement companies is shown by the following representative analyses:

Analyses of cement materials near Iola, Kans.

\begin{tabular}{|c|c|c|c|c|c|}
\hline & 1 & 2 & 3 & 4 & 5 \\
\hline 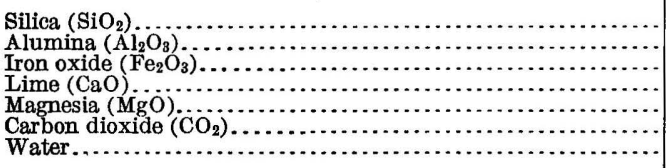 & $\begin{array}{r}0.86 \\
.29 \\
55.74 \\
4.51 \\
42.76 \\
.04\end{array}$ & $\left\{\begin{array}{r}1.19 \\
.95 \\
1.28 \\
53.13 \\
1.36 \\
42.66\end{array}\right.$ & $\begin{array}{r}54.18 \\
19.17 \\
6.11 \\
7.05 \\
1.89 \\
11.95\end{array}$ & $\begin{array}{r}1.1 \\
1.8 \\
51.7 \\
2.0 \\
43.3\end{array}$ & $\begin{array}{r}56.0 \\
22.1 \\
8.0 \\
1.5 \\
10.7\end{array}$ \\
\hline
\end{tabular}

1. Limestone from Iola, Kans. H. N. Stokes, analyst. Bull. U. S. Geol. Survey No. 78, 1891, p. 124.

2. Limestone used by lola Portland Cement Co.

3 . Shale used by Iola Portland Cement Co.

4. Limestone used by Kansas Portland Cement Co.

5. Shale used by Kansas Portland Cement Co.

The plant of the Western States Portland Cement Co., $1 \frac{1}{2}$ miles southeast of Independence, near the mouth of Rock Creek and Verdigris River, is built on the Drum limestone, which underlies the Chanute shale. This limestone here attains a thickness of nearly 100 feet and outcrops over an area of several square miles. It is massive or heavy bedded, semicrystalline, medium to coarse grained, and fossiliferous. Analyses show it to be a very pure lime carbonate. Shale overlies the limestone, but in practice it has been found more advantageous to use a Quaternary clay from the adjacent flood-plain of Verdigris River, rather than the shale. Fuel is obtained from the near-by gas wells and water from Verdigris River. The plant uses the dry process and has a capacity of 2,500 barrels a day. It is run by electric motors driven by steam power generated by gas. The company holds leases on about 1,200 acres of gas land and obtained at first an abundant supply of gas from five good wells that produced $15,000,000$ to $20,000,000$ cubic feet in 24 hours. The plant is connected with the Missouri Pacific Railway by 3 miles of branch line.

At Neodesha the plant of the United Kansas Portland Cement Co., which has been idle for two or three years, used the Plattsburg ("Allen") limestone, which caps the hill known as Little Bear Mound about a mile northwest of town, where it has been found to have a thickness of 55 to 70 feet. Suitable shale is present underneath the limestone, and both oil and gas for fuel are available. 
Analyses of the limestone and shale at Neodesha are as follows:

Analyses of cement materials at Neodesha, Kans.

\begin{tabular}{|c|c|c|}
\hline . & $\begin{array}{l}\text { Plattsburg ("Allen") } \\
\text { limestone member. }\end{array}$ & $\begin{array}{l}\text { Lane ("Concreto") } \\
\text { shale member. }\end{array}$ \\
\hline $\begin{array}{l}\text { Silica }\left(\mathrm{SiO}_{2}\right) \\
\text { Alumina }\left(\mathrm{Al}_{2} \mathrm{O}_{3}\right) \\
\text { Iron oxide }\left(\mathrm{Fe}_{2} \mathrm{O}_{3}\right) \\
\text { Lime }(\mathrm{CaO}) \\
\text { Magnesia }(\mathrm{MgO}) \\
\text { Sulphuric anhydride }\left(\mathrm{SO}_{3}\right) \\
\text { Loss on ignition. }\end{array}$ & $\begin{array}{r}3.11 \\
1.06 \\
52.40=93.58 \mathrm{CaCO}_{3} \\
\text { Tr. } \\
\text { None. } \\
42.45\end{array}$ & $\begin{array}{r}50.80 \\
16.75 \\
4.83 \\
8.83=15.7 \mathrm{CaCO}_{3} \\
2.19 \\
\text { None. } \\
12.24\end{array}$ \\
\hline
\end{tabular}

The United Kansas Portland Cement Co. operates another plant at the west base of Table Mound, on Elk River. (See p. 183 for analysis of the Stanton limestone used.)

West of Chanute the Stanton limestone is utilized in another plant.

The gradual decline in the productivity of the Iola and other natural-gas fields of southeastern Kansas has slightly reduced the eagerness of cement manufacturers and promoters to establish new plants in that section of the State. The plant of the Bonner Brand Portland Cement Co. at Bonner Springs, which uses Carboniferous limestone and shale, and the plant of the United States Portland Cement Co. at Yocemento, which uses Cretaceous limestone and shale, are the only Kansas plants not in the gas belt. In 1912 most of the plants began installing coal burners.

\section{BIBLIOGRAPHY.}

The following brief list contains the titles of some of the more important publications dealing with the Portland cement materials of Kansas. Much additional information is contained in the reports of the Kansas Geological Survey.

Haworth, Erasmus, Ann. Bull. Mineral Resources of Kansas, 1898, et seq.

ADAMs, G. I., and others, Stratigraphy and paleontology of the upper Carboniferous rocks of the Kansas section: Bull. U. S. Geol. Survey No. 211, 1903, p. 123.

Economic geology of the Iola quadrangle, Kansas: Bull. U. S. Geol. Survey No. 238,1904, p. 83.

Schrader, F. C., Independence folio (No. 159), Geol. Atlas U. S., U. S. Geol. Survey, 1908.

Schrader, F. C., and Haworth, E., Economic geology of the Independence quadrangle, Kansas: Bull. U. S. Geol. Survey No. 296, 1906, p. 74.

\section{PORTLAND CEMENT RESOURCES OF KENTUCKY. ${ }^{1}$ PORTLAND CEMENT MATERIALS.}

SUBDIVISIONS.

Limestones prevailingly low in magnesia and otherwise satisfactory as cement materials occur in Kentucky in four different geologic divisions (Pl. VIII), as follows, beginning with the oldest:

Ordovician limestones of Trenton and Stones River age (Highbridge, Lexington, and Winchester limestones).

\footnotetext{
1 For much of the data presented in regard to Kentucky cement materials the writer is indebted to E. 0 . Ulrich, of the United States Geological Survey.
} 
Ordovician limestones of Cincinnatian age (Winchester, Maysville, and Richmond formations).

Mississippian ("Lower Carboniferous") limestones.

Pennsylvanian ("Coal Measures") limestones.

\section{LIMESTONES OF TRENTON AND STONES RIVER AGE.}

The limestones of Trenton and Stones River age are represented by the Highbridge, Lexington, and Winchester limestones as mapped in publications of United States Geological Survey. These formations occupy much of the counties of Franklin, Scott, Bourbon, Woodford, Fayette, Jessamine, and smaller portions of Boyle, Clark, Mercer, Owen, Henry, and Anderson. They are generally low in magnesia and high in lime carbonate, the latter commonly ranging from 90 to 95 per cent. They represent a combined thickness of about 700 feet of solid, chiefly nonmagnesian limestone. The magnesian beds are practically confined to the lower 400 feet and probably do not reach an aggregate thickness of 150 feet. According to E. O. Ulrich the Highbridge limestone is of Stones River and Black River age, the Lexington limestone is of Trenton age, and the Winchester limestone is of Trenton age in the lower part and of Cincinnatian age in the upper part.

The following table gives analyses of limestones of Trenton age in Kentucky. ${ }^{1}$

Analyses of limestones of Trenton age in Kentucky.

[R. Peter, analyst.]

\begin{tabular}{|c|c|c|c|c|c|c|c|c|c|}
\hline & 1 & 2 & 3 & 4 & 5 & 6 & 7 & 8 & 9 \\
\hline Silica $\left(\mathrm{SiO}_{2}\right)$ & 5.92 & 2.38 & 2.18 & 2.08 & 6.94 & 1.88 & 5.18 & 1.58 & 2.18 \\
\hline Alumina $\left(\mathrm{Al}_{2} \mathrm{O}_{3}\right)$ & 3.28 & 3.98 & 2.42 & .77 & .12 & 2.70 & 1.53 & .38 & .63 \\
\hline Lime carbonate $\left(\mathrm{CaCO}_{3}\right)$ & 85.56 & 91.48 & 92.73 & 95.38 & 89.63 & 90. 72 & 91.33 & 95.68 & 94.75 \\
\hline Magnesium carbonate $\left(\mathrm{MgCO}_{3}\right)$ & 3.57 & 1.04 & .63 & 1.51 & .88 & 4.61 & .56 & 2.04 & 1.96 \\
\hline Alkalies $\left(\mathrm{K}_{2} \mathrm{O}, \mathrm{Na}_{2} \mathrm{O}\right)$ & .88 & .55 & .51 & .14 & .52 & .35 & .77 & .24 & .26 \\
\hline Sulphur trioxide $\left(\mathrm{SO}_{3}\right)$. & .47 & .32 & .34 & .58 & .68 & n.d. & .33 & .17 & .30 \\
\hline
\end{tabular}

1. Clark County.

2. Fayette County.

3. Fayette County.

4. Franklin County.

5. Franklin County.
6. Mercer County.

7. Woodford County.

8. Wayette County.

At Mentor a shaly limestone of Trenton age outcrops in a narrow strip along the Ohio River in Kenton and Campbell counties. Below Ludlow the same limestone (100 feet thick) caps the hills, overlying the Eden shale, which forms the slope of the hills, to a height of 250 feet or more. The limestone of Trenton age runs higher in silica along Ohio River than in central Kentucky, but the magnesium carbonate is generally less than 2 per cent. 


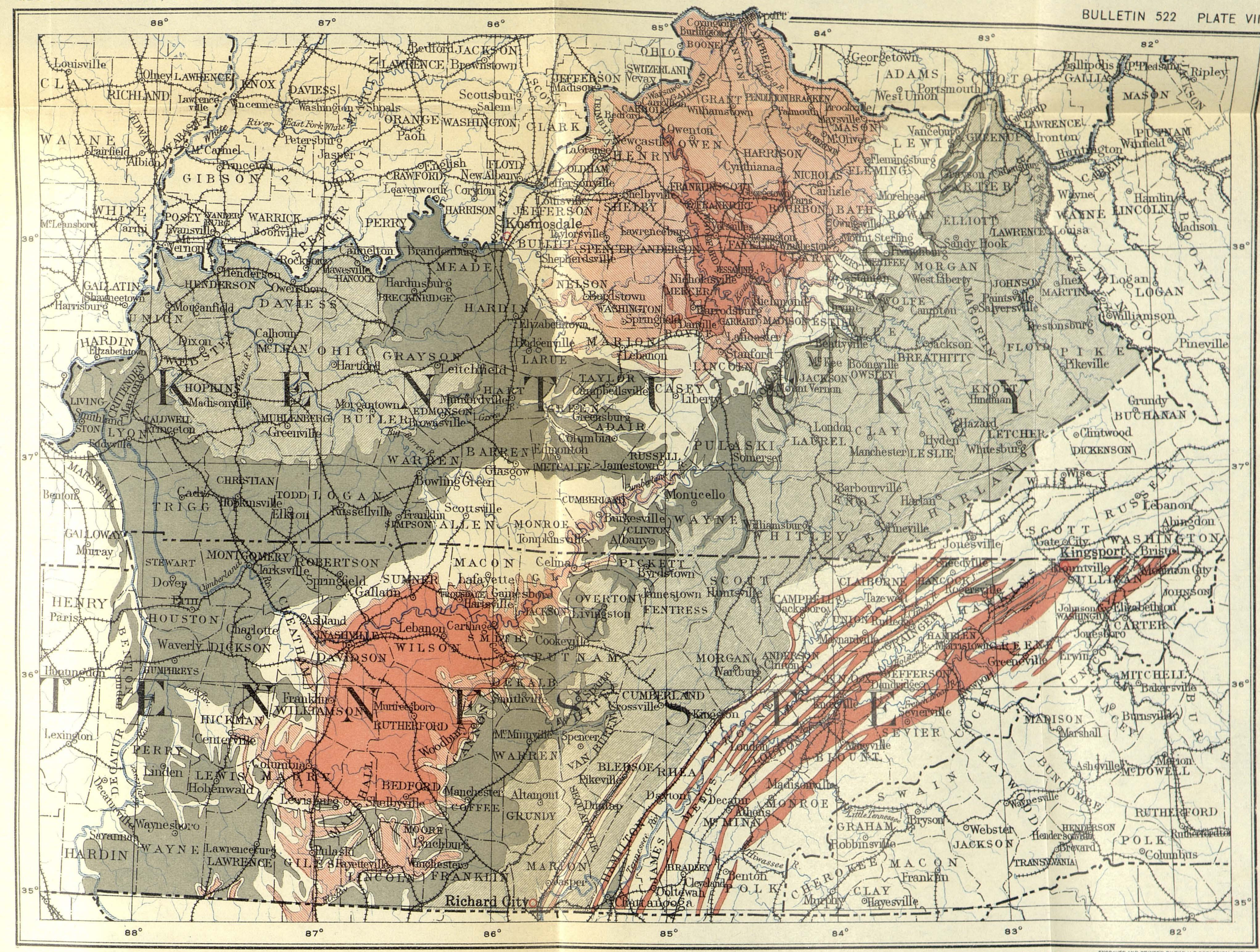

LEGEND

Pennsylvania

"Coal Measures",

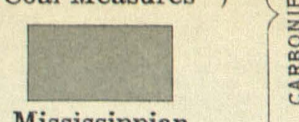

Mississippian
limestone

$\square$

Cincinnatian shale

imestones of Trenton and Stones River age

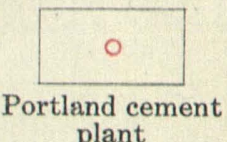

plant

NOTE: ". Coal Measures" in.
clude Mississippian limestone in

tud e Misassippian limestone
he Sequatchie Valley and along

the easterne
land Plateau

MAP OF KENTUCKY AND TENNESSEE SHOWING LIMESTONE FORMATIONS Revised from maps of the Kentucky and Tennessee geological survess

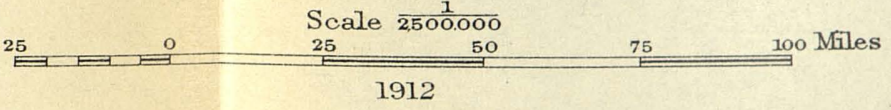





\section{CINCINNATIAN (UPPER ORDOVICIAN) LIMESTONES.}

The shales and limestones which make up the Cincinnatian series in Kentucky occupy most of the north-central portion of the State. They consist of dark-blue, argillaceous, thin-bedded limestones, with many interbedded shale layers. The limestones are generally satisfactory for cement materials. Many of the shales are sandy in the south and west, but it is probable that even there careful search would disclose shale beds of satisfactory composition. Four forma_ tions are represented - the Winchester limestone and Eden shale at the base, the Maysville formation in the middle, and the Richmond formation at the top.

North of a line connecting Madison, Ind., and Maysville, $\mathrm{Ky}_{\mathrm{y}}$, these limestones are pure and the shales are calcareous and nowhere arenaceous. Southward from this line both the shales and the limestones, particularly those in the middle of the series, gradually grow more and more sandy. Along Cumberland River (in southern Kentucky) practically the whole series is represented by a finegrained sandstone, called by Shaler the Cumberland sandstone.

The following analyses are of limestones from the Cincinnatian series from Kentucky. ${ }^{1}$

Analyses of limestones from Cincinnatian series, Kentucky.

[R. Peter, analyst.]

\begin{tabular}{|c|c|c|c|c|c|c|c|c|c|c|}
\hline & 1 & 2 & 3 & 4 & 5 & 6 & 7 & 8 & 9 & 10 \\
\hline Silica $\left(\mathrm{SiO}_{2}\right.$ & 14.44 & 6.38 & 13.98 & 10.42 & 1.89 & 3.68 & 7.18 & 16.64 & 1.72 & \\
\hline Alumina $\left(\mathrm{Al}_{2} \mathrm{O}_{3}\right)$ & 3.75 & 2.20 & 3.91 & 2.03 & .54 & 1.19 & 2.34 & 2.48 & 3.58 & 1. \\
\hline Lime carbonate ( $\mathrm{CaCO}$ & 75.44 & 87.98 & 77.36 & 85.20 & 96.51 & 92.65 & 88.90 & 78.68 & 92.92 & 96.2 \\
\hline M agnes i u m car bonate & 4.78 & 1.72 & 2.31 & 1.24 & 1.05 & 1.54 & 1.47 & 1.57 & .56 & \\
\hline Alkalies $\left(\mathrm{K}_{2} \mathrm{O}, \mathrm{Na}_{2} \mathrm{O}\right)$ & .83 & .34 & .49 & $\begin{array}{l}.01 \\
.79\end{array}$ & .25 & .43 & $\begin{array}{r}1.71 \\
.22\end{array}$ & $\begin{array}{l}.04 \\
.35\end{array}$ & .32 & \\
\hline Sulphur trioxide (S & .47 & .37 & 2.43 & .17 & .18 & 1.27 & .24 & .27 & .34 & .18 \\
\hline
\end{tabular}

1. Mason County.

2. Mason County.

3. Mason County.

4. Anderson County.

5. Bourbon County.
6. Franklin County.
7. Mercer County.
8. Nicholas County.
9. Owen County.
10. Woodford County.

Except 5 and 10, which are uncommonly pure for their respective localities, and 9, which is nearly normal for the northern part of the Cincinnatian outcrop, all these analyses illustrate the increase in silica southward. In the central counties north of the MaysvilleMadison line the limestones contain very little silica and agree closely with those in southwestern Ohio.

\section{MISSISSIPPIAN ("LOWER CARBONIFEROUS") LIMESTONES.}

The Mississippian limestones are commonly low in magnesia; and in most of the area covered by them in Kentucky they are high in 
lime carbonate. Toward the Tennessee-Kentucky State line, however, interbedded layers of chert become more and more common, until the lower part of the series becomes too siliceous to be of much promise as a source of Portland cement materials.

The lower Mississippian sandstone (see Pl. VIII) lies on the east side of the Cincinnati axis and north of Jackson County, Ky. South of Jackson County and west of the Cincinnati axis the equivalent strata consist, in central Kentucky, principally of shale, in which may occur considerable beds of siliceous limestone, and in west Kentucky and middle Tennessee, principally of siliceous limestone, with more or less shale in the lower part.

In the Mississippian series two beds, both oolitic, are important as future sources of Portland cement material. The first, which underlies the St. Louis limestone and is equivalent to the Spergen limestone of Indiana, forms a generally broad strip passing through Meade, Hardin, Larue, Barren, Warren, Todd, Christian, and Trigg counties. The second, the Ste. Genevieve limestone, is limited to Christian, Caldwell, Crittenden, and Livingston counties, in western Kentucky. Between the first strip and the border of the western Kentucky coal field there is first a broad strip of St. Louis limestone, which is usually too siliceous and too magnesian for use in making Portland cement, and then, near or just outside of the coal field, the Chester group, which contains several beds of apparently promising limestone closely associated with beds of shale.

No good limestones occur in west-central Tennessee, except in Montgomery and Robertson counties, where the lower oolite is present. However, the St. Louis limestone here, as also in Kentucky, contains many beds of only slightly siliceous and probably nonmagnesian limestone.

Of the analyses below, Nos. 1 and 7 are Spergen limestone, Nos. 3, 5, and 6 St. Louis limestone, and Nos. 2, 4, and 8 limestones of the Chester group, though the last is extraordinarily pure for a limestone of that group.

Analyses of upper Mississippian limestones from Kentucky.

[R. Peter, analyst.]

\begin{tabular}{|c|c|c|c|c|c|c|c|c|}
\hline & 1 & 2 & 3 & 4 & 5 & 6 & 7 & 8 \\
\hline 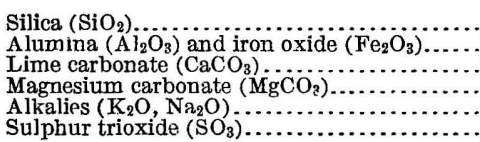 & $\begin{array}{r}1.06 \\
.51 \\
98.05 \\
.36 \\
.44 \\
.26\end{array}$ & $\begin{array}{r}2.76 \\
.92 \\
93.02 \\
2.09 \\
(a) \\
.60\end{array}$ & $\begin{array}{l}3.06 \\
1.39 \\
95.15 \\
.24 \\
\text { (a) } \\
\text { Tr. }\end{array}$ & $\begin{array}{r}7.48 \\
2.56 \\
85.68 \\
2.50 \\
.36 \\
.84\end{array}$ & $\begin{array}{r}9.56 \\
.15 \\
88.15 \\
.38 \\
(a)\end{array}$ & $\begin{array}{r}4.46 \\
1.49 \\
92.05 \\
.22 \\
(a) \\
.20\end{array}$ & $\begin{array}{r}0.38 \\
.46 \\
98.58 \\
.63 \\
.18 \\
.27\end{array}$ & $\begin{array}{r}0.49 \\
.22 \\
97.63 \\
.65 \\
.6)^{63} \\
.34\end{array}$ \\
\hline
\end{tabular}

$a$ Not determined.

1. Glasgow Junction, Barren County.

2. Barren River, Butler County.

5. Old Town Creek, Greenup County.

3. Iron Hills Furnace, Carter County.

4. Grayson County.

6. Kenton Furnace, Greenup County.

7. Hardin County.

8. Litchfield, Grayson County.

Analyses 1 to 7 from Geol. Survey Kentucky, Rept. A, vol. 2, 1885, pp. 119-120; analysis 8 from Twentieth Ann. Rept. U. S. Geol. Survey, pt. 6 (continued), 1899, p. 545. 


\section{PENNSYLVANIAN ("COAL MEASURES") LIMESTONES.}

A number of limestone beds occur interbedded with the Pennsylvanian shales and sandstones. These limestones are usually low in magnesia but rarely carry more than 80 to 90 per cent of lime carbonate. They are so thin, compared with the thick Mississippian limestones, that they would be of but little importance if it were not for their advantageous location near supplies of fuel.

The following analyses ${ }^{1}$ are of Pennsylvanian limestones from Kentucky:

Analyses of Pennsylvanian limestones from Kentucky.

\begin{tabular}{|c|c|c|c|c|c|}
\hline & 1 & 2 & 3 & 4 & 5 \\
\hline 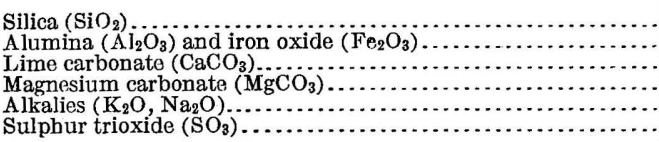 & $\begin{array}{r}14.70 \\
6.40 \\
75.75 \\
.57 \\
(a) \\
.78\end{array}$ & $\begin{array}{r}5.96 \\
3.76 \\
88.41 \\
.79 \\
.51 \\
.04\end{array}$ & $\begin{array}{r}3.28 \\
1.76 \\
88.38 \\
3.68 \\
.35 \\
.17\end{array}$ & $\begin{array}{r}4.26 \\
4.33 \\
82.88 \\
4.20 \\
.29 \\
4.72\end{array}$ & $\begin{array}{r}1.15 \\
.65 \\
97.15 \\
.93 \\
\hdashline .9 .\end{array}$ \\
\hline
\end{tabular}

$a$ Not determined.

1. Mount Savage Furnace, Carter County.

2. Pea Ridge, Greenup County.

4. Muhlenberg County.

3. Henderson County.

5. Hayward, Carter County.

\section{PORTLAND CEMENT INDUSTRY IN KENTUCKY.}

Though the establishment in Kentucky of numerous Portland cement plants has been discussed only one plant has so far been actually built. It is located at Kosmosdale near Louisville and is operated by the Kosmos Portland Cement Co. It uses a mixture of limestone and clay.

\section{PORTLAND CEMEN'T RESOURCES OF LOUISIANA.}

The great chalk formations, which seem destined to be such important sources of Portland cement material in the neighboring States of Texas, Arkansas, Mississippi, and Alabama, occur in Louisiana only in small isolated outcrops. The State is practically devoid of limestone and hardly to be considered as a possible future producer of Portland cement. The few limestone outcrops that appear within its limits are described below: ${ }^{2}$

The beds of limestone seem to be almost entirely confined to the Cretaceous. Of the three outcrops which occur in the State, the Winnfield limestone is of very doubtful value as a building stone, but the Coochie Brake and Bayou Chicot deposits may be utilized for that purpose.

The Winnfield limestone is a highly crystallized blue and white banded stone. It $i^{s}$ full of cracks and pockets and other flaws, which will render it useless as an ornamental or building stone. It can doubtless be used to advantage for making lime.

\footnotetext{
1 Analyses 1 to 4 (by R. Peter) from Geol. Survey Kentucky, Rept. A, vol. 2, 1885, p. 119; analysis 5 communicated by F. E. Hayward.

2 Prelim. Rept. Geology Louisiana, 1899, pp. 130-131.
} 
The quantity of the stone in sight is large and it can be very economically quarried. Several kilns of lime have already been burned here for local use.

The purity of the stone is shown by the following analysis by W. F. Hillebrand: ${ }^{1}$

Analysis of limestone from Winnfield, La.

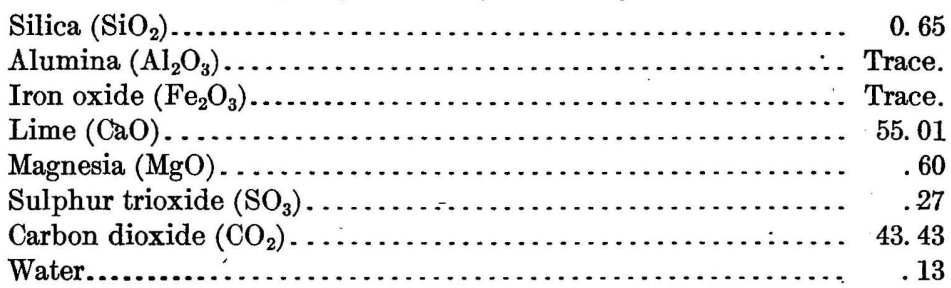

The Coochie Brake stone is a light-yellow or bluish-yellow, coarse-grained, sandy limestone. It is of excellent quality for building purposes, but its value is somewhat impaired by the presence of small nodules of iron pyrites. These will restrict its use to situations where a good external appearance is not one of the qualities required of the stone. The pyrite, if the quantity proves to be large, may destroy its value altogether. The quantity of stone at this locality is large, and it is easily obtained.

The Bayou Chicot stone is the best for building that we have seen in the State. It is a fine-grained dark-gray limestone. Only two very small outcrops of it were seen, and from these no very satisfactory ideas of the extent of the deposit could be gained. In the two outcrops the dip is very great, and the cost of uncovering the stone would probably be large. Borings are needed to show the depth of the deposit. In the early history of the country lime was made at this place. The ruins of the old limekilns are to be seen near the larger outcrop.

Many of the Tertiary limestone concretions are large and have been used locally for the foundations of houses. At Shreveport large calcareous concretions are crushed and used on the streets and in concrete work. Hopkins reports a place 5 miles from Natchitoches, called the Kilns, where large concretions have been burned for lime.

At Rocky Spring Church lime was burned from a little outcrop of Midway limestone for the masonry of Fort Jessup.

The following analysis was made by R. B. Riggs: ${ }^{2}$

Analysis of limestone from Rayborn's salt lick, Bienville Parish, La.

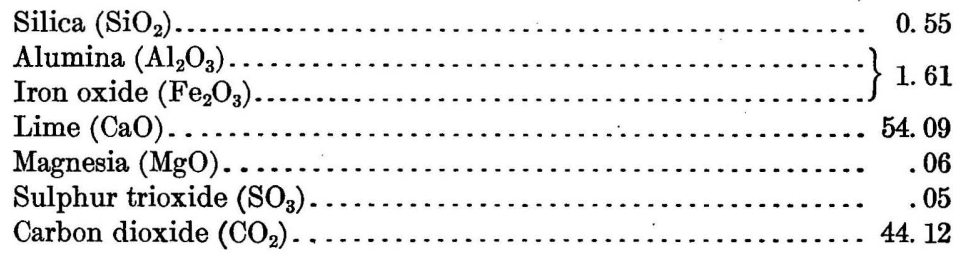

PORTLAND CEMEN'T RESOURCES OF MAINE. PORTLAND CEMENT MATERIALS.

GENERAL FEATURES.

Numerous areas of limestone, of more or less importance as to extent and thickness, occur in Maine; and many of these would yield stone which could be used satisfactorily as Portland cement material, so far as composition alone is concerned. In spite of this

1 Bull. U. S. Geol. Survey No. 60, 1890, p. 160.

2 Bull. U. S. Geol. Survey No. 168, 1902, p. 258. 
fact, however, few of the deposits are worthy of serious consideration. Most of them are far from fuel supplies and from cement markets, and the transportation question is particularly serious in a State having so low a railroad mileage as Maine.

Geologic mapping of the interior of the State has not progressed sufficiently to give even a fairly accurate map or description of the limestones of the entire State, and few satisfactory analyses are available. On the other hand, very complete data are fortunately avilable on the only area in Maine which seems to be really promising.

Under present conditions as to fuel supply and transportation, it is practically certain that the only limestones in Maine on which a Portland cement industry can be based are those which outcrop along or near the Atlantic coast. Of these by far the most promising are the limestones now so extensively utilized for lime burning in the Rockland-Rockport region of Knox County. These deposits will therefore be described in some detail, after which analyses of scattered limestones from other sections of the State will be presented.

LIMESTONES AND CLAYS OF THE ROCKLAND-ROCKPORT REGION:

The limestone deposits of the Rockland-Rockport area are large compared with other Maine deposits and are situated on or near deep water. They have long been utilized in the lime industry and have at intervals attracted attention as possible sources of Portland cement material.

In a recent report, ${ }^{1}$ to which reference should be made for details additional to those given in the present bulletin, Bastin describes the areal distribution of these limestones as follows:

The limestone areas form, in general, long, narrow, somewhat irregular strips trending northeast and southwest and surrounded by quartz rocks and schists. The largest continuous area extends from Chickawaka Pond, 2 miles north of Rockland; in a southwesterly direction somewhat over 5 miles to Thomaston, where its southernmost exposures are seen in the yard of the State prison. In some places this belt has a width of nearly a mile, although all of the rock is not of commercial quality. The second largest deposit extends from the east shore of Rockport Harbor, near the Henry cottage, northward to Lily Pond, and thence assumes a more westerly trend; it takes in the Jacobs quarry on the trolley road between Rockport and Camden and extends to the west of this road for a little over a mile. After a short interruption the same belt appears again just west of Simontons Corners, where it includes the Eells quarry. Next in commercial importance is the deposit occurring 2 miles northwest of the village of Warren; this deposit was not mapped in detail, but enough was learned of it to show that it was relatively small and that its trend was similar to that of most of the other areas. Several narrow belts occur between the Warren deposits and Alford Lake, but none of these are now worked. Southwest of Rockland there are several narrow belts nearly parallel to the main limestone belt. On the easternmost of these belts is located the pulp-rock quarry, now being operated by Mr. S. P. Dunton for the McLoon \& Stover Lime Co.

1 Bastin, E. S., The lime industry of Knox County, Maine: Bull. U. S. Geol. Survey No. 285, 1906, pp. 393-400.

$48834^{\circ}-$ Bull. $522-13-13$ 
All the limestones of the district are highly crystalline. In composition they include two quite distinct types of stone. One type is high in magnesia, in many places approaching dolomite, and the other is characteristically very low in magnesia, in few placis carrying over 3 per cent. Bastin, in the report already referred to, states that the magnesian limestones underlie the nonmagnesian beds, though this simple relationship is masked by the closely compressed folding to which all the rocks of the region have been subjected.

So far as chemical composition is concerned, most of the limestones of the Rockland-Rockport region would make very satisfactory Portland cement materials. The following table contains several analyses which are fairly representative of the low-magnesia rocks:

Analyses of limestones from Knox County, Maine.

\begin{tabular}{|c|c|c|c|}
\hline & 1 & 2 & 3 \\
\hline 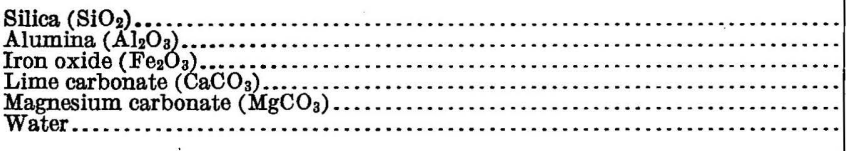 & $\begin{array}{r}1.08 \\
.07 \\
.08 \\
98.17 \\
.09 \\
\text { n. d. }\end{array}$ & \begin{tabular}{r}
1.00 \\
\hdashline Trace. \\
95.20 \\
1.00 \\
2.70
\end{tabular} & $\begin{array}{r}0.43 \\
.71 \\
.25 \\
97.69 \\
.82 \\
\text { n. d. }\end{array}$ \\
\hline
\end{tabular}

1. McNamara quarry, Rockland. J. C. Robinson, analyst. Twentieth Ann. Rept. U. S. Geol. Survey, pt. 6 (continued), 1899 , p. 398 .

2. Bachelder quarry, Union. J. C. Robinson, analyst. Idem.

3. Rockland-Rockport Lime Co. Communicated by G. O. Smith, 1904.

Extensive deposits of marine clays are described by Bastin ${ }^{1}$ as occurring along the lowlands of the coastal region in the same general area as the excellent low-magnesia limestones which have just been discussed. Analyses of several of these clays are quoted below from the report cited.

Analyses of marine clays from Knox County, Maine.

\begin{tabular}{|c|c|c|c|}
\hline & 1 & 2 & 3 \\
\hline 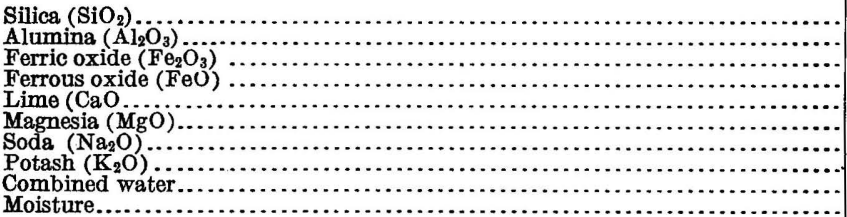 & $\begin{array}{r}62.80 \\
17.36 \\
4.40 \\
2.00 \\
0.88 \\
1.58 \\
1.48 \\
3.05 \\
4.39 \\
1.31\end{array}$ & \begin{tabular}{r|}
62.33 \\
17.70 \\
5.19 \\
1.72 \\
1.00 \\
1.53 \\
2.38 \\
2.41 \\
3.81 \\
1.11
\end{tabular} & $\begin{array}{r}61.59 \\
19.10 \\
7.53 \\
1.68 \\
1.87 \\
\text { n. d. } \\
\text { n. d. } \\
\text { 5. } 51\end{array}$ \\
\hline
\end{tabular}

1. Clay from brickyards at Thomaston, Maine. W. T. Schaller, analyst.

2. Clay from Hayden Point, near South Thomaston, Maine. W. T. Schaller, analyst.

3. Clay from property of Rockland-Rockport Lime Co., near Rockland, Maine.

1 Bastin, E. S., Clays of the Penobscot Bay region, Maine: Bull. U. S. Geol. Survey No. 285, 1906, pp. $428-431$. 
LIMESTONES FROM OTHER LOCALITIES IN MAINE.

Limestone beds of considerable extent also occur near Islesboro. A specimen from this locality, collected by George Otis Smith, was analyzed by W. T. Schaller in the laboratory of the United States Geological Survey, and proved to be a very pure limestone, low in magnesia.

Analysis of limestone from Islesboro, Maine.

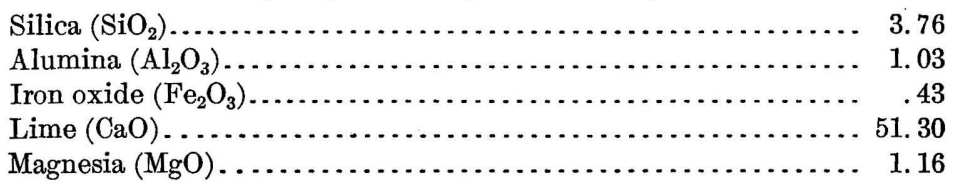

The analyses of limestones given in the following table are quoted from an early report by Prof. Hitchcock on the geology of Maine. They are inserted here, as they may serve to some extent as a guide to the limestone prospector. It should be noted, however, that the quality of the analyses is not above suspicion, and also that many of the beds analyzed may be entirely too small to work with profit:

Analyses of Maine limestones.

\begin{tabular}{|c|c|c|c|c|c|}
\hline No. & County. & Locality. & Insoluble. & $\mathrm{Fe}_{2} \mathrm{O}_{3}$ & $\mathrm{CaCO}_{3}$. \\
\hline 1 & Androsco & Turner. & 25.0 & 0.4 & \\
\hline 2 & Franklin. & Carthage.. & 8.8 & $\begin{array}{l}0.4 \\
1.4\end{array}$ & \\
\hline 3 & ......do... & & 23.4 & & \\
\hline 4 & .....do.. & Farmington. & 6.4 & 4.8 & \\
\hline 5 & .....do.. & Farmington $\mathrm{Hi}$ & 14.4 & 1.2 & \\
\hline 6 & ..... do... & Industry... & 21.2 & 2.8 & \\
\hline 7 & ..... do... & Livermore Fal & 34.0 & 3. 2 & \\
\hline 8 & .....do... & New Sharon. & 36.0 & 10.2 & 53 \\
\hline 9 & ..... do.. & .....do... & 20.6 & 2.4 & 77. 0 \\
\hline 10 & ......do.. & $\ldots$....... & 10.2 & & \\
\hline 11 & ...... do. & Phillips.... & 34.4 & & 64 \\
\hline 12 & ..... do. & ..... do ... & 26.8 & 5.6 & 67 \\
\hline 13 & …..do. & .....do.. & 34.6 & .4 & 65 \\
\hline 14 & ......do.. & Strong... & 8.4 & 1.0 & \\
\hline 15 & $\ldots .$. do $\ldots$ & Temple... & 28.4 & 1.4 & 702 \\
\hline 16 & Kennebec & Clinton... & 17.2 & .6 & 768 \\
\hline 17 & ......do. & Winslow. & 24.2 & 2.0 & \\
\hline 18 & ......do. & .... do... & 31.0 & .6 & \\
\hline 19 & .....do.. & .....do... & 16. 2 & 2.0 & 81 \\
\hline 20 & .....do.. & .... do....... & 20.6 & 1.6 & \\
\hline $\begin{array}{l}21 \\
22\end{array}$ & O..do.. & \#ixfield & 20.2 & 1.0 & \\
\hline $\begin{array}{l}22 \\
23\end{array}$ & $\begin{array}{l}\text { Oxford. } \\
\text {......do.. }\end{array}$ & $\begin{array}{l}\text { Dixfield......... } \\
\text {......do........ }\end{array}$ & 29.2 & 1.4 & 694 \\
\hline 24 & ......do....... & Rumford Falls .................... & $\begin{array}{l}20.0 \\
20.8\end{array}$ & .1 .2 & $\begin{array}{l}796 \\
780\end{array}$ \\
\hline 25 & Penobscot.. & Dexter........................... & 8.6 & 1.4 & 900 \\
\hline 26 & .....do...... & ......do.......... & 9.6 & 1.2 & 89 \\
\hline $\begin{array}{l}27 \\
28\end{array}$ & .....do....... & …............. & 20.0 & 1.8 & 78 \\
\hline 29 & 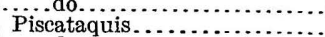 & Abbot.............. & 14.4 & 1.6 & $\begin{array}{ll}840 \\
740\end{array}$ \\
\hline 30 & …do do............... & Dover.. & $\begin{array}{l}24.8 \\
25.4\end{array}$ & 4.2 & 706 \\
\hline 31 & .... do & Guilford....... & 13.8 & 1.4 & 848 \\
\hline $\begin{array}{l}32 \\
33\end{array}$ & Somerset...................... & 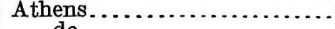 & 25.2 & 4.4 & \\
\hline $\begin{array}{l}33 \\
34\end{array}$ & (n) & Harmony & 2.8 & $\dddot{2}$ & 726 \\
\hline 35 & ......do.. & Norridgewock. & $\begin{array}{l}36.4 \\
10.6\end{array}$ & 12.2 & $68 \frac{4}{2}$ \\
\hline 36 & ... do & West Waterville.................... & $\begin{array}{l}10.0 \\
24.8\end{array}-10$ & 1.4 & $\begin{array}{l}882 \\
738\end{array}$ \\
\hline 37 & .. do & 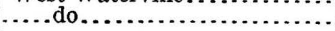 & 9.0 & 1.2 & 898 \\
\hline
\end{tabular}




\section{PORTLAND CEMENT RESOURCES OF MARYLAND. PORTLAND CEMENT MATERIALS.}

\section{DISTRIBUTION.}

Maryland is excellently supplied with raw materials for the Portland cement industry and is advantageously situated in regard to fuel, and hence will always possess a certain amount of interest as a cement producer. Traffic conditions, however, are against any very great expansion, for rail and water rates to important markets are so low that fow Maryland cement locations offer any marked advantage over those in the adjoining States.

Several geologic divisions in Maryland contain limestones that are sufficiently extensive to be of commercial importance, and are at the same time low in magnesia and otherwise satisfactory as Portland cement material. (See Pl. XIX, p. 350.)

The divisions, named in descending geologic order, that are sufficiently important to merit separate description are:

Greenbrier limestone.................... Mississippian.

Helderberg limestone..................... Devonian.

Limestones of Cayuga group............... Silurian.

Limestones of Shenandoah group............ Cambrian and Ordovician.

Metamorphic limestone................... Probably Cambrian and Ordovician.

In addition, a number of other limestone-bearing formations occur in Maryland, but their stone is normally too high in magnesia, is too siliceous, or is otherwise not well adapted to use in Portland cement manufacture. The Tertiary shell marls of the coastal plain, for example, are in Maryland too low in lime carbonate to be seriously considered.

The five limestone-bearing divisions above listed will be described in the order in which they are named. (See Pl. XIX.)

\section{GREENBRIER LIMESTONE AND ADJACENT SHALES.}

The Greenbrier limestone outcrops only in Allegany and Garrott counties. . (See Pl. XIX.) A single belt passes about S. $30^{\circ} \mathrm{W}$. through the western part of Allegany County, crossing the Potomac River about midway between Westernport, Md., and Keyser, W. Va.

In Garrett County the Greenbrier is better shown, appearing in a number of belts or areas. As described by the Maryland Geological Survey, ${ }^{1}$ there are six belts, distributed as follows:

The most easterly of these areas is situated parallel to and about one-half mile west of the crest of Savage and Backbone mountains. It enters the county from Pennsylvania one-half mile west of the northeast corner of the county, and extends 
in a southwesterly direction to the West Virginia line, 1 mile north of Potomac Stone. This belt is about 45 miles long and from one-fourth to one-half mile wide. It occupies a valley between the Pottsville (Savage Mountain) and the Pocono (Little Savage Mountain) ridges. This valley is drained at the north by the headwaters of Laurel Run and Savage River, and farther south by Little Savage River, Swamp Run, and Pine Swamp Run. Along the northern end of Backbone Mountain the line of outcrop is for a large part of the way up on the mountain side, but farther south it occupies a series of valleys like those along Savage Mountain, but less pronounced.

The second Garrett County area extends along the eastern side of Meadow Mountain in the valleys of Red Run and Meadow Creek Run as far as the confluence of the latter with Deep Creek, near Thayerville. Thence it extends in the same southwesterly direction, in a similar series of valleys between Hoop Pole Ridge and the ridge of Pottsville rocks to the west of it, to the West Virginia line at a point about 7 miles southwest of Oakland. This series of valleys is drained by branches of Deep Creek and of Miller Run and by White Meadow Run and Rhine Creek. The limestone belt is about 37 miles long and from one-eighth to one-half mile in width.

The third belt extends from a point near Thayerville on the one last described down the valley of Deep Creek to the mouth of Marsh Run, thence up the valley of Marsh Run to McHenry, thence in a westerly direction for 1 mile, where it bifurcates. One prong extends down the valley of Hoyes Run for about 1 mile, and then disappears under overlying formations. The other prong extends in a northwesterly direction through a valley to Sang Run. From here it extends down the Youghiogheny River to points $1 \frac{1}{2}$ miles north and $2 \frac{1}{2}$ miles south of Sang Run, where it dips under the overlying formation.

The fourth area extends from a point on the one last described at McHenry in a north-northeasterly direction in the valley parallel to and about one-half mile west of Negro Mountain as far as across the Pennsylvania line. This belt is about 15 miles long and one-eighth of a mile wide.

The fifth belt extends from a point on the third one, about 1 mile east of Sang Run, in a northerly and northeasterly direction, crossing the Pennsylvania line at Oakton. It occupies a sinuous line of valleys parallel to and about one-half mile east of the crest of Winding Ridge. The belt is about 13 miles long and one-eighth of a mile wide.

The sixth area enters the county from West Virginia near Cranesville and extends south along the valley occupied by Pine Swamp and Muddy Creek as far as Browning Mill and thence up the valley lying west of Snaggy Mountain for about 4 miles. Here it extends across the line into West Virginia.

The Greenbrier limestone, where best developed in Maryland, consists of three distinct members. The lowest is a series of limestones commonly siliceous near the base and ranging from 27 to 46 feet in thickness. The middle member consists largely of shales, thin sandstones, and so forth, and varies from 88.to 98 feet in thickness. The upper member consists almost entirely of very pure limestones and is from 65 to 85 feet thick. 
The section below ${ }^{1}$ illustrates the characters of the several members of the Greenbrier limestone:

Section of Greenbrier limestone at Crabtree, Garrett County, Md.

Upper member:

Feet.

Argillaceous limestone...................................... $4 \frac{1}{2}$

Massive sandy limestone..................................... 13

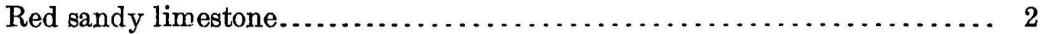

Gray limestone......................................... 3

Red calcareous shale..................................... $3 \frac{1}{2}$

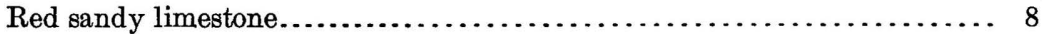

Gray sandy limestone with red bands.......................... 21

Gray limestone.............................................. 10

Middle member:

Red shale, with thin bands of gray sandstone...................... 80

Pure white sandstone..................................... 8

Lower member:

Gray limestone........................................... 27

The upper member of the. Greenbrier limestone consists very largely of thick beds of pure limestone. These have been very extensively used for flux and for lime burning, and their range in composition is fairly well established.

The analyses given below represent these upper limestones. Commonly they are very low in magnesium carbonate, though a few beds show a prohibitive percentage of that ingredient. In some places they carry sufficient silica, alumina, and iron oxide to approximate the composition of the cement rock of the Lehigh district, but in most places it is necessary to add a considerable proportion of clay or shale to bring the mixture up to correct composition for Portland cement.

The following analyses, made by T. M. Price, are taken from the publication of the Maryland Geological Survey: ${ }^{2}$

Analyses of Greenbrier limestone from Maryland.

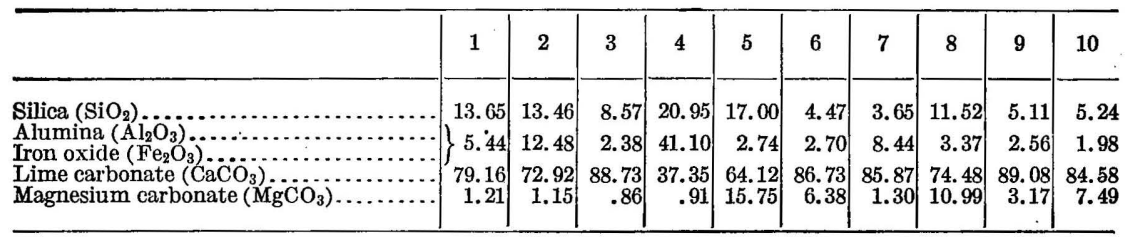

1. Gerringer \& Inglehart's quarry, Garrett County.

2. Offutt's quarry, Garrett County.

3. Crabtree, Garrett County.

4. South of Negro Mountain, Garrett County.

5. Offutt's quarry, Garrett County.

6. Findley's quarry, Piney Run, Garrett County.

7-9. Mouth of Stony Run, Allegany County.

10. Barrellville, Allegany County. 
The following additional analyses of Greenbrier limestone, made by M. R. Schmidt, have been recently published: ${ }^{1}$

Analyses of Greenbrier limestone from Maryland.

\begin{tabular}{|c|c|c|c|}
\hline & 1 & 2 & 3 \\
\hline 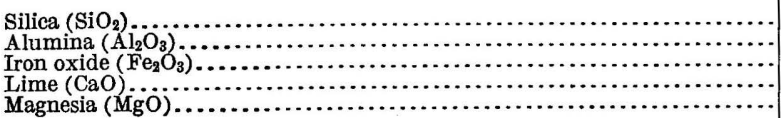 & $\begin{array}{r}19.99 \\
2.45 \\
1.07 \\
42.29 \\
.57\end{array}$ & $\begin{array}{r}13.86 \\
4.58 \\
1.61 \\
43.21 \\
1.50\end{array}$ & $\begin{array}{r}2.94 \\
1.09 \\
.68 \\
53.44 \\
.10\end{array}$ \\
\hline
\end{tabular}

1. Barrellville, Allegany County.

2, 3. Westernport, Allegany County.

The following analyses ${ }^{2}$ of Carboniferous shales from near Corinth, Garrett County, illustrate the range of composition. Most of them carry high percentages of iron oxide, and in few of them does the ratio $\frac{\text { silica }}{\text { alumina }+ \text { iron oxide }}$ rise much above 2.5 and in many it falls below 2 .

Analyses of Carboniferous shales from near Corinth, Md.

\begin{tabular}{|c|c|c|c|c|c|c|c|c|}
\hline & 1 & 2 & 3 & 4 & 5 & 6 & 7 & 8 \\
\hline 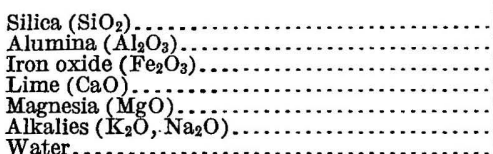 & $\begin{array}{c}56.42 \\
20.94 \\
10.60 \\
\text { Trace. } \\
1.32 \\
7.30\end{array}$ & $\begin{array}{r}69.51 \\
22.27 \\
.80 \\
\text { Trace. } \\
\text { Trace. } \\
\text { Trace. } \\
7.45\end{array}$ & $\begin{array}{r}62.98 \\
18.54 \\
5.70 \\
2.44 \\
.97 \\
8.85\end{array}$ & $\begin{array}{r}51.53 \\
22.60 \\
6.80 \\
5.40 \\
1.87 \\
11.77\end{array}$ & $\begin{array}{r}53.49 \\
22.83 \\
6.90 \\
2.91 \\
1.84 \\
9.44\end{array}$ & $\begin{array}{r}56.36 \\
24.18 \\
6.40 \\
.50 \\
.82 \\
7.50\end{array}$ & $\begin{array}{r}61.70 \\
22.24 \\
5.60 \\
\text { Trace. } \\
1.44 \\
\ldots\end{array}$ & $\begin{array}{r}56.32 \\
23.00 \\
5.80 \\
1.47 \\
.79 \\
\hdashline \ldots . .\end{array}$ \\
\hline
\end{tabular}

1. Red clay (bottom).

2. Fire clay or flint.

3. Buff clay.

4. Bottom blue clay.
5. Top blue clay.

6. Cistern

7. Railroad clay.

8. Black shale, coal mine.

\section{HELDERBERG LIMESTONE AND ADJACENT SHALES.}

The Helderberg limestone. outcrops in Maryland in several belts, most of them in the west-central part of Allegany County, though some are in western Washington County. The distribution in Allegany County is described as follows by C. C. O'Harra: ${ }^{3}$

The easternmost and largest area, shaped like a much constricted letter $\mathrm{W}$, lies to the east, west, and south of Tussey Mountain, and by its prominent double bifurcation makes up a large part of Warrior Mountain and Martin Mountain. On the State line east of Tussey Mountain the Helderberg belt is less than one-half mile wide, while the width of the corresponding outcrop on the western side is considerably greater. Southward, owing to the pitching of the Tussey Mountain anticline, these bands gradually approach each other until, at a point near Rush, the two coalesce. Within less than 1 mile southward the area again becomes bifurcated, but this time, owing to the synciinal nature of the fold, the projecting parts are separated by the

1 Maryland Geol. Survey, vol. 8, 1909, pp. 461-462.

2 Garrett County: Maryland Geol. Survey, 1902, p. 219.

${ }^{3}$ Allegany County: Maryland Geol. Survey, 1900, pp. 94-96. 
Oriskany formation, which immediately follows the Helderberg. Of the two southern Helderberg projections, the one farthest east is the more extensive, and includes within it Flakes Knob, the highest point in the county east of the Allegany Front. This part of the area narrows southward, but caps Warrior Mountain to within almost a mile of where the mountain ceases to be a distinct topographic feature. The projection lying farther west is much narrower than the one to the east, but continues almost as far south and acts as a capping for Collier Mountain.

The next area of Helderberg lies farther west and flanks the outcrop of Salina around Evitts Mountain in much the same way that the first area does the Salina around Tussey Mountain. The bifurcation at the north caused by the Evitts Mountain anticline is quite like that produced by the Tussey Mountain anticline. The formation continues southward in one long, continually narrowing band to within $1 \frac{1}{2}$ miles of the Potomac, where the Helderberg ending in a sharp point passes beneath the Oriskany to appear again at the roadside by the canal where the Potomac has cut entirely through the overlying Oriskany and into the Helderberg for a distance of fully a hundred feet. The eastern part of this area forms much of the crest and western slope of Nicholas Mountain, while the contact line along the western side is clearly marked by a row of hills extending from the State line southward. This row of hills reaches almost as far south as does the Helderberg outcrop, but finally coalesces with Nicholas Mountain.

East of Wills Mountain a belt of Helderberg averaging less than one-half mile in width comes into the county from the north, and extending southward along the western slope of Shriver Ridge passes through the western part of Cumberland and across the Potomac into West Virginia. The Potomac in its very perceptible eastward bend nearly 3 miles above Cumberland, and again in the more prominent eastward bend about 6 miles above Cumberland, has carved out two small portions of this belt from the West Virginia area. These patches are mostly concealed, but their contact with the Salina is fairly well shown. Northward the Helderberg-Salina contact is largely concealed, but the limestone quarries which occur in the lower part of the Helderberg along the western base of Shriver Ridge afford a convenient means of judging the approximate western outcrop of the Helderberg. Shriver Ridge marks the eastern limit, as the contact lies on its western slope a short distance below the top.

West of Wills Mountain there is a band of Helderberg corresponding in position to the eastern belt, but by reason of the perpendicular attitude of the strata this belt is considerably narrower than the one on the eastern side. Following closely the general direction of Wills Mountain, it crosses the Potomac River at Potomac station. Along the belt north of the National Road the Helderberg-Salina contact is usually not well shown, but the Helderberg-Oriskany contact is prominent, the latter being represented by the steep ridges to the north and south of Corriganville. South of the National Road neither contact is well shown, although slight topographic features usually indicate their positions with reasonable accuracy.

Another Helderberg area of considerable extent is exposed south of Rawlings. This forms the body of the steep isolated ridge known as Fort Hill, which extends southward along the Potomac for a distance of about 4 miles.

In addition to the above-mentioned areas, two very slight exposures may be seen along the West Virginia Central Railroad, on the north and south sides of Monster Rock, near Keyser, W. Va. They are of little importance, except in so far as they are of value in helping to work out the structure in that part of the county.

Four narrow belts of the Helderberg limestone outcrop in western Washington County. (See Pl. XIX, p. 350.) The best exposures, so far as location is concerned, are those near Hancock, on Potomac River. 


\section{The lithology of the Helderberg limestone is thus described by O'Harra: ${ }^{1}$}

Lithologically, the Helderberg is preeminently a limestone formation. Argillaceous materials occur as impurities in some of the beds, but these are not important, and sandstones are almost wholly lacking. Thin bands of chert, which are white or yellowish-white in color, occur sparingly throughout the upper part of the formation. Most of the limestone in the upper part is heavily bedded, and much of it is highly fossiliferous. The lower part of [Beneath ${ }^{2}$ ] the Helderberg is a dark-blue thin-bedded limestone, which in breaking gives a decided ring. This corresponds to the Tentaculite limestone of New York, which in Maryland is over 400 feet thick. In the field the contact between the Salina and the Tentaculite limestone is very marked because of the different weathering qualities of the two rocks. The Salina rock weathers into soil very completely, while the Tentaculite limestone leaves innumerable small, thin, dark-blue slabs upon the surface.

The thickness of the formation is nearly 800 feet. The two partial sections given below are believed to represent the full thickness as well as a duplication of some of the middle beds, as indicated. The Potomac section extends from the bottom of the formation to and includes a few inches of the coralline ledge. The 36-foot massive Stromatopora bed of the Devils Backbone section is believed to come in immediately above this, the other beds of the section continuing upward in the order named to the top of the formation.

The Devils Backbone section, measured along the Huntingdon \& Broadtop Railroad east of Wills Creek, is as follows:

Devils Backbone section, Maryland.

Helderberg-Oriskany contact.

Concealed................................................ 42

Light-gray fossiliferous limestone with numerous layers; a very light-colored chert................................................... 22

Light-gray massive fossiliferous limestone; breaks into rectangular blocks.... 16

Shaly limestone .......................................... $\quad \mathbf{1}_{\frac{1}{2}}$

Bluish-gray limestone, breaking into shaly fragments; weathering indicates much argillaceous material.................................... 18

Massive Stromatopora beds.................................. 36

Shaly limestone somewhat nodular............................ 10

Light-gray massive limestone, with upper part containing layers of lightcolored chert.............................................. 45

Thin-bedded limestone; the weathered surface covered with small bryozoans.. 16

Dark-blue massive limestone, very hard and difficult to break; upper part

filled with Pentamerus galeatus.................................. $\quad 36$

Fine, shaly fossiliferous limestone........................... 16

Massive, dark-blue fossiliferous limestone...................... 40

Slightly argillaceous, thin-bedded, fossiliferous limestone................ 14

Gray, arenaceous, fossiliferous limestone, with layers of cherty material....... 16

Concealed to bottom of formation.

Total thickness of exposure at this place................... $328 \frac{1}{2}$

1 Allegany County, Maryland Geol. Survey, pp. 96-98.

2 This description includes in the Helderberg a part of the underlying Cayuga group (the "Tentaculite" limestone). 
The measurements made at Potomac station are as follows:

Section at Potomac station, Md.

Upper beds concealed; very massive light-gray limestone, with a few feet of nodular limestone near the top; coralline layer near the top...............

Mostly concealed, but sufficiently exposed to show that the beds are generally made up of thin grayish limestones; some massive beds are present........

Generally thin-bedded, dark-blue limestone, but with some heavy beds;

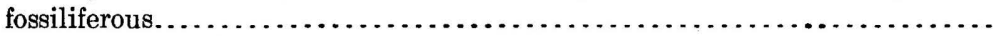

Thinly bedded, dark-blue fossiliferous limestones, with occasional papery shales................................................. 92

Total thickness of exposure.............................

Analyses of Helderberg limestone, Maryland.

\begin{tabular}{|c|c|c|c|c|c|c|c|c|c|}
\hline & 1 & 2 & 3 & 4 & 5 & 6 & 7 & 8 & 9 \\
\hline 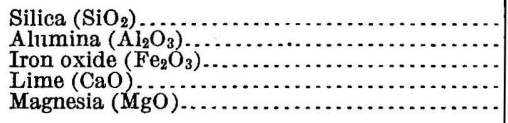 & \begin{tabular}{r|r}
7.27 & \\
.46 & \\
.66 & \\
50.08 & 5 \\
.98 &
\end{tabular} & $\begin{aligned} & \text { n.d. } \\
& \text { n.d. } \\
& \text { n.d. } \\
& 51.52 \\
& .76\end{aligned}$ & $\begin{array}{r}3.27 \\
.60 \\
.53 \\
52.24 \\
1.06\end{array}$ & $\begin{array}{r}3.6 \\
.7 \\
.38 \\
51.8 \\
1.5\end{array}$ & \begin{tabular}{|r|r|}
2 & 10.29 \\
2 & 1.65 \\
8 & .44 \\
18.73 \\
8
\end{tabular} & $\begin{array}{r}15.63 \\
2.66 \\
.81 \\
42.63 \\
2.32\end{array}$ & $\begin{array}{r}8.00 \\
.66 \\
.38 \\
50.24 \\
.65\end{array}$ & $\left|\begin{array}{r}12.27 \\
12.88 \\
41.14 \\
.41\end{array}\right|$ & $\begin{array}{r}3.51 \\
3.30 \\
52.13 \\
3.05\end{array}$ \\
\hline & 10 & 11 & 12 & & 13 & 14 & 15 & 16 & 17 \\
\hline 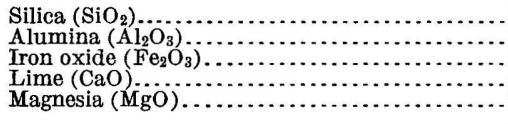 & $\begin{array}{r}12.01 \\
1.54 \\
.75 \\
47.06 \\
1.05\end{array}$ & $\left\{\begin{array}{r}0.7 \\
9.0 \\
48.7 \\
1.2\end{array}\right.$ & \begin{tabular}{l|l}
79 & 30 \\
72 & 38 \\
78
\end{tabular} & $\begin{array}{r}.61 \\
.62 \\
.70 \\
.08 \\
.81\end{array}$ & $\begin{array}{r}13.47 \\
2.69 \\
.95 \\
43.11 \\
3.37\end{array}$ & $\begin{array}{r}12.95 \\
.47 \\
.68 \\
47.71 \\
.90\end{array}$ & $\begin{array}{r}11.72 \\
1.19 \\
.75 \\
46.54 \\
2.34\end{array}$ & $\begin{array}{r}21.72 \\
5.88 \\
1.85 \\
36.91 \\
2.10\end{array}$ & $\begin{array}{r}19.71 \\
6.33 \\
1.48 \\
34.06 \\
6.47\end{array}$ \\
\hline
\end{tabular}

1-3. Warrior Mountain, near Oldtown, Allegany County. Sampled by E. C. Eckel; analyzed by Lehigh Valley testing laboratory.

4-7. Corriganville, Allegany County. M. R. Schmidt, analyst. Rept. Maryland Geol. Survey, vol. 8, p. 461 .

8,9. Cumberland, Allegany County. T. M. Price, analyst. Idem, p. 461.

10. Allegany Grove, Allegany County. M. R. Schmidt, analyst. Idem, p. 461.

11. Potomac, Allegany County. T. M. Price, analyst. Idem, p. 462.

12-15. Rawlins, Allegany County. Zies and Gill, analysts. Idem, p. 462.

16,17. Great Cacapon, Washington County. E. G. Zies, analyst. Idem, p. 443.

The Helderberg limestone is everywhere closely associated with good shales for cement purposes. Analyses of a number of Devonian shales follow:

Analyses of Devonian shales, Maryland.

\begin{tabular}{|c|c|c|c|c|c|}
\hline & 1 & 2 & 3 & 4 & 5 \\
\hline 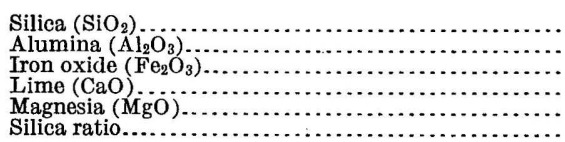 & $\begin{array}{r}68.03 \\
18.70 \\
5.91 \\
.65 \\
1.41\end{array}$ & $\begin{array}{r}65.65 \\
14.65 \\
6.17 \\
1.28 \\
.50\end{array}$ & $\begin{array}{c}65.32 \\
17.19 \\
3.70 \\
\text { n.d. } \\
\text { n.d. } \\
\text { 3.10 }\end{array}$ & $\begin{array}{r}54.31 \\
17.43 \\
6.09 \\
\text { n.d. } \\
\text { n.d. } \\
2.30\end{array}$ & $\begin{array}{r}62.05 \\
18.32 \\
7.52 \\
.99 \\
.71 \\
\ldots . . .\end{array}$ \\
\hline
\end{tabular}

1, 2. Great Cacapon, Washington County. E. G. Zies, analyst. Rept. Maryland Geol. Survey, vol. 8,1909 , p. 444 .

3, 4. Warrior Mountain, near Oldtown, Allegany County. Sampled by E. C. Eckel; analyzed by Lehigh Valley testing laboratory.

5. Corriganville, Allegany County. M. R. Schmidt, analyst. Rept. Maryland Geol. Survey, vol. 8, 1909, p. 462.

\section{LIMESTONES OF THE CAYUGA GROUP.}

The Cayuga group (Silurian) underlies the Helderberg limestone (Devonian) previously described, and its outcrops parallel those of the Helderberg, so that no separate description of its geographic 
distribution is necessary. The importance of the Cayuga group in the present connection arises from the fact that it includes one or more rather thin but very persistent beds of low-magnesia limestone. These low-magnesia limestones are high in clayey matter and in places closely approximate the composition of the well-known cement rock of the Lehigh district of Pennsylvania.

The following table gives a number of analyses of limestones of the Cayuga group from Maryland localities: ${ }^{1}$

Analyses of limestones of Cayuga group, Maryland.

\begin{tabular}{|c|c|c|c|c|c|c|c|c|c|c|c|c|}
\hline & 1 & 2 & 3 & 4 & 5 & 6 & 7 & 8 & 9 & 10 & 11 & 12 \\
\hline $\begin{array}{l}\text { Silica }\left(\mathrm{SiO}_{2}\right) \\
\text { Alumina }\left(\mathrm{Al}_{2} \mathrm{O}_{3}\right) \\
\text { Iron oxide }\left(\mathrm{Fe}_{2} \mathrm{O}_{3}\right) \ldots \ldots \\
\text { Lime }(\mathrm{CaO}) \ldots \ldots \\
\text { Magnesia }(\mathrm{MgO}) \ldots \ldots \\
\ldots \ldots \ldots\end{array}$ & $\begin{array}{r}5.65 \\
2.57 \\
.68 \\
50.48 \\
.76\end{array}$ & $\mid \begin{array}{r}3.80 \\
4.00 \\
50.14 \\
1.16\end{array}$ & $\left|\begin{array}{r}19.81 \\
7.35 \\
2.41 \\
35.76 \\
3.18\end{array}\right|$ & $\left\{\begin{array}{r}27.10 \\
1.50 \\
36.40 \\
2.52\end{array}\right.$ & $\mid \begin{array}{r}26.07 \\
11.40 \\
3.17 \\
28.05 \\
3.44\end{array}$ & $\begin{array}{r}20.16 \\
6.34 \\
1.36 \\
28.56 \\
2.07\end{array}$ & $\begin{array}{r}26.57 \\
3.96 \\
1.73 \\
34.95 \\
1.96\end{array}$ & $\begin{array}{r}16.45 \\
2.94 \\
1.24 \\
42.23 \\
2.26\end{array}$ & $\begin{array}{r}28.72 \\
12.28 \\
5.22 \\
25.54 \\
1.10\end{array}$ & $\begin{array}{r}24.74 \\
16.74 \\
6.30 \\
23.41 \\
4.10\end{array}$ & $\begin{array}{r}26.43 \\
8.18 \\
30.32 \\
6.12\end{array}$ & $\left\{\begin{array}{r}17.60 \\
5.66 \\
3.01 \\
35.44 \\
4.77\end{array}\right.$ \\
\hline & 13 & 14 & 15 & 16 & 17 & 18 & 19 & 20 & 21 & 22 & 23 & 24 \\
\hline $\begin{array}{l}\text { Silica }\left(\mathrm{SiO}_{2}\right) \ldots \ldots \ldots \\
\text { Alumina }\left(\mathrm{Al}_{2} \mathrm{O}_{3}\right) \ldots . . \\
\text { Iron oxide }\left(\mathrm{Fe}_{2} \mathrm{O}_{3}\right) \ldots \\
\text { Lime }(\mathrm{CaO}) \ldots \\
\text { Magnesia }(\mathrm{MgO}) \ldots \ldots\end{array}$ & $\left|\begin{array}{r}17.91 \\
6.14 \\
40.95 \\
1.36\end{array}\right|$ & $\begin{array}{r}20.90 \\
33.14 \\
20.69 \\
4.12\end{array}$ & $\begin{array}{r}14.50 \\
4.40 \\
44.46 \\
.57\end{array}$ & $\begin{array}{r}34.01 \\
5.60 \\
33.06 \\
.86\end{array}$ & $\begin{array}{r}16.33 \\
14.48 \\
35.08 \\
2.95\end{array}$ & $\left\{\begin{array}{r}7.30 \\
1.85 \\
.87 \\
49.65 \\
.88\end{array}\right.$ & $\begin{array}{r}9.11 \\
2.18 \\
.99 \\
47.76 \\
.96\end{array}$ & $\begin{array}{r}11.26 \\
2.39 \\
.97 \\
47.03 \\
.88\end{array}$ & $\begin{array}{r}3.69 \\
1.27 \\
51.62 \\
1.04\end{array}$ & $\begin{array}{r}3.82 \\
.75 \\
.58 \\
51.06 \\
1.56\end{array}$ & $\begin{array}{r}10.67 \\
1.28 \\
1.16 \\
44.55 \\
3.28\end{array}$ & $\begin{array}{r}9.17 \\
.90 \\
.72 \\
49.36 \\
1.60\end{array}$ \\
\hline
\end{tabular}

1. Hancock, Washington County. E. G. Zies, analyst.

2. Hancock, Washington County. T. M. Price, analyst

3. Round Top, Washington County. C. Richardson, analyst.

4. Round Top, Washington County. C. Huse, analyst.

5,6. Round Top, Washington County. E. G. Zies, analyst.

7, 8. Corriganville, Allegany County. M. R. Schmidt, analyst.

9. Cumberland, Allegany County. C. Richardson, analyst.

\section{LIMESTONES OF THE SHENANDOAH GROUP.}

The limestones of the Shenandoah group (Cambrian and Ordovician age) occupy three principal areas in Maryland-two in Washington County and one in Frederick County.

The westernmost area enters Maryland from Pennsylvania in central Washington County and runs slightly west of south to Potomac River, which it reaches between Cherry Run and Williamsport. Its eastern border lies just west of Conococheague Creek. Little Conococheague Creek flows through it, and Fairview, Reiffs, Hicksville, and Clear Spring are situated on the limestone.

The central limestone belt covers almost all of the eastern third of Washington County. It enters from Pennsylvania as a belt 15 miles wide and underlies the Hagerstown Valley, Antietam Creek running down its middle for its entire extent. Hagerstown and Sharpsburg are located near its middle; Blue Mountain, Edgemont,

1 Maryland Geol. Survey, vol. 8, 190؟ pp. 443, 461-462. 
and Weverton lie on or near its eastern edge; and Williamsport, Salisbury, and Mangansville are on or near its western border.

The third and easternmost area is in the eastern portion of Frederick County, along the valley of Monocacy River. Frederick, Adamstown, Frederick Junction, Woodsboro, and Walkersville are in this area of limestone.

In discussing the Shenandoah group in an adjoining and closely similar section in Pennsylvania, Stose has recognized the following formations, here listed in descending geologic order:

Ordovician:

1. Chambersburg limestone.

2. Stones River limestone.

3. Beekmantown limestone.

Cambrian:

4. Conococheague limestone.

5. Elbrook formation.

.6. Waynesboro formation.

7. Tomstown limestone.

Of the seven formations listed above, the Chambersburg and Stones River limestones are those which afford most of the possible Portland cement rock, though the Conococheague and the Elbrook also contain some beds of low-magnesia limestone.

The following table ${ }^{1}$ contains analyses of a number of limestones of the Shenandoah group, mostly from the Conococheague, Chambersburg, and Stones River formations, from Maryland localities:

Analyses of limestones of the Shenandoah group, Maryland.

\begin{tabular}{|c|c|c|c|c|c|c|c|c|c|c|}
\hline & 1 & 2 & 3 & 4 & 5 & 6 & 7 & 8 & 9 & 10 \\
\hline \multirow[t]{2}{*}{ 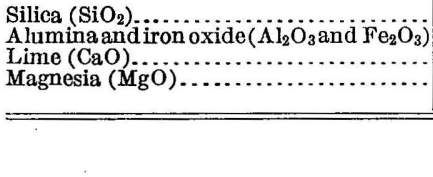 } & $\begin{array}{r}4.55 \\
1.61 \\
49.40 \\
3.25\end{array}$ & $\begin{array}{r}2.85 \\
1.15 \\
54.00 \\
.49\end{array}$ & $\begin{array}{r}0.98 \\
1.19 \\
34.02 \\
17.11\end{array}$ & $\begin{array}{r}9.6 \\
3.0 \\
46.4 \\
3.0\end{array}$ & \begin{tabular}{r|r|}
65 & 6.49 \\
08 & 1.33 \\
42 & 47.40 \\
04 & 3.46
\end{tabular} & $\begin{array}{r}1.21 \\
.54 \\
50.07 \\
4.85\end{array}$ & $\begin{array}{r}1.20 \\
1.50 \\
52.30 \\
2.35\end{array}$ & $\begin{array}{r}7.52 \\
3.50 \\
48.92 \\
1.76\end{array}$ & \begin{tabular}{r|r}
2.76 \\
2.92 \\
48.76 \\
2.48
\end{tabular} & $\begin{array}{r}19.40 \\
5.30 \\
40.80 \\
1.43\end{array}$ \\
\hline & 11 & 12 & 13 & & 14 & 15 & 16 & 17 & 18 & 19 \\
\hline 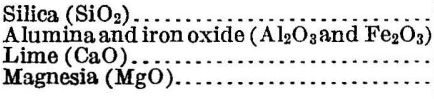 & $\begin{array}{r}6.04 \\
1.87 \\
49.68 \\
2.60\end{array}$ & $\begin{array}{r}3.10 \\
1.70 \\
47.25 \\
5.72\end{array}$ & \begin{tabular}{r|r}
10 & 1. \\
0 & 1. \\
51. & 51. \\
7 &
\end{tabular} & $\begin{array}{l}.12 \\
.56 \\
.70 \\
.69\end{array}$ & $\begin{array}{r}9.90 \\
1.82 \\
47.54 \\
1.99\end{array}$ & $\begin{array}{r}14.17 \\
4.17 \\
40.32 \\
4.18\end{array}$ & $\begin{array}{r}3.14 \\
.72 \\
51.94 \\
1.61\end{array}$ & $\begin{array}{r}3.60 \\
1.80 \\
51.00 \\
2.39\end{array}$ & $\begin{array}{r}3.21 \\
4.21 \\
51.44 \\
.34\end{array}$ & $\begin{array}{r}3.40 \\
1.34 \\
47.60 \\
5.32\end{array}$ \\
\hline
\end{tabular}

1, 2. Chambersburg limestone,Le Gore, Frederick County. Zies \& Schmidt, analysts. Rept. Maryland Geol. Survey, vol. 8, 1909, p. 396 .

3, 4. Chambersburg limestonc, Frederick, Frederick County. Zies and Gill, analysts. Idem.

5. Chambersburg limestone, Buckeystown, Frederick County. E. G. Zies, analyst. Idem.

6. Tomstown limestone, Cavetown, Washington County. E. G. Zies, analyst. Idem, p. 438.

7. Elbrook formation, Chewsville, Washington County. T. M. Price, analyst. Idem.

8. Conococheague limestone, Hagerstown, Washington County. O. E. Bransky, analyst. Idem, p. 440.

9. Beekmantown limestone, Hagerstown, Washington County. J. J. Porter, analyst. Idem.

10. Conococheague limestone, Hagerstown, Washington County. R. S. Williamson, analyst. Idem, p. 440 .

11. Beekmantown limestone, Williamsport, Washington County. Zies \& Gill, analysts. Idem.

12. Stones River limestone, Pinesburg, Washington County. Zies and Gill, analysts. Idem, p. 441.

13, 14. Stones River limestone, Pinesburg, Washington County. Catlett and Porter, analysts. Idem

15, 16. Beekmantown limestone, Charlton, Washington County. T. H. Bates, analyst. Idem, p. 442.

17. Beekmantown limestone, Grimes, Washington County. R. S. Williamson, analyst. Idem, p. 443.

18. Conococheague limestone, Keedysville, Washington County. T. M. Price, analyst. Idem.

19. Conococheague limestone, Sharpsburg, Washington County. R. S. Williamson, analyst. Idem. 


\section{METAMORPHIC LTMESTONES OF THE PIEDMONT AREA.}

In the Piedmont region of eastern Maryland many areas of crystalline limestones or marbles occur, being particularly large and numerous in Carroll, Baltimore, and Howard counties, and smaller and less important in Frederick County.

Considerable difference of opinion has been expressed as to the geologic age of these metamorphic limestones. It seems probable, however, that many if not all of them are of the same age as the unaltered Cambrian and Ordovician limestones farther west, from which they differ merely in being highly crystalline, the effect of pressure and heat.

In composition the metamorphic limestones vary, just as do the unmetamorphosed Cambrian and Ordovician limestones. The Cockeysville marble, for example, is highly magnesian, whereas much of the metamorphic limestone from Texas and Union Bridge is as low in magnesia as the best unaltered Trenton limestone.

The following table ${ }^{1}$ contains a number of analyses of low-magnesia metamorphic limestones from different localities in the Piedmont region of Maryland:

Analyses of metamorphic limestones, Maryland.

\begin{tabular}{|c|c|c|c|c|c|c|c|c|c|c|c|c|}
\hline & 1 & 2 & 3 & 4 & 5 & 6 & 7 & 8 & 9 & 10 & 11 & 12 \\
\hline $\begin{array}{l}\text { Silica }\left(\mathrm{SiO}_{2}\right) \\
\text { Alumina }\left(\mathrm{Al}_{2} \mathrm{O}_{3}\right) \\
\text { Iron oxide }\left(\mathrm{Fe}_{2} \mathrm{O}_{3}\right) \\
\text { Lime }(\mathrm{CaO}) \\
\text { Magnesia }(\mathrm{MgO})\end{array}$ & $\left\{\begin{array}{r}0.36 \\
0.20 \\
55.72 \\
0.19\end{array}\right.$ & $\begin{array}{r}2.10 \\
0.61 \\
53.70 \\
0.61\end{array}$ & $\begin{array}{r}4.90 \\
1.11 \\
50.92 \\
1.34\end{array}$ & $\left\{\begin{array}{r}3.34 \\
1.44 \\
0.80 \\
50.43 \\
1.85\end{array}\right.$ & $\begin{array}{r}8.06 \\
3.80 \\
1.68 \\
47.34 \\
1.43\end{array}$ & $\begin{array}{r}2.50 \\
0.61 \\
0.58 \\
52.62 \\
1.40\end{array}$ & $\left\{\begin{array}{r}0.68 \\
0.51 \\
53.53 \\
1.92\end{array}\right.$ & $\left\{\begin{array}{r}4.94 \\
2.64 \\
0.39 \\
48.25 \\
2.17\end{array}\right.$ & $\left\{\begin{array}{r}2.56 \\
0.45 \\
50.19 \\
4.28\end{array}\right.$ & $\left\{\begin{array}{r}16.25 \\
4.81 \\
1.68 \\
40.46 \\
2.95\end{array}\right.$ & $\left\{\begin{array}{r}1.81 \\
0.78 \\
53.88 \\
1.07\end{array}\right.$ & $\left\{\begin{array}{r}3.77 \\
1.03 \\
0.28 \\
49.80 \\
2.90\end{array}\right.$ \\
\hline
\end{tabular}

1-3. Texas, Baltimore County. Zies and Schmidt, analysts. Rept. Maryland Geol. Survey, vol. 8, 1909, p. 348.

4,5. Springville, Carroll County. M. R. Schmidt, analyst. Idem, p. 378.

6. Spring Mills, Carroll County. M. R. Schmidt, analyst. Idem, p. 378.

7. New Windsor, Carroll County. Zies and Schmidt, analysts. Idem, p. 378.

8. New Windsor, Carroll County. E. G. Zies, analyst. Idem, p. 378.

9. Linwood, Carroll County. Zies and Schmidt, analysts. Idem, p. 378.

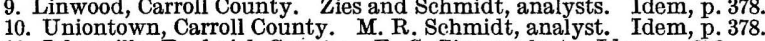

11. Johnsville, Frederick County. E. G. Zies, analyst. Idem, p. 378.

12. Norris, Frederick County. Zies and Schmidt, analysts. Idem p. 378.

\section{PORTLAND CEMENT INDUSTRY IN MARYLAND.}

Two Portland cement plants, that of the Security Cement \& Lime Co., at Security, in the western part of the State, and that of the Tidewater Portland Cement Co., at Union Bridge, in the eastern part, are now in operation in Maryland.

The plant of the Security Cement \& Lime Co. was built during 1907 and went into operation early in 1908. Since that date the original plant has been increased in size, and the company has taken up several related industries including the manufacture of lime, and the quarrying and preparing of fluxing stone, road metal, railway 
ballast, and so forth, both at Security, Md., and at Martinsburg, W. Va. The cement plant of the company is at Security, a station on the Western Maryland Railway a few miles east of Hagerstown. Limestone and shale are used, the limestone being obtained from lowmagnesia beds of the Conococheague limestone (Cambrian) in the immediate vicinity of the cement plant and the shale (Martinsburg shale of Ordovician age) from property owned by the company near Pinesburg.

The following table gives analyses of the limestone and shale used at the plant of the Security Cement \& Lime Co. ${ }^{1}$

Analyses of cement materials used at Security, Md.

\begin{tabular}{|c|c|c|c|c|c|c|}
\hline & \multicolumn{3}{|c|}{ Limestones. } & \multicolumn{3}{|c|}{ Shales. } \\
\hline & 1 & 2 & 3 & 1 & 2 & 3 \\
\hline $\begin{array}{l}\text { Silica }\left(\mathrm{SiO}_{2}\right) \\
\text { Alumina }\left(\mathrm{Al}_{2} \mathrm{O}_{3}\right) \\
\text { Iron oxide }\left(\mathrm{Fe}_{2} \mathrm{O}_{3}\right) \ldots \ldots \\
\text { Lime }(\mathrm{CaO}) \\
\text { Magnesia }(\mathrm{MgO}) \\
\text { Ignition loss } \ldots \ldots \ldots \ldots \ldots\end{array}$ & \begin{tabular}{r|}
7.06 \\
1.08 \\
1.01 \\
49.14 \\
1.70 \\
40.02
\end{tabular} & $\begin{array}{r}6.04 \\
1.96 \\
.62 \\
48.88 \\
1.74 \\
39.30\end{array}$ & $\begin{array}{r}5.62 \\
1.21 \\
.81 \\
49.78 \\
1.58 \\
40.96\end{array}$ & $\begin{array}{r}62.60 \\
21.25 \\
5.23 \\
.36 \\
.94 \\
\text { n. } \\
.\end{array}$ & $\begin{array}{r}63.91 \\
18.73 \\
8.11 \\
\text { None. } \\
1.83 \\
7.41\end{array}$ & $\begin{array}{r}59.74 \\
22.63 \\
3.16 \\
.73 \\
2.43 \\
7.73\end{array}$ \\
\hline
\end{tabular}

The plant of the Tidewater Portland Cement Co., which commenced operations in October, 1911, is situated in Frederick County, near Union Bridge, on the Western Maryland Railway. It is the intention to manufacture not only a normal Portland cement but also a white Portland cement, building lime, and hydrated lime. The company's engineers report that raw materials for the manufacture of all these products exist on the property.

The raw materials available at Union Bridge are limestone and slaty rocks. The limestone is the metamorphosed and highly crystalline stone commonly found in the Piedmont district, and the "shales" are slaty rocks of volcanic origin. Analyses ${ }^{2}$ of both calcareous and argillaceous materials, R. K. Meade, analyst, are given in the following table:

Analyses of raw materials, Union Bridge, Md.

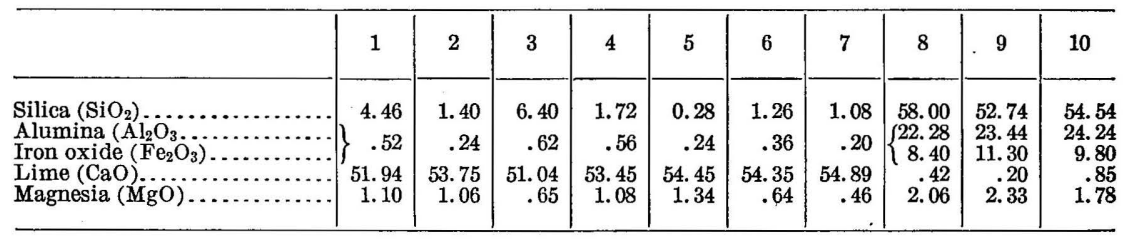

1-7. Crystalline limestone.

8-10. Volcanic slate. 


\section{BIBLIOGRAPHY.}

Mathews, E. B., and Grasty, J. S., The limestones of Maryland, with special reference to their use in the manufacture of lime and cement: Maryland Geol. Survey, vol. 8, 1909, pp. 227-484.

Ries, HeINRICH, Report on the clays of Maryland: Maryland Geol. Survey, vol. 4, 1902, pp. 203-505.

In addition to the reports above cited, which deal with the clays and limestones of the entire State, valuable data on the resources of certain areas are found in other reports issued by the State Survey. Among these, for example, are the volumes devoted to the geology and mineral resources of Allegany and Garrett counties.

\section{PORTLAND CEMENT RESOURCES OF MASSACHUSETTS.}

In the western part of Massachusetts extensive quarries are operated for both marble and lime. The stone quarried is a highly crystalline limestone or marble of Cambrian and Ordovician age. Much of this stone is highly magnesian, but all of that produced in the northwestern portion of the State, in Berkshire County, seems to be low in magnesia. The analyses given below are fairly representative of this product.

Unfortunately for the prospects of a Portland cement industry in the State no shales occur near these limestones, and the glacial clays generally contain too much sand and pebbles to be worth considering. This fact, taken in connection with the cost of fuel in this district, renders it improbable that Massachusetts will become a successful producer of Portland cement on a large scale.

Analyses of limestones from Massachusetts.

\begin{tabular}{|c|c|c|c|c|}
\hline$=$ & 1 & 2 & 3 & 4 \\
\hline Silica $\left(\mathrm{SiO}_{2}\right) \ldots \ldots \ldots \ldots \ldots \ldots \ldots$ & 0.69 & 0.31 & n. d. & 0.63 \\
\hline $\begin{array}{l}\text { Alumina } \\
\text { Iron oxide }\left(\mathrm{Al}_{2} \mathrm{O}_{3}\right) \\
\left.\mathrm{Fe}_{2} \mathrm{O}_{3}\right) \ldots \ldots \ldots \ldots \ldots \ldots\end{array}$ & .06 & .23 & n. d. & .55 \\
\hline Lime carbonate $\left(\mathrm{CaCO}_{3}\right)$ & 93.86 & 98.80 & 99.03 & 99. 60 \\
\hline 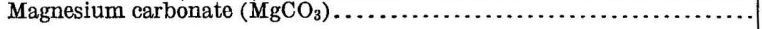 & 5.34 & & .27 & .49 \\
\hline
\end{tabular}

1. North Adams Marble Co., North Adams, Berkshire County. W. P. Mason, analyst. Twentieth Ann. Rept. U. S. Geol. Survey, pt. 6 (continued), 1899, p. 406.

2. Cheshire Manufacturing Co., Cheshire, Berkshire County. Davenport \& Williams, analysts. Idem, p. 410 . p. 410 . H. Hastings's quarry, West Stockbridge, Berkshire County. J. B. Britton, analyst. Idem,
p. 411 .

4. Adams Marble Co., Renfrew, Berkshire County. E. E. Olcott, analyst. Idem, p. 410.

Though the prospects for the development of a normal Portland cement industry in Massachusetts are far from bright, an interesting special product-white Portland cement-was made on a small scale for several years by the Berkshire White Portland Cement Co. at Clayton, Berkshire County, from the pure crystalline Silurian limestones of that area. The manufacture of this cement was discontinued in 1909. 


\section{PORTIAND CEMENT RESOURCES OF MICHIGAN: PORTLAND CEMENT MATERIALS.}

\section{LIMESTONES.}

Of the formations that outcrop in Michigan three-the Dundee limestone, the Traverse formation, and the Quaternary marl-have been utilized in the manufacture of Portland cement. Anotherthe Bayport limestone-yields limestones which so far have not been utilized, though low in magnesia and otherwise satisfactory as cement materials.

\section{DUNDEE IIMESTONE.}

The Dundee limestone lies at the base of the Devonian system, and although generally concealed beneath glacial drift and surficial deposits comes to the surface (see Pl. IX) in a belt 2 to 9 miles wide, trending northeast and southwest across Wayne, Monroe, and Lenawee counties, in the southeast corner of the State. The Dundee occurs also at the extreme northern end of the southern peninsula and on Mackinac and neighboring islands as well as in the adjacent portion of the northern peninsula $(\mathrm{Pl} . \mathrm{X})$. The purest layer of limestone in the Dundee thus far discovered is extensively quarried at Sibley and Bellevue, near Trenton, in Wayne County, and is used in the manufacture of sodium bicarbonate, soda ash, and caustic soda near Detroit. The finely powdered calcium carbonate resulting as a by-product from the manufacture of caustic soda is used by the Michigan Alkali Co. for making Portland cement at Wyandotte. This same limestone, on account of its uncommon purity, is also extensively used in the manufacture of beet sugar.

The Dundee contains several beds of limestone, most of which, however, carry too high a percentage of magnesia to permit their use in making Portland cement under the standard now required. Thus far only one layer, the celebrated 9-foot bed, best exposed at the Sibley quarries (pp. 209-210), has been found sufficiently pure to be utilized. The composition of the rock quarried at Bellevue and used by the Michigan Alkali Co. at Wyandotte is as follows:

Analysis of Dundee limestone at Bellevue.

[Analyst, O. Button.]

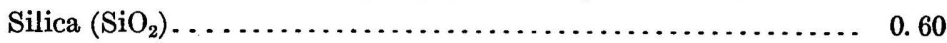

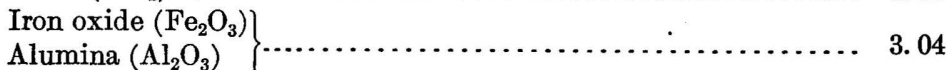

Calcium carbonate $\left(\mathrm{CaCO}_{3}\right) \ldots \ldots \ldots \ldots \ldots \ldots \ldots \ldots \ldots \ldots \ldots . .24$

Magnesium carbonate $\left(\mathrm{MgCO}_{3}\right) \ldots \ldots \ldots \ldots \ldots \ldots \ldots \ldots \ldots \ldots, 1.00$ 


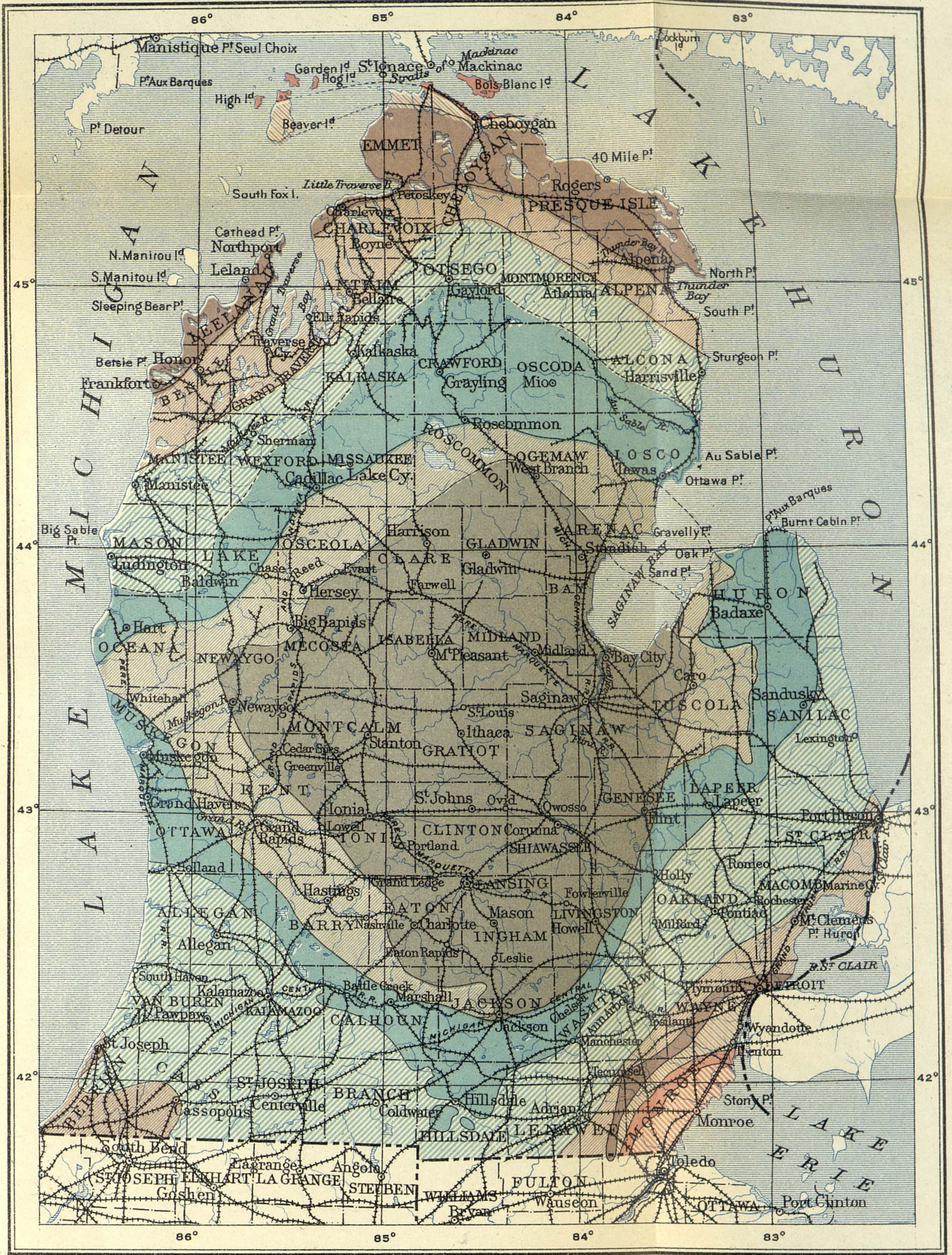

LEGEND

Saginaw formation (shale, sandstone, and clay)

Parma sandstone and Grand Rapids group (including Bayport limestone and Michigan formation)

(shale, limestone, and gypsum)

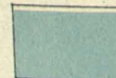

Marshall formation Chiefly sandstone)

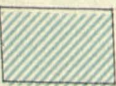

Coldwater shale

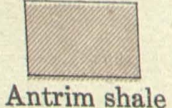

Antrim shale

Traverse formation (limestone, dolomite, and shale)

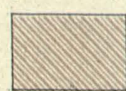

Dundee limestone

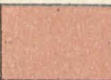

Monroe formation above Sylvania sandstone member (dolomite and limestone)

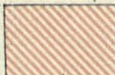

Monroe formation including and below Sylvania sandstone member

(dolomite and shale)

Note: The boundary between the

GEOLOGIC MAP OF THE LOWER PENINSULA OF MICHIGAN

Geology from Water-Supply Paper 182, Plate II

Scale $\frac{1}{2,500,000}$

$\frac{25 \quad \begin{array}{l}\text { Scale } \frac{1}{2,500,000} \\ 25\end{array} \quad \text { 100 Miles }}{1912}$





\section{C. Russell describes ${ }^{1}$ the Dundee limestone as follows:}

The limestone of the Dundee formation is also quarried 2 miles northeast of Dundee, Monroe County, where four layers of limestone are exposed, the composition of which is shown below: ${ }^{2}$

Analyses of Dundee limestone from the "Christiancy quarry," near Dundee.

[Analyses 1, 3, 5, and 6 by G. A. Kirschmeier, and analyses 2 and 4 by K. J. Sundstrom.]

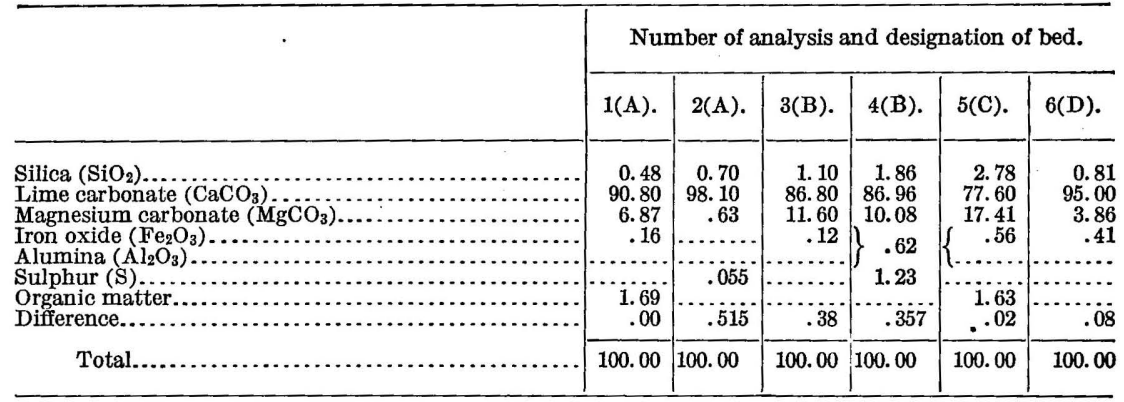

Bed A is uppermost; a gray limestone 1 to 2 feet thick, fossiliferous.

Bed $B$ is a compact brownish limestone, bituminous, 4 to $4 \frac{1}{2}$ feet thick, fossiliferous.

Bed $\mathbf{C}$ is a soft, dark-gray limestone, without seams, 7 to 8 feet thick.

Bed $D$ is similar to bed C, 8 feet thick; bottom of quarry.

The rocks exposed in the quarry near Dundee are considered by Sherzer as the identical layers that are extensively quarried near Trenton. When sufficiently low in magnesia the beds are evidently favorable for use in making Portland cement, the only questionable features seeming to be the expense of quarrying and crushing. Certain of the layers at Dundee contain petroleum, the influence of which on the mixing of slurry is not known.

The following notes concerning the Sibley quarry at Trenton, Wayne County, have been kindly furnished by Mr. Frank Leverett:

The quarry occupies an area of 35 acres. The rocks dip westward at the rate of about 5 feet in 100 . There is a low anticlinal arch trending approximately east and west, which passes through the midst of the excavation, from the crest of which the beds dip away at the rate of about 1 foot in 100. The strata are cut by two systems of joints, bearing about N. $20^{\circ} \mathrm{E}$. and N. $60^{\circ} \mathrm{E}$. The quarry is situated in an irregular hill which rises about 30 feet above the level of the adjacent portion of Detroit River. On the higher portions of the hill there is no covering of drift, but on the sides the solid rock is concealed beneath several feet of till. Where the glacial deposits have been removed, the surface of the rock beneath is intensely glaciated. There are two sets of glacial grooves, of which the earlier bears about S. $28^{\circ} \mathrm{W}$. and the later approximately N. $30^{\circ} \mathrm{W}$.

The strata exposed in the quarry follow, beginning at the surface.

\footnotetext{
1 Russell, T. C., The Portland cement industry in Michigan: Twenty-second Ann. Rept. U. S. Geol. Survey, pt. 3, 1902, pp. 642-643.

2 Sherzer, W. H., Geological report on Monroe County, Mich.: Geol. Survey Michigan, vol. 7, pt. 1, 1900, pp. 76, 177-178.
} $48834^{\circ}-$ Bull. $522-13-14$ 
Section at Sibley quarry at Trenton, Wayne County, Mich.

1. Thin-bedded gray limestone, suitable for use as a flux

2. "Upper 6-foot bed," a gray limestone, containing 96 per cent $\mathrm{CaCO}_{3}$; used in alkali works; a portion of the lower part of the bed, about 8 inches in thickness, is now rejected on account of its containing too much bituminous matter...

3. Fossiliferous blue-gray limestone, containing 90 per cent $\mathrm{CaCO}_{3}$; suitable for use in alkali works.

4. "Second 6-foot bed," a blue-gray limestone, containing from 94 to 95 per cent $\mathrm{CaCO}_{3}$; used as a building stone and in alkali works..............

5. "Five-foot bed," very similar to "Upper 6-foot bed"...................

6. "Cherty bed," a cherty limestone, not at present utilized...............

7. "Third 6-foot bed," a blue-gray limestone, with a little chert in its lower portion; used in alkali works and as a building stone.................

8. "Nine-foot bed," a fossiliferous gray limestone; used in the manufacture of beet sugar and suitable for making Portland cement.................

9. "The 6-foot magnesian limestone," dove colored.....................

10. "The 8-foot bed," a thick-bedded gray limestone; used as building stone.

11. "The 10-foot bed," a gray limestone, of which the upper 3 feet contains about 85 per cent, the next 3 feet 95 per cent, and the lower 4 feet about 80 per cent $\mathrm{CaCO}_{3}$; the lower portion contains from 3 to 4 per cent $\mathrm{SiO}_{2}$; the middle portion of the bed is very fossiliferous..................

12. Brownish limestone, containing 15 per cent $\mathrm{SiO}_{2}, 0.5$ per cent $\mathrm{MgO}$, and about 85 per cent $\mathrm{CaCO}_{3}$; this rock is marked with white spots, thought to be aluminum silicate; used as building stone; opened to a depth of about

Total

Chemical analyses of certain of the beds described above are given below:

Analyses of limestone from Sibley quarries at Trenton, Mich.

[Analyst, K. J. Sundstrom.]

\begin{tabular}{|c|c|c|c|c|c|c|c|c|c|}
\hline Constituent. & $\begin{array}{l}\text { South } \\
\text { part of } \\
\text { quar- } \\
\text { ry. }\end{array}$ & $\begin{array}{c}5 . \\
\text { North } \\
\text { part of } \\
\text { quar- } \\
\text { ry. }\end{array}$ & 6. & $\begin{array}{c}8 . \\
\text { Upper } \\
\text { part. }\end{array}$ & $\begin{array}{c}8 . \\
\text { Cen- } \\
\text { tral } \\
\text { part. }\end{array}$ & $\begin{array}{l}8 . \\
\text { Lower } \\
\text { part. }\end{array}$ & 9. & 10. & $\begin{array}{l}11 . \\
\text { Cen- } \\
\text { tral } \\
\text { part. }\end{array}$ \\
\hline \multirow[t]{2}{*}{ 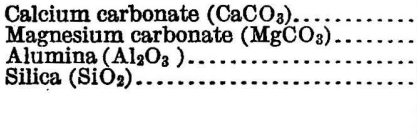 } & $\begin{array}{r}95.50 \\
2.36 \\
.30 \\
1.04\end{array}$ & $\begin{array}{r}99.26 \\
.21 \\
\mathrm{Tr} . \\
.50\end{array}$ & $\begin{array}{r}93.28 \\
4.11 \\
.40 \\
1.90\end{array}$ & $\begin{array}{r}97.33 \\
1.84 \\
\text { Tr. } \\
.64\end{array}$ & $\begin{array}{r}99.00 \\
.22 \\
\text { Tr. } \\
.54\end{array}$ & $\begin{array}{r}95.62 \\
3.15 \\
\text { Tr. } \\
.96\end{array}$ & $\begin{array}{r}80.04 \\
15.96 \\
2.70 \\
1.02\end{array}$ & $\begin{array}{r}89.05 \\
8.08 \\
\text { Tr. } \\
2.20\end{array}$ & $\begin{array}{r}95.00 \\
4.00 \\
\mathrm{Tr} . \\
.56\end{array}$ \\
\hline & 99.20 & 99.97 & 99.69 & 99.81 & 99.76 & 99.73 & 99.72 & 99.33 & 99.56 \\
\hline
\end{tabular}

TRÁVERSE FORMATION.

\section{Russell describes the Traverse formation as follows: ${ }^{1}$}

The rocks designated by this name consist principally of shale and limestone, occur in succession next above the Dundee formation, and belong to the Devonian system. They form a belt about 2 miles wide, which crosses Wayne and Monroe counties, *** but are there concealed beneath surficial deposits, and also form a broad area, which crosses the northern end of the southern peninsula from 
U. S. GEOLOGICAL SURVEY

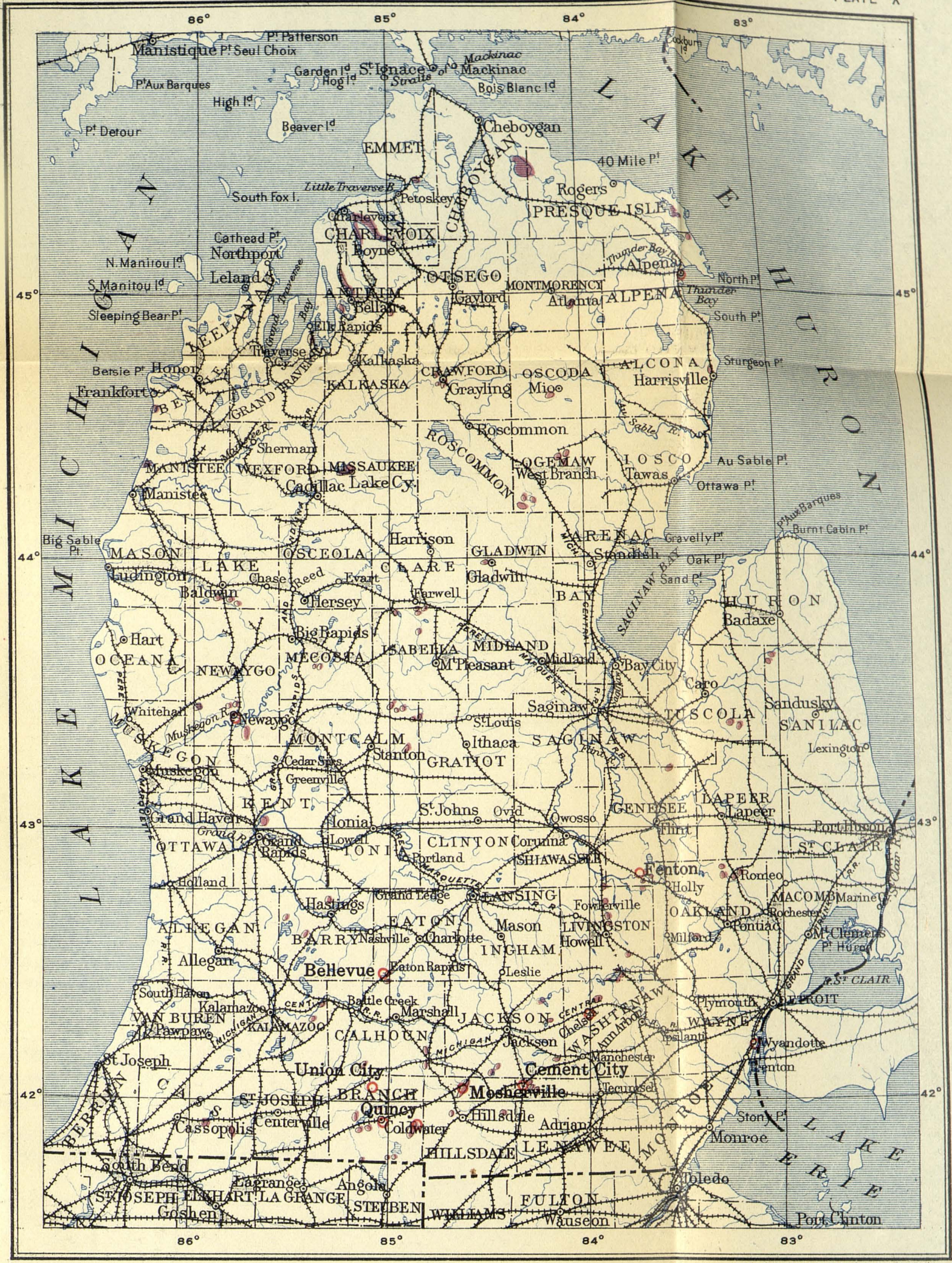

MAP OF THE LOWER PENINSULA OF MICHIGAN SHOWING MARL DEPOSITS AND PORTLAND CEMENT PLANTS

By I. C. Russell

Revised by E. C. Eckel

Scale $\frac{1}{2,500,000}$

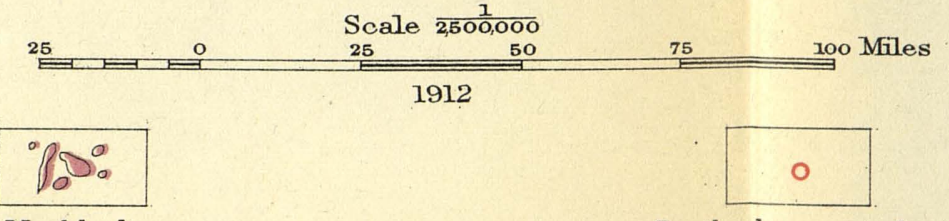

Marl beds

Portland cement plant 

Alpena, on the border of Lake Huron, to Frankfort, on the shore of Lake Michigan. The limestone of the Traverse group comes to the surface at Alpena and is utilized by the Alpena Portland Cement Co. In the quarry where it is well exposed it is a light-colored compact rock, carrying corals and other fossils. Its composition is as rollows:

Analyses of limestone from the quarries of the Alpena Portland Cement Co., Alpena, Mich.

[Analyst, F. H. Haldeman.]

\begin{tabular}{|c|c|c|c|c|c|c|c|c|c|}
\hline Constituent. & 1 & 2 & 3 & 4 & 5 & 6 & 7 & 8 & 9 \\
\hline $\begin{array}{l}\text { Silica }\left(\mathrm{SiO}_{2}\right) \ldots \ldots \\
\text { Calcium carbonate }\left(\mathrm{CaCO} \mathrm{O}_{3}\right) \ldots \ldots \\
\text { Magnesium carbonate }\left(\mathrm{MgCO}_{3}\right) \ldots \ldots \\
\text { Iron oxide }\left(\mathrm{Fe}_{2} \mathrm{O}_{3}\right) \ldots \ldots \ldots\end{array}$ & $\begin{array}{r}0.36 \\
95.91 \\
3.63 \\
.13\end{array}$ & $\begin{array}{r}1.77 \\
89.10 \\
8.67 \\
.35\end{array}$ & $\begin{array}{r}0.33 \\
98.37 \\
.92 \\
.18\end{array}$ & $\begin{array}{r}0.38 \\
98.03 \\
1.36 \\
.19\end{array}$ & $\begin{array}{r}1.38 \\
96.35 \\
.94 \\
1.21\end{array}$ & $\begin{array}{r}1.64 \\
96.50 \\
1.26 \\
.27\end{array}$ & $\begin{array}{r}1.46 \\
96.92 \\
1.46 \\
.54\end{array}$ & $\begin{array}{r}0.42 \\
98.04 \\
.98 \\
.18\end{array}$ & $\begin{array}{r}0.68 \\
98.03 \\
1.05 \\
.26\end{array}$ \\
\hline & 100.03 & 99.89 & 99.80 & 99.96 & 99.88 & 99.67 & 99.90 & 99.72 & 100.02 \\
\hline
\end{tabular}

1. Quarry C: Shell to be removed in stripping; 1 to 2 feet thick.

2. Quarry C: Top stratum, 2 feet thick.

3. Quarry C: Second stratum, 2 feet thick.

4. Quarry C: Third stratum, 4 feet thick.

5. Quarry C: Fourth stratum, 2 feet thick.

6. Quarry F: First stratum, 2 feet thick.

7. Quarry F: Second stratum, 1 foot thick.

8. Quarry F: Third stratum, 2 feet thick.

9. Quarry F: Fourth stratum, floor of quarry.

All samples show traces of sulphates and phosphates.

The favorable results in the manufacture of Portland cement obtained from the use of the limestones just considered will no doubt stimulate further search for favorably situated outcrops of the same formations, in which the accompanying map, showing where they may be expected to occur, will be of assistance.

GRAND RAPIDS GROUP.

The Grand Rapids group is composed of the Bayport limestone at the top and the Michigan formation at the bottom. Russell describes the rocks as follows: ${ }^{1}$

Another formation containing limestone, present in southern Michigan is designated as the "Michigan series" on the map [Pl. IX], and belongs to the $* * *$ Mississippian $* * *$. The limestones occur principally in the upper portion of the system and outcrop on the borders of the coal-bearing rocks which form the surface. They are in great part concealed by glacial drift and other surficial rocks over an extensive area in the central part of the southern peninsula.

The limestone of the Michigan series outcrops at Bayport and Sebewaing, in Huron County, on the east side of Saginaw Bay; on the Charity Islands; at Bellevue, in the southwestern part of Eaton County; and near the Portage River, about 5 or 6 miles north of Jackson. Other localities where it is accessible no doubt occur. It has been quarried at Bayport, Bellevue, and near Jackson and calcined to make lime. Its composition, as indicated by the following analyses (stated as published), is such as to make it suitable for use in the manufacture of Portland cement, but up to the present time it has not been utilized for this purpose. 
Analysis of limestone from Bayport, Mich..

[Analyst, J. W. Langley.]

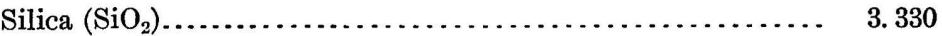

Oxide of iron $\left(\mathrm{Fe}_{2} \mathrm{O}_{3}\right)$ and alumina $\left(\mathrm{Al}_{2} \mathrm{O}_{3}\right) \ldots \ldots \ldots \ldots \ldots \ldots . . .334$

Carbonate of magnesia $\left(\mathrm{MgCO}_{3}\right) \ldots \ldots \ldots \ldots \ldots \ldots \ldots \ldots \ldots \ldots . .944$

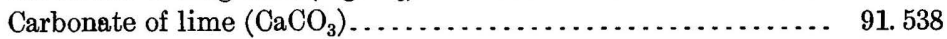

Phosphorus and sulphur............................ Trace.

Organic matter and loss.............................. 2.854

(Quicklime, 51.29.)

100. 000

Analysis of limestone from Bellevue, Mich.

[Analyst, Carl Rominger.]

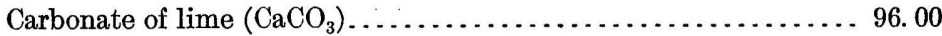

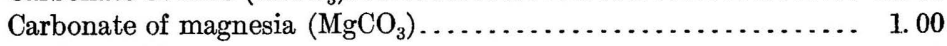

Hydrate of iron oxide................................. $\quad .50$

Insoluble residue................................. 1.50

Analysis of limestone from Portage River, Mich.

99.00

[Analyst, Carl Rominger.]

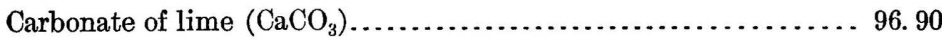

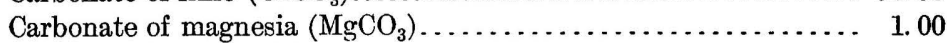

Alumina $\left(\mathrm{Al}_{2} \mathrm{O}_{3}\right)$ and iron $\left(\mathrm{Fe}_{2} \mathrm{O}_{3}\right) \ldots \ldots \ldots \ldots \ldots \ldots \ldots \ldots \ldots \ldots \ldots \ldots \ldots \ldots \ldots \ldots \ldots$

Insoluble residue................................ 1.40

99.00

The limestone of the "Michigan series" contains layers that are high in magnesia or are otherwise unfavorable for cement making, but in spite of this the formation is evidently worthy of careful attention from persons interested in the industry under review wherever it occurs near deposits of clay or shale and is suitably situated in reference to transportation facilities, etc.

All of the limestones referred to above are of marine origin and usually contain fossils, among which coral is frequently conspicuous. The rocks are usually compact and hard and if employed in the manufacture of Portland cement must be crushed and ground to a fine powder. Except for the expense thus involved they are in certain instances as favorable for the use indicated as the marls described below.

\section{MARL DEPOSITS.}

\section{Russell describes the marl deposits as follows: ${ }^{1}$}

Some idea of the abundance and wide distribution of marl deposits in the southern peninsula may be obtained from the map [Pl. IX], on which those it has been convenient to locate are indicated. This is by no means a complete index of the total number of marl deposits that occur in the area represented, as it has not.been found practicable to make a detailed survey for the purpose of mapping them. It is safe to say that those shown on the map are probably less than one-fourth of the total number that exists in the southern peninsula. Those indicated on the map, with possibly a few exceptions, have an area in excess of 50 acres, and an average depth 
of 10 feet or more. The marl beds of Michigan only are considered in this report, but deposits of the same character are known to occur in neighboring States, as well as in the adjacent portions of Canada, but their entire distribution and their precise relation to climatic and geological conditions, etc., have not been determined. In extent the marl beds vary from a few acres up to several hundred acres. Some of the Portland cement companies, it is stated, have marl beds from 500 to 1,000 acres in area, with an average depth of 20 feet or more. In most instances these figures probably refer to two or more separate but perhaps closely adjacent beds. It is safe to say, however, that single beds from 100 to 300 acres in area and with an average depth of 20 feet or more are not rare.

In depth the marl beds vary from a few inches up to over 35 feet, as has been demonstrated by the writer by actual borings. Other observers report depths up to 50 and even in excess of 70 feet, which are no doubt reliable measures.

The marl beds occur principally in the basins of existing lakes, but frequently extend beyond the present water margins and underlie the bordering swamp. They are present also in many instances beneath beds of peat or muck, from a few inches to several feet thick, on which tamarack and other trees grow. The presence of marl beds about the borders of existing lakes and at an elevation in some cases of 10 or 15 feet above their surfaces shows that the lakes have been lowered, usually by the cutting down of their outlets, since the marl began to form. In some examples peat occurs beneath extensive marl beds, and in a few cases two or three alternations of layers of peat and marl have been discovered. Usually, however, there is but one bed of marl present, which rests on a sandy or clayey bottom. It is evident in all instances that the marl was deposited in a lake, and that the swamps, or in some instances the now well-drained tracts, where it is found, were formerly flooded. 
Analyses of Michigan marls.

\begin{tabular}{|c|c|c|}
\hline Locality. & Analyst. & $\begin{array}{c}\text { Silica } \\
\left(\mathrm{SiO}_{2}\right) .\end{array}$ \\
\hline $\begin{array}{l}\text { Alpena........ } \\
\text { Bronson..... } \\
\text { Cold water... }\end{array}$ & $\begin{array}{l}\text { E. D. Campbell..... } \\
\text { W. H. Simmons.... } \\
\text { E. D. Campbell.... }\end{array}$ & $\begin{array}{r}8.13 \\
1.75 \\
.52\end{array}$ \\
\hline $\begin{array}{l}\text { Do....... } \\
\text { Do...... }\end{array}$ & 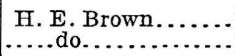 & 8.60 \\
\hline Crapo Lake & $\left\{\begin{array}{c}\text { L athbury and } \\
\text { Spackman. }\end{array}\right.$ & 1.46 \\
\hline $\begin{array}{r}\text { Fenton..... } \\
\text { Do...... } \\
\text { Do..... }\end{array}$ & 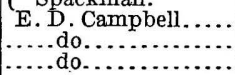 & $\begin{array}{r}.48 \\
1.36 \\
.55\end{array}$ \\
\hline Do.. & ......do... & .90 \\
\hline Fourmile Lake.. & ....do............... & 6.66 \\
\hline Grayling Lake. & R. C. Kedzie.......... & 1.90 \\
\hline Jackson........ & E. D. Campbell & 2.73 \\
\hline Lime Lake.. & $\left\{\begin{array}{l}\text { Dearborn Drug \& } \\
\text { Chemical Works, }\end{array}\right.$ & 1.30 \\
\hline Ludington. & E. D. Campbell..... & 1.85 \\
\hline Lupton.. & $\left\{\begin{array}{r}\text { Lath bury and } \\
\text { Spackman. }\end{array}\right.$ & .24 \\
\hline Do.. & ....do..................... & .25 \\
\hline Mills Lake... & . .....do.............. & .70 \\
\hline Mosherville... & (Not given)........... & .91 \\
\hline Do......... & E. D. Campbell... & .20 \\
\hline $\begin{array}{l}\text { Pleasant Lake.. } \\
\text { Plummer Lake.. }\end{array}$ & $\left\{\begin{array}{l}\text { L a thb ury and } \\
\text { Spackman. }\end{array}\right.$ & $\begin{array}{r}.84 \\
1.78\end{array}$ \\
\hline Runyan Lake... & E. D. Campbell..... & .28 \\
\hline
\end{tabular}

\begin{tabular}{|c|c|c|c|c|c|c|}
\hline $\begin{array}{c}\text { Alum } \\
\text { ina } \\
\left(\mathrm{Al}_{2} \mathrm{O}_{3}\right.\end{array}$ & $\begin{array}{c}\text { Iron } \\
\text { oxide } \\
\left(\mathrm{Fe}_{2} \mathrm{O}_{3}\right)\end{array}$ & $\begin{array}{l}\text { Iime } \\
(\mathrm{CaO}) .\end{array}$ & $\begin{array}{c}\text { Lime } \\
\text { carbon- } \\
\text { ate } \\
\left(\mathrm{CaCO}_{3}\right) .\end{array}$ & $\begin{array}{l}\text { Magne- } \\
\text { sia } \\
\text { (MgO). }\end{array}$ & $\begin{array}{l}\text { Magne- } \\
\text { sium } \\
\text { carbon- } \\
\text { ate } \\
\left(\mathrm{MgCO}_{3}\right)\end{array}$ & $\begin{array}{c}\text { Sul- } \\
\text { phur } \\
\text { triox- } \\
\text { ide } \\
\left(\mathrm{SO}_{3}\right) \text {. }\end{array}$ \\
\hline \multicolumn{2}{|c|}{$\begin{array}{l}\text { 3. } 06 \\
1.57\end{array}$} & $\begin{array}{r}43.09 \\
409\end{array}$ & a 76 & 0.54 & a 1.13 & \multirow{2}{*}{$\begin{array}{r}0.15 \\
.89\end{array}$} \\
\hline W & $\left.\right|^{57} .53$ & $\begin{array}{r}a 49.24 \\
51.66\end{array}$ & $\begin{array}{r}87.92 \\
a 92.25\end{array}$ & $\begin{array}{c}a .44 \\
1.37\end{array}$ & $\begin{array}{r}.92 \\
a .87\end{array}$ & \\
\hline \multirow[t]{2}{*}{$\begin{array}{r}.2 \\
1.3\end{array}$} & $\begin{array}{r}19 \\
1.54\end{array}$ & $\begin{array}{l}46.20 \\
54.69\end{array}$ & $\begin{array}{l}a 82.51 \\
{ }_{997.52}\end{array}$ & $\begin{array}{r}.88 \\
2.78\end{array}$ & $\begin{array}{l}a 1.85 \\
a 5.84\end{array}$ & \\
\hline & & 50.75 & $a 90.62$ & 1.46 & $a 3.07$ & \multirow{3}{*}{$\begin{array}{l}.55 \\
.69\end{array}$} \\
\hline \multirow{2}{*}{$\begin{array}{r}.17 \\
.55 \\
.14\end{array}$} & $\begin{array}{l}.51 \\
.36 \\
54\end{array}$ & $\begin{array}{l}52.28 \\
50.03 \\
51\end{array}$ & $\begin{array}{l}a 93.25 \\
a 89.34\end{array}$ & $\begin{array}{l}1.85 \\
1.95\end{array}$ & $\begin{array}{l}\text { a } 3.88 \\
\text { a } 4.10\end{array}$ & \\
\hline & .54 & 51.76 & $a 92.15$ & 1.90 & $a 3.99$ & \\
\hline \multirow{2}{*}{$\begin{array}{r}.2 \\
3.1\end{array}$} & . 39 & 51.57 & $a 92.09$ & 1.68 & $a 3.52$ & \multirow{2}{*}{$\begin{array}{l}\because 46 \\
1.25\end{array}$} \\
\hline & 1.36 & $a$ a 47.09 & 84.09 & $a_{1.77}$ & 3. 72 & \\
\hline 1 & . 10 & 45.16 & $a 79.86$ & .32 & $a .67$ & .56 \\
\hline \multirow[t]{2}{*}{2} & .46 & 50.58 & $a 90.32$ & 1.61 & a 3.39 & .39 \\
\hline & 70 & a 53.19 & 94.98 & 1.44 & a 3.02 & \multirow{2}{*}{$\begin{array}{c}\text { Trace. } \\
.22\end{array}$} \\
\hline \multirow[t]{3}{*}{.65} & \multirow[b]{2}{*}{.08 } & 51.83 & a 92.50 & 1.03 & $a 2.16$ & \\
\hline & & 52.97 & $a 94.58$ & 1.13 & $a_{2.37}$ & $\begin{array}{l}.22 \\
.08\end{array}$ \\
\hline \multirow{2}{*}{\multicolumn{2}{|c|}{.19}} & 52.28 & $a 93.53$ & 1.14 & $\begin{array}{l}a 2.39 \\
\end{array}$ & \multirow{2}{*}{.18} \\
\hline & & 50,43 & $a 90.07$ & 1.26 & $a 2.65$ & \\
\hline \multicolumn{2}{|c|}{.29} & a 52.15 & 93.12 & $a 1.42$ & 2. 98 & \multirow{2}{*}{$\begin{array}{l}.31 \\
.58\end{array}$} \\
\hline .50 & .60 & 50.12 & a 89.50 & .83 & a 1.74 & \\
\hline \multicolumn{2}{|c|}{.2} & 51.28 & a 91.57 & 1.77 & & \\
\hline & 52.38 & a 93.53 & 1.49 & $a 3.13$ & \\
\hline 65 & .67 & 52.6 & $a 94$ & 1.75 & a 3.67 & .38 \\
\hline
\end{tabular}

\begin{tabular}{|c|c|c|}
\hline $\begin{array}{l}\text { Loss on } \\
\text { igni- } \\
\text { tion. }\end{array}$ & $\begin{array}{c}\text { Organic } \\
\text { matter. }\end{array} \mid$ & Remarks. \\
\hline 44.99 & & \multirow{9}{*}{ 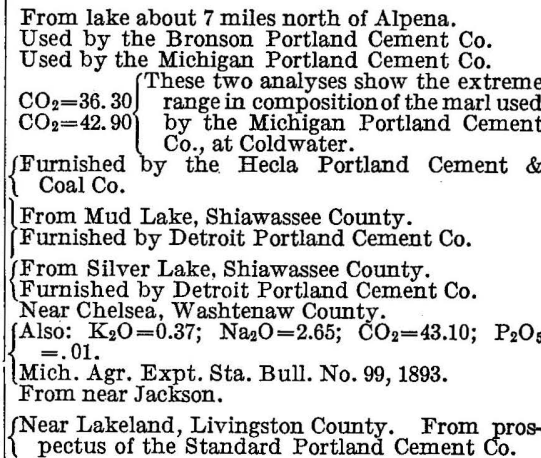 } \\
\hline & & \\
\hline & $\begin{array}{r}.05 \\
10.50\end{array}$ & \\
\hline 45.02 & & \\
\hline $\begin{array}{l}44.47 \\
45.72\end{array}$ & & \\
\hline & & \\
\hline & 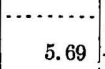 & \\
\hline & & \\
\hline & & \\
\hline 45.49 & & $\left\{\begin{array}{l}\text { In Ogemaw County. From prospectus of the } \\
\text { Lupton Portland Cement Co. }\end{array}\right.$ \\
\hline $\begin{array}{l}46.05 \\
47.08\end{array}$ & & fIn Ogemaw County. Furnished by Hecla Port- \\
\hline & 2.13 & $\begin{array}{l}\text { Furnished by the Omega Portland Cement Co. } \\
\text { Uused by the Omega Portland Cement Co. }\end{array}$ \\
\hline 45.86 & & $\begin{array}{l}\text { Y the Omega Portland Cement Co. } \\
\text { Omega Portland Cement Co. }\end{array}$ \\
\hline 45.60 & & $\begin{array}{l}\text { Near Three Rivers. Furnished by Three Rivers } \\
\text { Portland Cement Co. }\end{array}$ \\
\hline 44.31 & & $\begin{array}{l}\text { In Ogemaw County. Furnished by Hecla Port- } \\
\text { land Cement \& Coa JCo. }\end{array}$ \\
\hline & & ar Fenton, in Living \\
\hline
\end{tabular}




\begin{tabular}{|c|c|c|c|c|c|c|c|c|c|c|c|c|}
\hline $\begin{array}{l}\text { Union City...... } \\
\text { Do............. }\end{array}$ & $\mid \begin{array}{l}\text { A. Lundteigen....... } \\
\text {.....do.............. }\end{array}$ & $\begin{array}{r}1.95 \\
.50\end{array}$ & 1. & & $\begin{array}{l}52.25 \\
44.95\end{array}$ & $\begin{array}{l}a 93.32 \\
a 80.32\end{array}$ & & & & $\begin{array}{l}42.40 \\
36.30\end{array}$ & & $\left\{\begin{array}{l}\text { Moisture and organic matter in air-dried sample, } \\
13.95 \text { in first and } 4.97 \text { in second anaiysis. These } \\
\text { two analyses show range in composition of marl }\end{array}\right.$ \\
\hline $\begin{array}{l}\text { Wetzell............ } \\
\text { Do.......... }\end{array}$ & \begin{tabular}{|l|} 
E. D. Campbell...... \\
......................
\end{tabular} & $\begin{array}{r}1.44 \\
.82\end{array}$ & $\begin{array}{l}.28 \\
.49\end{array}$ & .16 & $\begin{array}{l}51.93 \\
52.94\end{array}$ & $\begin{array}{l}a 92.75 \\
a 94.53\end{array}$ & $\begin{array}{r}1.15 \\
.92\end{array}$ & $\begin{array}{l}a 2.41 \\
a 1.93\end{array}$ & .034 & $\begin{array}{l}44.25 \\
44.50\end{array}$ & & $\begin{array}{l}\text { From Lake Wetzell, Antrim County. } \\
\text { Do. }\end{array}$ \\
\hline White Pigeon & H. A. Huston.. & .37 & & & 51 & $a 91.09$ & 1.02 & $a 2.14$ & & & 4. 01 & $\left\{\begin{array}{l}\text { Also: } \mathrm{K}_{2} \mathrm{O}=0.17 ; \quad \mathrm{Na}_{2} \mathrm{O}=052 ; \mathrm{CO}_{2}=40.08 . \\
\text { Sulphates }=\text { trace. From prospectus German Port- } \\
\text { land Cement Co. }\end{array}\right.$ \\
\hline Woodstock. & J. G. Dean..... & .38 & & & 50.76 & $a 90.66$ & .86 & $a 1.81$ & Trace. & 46.62 & & $\left\{\begin{array}{l}\text { From Goose Lake, Lenawee County. } \\
\text { Used by the Peninsular Portland } \text { Cement Co. }\end{array}\right.$ \\
\hline Zukey Lake. & E. D. Campbell..... & .96 & & .62 & $a 52.60$ & $a 93.92$ & 1.79 & $a 2.76$ & .58 & & & $\left\{\begin{array}{l}\text { In Livingston County. } \\
\text { Furnished by the Standard Portland Cement Co. }\end{array}\right.$ \\
\hline Do..... & $\begin{array}{l}\text { Dearborn Drug \& } \\
\text { Chemical Works, } \\
\text { Chicago. }\end{array}$ & 1.30 & & & 52.93 & $a 94.52$ & 1.44 & $a 3.02$ & Trace. & & & Do. \\
\hline
\end{tabular}

$a$ Computed from the analyses as reported. 
SHALES AND CLAYS.

Surface clays as well as shales from the Traverse and Coldwater formations have been used in Portland cement plants in Michigan. In addition, shales from the Antrim and Saginaw formations may furnish supplies in the future.

The following descriptions of shales and clays are taken from Russell's report: ${ }^{1}$

\section{TRAVERSE FORMATION.}

The shale of the Traverse group is utilized by the Alpena Portland Cement Co. in connection with limestone from the same formation and is obtained from quarries about 7 miles north of Alpena and near the shore of Lake Huron. The strata are nearly horizontal and consist of alternating layers of fine-grained and uniform bluishblack shale alternating with thin-bedded impure limestone. At the locality where the quarries are located the shale occurs at the surface, being covered only by 2 or 3 feet of peat. The same bed is understood to occur in the low bluff bordering the neighboring portion of Lake Huron. The surface portion of the shale where now exposed is disintegrated to a depth of a few inches, so as to form a stiff blue clay, and both the surface material and the unweathered shale beneath are suitable for cement making. The general composition of the shale is indicated by the following analyses: ${ }^{2}$

Analyses of shale of the Traverse formation near Alpena, Mich.

[Analysts, A. N. Clark (A) and H. Ries (B).]

\begin{tabular}{|c|c|c|}
\hline Constituent. & A. & B. \\
\hline 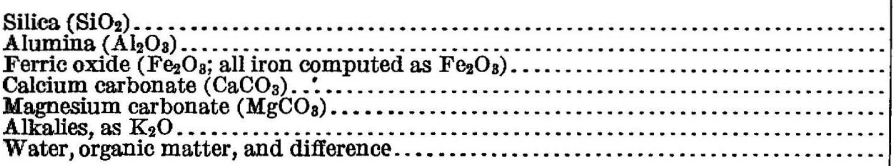 & $\begin{array}{r}55.95 \\
17.43 \\
7.67 \\
2.14 \\
1.55 \\
2.86 \\
12.40\end{array}$ & $\begin{array}{r}58.60 \\
17.66 \\
7.44 \\
2.14 \\
2.14 \\
11.97\end{array}$ \\
\hline Ferrous iron $(\mathrm{FeO}) \ldots \ldots \ldots \ldots$ & $\begin{array}{r}100.00 \\
.50\end{array}$ & $\begin{array}{r}100.00 \\
\ldots \ldots\end{array}$ \\
\hline
\end{tabular}

Another analysis of shale from the same locality as the above, supplied by the Alpena Portland Cement Co., is as follows:

Analysis of shale of the Traverse formation near Alpena, Mich.

[Analyst, S. H. Ludlow.]

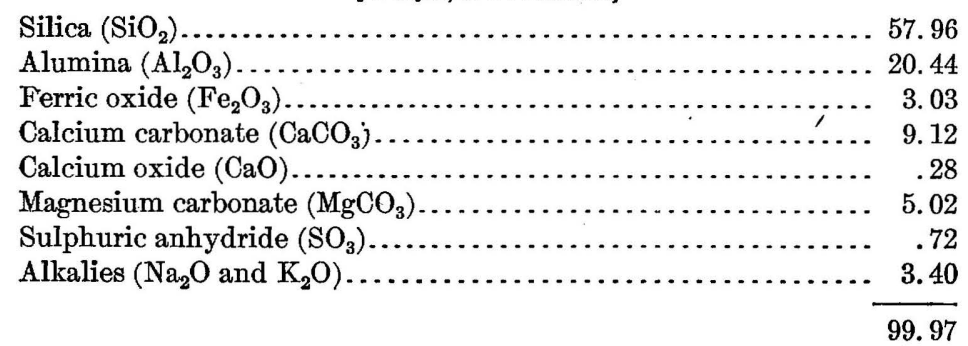

The region in the northern portion of the southern peninsula in which shales of the Traverse group may outcrop on the borders of lakes or along streams, or may be discovered by making small excavations, is indicated on the map. 


\section{ANTRIM SHALE.}

In addition to the deposits briefly described above, there are two formations in the southern peninsula which contain shales that, in certain instances at least, are worth investigating in connection with the industry here considered. These are the Antrim shales, which occur at the summit of the Devonian system, and the Saginaw formation, which forms the upper portion of the Carboniferous system as developed in Michigan.

The Antrim shales usually contain a high percentage of organic matter and yield petroleum, gas, etc., on distillation. No attempts have yet been made to utilize them for making cement, although their physical properties (except, perhaps, their toughness, which renders them somewhat difficult to quarry or to reduce to a powder) and their chemical composition make them worthy of experiment in that connection. An analysis of probably unweathered Antrim shale, made for the purpose of testing its fuel value, published by Ries, ${ }^{1}$ is as follows:

\section{Analysis of Antrim shale.}

[Analyst, W. H. Johnson.]

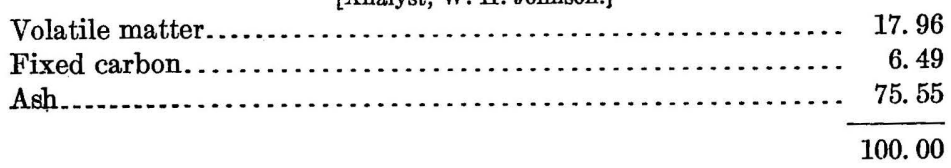

Analysis of the ash.

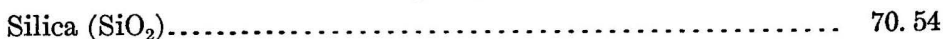

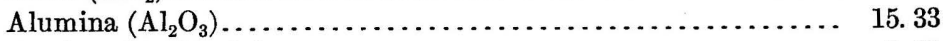

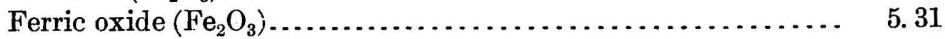

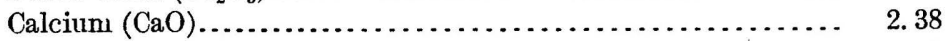

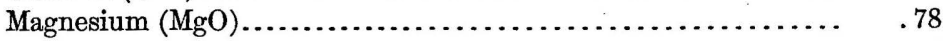

Alkalies, etc., by difference......................... 5.56

100.00

As remarked by Ries, the ratio of silica to alumina in this analysis is unusually high, but so far as can be judged this material is worth careful investigation on the part of cement makers.

The Antrim shales are exposed on the shore of Thunder Bay and also at several localities in Charlevoix County, where they are associated with marl deposits. The availability of these shales in manufacturing Portland cement and the utilization of the organic matter they contain as a by-product seems to be a possibility worthy of consideration.

\section{COLDWATER SHALE.}

The Coldwater shales are now being quarried at a locality about $1 \frac{1}{2}$ miles east of Union City and utilized by the Peerless Portland Cement Co. At the quarry referred to the shales are well exposed to a depth of from 20 to 35 feet, are thin bedded, horizontal, and contain irregular concretions of ferrous carbonate, some of which are charged with fossil marine shells. The rocks near the surface are much weathered and so completely disintegrated that the evenly bedded bluish shales below pass upward into yellowish mottled clays near the surface. In the manufacture of Portland cement an approximately equal mixture of the weathered and unweathered material is now used. The range in percentage of the several constituents composing the shale is as follows: 


\section{Analyses of Coldwater shale near Union City, Mich.}

[Analyst, A. Lundteigen.]

Silica $\left(\mathrm{SiO}_{2}\right)$

[A A

Iron and aluminum oxides $\left(\mathrm{Fe}_{2} \mathrm{O}_{3}\right.$ and $\mathrm{Al}_{2} \mathrm{O}_{3} \ldots \ldots \ldots \ldots 29.89$ to 23.33

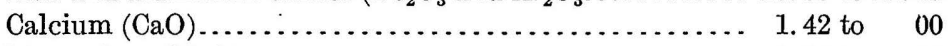

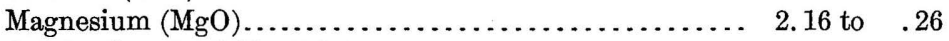

Sulphuric anhydride $\left(\mathrm{SO}_{3}\right) \ldots \ldots \ldots \ldots \ldots \ldots \ldots \ldots \ldots \ldots \ldots \ldots \ldots \ldots$ Trace to 00

Alkalies, by difference.......................... 8.55 to 6.00

Moisture, including water of composition........... 20.50 to 10.00

The Coldwater shales are also used at the works of the Wolverine Portland Cement Co., near Coldwater, and there present about the same characteristics as at Union City. Their range in composition is as follows:

\section{Analyses of Coldwater shale near Coldwater, Mich.}

[Analyst, H. E. Brown.]

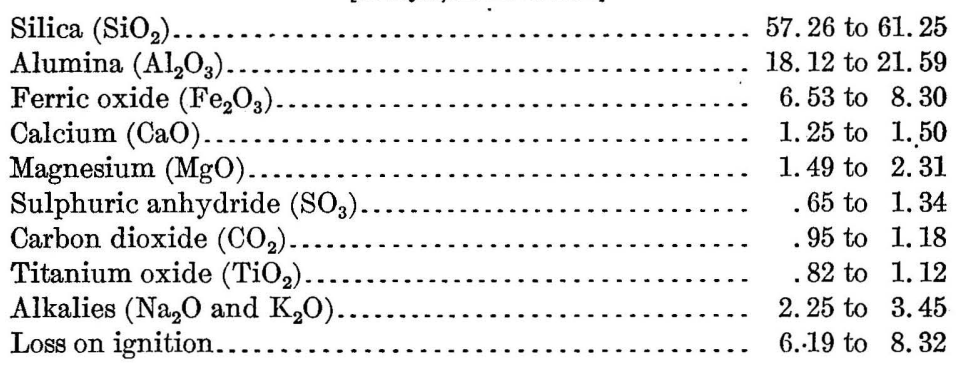

The shales of this formation were formerly used by the Bronson Portland Cement Co. but have been superseded by surface clays obtained in northern Ohio. The shale formerly used at Bronson is reported to have the following composition:1

\section{Analysis of Coldwater shale near Bronson, Mich.}

[Analyst, C. J. Wheeler.]

Silica $\left(\mathrm{SiO}_{2}\right)$ 62.00

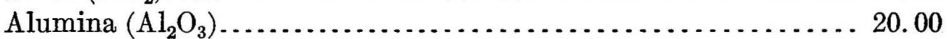

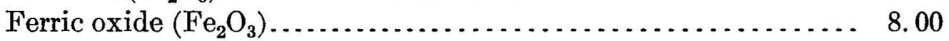

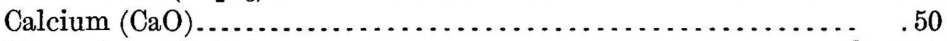

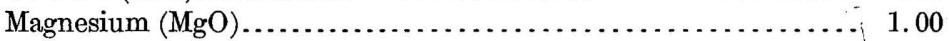

Sulphuric anhydride $\left(\mathrm{SO}_{3}\right) \ldots \ldots \ldots \ldots \ldots \ldots \ldots \ldots \ldots \ldots \ldots \ldots \ldots, \quad .50$

Organic matter.................................. 8.00

100.00

\footnotetext{
${ }^{1}$ Lewis, H., the plant of the Bronson Portland Cement Co., Bronson, Mich., Eng. Rec., vcl. 37, 1898, pp. 470-472; reprinted in The Cement Industry, New York, 1900, pp. 33-44.
} 
Other analyses of the shales of this formation occurring near Bronson, Coldwater, and at White Rock, compiled from Ries's report, are as follows:

\section{Analyses of Coldwater shale from Michigan.}

[Analyst, H. Ries.]

\begin{tabular}{|c|c|c|c|}
\hline Constituent. & Bronson. & $\begin{array}{l}\text { Cold- } \\
\text { water. }\end{array}$ & $\begin{array}{l}\text { White } \\
\text { Rock. }\end{array}$ \\
\hline 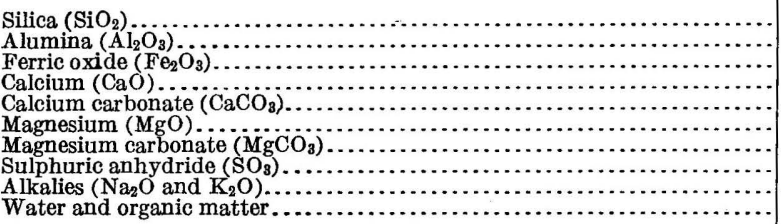 & $\begin{array}{r}62.10 \\
20.09 \\
7.81 \\
.65 \\
.96 \\
.49 \\
7.90\end{array}$ & $\begin{array}{r}53.44 \\
24.80 \\
.76 \\
.25 \\
\cdots \\
\cdots \\
20.75\end{array}$ & $\begin{array}{r}58.70 \\
18.31 \\
\\
1.80 \\
.98 \\
3.67 \\
9.35\end{array}$ \\
\hline 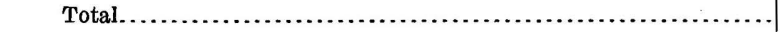 & 100.00 & 100.00 & 100.00 \\
\hline
\end{tabular}

The Coldwater shales occur beneath the surficial deposits throughout an extensive area in the southern peninsula, *** but are seldom well exposed at the surface. As noted by Ries, ${ }^{1}$ however, extensive outcrops occur along the shore of Lake Huron between White Rock and Forsyth and are favorably situated for shipping by water.

At many localities where suitable surface clays can not be had in connection with extensive marl deposits it may be found practicable to mine the underlying Coldwater shales, as was formerly done near Bronson, for use in cement making.

\section{SAGINAW FORMATION.}

The shales of the coal-bearing rocks, which underlie an extensive area in the central portion of the southern peninsula and are well developed in the productive coal field of the Saginaw Valley, although frequently containing sand, have in some instances approximately the physical and chemical composition desired in cement making. The fact that these shales are frequently removed in the process of coal mining and that facilities for transportation are available claim for them careful attention as a source of material for use in manufacturing Portland cement.

As stated by Ries, ${ }^{2}$ three types of shale in the Saginaw formation may be recognized, between which there are intermediate gradations. These are-

First. A light-gray, sandy, shaly clay, often quite hard, called "fire clay," and not infrequently containing fossil plants. Shale of this character is present beneath a coal seam at the mines of the Standard Mining Co., near Saginaw, and has the following composition:

Analysis of shale from Saginaw, Mich.

[Analyst, H. Ries.]

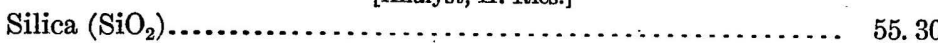

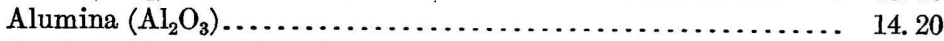

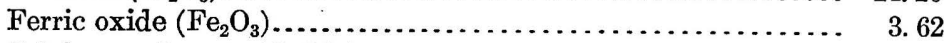

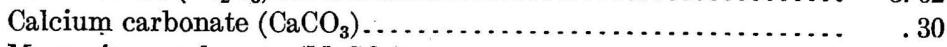

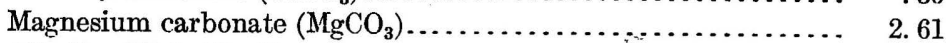

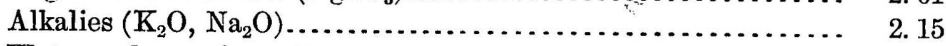

Water and organic matter............................. 21.82

Fluxes 100.00 
This shale is evidently too low in alumina and iron in proportion to the silica present to be used to advantage in the manufacture of Portland cement as now practiced.

Second. A black, fine-grained, brittle shale, with dull luster, sometimes termed "cannel coal." It contains much bituminous matter and would not serve well for the manufacture of clay products (Ries).

Third. A dark, grayish-black, fine-grained, hard, yet brittle, shale, which is appreciably plastic when ground and mixed with water. Shale of this type is found in several of the mines near Saginaw and Bay City and is quarried at Flushing for the manufacture of paving brick. Similar shales are associated with coal seams near Jackson and may be expected to occur throughout the area indicated as being occupied by the Saginaw formation.

The chemical composition of the shales just referred to is indicated by the following analyses:

Analyses of shales of the Saginaw formation.

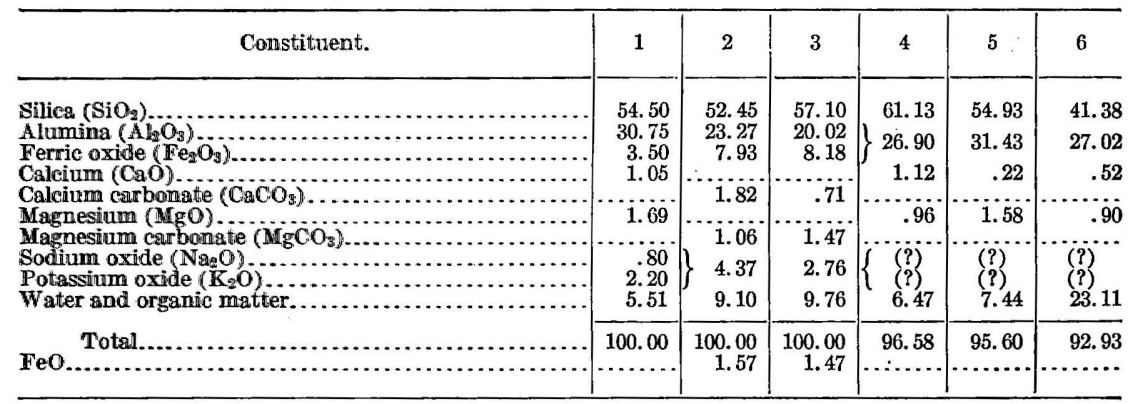

1. Fine-grained black shale from Flushing. Analyst, H. Ries. Geol. Survey Michigan, vol. 3, pt. 1, 1900, p. 30 .

2 and 3. Shales associated with coal at Bay City. Analyst, A. N. Clark. Idem, pp. 35-36.

4,5 , and 6 . Coal mines at Bay City. Analyses furnished by the Hecla Portland Cement and Coal Co. Analysts, Lathbury and Spackman.

As shown by these analyses, the shales of the Saginaw formation as a rule are lower in silica than is deemed desirable for use in making Portland cement, but certain beds have been recommended by experts in that industry. Evidently any layer of shale in the Saginaw formation which can be economically mined, and which is free from sand and other objectionable substances visible to the eye, should be carefully tested and experimented with in connection with the industry under review.

\section{CLAY.}

Surface clays deposited during the Pleistocene period of geological history-that is, at a late date and after the land had about its present relief-are abundant through- . out Michigan. These clays were in part left on the surface of the country directly by the glaciers during the last ice invasion of the Glacial epoch or, in some instances, by streams flowing from the glaciers; in part were laid down in small lakes and in the waters of the Great Lakes when more widely expanded in certain directions than at present, and in part were spread out in the flood plains of streams. These three varieties may be termed, to adopt the classification used by Ries, ${ }^{1}$ drift clays, lake clays, and river silts.

The drift clays are invariably calcareous and usually contain sand, stones, and bowlders and show much variation in composition. They are the most abundant of the surface clays and frequently form the hills and upland. In numerous instances they are used in the manufacture of bricks, tiles, etc., although in general not well adapted for this purpose. On account of their usual sandy and stony character and 
irregularities in composition, they are seldom worth investigating in reference to the making of Portland cement. In some exceptional instances, however, the glacial clays are essentially free from gravel and sand but contain at intervals irregular nodules of calcium carbonate, which, if the material were used in making cement, would necessitate great care in mixing and grinding to form a slurry.

The chemical composition of typical examples of drift clay, when free from gravel and sand, is here presented:

Analyses of drift clays.

\begin{tabular}{|c|c|c|c|c|c|c|}
\hline Constituent. & 1 & 2 & 3 & 4 & 5 & 6 \\
\hline 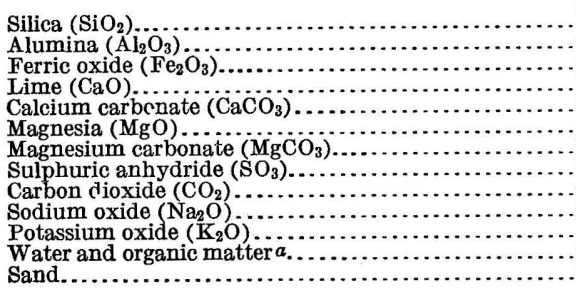 & $\begin{array}{r}54.94 \\
12.14 \\
4.88 \\
9.13 \\
\ldots 3.65 \\
\text { None. } \\
(?) \\
(?) \\
12.44 \\
\ldots \ldots . .\end{array}$ & 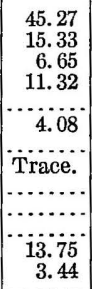 & \begin{tabular}{r}
46.22 \\
15.02 \\
5.49 \\
10.85 \\
$\ldots . .$. \\
4.52 \\
\hdashline$\ldots \ldots . .$. \\
\hdashline Trace. \\
\hdashline$\ldots \ldots . .$. \\
\hdashline 15.31 \\
1.20
\end{tabular} & $\begin{array}{r}40.15 \\
11.25 \\
4.88 \\
\cdots 21.43 \\
\cdots 8.93 \\
\hdashline \ldots . . \\
\hdashline 2.06 \\
11.30 \\
\hdashline \ldots \ldots\end{array}$ & $\begin{array}{r}41.86 \\
10.70 \\
5.02 \\
14.33 \\
\hdashline 2.81 \\
\hdashline 14.56 \\
2.80 \\
8.00 \\
\hdashline \ldots . .\end{array}$ & \begin{tabular}{r}
52.26 \\
22.95 \\
8.15 \\
4.48 \\
$\ldots . \ldots$ \\
1.32 \\
$\ldots \ldots \ldots$ \\
\hdashline$\ldots \ldots \ldots$ \\
\hdashline$\ldots \ldots \ldots$ \\
10.56 \\
$\ldots \ldots \ldots$
\end{tabular} \\
\hline Total. & 97.16 & 98.84 & 98.61 & ............ & 100.08 & 99.72 \\
\hline
\end{tabular}

$a$ Loss on ignition.

1. Brickyard near Pinckney, Livingston County. Furnished by Standard Portland Cement Co. Analysis by E. D. Campbell.

2. From 3 miles north of Jackson. Furnished by Standard Portland Cement Co. Analysis by E. D. Campbell.

3. From near Stockbridge, Ingham County. Analysis by E. D. Campbell.

4. From Ionia, Ionia County. Analysis by A. N. Clark. Geol. Survey Michigan, vol. 8, pt. 1, 1900, pp. $51-53$.

5. From near Jackson, Jackson County. Analysis by H. Ries. Geol. Survey Michigan, vol. 8, pt. 1, 1900 , pp. 56-59.

6. From Springport Township, Jackson County. Analysis by Mariner and Hoskins. Geol. Survey Michigan, vol. 8, pt. 1, 1900, p. 60 .

The lake clays are well represented, especially about the border of the southern peninsula, as between Detroit and Ypsilanti, about Port Huron, South Haven, widely over the Saginaw Valley, and in numerous local basins throughout the State. In the Upper Peninsula extensive deposits of exceedingly fine grained, laminated pinkish clay, deposited from the water of Lake Superior when more widely expanded than now, occur in abundance at Sault Ste. Marie and have a wide distribution westward, as at Marquette, Escanaba, etc. The chemical composition of this extensive deposit is indicated by analysis 6 in the following table, which shows that it is suitable for cement making.

The river silts occur on the border of many streams, sometimes in terraces a few feet above their surfaces. Although in many instances available for brick and tile making, they are usually too sandy to be employed in manufacturing Portland cement without being ground, so as to have the requisite degree of fineness-that is, so as to pass through a sieve with 150 to 200 meshes to the linear inch. No analyses of typical examples of the river silts are available, but as the deposits are derived mainly from the drift clays, they no doubt have the same composition, lacking, perhaps, some of the calcium carbonate and alkaline salts.

The lake clays here referred to are characteristically fine grained, many times almost entirely free from grit, highly plastic, and uniform in composition. As shown by numerous chemical analyses, however, they are what are termed "lean clays"; that is, not high in alumina and ferric oxide in proportion to the silica present, and not, as a rule, considered favorable for cement making. These properties and the usual presence of lime, together with the frequent occurrence of sulphuric anhydride, are shown by the analyses following. 
Analyses of lacustral clays from Michigan.

\begin{tabular}{|c|c|c|c|c|c|c|}
\hline Constituent. & 1 & 2 & 3 & 4 . & 5 & 6 \\
\hline 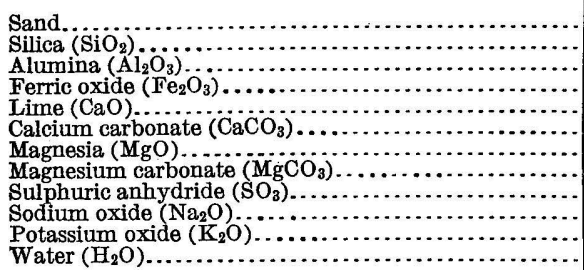 & \begin{tabular}{r}
49.75 \\
13.06 \\
5.31 \\
10.86 \\
44.28 \\
\hdashline$(?)$ \\
$(?)$ \\
$a 15.07$
\end{tabular} & \begin{tabular}{r}
49.34 \\
14.50 \\
5.37 \\
9.75 \\
\hdashline 4.77 \\
.33 \\
$(?)$ \\
$(?)$ \\
$a 15.55$
\end{tabular} & $\begin{array}{r}1.51 \\
66.49 \\
9.87 \\
4.87 \\
4.72 \\
1.22 \\
\\
(? .62 \\
(?) \\
(?) \\
9.36\end{array}$ & \begin{tabular}{r}
47.75 \\
17.60 \\
9.13 \\
2.60 \\
.70 \\
\hdashline 2.21 \\
22.01
\end{tabular} & $\begin{array}{r}(?) \\
40.40 \\
16.40 \\
\hdashline 25.36 \\
4.30 \\
\hdashline \ldots . . . \\
\hdashline 7.00\end{array}$ & $\left\{\begin{array}{r}61.62 \\
17.20 \\
5.99 \\
5.62 \\
\hdashline 2.82 \\
.46 \\
\hdashline a 5.34\end{array}\right.$ \\
\hline Total. & 99.13 & 99.25 & 98.66 & 100.00 & 99.46 & 99.00 \\
\hline
\end{tabular}

$a$ Loss on ignition.

1. Near Chelsea, Washtenaw County. Analysis by E. D. Campbell.

2. Near Fenton, Genesee County. Analysis by E. D. Campbell.

3. Near Farmington, Oakland County. Analysis by E. D. Campbell.

4. Near Saginaw. Ánalysis by H. Ries. Geol. Survey Michigan, vol. 8, pt. 1, 1900, p. 55.

5. Wyandotte; used in cement making by the Michigan Alkali Co. Analysis by O. Button.

6. Sault Ste. Marie. Analysis by E. D. Campbell.

In general it may be said that the surface clays of the Southern Peninsula are not favorable for use in making Portland cement, although some of the stony clays, if crushed sufficiently fine, may be employed for that purpose. Reference is not here made to the decomposed outcrop of the shales described in the preceding section, which might perhaps be taken for surface clays, some of which have been used with favorable results. In reference to the surface clays of the Northern Peninsula little accurate information is available, excepting the analysis of a representative sample of the extensive deposit of pink clay near Sault Ste. Marie, given above.

In a summary of the results of Ries's investigations of the shales and clays of Michigan, already referred to several times, A. N. Clark remarks as follows: ${ }^{1}$

"For use in the manufacture of Portland cement the shales of the Coldwater series are best adapted. The shales of the Michigan series are also good if not too high in soluble salts. Some of the Coal Measure shales, which are often too gritty, and some of the clays derived from the weathering of these shales or the Devonian black shales, may be suitable. Surface deposits of clay of any size are, almost without exception, either too calcareous and irregular in composition or too gritty to be desirable."

The difficulty of obtaining a suitable clay to use in connection with the marl deposits of the southern portion of the Southern Peninsula has led several of the Portland cement companies now in operation in that region to employ clay brought from Ohio. The most of this material comes from Milbury and Bryan and is a lacustral clay, deposited from the waters of the Erie basin (Glacial Lake Warren) when more widely expanded to the southwestward than now. Its composition is as follows:

Analyses of Ohio clays.

\begin{tabular}{|c|c|c|c|}
\hline & Constituent. & 1 & 2 \\
\hline \multirow{2}{*}{\multicolumn{2}{|c|}{ 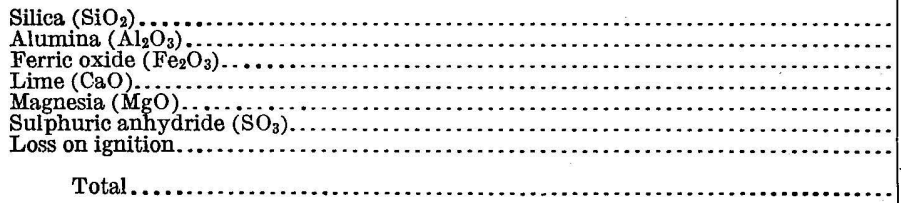 }} & $\begin{array}{r}\text { a } 62.55 \\
17.46 \\
5.08 \\
2.30 \\
1.67 \\
\text { Trace. } \\
\mathbf{5 . 5 5}\end{array}$ & $\begin{array}{r}61.03 \\
18.10 \\
6.65 \\
1.29 \\
.53 \\
1.05 \\
9.21\end{array}$ \\
\hline & & 98.37 & 89.86 \\
\hline
\end{tabular}

$a$ With the silica is included 3.76 per cent of fine sand.

1. Milbury. Analysis by E. D. Campbell.

2. Bryan. Analysis by John G. Dean and N. S. Potter, jr. 


\section{PORTLAND CEMENT INDUSTRY IN MICHIGAN.}

After one attempt to manufacture Portland cement in Michigan in the early seventies, no serious effort was made to reestablish the industry until 1897, when the Peerless and Bronson plants went into operation. From then on the growth of the Michigan industry was for a time very rapid but along rather peculiar lines. The abundant deposits of fresh-water marl in the State led to the erection of a number of plants to use this raw material, and the use of a naturally wet raw material led in turn to the general adoption of the wet process of manufacture. This was carried so far that at the original Alpena plant a hard dry limestone was treated by the wet process.

Writing of the industry as it was in 1901 , Russell ${ }^{1}$ presents a table showing that 7 plants were in actual operation at the beginning of that year and that 17 more were in different stages of construction or promotion. Of this total of 24 plants, no less than 22 were designed. to use marl as a raw material, one to use limestone by wet process, and the other to use alkali waste by the wet process. This curious development, it must be borne in mind, had taken place in a State with no local supply of good fuel, for all of these wet process plants were run on coal brought into the State, mostly from West Virginia.

As early as 1900 Michigan had attained third rank among the States as a cement producer, being surpassed only by Pennsylvania and New Jersey. This rank was maintained through 1904, but in 1905 Michigan dropped to fourth, being displaced by Indiana. In 1908 Kansas and Illinois also outranked Michigan as producers, while in 1909 the increase in California and Missouri pushed Michigan back to eighth place, where it remained until 1911. Eleven plants were in operation in Michigan in 1911.

It is perhaps hardly necessary to say that this gradual fall in rank as a producer does not imply any decrease in the actual annual output of the Michigan plants; on the contrary the State is now a larger producer than ever before, its output during 1911 having been more than 3,500,000 barrels. The loss in relative standing is simply due to the more rapid growth of the industry in other States.

In 1911 there were 11 plants producing Portland cement in Michigan. At Alpena the Huron Portland Cement Co. utilizes local limestone of the Traverse formation and shale, also of Devonian age, from 9 miles west of Alpena. The Burt Portland Cement Co., at Bellevue, uses limestone and clay; the Newago Portland Cement Co., at Newago, whose plant was built to use marl, now uses limestone and clay; the Elk Cement \& Lime Co., at Elk Rapids, uses limestone and shale; the Wyandotte Portland Cement Co., at Wyandotte, uses limestone and clay; and the following plants all use marl and clay: The Peninsular Portland Cement Co., at Cement City; the Wolverine Portland Cement Co., at Quincy and Coldwater; the New Etna Portland Cement Co.,

1 Twenty-second Ann. Rept. U. S. Geol. Survey, pt. 3, 1902, pp. 684-685. 
at Fenton; the Omega Portland Cement Co., at Mosherville, and the Peerless Portland Cement Co., at Union City.

The Michigan Portland Cement Co. rebuilt on the site of the former Millen Portland Cement Co., at Chelsea, and began manufacturing in 1911. The New Bronson Portland Cement Co., at Bronson, is undergoing reorganization; the plant of the Egyptian Portland Cement Co., at Fenton, is reported to be idle, as well as that of the Alpena Portland Cement Co., at Alpena. All the inactive plants used marl and clay exclusively, except the Alpena plant, which used also limestone from the Traverse formation. Coal is used as fuel in all the Michigan plants.

\section{BIBLIOGRAPHY.}

Davis, C. A., A contribution to the natural history of marl: Michigan Geol. Survey, vol. 8, pt. 3, 1904, pp. 65-102.

Fatl, Delos, Marls and clays in Michigan: Michigan Geol. Survey, vol. 8, pt. 3, pp. 343-348.

HaLE, D. J., Marl and its application to the manufacture of Portland cement: Michigan Geol. Survey, vol. 8, pt. 3, pp. 1-64, 103-190.

LANE, A. C., Coal of Michigan; its mode of occurrence and quality: Michigan Geol. Survey, vol. 8, pt. 2, 1902, pp. 1-233.

- Notes on the origin of Michigan bog limes: Michigan Geol. Survey, vol. 8, pt. 3, pp. 199-223.

List of marl localities and Portland-cement mills in Michigan: Michigan Geol. Survey, vol. 8, pt. 3, pp. 224-342.

LAthBuRY, B. B., The development of marl and clay properties for the manufacture of Portland cement: Michigan Geol. Survey, vol. 8, pt. 3, 1903, pp. 191-198.

- The Michigan Alkali Company's plant for manufacturing Portland cement from caustic soda waste: Engineering News, June 7, 1900.

Lewis, F. H., The plant of the Michigan Portland Cement Company, Coldwater, Mich.: Engineering Kecord, Feb. 25, 1899.

The plant of the Bronson Portland Cement Company, Bronson, Mich.: Engineering Record, Apr. 30, 1898.

Ries, Hernrich, Clays and shales of Michigan: Michigan Geol. Survey, vol. 8, pt. 1, 1900, pp. 1-67.

Russeil, I. C., The Portland-cement industry in Michigan: Twenty-second Ann. Rept. U. S. Geol. Survey, pt. 3, 1902, pp. 629-685.

\section{PORTLAND CEMENT RESOURCES OF MINNESOTA.}

Of the limestones occurring in Minnesota, only one (the Platteville limestone, pp. 175-177) is commonly sufficiently low in magnesium carbonate to be considered as a Portland cement material. Ulrich states that this nonmagnesian formation is well developed in southern Minnesota, particularly in the vicinity of Wyckoff and Spring Valley. It is also well exposed near Faribault. The pure limestone beds in these localities are both underlain and overlain by shale, which might prove available for use in mixture.

In addition to the rather scanty natural raw materials whose presence in Minnesota is briefly noted above, the large amounts of slag available at the Duluth blast furnaces of the United States Steel Corporation furnish another and more important source of supply. 
PORTLAND CEMENT MATERIALS OF UNITED STATES.

\section{PORTLAND CEMENT RESOURCES OF MISSISSIPPI.}

\section{PORTLAND CEMENT MATERIALS.}

\section{DISTRIBUTION.}

No cement, either natural or Portland, has ever been manufactured in Mississippi. Several large areas of limestone occur in the State, however, and at least one of these areas is so well located with respect to transportation routes as to give promise of future importance as a source of Portland cement material. This area in one portion has access to excellent fuel supplies at low cost.

The available cement limestones of the State may be grouped as: (1) Devonian and Mississippian ("Lower Carboniferous") limestones of northeastern Mississippi; (2) Cretaceous limestones (Selma chalk or "Rotten limestone") of eastern Mississippi; (3) Tertiary limestone (Vicksburg limestone) of central Mississippi. The Tertiary limestones are the most promising as the possible basis of a cement industry.

The distribution of these three limestone groups is shown on the geologic map (Pl. II), which is based on the work of A. F. Crider and the writer for the Mississippi and United States geological surveys.

DEVONIAN AND MISSISSIPPIAN ("LOWER CARBONIFEROUS") LIMESTONES.

In the extreme northeast corner of Mississippi, in the counties of Itawamba and Tishomingo, a small area of Devonian and Carboniferous rocks includes shales, thin sandstones, and limestones. The limestones, which are of both Devonian and Mississippian ("Lower Carboniferous") age, are commonly low in magnesia and are otherwise suitable for Portland cement materials. At present, however, the most promising localities have no adequate transportation facilities. This fact, together with the nearness of the soft and easily crushed Selma chalk, will probably serve to prevent any great development in this area in the near future.

The following section from this region, by A. F. Crider, ${ }^{1}$ is fairly representative of the Devonian rocks here:

Section of Devonian rocks on Yellow Creek, Miss.

1. Thin-bedded impure limestone at base, changing gradually to a bluish lime-

stone at top of cliff. . . . . . . . . . . . . . . . .

2. Compact blue limestone, nonfossiliferous........................ 40

3. Dark-gray limestone containing many Devonian fossils................. 10

4. Dark pure limestone to water's edge........................... 5 
From other exposures and well data it is probable that the total thickness of the Devonian limestones in this area is far in excess of that shown in the above section and that it may reach 500 feet or more.

The following analyses ${ }^{1}$ are of samples of Devonian limestones from this portion of Mississippi:

Analyses of Devonian limestone, northeastern Mississippi.

\begin{tabular}{|c|c|c|c|c|}
\hline & 1 & 2 & 3 & 4 \\
\hline $\begin{array}{l}\text { Silica }\left(\mathrm{SiO}_{2}\right) \\
\text { Alumina }\left(\mathrm{Al}_{2} \mathrm{O}_{3}\right) \\
\text { Iron oxide }\left(\mathrm{Fe}_{2} \mathrm{O}_{3}\right) \\
\text { Lime }(\mathrm{CaO}) \\
\text { Magnesia }(\mathrm{Mg}, \ldots \ldots \ldots \\
\text { Carbon dioxide }\left(\mathrm{CO}_{2}\right) \\
\text { Water }\left(\mathrm{H}_{2} \mathrm{O}\right)\end{array}$ & $\begin{array}{r}54.20 \\
1.06 \\
.90 \\
23.25 \\
.79 \\
15.57 \\
3.75\end{array}$ & $\begin{array}{r}35.28 \\
1.91 \\
1.58 \\
32.60 \\
.63 \\
27.64\end{array}$ & $\begin{array}{r}42.00 \\
1.98 \\
6.02 \\
23.25 \\
.27 \\
24.10 \\
.40\end{array}$ & $\begin{array}{r}48.18 \\
3.43 \\
3.13 \\
39.47 \\
3.19 \\
5.06 \\
.40\end{array}$ \\
\hline
\end{tabular}

None of the above analyses are above suspicion, but they are the best at present available. If correct, they indicate cherty rather than shaly limestones.

In the Mississippian ("Lower Carboniferous") rocks of this area occur beds of oolitic limestone closely similar in character, composition, and geologic age to the well-known oolitic limestones of the Bedford, Ind., district.

The following analyses ${ }^{2}$ are of samples of Carboniferous limestones and shales from Tishomingo County, in northeast Mississippi:

Analyses of Carboniferous limestones and shale, Tishomingo County, Miss.

\begin{tabular}{|c|c|c|c|}
\hline . & 1 & 2 & 3 \\
\hline 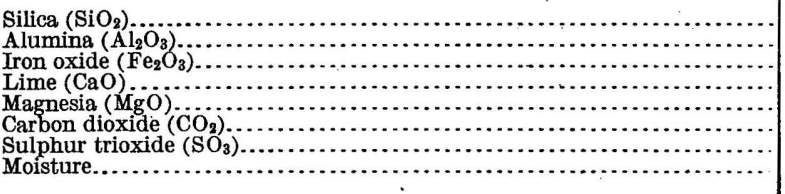 & $\begin{array}{r}1.57 \\
1.94 \\
1.69 \\
52.75 \\
.36 \\
40.80 \\
.32 \\
.15\end{array}$ & $\begin{array}{r}10.91 \\
8.17 \\
5.00 \\
47.06 \\
.16 \\
27.00 \\
.85 \\
1.10\end{array}$ & $\begin{array}{r}54.46 \\
14.92 \\
12.50 \\
2.56 \\
\ldots . . . \\
a 15.60\end{array}$ \\
\hline
\end{tabular}

$a$ Moisture and carbon dioxide.

1. Limestone from Cypress Pond.

2. Limestone from Mingo Bridge, Bear Creek.

3. Shale from Mingo Bridge, Bear Creek.

CRETACEOUS LIMESTONE (SELMA CHALK OR "ROTTEN LIMESTONE") GENERAL FEATURES.

The Selma formation of the Cretaceous is a thick series of chalks, chalky limestones, and more or less limy clays, well exposed in eastern and northeastern Mississippi. (See Pl. II, p. 68; and pp. 77-82.) 
The Selma chalk attains its maximum thickness in central Alabama, reaching a total of about 1,200 feet. Westward it thins slightly, the well at Livingston, Sumter County, Ala., giving a total of 930 feet, and the well at Starkville, Oktibbeha County, Miss., taken in connection with surrounding outcrops, indicating a thickness of at least 700 feet. As the belt turns northward toward Tennessee the Selma chalk decreases rapidly in thickness and the limestone beds contained in the formation become fewer and thinner until in Tennessee the Selma is a thin series of somewhat calcareous clays, with only a few beds of chalk.

Owing to the rapidity with which the Selma chalk disintegrates when exposed to atmospheric action, surface outcrops give comparatively little information in regard to the succession of the beds. Fortunately, a very precise section of the Selma chalk where it is of almost maximum thickness is embodied in the record of a well at Livingston, Sumter County, Ala., ${ }^{1}$ just south of the boundary between the Selma and Ripley formations. The well reached a depth of 1,062 feet, passing through the entire thickness of the Selma chalk and into the underlying Eutaw formation.

According to Smith, the upper 20 feet are probably in part Lafayette and in part Ripley. From 20 to 950 feet the well was in the Selma chalk and from 950 to 1,062 feet it was in the Eutaw formation.

The section of this well is given below:

Section of well at Livingston, Sumter County, Ala.

\begin{tabular}{|c|c|c|}
\hline & $\begin{array}{l}\text { Thick- } \\
\text { ness. }\end{array}$ & Depth. \\
\hline $\begin{array}{l}\text { Lafayette and Ripley formations: } \\
\text { Sandy loam. }\end{array}$ & Feet. & Feet. \\
\hline 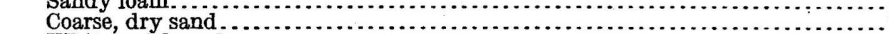 & 12 & 13 \\
\hline White quicksand....................... & 7 & 20 \\
\hline $\begin{array}{l}\text { Selma chalk: } \\
\text { Soft blue limestone, many shells and pyrite nodules. }\end{array}$ & 180 & \\
\hline White limestone, harder, few shells or pyrite nodules. & 50 & 250 \\
\hline Hard blue limestone, no shells or nodules. & 7 & 257 \\
\hline Bluish-white limestone, less hard, no shells or nodules. & 38 & 325 \\
\hline White limestone, very hard ......................... & 55 & 380 \\
\hline Light-blue limestone, softer.................... & 47 & 427 \\
\hline Bluish-brown rock, small shells, some sand. & 58 & 485 \\
\hline Hard, white limestone.... & 105 & 590 \\
\hline Soft, reddish-brown rock............... & 2 & 592 \\
\hline Soft, deep-blue rock.......................... & 20 & 612 \\
\hline 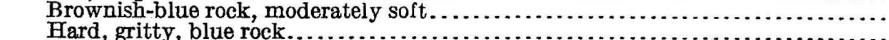 & 78 & $\begin{array}{l}690 \\
690 t\end{array}$ \\
\hline Dark-bluish rock, soft & $0_{1}^{\frac{2}{2}}$ & 700 \\
\hline Soft, whitish limestone.. & $250^{2}$ & 950 \\
\hline $\begin{array}{l}\text { Eutaw formation: } \\
\text { Hard sandstone }\end{array}$ & & \\
\hline $\begin{array}{l}\text { Hard sandstone........... } \\
\text { Sand.................. }\end{array}$ & $\begin{array}{r}6 \\
10\end{array}$ & $\begin{array}{l}956 \\
966\end{array}$ \\
\hline Sand rock................. & 1 & 967 \\
\hline Coarse greensand......... & 38 & 1,005 \\
\hline Sandstone...$\ldots \ldots \ldots \ldots \ldots \ldots \ldots \ldots \ldots \ldots \ldots \ldots \ldots \ldots \ldots \ldots$ & 2 & 1,007 \\
\hline Greensand...$\ldots \ldots \ldots \ldots \ldots$ & 25 & 1,032 \\
\hline & & 1,034 \\
\hline (n.................... & 18 & 1,052 \\
\hline 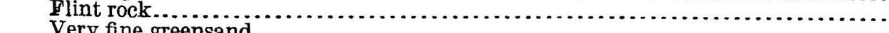 & 1 & 1,053 \\
\hline & 9 & 1,062 \\
\hline
\end{tabular}

1 Smith, E. A., Report on the geology of the Coastal Plain of Alabama, pp. 277-278. 
IOCAL OCCURRENCES.

During 1904 the Selma chalk was carefully mapped throughout the Tombigbee River basin by A. F. Crider and the writer for the United States Geological Survey. In later years Crider, as State geologist of Mississippi, covered the Mississippi localities not visited in 1904. (See Pl. II, p. 68.) The following descriptions of localities were taken from Crider's manuscript notes and from his published reports, and rearranged by the present writer consecutively, beginning at the Mississippi-Alabama State line and going northward to the MississippiTennessee State line.

KEMPER COUNTY.

In Kemper County, $2 \frac{1}{2}$ miles east of Scooba, on the west bank of a creek (PI. II), is the first outcrop of Selma chalk on the Scooba and Gainesville road. A sample taken from this outcrop by A. F. Crider and analyzed by W. S. McNeil, in the laboratory of the United States Geological Survey, gave the following result:

Analysis of Selma chalk near Scooba, Miss.

Silica $\left(\mathrm{SiO}_{2}\right)$ 16.48

Alumina $\left(\mathrm{Al}_{2} \mathrm{O}_{3}\right)$

Iron oxide $\left(\mathrm{Fe}_{2} \mathrm{O}_{3}\right)$

Lime carbonate $\left(\mathrm{CaCO}_{3}\right)$

Mater.

On the west side of Quilby Creek, where it runs south along the State line, 7 miles east of Sucarnooche, the Selma chalk forms a small bluff. The prairie soil extends 2 miles farther west. On the east side of the creek, in Alabama, the Selma chalk forms a bluff a little higher than on the opposite bank in Mississippi, exposing what is taken to be the top of the Selma chalk. The top of the bluff is capped by a coarse-grained sandstone, cemented by lime carbonate. In it are lime concretions the size of a man's fist.

The upper beds of the Selma chalk also appear in the bluff on the east side of Quilby Creek, 7 miles east of Sucarnooche.

A sample collected by Crider from an outcrop of Selma chalk on Scooba and Fox Prairie road, where it crosses Bodea Creek, about 2 miles west of the State line, was analyzed in the laboratory of the United States Geological Survey by W. S. McNeil, with the following results:

\section{Analysis of Selma chalk from Bodea Creek, Miss.}

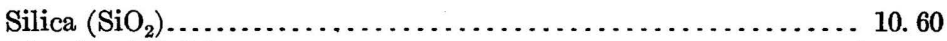

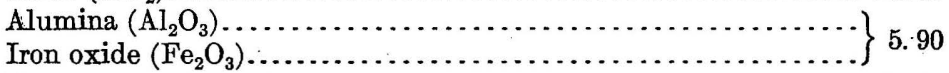

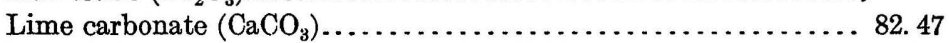

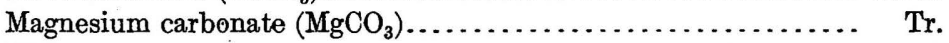

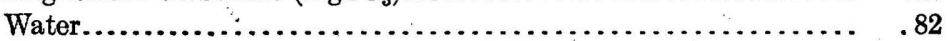


Three miles north of Scooba the west border of the Selma chalk outcrops in a series of hills forming the south bank of Wahalak Creek. The bottom of the Wahalak is here $1 \frac{1}{2}$ miles wide, the south bank retreating more sharply than the north. The creek has cut its channel into the Selma chalk, which outcrops almost continuously throughout its course. The limestone occurs up the creek about $6 \frac{1}{2}$ to 7 miles northwest from Wahalak, but the Porters Creek clay occupies the country on either side. The hill just east of Wahalak is of Porters Creek clay, which is not over 15 feet thick.

A sample, collected by Crider from the bed of Wahalak Creek, about $1 \frac{1}{2}$ miles south of Wahalak, was analyzed by W. S. McNeil in the laboratory of the United States Geological Survey, with the following results:

Analysis of Selma chalk near Wahalak, Miss.

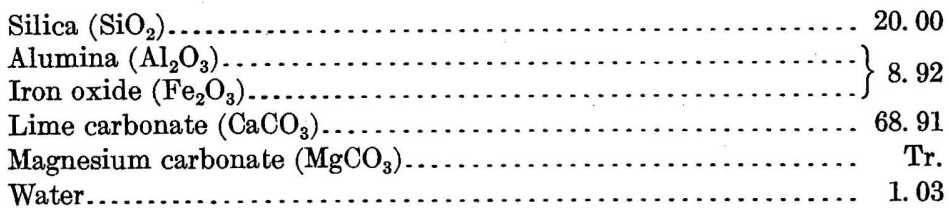

NOXUBEE AND LOWNDES COUNTIES.

A sample of Selma chalk was taken north of Lime Rock, 5 miles east of Shuqualak, on Oaknoxubee River, Noxubee County, from a bluff 50 feet high composed of typical Selma chalk. The following analysis of this sample was made by W. S. McNeil in the laboratory of the United States Geological Survey:

Analysis of Selma chalk near Shuqualak, Miss.

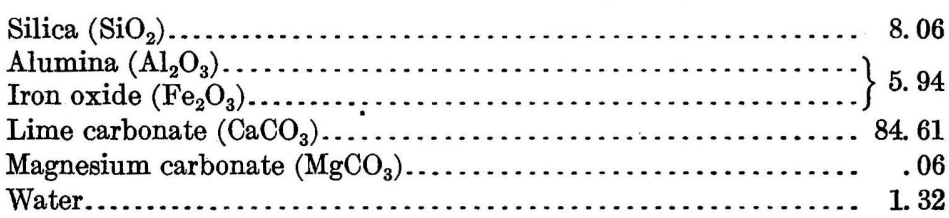

A sample of sandy limestone was obtained from the mouth of James Creek, on Tombigbee River, from an exposure of a greensand clay containing a large amount of lime. Fifty feet above the river, $1 \frac{1}{2}$ miles west of the mouth of James Creek, another sample of limestone, similar in color and general aspect, except that it has less greensand, was collected.

Farther west the limestone rarely shows at the surface. It is clayey in character and is easily dissolved by the weathering agents, so that it breaks down into soil faster than it is carried away by erosions. 
Near Cliftonville, which is 75 feet above Tombigbee River (barometric reading), a hard cap rock, 2 to 4 feet thick, is found on top of the hills. This is a hard "lime" rock, similar to that found at Prairie Point.

Below this hard cap rock comes what is called the "blue rock." A sample of it seen at a well dug years ago shows that it is similar to the rock at Cunningham Hill, except that it contains no sand. Where the blue rock comes to the surface it forms a belt of very deep, black, and loose soil-the richest in the prairie region. More cotton and corn are raised to the acre here than in any other part of the State.

West of this region the land becomes higher, and the Lafayette occupies the surface on the ridges.

The limestone at and near Macon deserves special mention on account of its abundance, the ease with which it can be quarried, its nearness to deposits of clay, and the facilities offered for its transportation.

The bluff on Noxubee River at the mouth of Macon Creek, near the town of Macon, is about 40 feet high and extends more or less unbroken to the mouth of Noxubee River. The entire bluff, except 5 or 10 feet of surface soil, is formed of the Selma chalk. Other outcrops occur along all the principal streams flowing into Noxubee River and in the railway cuts as far south as Scooba.

The limestone, viewed from a distance, appears to be a homogeneous mass of white chalk. On close examination, however, it is found to have an amygdaloidal structure, as if small fragments of limestone had been cemented into a compact mass. A few joints or stratification lines are visible. In places concretions of iron pyrite ranging in size from a buckshot to a hen's egg are embedded in the limestone. After long exposure to weathering agents the sulphide of iron changes to the oxide, leaving rusty iron stains on the rocks.

The following are analyses of the limestone from the bluff at Macon:

Analyses of Selma chalk from Macon, Miss.

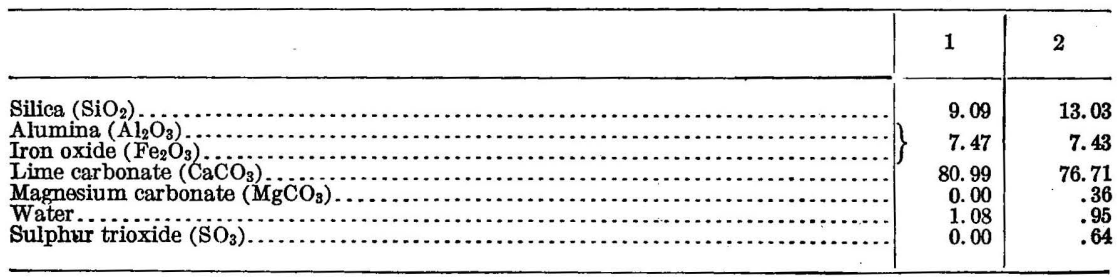

1. W. S. McNeil, U. S. Geol. Survey, analyst.

2. W. F. Hand, State chemist, Agricultural College, analyst. 
A sample of limestone was collected from the ridge land 3 miles north of Macon and analyzed in the laboratory of the United States Geological Survey with the following results:

Analysis of Selma chalk from locality north of Macon, Miss.

Silica $\left(\mathrm{SiO}_{2}\right)$

Alumina $\left(\mathrm{Al}_{2} \mathrm{O}_{3}\right)$

Lime carbonate $\left(\mathrm{CaCO}_{3}\right)$

Magnesium carbonate $\left(\mathrm{MgCO}_{3}\right)$

Water.

1.00

Farther south, along the Macon and Columbus road, the limestone shows in every gully and on every hillside. At some places on level ground the soil is not over 12 inches deep. In this vicinity are the bald prairies, where large areas of this white limestone are exposed without a particle of soil or a blade of grass. A sample of the rock was taken 3 miles north of Macon.

A sample of Selma chalk was taken from an old rock quarry on the southwest side of Bogue Chitto Creek, one-half mile east of Prairie Rock, which is 12 miles east of Macon. This limestone is much harder than that along Oaknoxubee River, in the vicinity of Macon. In the unweathered state of the Macon rock it is very soft and noncrystalline and can easily be pierced by a pick; but the limestone near Prairie Rock, however, is a hard so-called "flint rock," crystalline in character, and is used for building purposes. The rock at Macon, when exposed to the weather, becomes white as chalk; that near Prairie Rock weathers to a dirty gray and contains some traces of iron stain on the weathered surfaces. This is due to the oxidation of the iron sulphide (pyrite), which is found in small concretions in the fresh rock.

An analysis of this limestone at Prairie Rock, made by W. S. McNeil in the laboratory of the United States Geological Survey, shows that the stone is very pure, in spite of the manner in which it discolors on weathering.

Analysis of Selma chalk from Prairie Rock, Miss.

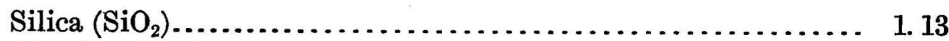

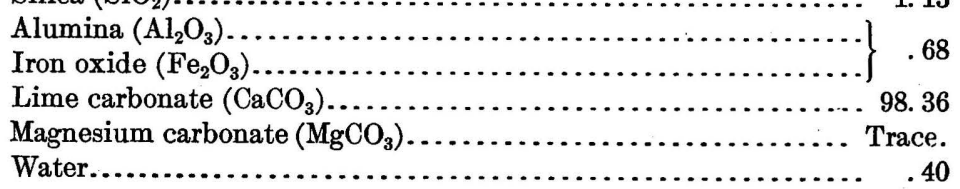

The rock breaks down easily when exposed to the weather and hence is not now extensively used for building purposes. It is, however, the only road material found in this section of the country. 
It has been used on the road across Bogue Chitto swamp but is unsatisfactory.

In southwestern Lowndes County excellent Portland cement materials are found along the divide between Tombigbee and Noxubee rivers.

On J. B. Brooks's land, near Crawford, much of the overburden has been removed, leaving the white Selma chalk at the surface. The limestone from this place contains about the proper proportions of lime carbonate, alumina, and iron oxide for Portland cement. It contains a small amount of magnesia but not enough to injure it. To make a suitable cement this limestone must be mixed with a clay containing a low per cent of silica.

Analysis of Selma chalk from Crawford, Miss.

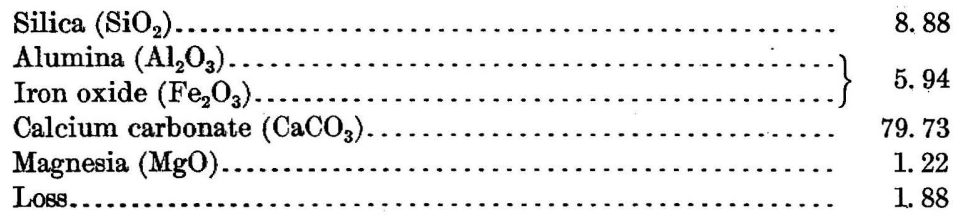

OKTIBBEHA COUNTY.

In the eastern half of Oktibbeha County the Selma chalk is characteristically developed. A few small patches of the Lafayette remain on some of the divides, but the rest of the surface is formed by the residual loam of the "prairie soil" and the white rock of the Selma. One to ten feet of Selma chalk may be seen in almost every cut along the Illinois Central Railroad from Starkville to West Point, and similar outcrops occur along the Mobile \& Ohio Railroad from Starkville to Artesia. The thickness of the Selma in the city well at Starkville is about 750 feet, and 50 feet or more is exposed in the hills to the north.

The following samples of Selma chalk, collected by W. N. Logan from Oktibbeha County, were analyzed with the following results:

Analyses of Selma chalk from Oktibbeha County, Miss.

\begin{tabular}{|c|c|c|c|c|c|c|}
\hline & 1 & 2 & 3 & 4 & 5 & 6 \\
\hline 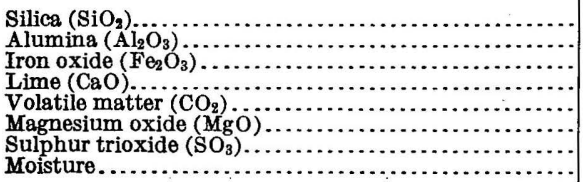 & $\begin{array}{r}29.98 \\
5.45 \\
5.60 \\
31.62 \\
24.50 \\
.14 \\
.21 \\
1.50\end{array}$ & $\begin{array}{r}25.27 \\
4.81 \\
10.35 \\
32.85 \\
25.60 \\
.84 \\
.62 \\
.40\end{array}$ & $\begin{array}{r}9.84 \\
.19 \\
2.58 \\
38.65 \\
42.05 \\
.18 \\
2.05 \\
.94\end{array}$ & $\begin{array}{r}20.60 \\
7.63 \\
4.62 \\
21.81 \\
23.15 \\
.81 \\
.25 \\
.85\end{array}$ & $\begin{array}{r}17.03 \\
21.00 \\
3.38 \\
29.29 \\
28.20 \\
.00 \\
.72 \\
.75\end{array}$ & $\begin{array}{r}18.82 \\
.23 \\
2.80 \\
40.02 \\
34.02 \\
.96 \\
2.53 \\
1.15\end{array}$ \\
\hline
\end{tabular}

1. Agricultural College.

2. Near Osborn.

3. Reynolds farm, a mile west of Starkville.
4. Howard brickyard, Starkville.

6. Mayhew road a mile east of Agricultural College. 
The character of the limestone from other localities in Oktibbeha County is shown by the following analyses:

Analyses of Selma chalk from Oktibbeha County, Miss.

\begin{tabular}{|c|c|c|c|c|c|}
\hline & 1 & 2 & 3 & 4 & Average. \\
\hline Silica $\left(\mathrm{SiO}_{2}\right)$ & 2.89 & 2.33 & 3.03 & 2.55 & 2.70 \\
\hline $\begin{array}{l}\text { Alumina }\left(\mathrm{Al}_{2} \mathrm{O}_{3}\right)_{-} \\
\text {Iron oxide }\left(\mathrm{Fe}_{2} \mathrm{O}_{3}\right)\end{array}$ & 1.53 & 1.72 & 1.92 & 1.96 & 1.78 \\
\hline 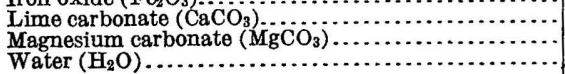 & $\begin{array}{r}94.10 \\
1.84 \\
.36\end{array}$ & $\begin{array}{r}94.35 \\
182 \\
.44\end{array}$ & $\begin{array}{r}93.60 \\
1.64 \\
.42\end{array}$ & $\begin{array}{r}94.07 \\
2.12 \\
.52\end{array}$ & $\begin{array}{r}94.03 \\
1.85 \\
.44\end{array}$ \\
\hline
\end{tabular}

CHICKASAW AND MONROE COUNTIES.

One of the best exposures of the Selma chalk in the northern and central portions of the Selma area is found in the town and vicinity of Okolona, in Chickasaw. County. In a few places the sandy loam of the Lafayette formation is present, but over the greater portion of the area it has been removed, leaving large patches of exposed limestone known as "bald prairie." The limestone has become white by reason of long exposure to sun and rain, in this respect resembling the "white chalk" exposed in the bluffs along Noxubee and Tombigbee rivers.

Numerous outcrops of the Selma in southeastern Chickasaw and western Clay counties have been carefully described by Hilgard. ${ }^{1}$

The country is dotted with outcrops of the Selma chalk along Chookatonkshie, Houlka, and Okatibbeha or Tibby creeks and on the eastern slope of Pontotoc Ridge, projections of which extend southward between the above-mentioned streams. The limestone in northwestern Clay County has been penetrated in wells at a depth of about 500 feet.

A sample of the limestone from the railroad cut at the Mobile \& Ohio station at Okolona was burned in a forge at a white heat for 15 minutes and was slaked by pouring water on it; it immediately broke down into a beautiful white lime. The following analyses were made of this limestone:

Analyses of Selma chalk from Okolona, Miss.

\begin{tabular}{|c|c|c|}
\hline & 1 & 2 \\
\hline 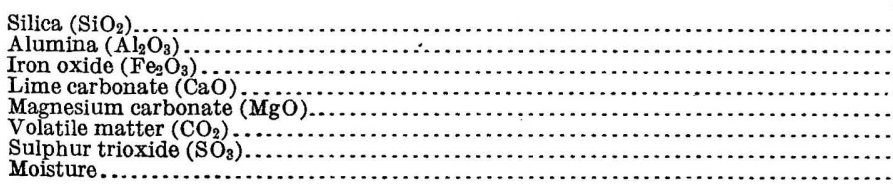 & $\begin{array}{r}8.80 \\
2.86 \\
4.08 \\
45.51 \\
.36 \\
31.11 \\
.38 \\
6.35\end{array}$ & $\begin{array}{r}8.70 \\
.00 \\
6.00 \\
45.62 \\
1.72 \\
34.40 \\
1.11 \\
1.10\end{array}$ \\
\hline
\end{tabular}

1 Hilgard, E. W., Report on the geology of Mississippi, 1860. 
LEE COUNTY.

The town of Tupelo is built in the valley of Oldtown Creek, a large tributary to Tombigbee River. In the lower portions of the town the alluvial soil is 20 feet thick. The hills to the east have a thin covering of Lafayette. To the northwest the Lafayette and residual Selma form the fertile farming land. The Selma chalk itself is found only in sells. Below is the record of an average artesian well in Tupelo:

Record of artesian well in Tupelo, Miss.

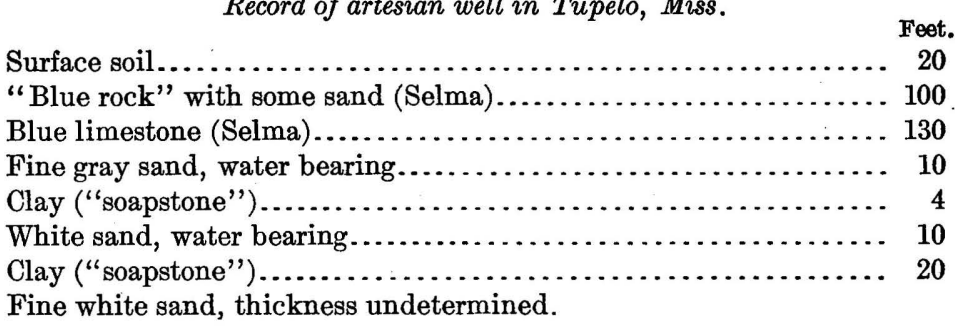

The above record shows 230 feet of Selma chalk. The upper 100 feet of "blue rock" is reported as containing some sand and is perhaps a calcareous greensand or else is a stratum in the Selma not yet discovered at the surface. The latter theory is hardly probable, however, as so great a thickness would not have escaped detection in the detailed work on the formation in Alabama and along Tombigbee River in Mississippi.

The first cut on the Mobile \& Ohio Railroad south of Tupelo exposes the Selma from the surface to the bottom of the cut. All the deep cuts from Tupelo to Verona penetrate the surface soils and reach the Selma, which is also shown by outcrops on the sides of the wagon road and in the open field about $2 \frac{1}{2}$ miles south of Tupelo. In other places along the road between Tupelo and Verona and in numerous places west of Verona the Lafayette has been removed by erosion, exposing the Selma. On the more level lands the residual soil of the Selma forms the well-known "prairie soil." During the rainy season the constant kneading of the "prairie soil" by wheels of vehicles and horses' feet forms a tough, plastic clay, which, when once recognized, can never be mistaken. Even if there is no outcrop of the Selma near, the "prairie soil" indicates that the Selma is but a few feet or perhaps a few inches below the surface.

A sample of the Selma collected from the roadside about $2 \frac{1}{2}$ miles south of Tupelo shows the following analysis: 
Analysis of Selma chalk $2 \frac{1}{2}$ miles south of Tupelo, Miss.

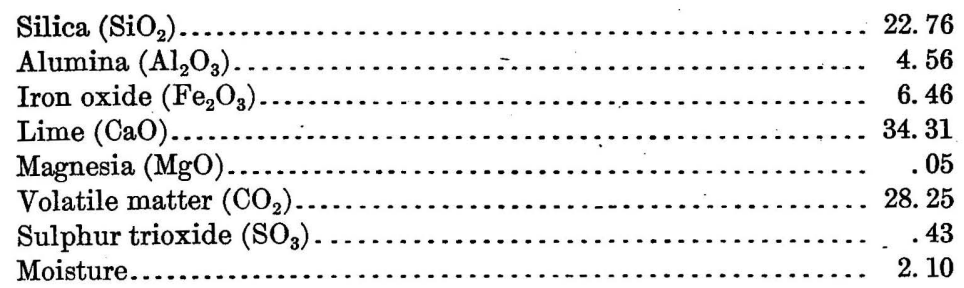

Fine exposures of the Selma are found on Coonewah Creek, about 5 miles west of Tupelo. It is overlain in places by 6 to 10 feet of yellow clay. The Selma continues westward to 3 or 4 miles of Pontotoc. In southeastern Pontotoc County it is reported to be 750 feet thick.

A sample of the Selma, collected by W. N. Logan a mile west of Tupelo, on the Tupelo and Pontotoc road, shows the following analysis:

Analysis of Selma chalk a mile west of Tupelo, Miss.

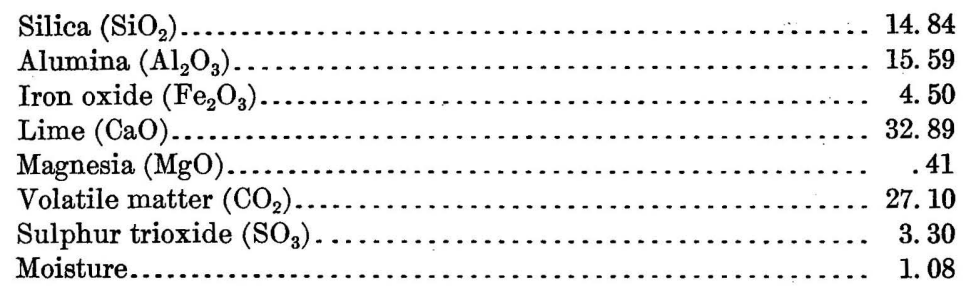

PRENTISS COUNTY.

In the deep cut on the Mobile \& Ohio Railroad in the town of Booneville, the typical Selma chalk is exposed beneath a thick covering of sandy loam (Lafayette). The compact nature of the Selma prevents water from penetrating it, hence many wells obtain water from the base of the Lafayette, and many small springs issue from its contact with the underlying Selma.

From a well record it is found that the limestone at Booneville is 52 feet thick. One-fourth of a mile east it is only 25 feet thick, and three-fourths of a mile east it is absent. It outcrops in the hills west of the town and is encountered in all the deep wells as far west as Jumpertown. The Mobile \& Ohio Railroad follows approximately the eastern limit of the Selma between Booneville and Tupelo. The eastward extension of the Selma at Booneville is due to the fact that the divide between the waters of Tuscumbia and Tombigbee rivers has suffered but little erosion. South of the divide the headwaters of Tombigbee River have carried away a large amount of the Selma and have caused the outcrop of the contact between the Selma chalk and the underlying greensands of the Eutaw formation to swing westward in the vicinity of Wheeler, Baldwin, and Guntown. 
At Guntown the lowest beds of the Selma are exposed just north of the station in a railway cut that shows a compact ledge of fossiliferous limestone about 2 feet thick dipping strongly south and underlain by a bed of greensand, which extends to the bottom of the cut. The main body of the Selma lies west of Guntown. The basal members here as elsewhere contain too much sand to be used in the manufacture of Portland cement.

\section{ALCORN COUNTY.}

Corinth is built in the valley of a small stream which flows into Tuscumbia River. On the west side of the town a low range of hills, rising 30 to 40 feet above the valley, is cut by the Southern Railway about one-eighth mile west of the station. The cut shows 5 to 8 feet of surface sandy loam, underlain by an equal thickness of Selma chalk extending to the bottom of the cut. The Selma at this place can hardly be called a limestone. It is the "blue rock" which occurs near the bottom of the formation and is more properly a compact calcareous clay, which can be broken into rectangular blocks, and which shows small needle-like crystals of selenite in the cracks and on exposed surfaces. The thickness of the Selma at Corinth is less than 100 feet.

The following analysis shows a high percentage of silica, a condition characteristic of the lower beds of the Selma. Higher in the formation the percentage of lime steadily increases, and the siliceous material correspondingly decreases. Purer limestone is found in the railway cuts west of Corinth.

Analysis of Selma chalk from Corinth, Miss.

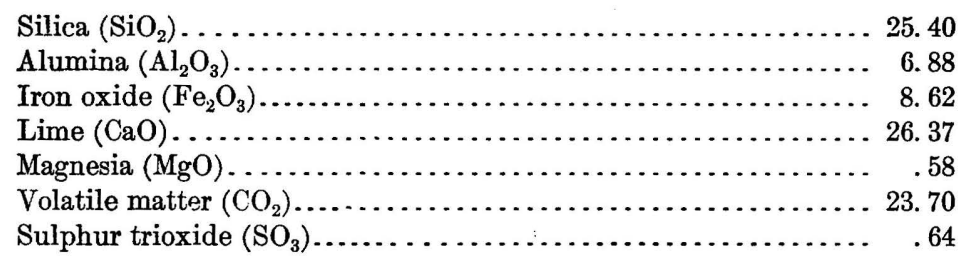

The Selma underlies the surface covering for 6 to 10 miles west of Corinth and for 3 miles east. It gradually thins to the east and disappears completely in the low north-south hills 3 miles east of town.

At the western end of the 90-foot cut on the new line of the Illinois Central Railroad, 3 miles east of Corinth, the blue limestone of the Selma extends to the bottom. At the eastern end it forms a thin stratum and farther on disappears. The lowest member of the Selma is underlain by a bed of oxidized calcareous sand bearing fossils.

The Selma is exposed in almost every cut of any depth along the Southern Railway from Corinth to the Tennessee State line. A few 
hundred yards west of Wenasoga, 12 feet or more of bluish calcareous clay are exposed in the railway cut. At the little town of Chewalla, across the line in Tennessee, it was penetrated in a well having a depth of 350 feet, at least 300 feet of which is limestone.

The Selma is encountered in wells at Danville, Rienzi, and Thrasher near the eastern edge of the Selma, where, as shown by the well records, it contains more or less sand. The towns are on the Mobile \& Ohio Railroad, which follows along the second bottoms of Tuscumbia River, where no outcrops of the Selma appear.

\section{TERTIARY LIMESTONE (VICKSBURG LIMESTONE).}

\section{DISTRIBUTION.}

A narrow belt of limestone of Tertiary age crosses the State from near Waynesboro to near Vicksburg. This is the Vicksburg limestone which, together with the underlying Jackson formation (marls and clays), is equivalent to the St. Stephens limestone of Alabama. (See pp. 82-85, and Pl. II, p. 68.) In Mississippi the Vicksburg limestone generally outcrops in a low ridge that trends generally a little north of west. The southern slope of this ridge is gentle, but its northern face is sharp, making it easy both to locate the outcrop and to quarry the limestone.

\section{LOCAI OCCURRENCES OF VICKSBURG LIMESTONE.}

By A. F. Crider.

GENERAL FEATURES.

In Mississippi the Vicksburg includes thin beds of fine-grained nonmagnesian limestone 1 to 4 feet thick, alternating with highly calcareous marl beds more or less indurated in places and bearing a rich fauna of Oligocene age. Some of the ledges of limestone make excellent building stone and lime, but the great amount of interbedded marl and surface material make quarrying unprofitable.

The alternating nature of the limestone and marl is shown in the following section of the bluff at Vicksburg, ${ }^{1}$ between the city and the National Cemetery:

Section of the bluff at Vicksburg, Miss.

Inches.

1. First stratum of limestone from top, overlain by loess. . . . . . . . . . 10

2. Gray to yellowish marl . . . . . . 9

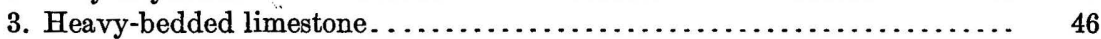

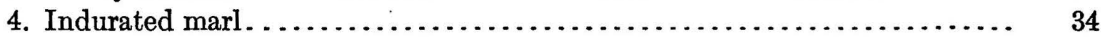

5. Thin calcareous plastic clay ................................. 2

6. Indurated marl .............................................. 6

7. Clay similar to No. $5 . \ldots \ldots \ldots \ldots \ldots \ldots \ldots \ldots \ldots \ldots \ldots \ldots \ldots \ldots \ldots \ldots \ldots \ldots \ldots, 2$

1 Crider, A. F., Geology and mineral resources of Mississippi: Bull. U. S. Geol. Survey No. 283, 1906, p. 38 . 
Inches.

8. Indurated marl. ......................................... 5

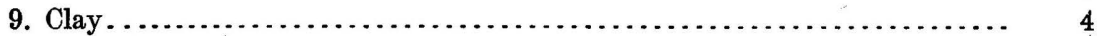

10. Hard limestone........................................... 18

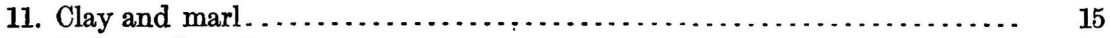

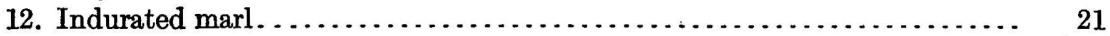

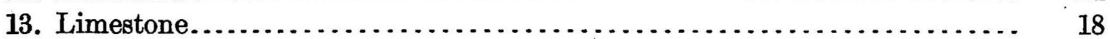

14. Gray marl................................................... 18

15. Limestone.................................................. 18

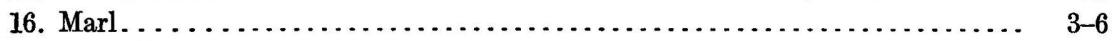

17. Hard limestones.......................................... 52

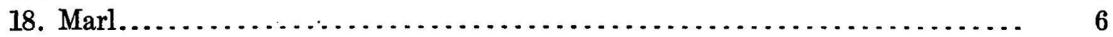

19. Limestone.................................................... 27

20. Marl................................................... 17

21. Limestone............................................... 20

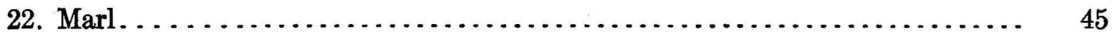

The above section contains 17 feet 5 inches of hard limestone and 16 feet 8 inches of marl and clay. The impracticability of using the hard limestone without using the marl and the clay is at once apparent.

One of the special features in the study of this formation has been to determine the possibility of utilizing the marls in combination with the limestone in the manufacture of Portland cement. A large number of analyses of the morls from different localities show that they contain no large amounts of injurious properties and can be used for cement as they come from the quarry. The marls and the clays supply the silica and alumina for Portland cement and are therefore of equal value to the limestone. In fact, a general average of the analyses of the limestones and the interbedded marls gives the desired mixture for a Portland cement, without the addition of other materials.

In the central and eastern parts of the State the Vicksburg is more homogeneous than it is in the western part. In Smith County it is a soft porous limestone known as the "chimney rock." It is quarried for chimneys and foundation pillars by sawing it into any desired shape with a large saw. On exposure to the air it hardens and lasts for 30 to 40 years. The "chimney rock" is one of the purest forms of the Vicksburg limestone.

VICKSBURG.

The typical locality of the Vicksburg limestone is in the bluff in and near the city of Vicksburg. In the bluff overlooking Mississippi River just below the oil mill, one-half mile south of the confluence of Yazoo and Mississippi rivers, is a limestone outcrop 800 feet long. On the slope above the oil mill the limestone underlies a thin veneer of soil. It is exposed in a few places between the oil mill and the National Cemetery. Its top forms a benchlike terrace which extends back to the foot of the loess bluff. 


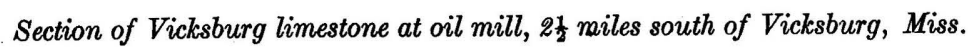

1. Loess in the bluff back from the river. . . . . . . . . . . . . . . . . . 100

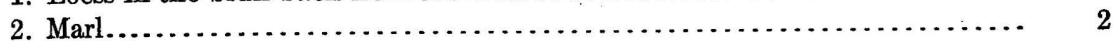

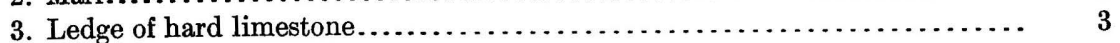

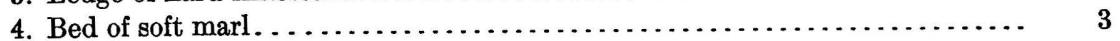

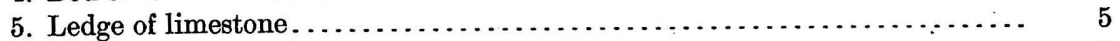

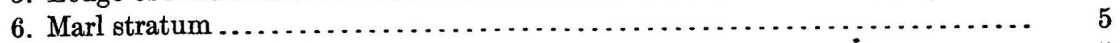

7. Ledge of hard limestone................................ 5

8. Hard limestone. . . . . . . . . . . . . . . . . . . . . .

9. Bed of compact marl..................................... 5

Water's edge.

The thickness of the exposure in the above section is about onethird the entire thickness of the Vicksburg limestone.

Analyses of each stratum from 3 to 9 inclusive appear, correspondingly numbered, in the table below. Analysis 10 is of a limestone from Steels Bayou, Vicksburg.

Analyses of limestone and marls from Vicksburg limestone at Vicksburg, Miss.

\begin{tabular}{|c|c|c|c|c|c|c|c|c|c|}
\hline & 3 & 4 & 5 & 6 & 7 & 8 & 9 & A verage. & 10 \\
\hline 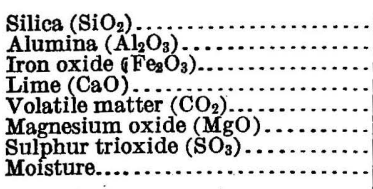 & $\begin{array}{r}3.10 \\
.25 \\
1.62 \\
50.63 \\
41.00 \\
.99 \\
.60 \\
.60\end{array}$ & $\begin{array}{r}13.62 \\
3.00 \\
2.75 \\
40.37 \\
33.66 \\
1.72 \\
.98 \\
2.75\end{array}$ & $\begin{array}{r}5.58 \\
1.00 \\
2.18 \\
49.97 \\
39.26 \\
1.01 \\
.30 \\
.82\end{array}$ & $\begin{array}{r}25.27 \\
4.50 \\
5.37 \\
29.50 \\
24.10 \\
1.99 \\
2.76 \\
3.95\end{array}$ & $\begin{array}{r}7.39 \\
1.02 \\
2.48 \\
47.50 \\
38.65 \\
1.45 \\
.51 \\
1.10\end{array}$ & $\begin{array}{r}6.43 \\
.31 \\
2.00 \\
50.25 \\
39.00 \\
1.36 \\
.36 \\
.61\end{array}$ & $\begin{array}{r}32.45 \\
2.12 \\
2.05 \\
34.20 \\
26.65 \\
.38 \\
.08 \\
1.60\end{array}$ & $\begin{array}{r}13.41 \\
1.74 \\
2.63 \\
43.20 \\
34.62 \\
1.29 \\
.79 \\
1.63\end{array}$ & $\begin{array}{r}7.08 \\
.61 \\
2.50 \\
50.44 \\
37.22 \\
1.07 \\
.38 \\
.40\end{array}$ \\
\hline
\end{tabular}

A small fragment of limestone from each of stratums $3,5,7$, and 8 was pulverized and the mixture analyzed with the results given in column 1 below. A similar analysis was made from a mixture of the marls with the results given in column 2 .

Analyses of limestone and marls from Vicksburg limestone at Vicksburg, Miss.

\begin{tabular}{|c|c|c|c|}
\hline & 1 & 2 & Average. \\
\hline 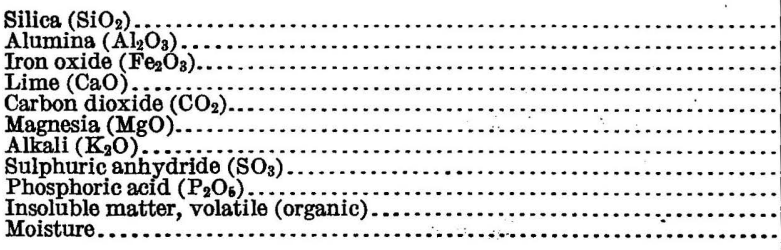 & $\begin{array}{r}4.95 \\
.56 \\
2.47 \\
50.11 \\
39.30 \\
1.13 \\
.15 \\
.25 \\
.03 \\
.84 \\
.20\end{array}$ & $\begin{array}{r}24.97 \\
6.49 \\
1.36 \\
33.97 \\
26.38 \\
1.60 \\
.70 \\
1.00 \\
.07 \\
2.24 \\
.82\end{array}$ & $\begin{array}{r}14.96 \\
5.46 \\
42.04 \\
32.84 \\
1.37 \\
.43 \\
.63 \\
.06 \\
1.54 \\
.51\end{array}$ \\
\hline
\end{tabular}

The Vicksburg outcrops at intervals in the bluff from the city of Vicksburg to the town of Redwood or beyond; the limestone occurs beneath a thick overburden of Lafayette and loess, which attains a maximum thickness of about 175 feet. 
In the hills south of Vicksburg the "Grand Gulf clays" are found. on the hillsides and in the bluffs beneath the loess and the Lafayette, in places as a highly plastic gray clay interbedded with aluminous sandstone. A sample collected 5 miles south of Vicksburg, on the old Roche land, was analyzed with the following results: ${ }^{1}$

Analysis of clay 5 miles south of Vicksburg, Miss.

Silica $\left(\mathrm{SiO}_{2}\right)$

Alumina $\left(\mathrm{Al}_{2} \mathrm{O}_{3}\right)$

Ferric oxide $\left(\mathrm{Fe}_{2} \mathrm{O}_{3}\right)$.

Lime $(\mathrm{CaO})$

Magnesia $(\mathrm{MgO})$

Sulphur trioxide $\left(\mathrm{SO}_{3}\right)$

Moisture

3.19

Loss on ignition.

8. 26

BYRAM.

The Vicksburg limestone outcrops in the hills northwest of Byram and is exposed in the railway cut a mile north of the station. The hard limestone on the little hill west of this exposure was formerly used for making lime.

Hard limestone interbedded with indurated marl is exposed in the banks of Pearl River from about one-fourth mile below to $2 \frac{1}{2}$ miles above Byram. The rocks show a gentle fold whose axis extends approximately east and west.

Samples of limestone and marl from the bank of the river at Byram were analyzed, with the following results:

Analyses of limestone and marl from Vicksburg limestone at Byram, Miss.

\begin{tabular}{|c|c|c|}
\hline . & $\begin{array}{l}\text { Lime- } \\
\text { stone. }\end{array}$ & Marl. \\
\hline 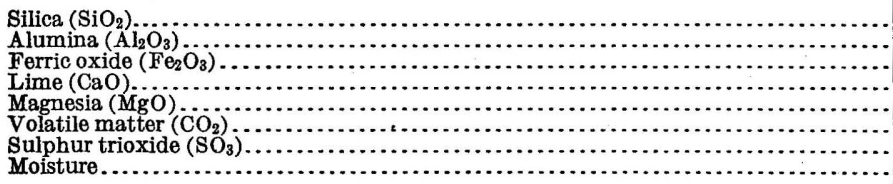 & $\begin{array}{r}2.28 \\
2.42 \\
2.19 \\
50.55 \\
1.40 \\
40.87 \\
.30 \\
.31\end{array}$ & $\begin{array}{r}26.42 \\
8.25 \\
5.20 \\
27.77 \\
1.44 \\
26.00 \\
2.00 \\
3.00\end{array}$ \\
\hline
\end{tabular}

About $2 \frac{1}{2}$ miles north of Byram, on the east bank of Pearl River; the following section is exposed:

Section of Vicksburg limestone $2 \frac{1}{2}$ miles north of Byram, Miss.

Iimestone, gray, rotten; containing graing of glaucones. containing grains of glauconitic sand ................. 24

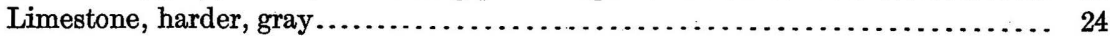

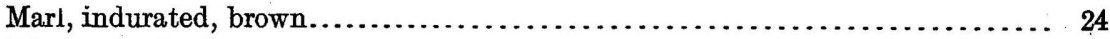

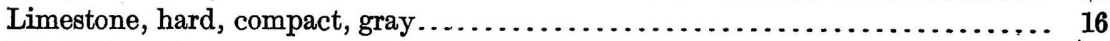

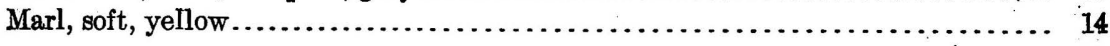




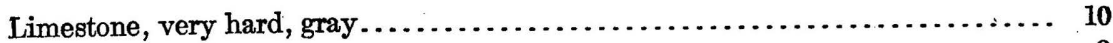

Clay, gray, marly............................................ 8

Limestone, compact......................................... 20

Marl, indurated, white to gray..................................... 20

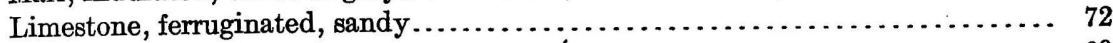

Greensand marl; base of exposure............................... 60

PLAIN.

The Vicksburg limestone outcrops in the first cut south of Plain, on the Gulf \& Ship Island Railroad, in an exposure composed, as at Vicksburg, of alternating beds of limestone and marl. At the top of the formation is a plastic calcareous red clay, formed from the decomposition of the limestone and the marl. Samples of each stratum in the cut were analyzed, with the following results:

Analyses of limestone and marls from Vicksburg limestone near Plain, Miss.

\begin{tabular}{|c|c|c|c|c|c|c|c|}
\hline & 1 & 2 & 3 & 4 & 5 & 6 & $\begin{array}{l}\text { Aver- } \\
\text { age. }\end{array}$ \\
\hline 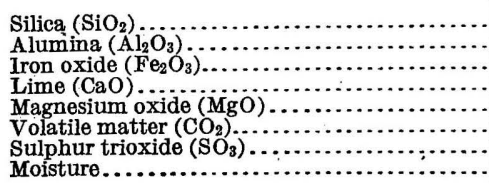 & $\begin{array}{r}7.57 \\
1.23 \\
5.50 \\
46.33 \\
.02 \\
38.54 \\
.09 \\
.27\end{array}$ & $\begin{array}{r}1.85 \\
1.37 \\
1.75 \\
52.12 \\
. .49 \\
41.87 \\
.25\end{array}$ & $\begin{array}{r}4.95 \\
4.00 \\
47.50 \\
1.16 \\
39.25 \\
.25 \\
1.25\end{array}$ & $\begin{array}{r}12.52 \\
4.75 \\
5.50 \\
39.75 \\
.81 \\
34.50 \\
1.56\end{array}$ & $\begin{array}{r}14.11 \\
2.87 \\
6.60 \\
39.78 \\
.40 \\
34.33 \\
.17 \\
1.62\end{array}$ & $\begin{array}{r}17.53 \\
1.42 \\
15.15 \\
29.87 \\
.02 \\
27.45 \\
5.25\end{array}$ & $\begin{array}{r}9.76 \\
1.94 \\
6.46 \\
42.56 \\
.48 \\
35.99 \\
.17 \\
1.70\end{array}$ \\
\hline
\end{tabular}

The Vicksburg limestone can be easily traced by the outcrops in the hills from the exposure in the railway cut south of Plain westward to Pearl River and eastward to Brandon. The thickness exposed is nowhere great, in few places amounting to more than 20 feet and in many places to much less.

BRANDON.

The Vicksburg limestone is exposed at the railway station at Brandon and for one-fourth mile to the west. Another exposure is at the old Yost limekiln site, a mile east of the station.

The most complete exposure of the Vicksburg, east of Pearl River, is at the old Robinson quarry, about 4 miles southeast of Brandon, where the formation is made up of hard ledges of crystalline limestone alternating with beds of calcareous marl of about equal thickness. This rock was quarried for some time by a firm in Jackson and was crushed and used in the foundation of the new State capitol. Work was discontinued because of the great amount of useless marl which had to be removed to get the rock. The analyses given below show that the marl and limestone could all be used in making Portland cement.

This material is easily quarried, as there is little or no superincumbent matter. A spur from the main line of the Alabama \& $48834^{\circ}-$ Bull. $522-13-16$ 
Vicksburg Railway has been built from Rankin to the quarry, giving an easy outlet.

Analyses of Vicksburg limestone from Robinson quarry, 4 miles southeast of Brandon, Miss.

\begin{tabular}{|c|c|c|c|c|c|}
\hline & 1 & 2 & 3 & 4 & 5 \\
\hline 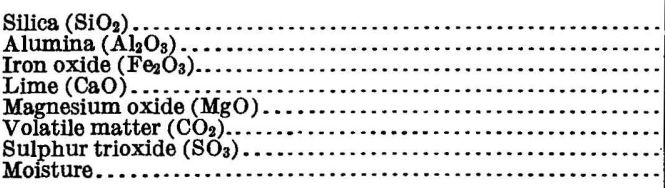 & $\begin{array}{r}4.22 \\
.75 \\
4.37 \\
49.62 \\
40.09 \\
40.05 \\
.36 \\
.88\end{array}$ & $\begin{array}{r}4.55 \\
.00 \\
4.25 \\
49.92 \\
.09 \\
39.61 \\
.72 \\
.95\end{array}$ & \begin{tabular}{r|}
5.56 \\
1.09 \\
4.01 \\
48.44 \\
38.78 \\
.24 \\
1.61
\end{tabular} & $\begin{array}{r}1.58 \\
4.40 \\
3.31 \\
48.40 \\
1.27 \\
39.70 \\
.45 \\
.60\end{array}$ & $\begin{array}{r}16.88 \\
5.70 \\
3.59 \\
36.86 \\
.99 \\
33.16 \\
.24 \\
2.10\end{array}$ \\
\hline
\end{tabular}

BAYSPRING.

Numerous outcrops of the Vicksburg limestone appear between Brandon and Bayspring, but all are so far removed from lines of transportation that their immediate value is small. Only the most important outcrop will be described in this report.

On the east side of Tallahala Creek, about 4 miles west of Bayspring, the Vicksburg limestone outcrops in the road and on the side of the hill. Above the limestone is a pink plastic clay very similar to the clay overlying the limestone $1 \frac{1}{2}$ miles south of Plain (see above). The thickness of the Vicksburg here is 65 feet.

The uppermost member of the Vicksburg is a ledge of hard, bluishgray limestone, which is so much more resistant than the overlying "Grand Gulf clay" that it forms a marked bench along the hillside. The absence of marl beds alternating with harder ledges of limestone is noticeable. The top of the formation is capped with hard limestone, but all the material underneath this to the bottom of the hill is a soft, porous, white to yellowish limestone. The harder ledges of limestone were formerly used for burning lime.

SYLVARENA.

On Mr. Houston's land, 2 miles west of Sylvarena, is a quarry where for 17 years the soft porous limestone has been sawed out for building chimneys. The rock for 3 to 4 feet below the surface has disintegrated into a rotten mass, easily picked to pieces with a spade, but below this it is sufficiently compact to be used. Chimneys built of this rock first disintegrate at the top. The rock is very porous; it fills with water, which freezes in the winter and causes it to break. The rock has also been used for making lime and doubtless is very desirable for this purpose, as it is almost pure lime carbonate. The hard upper ledges of the Vicksburg outcrop in the hills north and east of the town of Vosburg. 
NANCY.

Two samples of limestone were collected near Nancy, Clarke County, by W. N. Logan and analyzed with the following results:

Analyses of Vicksburg limestone near Nancy, Clarke County, Miss.

\begin{tabular}{|c|c|c|}
\hline & 1 & 2 \\
\hline 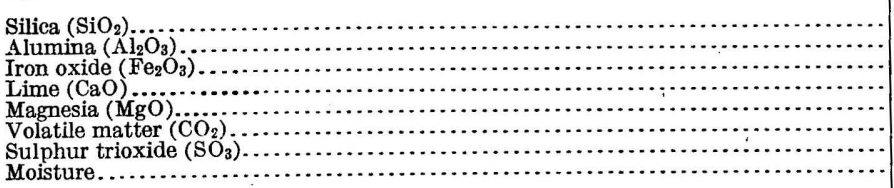 & \begin{tabular}{r|}
7.31 \\
13.61 \\
4.00 \\
36.62 \\
.29 \\
35.20 \\
2.78 \\
1.00
\end{tabular} & $\begin{array}{r}6.77 \\
4.68 \\
2.00 \\
45.51 \\
.64 \\
35.40 \\
3.00 \\
1.79\end{array}$ \\
\hline
\end{tabular}

RED HILL.

Near Red Hill ${ }^{1}$ in Wayne County, on Limestone Creek, the Mobile \& Ohio Railroad is cut through a considerable hill, where the Eocene limestones are well exhibited. Limestone Creek, which runs south of the cut on the railroad and empties into Chickasawhay River about 400 yards from it, contains large ledges of hard compact limestone. About $1 \frac{1}{2}$ miles southeast of the cut sandstone, which appears south of the cut and is not well cemented, crops out as a hard limestone, an excellent material for building. Three analyses of the limestone are given by Harper: ${ }^{2}$

Analyses of Vicksburg limestone from Red Hill, Wayne County, Miss.

\begin{tabular}{|c|c|c|c|}
\hline & 1 & 2 & 3 \\
\hline Silica $\left(\mathrm{SiO}_{2}\right) \ldots$ & 6.30 & 15.05 & 9.20 \\
\hline 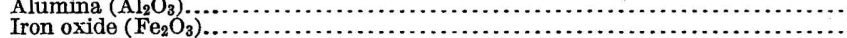 & 7.20 & 5.35 & 6.65 \\
\hline Lime $(\mathrm{CaO})$ & 48.44 & 44.58 & 47.12 \\
\hline 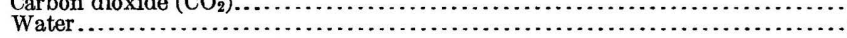 & $\begin{array}{l}38.06 \\
\text { n. d. }\end{array}$ & $\begin{array}{l}35.02 \\
\text { n. d. }\end{array}$ & $\begin{array}{l}37.03 \\
\text { n. d. }\end{array}$ \\
\hline
\end{tabular}

Hilgard, ${ }^{3}$ in speaking of the Vicksburg limestone, says:

On the Chickasawhay, between Red Bluff and the latitude of Waynesboro, both marls and limestone crop out with frequency; the same is the case on the creeks on the east side, as on Cakcheys Mill Creek and Limestone Creek, especially near the mouth of the latter, at the foot of the hill on which Dr. E. A. Miller lives-the most southerly outcrop of the calcareous Vicksburg on the Chickasawhay. The sections exhibited here in the river banks and cuts of the railroad correspond so closely to those between Yost's limekiln and Brandon depot that the specimens can hardly be distinguished from each other when placed side by side, the only difference being the great abundance of Orbitoides in the soft white marl intervening between the strata of rock. The ledges of hard limestone (in Wayne County) are not so well definedthe rock being softer and whitish.

1 Harper, L., Geology and agriculture of Mississippi, 1857, p. 140.

2 Idem, p. 166.

8 Hilgard, E. W., Geology of Mississippi, 1860, p. 146. 
CLAYS.

Clay for addition to the purer grades of Selma chalk, where such addition is required to make a good cement mix, may be obtained from the residual beds of the Selma or from the Porters Creek clay.

RESIDUAL CLAYS OF THE SELMA CHALK。

The Selma chalk on weathering leaves behind heavy deposits of residual clay. These can generally be found in close proximity to the chalk beds and are for that reason the most available supply for cement plants. They are, however, commonly low in silica and relatively high in alumina and iron.

The following analyses ${ }^{1}$ indicate the range in composition of the residual clays of the Selma:

Analyses of residual clays of Selma chalk, Mississippi.

\begin{tabular}{|c|c|c|c|c|c|c|c|}
\hline & 1 & 2 & 3 & 4 & 5 & 6 & 7 \\
\hline 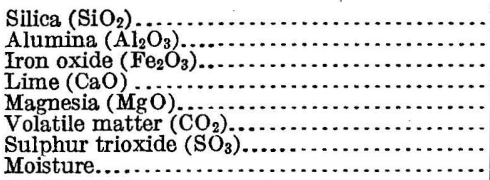 & $\begin{array}{r}63.63 \\
10.34 \\
8.25 \\
3.75 \\
.50 \\
7.77 \\
.34 \\
4.25\end{array}$ & $\begin{array}{r}75.95 \\
9.62 \\
5.08 \\
1.25 \\
.74 \\
2.52 \\
.34 \\
3.50\end{array}$ & $\begin{array}{r}72.32 \\
8.74 \\
7.44 \\
1.55 \\
.47 \\
5.58 \\
.51 \\
3.45\end{array}$ & $\begin{array}{r}65.30 \\
12.63 \\
12.18 \\
1.50 \\
.63 \\
2.27 \\
.25 \\
4.75\end{array}$ & $\begin{array}{r}56.97 \\
15.09 \\
10.40 \\
1.00 \\
.54 \\
10.90 \\
.34 \\
2.95\end{array}$ & $\begin{array}{r}63.35 \\
13.70 \\
7.90 \\
.80 \\
.60 \\
6.50 \\
.34 \\
6.02\end{array}$ & $\begin{array}{r}67.60 \\
12.55 \\
7.60 \\
.80 \\
.78 \\
5.00 \\
.17 \\
5.50\end{array}$ \\
\hline
\end{tabular}

1-3. West Point.

4. Starkville.

5-7. Agricultural College.

PORTERS CREEK CLAY.

Adjoining the Selma chalk belt on the west and in some places overlying the chalk deposits is the Porters Creek clay, a series of clays which for the most part are excellent for use with the Selma chalk in a cement mixture. The Porters Creek clay is described as follows by Crider: 2

Immediately above the Selma limestone, south of Houston, the Porters Creek clay outcrops in a belt 2 to 15 miles wide. North of Houston the Ripley and Clayton limestones intervene between the Selma and the Porters Creek formations. It is known as the "Flatwoods" country and in places is characterized by low flat land resembling the broad bottom of a large river. The Porters Creek clay is a dark clay which has a tendency to break into rectangular blocks when exposed to the sun. - It contains small flakes of mica, which in places have been segregated into small dikes.

Excellent exposures of the Porters Creek formation occur throughout the State where the Lafayette has been removed. The Mobile, Jackson \& Kansas City Railroad has made deep cuts into the clay at Walnut, Ripley, and along the divide between Houston and Maben. The Southern Railway, from West Point to Winona, cuts into the Porters Creek in the hills between Maben and Pheba.

A sample of the residual Porters Creek clay from 1 mile west of Starkville was analyzed, with the results following. 
Analysis of residual Porters Creek clay from 1 mile west of Starkville.

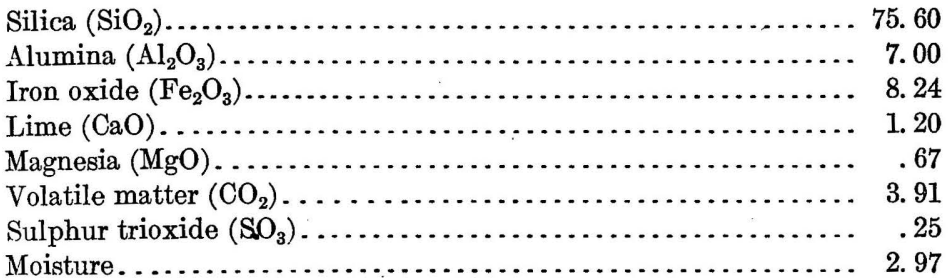

The following analyses of the Porters Creek clay were made from differentlocalities in the State:

Analyses of Porters Creek clay.

\begin{tabular}{|c|c|c|c|}
\hline 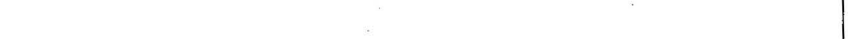 & 1 & 2 & 3 \\
\hline 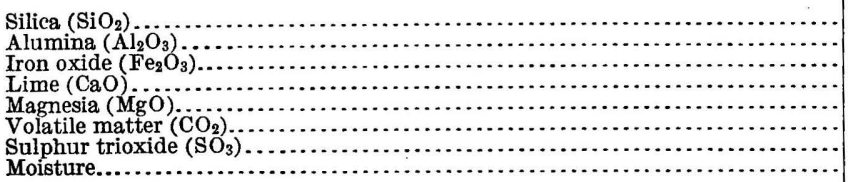 & $\begin{array}{r}57.25 \\
6.17 \\
18.95 \\
1.05 \\
.95 \\
7.75 \\
.21 \\
7.59\end{array}$ & $\begin{array}{r}71.47 \\
9.45 \\
6.97 \\
.40 \\
.63 \\
5.04 \\
.13 \\
5.65\end{array}$ & $\begin{array}{r}61.62 \\
8.87 \\
16.29 \\
.91 \\
.69 \\
7.77 \\
.28 \\
4.50\end{array}$ \\
\hline
\end{tabular}

1. Residual clay from near Macon.

2. Residual clay from Wahalak.

3. Porters Creek clay from Winston County.

The Illinois Central Railroad from Starkville to Ackerman crosses the Porters Creek clay, showing deep cuts of laminated grayish clay.

Again, on the Mobile \& Ohio Railroad, between Scooba and Lauderdale, occurs the same characteristic clay which has been traced across Alabama, Mississippi, western Tennessee, and Kentucky.

A sample of the Porters Creek clay from the town of Scooba was analyzed in the laboratory of the United States Geological Survey ${ }^{1}$ with the following results:

Analysis of Porters Creek clay from Scooba, Miss.

[W. S. McNiel, analyst.]

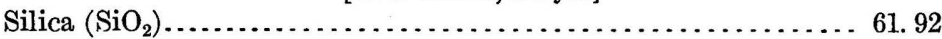

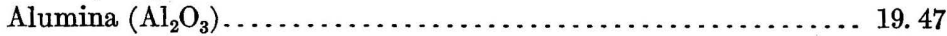

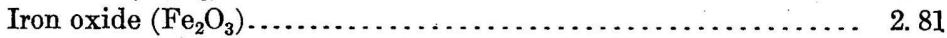

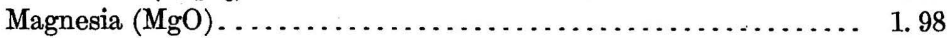

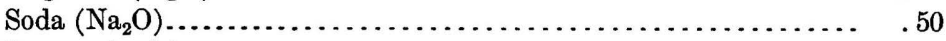

Loss on ignition..................................... 12.29

BIBLIOGRAPHY.

The following papers and reports contain detailed data relative to the economic geology and cement resources of the State of Mississippi: Crmer, A. F., Portland cement materials of Mississippi: Bull. Mississippi Geol. Survey No. 1, 1907.

— and ECKEL, E. C., Geology and mineral resources of Mississippi: Bull. U. S. Geol. Survey No. 283, 1906.

Eckel, E. C., Stoneware and brick clays of western Tennessee and northwestern Mississippi: Bull. U. S. Geol. Survey No. 213, 1903, pp. 382-391.

- and CrIDer, A. F., Geology and cement resources of the Tombigbee River district, Mississippi-Alabama: S. Doc. No. 165, 58th Cong., 3d sess., 1905, 23 pp., map.

JGeology and mineral resources of Mississippi: Bull. U. S. Geol. Survey No. 283, 1906, p. 55. 


\section{PORTLAND' CEMENT RESOURCES OF MISSOURI.}

\section{GENERAL FEATURES.}

Missouri now ranks seventh among the States as a producer of Portland cement, its output during 1911 having been more than $4,000,000$ barrels. This output comes from four plants, one of which is of very large capacity. It is probable that in the future the output will show still further increases.

The probability that Missouri will always maintain high rank as a cement producer is due to the fact that the thickest and purest limestone beds of the State outcrop along Mississippi and Missouri rivers. Plants located on these limestones are therefore assured of cheap fuel and of both water and rail transportation to a number of important cement markets. The extensive areas of good limestone in western Missouri are also assuming increased importance, owing to the falling off in the natural gas supply in the Kansas cement area and the resulting tendency to equalization of costs with that competing district.

\section{PORTLAND CEMENT MATERIALS.}

\section{DISTRIBUTION.}

The limestones of Missouri best adapted for use as Portland cement materials are mostly of Mississippian and Ordovician age, the Cambrian limestones, which cover nearly all of the southeastern portion of the State, being almost all too high in magnesium carbonate to be available. It must be noted, however, that certain Silurian formations, including those outcropping along Mississippi River between Chester, Ill., and Cape Girardeau, Mo., include limestone beds sufficiently low in magnesia to be worthy of investigation. (See Pl. XI.)

The geologic relations of the limestones and of the shales and clays which will be required for mixture with them are indicated below:

\section{Portion of geologic column in Missouri.}

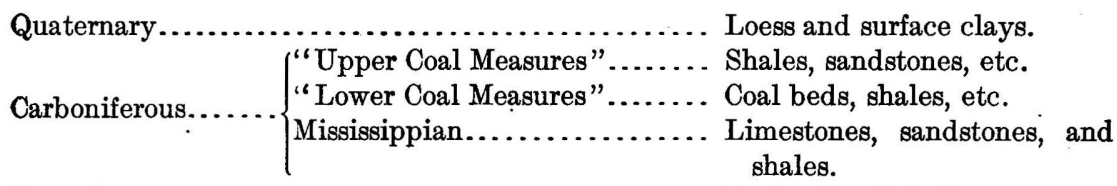

Devonian................................ Dark-colored shales.

Silurian ......................................... Magnesian limestones in part.

Upper and Middle
Ordovician.......

Lower Ordovician and Cambrian............... Magnesian limestones, sandstone, etc. 


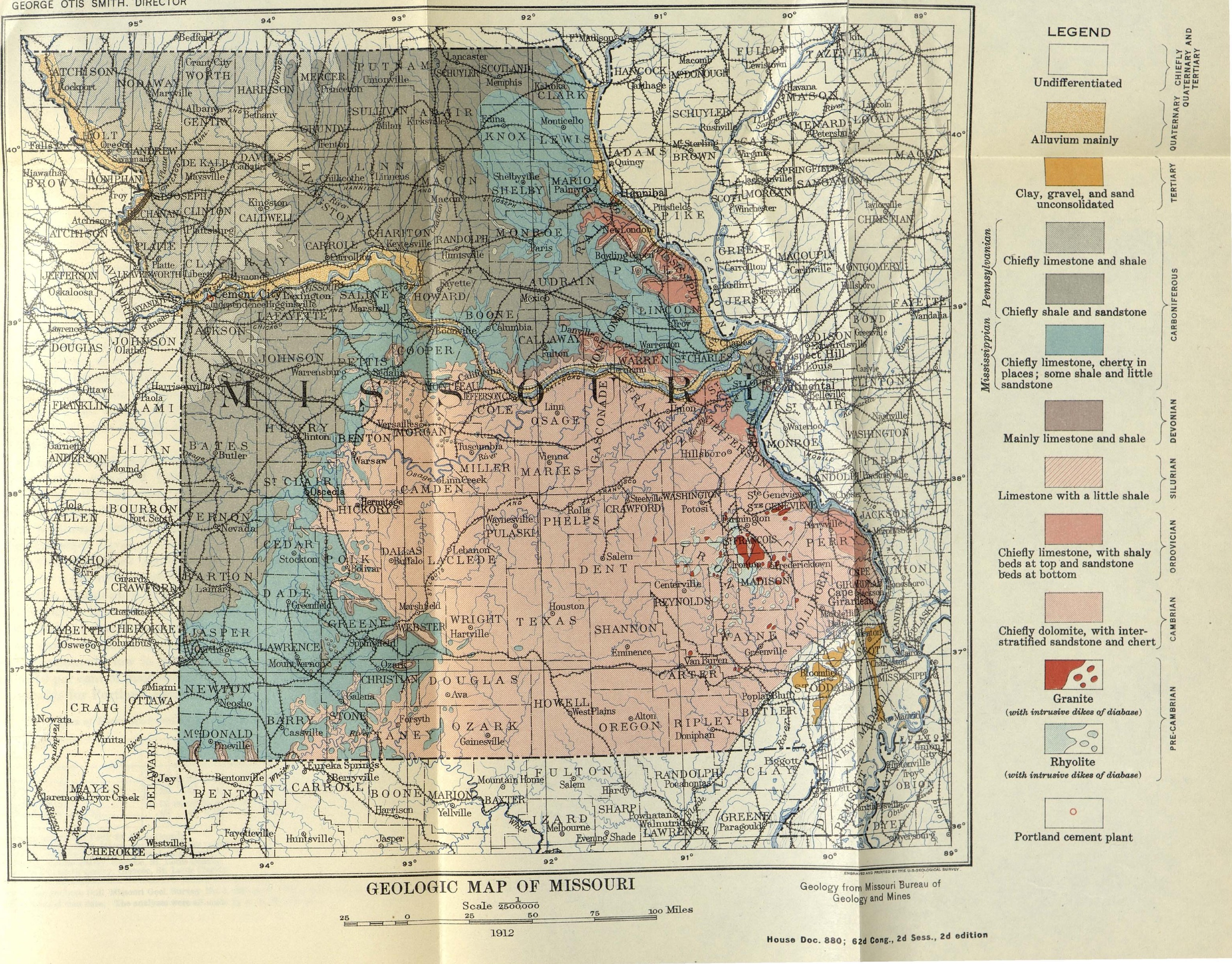



In the following descriptions attention is paid mainly to the Kimmswick and Plattin limestones (formerly called "Trenton" limestone) and to the Mississippian, which contain most of the nonmagnesian limestones occurring in the State.

\section{KIMMSWICK AND PLATTIN LIMESTONES.}

The Kimmswick and Plattin limestones occur in two separate belts in eastern Missouri, both of which are well located with regard to railroad and water transportation.

The smaller belt lies in Ralls, Pike, and Lincoln counties, the limestones outcropping as a belt 1 to 3 miles wide, commencing near Spalding, Ralls County, and running southeastward to Mississippi River near Busch, about 10 miles south of Hannibal. From Busch the belt follows the river southward to near Cap au Gris, Lincoln County, where it turns sharply northwest and runs nearly to Edgewood, Pike County.

The second and much larger belt commences in southern Callaway County and runs eastward parallel to and a few miles north of Missouri River, through Montgomery, Warren, and St. Charles counties. It crosses Missouri River at Hamburg, St. Charles County, and turns southeastward through St. Louis and Jefferson counties, reaching Mississippi River at Kimmswick. From this point south to Cape Girardeau it follows the river closely, appearing either in the bluffs or only a few miles west of them.

The Plattin limestone is generally bluish to gray and black, and the Kimmswick is light colored, in places almost white; locally, thin transition beds of shale or earthy limestone intervene between the two. As shown by the analyses in the following table, ${ }^{1}$ both limestones are commonly low in magnesia, and though some beds may show 5 to 10 per cent of magnesium carbonate the mass of the formation is suitable for Portland cement material.

Analyses of Kimmswick and Plattin limestones from Missouri.

\begin{tabular}{|c|c|c|c|c|c|c|c|c|c|c|}
\hline & 1 & 2 & 3 & 4 & 5 & 6 & 7 & 8 & 9 & 10 \\
\hline 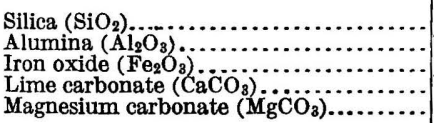 & $\mid \begin{array}{r}0.35 \\
.35 \\
97.75 \\
.45\end{array}$ & $\begin{array}{r}12.15 \\
.45 \\
86.00 \\
.46\end{array}$ & $\begin{array}{r}2.25 \\
.30 \\
89.40 \\
6.96\end{array}$ & $\begin{array}{r}0.45 \\
.65 \\
97.20 \\
.46\end{array}$ & $\begin{array}{r}6.00 \\
1.05 \\
82.55 \\
9.27\end{array}$ & $\begin{array}{r}1.00 \\
.55 \\
96.40 \\
.42\end{array}$ & $\begin{array}{r}0.46 \\
.40 \\
98.60 \\
.34\end{array}$ & $\begin{array}{r}0.70 \\
.25 \\
97.40 \\
.42\end{array}$ & $\begin{array}{r}0.35 \\
.30 \\
97.75 \\
.27\end{array}$ & $\begin{array}{r}0.55 \\
.60 \\
96.75 \\
.27\end{array}$ \\
\hline
\end{tabular}

1. Dorenheim quarry, St. Paul, St. Louis County.

2. Thorn \& Hunkin quarry, Mínck station, St. Louis County.

3. Glencoe Co., south quarry, Glencoe, St. Louis County.

4. Glencoe Co., middle quarry, Glencoe, St. Louis County.

5-10. Glencoe Co., north quarry, Glencoe, St. Louis County.

1 These analyses are from Bull. Missouri Geol. Survey No. 3, 1890, p. 80. The quarries are named according to their owners at that date. The analyses were all made by A. E. Woodward. 


\section{LATE ORDOVICIAN SHALE.}

Overlying the Kimmswick limestone is a late Ordovician bluish to greenish shale, much of which contains a large percentage of lime. North of Lincoln County thin bands of pure limestone, varying from a few inches to a few feet in thickness, are commonly interbedded with the shale. These limestone bands become more numerous and thicker as the base of the shale is approached. The shale varies from a knife-edge to over 100 feet in thickness. In its exposures near Mississippi River, in Ralls, Pike, and Lincoln counties, it is generally overlain either by Devonian shales or by the great series of Mississippian limestones described on a later page. The following analysis ${ }^{1}$ is of a specimen from near the base of the river bluff at Louisiana, Pike County:

Analysis of late Ordovician shale from Louisiana, Pike County, Mo.

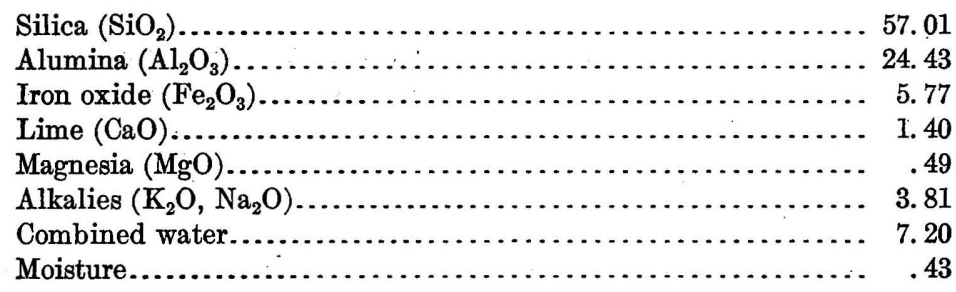

DEVONIAN SHALES.

In the northern portion of Missouri (see Pl. XI) dark-colored shales of Devonian age appear in places above the late Ordovician shales and below the Mississippian limestones. These Devonian shales vary from 10 feet or less to 50 feet in thickness. At Louisiana, Pike County, 8 feet of Devonian shales appear in the river bluffs, overlying the Ordovician shale, whose analysis is given in the preceding table. In Jefferson County, as at Sulphur Springs, similar shales rest on the Kimmswick limestone, but their distribution is very irregular.

\section{MISSISSIPPIAN ("LOWER CARBONIFEROUS") LIMESTONES AND SHALES.}

The Mississippian limestones are the surface formations over almost one-fourth of Missouri. Their three most prominent areas of outcrop, which lie along Mississippi and Missouri rivers and in southwestern Missouri, are connected by narrow bands so as to really form portions of one large area, but for convenience they are diseussed separately. The Mississippi River area, which is the most promising of the three, is discussed in greater detail than the others.

In southwestern Missouri the Mississippian limestones form the surface of the greater part of McDonald, Newton, Jasper, Barry, Lawrence, Stone, Christian, Greene, Dade, and Cedar counties, 
the southwestern half of Polk, and smaller portions of Barton, St. Clair, Hickory, and Benton counties. This extensive limestone area is crossed by several railroads, but the competition of Kansas plants using natural gas would make against the success of a cement plant.

On and near Missouri River the Mississippian limestones cover most of Pettis, Saline, and Cooper counties, on the south bank, and outcrop continuously along the north bank from Miami station, Carroll County, through southern Howard County to below Rocheport, Boone County. The limestone belt then leaves Missouri River and turns eastward, through Boone, Callaway, and Montgomery counties, to join the Mississippi River limestone belt discussed below.

In northeastern and eastern Missouri, along Mississippi River, a very extensive and important area of Mississippian limestones cover the eastern half of Clark, all or almost all of Lewis, Knox, Shelby, Marion, Monroe, Ralls, Pike, Lincoln, and St. Charles counties, and portions of Montgomery, Warren, St. Louis, Jefferson, Ste. Genevieve, and Perry counties. The distribution of the limestones in these counties is shown in detail on the geologic map of northeastern Missouri. (See Pl. XI.)

The limestones appear continuously in the river bluffs or in stream cuts along the west bank of the Mississippi from the Iowa State line to a point about 10 miles south of Hannibal. Here the Mississippian limestones leave the river for some distance, Silurian rocks appearing in the bluffs from below Saverton to Cap au Gris. At Cap au Gris the limestones again appear and form the river bluffs as far south as Kimmswick, in Jefferson County. Ordovician rocks then appear on the river bank for about 12 miles, but from about 5 miles below Crystal City the Mississippian limestones show almost continuously to less than a mile south of Wittenberg, where they finally disappear.

The Mississippian rocks of Missouri include several thick limestone formations and at least one thick series of shales. The limestones are almost invariably good Portland cement materials.

The following section is exposed in the river bluffs at. Louisiana:

Section of river bluff at Louisiana, Pike County, Mo.

Feet.

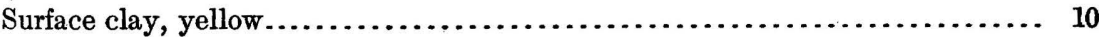

Mississippian:

Limestone............................................ 70

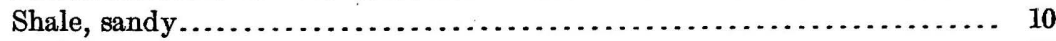

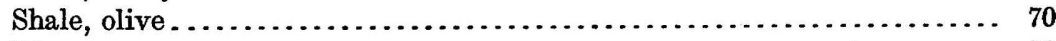

Limestone................................................... 50

Devonian:

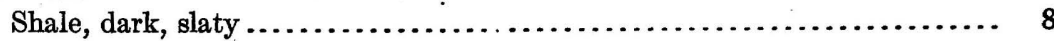

Silurian:

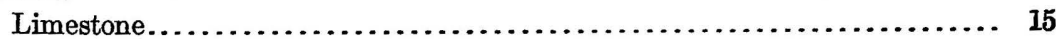

Ordovician:

Shale, blue............................................... 60 
Analyses of Mississippian limestones, Missouri.

\begin{tabular}{|c|c|c|c|c|c|c|c|c|c|c|c|c|c|}
\hline & 1 & 2 & 3 & 4 & 5 & 6 & 7 & 8 & 9 & 10 & 11 & 12 & 13 \\
\hline $\begin{array}{l}\text { Silica }\left(\mathrm{SiO}_{2}\right) \\
\text { Alumina }\left(\mathrm{Al}_{2} \mathrm{O}_{3}\right) \text { and iron oxide } \\
\left(\mathrm{Fe}_{2} \mathrm{O}_{3}\right) \ldots \ldots \\
\left.\text { Lime carbonate }(\mathrm{CaCO})_{8}\right) \\
\left.\text { Magnesium carbonate }(\mathrm{MgCO})_{3}\right)\end{array}$ & $\begin{array}{r}1.10 \\
.40 \\
94.00 \\
3.18\end{array}$ & $\begin{array}{r}2.00 \\
.40 \\
95.15 \\
.64\end{array}$ & $\begin{array}{r}4.35 \\
1.75 \\
77.95 \\
14.84\end{array}$ & $\begin{array}{r}1.24 \\
.37 \\
97.71 \\
.68\end{array}$ & $\begin{array}{r}4.05 \\
.37 \\
93.21 \\
.79 \\
\end{array}$ & $\begin{array}{r}2.86 \\
.35 \\
89.26 \\
473\end{array}$ & $\begin{array}{r}3.20 \\
.40 \\
93.20 \\
1.44\end{array} \mid$ & $\begin{array}{r}5.77 \\
.43 \\
89.95 \\
2.23\end{array}$ & $\begin{array}{r}4.71 \\
.22 \\
94.15 \\
1.48\end{array}$ & $\begin{array}{r}2.47 \\
.31 \\
92.30 \\
1.88\end{array}$ & $\begin{array}{r}0.72 \\
.60 \\
98.06 \\
.61\end{array}$ & $\begin{array}{r}99.64 \\
.21\end{array}$ & $\begin{array}{r}0.08 \\
.40 \\
98.80 \\
.05\end{array}$ \\
\hline
\end{tabular}

1. Valley Park railroad cut, St. Louis County. Bull. Missouri Geol. Survey No. 3, 1890, p. 77.

2. Vigus station quarry, St. Louis County. Idem.

3. St. Louis, St. Louis County. Idem.

4. Goetz quarry, Bartold Valley, St. Louis County. Idem.

5-6. Workhouse quarry, St. Louis County. Idem.

7-8. Lorentz quarry, near Cahokia Street, St. Louis, St. Louis County. Idem, p. 76.

9-10. Quarry, foot of Barton Street, St. Louis, St. Louis County. Idem.

11. Carthage Marble Co. W. B. Potter, analyst.

12. Star Lime Co.'s quarry, near Hannibal, Marion County. Twentieth Ann. Rept. U. S. Geol. Survey, pt. 6 (continued), 1899 , p. 415.

13. Hannibal Lime Co.'s quarry, near Hannibal, Marion County. Idem.

Analyses of Mississippian shales, Missouri.

\begin{tabular}{|c|c|c|c|c|c|c|}
\hline & 1 & 2 & 3 & 4 & 5 & 6 \\
\hline 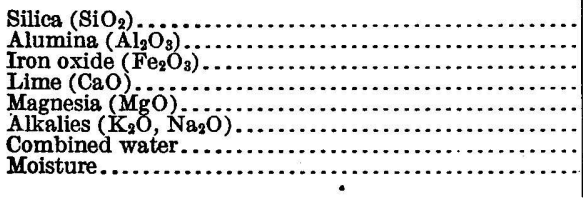 & $\begin{array}{r}75.70 \\
9.61 \\
1.79 \\
2.54 \\
2.11 \\
2.65 \\
6.16 \\
\text { n. d. }\end{array}$ & $\begin{array}{r}56.82 \\
24.48 \\
3.82 \\
.83 \\
1.81 \\
3.80 \\
8.16 \\
\text { n. d. }\end{array}$ & \begin{tabular}{|r}
46.26 \\
10.26 \\
2.65 \\
11.08 \\
7.84 \\
3.17 \\
$a 18.02$ \\
n. d.
\end{tabular} & $\begin{array}{r}49.69 \\
17.40 \\
4.01 \\
8.07 \\
4.16 \\
2.73 \\
13.37 \\
1.16\end{array}$ & $\begin{array}{r}59.97 \\
21.15 \\
5.20 \\
1.55 \\
1.10 \\
3.88 \\
5.71 \\
1.25\end{array}$ & $\begin{array}{r}55.84 \\
22.78 \\
5.24 \\
.73 \\
1.26 \\
4.10 \\
9.84 \\
\text { n. d. }\end{array}$ \\
\hline
\end{tabular}

$a$ Probably includes $\mathrm{CO}_{2}$ - E. C. E.

1. Hannibal, Marion County. Missouri Geol. Survey, vol. 11, 1896, p. 400.

2. Humansville, Polk County. Idem, p. 406.

3. Aldrich, Polk County. Idem, p. 407.

4. Barrett, St. Louis County. Idem, p. 422

5. Ste. Gonevieve, Ste. Genevieve County. Idem, p. 417.

6. Joplin, Jasper County. Idem, p. 392.

\section{PENNSYLVANIAN ("COAL MEASURES") LIMESTONES AND SHALES.}

Almost all northern and western Missouri is covered by the Pennsylvanian series ("Coal Measures"), which overlie the Mississippian series last described. The Pennsylvanian series consists of thick shales and sandstones, with intervening thin beds of limestone and numerous coal seams. In the present connection it is of interest chiefly as a source of fuel and shales, though possibly some of its limestones may be of value as cement materials.

The following analysis ${ }^{1}$ of a limestone, 4 to 6 feet thick, which overlies the Meadows coal seam in Lincoln County, shows it to be highly siliceous though very low in magnesia. In most places in Missouri, as elsewhere, the Pennsylvanian limestones are probably sufficiently low in magnesia to be available for use as Portland cement materials. They generally occur in thin beds, however, and it is usually necessary to excavate them by mining. Their common

1 Lincoln County. Chauvenet, analyst. Rept. Missouri Geol. Survey for 1872, pt. 2, 1873, p. 287. 
advantage is, of course, that they are found in close proximity to coal beds and to shales.

\section{Analysis of Pennsylvanian limestone, Missouri.}

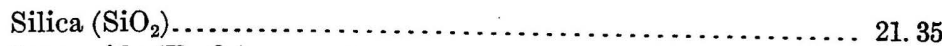

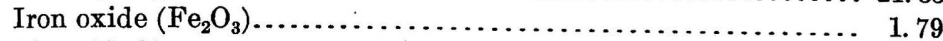

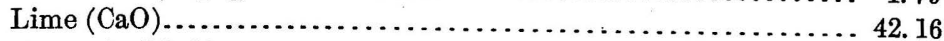

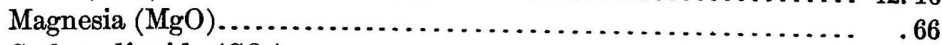

Carbon dioxide $\left(\mathrm{CO}_{2}\right) \ldots \ldots \ldots \ldots \ldots \ldots \ldots \ldots \ldots \ldots \ldots \ldots \ldots \ldots \ldots \ldots \ldots \ldots \ldots, 34.14$

Analyses of Pennsylvanian' shales, Missouri.

\begin{tabular}{|c|c|c|c|c|c|c|c|c|c|c|c|}
\hline & 1 & 2 & 3 & 4 & 5 & 6 & 7 & 8 & 9 & 10 & 11 \\
\hline 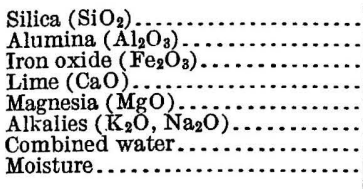 & $\begin{array}{l}60.70 \\
18.20 \\
7.58 \\
2.68 \\
\text { Tr. } \\
3.67 \\
6.77 \\
\text { n. d. }\end{array}$ & $\begin{array}{r}59.96 \\
15.76 \\
7.72 \\
.60 \\
.93 \\
3.66 \\
7.70 \\
4.00\end{array}$ & \begin{tabular}{|r|}
54.57 \\
23.61 \\
7.88 \\
.52 \\
1.48 \\
3.55 \\
6.67 \\
1.03
\end{tabular} & \begin{tabular}{|r|}
56.86 \\
17.97 \\
9.35 \\
1.67 \\
1.12 \\
2.61 \\
6.96 \\
2.45
\end{tabular} & $\begin{array}{r}63.11 \\
23.11 \\
1.79 \\
.42 \\
.70 \\
3.71 \\
7.05\end{array}$ & $\begin{array}{r}60.12 \\
21.35 \\
7.06 \\
.82 \\
1.08 \\
3.43 \\
6.32\end{array}$ & \begin{tabular}{|r|}
54.69 \\
25.96 \\
4.97 \\
.18 \\
.15 \\
3.58 \\
8.90
\end{tabular} & $\begin{array}{r}53.24 \\
23.62 \\
9.02 \\
1.17 \\
1.41 \\
4.38 \\
6.94\end{array}$ & $\mid \begin{array}{r}58.50 \\
30.50 \\
2.34 \\
1.20 \\
.51 \\
.30 \\
6.74 \\
.40\end{array}$ & $\begin{array}{r}54.03 \\
22.50 \\
7.90 \\
.85 \\
2.70 \\
4.12 \\
7.54 \\
\ldots \ldots\end{array}$ & $\begin{array}{r}55.96 \\
20.63 \\
8.12 \\
1.91 \\
1.96 \\
3.34 \\
7.32\end{array}$ \\
\hline
\end{tabular}

1. Prospect Hill, St. Louis County. R. Chauvenet, analyst. Missouri Geol. Survey, vol. 11, 1896, p. 419.

2, 3. Laclede fire-clay mine, Cheltenham, St. Louis County. Idem, p. 421.

4. Huntsville, Randolph County. Idem, p. 411.

5. Billings, Christian County. Idem, p. 375 .

6. Deepwater, Henry County. Idem, p. 387.

7. Clinton, Henry County. Idem, p. 382.

8. Boonville, Cooper County. Idem, p. 377.

9. Lakenan, Shelby County. Idem, p. 424.

10. Lexington, Lafayette County. Idem, p. 395.

11. Foster, Bates County. Idem, p. 369.

\section{LOESS AND SURFACE CLAYS.}

Along the banks of Mississippi and Missouri rivers thick deposits of loess clays occur in the river bluffs. These are fine-grained clays, carrying a considerable percentage of very fine sand, and will be valuable for use at cement plants located near these rivers. Smaller local deposits of surface clays also occur all over the State. The table below contains analyses of representative clays of both types:

Analyses of loess and surface clays, Missouri.

\begin{tabular}{|c|c|c|c|c|c|c|c|c|}
\hline & 1 & 2 & 3 & 4 & 5 & 6 & 7 & 8 \\
\hline 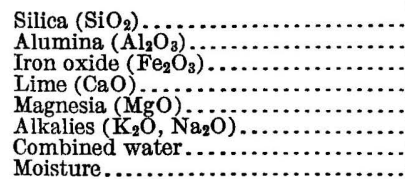 & $\begin{array}{r}73.92 \\
11.65 \\
4.74 \\
1.43 \\
.60 \\
3.13 \\
3.08\end{array}$ & $\begin{array}{r}73.80 \\
13.19 \\
3.43 \\
.86 \\
.68 \\
2.94 \\
5.26\end{array}$ & $\begin{array}{r}72.00 \\
11.97 \\
3.51 \\
1.80 \\
1.35 \\
3.25 \\
6.42\end{array}$ & $\begin{array}{r}71.11 \\
11.62 \\
3.90 \\
2.37 \\
1.47 \\
3.14 \\
6.71\end{array}$ & $\begin{array}{r}74.39 \\
12.03 \\
4.06 \\
1.50 \\
1.53 \\
3.01 \\
3.17\end{array}$ & $\begin{array}{r}61.19 \\
15.48 \\
5.49 \\
1.95 \\
1.56 \\
2.82 \\
9.02 \\
3.11\end{array}$ & $\begin{array}{r}62.80 \\
17.22 \\
5.21 \\
.98 \\
.78 \\
3.63 \\
7.82 \\
2.06\end{array}$ & $\begin{array}{r}54.90 \\
18.03 \\
6.03 \\
2.88 \\
1.10 \\
3.40 \\
6.90 \\
6.72\end{array}$ \\
\hline
\end{tabular}

1. Loess clay, St. Louis, St. Louis County. Missouri Geol. Survey, vol. 11, 1896, p. 486.

2. Loess clay, Hannibal, Marion County. Idem.

3. Loess clay, Kansas City, Jackson County. Idem.

4. Loess clay, Boonville, Cooper County. Idem.

5. Loess clay, Jefferson City, Cole County. Idem.

6. Gumbo clay, Elm Point, St. Charles County. Idem, p. 548.

7. Gumbo clay, Clifton, Randolph County. Idem, p. 547.

8. Gumbo clay, Norborne, Carroll County. Idem, p. 546. 


\section{PORTLAND CEMENT INDUSTRY IN MISSOURI.}

Prior to 1902 no Portland cement plants were in operation in Missouri. In that year, however, the St. Louis Portland Cement Co. commenced shipments, and during 1903 the Hannibal plant of the Atlas Portland Cement Co. went into operation. In 1908 the plant of the Kansas City Portland Cement Co. was added to the producing list, followed the next year by that of the Continental Portland Cement Co., and in 1912 by that of the Cape Girardeau Portland Cement Co.

At present, therefore, five plants are producing Portland cement in Missouri. Two of these-built by the St. Louis and Kansas City companies, respectively-are now under the same ownership, both being controlled by the Union Sand \& Material Co. In addition to the plants operating, several others are in different stages of promotion.

In 1911 Missouri ranked seventh among the States as a producer of Portland cement, its output for that year having been 4,114,859 barrels. The four plants which contributed to this total production were all dry-process plants, using limestone, with clay or shale, for their raw mix.

The plant of the Atlas Portland Cement Co., at Ilasco, Pike County, a few miles south of Hannibal, uses limestone of Mississippian age, obtained from a quarry adjoining the mill. Selected specimens of the stone from this quarry analyze as follows:

Analyses of Mississippian limestones, Ilasco, Mo.

\begin{tabular}{|c|c|c|c|}
\hline & 1 & 2 & 3 \\
\hline 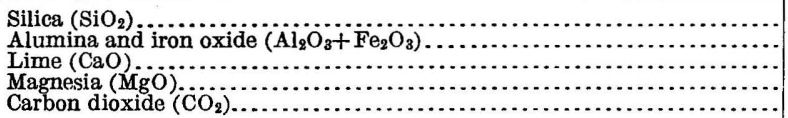 & $\begin{array}{r}0.40 \\
.44 \\
54.87 \\
.20 \\
43.34\end{array}$ & $\begin{array}{r}0.54 \\
54.73 \\
.19 \\
43.22\end{array}$ & $\begin{array}{r}0.24 \\
.38 \\
55.46 \\
.26 \\
43.86\end{array}$ \\
\hline
\end{tabular}

During the early operation of the Atlas plant an Ordovician shale, quarried near Severton, Mo., was used. Later, shale of good quality was found to underlie the limestone in the Ilasco quarry at some depth, and this shale is now mined and used.

The plant of the St. Louis Portland Cement Co., located at Prospect Hill station, near the northern limits of the city of St. Louis, uses a limestone of Mississippian age, quarried at Fort Bellefontaine. An interesting point in the operation is the use of the hydraulicking method for stripping. Shales of Pennsylvanian age are quarried near the cement plant and together with the loess clays, which overlie the shales at this locality, are used for mixing with the limestone.

The plant of the Continental Portland Cement Co. at Continental, 3 miles south of St. Louis, uses Mississippian limestone mixed with loess clays. The plant of the Kansas City Portland Cement Co., now controlled by the Union Sand \& Material Co., at Cement City, Mo., 10 miles east of Kansas City, uses Pennsylvanian limestone and shales. 
At the Cape Girardeau plant Joachim limestone (Ordovician) and Quaternary clays furnish the raw materials. No analyses are at present available.

\section{PORTLAND CEMENT RESOURCES OF MONTANA. PORTLAND CEMENT MATERIALS.}

By W. H. WeEd.

Limestone is confined practically to the western, mountainous part of the State, where it is found in great abundance along the flanks of the mountain ranges. In the Plains region, which comprises the eastern two-thirds of the State, only Cretaceous rocks are found, except in the local dome-shaped uplifts of the Little Rock, Judith, and Snowy mountains. The Cretaceous formations hold lenses and concretions of limestone, which are locally available for burning to quicklime where better material is too far distant for economical use.

All the Paleozoic formations contain limestone beds, but the great limestone series is that of the Carboniferous (Mississippian), whose massive beds flank the great ranges of the State and form its most picturesque scenery. The overlying Jurassic limestone is argillaceous and of uncertain development; the Devonian and Silurian limestones are impure; and the Cambrian limestones are thin bedded and in general are not uniform in composition.

The limestones are found along the northern slope of the mountain front from Red Lodge in Carbon County westward to Livingston, and thence northward about the flank of the Bridger and little Belt and Belt ranges to the main range west of Great Falls. Practically all the southern ranges of the western part of the State are uplifts with cores of gneiss or granite mantled by limestones of different ages. Such rocks occur westward almost to the Bitterroot Valley.

North of the line of the Northern Pacific Railway the Carboniferous limestones soon disappear, though the Cambrian rocks form the mountain summits almost to the Canadian line. The northwestern part of the State, however, is composed mostly of Algonkian rocks, chiefly argillaceous, comprising the well-known Belt series, of which the oolitic Newland limestone is a constant feature.

The following analyses of limestones from Montana are on record: Analyses of limestones, Montana.

\begin{tabular}{|c|c|c|c|c|c|}
\hline & 1 & 2 & 3 & 4 & 5 \\
\hline 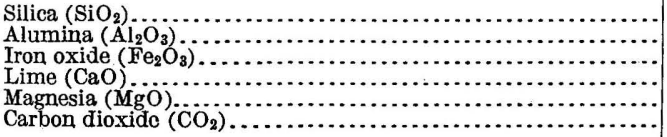 & $\begin{array}{r}1.45 \\
.16 \\
.76 \\
49.42 \\
2.74 \\
41.73\end{array}$ & $\begin{array}{r}0.40 \\
4.45 \\
.20 \\
52.15 \\
1.02 \\
42.07\end{array}$ & 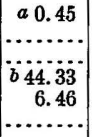 & 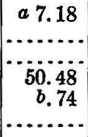 & 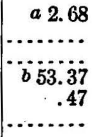 \\
\hline
\end{tabular}

$a$ Insoluble in hydrochloric acid.

$b$ Soluble in hydrochloric acid.

1. Persell Limestone Co., near Helena. E. Starz, analyst.

2. Montana Marble \& Mining Co., near Helena. C. M. Fassett, analyst.

3. Cambrian limestone, near Cable. W. T. Schaller, analyst, U. S. Geol. Survey.

4. Madison limestone (lower Mississippian). W. T. Schaller, analyst, U. S. Geol. Survey.

5. Jefferson limestone (Devonian). W. T. Schaller, analyst, U. S. Geol. Survey. 
The first two analyses, but particularly the first, represent limestones whose composition is satisfactory from the Portland cement manufacturers' point of view.

The last three analyses were furnished by F. C. Calkins, who has been engaged in geologic studies of the Philipsburg quadrangle.

Deposits of cement material about 5 miles south of Havre, Mont., have recently been described ${ }^{1}$ in a rather detailed report by Pepperberg. The materials consist of limestones of various grades and shale. The limestones are notable because, as a result of igneous intrusions, they contain much wollastonite. Much of the lime shown by the analyses therefore occurs as lime silicate and not as lime carbonate. Analyses of these interesting cement materials follow:

Analyses of cement materials near Havre, Mont.

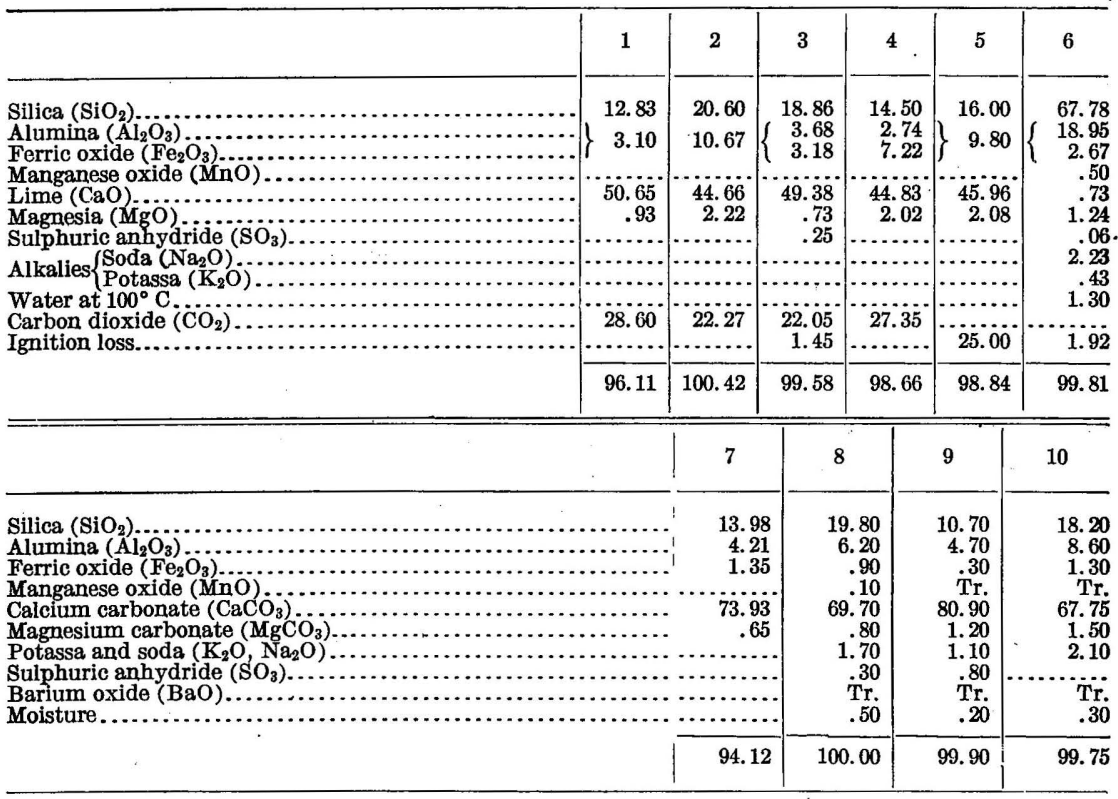

1. Gray limestone, analyzed by R. G. Brobst, U. S. Geol. Survey. Carbon dioxide determined by J. D. Davis, U. S. Geol. Survey.

2. White limestone, analyzed by R. G. Brobst, U. S. Geol. Survey. Carbon dioxide determined by Chase Palmer, U. S. Geol. Survey.

3. Limestone, analyzed by Ricketts \& Banks.

4. Limestone, analyzed by Prof. A. H. Phillips, Princeton University.

5. Limestone, analyzed by W. H. Andrews, chemist and superintendent Union Portland Cement Co. Rushsylvania, Ohio.

6. Shale, analyzed at U. S. Geol. Survey.

7. Limestone, analyzed by $\mathrm{H}$. J. Detweiler, Allentown, $\mathrm{Pa}$

8, 9, 10. Limestone, analyzed by Paul Reisinger.

The following analyses of high-calcium limestones have been published recently: ${ }^{2}$

1 Pepperberg, L. J., Cement material near Havre, Mont.: Bull. U. S. Geol. Survey No. 380, 1909, pp. 327-336.

2 Burchard, E. F., The production of lime in 1911: Mineral resources U. S. for 1911, pt. 2, U. S. Geol. Survey, 1912, pp. 645-718. 
Analyses of limestone quarried in Montana.

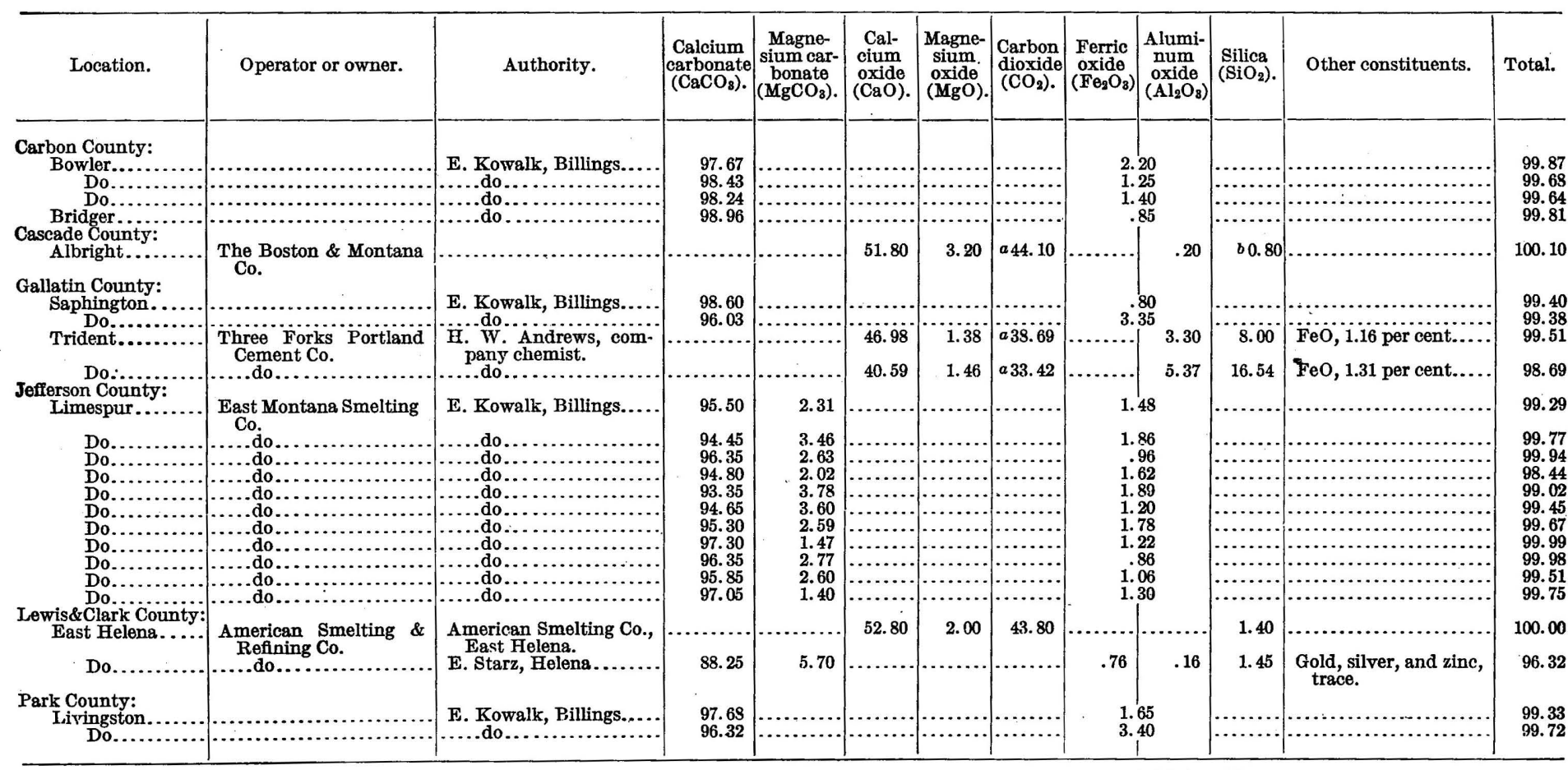

a Loss by ignition.

$b$ Insoluble in acid. 


\title{
PORTLAND CEMENT INDUSTRY IN MONTANA.
}

\author{
By E. F. Burchard.
}

One Portland cement plant, that of the Three Forks Portland Cement Co., has recently been established in Montana, at Trident. Limestone, cement rock, and shale are used at this plant, and the clinker is burned with coal. The erection of at least one other plant in Montana is contemplated.

\section{PORTLAND CEMENT RESOURCES OF NEBRASKA.i PORTLAND CEMENT MATERIALS.}

The possible sources of cement materials in Nebraska are confined to formations of Carboniferous and Cretaceous age. Named in order from above downward these include the following:

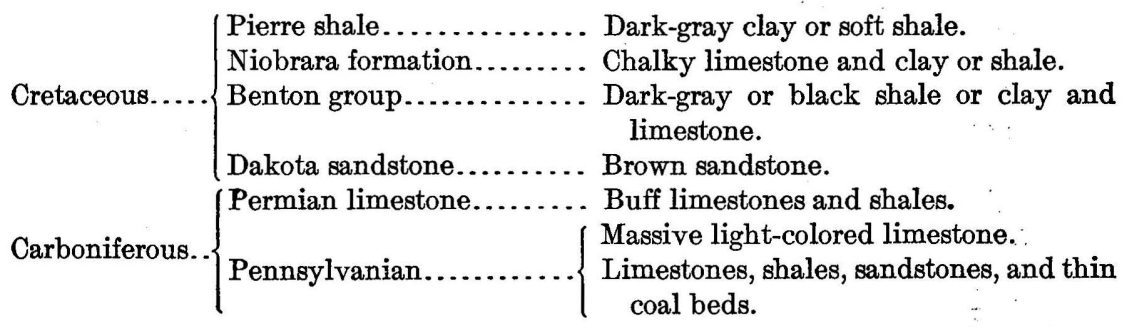

\section{CARBONIFEROUS FORMATIONS.}

The Carboniferous limestones, shales, and sandstones underlie all of Nebraska, rising to the north and northwest about the Black Hills and on the slopes of the Rocky Mountains. The outcrops in eastern Nebraska are in Douglas, Sarpy, Cass, Lancaster, Otoe, Gage, Johnson, Pawnee, Nemaha, and Richardson counties. The rocks are hard and would give rise to more prominent features if it were not for the heavy covering of glacial drift and loess. As it is, the exposures constitute cliffs along Platte River from Ashland to Plattsmouth and thence at intervals along Missouri River to the southeast corner of the State and occur in scattered outcrops along the valleys of Big Blue, Nemaha, and Little Nemaha rivers and Weeping Water, Turkey, and Southeast Salt creeks and their branches.

The Carboniferous rocks in this region comprise formations of Permian and Pennsylvanian age. The Permian outcrops are probably restricted to the valley of Big Blue River from Beatrice southward. The rocks are mainly magnesian limestones of light color, with interbedded shales. They are extensively exposed south of Beatrice, at Rockford, Bluesprings, Wymore, and Holmesville. The Pennsylvanian rocks consist of limestones, shaies, and sandstones, which contain thin coal beds in some localities. Prof. Prosser has made a

1 See Darton, N. H., Preliminary report on the geology and water resources of Nebraska west of the one hundred and third meridian: Prof. Paper U. S. Geol. Survey No. 17, pp. 14-20, and Pl. IX. The data concerning Nebriska cement material have been obtained from Darton's report, which is in part cited verbatim. 
preliminary examination of the Carboniferous formations of Nebraska, and identifies as Wabaunsee the exposures about Peru, Aspinwall, Nebraska City, Auburn, Tecumseh, Dunbar, Nehawka, Weeping Water, and along Platte River near Louisville. He identified as Cottonwood limestone a massive bed full of Fusulina west of Auburn, about Glenrock and Johnson, and on the higher lands of western Richardson and Pawnee counties. ${ }^{1}$ In deep borings in the southeast corner of the State the Carboniferous formations have shown a total thickness of about 1,200 feet, of which about 200 feet are Permian.

\section{NIOBRARA FORMATION AND BENTON GROUP.}

Underlying the Pierre shale is a series of shales and chalky limestones known as the Benton group and the Niobrara formation. They have a thickness of about 450 feet to the east but thicken to the west and south. At the base of the Benton group there are about 200 feet of dark shales (Graneros shale), overlain by slabby limestones containing Inoceramus (Greenhorn limestone) followed by a series of shales with few thin sandy layers (Carlile shale). Overlying the Benton group is the Niobrara formation with its chalky deposits, characterized by thin hard beds filled with Ostrea congesta. The formations cross the eastern part of the State and underlie all the area west of the ninety-seventh meridian but are so deeply buried under drift and loess that they outcrop in few places. The most extensive exposures are along Missouri River, extending from near the ninety-seventh to the ninety-ninth meridian, and along the Republican Valley from Alma to near Superior. The formations are exposed at intervals across the eastern portion of the State in each of the larger valleys and some of the branches. The more notable of these small outcrops are at Genoa, north of Germantown, near Crete, at Pleasanthill, and in Beaver Creek north of Dorchester. There is an exposure of dark Graneros shale under some ledges of Greenhorn limestone in Big Blue River at Milford. Benton and Niobrara also occur in a prominent anticline along White River in the vicinity of Beaver and Alkali creeks, in the northwestern part of the State.

Darton has recently published ${ }^{2}$ some valuable data on the character and composition of the limestones of the Niobrara formation of Nebraska, with special reference to their possible utilization as Portland cement materials. The following quotations cover such of his remarks as are of principal interest in this connection:

Although the Niobrara formation consists largely of limestone, some of the beds contain much clay. This material occurs mostly as an admixture in the impure "chalk rock," but some beds contain so much that they are calcareous shales. Ordi-

1 Jour. Geology, vol. 5, 1897, pp. 1-16.

2 Darton, N. H., Cement materials in Republican Valley, Nebraska: Bull. U. S. Geol. Survey No. 430, 1910, pp. 381-387.

$48834^{\circ}-$ Bull. $522-13-17$ 
narily the Niobrara strata are interbedded deposits of soft limestone or chalk and calcareous clay from 5 to 30 feet thick. Flint occurs in the upper beds. Two members of the formation have been recognized. The lower one, averaging 50 feet in thickness and consisting mainly of soft limestone or compact chalk of. light-gray color, represents the Fort Hays limestone of Kansas. The upper member consists of about 300 feet of alternations of "chalk rock" or chalky limestone and limy shales, all of light-gray color. The chalk rock deposits vary greatly in thickness, in some places attaining 20 feet. This member represents the Smoky Hill chalk or "Pteranodon beds" of Kansas. A characteristic feature of the Niobrara rocks is their tendency to weather to a light yellow color, though in their unweathered condition they are lead gray or bluish gray.

The limestone beds in the Niobrara formation vary greatly in composition, owing largely to admixture of clay. The upper beds are cherty. Some representative samples were collected and analyzed in the laboratory of the United States Geological Survey with the following results, reported by S. S. Voorhees.

The analyses presented in the following table are those referred to by Darton in the preceding quotation. They have been rearranged, however, to bring them into conformity with other analyses in this volume.

Analyses of limestones of Niobrara formation, Nebraska.

\begin{tabular}{|c|c|c|c|c|}
\hline & 1 & 2 & 3 & 4 \\
\hline 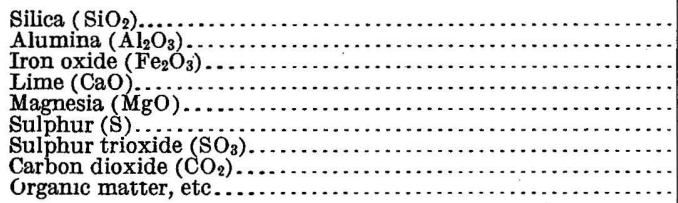 & $\begin{array}{r}6.9 \\
3.3 \\
1.0 \\
45.3 \\
.8 \\
.5 \\
1.6 \\
35.2 \\
4.1\end{array}$ & $\begin{array}{r}14.7 \\
7.1 \\
1.7 \\
37.3 \\
1.0 \\
.6 \\
.2 \\
29.3 \\
6.3\end{array}$ & $\begin{array}{r}9.7 \\
5.0 \\
1.7 \\
43.3 \\
.6 \\
.5 \\
.04 \\
33.9 \\
4.2\end{array}$ & $\begin{array}{r}1.5 \\
1.8 \\
.4 \\
53.6 \\
.4 \\
.0 \\
.03 \\
42.5 \\
.7\end{array}$ \\
\hline
\end{tabular}

1. Riverton, Nebr.

2. Two miles southeast of Red Cloud.

3. Sonth of Guide Rock.

4. South of Superior.

PIERRE SHALE.

All of Nebraska west of the ninety-eighth meridian is underlain by the Pierre shale. Its surface outcrops are in the lower portion of the Niobrara Valley, the Republican Valley, and the extreme northwest corner of the State, but it is probable that careful search will reveal outcrops in the valley of the Platte River in the vicinity of the ninetysixth meridian. The formation is a thick mass of dark-gray or bluish clay or soft shale at least 2,000 feet thick in the west-central portion of the State.

Prof. G. E. Condra has called attention to the availability of the Niobrara limestone and the Pierre shale along Missouri River from Dixon County to northern Boyd County. ${ }^{1}$ After describing the Portland cement plant at Yankton, S. Dak., Prof. Condra adds:

The formations worked at Yankton are exposed in Nebraska along Missouri River from Dixon County to northern Boyd County and afford a vast supply of the raw materials. The principal factors to be considered in the establishment of a plant, besides

\footnotetext{
1 Condra, G. E., Geology and water resources of a portion of the Missouri River valley in northeastern Nebraska: Water-Supply Paper U. S. Geol. Survey No. 215, 1908, pp. 23-24.
} 
the presence of suitable cement materials, are the condition in which they are found so as to avoid waste in quarry strippings, the water supply, fuel, and a suitable location, especially in relation to transportation facilities. All of these conditions except cheap fuel exist at many places on the Nebraska side of the river. At Niobrara the chalk rock is of good quality and in large supply, and this place is favorably situated for railroads and river transportation; artesian water and a suitable location for a plant can also be had.

E. F. Burchard ${ }^{1}$ has discussed the possibilities of manufacturing cement in Dakota County from a mixture of Greenhorn limestone and shale of the Benton group, both of which occur in immense quantities in the bluffs of Missouri River north of Jackson, Nebr.

\section{PORTLAND CEMENT RESOURCES OF NEVADA:}

Nevada contains numerous areas of low-magnesia limestone, mostly of Carboniferous age, and also some of later date. The principal outcrops of the Carboniferous limestones are in the eastern third of the State. Much of this material would be suitable for use in making Portland cement, but at present, with a scanty population, expensive fuel, and practically no local demand for cement, it is evident that such an industry could hardly be even moderately successful.

The following analyses indicate the character of the limestones of Nevada. Many of these, though low in magnesia, are very siliceous.

Analyses of limestones from Nevadà.

\begin{tabular}{|c|c|c|c|c|c|c|c|c|c|c|}
\hline & 1 & 2 & 3 & 4 & 5 & 6 & 7 & 8 & 9 & 10 \\
\hline 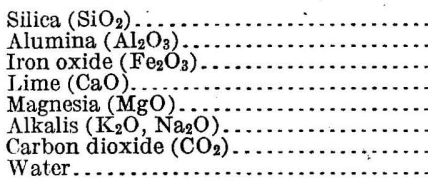 & $\left\{\begin{array}{l}31.51 \\
3.79 \\
34.33 \\
1.12 \\
\text { n.d. } \\
27.77 \\
1.25\end{array}\right.$ & $\begin{array}{r}20.99 \\
1.09 \\
39.77 \\
2.80 \\
\operatorname{tr} . \\
32.80 \\
1.06\end{array}$ & $\begin{array}{r}1.25 \\
.36 \\
54.51 \\
.27 \\
\text { tr. } \\
43.13 \\
.11\end{array}$ & $\left\{\begin{array}{r}0.04 \\
.05 \\
\text { n.d. } \\
55.16 \\
.76 \\
.61 \\
43.54 \\
\text { n. d. }\end{array}\right.$ & $\left\{\begin{array}{l}4.53 \\
51.69 \\
1.04 \\
\text { n: d. } \\
41.75 \\
\text { n.d. }\end{array}\right.$ & $\begin{array}{r}1.61 \\
.26 \\
52.16 \\
2.47 \\
\text { n. d. } \\
43.70 \\
\text { n. d. }\end{array}$ & $\left\{\begin{array}{l}7.38 \\
.80 \\
.68 \\
48.52 \\
2.46 \\
\text { n. d. } \\
40.84 \\
\text { n. d. }\end{array}\right.$ & $\left\{\begin{array}{r}31.12 \\
.43 \\
35.82 \\
.86 \\
\mathrm{n} . \mathrm{d} . \\
29.16 \\
2.10\end{array}\right.$ & $\left\{\begin{array}{r}12.07 \\
\{1.28 \\
.57 \\
45.29 \\
1.86 \\
.90 \\
36.23 \\
2.65\end{array}\right.$ & $\begin{array}{r}22.00 \\
5.14 \\
2.04 \\
37.22 \\
1.89 \\
\text { n. d. } \\
28.53 \\
3.32\end{array}$ \\
\hline
\end{tabular}

1. Limestone from "Lower Coal Measures," Grand Peak, Nev.

2. Limestone from "Upper Coal Measures," Tenabo Peak.

3. Carboniferous, Fremonts Pass.

4. Triassic, between Pyramid Lake and Winnemucca Lake.

5. Triassic, Star Canyon.

6. Triassic, Coftonwood Canyon.

7. Miocene, Fossil Hill.

8. Miocene, Valley Wells.

9. Pliocene, Pine Valley.

10. Recent, shore of Pyramid Lake.

Analyst of Nos 1-9, B. E. Brewster, U. S. Geol. Expl. 40th Par., vol. 2.

Analyst of No. 10, T. M. Chatard, Bull. U. S. Geol. Survey No. 168, p. $7 ; 6$.

In a brief report ${ }^{2}$ on the building stones of Nevada, Reid mentions the occurrence of marbles at many points, notably in the Humboldt Mountains, in Lamoille Valley, and near Luning, Esmeralda County. No data as to chemical composition are given.

\footnotetext{
1 Burchard, E. F., Proc. Sioux City Acad. Sei. and Letters, vol. 1, 1904, p. 161.

2 Reid, J. A., Preliminary report on the building stones of Nevada: Bull. Dept. Geology and Mining Nevada University No. 1, 1904.
} 


\section{PORTLAND CEMENT RESOURCES OF NEW HAMPSHIRE.}

In common with most of New England, New Hampshire offers little opportunity for successful Portland cement manufacture. Limestones of satisfactory composition could probably be found in several parts of the State, but the difficulties with regard to fuel and markets seem to be too great to permit the development of the industry.

\section{PORTLAND CEMENT RESOURCES OF NEW JERSEY. 1}

\section{PORTLAND CEMENT MATERIALS.}

Limestones suitable for Portland cement manufacture occur in New Jersey in several different geologic formations. (See Pl. XVII, p. 310.) The deposits of argillaceous Ordovician limestone of Lowville to Trenton age (Jacksonburg limestone) are, however, the principal source of cement material, and in view of the great extent of these deposits, it seems probable that they will always furnish the bulk of the New Jersey raw materials. For this reason the distribution and character of these argillaceous limestones ("Trenton cement rock") of Warren and Sussex counties are most fully discussed.

\section{LIMESTONES OF WARREN AND SUSSEX COUNTIES.}

LITHOLOGY.

The part of the geologic column in New Jersey that supplies the cement materials contains four formations. These are, from the top downward:

1. Martinsburg shale (Ordovician).

2. Jacksonburg limestone (Ordovician).

3. Kittatinny limestone (Ordovician and Cambrian).

4. Hardyston quartzite (Cambrian).

The Jacksonburg limestone and Kittatinny limestone belong to the Shenandoah.group. The Jacksonburg limestone furnishes all the "cement rock," and the Kittatinny limestone, though in general highly magnesian, supplies the pure limestone for mixing therewith. The Martinsburg shale, though not at present used in the cement industry, can well be utilized for mixing with a "cement rock" that is too high in lime. As these three formations, therefore, are worthy of consideration in connection with the cement industry, they will be described separately in some detail. The Hardyston quartzite, though not directly connected with the cement industry, is an easily recognized formation whose outcrops in general limit the Kittatinny limestone belt on the south.

1 A very detailed description of the limestones of New Jersey available for use in Portland cement manufacture, with maps showing their distribution and outcrops, is given by H. B. Kümmel, in Ann. Rept. State geologist New Jersey for 1900, 1901, pp. 1-101. This valuable report has been freely used in the preparation of the present sketch, and many of the details regarding the formations are stated in Kümmel's words. 
At the base of the great limestone formation of the Kittatinny Valley a thin bed of sandstone or quartzite is found in many places. It rests upon the crystalline rocks (gneisses, schists, etc.) which form the highlands and is the earliest of the Paleozoic formations in this region. It differs considerably in composition and in thickness. In many places it is apparently only a coarse and more or less friable sandstone, the grains of which are cemented together by lime carbonate. When fresh its color is steel-blue, but the weathered portions are everywhere a rusty brown from iron oxide staining. Most, though not all, of it contains considerable feldspar. In other localities it is a true quartzite, made up of sand grains with siliceous cement. Still elsewhere it is a conglomerate, commonly of pebbles less than an inch in diameter, but in places containing well-rounded fragments 2 to 4 inches in size. The pebbles are chiefly of quartz, feldspar, granite, gneiss, and slate, with bits of mica. Locally the conglomerate, where it approaches the gneiss, can be distinguished only with great difficulty by the naked eye. It is simply a decomposed gneiss or granite, slightly reassorted and cemented to form a conglomerate.

The thickness of the quartzite varies from a few feet to 200 feet or more. Where the rock is thick it is a conglomerate or a coarse pebbly quartzite. Where thinner it is generally a calcareous sandstone, grading upward into a limestone, and perhaps having near its base one or more thin layers of siliceous sandstone or even quartzite. The crystalline foundation on which the quartzite rests was somewhat irregular, so that the formation differed greatly in thickness and lithological character. At the time of its deposition the land lay not far southeast of the present outcrop.

\section{MAGNESIAN KITTATINNY LIMESTONE.}

The Hardyston quartzite grades upward into a highly magnesian limestone formation of great thickness, known as the Kittatinny limestone, but commonly called the "blue" limestone to distinguish it from the white, coarsely crystalline limestone near Franklin Furnace and other localities in Sussex and northern Warren. Its color, however, is not always blue. It is in many places gray, in some places almost white, also drab, or even black. It is fine and even grained. Many of the beds are minutely crystalline, so that the freshly broken surface has a close resemblance to fine-grained lump sugar. But it is nowhere coarsely crystalline or marble-like.

The Kittatinny occurs in beds which differ greatly in thickness and regularity. Some beds are made up of thin leaf-like layers of limestone alternating with thin sheets of greenish shale. Other beds consist of layers of limestone an inch or more in thickness and are sepa- 
rated by thinner partings of shale or sandstone. Locally the limestone layers are apparently discontinuous, and the shale or sandy layers not only separate but inclose the more limy masses. In great part, however, this formation is composed of regular beds 1 to 3 feet or even more in thickness. Locally they are so massive and the formation is so regularly jointed that it is extremely difficult to determine the true position of the beds. Some layers, also, are oolitic, that is, are made up of minute rounded particles resembling fish roe. The oolitic layers are apparently confined to the lower portion of the formation.

.A marked feature of the Kittatinny is the chert, or black flint, which occurs either as seams, in places 8 or 10 inches thick, or as separate masses. The chert layers are in most places, but not in all, parallel to the bedding planes. Owing to the large percentage of magnesia nearly everywhere present in this limestone it is of no value in the manufacture of Portland cement. In some localities, however, it has been extensively burned for lime.

Its thickness is apparently between 2,500 and 3,000 feet, but accurate measurements can not be obtained. More than 99 per cent of the limestone of Sussex, Warren, and Hunterdon counties belongs to this formation.

The following table gives analyses ${ }^{1}$ of the magnesian Kittatinny limestone from New Jersey:

Analyses of magnesian Kittatinny limestone, New Jersey.

\begin{tabular}{|c|c|c|c|c|c|c|c|c|c|c|c|c|c|}
\hline . & 1 & 2 & 3. & 4 & 5 & 6 & 7 & 8 & 9 & 10 & 11 & 12 & 13 \\
\hline $\begin{array}{l}\text { Lime }(\mathrm{CaO}) \\
\text { Magnesia }(\mathrm{MgO}) \ldots \ldots \ldots \ldots \ldots \ldots \\
\text { Carbonic acid }\left(\mathrm{CO}_{2}\right) \ldots \ldots \ldots \ldots \ldots\end{array}$ & $\begin{array}{l}27.6 \\
17.9 \\
41.9\end{array}$ & $\begin{array}{l}30.4 \\
19.1 \\
44.9\end{array}$ & $\begin{array}{l}30.0 \\
19.4 \\
44.9\end{array}$ & \begin{tabular}{|l|}
29.3 \\
19.5 \\
44.6
\end{tabular} & $\begin{array}{l}29.1 \\
19.3 \\
43.6\end{array}$ & $\begin{array}{l}27.9 \\
17.7 \\
41.4\end{array}$ & \begin{tabular}{|l|}
30.3 \\
16.2 \\
41.6
\end{tabular} & $\begin{array}{l}23.6 \\
16.2 \\
36.04\end{array}$ & $\begin{array}{l}26.5 \\
18.4 \\
40.4\end{array}$ & \begin{tabular}{|l|}
29.4 \\
20.3 \\
45.7
\end{tabular} & $\begin{array}{l}28.6 \\
18.1 \\
34.5\end{array}$ & $\begin{array}{l}29.0 \\
20.2 \\
44.9\end{array}$ & $\begin{array}{l}28.5 \\
17.3 \\
41.5\end{array}$ \\
\hline 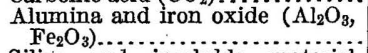 & 1.7 & .8 & 2.7 & 2.2 & 1.2 & .9 & .6 & 6.0 & 5.43 & .6 & .9 & .9 & 1.7 \\
\hline $\begin{array}{l}\text { Silica and insoluble material } \\
\left(\mathrm{SiO}_{2}\right) \ldots \ldots \ldots \ldots \ldots \ldots \ldots \ldots \ldots \ldots\end{array}$ & 9.9 & 3.6 & 2.3 & 4.0 & 6.4 & 11.2 & 9.8 & 15.7 & 7.0 & 1.8 & 9.3 & 4.8 & 9.9 \\
\hline
\end{tabular}

1. Chandlers Island, Vernon Township, Sussex County.

2. Near William Richey's, Vernon Township, Sussex County.

3. Near David Perry's, Wantage Township, Sussex County.

4. Near Samuel Vanderhoof's, Wantage Township, Sussex County.

5. Near William Dewitt's, Wantage Township, Sussex County.

6,7 . On property of Edward Lewis, Wantage Township, Sussex County.

8, 9. Railroad cut one-fourth mile northwest of Hamburg station, on the New York, Susquehanna \& Western Railroad.

$10,11,12$. Moore \& Cutler's quarry, Newton, Sussex County.

13. Near Sparta, Sussex County. 
Analyses of magnesian Kittatinny limestone, New Jersey-Continued.

\begin{tabular}{|c|c|c|c|c|c|c|c|c|c|c|c|c|c|}
\hline & 14 & 15 & 16 & 17 & 18 & 19 & 20 & 21 & 22 & 23 & 24 & 25 & 26 \\
\hline 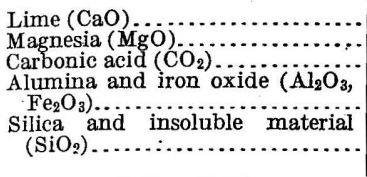 & $\begin{array}{r}29.6 \\
20.0 \\
45.4 \\
1.4 \\
2.3\end{array}$ & \begin{tabular}{r|}
29.6 \\
19.2 \\
46.2 \\
1.4 \\
2.9
\end{tabular} & \begin{tabular}{r|}
29.2 \\
18.8 \\
43.6 \\
2.4 \\
3.6
\end{tabular} & $\begin{array}{r}30.1 \\
20.1 \\
44.4 \\
.8 \\
3.5\end{array}$ & $\begin{array}{c}30.8 \\
19.2 \\
45.4 \\
1.1 \\
3.6\end{array}$ & $\begin{array}{r}29.8 \\
19.9 \\
45.4 \\
1.0 \\
3.4\end{array}$ & $\begin{array}{r}28.2 \\
17.7 \\
41.7 \\
.9 \\
10.8\end{array}$ & \begin{tabular}{r|}
29.4 \\
17.8 \\
42.8 \\
.8 \\
8.8
\end{tabular} & \begin{tabular}{|c|c|}
4 & 29.9 \\
$(a)$ & $(a)$ \\
8 & $(a)$ \\
8 & 2.0
\end{tabular} & $\mid \begin{array}{c}29.6 \\
(a) \\
(a) \\
(a) \\
2.8\end{array}$ & $\left|\begin{array}{c}25.7 \\
(a) \\
(a) \\
(a) \\
1.9\end{array}\right|$ & $\begin{array}{c}26.6 \\
(a) \\
(a) \\
(a) \\
4.1\end{array}$ & $\begin{array}{r}28.2 \\
20.2 \\
44.3 \\
1.3 \\
5.5\end{array}$ \\
\hline . & 27 & 28 & 29 & 30 & 31 & 32 & 33 & 34 & 35 & 36 & 37 & 38 & 39 \\
\hline $\begin{array}{l}\mathrm{Lime}(\mathrm{CaO}) \\
\text { Magnesia }(\mathrm{MgO}) \\
\text { Carbonic acid }(\mathrm{CO})_{2} \\
\text { Alumina and iron oxide }\left(\mathrm{Al}_{2} \mathrm{O}_{3},\right. \\
\left.\quad \mathrm{Fe} \mathrm{O}_{3}\right) \ldots \ldots \\
\text { Silica and insoluble material } \\
\quad\left(\mathrm{SiO}_{2}\right) \ldots \ldots\end{array}$ & \begin{tabular}{|r|}
27.7 \\
17.4 \\
43.0 \\
1.9 \\
7.2
\end{tabular} & \begin{tabular}{|r|}
26.4 \\
15.1 \\
45.0 \\
3.7 \\
9.8
\end{tabular} & $\begin{array}{r}27.3 \\
14.6 \\
44.8 \\
6.5 \\
4.9\end{array}$ & $\begin{array}{r}32.4 \\
15.5 \\
42.5 \\
8.4 \\
2.0\end{array}$ & $\mid \begin{array}{c}26.3 \\
17.4 \\
41.1 \\
5.3 \\
8.0\end{array}$ & $\begin{array}{r}30.3 \\
18.3 \\
44.1 \\
1.6 \\
4.1\end{array}$ & \begin{tabular}{|r|}
31.6 \\
18.3 \\
45.2 \\
3.0 \\
1.6
\end{tabular} & $\begin{array}{l}1.90 \\
8.13\end{array}$ & $\begin{array}{l}28.61 \\
44.88 \\
1.10 \\
5.90\end{array}$ & $\begin{array}{l}1.06 \\
4.92\end{array}$ & $\begin{array}{c}30.13 \\
21.71 \\
\cdots \cdots \\
1.40 \\
1.95\end{array}$ & $\begin{array}{r}28.27 \\
15.30 \\
38.88 \\
.98 \\
16.9\end{array}$ & \begin{tabular}{|c}
29.8 \\
19.93 \\
$\cdots \ldots$ \\
.84 \\
7.23
\end{tabular} \\
\hline
\end{tabular}

$a$ Undetermined.

14. East of Van Kirk's tavern, Columbia, Warren County.

15. Quarry in the town of Belvidere.

16. Robert Shimer's quarry, Springtown, Warren County.

17. Henry R. Kennedy's quarry, Springtown, Warren County.

18. Charles Twinning's quarry, south of Phillipsburg.

19. James Riddle's quarry, New Hampton, Warren County.

20. Railroad cut east bank of creek, Changewater, Warren County.

21. Mahlon Fox's quarry, 1 mile southwest of Asbury, Warren County.

22-25. Quarries at Pennwell (Penville), Musconetcong Valley.

26. Quarry at Oxford furnace.

27. S. H. Leigh's quarry, near Hoffiman's mill, south of Lebanon, Hunterdon County.

28. Near Clinton, Hunterdon County.

29. T. Mulligan \& Bros.' quarry, Clinton.

30. Pottersville, Somerset County.

31. Henry Hilliard's quarry, north of Peapack.

32. Moses Craig's quarry, Peapack.

33. Peapack.

34. O'Donnell \& McManniman's quarry, Newton. Middle of a thick, dense, even-textured, blue limestone 3 feet from the top.

35. The same. Middle of a massive blue layer 8 feet thick, 7 feet below specimen 34 .

36. The same. Layer 3 inches thick, 4 feet below specimen 35 . Rock a pale blue, with faint streaks of pale yellow.

37. The same. Granular layer 8 feet below No. 36. Rock dark colored and semicrystalline.

38. Gano's quarry, Annandale.

39. Mulligan Bros.' quarry, Clinton.

\section{JACKSONBURG LIMESTONE.}

Above the magnesian Kittatinny limestone and resting on it is a dark-blue or black fossiliferous limestone. In the early reports of the New Jersey Geological Survey it is called the "fossiliferous" limestone, in distinction from the magnesian or Kittatinny limestone, in which fossils had not been found at that time. It contains Lowville, Black River, and Trenton fossils.

A continuous section of this formation is nowhere exposed, but the general succession of the beds is about as follows:

\section{Section of black fossiliferous Jacksonburg limestone of New Jersey.}

Black calcareous shales or earthy limestone gradually becoming less calcareous and more siliceous or clayey and grading into the overlying slate. Apparently of different thicknesses.

A rough, irregularly bedded, dark-blue limestone, breaking into knotty slabs. .

Probably calcareous shale, generally not exposed......................

Blue-black earthy limestone, rather evenly bedded, weathering to a light

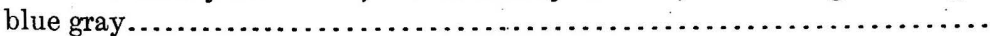


In Sussex County the total thickness is uniformly about 135 to 150 feet, except where faults have probably repeated some layers. The formation, however, thickens to the southwest, reaching probably at least 300 feet at the Delaware, and possibly even more than this in the Lehigh Valley region, Pennsylvania. The increase in thickness is apparently in the upper calcareous shaly beds.

The Jacksonburg rests upon the eroded surface of the Kittatinny limestone, so that there is here a break in the geologic record. At many places the lowest Jacksonburg beds form a conglomerate composed solely of pebbles and bowlders of the underlying magnesian limestone and chert. Elsewhere pebbles of magnesian limestone and chert are included in a matrix of pure limestone, in places fossiliferous.

Many analyses have been made of specimens both of the limestone and of the calcareous shales of the Jacksonburg limestone. The more massive beds contain from 85 to 95 per cent of carbonate of lime and only small amounts of magnesia. Some of the more shaly layers contain 65 to 75 per cent of carbonate of lime, with sufficient alumina and silica to make a good cement rock. It is this rock which is used with such success in manufacturing Portland cement near Philippsburg, Warren County, N. J., and in Berks, Lehigh, and Northampton counties, Pa. The purer limestone beds can be mixed with the "cement rock" to raise the percentage of lime to the necessary figure. The following analyses ${ }^{1}$ may be quoted:

Analyses of Jacksonburg limestone, New Jersey.

\begin{tabular}{|c|c|c|c|c|c|c|c|c|c|c|c|c|}
\hline . & 1 & 2 & 3 & 4 & 5 & 6 & 7 & 8 & 9 & 10 & 11 & 12 \\
\hline \multirow[t]{2}{*}{$\begin{array}{l}\text { Silica }\left(\mathrm{SiO}_{2}\right) \ldots \ldots \ldots \ldots \\
\text { Alumina }\left(\mathrm{Ai}_{2} \mathrm{O}_{3}\right) \text { and iron } \\
\text { oxide }\left(\mathrm{Fe}_{2} \mathrm{O}_{3}\right) \ldots \ldots \ldots \ldots \ldots \\
\text { Lime }(\mathrm{CaO}) \ldots \ldots \ldots \\
\text { Magnesia }(\mathrm{MgO}) \ldots \ldots \ldots \ldots \\
\text { Carbon dioxide }\left(\mathrm{CO}_{2}\right) \ldots \ldots \ldots\end{array}$} & $\begin{array}{r}17.71 \\
7.91 \\
41.79 \\
.38 \\
33.25\end{array}$ & $\begin{array}{r}14.59 \\
6.86 \\
40.30 \\
.67 \\
32.50\end{array}$ & $\begin{array}{r}10.71 \\
5.98 \\
40.00 \\
.65 \\
32.15\end{array}$ & $\begin{array}{r}10.26 \\
7.19 \\
44.72 \\
1.40 \\
36.68\end{array}$ & $\begin{array}{r}20.58 \\
5.44 \\
39.84 \\
.63 \\
32.00\end{array}$ & $\begin{array}{r}8.42 \\
2.30 \\
44.64 \\
.36 \\
34.47\end{array}$ & $\begin{array}{r}18.60 \\
5.80 \\
38.76 \\
.66 \\
31.20\end{array}$ & $\begin{array}{r}2.27 \\
.46 \\
54.98 \\
.84 \\
\cdots \cdots\end{array}$ & $\begin{array}{r}11.86 \\
1.09 \\
48.36 \\
.56\end{array}$ & $\begin{array}{r}43.38 \\
4.37 \\
24.89 \\
3.74 \\
\cdots . .\end{array}$ & $\begin{array}{r}10.49 \\
.75 \\
49.10 \\
1.13 \\
\cdots \cdots\end{array}$ & $\begin{array}{r}1.8 \\
.2 \\
54.7 \\
73.00\end{array}$ \\
\hline & & 13 & 14 & 15 & 16 & 17 & 18 & 19 & 20 & 21 & 22 & 23 \\
\hline $\begin{array}{l}\text { Silica }\left(\mathrm{SiO}_{2}\right) \\
\text { Alumina }\left(\mathrm{Al}_{2} \mathrm{O}_{3}\right) \\
\quad\left(\mathrm{Fe}_{2} \mathrm{O}_{3}\right) \\
\mathrm{Lime}(\mathrm{CaO}) \\
\text { Magnesia }(\mathrm{MgO}) \\
\text { Carbon dioxide }\left(\mathrm{CO}_{2}\right) \ldots\end{array}$ & oxide & $\begin{array}{r}15.8 \\
1.6 \\
43.2 \\
2.2 \\
31.4\end{array}$ & $\begin{array}{r}.97 \\
.86 \\
55.70 \\
.45 \\
\cdots . .\end{array}$ & $\begin{array}{r}8.10 \\
2.38 \\
48.04 \\
2.84\end{array}$ & $\begin{array}{r}4.30 \\
1.23 \\
52.58 \\
.65 \\
\cdots \cdots\end{array}$ & $\begin{array}{r}2.62 \\
.38 \\
54.00 \\
1.00 \\
\cdots \cdots\end{array}$ & $\begin{array}{r}14.27 \\
1.48 \\
46.66 \\
.31 \\
\ldots \ldots . .\end{array}$ & $\begin{array}{r}13.00 \\
1.03 \\
47.80 \\
1.35 \\
\cdots \cdots\end{array}$ & $\begin{array}{r}2.54 \\
1.14 \\
53.64 \\
.81 \\
42.72\end{array}$ & $\begin{array}{r}10.67 \\
1.49 \\
49.03 \\
.70 \\
\ldots . .\end{array}$ & $\begin{array}{r}26.51 \\
1.63 \\
43.09 \\
.78\end{array}$ & $\begin{array}{r}9.53 \\
1.81 \\
49.11 \\
.65\end{array}$ \\
\hline
\end{tabular}

1-5. Murphy farm, near Carpentersville. 6-7. One mile southwest of Pattenburg. 8. Near Branchville.

9. Near Myrtle Grove.

10. Near Swartswood station.

11. Swartswood village.

12-13. Northwest of Stillwater.
14. Near Jacksonburg.

15. Hainesburg.

16. Columbia.

17-20. Near Beaver Run.

21-22. Near Monroe Corners.

23. Near Lafayette.

1 Ann. Rept. State Geologist New Jersey for 1900, 1901, pp. 42-94. 
Analyses of Jacksonburg limestone, New Jersey—Continued.

\begin{tabular}{|c|c|c|c|c|c|c|c|c|c|c|c|}
\hline & 24 & 25 & 26 & 27 & 28 & .29 & 30 & 31 & 32 & 33 & 34 \\
\hline \multirow[t]{2}{*}{ 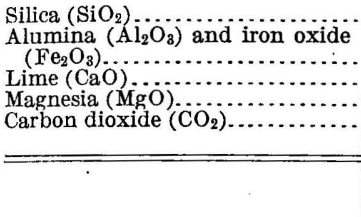 } & $\begin{array}{r}13.41 \\
1.46 \\
49.13 \\
.34\end{array}$ & $\begin{array}{r}13.52 \\
.61 \\
39.12 \\
8.21\end{array}$ & $\begin{array}{r}17.23 \\
2.44 \\
41.12 \\
3.78 \\
\cdots\end{array}$ & $\begin{array}{r}8.48 \\
1.04 \\
37.95 \\
11.68 \\
\hdashline . .\end{array}$ & \begin{tabular}{|r}
24.91 \\
2.37 \\
30.46 \\
9.82
\end{tabular} & $\begin{array}{c}5.8 \\
4.7 \\
49.00 \\
.9\end{array}$ & $\begin{array}{c}4.33 \\
1.1 \\
52.76 \\
.84\end{array}$ & $\begin{array}{r}3.19 \\
1.27 \\
52.85 \\
.76\end{array}$ & \begin{tabular}{|r}
2.87 \\
1.82 \\
54.04 \\
.81
\end{tabular} & $\begin{array}{r}13.05 \\
1.42 \\
47.95 \\
.57\end{array}$ & $\begin{array}{r}11.96 \\
1.60 \\
46.88 \\
.40 \\
\ldots . . .\end{array}$ \\
\hline & 35 & 36 & 37 & 38 & 39 & 40 & 41 & 42 & 43 & 44 & 45 \\
\hline $\begin{array}{l}\text { Silica }\left(\mathrm{SiO}_{2}\right) \\
\mathrm{Alumina}\left(\mathrm{Al}_{2} \mathrm{O}_{3}\right) \text { and iron oxide } \\
\quad\left(\mathrm{Fe} \mathrm{O}_{3}\right) \ldots \ldots \\
\mathrm{Lime}(\mathrm{CaO}) \\
\text { Magnesia }(\mathrm{MgO}) \\
\text { Carbon dioxide }\left(\mathrm{CO}_{2}\right) \ldots \ldots\end{array}$ & $\begin{array}{r}5.50 \\
1.94 \\
50.16 \\
1.67\end{array}$ & $\begin{array}{r}14.85 \\
1.41 \\
47.55 \\
.65\end{array}$ & $\begin{array}{r}1.70 \\
.81 \\
54.26 \\
1.09\end{array}$ & $\begin{array}{r}6.6 \\
.80 \\
49.04 \\
1.00 \\
40.1\end{array}$ & $\begin{array}{r}7.83 \\
1.19 \\
50.65 \\
.55 \\
40.41\end{array}$ & $\begin{array}{r}29.78 \\
8.29 \\
30.10 \\
2.13 \\
\ldots \ldots .\end{array}$ & $\begin{array}{r}2.64 \\
.82 \\
53.88 \\
.72\end{array}$ & $\begin{array}{r}27.08 \\
8.76 \\
31.00 \\
1.83\end{array}$ & $\begin{array}{r}11.72 \\
1.00 \\
47.37 \\
2.06\end{array}$ & $\begin{array}{r}5.46 \\
1.83 \\
49.38 \\
2.26\end{array}$ & $\begin{array}{r}22.72 \\
8.15 \\
35.78 \\
1.86\end{array}$ \\
\hline
\end{tabular}

34-25. Near Lafayette.

26-30. Near Newton.

21-33. Near Drakes Pond.

34. Three miles southwest of Newton.

35-36. Near Huntsburg (Hunt's mills).
37-40. Springdale.

41. Swayze's mills.

42. Near Hope.

43-44. Sarepta.

The Jacksonburg limestone can be readily distinguished from the Kittatinny by these differences: (1) The Jacksonburg is commonly fossiliferous, some surfaces being covered entirely with imprints of shells. Beds otherwise unfossiliferous generally contain crinoid stems, which are best seen on weathered surfaces as small disks, commonly with a hole in the center. The fossils of the Kittatinny limestone, on the other hand, are so few and so obscure that only an expert can detect them, so for practical purposes the formation can be considered unfossiliferous. (2) The dark-blue or black color of the Jacksonburg weathers to a light gray-blue entirely unlike most of the Kittatinny beds. So too the rough, knotty character of the bedding and of the weathered slabs is characteristic of the Jacksonburg limestone. (3) A drop of hydrochloric acid will cause the Jacksonburg limestone to effervesce vigorously, whereas the cold acid dropped on the Kittatinny limestone acts weakly or not at all. (4) The Jacksonburg commonly lies on top of the Kittatinny limestone and beneath the slate, which is the next higher formation, so that its outcrop forms a narrow strip between the wider belts of these rocks. In places, however, it is cut out by faulting that has brought the slate against the Kittatinny limestone, and in other places it is faulted into the midst of the Kittatinny limestone areas. (5) The Kittatinny limestone contains numerous masses of black flint or chert, such as are nowhere found in the Jacksonburg limestone in New Jersey, except as waterworn pebbles in the basal conglomerate. 
MARTINSBURG SHALE.

The shaly limestones of the Jacksonburg, formerly known as the "Hudson shales," become more clayey and less limy upward and gradually pass into a series of shales, slates, and sandstones. The shales are commonly black or dark gray, although in a few places green and red. Much of this rock has a marked tendency to split into thin sheets. This cleavage is not along the bedding planes or layers in which the slate was deposited but cuts across them at various angles. This tendency to split smoothly and regularly into thin layers causes some zones to yield excellent roofing slates, and in some localities, as at Newton, N. J., and Slatington, $\mathrm{Pa}$., they are largely quarried for this purpose.

There is considerable difference in the chemical constitution of various members of this formation, owing to the variations from shale and slate to sandstone.

Analyses of Martinsburg shale, New Jersey.

\begin{tabular}{|c|c|c|c|c|c|c|}
\hline 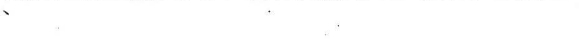 & 1 & 2 & 3 & 4 & 5 & $6^{\circ}$ \\
\hline Silica $\left(\mathrm{SiO}_{2}\right) \ldots \ldots$ & 56.60 & 68.00 & $a 77.53$ & $a 76.22$ & a 79.36 & $a 81.17$ \\
\hline $\begin{array}{l}\text { Alumina }\left(\mathrm{Al}_{2} \mathrm{O}_{3}\right) \\
\text { Iron oxide }\left(\mathrm{Fe}_{2} \mathrm{O}_{3}\right.\end{array}$ & $\begin{array}{r}21.00 \\
5.65\end{array}$ & $\begin{array}{r}14.40 \\
5.40\end{array}$ & 10.10 & 13.05 & 10.73 & 9.80 \\
\hline Lime (CaO).... & $\begin{array}{l}3.08 \\
3.42\end{array}$ & 2.68 & 3.56 & 2.67 & 2.07 & 1.13 \\
\hline Magnesia (Mgó)...... & 2.30 & 1.51 & 4.28 & .93 & 2.57 & 2.48 \\
\hline Alkalies $\left(\mathrm{KO}_{2}, \mathrm{Na}_{2} \mathrm{O}\right) \ldots$ & .50 & .11 & .......... & ... & ........... & .......... \\
\hline $\begin{array}{l}\text { Sulphur (S) } \\
\text { Carbon dioxide }\left(\mathrm{CO}_{2}\right)\end{array}$ &. .57 & 230 & & & & $\cdots \cdots \cdot \cdot$ \\
\hline Water.......... & 3.00 & 2.70 & & & (n...... & (n........ \\
\hline
\end{tabular}

$a$ Insoluble.

1. Delaware Water Gap. Ann. Rept. State Geologist New Jersey, 1868, p. 136.

2. One mile northwest of Coleville. Idem.

3. Near Annandale. Idem, 1901, p. 52 .

4. Near Lafayette. Idem, p. 74 .

5. Newton slate quarry. Idem, p. 77.

6. Near Drakes Pond. Idem, p. 78.

GEOLOGIC STRUCTURE.

The general relations of the Hardyston quartzite, the Kittatinny limestone, the Jacksonburg limestone, and the Martinsburg shale are generally very simple and easily understood. They have been bent into great folds, which originally formed a succession of arches and troughs. During the enormously long period which has elapsed since the folding occurred, hundreds, perhaps thousands, of feet of strata have been worn off from the arches, so that beds which were once deep below the surface are now exposed to view. The axes of these folds extend in a northeast-southwest direction, so that the formations lie in long and comparatively narrow belts that extend in the same direction. The oldest rock is exposed along the central line of an upfold of the strata or anticline, and the younger and higher beds are found toward the flanks. The Kittatinny limestone, being older 
than the Jacksonburg and Martinsburg, occurs along the central line of the anticlines.

The reverse relations are true where the strata are downfolded, that is, at the synclines. Here the younger beds are found along the medial line, toward which the strata dip, and the older beds are found on the flanks.

The simple structure of anticlinal and synclinal folds is in many places complicated by faults or fractures, along which the strata have moved past one another. The fault planes may be inclined at various angles, and the motion may have been in any direction along them. As a result of faulting a given bed may not appear at the surface; or it may be repeated and form a double line of outcrops. Consequently the Jacksonburg limestone does not occur everywhere between the outcrops of slate and Kittatinny limestone where it is expected, and in some places it does occur in the midst of the older limestone formation where it is not expected. For long intervals it may be buried beneath thick accumulations of glacial drift, but in such localities it can always be found by digging.

\section{SILURIAN LIMESTONES OF UPPER DELAWARE VALLEY.}

Silurian limestones and calcareous shales of different kinds are found along Wallpack Ridge, from Tristates to Wallpack Bend, on Delaware River. Except.near Tristates all this area is so far removed from any railroad that the cement rock and limestone within it must remain undeveloped for many years. For this reason these limestones were not studied with the same care as those of the Kittatinny Valley.

Analyses of specimens from many horizons, published by Dr. Cook in 1868 , indicate that many of the beds have a high percentage of carbonate of lime and are practically free from magnesia. ${ }^{1}$ Finely ground and mixed with clay in the right proportion they would make good Portland cement or could be used to raise the percentage of lime in a deficient cement rock.

A specimen of the Bossardville limestone of White and Weller (Cook's ribbon limestone), from Richard Stoll's farm near Wallpack Center, had the following composition:

Analysis of limestone near Wallpack Center, N. J.

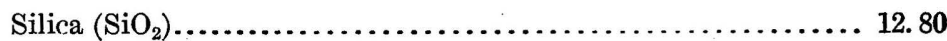

Alumina and iron oxide $\left(\mathrm{Al}_{2} \mathrm{O}_{3}\right.$ and $\left.\mathrm{Fe}_{2} \mathrm{O}_{3}\right) \ldots \ldots \ldots \ldots \ldots \ldots \ldots \ldots \ldots . .10$

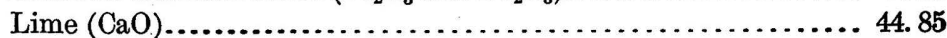

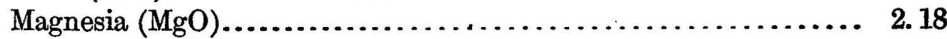

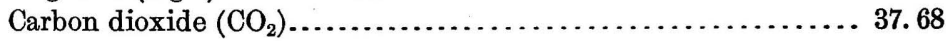

1 Weller, Stuart, Ann. Rept. State Geologist Now Jersey for 1899, 1900, pp. 1-46. 
Outcrops of this limestone are numerous from Flatbrookville to Peters Valley, along the eastern foot of the ridge. At the Nearpass quarry, near Tristates, it is exposed just above the base of the section, with a thickness of 12 feet 4 inches.

Specimens from other limestone formations exposed in the Nearpass quarry were analyzed by Cook, with the following results:

Analyses of limestones from Nearpass quarry, near Tristates, $N . J$.

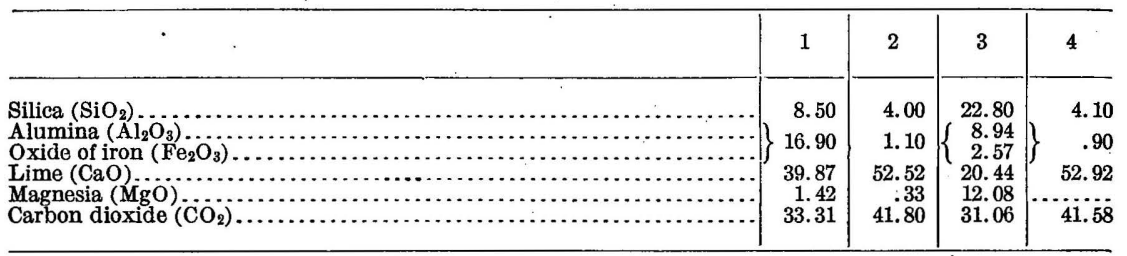

1. Cook's "firestone," a part of the Decker limestone.

2. Cook's "old-quarry stone," the identification of which is somewhat indefinite.

3. The so-called "pethstone," which, according to Weller, is No. 7 of the Rondout limestone. Ann.

Rept. State geologist New Jersey for 1899, p. 20 .
4. "Quarry stone," according to Weller (idem), the Manlius limestone. Another specimen of No. 4 had 51.5 per cent of lime and 5.5 per cent of silica and quartz.

The Nearpass quarry is not so far removed from the railroad at Port Jervis but that some of these beds may be profitably utilized. Analyses 2 and 4 above show that the "old-quarry stone" and the "quarry stone" are high-grade limestones. Analysis of the shaly layers in the quarry may show one with. the right proportions of alumina and silica. In Weller's report for 1899 some of the important exposures of these formations are noted.

Cook also gives the following analyses of specimens whose exact geologic horizon can not be determined from the record:

\section{Analyses of Silurian limestones.}

\begin{tabular}{|c|c|c|c|}
\hline & 1 & 2 & 3 \\
\hline 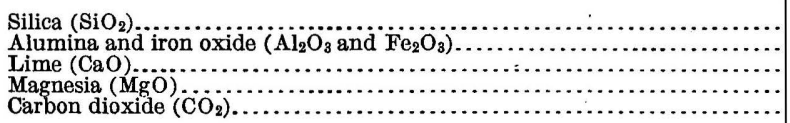 & $\begin{array}{r}9.80 \\
2.10 \\
48.88 \\
.35 \\
38.90\end{array}$ & $\begin{array}{r}8.70 \\
1.50 \\
49.67 \\
.69 \\
40.00\end{array}$ & $\begin{array}{r}10.80 \\
2.60 \\
45.19 \\
.80 \\
36.75\end{array}$ \\
\hline
\end{tabular}

1. Limestone from John Schooley's farm, near Peters Valley.

2. Limestone from farm of Joshua Cole, Montague.

3. Limestone from farm of Calvin Decker, Wallpack Ridge.

\section{WHITE CRYSTALLINE LIMESTONES OH THE HIGHLANDS.}

A series of white crystalline limestones, considered to be of preCambrian age, occurs in the Highlands of New Jersey and requires brief discussion here because of its possible relation to the cement industry.

These white limestones outcrop in a continuous narrow belt, extending from the New York-New Jersey line near Glenwood 
southwestward nearly to Sparta, N. J. In addition it outcrops in a number of smaller and disconnected areas in New Jersey, the more extensive being near Andover, east of Oxford Church, and along the northeastern side of Jenny Jump Mountain.

The rock is normally a generally white, very coarsely crystalline limestone, which varies in composition from a very pure calcite limestone, practically free from magnesia, to a highly magnesian stone, close to typical dolomite. Unfortunately there is at present no clue to the occurrence of these variations from place to place or from bed to bed. The use of the stone is therefore highly speculative, and it is doubtful if it can become of serious value to the cement industry.

The great irregularity in the distribution of magnesia throughout this formation can be best exemplified by reproducing, with analyses, a record of an actual drill hole, ${ }^{1}$ put down near Hamburg, N. J., by the Alpha Portland Cement Co. Better results were obtained from other drill holes in the same vicinity, but the record here reproduced. is the most interesting.

Analyses of white limestone near Hamburg, $N . J$.

\begin{tabular}{|c|c|c|c|c|}
\hline Depth. & $\begin{array}{c}\text { Silica } \\
\left(\mathrm{SiO}_{2}\right)\end{array}$ & $\begin{array}{c}\text { Alumina } \\
\text { and iron } \\
\text { oxide } \\
\left(\mathrm{Al}_{2} \mathrm{O}_{3} \text { and }\right. \\
\left.\mathrm{Fe}_{2} \mathrm{O}_{3}\right) \text {. }\end{array}$ & $\begin{array}{c}\text { Lime car- } \\
\text { bonate } \\
\left(\mathrm{CaCO}_{3}\right) .\end{array}$ & $\begin{array}{l}\text { Magnesium } \\
\text { carbonate } \\
\left(\mathrm{MgCO}_{3}\right) .\end{array}$ \\
\hline $\begin{array}{c}\text { Feet. } \\
7 \ldots \ldots \\
11 \ldots \ldots \\
15 \ldots \ldots \\
19 \ldots \ldots \\
23 \ldots \ldots \\
27 \ldots \ldots \\
31 \ldots \ldots \\
35 \ldots \ldots \\
39 \ldots \ldots \\
43 \ldots \ldots \\
47 \ldots \ldots \\
51 \ldots \ldots \\
55 \ldots \ldots \\
59 \ldots \ldots \\
63 \ldots \ldots \\
67 \ldots \ldots \\
75 \ldots \ldots \\
79 \ldots \ldots \\
83 \ldots \ldots \\
87 \ldots \ldots \\
91 \ldots \ldots \\
95 \ldots \ldots \\
\end{array}$ & $\begin{array}{r}2.80 \\
.83 \\
2.14 \\
2.08 \\
2.24 \\
1.36 \\
.82 \\
.90 \\
1.04 \\
1.16 \\
2.88 \\
.80 \\
2.14 \\
2.34 \\
5.42 \\
1.78 \\
1.20 \\
2.16 \\
1.60 \\
1.24 \\
.92 \\
1.68 \\
3.24\end{array}$ & $\begin{array}{r}1.84 \\
.66 \\
.54 \\
.72 \\
.36 \\
.32 \\
.42 \\
.40 \\
.32 \\
.34 \\
.48 \\
.34 \\
.46 \\
.44 \\
.84 \\
.56 \\
.48 \\
.68 \\
.72 \\
.62 \\
.44 \\
.34 \\
.40\end{array}$ & $\begin{array}{l}55.20 \\
74.65 \\
88.08 \\
83.12 \\
91.06 \\
91.22 \\
85.52 \\
91.75 \\
92.11 \\
91.22 \\
92.87 \\
94.72 \\
92.28 \\
94.20 \\
84.34 \\
80.11 \\
94.20 \\
94.29 \\
94.32 \\
94.72 \\
95.79 \\
94.32 \\
92.58\end{array}$ & $\begin{array}{r}39.95 \\
24.09 \\
8.65 \\
13.97 \\
6.07 \\
6.13 \\
12.68 \\
6.66 \\
6.69 \\
6.83 \\
3.85 \\
3.96 \\
2.14 \\
2.27 \\
9.28 \\
17.04 \\
4.54 \\
2.54 \\
2.50 \\
2.39 \\
1.89 \\
2.02 \\
2.94\end{array}$ \\
\hline
\end{tabular}

WHITE MARL DEPOSITS.

In addition to the limestones described, Sussex and Warren counties contain shell-marl deposits, many of which are extensive and some of which may be sufficiently pure tó be used for Portland cement in combination with clay. No recent study of these deposits has been made, but the data ${ }^{2}$ following may be of value. 
Analyses of marls in Sussex and Warren counties, $N . J$.

\begin{tabular}{|c|c|c|c|c|c|c|c|c|c|c|c|c|c|c|}
\hline & 1 & 2 & 3 & 4 & 5 & 6 & 7 & 8 & 9 & 10 & 11 & 12 & 13 & 14 \\
\hline Calcium carbona te $(\mathrm{CaC}$ & 98.33 & 88.86 & 97.73 & 95.34 & 96.32 & 92.25 & 89.87 & 96.54 & 84.52 & 90.18 & 99.04 & 68.73 & 94.75 & 64.20 \\
\hline $\begin{array}{l}\text { Magnesium c a r b o n a te } \\
\left(\mathrm{MgCO}_{3}\right) \ldots \ldots \ldots\end{array}$ & & & & 2.18 & 1.57 & 2.98 & 2.29 & 1.47 & 1.76 & .00 & .00 & .00 & .00 & .00 \\
\hline Sand and clay & .90 & 9.96 & .60 & .98 & 1.16 & 1.56 & .97 & 2.05 & 8.46 & 9.75 & .55 & 23.99 & .71 & 16.21 \\
\hline $\begin{array}{l}\text { Water, vegetable material, } \\
\text { etc............................ }\end{array}$ & .67 & 2.16 & 1.59 & 1.50 & .96 & 3.21 & 6.87 & .00 & 5.26 & & .41 & 7.28 & 4.54 & 16.59 \\
\hline
\end{tabular}

1. Andover, Sussex County. White, pulverulent; no vegetable matter.

2. Peters Valley, Sussex County. Precipitate from water.

3. Shiloh, Warren County. White, dense, fine.

4. Shiloh, Warren County. Surface marl, white, solid, fine.

5. Hunt's mill, Sussex County. Drab white, fine and with shells.

6. Marksboro, Warren County. White, pure, some grass roots.

7. Hope, Warren County. Ash colored, many shells, light.

8. Newton, Sussex County. White, very fine, medium density.

9. Newton, Sussex County. Surface marl.

10. Lincoln, Warren County. White, very dense, thick shells.

11. Lincoln, Warren County. White, very light, pure.

12. Montague, Sussex County. Dark-colored shells and vegetable matter.

13. Monroe Corners, Sussex County. White, very light, pure.

14. Centerville, Sussex County. White shells and clay.

\section{PORTLAND CEMENT INDUSTRY IN NEW JERSEY.}

For a number of years New Jersey ranked second among the States as a producer of Portland cement, being surpassed only by Pennsylvania. Recently, however, the development of the industry has been more rapid in certain Western States than in New Jersey, and the latter ranked sixth in 1911. The production of the State in that year was 4,411,890 barrels, this total being made up by three large plants.

Of the companies now operating in New Jersey, the Alpha Port land Cement Co., with mills at Alpha, is the oldest, having commenced operation in 1891. The Vulcanite Portland Cement Co. erected a mill at Vulcanite in 1894. The plant of the Edison Portland Cement Co., at New Village, was put into operation in 1893. All the New Jersey plants are located in Warren County and all use the "Trenton cement rock" (Jacksonburg limestone) as their principal raw material. In raw materials and general practice these plants agree with the others of the Lehigh district, described on pages 314-317.

\section{BIBLIOGRAPHY.}

Eckel, E. C., Cement-rock deposits of the Lehigh district, Pennsylvania-New Jersey: Bull. U. S. Geol. Survey No. 225, 1904, pp. 448-450.

Hamilton, S. H., The cement industry [in New Jersey, 1903]: Ann. Rept. N. J. State Geologist for 1903, pp. 112-118.

KümmeL, H. B., Report on the Portland cement industry (in New Jersey): Ann. Rept. N. J. State Geologist for 1900, pp. 9-101.

The chemical composition of the white crystalline limestones of Sussex and Warren counties: Ann. Rept. N. J. State Geologist for 1905, pp. 173-192.

Lewis, F. H., The Vulcanite Portland Cement Company's works, Vulcanite, N. J.: Engineering Record, May 6, 1899;" "Cement Industry," 1900, pp. 96-106.

Rres, HeInRICH, and others, The clays and clay industry of New Jersey: Final Rept. N. J. State Geologist, vol. 6, 1904, 548 pp. 
Anonymous, Edison Portland Cement Company: Ircn Age, Dec. 24, 1903.

Visit to plant of. Edison Portland Cement Company: Engineering News, May 29, 1902.

- The works of the Edison Portland Cement Company: Engineering Record, vol. 48, Dec. 26, 1903, pp. 796-802.

The Edison Portland Cement Works at New Village, N. J.: Engineering News, vol. 50,1903 , pp. 555-559.

\section{PORTLAND CEMENT RESOURCES OF NEW MEXICO.}

Almost all detailed geologic work within the limits of New Mexico has been done with reference to metallic deposits and to coal areas. The result is that practically nothing is definitely known concerning the composition of the limestones of the State, not a single satisfactory analysis of a limestone from New Mexico being recorded anywhere in the literature.

Limestones are known to occur in the Ordovician, the Silurian, the Mississippian ("Lower Carboniferous"), the Pennsylvanian ("Upper Carboniferous"), and the Cretaceous. It may reasonably be assumed that the Pennsylvanian limestones will prove of most service as sources of Portland cement material, so far as extent, thickness, and probable composition are concerned, and it may also be accepted, on the basis of experience many years ago with a little natural-cement plant at Springer, that the Cretaceous beds also will yield possible cement materials.

In the vicinity of Carthage, ${ }^{1}$ Socorro County, an area of limestone and shale is so situated with regard to fuel and market as to warrant practical tests of the raw materials and a thorough study of the conditions. The San Andreas limestone of the Manzano group of the Pennsylvanian series, having a thickness of about 200 feet, outcrops in the southwest quarter of T. 5 S., R. 2 E. of the New Mexico principal meridian. In the immediate locality thick beds of clay. shale of Benton and Montana age (Upper Cretaceous) are exposed. Both the limestone and the shale show every physical appearance of being suitable for combination in the making of cement.' This area is within one-half mile of the New Mexico Midland Railway, which draws high-grade coal from Carthage, less than 2 miles distant, and which connects at San Antonio, N. Mex., with the Atchison, Topeka $\&$ Santa Fe Railway.

\section{PORTLAND CEMENT RESOURCES OF NEW YORK. PORTLAND CEMENT MATERIALS.}

\section{DISTRIBUTION.}

Of the many different limestone formations which outcrop in New York State, six are sufficiently satisfactory in thickness, areal extent, chemical composition, and market advantages to be worth con-

1 Personal communiçation frọm Jamẹs H. Gardner, geologist, Lexington, Ky. 
sidering as possible sources of Portland cement material. Many other limestones occur in the State, but these others may be disregarded here as being either too thin, of improper chemical composition, or too badly located with regard to transportation routes, markets, or sources of fuel supply.

The six available limestones, named in their geologic order from above downward, are as follows:

1. Marls..................................... Quaternary.

2. Tully limestone........................... Devonian.

3. Helderberg group and Onondaga limestone............. Devonian.

4. Clinton formation............................. Silurian.

5. Mohawkian limestones (Trenton, Black River, and Lowville $) . . \ldots \ldots \ldots \ldots \ldots \ldots \ldots \ldots \ldots \ldots . . . \ldots$ Ordovician.

6. Chazy limestone ............................... Ordovician.

All these limestones except the Chazy and those of Clinton age are at present utilized in Portland cement manufacture in New York State.

The actual distribution in New York State of the Tully, Helderberg, Onondaga, Mohawkian, and Chazy limestones is shown on the map (Pl. XII). The Quaternary marls are widely distributed throughout the State, but generally occur in small deposits, and the workable limestones of Clinton age exist only in one small but important area in western New York; for this reason neither the marl deposits nor the limestones of Clinton age are shown on the map.

\section{CHAZY LIMESTONE.}

The Chazy limestone is confined practically to the Lake Champlain valley. It outcrops on the west shore of Lake Champlain a few miles south of Crown Point village and is also well shown in Crown Point itself. It appears again on the lake shore about 5 miles south of Westport, near Essex village, and on Willsboro Point. Its most characteristic and extensive outcrops, however, are in the eastern part of Clinton County. It is shown well on Valcour Island and on Isle la Motte, where it has been extensively quarried. On the mainland it occupies large areas north of Valcour and west of Plattsburg, where it is quarried. The largest single area is in the northeastern part of Clinton County, where it has been worked extensively for lime and building stone. This area extends almost without a break from the village of West Chazy to the lake shore and northward to the Canadian line near Rouse Point.

Local details concerning the distribution, thickness, and character of the Chazy limestone have been described by Cushing, ${ }^{1}$ who also gives geologic maps of the county.

1 Cushing, H. P., Report on the geology of Clinton County: Thirteenth Ann. Rept. New York State Geologist, 1894, pp. 473-490. 


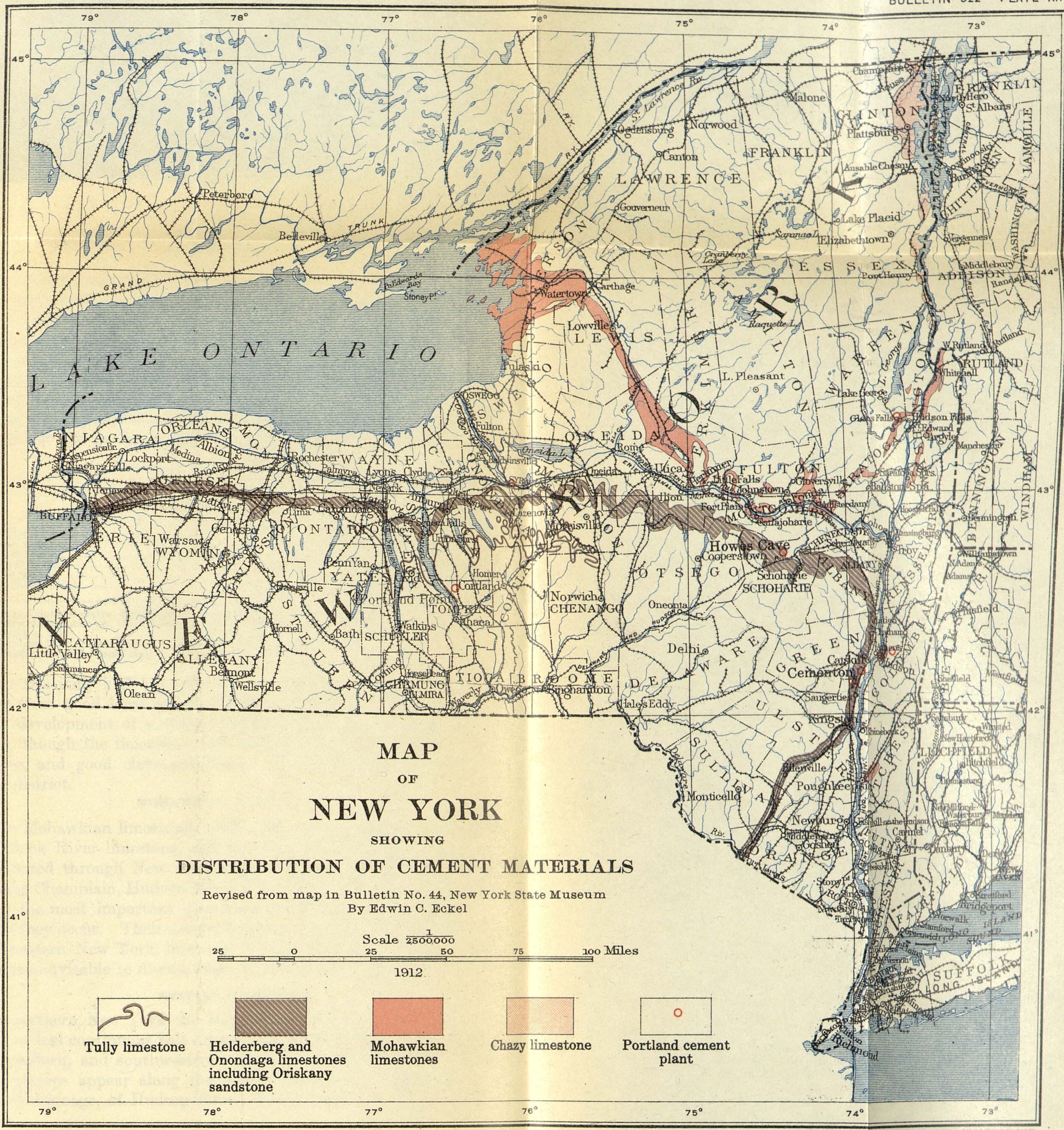



The Chazy is generally a very pure limestone, low in both magnesia and clayey matter. It is commonly bluish to grayish in color and has a slightly crystalline appearance. In places it carries notable percentages of silica, alumina, and other impurities, but these argillaceous phases are rare. Of the analyses in the following table 1 and 2 represent the purest type of the Chazy limestone, and 3, 5, and 6 contain more or less clayey matter. Analysis 4 is included as representing a highly argillaceous type, occurring in the same area as 3, 5 , and 6 ; but this particular analysis is old and of doubtful value.

Analyses of Chazy limestone, New York.

\begin{tabular}{|c|c|c|c|c|c|c|}
\hline & 1 & 2 & 3 & 4 & 5 & 6 \\
\hline 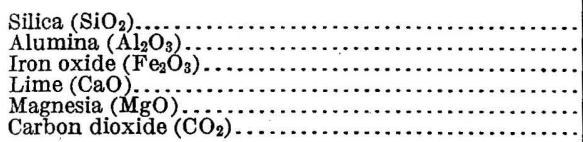 & $\begin{array}{r}0.72 \\
.39 \\
53.89 \\
1.21 \\
44.16\end{array}$ & $\begin{array}{r}0.72 \\
.39 \\
53.90 \\
1.44 \\
43.92\end{array}$ & $\begin{array}{r}2.43 \\
.41 \\
51.00 \\
1.00 \\
\text { n. d. }\end{array}$ & $\begin{array}{r}21.39 \\
3.61 \\
39.37 \\
.52 \\
31.51\end{array}$ & $\left\{\begin{array}{r}4.40 \\
7.10 \\
3.50 \\
44.35 \\
2.00 \\
37.05\end{array}\right.$ & $\begin{array}{r}4.60 \\
4.10 \\
1.90 \\
49.11 \\
.47 \\
39.10\end{array}$ \\
\hline
\end{tabular}

1. Chazy, Clinton County. Rept. New York State Geologist for 1897, p. 433.

2. Chazy Marble Lime Co., Clinton County. D. H. Newland, analyst. Bull. New York State Museum No. 44,1901, p. 755 .

3. Willsboro Point, EssexCounty. T. G. White, analyst. Idem, p. 783.

4-6. Willsboro Point, Essex County. E. C. Boynton, analyst. Idem, pp. 782, 783.

The relatively high cost of fuel in Champlain Valley and the distance from good local cement markets will probably prevent any great development of a cement industry based on the Chazy limestone, though the limestone itself is well adapted to cement manufacture, and good clays and shales are readily obtainable in the same district.

\section{MOHAWKIAN LIMESTONES.}

The Mohawkian limestones, which include the Trenton limestone, the Black River limestone, and the Lowville limestone, are widely distributed through New York State. They appear in the valleys of Lake Champlain, Hudson River, Mohawk River, and Black River, being the most important quarry stones of most of the districts in which they occur. Their developments in northern New York and in southeastern New York, however, differ so greatly in character that it seems advisable to discuss them under separate headings.

\section{NORTHERN NEW YORK.}

In northern New York the Mohawkian limestone is exposed as a more or less continuous belt circling the Adirondacks on the eastern, southeastern, and southwestern sides. (See Pl. XII.) The principal outcrops appear along the valleys of Lake Champlain and its related drainage, of Hudson River, of Mohawk River, and of Black River.

In the Lake Champlain region the limestone covers a considerable area and is exposed at numerous points along the shores of Lake $48834^{\circ}-$ Bull. 522-13-18 
Champlain itself. It is quarried more or less extensively on Isle la Motte, at Plattsburg, and on Larabees Point and Crown Point.

In the Hudson Valley a belt, which is quarried near Glens Falls, enters the State from Vermont, in northern Washington County, and passes southward through Whitehall, close to the line of the Delaware \& Hudson Railroad. (See Pl. XIII.) A short break occurs at Fort Ann, beyond which the limestone belt passes south to Sandy Hill, then west to Glens Falls, where it again turns south to Saratoga. In all this distance it lies close to railroads and in places is also near the canal. It is extensively quarried for Portland cement at Glens Falls and for lime and building stone at Sandy Hill, Glens Falls, and other points.

In the lower Mohawk Valley the areas covered by Mohawkian limestones are too irregular to be readily described. ${ }^{1}$ The limestones outcrop extensively in the vicinity of Cranesville, Amsterdam, Tribes Hill, Yosts, Sprakers, Palatine Bridge, St. Johnsville, Dolgeville, and Little Falls and are quarried at many of those places for lime or building stone. It should be noted, however, that another limestone-the Beekmantown ("Calciferous") limestoneunderlies the Mohawkian limestones at many of the places named. The Beekmantown limestone, however, is generally a very impure rock, high in magnesia, and should therefore be carefully distinguished from the Mohawkian limestones, which are normally very low in magnesia.

The most extensive area of Mohawkian limestone in the State lies mostly in Oneida, Lewis, and Jefferson counties, along the valleys of West Canada Creek and Black River. Commencing as a narrow belt near Middleville, Herkimer County, it passes northwestward, increasing to about 8 to 10 miles in width, and going through Trenton Falls, Prospect, Remsen; Boonville, Port Leyden, Lowville, and Copenhagen, at many of which places it is extensively quarried. The limestone belt here widens out greatly, being about 20 miles wide at Watertown, and extending along the St. Lawrence-Lake Ontario shore from near Clayton to near Port Ontario, a distance of over 50 miles. Within this broad area in Jefferson County the limestones are quarried at Cape Vincent, Chaumont, Clayton, Watertown, Theresa, and many other places.

The Mohawkian limestones are, in general, pure and nonmagnesian, dark gray to almost black in color, and commonly highly fossiliferous.

The analyses following, which represent the different phases of the limestone, are arranged in geographic order, from Washington County on the east to Lewis County on the west.

\footnotetext{
1 Darton, N. H., Geology of the Mohawk Valley: Thirteenth Ann. Rept. New York State Geologist, 1894, pp. 407-430.
} 


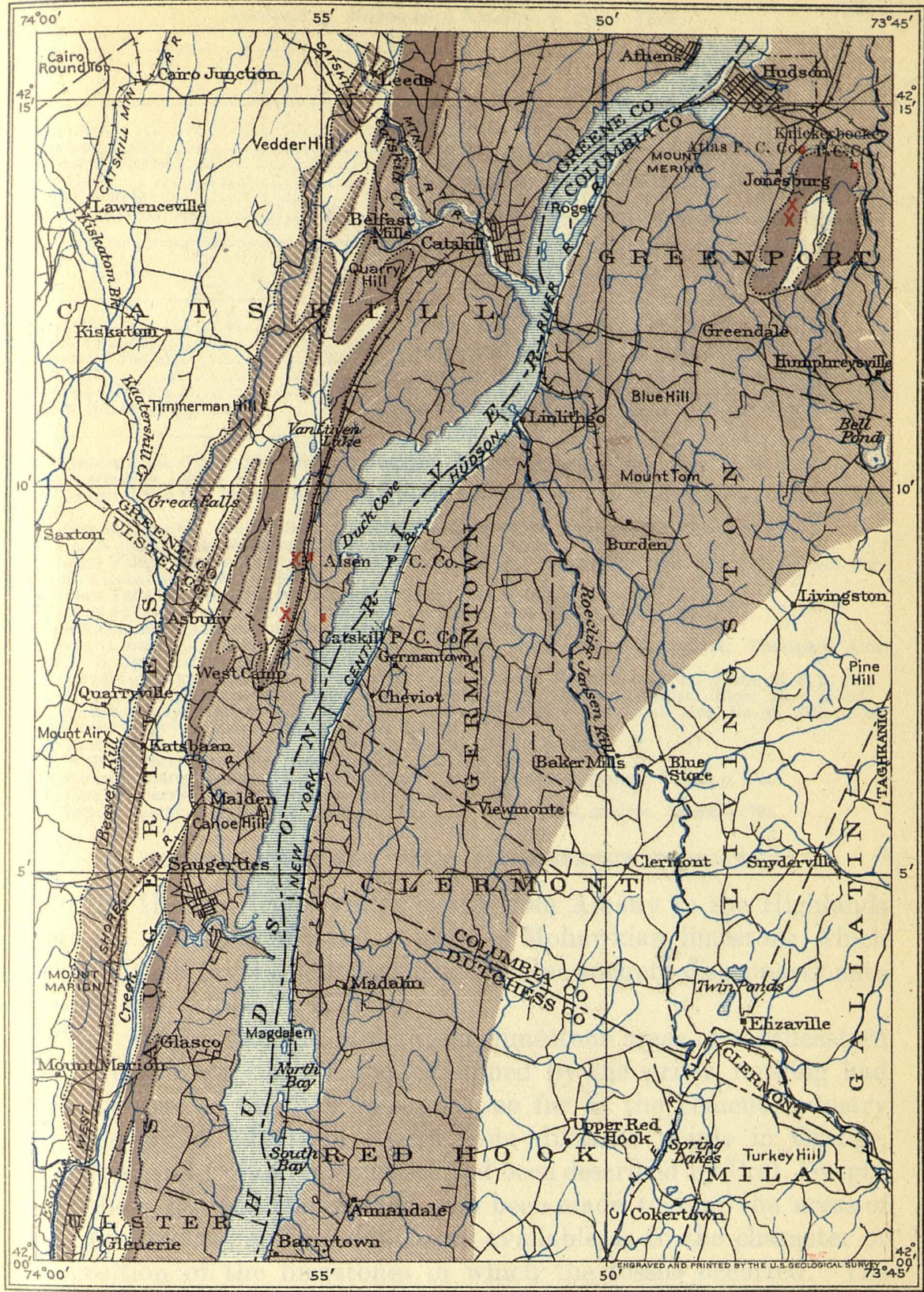

MAP OF THE HUDSON RIVER PORTLAND CEMENT DISTRICT, NEW YORK SHOWING LOCATION OF CEMENT PLANTS AND OF AVAILABLE LIMESTONES AND BHALES

$\begin{array}{llll}1 / 20 & 1 & 3 & \text { Geology compiled } \\ & & \text { trom maps by } \\ \text { LEGEND } & \text { N. H. Darton and } \\ & & \text { W. M. Davis }\end{array}$

DEVONIAN

NINS

limestone
OVICIAN AND CAMBRIAN

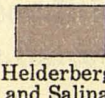

and Salina

limestones

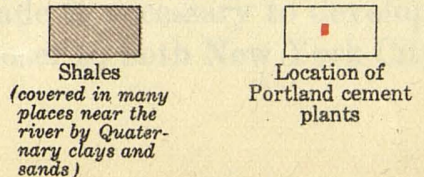



Analyses of Mohawkian limestones, New York.

\begin{tabular}{|c|c|c|c|c|c|c|c|c|c|}
\hline & 1 & 2 & 3 & 4 & 5 & 6 & 7 & 8 & 9 \\
\hline \multirow[t]{2}{*}{$\begin{array}{l}\mathrm{Silica}\left(\mathrm{SiO}_{2}\right) \\
\text { Alumina }\left(\mathrm{Al}_{2} \mathrm{O}_{3}\right) \\
\text { Iron oxide }\left(\mathrm{Fe}_{2} \mathrm{O}_{3}\right) \ldots \ldots\end{array}$} & $\begin{array}{r}0.97 \\
.08 \\
.02 \\
54.15 \\
.39 \\
42.95\end{array}$ & $\begin{array}{r}1.38 \\
.58 \\
55.26 \\
.72 \\
\text { n. d. }\end{array}$ & $\begin{array}{r}0.72 \\
1.50 \\
54.28 \\
480 \\
44.00\end{array}$ & $\begin{array}{r}0.70 \\
1.00 \\
.70 \\
53.09 \\
1.04 \\
42.05\end{array}$ & $\begin{array}{r}2.13 \\
1.26 \\
53.19 \\
\text { Tr. } \\
41.79\end{array}$ & $\begin{array}{r}3.30 \\
1.30 \\
52.15 \\
1.58 \\
40.98\end{array}$ & $\left\{\begin{array}{r}1.10 \\
.80 \\
.50 \\
53.17 \\
.75 \\
45.08\end{array}\right.$ & $\begin{array}{r}6.13 \\
.79 \\
.61 \\
49.55 \\
1.17 \\
40.22\end{array}$ & $\begin{array}{r}1.25 \\
3.00 \\
52.78 \\
42.97\end{array}$ \\
\hline & 10 & 11 & 12 & 13 & 14 & 15 & 16 & 17 & 18 \\
\hline 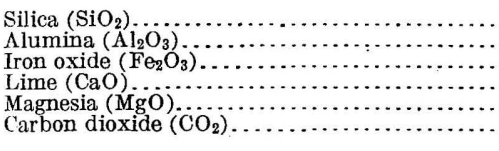 & $\left\{\begin{array}{l}3.82 \\
1.08 \\
52.46 \\
32.64\end{array}\right.$ & $\begin{array}{r}5.68 \\
2.76 \\
52.12 \\
39.44\end{array}$ & $\begin{array}{r}6.70 \\
3.03 \\
.21 \\
49.92 \\
\text { Tr. } \\
39.23\end{array}$ & $\begin{array}{r}8.45 \\
2.72 \\
.84 \\
47.38 \\
1.63 \\
39.01\end{array}$ & $\begin{array}{r}2.59 \\
1.21 \\
.61 \\
52.00 \\
1.04 \\
42.00\end{array}$ & $\left\{\begin{array}{l}3.96 \\
1.70 \\
51.11 \\
1.80 \\
42.14\end{array}\right.$ & $\left\{\begin{array}{r}3.09 \\
1.15 \\
.49 \\
52.70 \\
.78 \\
42.26\end{array}\right.$ & $\left\{\begin{array}{r}1.44 \\
.83 \\
54.52 \\
.49 \\
43.39\end{array}\right.$ & $\begin{array}{r}6.50 \\
1.67 \\
.76 \\
49.53 \\
1.28 \\
40.31\end{array}$ \\
\hline
\end{tabular}

1. Keenan Lime Co., Smiths Basin, Washington County. Twentieth Ann. Rept. U. S. Geol. Survey, pt. 6 (continued), 1899, p. 427.

2. Keenan Lime Co., Smiths Basin, Washington County. Bull. New York State Mus. No. 44,'1901, p. 826.

3. Keenan Lime Co., Smiths Basin, Washington County. H. Ries, analyst. Idem, p. 827.

4. Harris quarry, near Whitehall, Washington County. Idem.

5. Glens Falls, Warren County. J. H. Appleton, analyst. Seventeenth Ann. Rept. U. S. Geol. Survey, pt. 3 (continued), 1896, p. 801 .

6. Glens Falls, Warren County. Mineral Industry, vol. 6, 1898, p. 97.

7. Glens Falls, Warren County. Bull. New York State Mus. No. 44, 1901, p. 825.

8. Hewitt quarry, Amsterdam, Montgomery County. Idem, p. 749.

9. Hewitt quarry, Amsterdam, Montgomery County. J. M. Sherrerd, analyst. Twentieth Ann. Rept. U.S. Geol. Survey, pt. 6 (continued), 1899 p. 427.

10. Hewitt quarry, Amsterdam, Montgomery County. J. M. Sherrerd, analyst. Idem, pt. 6, p. 427.

11. Hewitt quarry, Amsterdam, Montgomery County. J. M. Sherrerd, analyst. Idem, pt. 6, p. 427.

12. Butler quarry, Ingham Mills, Herkimer County. Bull. New York State Mus. No. 44, 1901, p. 788.

13. Butler quarry, Ingham Mills, Herkimer County. Idem.

14. Prospect, Oneida County. J. D. Irving, analyst. Idem, p. 802.

15. Waters quarry, Lowville, Lewis County. Idem, p. 792

16. Roberts quarry, Collinsville, Lewis County. D. H. Newland, analyst.' Idem, p. 791

17. Christy quarry, Leyden, Iewis County. Idem, p. 791.

18. Snyder quarry, Port Leyden, Lewis County. D. H. Newland, analyst. Idem, p. 791.

\section{SOUTHEASTERN NEW YORK (POUGHKEEPSIE DISTRICT),}

In the Hudson River valley south from Albany to the Highlands there are a number of isolated areas of Mohawkian limestone, which owing to their favorable location have value entirely disproportionate to their size. (See Pl. XIV.)

Until 1909, when the Mohawkian limestone areas of southeastern New York were located and examined by the writer, nothing had been known as to their existence, so far as the cement industry was concerned. Trenton fossils from different points in Orange, Dutchess, and Columbia counties had been described by Prof. Dwight and others, but no attempt had ever been made to map the areas of their occurrence, and no data were available as to the character or composition of the limestones in which the fossils occurred. The senior writer had early considered the possibility of finding nonmagnesian limestones in this series in the lower Hudson Valley, but until very recently had not considered the matter of sufficient commercial importance to justify the expense of exploration. Early in. 1909, however, trade conditions made it necessary to develop some source of nonmagnesian limestone closer to both New York City and to New 
England. The possibility of finding the necessary supply in the Mohawkian series in the lower Hudson Valley was given careful consideration.

Examination showed that, with the exception of one unimportant little area north of Newburgh, Orange County offered little opportunity for developing the Mohawkian limestones in the region tributary to the Hudson River. On the east side of the Hudson, however, conditions were found to be more favorable, a belt of Mohawkian limestone being discovered within close reach of the Central New England Railway, now, a part of the New Haven system. Extensive sampling showed that in both composition and tonnage the beds would meet the requirements of the case, and they were accordingly taken over by the American Cement Co.

In the following table a number of analyses of the Mohawkian limestones from this district are presented; all were made by the Spackman testing laboratory on material sampled by the senior writer:

Analyses of Mohawkian limestones, Poughkeepsie district, New York.

\begin{tabular}{|c|c|c|c|c|c|}
\hline 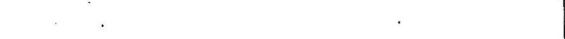 & 1 & 2 & 3 & 4 & 5 \\
\hline 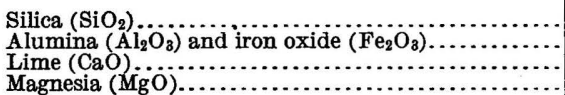 & $\begin{array}{r}3.42 \\
1.70 \\
47.14 \\
5.08\end{array}$ & $\begin{array}{r}8.02 \\
4.08 \\
46.28 \\
2.38\end{array}$ & $\begin{array}{r}\text { n. d. } \\
\text { n. d. } \\
47.92 \\
1.48\end{array}$ & $\begin{array}{r}9.22 \\
4.16 \\
45.24 \\
1.70\end{array}$ & $\begin{array}{l}\text { n. d. } \\
\text { n. d. } \\
48.26 \\
2.62\end{array}$ \\
\hline
\end{tabular}

The above analyses, which represent a very large series now on file, show that the Mohawkian limestones of the Poughkeepsie district furnish sufficiently satisfactory Portland cement materials. The magnesia, it is true, is always near the maximum limit; as it is in the cement rock of the Lehigh district. Otherwise, the rocks range from fairly pure limestone carrying 95 to 96 per cent of total carbonates down to cement rocks of a grade about like that of the Bath and Nazareth portions of the Lehigh district. None of the New York cement rocks require the addition of pure limestone, as do the cement rocks of the older part of the Lehigh region, but most of them do require the addition of clay or shale. Fortunately both Ordovician shales and Quaternary clays are convenient and abundant.

\section{LIMESTONES OF CLINTON AGE.}

The limestones of Clinton age in the western part of the State, though not particularly thick nor high grade, are of great value because of the lack of better stone in a region where the demand is great.

Throughout the eastern portion of its extent the Clinton is predominantly argillaceous, its limestone beds being few and so thin as to be negligible. At the type locality, Clinton, N. Y., the formation 
U. S. GEOLOGICAL SURYEY

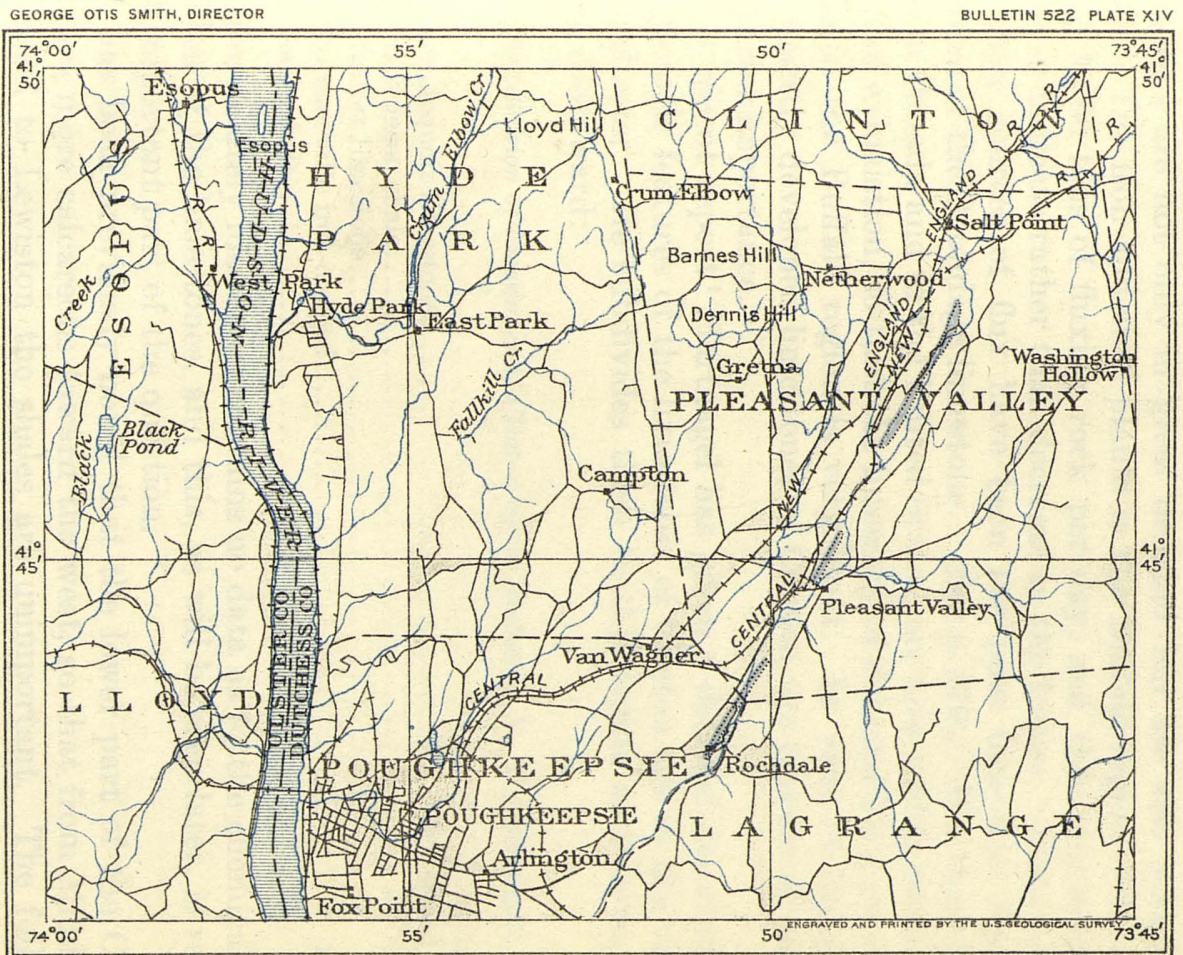

LEGEND

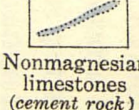

MAP OF CEMENT ROCK AREAS NEAR POUGHKEEPSIE, NEW YORK By E. C. Eckel

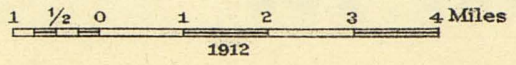

House Doc. 880; 62d Cong., 2d Sess., 2d edition 

contains at the top a representative of the Rochester shale, and contains Rochester fauna practically throughout. Westward from Rochester the beds of Clinton age beneath the Rochester shale become thinner and more and more calcareous, until where they cross Niagara River into Canada they form an essentially limestone formation with unimportant bands of interbedded shale.

This change in character takes place, it is to be noted, in approaching an area where, entirely aside from the cement industry, pure limestones are not only in great demand but are also particularly scarce. The iron and steel plants in the Buffalo region now require about 3,000 tons of fluxing rock per day, and this requirement is likely to increase rather than decrease in the future. Until recently the chief sources of flux have been the pure limestone lenses at the base of the Onondaga limestone. (See p. 279.) But these lenses, both in Canada and in the United States, are now within measurable reach of exhaustion, so that the intensity of demand for a pure limestone in the Buffalo region is very great. In view of these facts the recently developed limestones of Clinton age become of peculiar industrial importance.

In a recent report ${ }^{1}$ Hartnagel has given a detailed description of the geologic features of the limestones of Clinton age in the vicinity of Rochester. He subdivides them in this region as follows, from above downward:

Subdivision of limestones of Clinton age at Rochester, N. Y. (Hartnagel).

Ft. in.

Irondequoit limestone.......................... Not stated.

Williamson shale..................................... 24

Wolcott limestone..................................... 14

Furnaceville iron-ore bed............................... 12

Sodus shale....................................... 24

Unfortunately his report contains no data as to the chemical composition of the limestones, and this, as will be seen later, is really a very important part of the question.

It has been previously noted that the lower part of the Clinton becomes more calcareous toward the west, so that from Middleport westward to Lewiston the shales are unimportant. The following section will serve to summarize the stratigraphy:

General section of limestones of Clinton age in Lockport-Lewiston district.

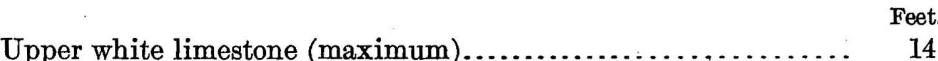

Middle gray limestone......................................... 8

Lower dark limestone................................. 8

Green shale....................................... to 2

Sandstones and shales (Medina).

1 Hartnagel, C. A., Geologic map of the Rochester and Ontario Beach quadrangles: Bull. New York State Mus. No. 114, 1907. 
Owing to erosion the upper limestone is rarely present in its full thickness. The quarries of the Lackawanna Steel Co., for example, near Pekin, show this limestone with a thickness ranging from 8 to 12 feet.

Owing to the work done by Conkling and Boardman for the Lackawanna Steel Co., a very thorough knowledge of the composition of the limestones of Clinton age in this latter region has now been obtained.

Chemically the three are very distinct in composition. The uppermost is fairly low in silica, alumina, and iron oxide and carries generally from 90 to 95 per cent lime carbonate and from 3 to 5 per cent magnesium carbonate. The middle limestone carries from 20 to 30 per cent of magnesium carbonate and is also high in insoluble matter. The bottom limestone, though higher in silica, alumina, and iron oxide than the top stone, carries a much lower percentage of magnesium carbonate.

The range in composition of the three limestones is well indicated in the following table of analyses, selected from a large series placed at the writer's disposal by Conkling and Boardman, who discovered and developed the property now worked by the Lackawanna Steel Co.:

Analyses of limestones of Clinton age from western New York.

\begin{tabular}{|c|c|c|c|c|c|c|c|c|c|c|c|c|c|c|}
\hline & 1 & 2 & 3 & 4 & 5 & 6 & 7 & 8 & 9 & 10 & 11 & 12 & 13 & 14 \\
\hline $\begin{array}{l}\text { Silica }\left(\mathrm{SiO}_{2}\right) \ldots \ldots \ldots \\
\text { Alumina and iron oxide } \\
\left(\mathrm{Al}_{2} \mathrm{O}_{3} \text { and } \mathrm{Fe}_{2} \mathrm{O}_{3}\right) \ldots \ldots \ldots \\
\text { Lime carbonate }\left(\mathrm{CaCO}_{3}\right) \ldots\end{array}$ & $\begin{array}{r}0.90 \\
.68 \\
92.99\end{array}$ & $\begin{array}{r}1.08 \\
.72 \\
91_{2} 55\end{array}$ & $\begin{array}{r}0.60 \\
.60 \\
95.17\end{array}$ & $\begin{array}{r}0.80 \\
.64 \\
94.58\end{array}$ & $\begin{array}{r}1.00 \\
.70 \\
93.98\end{array}$ & $\begin{array}{r}10.40 \\
5.20 \\
52.54\end{array}$ & $\begin{array}{c}11.80 \\
7.60 \\
52.00\end{array}$ & $\mid \begin{array}{l}15.20 \\
13.20 \\
49.23\end{array}$ & $\begin{array}{r}3.40 \\
.60 \\
93.72\end{array}$ & $\begin{array}{r}8.10 \\
1.60 \\
88.97\end{array}$ & $\begin{array}{r}5.60 \\
.60 \\
91.08\end{array}$ & $\begin{array}{r}3.40 \\
.70 \\
92.40\end{array} \mid$ & $\begin{array}{r}7.00 \\
2.60 \\
87.64\end{array}$ & $\begin{array}{r}4.40 \\
1.00 \\
92.40\end{array}$ \\
\hline $\begin{array}{r}\text { Magnesium carbonate } \\
\left(\mathrm{MgCO}_{3}\right) \ldots \ldots \ldots \ldots\end{array}$ & 4.95 & 5.43 & 3.15 & 3.60 & 3.60 & 30.2 & 4 & 20.24 & 1.50 & 1.80 & 1.65 & 3.60 & 2.40 & 1.35 \\
\hline
\end{tabular}

1-5. Top bed, Lockport, N. Y.

6-8. Middle bed, Lockport, N. Y.

9-14. Bottom bed, Lockport, N. Y.

\section{HELDERBERG GROUP AND ONONDAGA LIMESTONE.}

\section{DISTRIBUTION.}

Whether regarded as present or as possible future sources of Portland cement materials, the Helderberg group and Onondaga limestone of the Devonian system comprise the most important series of limestones in New York State. The two are separated in the greater part of their range by a comparatively thin bed of sandstone - the Oriskany sandstone-and in some areas also by the Schoharie and Esopus grits. The Helderberg group is divisible into several well-marked formations. These limestones, either in whole or in part, extend eastward from Buffalo, in Erie County (where only the Onondaga limestone is present), to Oriskany Falls, Oneida County. Here the belt turns about S. $30^{\circ}$ E. and continues nearly to South Bethlehem, Albany County. From this point the 
outcrops of the limestones trend almost parallel to and a little west of Hudson River nearly to Kingston. The belt then turns southwestward, passing through Ellenville and Port Jervis into Pennsylvania and New Jersey. (See Pl. XII.)

The character of the limestones varies considerably in different portions of this range. Because of this fact and because of the different commercial values in the different geographic localities, the distribution and character of the limestones are described in three separate sections-western New York, central New York, and the Hudson River valley.

\section{WESTERN NEW YORK.}

The term "western New York," as here used, covers the area included between Seneca County on the east and Erie County on the west. In this area the limestones are tributary to the Buffalo market. That is to say, if limestones of satisfactory grade could be found at any point from Seneca County west, freight rates would permit their transportation on a competitive basis to furnaces or cement plants located in or near Buffalo. The market for the rock is therefore assured, but unfortunately the supply so far developed is far smaller than the market could conveniently take. The Helderberg group of limestones does not appear in this portion of the State, and the Onondaga limestone carries normally a very large percentage of chert, so that through most of its outcrop it is too siliceous to be available for either flux or cement. The beds which do not carry chert are rather pure limestone, low in magnesia, and ordinarily range from 93 to 98 per cent in total carbonates. In Erie County a number of rather large lenses of nonsiliceous rock have been found near the base of the Onondaga limestone, and in times past these have furnished the bulk of the limestone used in the Buffalo district for flux, chemical uses, and building lime. The total tonnage available from these lenses is, however, limited, and unless new ones are discovered the supply from this source can not last for many years.

In the following table a number of analyses are given of the Onondaga limestone from western New York:

Analyses of Onondaga limestone, western New York.

\begin{tabular}{|c|c|c|c|c|}
\hline & 1 & 2 & 3 & 4 \\
\hline 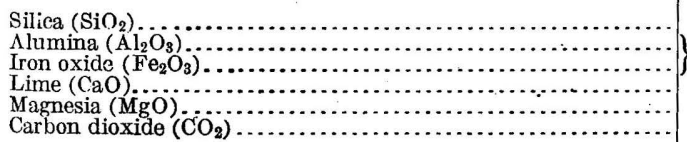 & $\begin{array}{r}1.17 \\
.64 \\
54.06 \\
.48 \\
43.00\end{array}$ & $\begin{array}{r}5.00 \\
.60 \\
51.78 \\
.88 \\
41.66\end{array}$ & $\begin{array}{r}5.96 \\
3.16 \\
1.34 \\
49.70 \\
1.44 \\
40.13\end{array}$ & $\begin{array}{r}14.85 \\
7.18 \\
1.57 \\
40.23 \\
1.95 \\
33.76\end{array}$ \\
\hline
\end{tabular}

1. Fogelsonger quarry, Williamsville, Erie County. H. Carlson, analyst. Twentieth Ann. Rept. U.S, Geol. Survey, pt. 6 (continued), 1899, p. 427.

2. Howells quarry, Leroy, Genesee County. Bull. New York State Mus. No. 44, 1901, p. 784.

3. Strobel quarry, Leroy, Genesee County. Idem, p. 784.

4. Babcock quarry, Waterloo, Seneca County. Idem, p. 819 . 
Most of the above analyses represent only the purest beds in the series, free from chert. Heavy'shipments from this region would involve the handling, in most localities, of at least as much cherty rock as pure limestone.

\section{CENTRAL NEW YORK.}

In central New York-the term being conveniently used to cover the counties between Albany and Seneca-these limestones offer greater possibilities in the way of securing a supply of nonmagnesian and nonsiliceous rock. The Onondaga limestone is not appreciably better, so far as silica is concerned, than in western New York; but members of the Helderberg group come in below it, and these furnish in places an excellent stone for chemical purposes or lime-burning. The same type of stone could, of course, be used as cement material. The following table contains a number of analyses of Helderberg and Onondaga limestones from central New York:

Analyses of Helderberg and Onondaga limestones, central New York. .

\begin{tabular}{|c|c|c|c|c|c|c|c|c|c|c|c|}
\hline , & 1 & 2 & 3 & 4 & 5 & 6 & 7 & 8 & 9 & 10 & 11 \\
\hline $\begin{array}{l}\text { Silica }\left(\mathrm{SiO}_{2}\right) \\
\text { Alumina }\left(\mathrm{Al}_{2} \mathrm{O}_{3}\right) \ldots \ldots \ldots \ldots \\
\text { Iron oxide }\left(\mathrm{Fe}_{2} \mathrm{O}_{3}\right) \ldots \ldots \ldots \\
\text { Lime }(\mathrm{CaO}) \\
\text { Magnesia }(\mathrm{MgO}) \\
\text { Carbon dioxide }\left(\mathrm{CO}_{2}\right) \ldots \ldots\end{array}$ & $\left\{\begin{array}{r}1.6 \\
.7 \\
54.32 \\
.53 \\
43.26\end{array}\right.$ & $\begin{array}{r}7.23 \\
1.64 \\
48.68 \\
1.84 \\
40.29\end{array}$ & $\begin{array}{r}1.92 \\
.36 \\
52.53 \\
.69 \\
42.03\end{array}$ & $\begin{array}{l}\text { n.d. } \\
\text { n. d. } \\
35.25 \\
8.94 \\
37.52\end{array}$ & $\begin{array}{r}\text { n. d. } \\
\text { n. d. } \\
43.22 \\
6.08 \\
40.65\end{array}$ & $\begin{array}{l}\text { n. d. } \\
\text { n. d. } \\
48.82 \\
1.48 \\
39.99\end{array}$ & $\begin{array}{r}5.53 \\
1.50 \\
50.25 \\
1.00 \\
40.49\end{array}$ & $\begin{array}{r}2.48 \\
.95 \\
53.52 \\
.46 \\
42.54\end{array}$ & $\begin{array}{r}5.56 \\
1.55 \\
50.47 \\
.83 \\
40.57\end{array}$ & $\begin{array}{r}2.57 \\
1.55 \\
52.69 \\
.84 \\
42.33\end{array}$ & $\begin{array}{r}5.66 \\
2.14 \\
50.25 \\
1.11 \\
40.70\end{array}$ \\
\hline & 12 & 13 & 14 & 15 & 16 & 17 & 18 & 19 & 20 & 21 & 22 \\
\hline 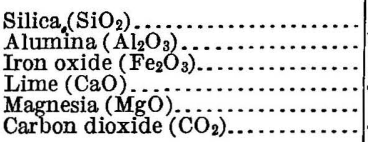 & $\begin{array}{r}5.46 \\
1.35 \\
50.80 \\
1.01 \\
41.02\end{array}$ & $\begin{array}{r}5.82 \\
1.38 \\
50.93 \\
.85 \\
40.87\end{array}$ & $\begin{array}{r}4.45 \\
.30 \\
50.06 \\
2.74 \\
42.36\end{array}$ & $\left\{\begin{array}{r}4.91 \\
.48 \\
.53 \\
51.82 \\
1.16 \\
41.90\end{array}\right.$ & $\left\{\begin{array}{r}4.31 \\
.97 \\
51.05 \\
1.65 \\
41.90\end{array}\right.$ & $\begin{array}{l}\text { 1. } 48 \\
\text { n.d. } \\
\text { n.d. } \\
53.62 \\
\text { n.d. } \\
\text { n.d. }\end{array}$ & $\begin{array}{c}\text { 4. } 12 \\
\text { n. d. } \\
\text { n.d. } \\
52.46 \\
\text { n.d. } \\
\text { n.d. }\end{array}$ & $\begin{array}{r}9.05 \\
6.66 \\
.99 \\
44.72 \\
1.98 \\
37.33\end{array}$ & $\begin{array}{r}5.12 \\
1.45 \\
.74 \\
48.34 \\
2.93 \\
41.22\end{array}$ & $\begin{array}{r}11.16 \\
3.35 \\
1.15 \\
44.27 \\
3.17 \\
38.27\end{array}$ & $\begin{array}{r}1.27 \\
.73 \\
54.51 \\
.66 \\
43.46\end{array}$ \\
\hline
\end{tabular}

1. Alvord quarry, Jamesville, Onondaga County. Bull. New York State Mus. No. 44, 1901, p. 806.

2-8. Clinton, Oneida County. A. H. Chester, analyst. Idem, p. 802.

9-14. Oriskany Falls, Oneida County. A. H. Chester, analyst. Idem, pp. 802, 803.

15. Manning quarry, Columbia, Herkimer County. Idem, p. 788.

16. Cobleskill, Schoharie County. C. F. McKenna, analyst. Twentieth Ann. Rept. U. S. Geol. Survey, pt. 6 (continued), 1899 , p. 427.

17, 18, 22. Howes Cave, Schoharie County. C. A. Schaeffer, analyst. Idem, p. 427.

19-21. South Bethlehem, Albany County. Bull. New York State Mus. No. 44, 1901, p. 771.

\section{HUDSON RIVER VALLEY.}

In the Hudson River valley the limestones of the Helderberg group attain their maximum importance, not only because of their character and composition, but because of the high-grade market to which their location makes them tributary. (See Pl. XIII.)

In this area the Helderberg forms a very thick group, which has been divided into a number of distinct formations. Before giving analyses it seems desirable to present sections showing the relations of the different formations one to another, and this is done in the following table: 
Sections of Helderberg group and Onondaga limestone and associated rocks in the Hudson River valley.

\begin{tabular}{|c|c|c|}
\hline$\cdots$ & $\begin{array}{c}\text { Ulster } \\
\text { County } \\
\text { (Darton). }\end{array}$ & $\begin{array}{l}\text { Becraft } \\
\text { Mountain, } \\
\text { Columbia } \\
\text { County } \\
\text { (Grabau). }\end{array}$ \\
\hline 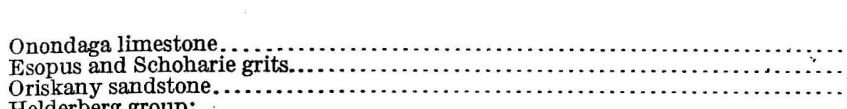 & $\begin{array}{r}\text { Feet. } \\
60 \\
200-300 \\
5-30\end{array}$ & $\begin{array}{r}\text { Feet. } \\
20-25 \\
300 \\
1-2\end{array}$ \\
\hline 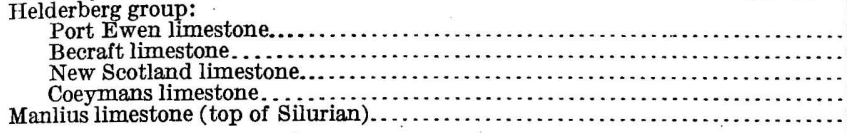 & $\begin{array}{r}30-125 \\
20-30 \\
60 \\
30-60 \\
20-40\end{array}$ & $\begin{array}{r}25 \\
40-45 \\
70-75 \\
42-45 \\
55\end{array}$ \\
\hline
\end{tabular}

Analyses of Becraft limestone (of Helderberg group) and Manlius limestone (Silurian), Hudson River valley, $N$. $Y$.

\begin{tabular}{|c|c|c|c|c|c|c|c|c|c|c|}
\hline & 1 & 2 & 3 & 4 & 5 & 6 & 7 & 8 & 9 & 10 \\
\hline 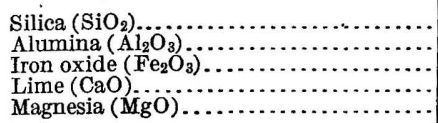 & $\begin{array}{r}1.84 \\
.63 \\
1.82 \\
51.40 \\
2.23\end{array}$ & $\begin{array}{r}1.89 \\
1.01 \\
51.55 \\
1.67\end{array}$ & $\begin{array}{l}19.3 \\
1.41 \\
53.88 \\
.29\end{array}$ & $\begin{array}{r}2.25 \\
1.15 \\
54.04 \\
.83\end{array}$ & $\begin{array}{r}3.11 \\
1.42 \\
52.82 \\
.87\end{array}$ & $\begin{array}{r}2.67 \\
1.23 \\
53.26 \\
.96\end{array}$ & $\begin{array}{l}2.75 \\
1.50 \\
1.60 \\
53.10 \\
\text { n. d. }\end{array}$ & $\begin{array}{r}4.34 \\
.54 \\
1.03 \\
52.13 \\
.19\end{array}$ & $\mid \begin{array}{r}3.59 \\
1.48 \\
52.01 \\
.82\end{array}$ & $\begin{array}{r}3.75 \\
1.56 \\
52.25 \\
.18\end{array}$ \\
\hline & 11 & 12 & 1 & 3 & 14 & 15 & 16 & 17 & 18 & 19 \\
\hline 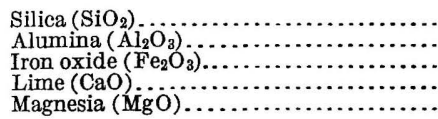 & $\left\{\begin{array}{r}2.52 \\
.98 \\
53.23 \\
.37\end{array}\right.$ & $\left\{\begin{array}{r}7.1 \\
2.5 \\
1.6 \\
45.2\end{array}\right.$ & \begin{tabular}{l|r}
10 & 3 \\
50 & 1 \\
65 & 1 \\
22 & 54 \\
r. &
\end{tabular} & $\begin{array}{l}87 \\
.07 \\
34 \\
\text { Tr. }\end{array}$ & $\begin{array}{r}4.26 \\
.26 \\
.59 \\
51.52 \\
1.03\end{array}$ & $\begin{array}{r}7.67 \\
.61 \\
.71 \\
48.78 \\
1.41\end{array}$ & $\left\{\begin{array}{r}3.52 \\
.72 \\
51.29 \\
1.15\end{array}\right.$ & $\begin{array}{r}6.47 \\
2.60 \\
48.18 \\
2.11\end{array}$ & $\begin{array}{r}4.45 \\
.75 \\
50.96 \\
\text { n. d. }\end{array}$ & $\begin{array}{r}8.85 \\
2.77 \\
47.80 \\
\text { n.d. }\end{array}$ \\
\hline
\end{tabular}

1-2. Becraft limestone. Atlas Portland Cement Co., Hudson, N. Y. Twentieth Ann. Rept. U. S. Geol. Survey, pt. 6 (continued), 1899, p. 427.

3. Becraft limestone. Knickerbocker Portland Cement Co., Hudson, N. Y. Sample by E. C. Eckel; analyzed by Lehigh Valley Testing Laboratory.

4-6. Becraft limestone. Knickerbocker Portland Cement Co., Hudson, N. Y. Sampled and analyzed by $\mathrm{H}$. E. Brown.

7. Becraft limestone. Holdredge quarry, Catskill, Greene County. H. Ries, analyst. Bull. New York

State Mus. No. 44, 1901, p. 787. Valley Testing Laboratory.

12. Becraft limestone (?). Turner quarry, Wilbur, Ulster County. H. Ries, analyst. Bull. New York State Mus. No. 44, 1901, p. 822 .

13. Becraft limestone. Rondout, Ulster County. Idem:

14-15. Manlius limestone. Near Alsen, Greene County. Sampled by E. C. Eckel; analyzed by Lehigh Valley Testing Laboratory.

16-17. Manliuslimestone. Knickerbocker Portland Cement Co., Hudson, N. Y. Idem.

18-19. Manlius limestone. Knickerbocker Portland Cement Co., Hudson, N. Y. Sampled and analyzed by H. E. Brown.

\section{TULLY LIMESTONE.}

The thinness of the Tully limestone would probably allow it to be disregarded as a Portland cement material if it were not for its advantageous distribution. It occurs only in central New York, but it occupies a greater area than any other limestone in that part of the State. Its line of outcrop, moreover, is crossed by all the Finger Lakes, on the shores of most of which it is well exposed, and by numerous railroad lines leading to the coal regions of Pennsylvania. With these advantages of position, even a relatively thin limestone bed is 
worth considering, and one Portland cement plant that uses the Tully. limestone is already in operation.

The most western known exposure of the Tully limestone is near Reed Corners, Ontario County, whence it runs southeastward through or near Gorham, Stanley, Hall Corners, and Dresden, disappearing below the waters of Seneca Lake opposite the village of Starkey. It reappears on the east shore of the lake about 5 miles south of Willard and is exposed almost continuously along the shore as far north as Willard. Here it turns eastward through Hayt Corners, then southeastward near Sheldrake to the Cayuga Lake shore east of Covert, and thence southward along the west shore through Trumansburg to Glenwood. Its most available outcrops are, however, on the east shore of Cayuga Lake, which it follows closely from Portland Point north to opposite Kings Ferry. Turning northeastward the limestone outcrop leaves the lake and passes through Poplar Ridge, Sherwood, and Scipio. From this point to its most eastern known outcrop, which is near Smyrna, Chenango County, the outcrop of the Tully limestone is too irregular for ready description. ' (See Pl. XII.) It is sufficient here to indicate its course by saying that the principal villages and stations on or near the outcrop are, in order eastward, Cascade, Locke, Moravia, Miles, Glenhaven, Scott, Spofford, Borodino, Otisco Valley, Tully, Truxton, Cuyler, Deruyter, Georgetown, and Smyrna.

The Tully limestone is low in magnesia, rarely carrying over $1 \frac{1}{2}$ per cent of magnesium carbonate. It commonly carries a rather large percentage of silica, alumina, and iron oxide, in places approximating in composition the cement rock of the Lehigh district. The analyses given below are fairly representative of its range in composition.

The limestone is immediately underlain by a series of shales which, as shown by the experience of the Portland cement plant near Ithaca, are well adapted to mixing with the limestone.

Analyses of Tully limestone, New York.

\begin{tabular}{|c|c|c|c|c|c|c|c|}
\hline e & 1 & 2 & 3 & 4 & 5 & 6 & 7 \\
\hline 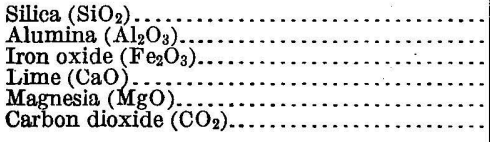 & $\begin{array}{r}9.72 \\
4.20 \\
.48 \\
47: 11 \\
.66 \\
\text { n. d. }\end{array}$ & $\begin{array}{r}6.30 \\
3.35 \\
50.25 \\
.22 \\
\text { n.d. }\end{array}$ & $\begin{array}{r}7.88 \\
4.01 \\
48.10 \\
.53 \\
\text { n. } d .\end{array}$ & $\begin{array}{c}5.7 \\
2.1 \\
49.56 \\
.67 \\
39.67\end{array}$ & $\begin{array}{r}4.0 \\
26.0 \\
33.6 \\
2.6 \\
\text { n. d. }\end{array}$ & $\begin{array}{r}15.0 \\
23.0 \\
30.0 \\
1.3 \\
\text { n.d. }\end{array}$ & $\left\{\begin{array}{r}4.50 \\
1.28 \\
1.36 \\
51.04 \\
1.11 \\
40.88\end{array}\right.$ \\
\hline
\end{tabular}

1. Top bed. Portland Point, Tompkins County. J. H. MeGuire, analyst.

2. Middle bed. Portland Point, Tompkins County. J. H. McGuire, analyst.

3. Bottom bed. Portland Point, Tompkins County. J. H. MeGuire, analyst.

4. Near Lansing, Tompkins County. H. Ries, analyst. Bull. New York State Mus. No, 44, 1901, p.820.

5. Willard, Seneca County. Trans. New York Agric. Soc. for 1850, p. 611.

6. Hayt Corners, Seneca County. Idem.

7. Dresden, Yates County. Sampled by E. C. Eckel. Analyzed by H. S. Spackman. 


\section{QUATERNARY MARLS.}

Small deposits of marl occur at many points.in eastern and northern New York, filling old lake basins and now forming swampy tracts, overlain by much impure peat. So far as known, none of the deposits in this part of the State are of workable size.

In western and central New York, however, large marl deposits have been found at many points. They are, or have been, utilized in the manufacture of Portland cement at Montezuma, Cayuga County; Jordan and Warners, Onondaga County; Caledonia, Genesee County; Wayland and Perkinsville, Steuben County; and Cassadaga Lake, Chau tauqua County. Other large deposits, as yet undeveloped, are $\mathrm{known}^{1}$ to occur northwest of Canastota, Oneida County; at Cortland, Cortland County; Clifton Springs, Ontario County; Clarendon, Orleans County; and Bergen, Genesee County.

The New York marls show, on analysis, the ordinary variations in composition. Most of those included in the table below are or have been actually used at Portland cement plants.

Analyses of Quaternary marls, New York.

\begin{tabular}{|c|c|c|c|c|c|c|c|c|c|c|c|}
\hline & 1 & 2 & 3 & 4 & 5 & 6 & 7 & 8 & 9 & 10 & 11 \\
\hline 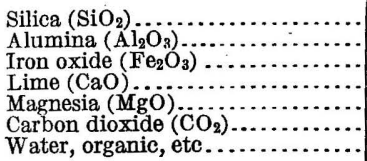 & $\begin{array}{r}0.40 \\
.20 \\
.20 \\
53.50 \\
.30 \\
\text { n. d. } \\
(a)\end{array}$ & $\left\{\begin{array}{l}1.10 \\
1.50 \\
54.54 \\
\text { Tr. } \\
\text { n.d. } \\
\cdots \cdots\end{array}\right.$ & $\begin{array}{r}0.49 \\
.35 \\
52.71 \\
\text { Tr. } \\
\text { n: d. } \\
(b)\end{array}$ & $\begin{array}{r}0.50 \\
2.00 \\
52.70 \\
1.09 \\
42.61 \\
\cdots\end{array}$ & $\left.\mid \begin{array}{r}0.42 \\
1.08 \\
52.36 \\
1.01 \\
42.26 \\
c .86\end{array}\right\}$ & $\begin{array}{r}0.54 \\
.56 \\
54.40 \\
2.34 \\
42.20\end{array}$ & $\begin{array}{r}0.14 \\
.36 \\
53.16 \\
1.50 \\
\text { n.d. }\end{array}$ & $\begin{array}{r}0.26 \\
.10 \\
52.86 \\
.18 \\
41.73 \\
4.64\end{array}$ & $\left\{\begin{array}{r}0.26 \\
.21 \\
.01 \\
50.98 \\
.19 \\
40.26 \\
7.98\end{array}\right.$ & $\begin{array}{r}6.22 \\
1.70 \\
.86 \\
47.86 \\
.04 \\
42.11 \\
(d)\end{array}$ & $\left\{\begin{array}{r}2.10 \\
1.93 \\
48.78 \\
1.10 \\
39.53\end{array}\right.$ \\
\hline
\end{tabular}

$a \mathrm{SO}_{2}, 1.7$ per cent. $\quad b \mathrm{CaSO}_{4}, 3.48$ per cent. $\quad c$ CaSO 4 , 2.01 per cent. $\quad d$ Alkalies, 2.20 per cent.

1. Iroquois Portland Cement Co., Caledonia, Livingston County.

2. 3 miles east of Mumford, Livingston County. Bull. New York State Mus. No. 44, 1901, p. 793.

3. 1 mile west of Bergen, Genesee County. J. A. Miller, analyst. Idem, p. 785.

4. Mumford, Monroe County. (Calcareous tufa.) Idem, p. 797.

5. Millen Portland Cement Co., Wayland, Steuben County.

6. Genesee Wayland Portland Cement Co., Perkinsville, Steuben County.

7. American Cement Co., Jordan, Onondaga County.

8, 9. Empire Portland Cement Co., Warners, Onondaga County.

10. Montezuma, Cayuga County. Mineral Industry, vol. 1, p. 52

11. Canastota, Madison County. Bull. New York State Mus. No. 44, 1901, p. 794.

\section{PORTLAND CEMENT INDUSTRY IN NEW YORK. .}

EARLY HISTORY.

The broad features of the development of the natural and Portland cement industry in New York have already been given in outlining the general growth of the industry throughout the country (pp. 20 23, $27,29)$. The following account gives details that could not be included in the general outline.

Portland cement manufacture in New York State started only a few years after cement making had been begun in the Lehigh district of Pennsylvania. The history of the New York industry was, however, 
entirely distinct from that of the Lehigh district. Men, materials, and methods were different, and in consequence the early history of the New York industry contains much of interest. For the data contained in a brief sketch given in the following pages the writer is indebted to Messrs. J. Gardner Sanderson and Edward Duryee, who placed at his disposal much material concerning the early plants with which they were connected.

The earliest experiments in the manufacture of Portland cement in New York appear to have been made about 1875-76 by a Mr. Dunderdale at East Kingston, Ulster County, in the Rosendale region. Messrs. Cornell and Coykendall furnished the capital. The materials used were marl, brought by Erie Canal from the Montezuma marshes, and a clay obtained near the plant. Cement of a very high grade was manufactured, but the materials and processes used were too expensive for financial success. The details of the experiments are not at present obtainable, but some idea of the methods followed and of the general high quality of the product may be gained from the following extract from the published report of Gen. Q. A. Gillmore, on the cements exhibited at the Philadelphia Exposition of 1876:

It is deemed proper as a subject of general interest to refer briefly to some cements not represented in the exhibition.

The National Portland Cement Co., of Kingston, Ulster County, N. Y., has recently been organized for making Portland cement by the fourth method above described. ${ }^{1}$ The materials employed are fuller's earth, kaolin, and lime. They are thoroughly ground and mixed together in suitable proportions by the wet process, although much less water is used than in the English works or in those at Boulogne. The mixture when completed is in a rather stiff semiliquid state. In this condition it is run out upon a floor underlaid with warming flues, where it is dried to the state of tempered brick clay. It is then passed through a brick. machine and subsequently burnt in common continuous upright kilns with anthracite coal.

Specimens of this cement have been tested several times by the writer with excellent results. On the last occasion the method adopted with the cements in the exhibition was strictly followed. One and one-half inch cubes seven days old, composed of equal parts of dry cement and sand, gave a crushing strength of 3,335 pounds per cube as an average of 20 trials, being a little higher than the best Portland cement exhibited, as shown by the table.

Next in point of date was a small plant at Low Point, Dutchess County, erected by the engineer and contractor for the first Poughkeepsie bridge. Some cement was made here and used in the tower foundations, but the failure of the bridge project also ended the cement experiments.

During the winter of 1877-78 J. Gardner Sanderson and T. T. Crane carried on a series of experiments at Croton-on-the-Hudson. A small upright kiln was used, with a Bogardus mill run by power which during the summer was used in brickmaking. These experiments

1 This "fourth method" here noted was the double-kilning process, in which the calcareous material was burned and slaked before being mixed with the clay. 
and the analysis of a large number of specimens of possible materials convinced the experimenters that the limestones of Hudson River generally contained too high a percentage of magnesium carbonate, and the clays too much free sand, to be suitable ingredients of a Portland cement. Certain strata of limestone, however, belonging to the Helderberg group and Onondaga limestone ${ }^{1}$ (see Pl. XIII), the outcrops of which extend approximately north and south a short distance west of Hudson River, crossing Rondout Creek near South Rondout, were found to be remarkably pure and free from magnesia and well adapted to their purpose. As above stated, most of the clay deposits near Hudson River carried too much sand to be of use. After careful search suitable clays were found away from the river, the best being found in an extensive deposit near Phœnicia, on the Ulster \& Delaware Railroad.

In 1880 the Wallkill Portland Cement Co. was organized. The limestone and clay properties above referred to were purchased, and an abandoned flour mill at Carthage Landing, on the Hudson, was leased and equipped with suitable machinery, a drying channel, and two upright kilns. The manufacture of Portland cement was commenced at these works early in 1881 . The product, though small in quantity, was of excellent quality and had a ready sale. Tests and reports by Clark and Maclay demonstrated the value of the cement, and the experimenters were satisfied that the manufacture could be made commercially successful on a larger scale. At both the Low Point and Carthage Landing plants gas-house coke was used for fuel.

Average analyses of the clay and limestone used are given on page 287. A typical analysis of the cement made at Carthage Landing follows:

Analysis of cement made at Carthage Landing, N.Y.

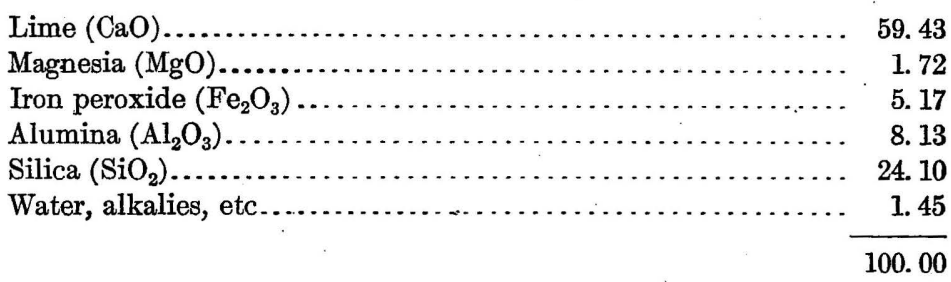

In the latter part of 1881 work was commenced on a plant on the limestone property near South Rondout, and in 1883 works with a capacity of 200 to 300 barrels a day were put in operation. These works were equipped with Blake crushers, cone grinders, buhrstone mills, mixers, and formers. Sixteen upright dome kilns were in use, with a drying channel connected and heated by the waste gases from

\footnotetext{
1 Limestone from the same horizon is now being used in the manufacture of Portland cement by two companies, the Catskill Cement Co. and Alsen's American Portland Cement Co., both of which are a short distance south of Catskill.
} 
the kilns. The limestone and clay were crushed, ground, and mixed dry, then steamed and formed into bricks, which were loaded on iron cars and run by gravity through the drying channels.

For some time after cement manufacture had been in progress at these works the gas companies of. New York and Albany had supplied the coke necessary for burning the material, but the introduction of the water-gas process cut off this source of fuel supply and left the plant dependent on Pennsylvania coke, the cost of which increased the cost of cement very largely. Mr. Sanderson therefore commenced experiments with crude Lima oil as fuel, but found that the clinkering of the cement materials in front of the burners prevented the heat from entering the charge. Knowing that this same difficulty had been met in metallurgic operations and overcome by the use of rotary furnaces, he began experimenting with a kiln which had been patented in 1881 by George Duryee, of New Jersey.

In October, 1888, a kiln 50 feet long and 50 inches in diameter was put into operation at the South Rondout works. The upper end was at first made 50 inches higher than the lower end, but later was lowered to 30 inches. This method was found to be very satisfactory, the one kiln handling all the material the mill could supply and producing a uniform and high-grade product. Of still greater importance was the fact that it was found possible to charge the mixed and ground raw material directly to the kiln without preliminary wetting, making into bricks, and drying. This was the first American plant at which this practice of direct charging was followed.

In 1889 the plant was entirely destroyed by fire, and Portland cement manufacture in the lower Hudson Valley ceased till 1900.

The following notes from the Rondout records establish some dates:

October 25, 1888.-Burned about 100 barrels to-day; oil fuel. Ground the limestone and clay separately dry, and mixed before feeding to kiln. Mixture-clay, 21 pounds; limestone, 80 pounds.

February 25, 1889.-Mixture burned-clay, 21 pounds; limestone, 100 poinds.

Analysis of resulting cement.

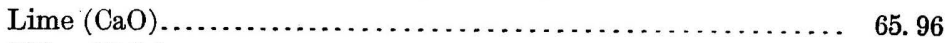

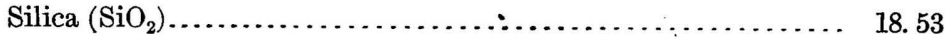

Alumina $\left(\mathrm{Al}_{2} \mathrm{O}_{3}\right)$ and oxide of iron $\left(\mathrm{Fe}_{2} \mathrm{O}_{3}\right) \ldots \ldots \ldots \ldots \ldots \ldots \ldots \ldots .11 .09$

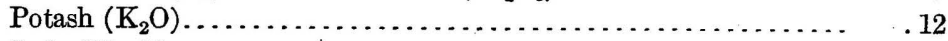

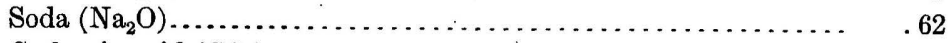

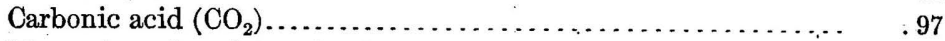

Magnesia and undetermined........................... 2.71

Physical tests of tensile strength.

100.00

7 days $=253$ pounds.

14 days $=466$ pounds.

Second tests:

7 days $=306$ pounds.

10 days $=509$ pounds. 
Representative analyses of the limestone and clay used at the Carthage Landing and South Rondout plants follow:

Analyses of limestone and clay used for cement making.

\begin{tabular}{|c|c|c|}
\hline & $\begin{array}{l}\text { Lime- } \\
\text { stone. }\end{array}$ & Clay. \\
\hline \multirow[t]{2}{*}{ 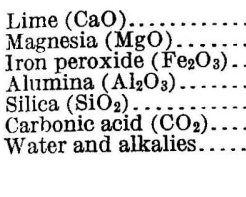 } & $\begin{array}{r}52.295 \\
.5 \\
.438 \\
.677 \\
4.405 \\
41.515 \\
.17\end{array}$ & $\begin{array}{r}1.255 \\
2.37 \\
9.144 \\
20.771 \\
54.011 \\
.4 \\
12.049\end{array}$ \\
\hline & 100.00 & 100.00 \\
\hline
\end{tabular}

In the fall of 1890 operations were commenced at Montezuma, N. Y., where the company owned 1,700 acres of land, underlain by a deposit of marl and clay from 4 to 20 feet thick. The deposit lay below the level of Cayuga River and near its shores. It was overlain by several feet of muck, which was first dredged off and used for filling and grading for a railroad. The marl and clay had a rather uniform composition, and it was found practicable to excavate both materials by a steam dredger, which brought up a ton every three minutes.

The marl, containing about 50 per cent water, was drawn by a steam hoist up an incline into the second story of the works and above the upper end of a mixing machine, into which the load was dumped without drying or other preliminary treatment. At the same time a weighed and ground portion of clay was added to standardize the mixture. The materials mixed as they gravitated toward the lower end of the machine. The entire process was practically continuous, a fresh charge being added at the upper end of the mixer every 10 minutes, while an equal amount was being drawn off from the lower end. The mixture then passed to a stone mill that completed the mixing and ground any coarse materials. From the mill the mixture was introduced directly by a screw conveyer. into the rotary kiln, oil being used as fuel. This was unique not only in its length, 75 feet, but in having opposite its lower end a gas retort or combustion chamber, heated by a coal fire, that vaporized the oil as it was sprayed into it. The air blast from a rotary fan blower also passed into this chamber.

W. A. Smith ${ }^{1}$ gives the following interesting contemporary account of this kiln:

Duryee's revolving furnace consists of a sheet-iron cylinder, 75 feet.long, inclined toward the firing end three-eighths inch to 1 foot. The lower hot end is 6 feet in diameter for a length of 20 feet, and is lined 9 inches thick with a mixture of ground fire brick and molasses. The remainder of the cylinder, 55 feet long, has a diameter 
of 5 feet, and is lined with 6 -inch fire brick. Only the lining at the hot end requires renewal, and this can be replaced in 10 hours, at a cost of $\$ 25$. The cylinder revolves on cast-iron rollers three times a minute. The power required is 5 horsepower.

At the lower end a small coal fire is kept up on a grate, but the chief fuel is crude petroleum, introduced in a jet which meets the hot-air blast. The consumption of oil is 8 gallons per barrel of cement clinker produced. Fifteen barrels of oil are required to heat the furnace ready for burning cement.

The clay and marl are mixed wet and run in as a slurry at the upper end. The mixture in drying forms a sand, which moves slowly downward with the turning of the cylinder, and is finally discharged at the lower end as cement clinker of the size of small gravel. It takes two hours to run the particles through. The operation is continuous, and the product is 250 barrels per day. It is claimed that all the mixture is burned to Portland clinker.

From a series of analyses and tests, furnished by Mr. Duryee, the following have been selected:

Analyses of materials used and resulting product at Montezuma, N. Y.

\begin{tabular}{|c|c|c|c|}
\hline & Marl. $a$ & Clay. & Cement. \\
\hline 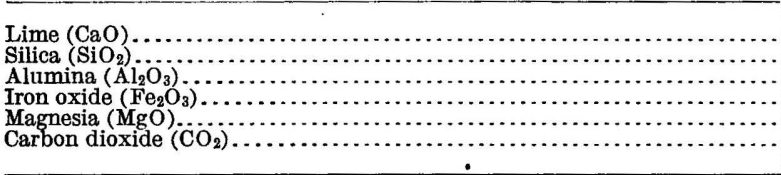 & $\begin{array}{r}47.68 \\
6.22 \\
1.70 \\
.66 \\
.52 \\
42.11\end{array}$ & $\begin{array}{r}59.22 \\
20.82 \\
3.09 \\
. . .\end{array}$ & $\left\{\begin{array}{r}62.22 \\
22.51 \\
9.17 \\
2.54 \\
1.08 \\
1.86\end{array}\right.$ \\
\hline
\end{tabular}

$a$ Calculated without moisture.

A report by W. W. Maclay, dated April 28, 1892, gives the average tensile strength obtained, as follows:

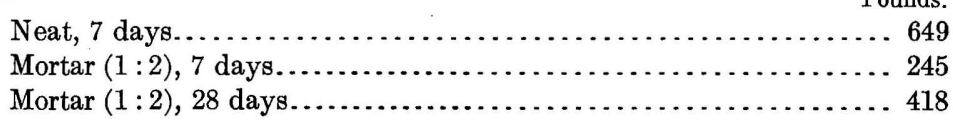

The works at Montezuma were entirely destroyed by fire in June, 1893 , and have never been rebuilt. The plant is of particular interest because of the advanced technologic methods there employed. It was the first American plant in which wet raw materials were fed, without drying or briquetting, directly into rotary kilns.

The history of the above plants, which bore a certain relationship to each other either in locality or management, overlaps in point of date the beginning of the present system of New York cement plants. The destruction by fire of the South Rondout and Montezuma plants terminated the connection of the early experimenters with New York's cement industry, and the early history of that industry may be said to end in 1893. As early as 1886 another Portland plant had been erected, but this plant was managed by an Englishman, and the problem was attacked in an entirely different manner. The earlier plants had been aggressively original and American; the plant at Warners, with its dome kilns and wet mixing, was ultra-English. Until within the last few years the typical 
New York plant has been one using marl and clay, ${ }^{1}$ mixing wet, briquetting and drying, and burning in dome kilns. The Warners Portland Cement Co. erected a rotary-kiln plant near Warners, Onondaga County, but it was in operation only a short time and has been shut down since 1894 .

\section{PRESENT CONDITION.}

Though New York took a prominent part in the early development of the Portland cement industry of the United States, it now ranks ninth as a cement producer. However, the extensive series of limestones which outcrop within its borders and its excellent local markets for cement and cement products will probably enable it to improve its rank as a Portland cement producer very materially within the next few years.

In 1911 seven Portland cement plants, with an output of 3,314,217 barrels, were in operation in New York State. Of these, one employs Trenton limestone with clay, four use limestones of the Helderberg group with clay or shale, one uses Tully limestone with shale, and two employ marl and clay. Two other plants, both using marl and clay, have been idle for several years but are described below in order to complete the record.

The plant of the Alsen American Portland Cement Co. is located at West Camp or Alsen station, near that of the Catskill Cement Co. The materials at first used by this company were the Becraft limestone of the Helderberg group and clays of Quaternary age. As elsewhere along Hudson River, considerable trouble has been experienced in using these clays for cement material, the difficulty being due in part to their low silica content and in part to the necessity for careful drying. Excellent shales, however, occur in the immediate vicinity of the plant and can be used with the limestone. The Becraft limestone is here, as in most places, fairly high in lime carbonate, ranging from 92 to 96 per cent, and is low both in clayey matter and in magnesium carbonate. Shaly limestones which also occur in the Helderberg can be combined with the Becraft limestone.

The plant of the American Cement Co., located 2 miles east of Jordan, Onondaga County, was erected in 1892. The works were operated without interruption until 1900, when they were shut down, owing to new construction by the company at Egypt, Pa.

The materials used were marl and clay, both obtained from a marsh near the works, another bed of marl being owned by the company nearer to Jordan station. The marl was white, varying in thickness from 8 to 15 feet. It was overlain by thin muck and underlain by blue clay. The muck was stripped, and the marl and clay were

1 There was, in fact, but one exception to this rule. The Glens Falls Portlend Cement Co., at Glens Falls, Warren County, has operated Schoefer kilns since 1894 on limestone and clay.

$48834^{\circ}$-Bull. $522-13-18$ 
dug and transported to the works by a wire ropeway. The clay was dried and ground separately, after which it was mixed with the marl in pug mills. The resulting slurry was spread out on a drying floor and cut into bricks. These bricks were then loaded on platform cars, dried in tunnels heated by coal fires, and fed to the kilns. Twelve kilns of the dome type were in use, coke being used as fuel.

The clinker was reduced first in Gates and Mosser crushers and finally in Griffin mills. The cement was marketed as the Giant (Jordan) brand. The following analyses of the raw materials and finished product were furnished by the company:

Analyses of cement materials and cement of American Cement Co., Jordan, N. Y.

\begin{tabular}{|c|c|c|c|}
\hline & Marl. & Slay. & Cement. \\
\hline 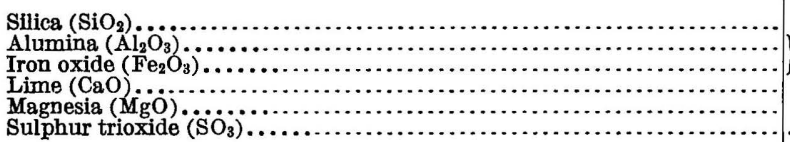 & $\begin{array}{r}0.14 \\
.36 \\
53.16 \\
1.50\end{array}$ & $\begin{array}{r}65.68 \\
24.08 \\
2.01 \\
1.75\end{array}$ & $\begin{array}{r}21.86 \\
7.17 \\
3.73 \\
61.14 \\
2.34 \\
1.94\end{array}$ \\
\hline
\end{tabular}

The Portland cement plant of the Catskill Cement Co. at Smith Landing, Greene County, was erected in 1899 and shipments were commenced in July, 1900. The materials used are clay from the river terraces and limestone of Helderberg age. A bucket cableway is used to transport the raw materials from the quarry and clay bank. The following average analyses of these materials were furnished by the company:

Analyses of limestone and clay used by Catskill Cement Co.

\begin{tabular}{|c|c|c|}
\hline . & Limestone. & Clay. \\
\hline 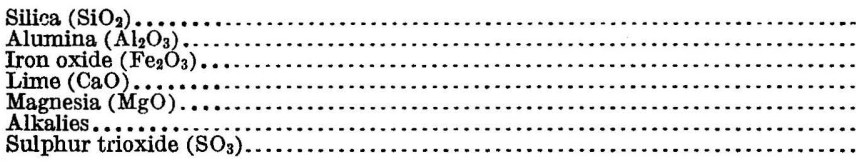 & $\begin{array}{r}1.54 \\
.39 \\
1.04 \\
53.87 \\
.52 \\
.00 \\
.00\end{array}$ & $\begin{array}{r}61.92 \\
16.58 \\
7.84 \\
2.01 \\
1.58 \\
3.64 \\
\text { Tr. }\end{array}$ \\
\hline
\end{tabular}

The cement is marketed as the Catskill brand. The following analyses of the finished product were furnished by the company, 1 and 2 having been made in its laboratory; and 3 by $\mathrm{H}$. E. Keifer:

Analyses of cement made by Catskill Cement Co.

\begin{tabular}{|c|c|c|c|}
\hline & 1 & 2 & 3 \\
\hline 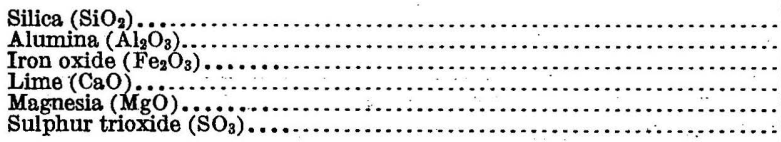 & \begin{tabular}{r|}
22.48 \\
6.52 \\
4.46 \\
62.93 \\
1.48 \\
1.30
\end{tabular} & $\begin{array}{r}21.94 \\
6.02 \\
4.38 \\
64.62 \\
1.25 \\
1.12\end{array}$ & $\begin{array}{r}23.44 \\
6.35 \\
3.99 \\
63.21 \\
1.15 \\
1.22\end{array}$ \\
\hline
\end{tabular}


The plant of the Cayuga Lake Cement Co. at Portland Point, Tompkins County, on the east shore of Cayuga Lake, uses Tully limestone and shales of the underlying Hamilton formation.

The following analyses, by J. H. McGuire, chemist of the Cayuga plant, show the composition:

Analyses of cement-making materials used by Cayuga Portland Cement Co.

\begin{tabular}{|c|c|c|c|c|c|c|}
\hline \multirow{4}{*}{$\begin{array}{l}\text { Silica }\left(\mathrm{SiO}_{2}\right) \\
\text { Alumina }\left(\mathrm{Al}_{2} \mathrm{O}_{3}\right) \\
\text { Iron oxide }\left(\mathrm{Fe}_{2} \mathrm{O}_{3}\right) \\
\text { Lime }(\mathrm{CaO}) \\
\text { Magnesia }(\mathrm{MgO}) \\
\mathrm{Mg}\end{array}$} & \multicolumn{3}{|c|}{ Limestone. } & \multicolumn{3}{|c|}{ Shale. } \\
\hline & 9.72 & 6.30 & 7.88 & 58.44 & 57.82 & $60.0 e$ \\
\hline & $\begin{array}{r}4.20 \\
.48\end{array}$ & 3.35 & 4.01 & 27.45 & 21.76 & 26.60 \\
\hline & $\begin{array}{r}47.11 \\
.66\end{array}$ & $\begin{array}{r}50.25 \\
.22\end{array}$ & $\begin{array}{r}48.10 \\
.53\end{array}$ & $\begin{array}{l}1.16 \\
2.23\end{array}$ & $\begin{array}{l}8.32 \\
1.81\end{array}$ & $\begin{array}{l}2.31 \\
1.62\end{array}$ \\
\hline
\end{tabular}

In $1886 \mathrm{~T}$. Millen \& Sons commenced the manufacture of Portland cement at Warners, Onondaga County. In 1890 the plant was purchased by the Empire Portland Cement Co., and the works were almost entirely rebuilt, a much larger output being secured by the improvements then introduced.

A few years ago the dome kilns formerly used at this plant were replaced by rotary kilns. This plant was not in operation in 1911.

The materials used are marl and clay, obtained from a. swamp in the vicinity of Warners, the present workings being located about three-fourths of a mile from the works. The marl bed covers several hundred acres, of which about 100 hundred acres had been excavated in 1905. A revolving derrick with clam-shell bucket is employed for excavating the marl, the clay being dug by hand. The materials are taken to the works over a narrow-gage railway owned by the company, on cars carrying from 3 to 5 tons each, drawn by a small locomotive. At the works the cars are hauled up an inclined track by means of a cable and drum to the mixing floor.

The swamp from which the raw materials are obtained shows sections, from top to bottom, approximately as follows:

Section in swamp at Warners, $N$. Y.

Feet.

Muck............................................ 1-2

Upper bed, white marl.................................. 4-7

Lower bed, gray to brown marl............................ 4-7

Sand ...............................................

Bluish clay........................................... 2-5

As might be expected from the relative color of the marls, the material from the lower bed shows on analysis more organic matter than that from the upper bed, for which reason more of it must be used with the same amount of clay. This distinction is accompanied by other slight but rather constant differences in chemical composition, which have also to be taken into account in preparing the cement mixture. 
Analyses 1 and 3 below are quoted by Cummings; ${ }^{1} 2$ and 4 were furnished by the Empire Co.

Analyses of cement-making materials used at Warners, N. Y.

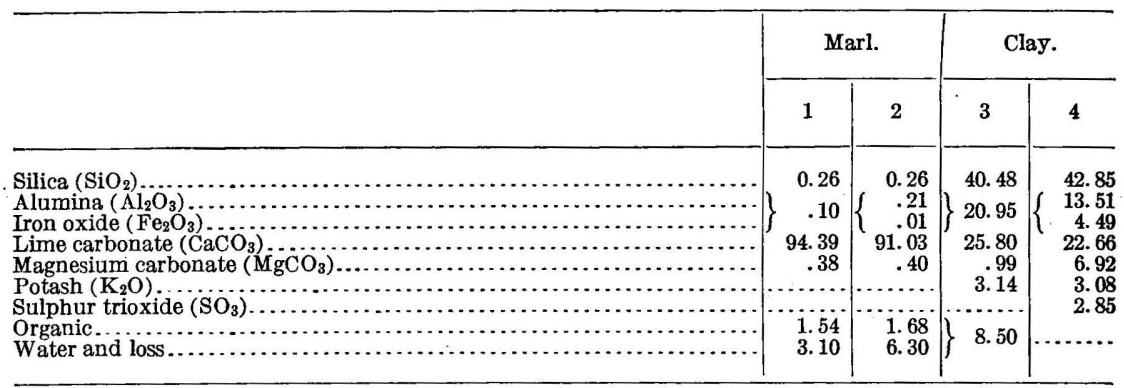

This clay runs higher in lime than any other in the State, the clay showing the nearest approach to it being that used at Wayland, which carries a little less than 20 per cent of lime carbonate.

Of the analyses of the Empire brand below, 1 is quoted by Cummings, ${ }^{2} 2$ by Lewis, ${ }^{3}$ and 3 was furnished by the company.

Analyses of cement made by Empire Cement Co., Warners, N. Y.

\begin{tabular}{|c|c|c|c|}
\hline & 1 & 2 & 3 \\
\hline $\begin{array}{l}\text { Silica }\left(\mathrm{SiO}_{2}\right) \\
\text { Alumina }\left(\mathrm{Al}_{2} \mathrm{O}_{3}\right) \\
\text { Iron oxide }\left(\mathrm{Fe}_{2} \mathrm{O}_{3}\right) \ldots \ldots \\
\mathrm{Lime}(\mathrm{CaO}) \\
\text { Magnesia }(\mathrm{MgO}) \ldots \ldots\end{array}$ & $\begin{array}{r}20.80 \\
7.39 \\
2.61 \\
64.00 \\
\cdots \\
\cdots\end{array}$ & $\begin{array}{r}22.04 \\
6.45 \\
3.41 \\
60.92 \\
3.53 \\
2.73\end{array}$ & $\begin{array}{r}21.98 \\
8.20 \\
3.70 \\
61.83 \\
1.43 \\
.84 \\
1.18\end{array}$ \\
\hline
\end{tabular}

In 1893 the Glens Falls Portland Cement Co. commenced the erection of a plant at Glens Falls, Warren County, and in 1894 put "Iron Clad" brand of cement on the market. Six shaft kilns of the Schoefer type were installed, the Glens Falls plant being the second in this country to make use of that type. Though highly economical in fuel, these kilns were rather expensive in both the quantity and quality of labor, and they have recently been replaced by rotary kilns.

The materials used are limestone and clay. The former is of Trenton age and is obtained from the Glens Falls quarries. Considerable care is required in selecting and mixing the stone from the different layers in order to obtain a suitable and uniform product. A very clean and uniform clay, overlying the limestone in this area, is the other ingredient. The composition of these materials and of the resulting cement follows:

${ }^{1}$ Cummings, Uriah, American cements, 1898, p. 253.

2 Op. cit., p. 36.

3 Mineral Industry, vol. 6, 1898, p. 99. 
Analyses of cement-making materials and cement from Glens Falls, N. Y.

\begin{tabular}{|c|c|c|c|}
\hline & $\begin{array}{l}\text { Lime- } \\
\text { stone. }\end{array}$ & Clay. & Cement. \\
\hline Silica $\left(\mathrm{SiO}_{2}\right) \ldots \ldots$ & 3.30 & 55.27 & 21.05 \\
\hline $\begin{array}{l}\text { Alumina }\left(\mathrm{A}_{2} \mathrm{O}_{3}\right) \ldots . \\
\text { Iron oxide }\left(\mathrm{Fe}_{2} \mathrm{O}_{3}\right) \text {.. }\end{array}$ & 1.30 & 28.15 & 10.50 \\
\hline Lime $(\mathrm{CaO}){ }_{\text {Magnesia }}(\mathrm{MgO}){ }_{1}$ & $\begin{array}{r}52.15 \\
1.58\end{array}$ & 5.84 & $\begin{array}{r}63.50 \\
1.80\end{array}$ \\
\hline Sulphur trioxide $\left(\mathrm{SO}_{3}\right)$ & .30 & .12 & 1.52 \\
\hline 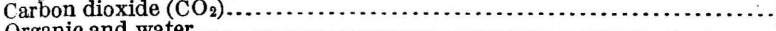 & 40.98 & …..... & (............. \\
\hline $\begin{array}{l}\left.\text { Organic and water }{ }_{\mathrm{K}} \mathrm{O} \text { and } \mathrm{Na}_{2} \mathrm{O}\right) \\
\text { Potash and soda }\left(\mathrm{K}_{2}\right.\end{array}$ & & & .40 \\
\hline
\end{tabular}

The plant of the Helderberg Cement Co. is located at Howes Cave, Schoharie County. Quarries in the Salina formation or Rondout limestone at this point have been long used for the manufacture of natural cement, while quarries higher up, both geologically and topographically, furnished a very pure limestone, which was burned into lime.

In 1898 the Helderberg Cement Co. began to utilize stone from these latter quarries in the manufacture of Portland cement. Though commenced on a small scale, the industry would seem to have prospered, for a much larger plant belonging to the same company was erected during 1900 and has been in operation continuously since that date. The materials used are limestone and clay. As noted below, the limestone used at this plant for Portland cement is obtained from the old lime quarries, and the clay is taken from a Quaternary deposit in the vicinity.

The limestone used in Portland cement manufacture is obtained from the Becraft and Manlius limestones exposed in quarries just west of the station, on the northern side of the railroad track. Partial analyses of these limestones, quoted by Prosser as having been made by C. A. Schaeffer, follow:

Analyses of limestones used at Howes Cave, N. Y.

\begin{tabular}{|c|c|c|}
\hline & $\begin{array}{c}\text { Manlius } \\
\text { limestone. }\end{array}$ & $\begin{array}{l}\text { Becraft } \\
\text { limestone. }\end{array}$ \\
\hline 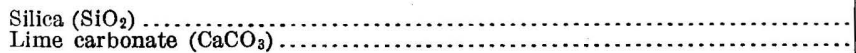 & $\begin{array}{r}1.48 \\
95.75\end{array}$ & $\begin{array}{r}4.12 \\
93.68\end{array}$ \\
\hline
\end{tabular}

Another sample analyzed by Schaeffer gave the results stated below.

Analysis of limestone used for making cement at Howes Cave, N. Y.

Silica $\left(\mathrm{SiO}_{2}\right)$

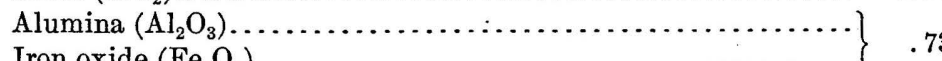

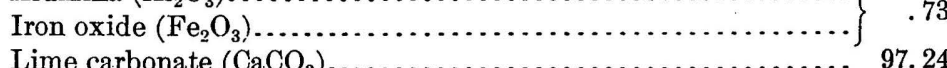

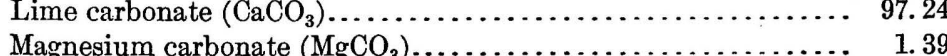

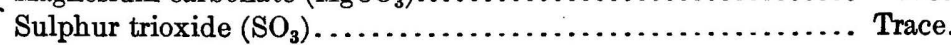


The plant of the former Hudson Portland Cement Co. was built some years ago in the city of Hudson, Columbia County, and was at that time the only cement plant in the United States east of Hudson River. Late in 1908 it was acquired by interests closely associated with the Atlas Portland Cement Co., and a new and much larger plant is being built a few miles from the site of the old one, and will be operated by the New York \& New England Cement \& Lime Co. The limestone used here is obtained near the new plant, from an outlying area of Helderberg limestone known as Becraft Mountain. Quaternary clays and shales of Ordovician age were used to complete the mixture. Other shales occur, however, as well as shaly limestone, and it is probable that in the future the cement will be made from some of these materials. Analyses by Heiberg and Roney of the clays and shales originally used at Hudson follow:

Analyses of cement-making materials used at Hudson, N. Y.

\begin{tabular}{|c|c|c|c|c|c|}
\hline & \multicolumn{2}{|c|}{ Shale. } & \multicolumn{3}{|c|}{ Clay. } \\
\hline Silica $\left(\mathrm{SiO}_{2}\right)$. & 54.70 & 64.30 & 58.90 & 52.00 & 52.10 \\
\hline Altumina $\left(\mathrm{Al}^{2} \mathrm{O}_{3}\right) \ldots$ & 31.68 & 33.60 & 27.50 & 31.00 & 35. \\
\hline $\begin{array}{l}\text { Lime (CaO) } \\
\text { Magnesia (Mgö) }\end{array}$ & $\begin{array}{l}1.15 \\
\text { n.d. }\end{array}$ & $\begin{array}{l}1.46 \\
1.30\end{array}$ & $\begin{array}{r}4.08 \\
.79\end{array}$ & $\begin{array}{l}7.10 \\
3.33\end{array}$ & $\begin{array}{l}5.90 \\
3.33\end{array}$ \\
\hline
\end{tabular}

The Marengo Portland Cement Co. formerly operated a plant near Caledonia, Livingston County. This plant was built in order to utilize a local marl deposit, the marl being mixed with clay brought from Canawangus, Genesee County. In 1909, however, limestone from near Leroy was substituted for the marl. Analyses of the marl and clay formerly used here follow:

Analyses of cement-making materials used near Caledonia, N. Y.

\begin{tabular}{|c|c|c|}
\hline & Marl. & Clay. \\
\hline $\begin{array}{l}\mathrm{Silica}\left(\mathrm{SiO}_{2}\right)_{2} \\
\text { Alumina }\left(\mathrm{Al}_{2} \mathrm{O}_{3}\right.\end{array}$ & $\begin{array}{r}0.4 \\
.2 \\
.2 \\
53.5 \\
.3 \\
1.7\end{array}$ & $\begin{array}{r}62.5 \\
20.2 \\
7.5 \\
.8 \\
1.8 \\
4\end{array}$ \\
\hline
\end{tabular}

The Empire Portland Cement Co. erected a plant at Wayland, Steuben County, which commenced producing in October, 1902, but which has now ceased operations. The materials used were marl and clay. The marl was obtained from a deposit near the mill, about 185 acres of marsh land being owned by the company. The marl bed in this marsh is about 6 feet thick. Unlike the deposits of Onondaga County, however, it is not underlain by clay, and the latter material is obtained near Mount Morris, in Livingston County, 
where it is one of a series which occur in the terraces bordering Canaseraga Creek and Genesee River, extending more or less continuously from Dansville nearly to Rochester. The clay for cement was worked at a point about 4 miles south of Mount Morris, and was shipped over the Lackawanna Railroad to the works, a distance of about 20 miles.

The following analyses of the raw materials and of the finished product are furnished by the company:

Analyses of clay, marl, and cement, Wayland, N. Y.

\begin{tabular}{|c|c|c|c|c|}
\hline & Clay. & Marl. & \multicolumn{2}{|c|}{ Cement. } \\
\hline Siliea $\left(\mathrm{SiO}_{2}\right)$ & 45.21 & 0.42 & 21.08 & 22.19 \\
\hline 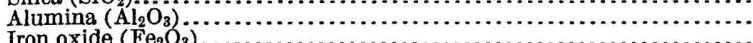 & 19.08 & 1.08 & 9.56 & 9.72 \\
\hline 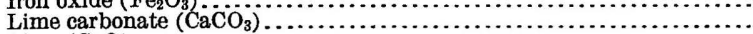 & 19. 94 & 93.5 & & \\
\hline 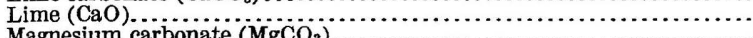 & & & 64.68 & 63.08 \\
\hline $\begin{array}{l}\text { Magnesium carbonate }\left(\mathrm{MgCO}_{3}\right) \ldots \ldots \ldots \ldots \\
\text { Magnesia }(\mathrm{MgO}) \\
\ldots\end{array}$ & 3.27 & 2.13 & 1.85 & 2.04 \\
\hline $\begin{array}{l}\text { Lime sulphate }\left(\mathrm{Ca}_{\mathrm{B}} \mathrm{SO}_{4}\right) \ldots \ldots \ldots \\
\text { Sulphur trioxide }\left(\mathrm{SO}_{3}\right) \ldots \ldots \ldots\end{array}$ & 1.55 & 2.01 & $\because 0$ & 1.75 \\
\hline Mois & $\dddot{4017}$ & .86 & 1.95 & 1.75 \\
\hline Alk & & & .9 & 1.22 \\
\hline
\end{tabular}

The analyses of the clinker were made for the company by F. E. Engelhardt, of Syracuse, N. Y.

The plant of the Wayland Portland Cement Co. was erected in 1896 in the town of Wayland, Steuben County. It uses a lightcolored marl from a deposit 2 to 14 feet thick, overlain by 6 inches to 3 feet of muck, which occurs in a marsh near the works, and a light-gray Pleistocene clay from Mount Morris, Livingston County. The marl is not underlain by clay. The following analyses of the raw materials were furnished by the company:

Analyses of marl and clay used at Wayland, N. Y.

\begin{tabular}{|c|c|c|}
\hline . & Marl. & Clay. \\
\hline 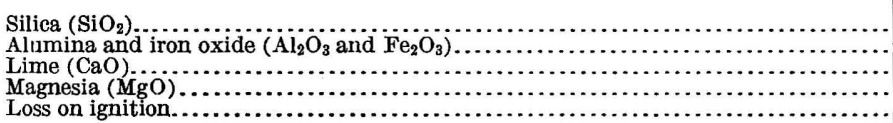 & $\begin{array}{r}0.54 \\
.56 \\
54.4 \\
2.34 \\
42.2\end{array}$ & $\begin{array}{r}53.5 \\
24.2 \\
5.15 \\
2.15 \\
14.1\end{array}$ \\
\hline
\end{tabular}

In addition to the plants above described, one other, that of the Knickerbocker Portland Cement Co., on the east side of the river near Hudson, began operation in 1911. This plant uses the Becraft and other limestones of the Helderberg group with clay or shale. 


\section{BIBLIOGRAPHY.}

The following list contains the more important papers and reports referring to the cement materials of New York State. It could be extended indefinitely, for most papers on general geology contain references of more or less importance to limestones, clays, and other cement materials, but it has been restricted to such papers as deal with important limestone areas.

Bishop, I. P., Structural and economic geology of Erie County: Fifteenth Ann. Rept.

New York State Geologist, vol. 1, 1897, pp. 305-392.

Cushing, H. P., Geology of Clinton County: Thirteenth Ann. Rept. New York State Geologist, 1894, pp. 473-490.

Darton, N. H., Geology of the Mohawk Valley: Thirteenth Ann. Rept. New York State Geologist, 1894, pp. 407-430.

- Report on the Helderberg limestones: Thirteenth Ann. Rept. New York State Geologist, 1894, pp. 197-228.

- Report on the geology of Albany County: Thirteenth Ann. Rept. New York State Geologist, 1894, pp. 229-262.

- Report on the geology of Ulster County: Thirteenth Ann. Rept. New York State Geologist, 1894, pp. 289-372.

- Preliminary description of the faulted region of Herkimer, Fulton, Montgomery, and Saratoga counties: Fourteenth Ann. Rept. New York State Geologist, 1895, pp. 30-56.

EckeL, E. C., Chapters on the cement industry in New York: Bull. New York State Mus. No. 44, 1901, pp. 849-897.

- The quarry industry in southeastern New York: Twentieth Ann. Rept. New York State Geologist, 1902, pp. 141-176.

GrabaU, A. W., Stratigraphy of Becraft Mountain, Columbia County: Bull. New York State Mus. No. 69, 1903, pp. 1030-1079.

Geology and paleontology of the Schoharie Valley: Bull. New York State Mus. No. 92, 1906, $310 \mathrm{pp}$.

Hartagee, C. A., Preliminary observations on the Cobleskill limestone of New York: Bull. New York State Mus. No. 69, 1903, pp. 1109-1175.

Lincoln, D. S., Report on the structural and economic geology of Seneca County: Fourteenth Ann. Rept. New York State Geologist, 1895, pp. 57-126.

Luther, D. D., The economic geology of Onondaga County: Forty-ninth Ann. Rept. New York State Mus., pt. 2, 1898, pp. 237-304.

Geologic map of the Buffalo quadrangle: Bull. New York State Mus. No. 99, $1906,29 \mathrm{pp}$.

Prosser, C. S., and Cumrngs, E. R., Lower Silurian formations on West Canada Creek and in the Mohawk Valley: Forty-ninth Ann. Rept. New York State Mus., pt. 2, 1898,.pp. 615-660.

RIEs, HeInRICH, Geology of Orange County: Forty-ninth Ann. Rept. New York State Mus., pt. 2, 1898, pp. 393-476.

Limestones of New York and their economic value: Seventeenth Ann. Rept. New York State Geologist, 1899, pp. 355-468.

Clays of New York: Bull. New York State Mus. No. 35, 1900, 455 pp.

Lime and cement industries of New York: Bull. New York State Mus. No. 44, 1901, pp. 640-848. 


\section{PORTLAND CEMENT RESOURCES OF NORTH CAROLINA.}

No cement plants have ever been operated in North Corolina, and the State will probably never be an important cement producer because of the conditions as to fuel and the lack of local markets. If commercial conditions should justify the erection of a cement plant, however, good raw materials are available.

\section{PORTLAND CEMENT MATERIALS.}

The limestones suitable for cement manufacture in North Carolina fall into two classes, distinct geographically as well as geologically. These are (1) the crystalline limestones of western North Carolina and (2) the soft limestones of eastern North Carolina.

\section{CRYSTALLINE LIMESTONES.}

In the extensive area of metamorphic and igneous rocks that covers the western half of North Carolina outcrops and beds of crystalline limestones, or marbles, are common. Many of these marbles are highly magnesian in composition, but the specimens used for the analyses below were low in magnesia.

Analyses of crystalline limestones, North Carolina.a

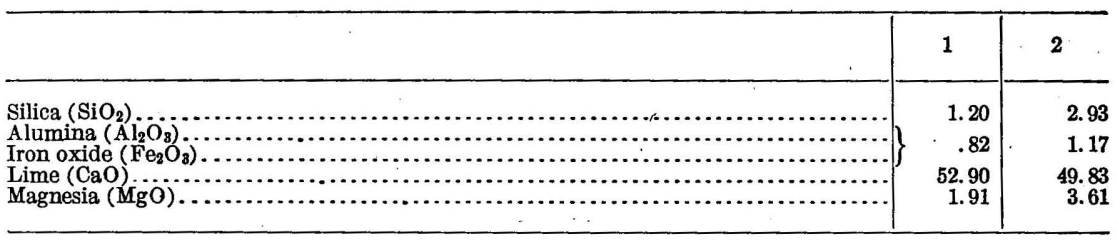

a Baskerville, analyst. Bull. North Carolina Geol. Survey No. 1, 1893, p. 233.

1. Culberson quarry, 11 miles southwest of Murphy, Cherokee County.

2. Kinsey quarry, 5 miles south west of Murphy, Cherokee County.

So far as composition goes, these are certainly satisfactory enough for use in cement manufacture, but commercial considerations would prevent the erection of a Portland cement plant in this part of the State.

SOFT LIMESTONES (SHELL MARLS).

In the eastern part of North Carolina heavy beds of soft limestone occur in the Eocene and Miocene formations of the coastal plain. These soft limestones are the "marls" of early geologic reports but should not be confused with the fresh-water marls now so largely used as cement materials. Most of the limestones of North Carolina are low in magnesia but contain considerable percentages of clayey matter or of sand. A deposit free from sand would furnish excellent material for Portland cement. Clays to complete the mixture could readily be obtained in the same formations. 
Analyses of soft limestones ("marls"), North Carolina. ${ }^{a}$

\begin{tabular}{|c|c|c|c|c|c|c|c|c|c|c|c|}
\hline & 1 & 2 & 3 & 4 & 5 & 6 & 7 & 8 & 9 & 10 & 11 \\
\hline $\begin{array}{l}\text { Silica }\left(\mathrm{SiO}_{2}\right) \mathrm{H}_{2} \ldots \ldots \ldots \\
\text { Alumina }\left(\mathrm{Al}_{2} \mathrm{O}_{3}\right) \text { and iron }\end{array}$ & 4.88 & 7.27 & 3.54 & 4.56 & 6.97 & 26.35 & 20.39 & 7.27 & 1.22 & 3.54 & 4.95 \\
\hline$\left(\mathrm{Fe}_{2} \mathrm{O}_{3}\right) \ldots \ldots$ & 1.60 & 5. 23 & .97 & 1.62 & .86 & 5.47 & 3.83 & 1.63 & 1.30 & .97 & 2.30 \\
\hline Lime $(\mathrm{CaO}) \ldots \ldots \ldots . . . . .$. & $\begin{array}{r}50.80 \\
.67\end{array}$ & $\begin{array}{r}48.55 \\
1.39\end{array}$ & $\begin{array}{l}51.74 \\
.50\end{array}$ & $\begin{array}{r}50.04 \\
1.72\end{array}$ & $\begin{array}{r}47.62 \\
1.03\end{array}$ & $\begin{array}{r}33.03 \\
.59\end{array}$ & $\begin{array}{r}39.96 \\
1.42\end{array}$ & $\begin{array}{r}48.55 \\
-1.39\end{array}$ & $\begin{array}{r}52.90 \\
1.07\end{array}$ & $\begin{array}{r}51.74 \\
.50\end{array}$ & 50. \\
\hline Alkalies $\left(\mathrm{K}_{2} \mathrm{O}, \mathrm{Na}_{2} \mathrm{O}\right)$ & 1.79 & 1.06 & 1.64 & .14 & .52 & .93 & .79 & 1.06 & .30 & 1.64 & \\
\hline Sulphur trioxide $\left(\mathrm{SO}_{3}\right)$. & .33 & .20 & .49 & .45 & .41 & .28 & .24 & .20 & .08 & .49 & \\
\hline $\begin{array}{l}\text { Carbon dioxide }\left(\mathrm{CO}_{2}\right) \ldots \ldots . \ldots \\
\text { Water and organic matter.. }\end{array}$ & $\begin{array}{r}40.60 \\
.27\end{array}$ & $\begin{array}{r}39.35 \\
.45\end{array}$ & $\begin{array}{r}40.61 \\
.16\end{array}$ & $\begin{array}{r}40.55 \\
.58\end{array}$ & $\begin{array}{r}38.15 \\
4.25\end{array}$ & $\begin{array}{r}24.89 \\
6.89\end{array}$ & $\begin{array}{r}32.46 \\
.52\end{array}$ & $\begin{array}{r}39.35 \\
.45\end{array}$ & $\begin{array}{r}42.33 \\
.46\end{array}$ & $\begin{array}{r}40.61 \\
.16\end{array}$ & $\begin{array}{r}40.29 \\
.26\end{array}$ \\
\hline 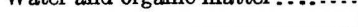 & & & & & & & & & & & \\
\hline
\end{tabular}

$a$ Analyses 1 to 6, Bogardus and Hanna, analysts; Tenth Census, vol. 6, 1884, p. 554. Analyses 7 to 11, quoted by Kerr, Rept. Geol. Survey North Carolina, vol. 1, 1893, p. 191.

1. Near Kingston, Neuse River.

2. Twenty-five miles north of Wilmington.

3. Wilmington.

4. Near Newbern

5. Lumber River, Robeson County.

6. Cape Fear River, 25 miles north of Wilmington.

7. Kenansville, Duplin County.

8, 9. Two miles above Rocky Point, New Hanover County.

10. One mile northeast of Wilmington, New Hanover County.

11. One mile west of Rocky Point, New Hanover County.

The shell marls or fragmental limestones just referred to, both in text and in table of analyses, occur in thin but fairly continuous beds along the entire coast of North Carolina but are exposed best along the larger streams. In the vicinity of Newbern, where they appear extensively along the Neuse and Trent rivers, the senior writer recently had an opportunity to examine them in some detail as a possible source of Portland cement material. Though the results of the examination were unfavorable to such utilization, they developed certain facts which are summarized for this bulletin.

The marl beds near Newbern vary from 5 to 15 feet in thickness. Except along the main streams, where they are exposed in the banks, they are commonly covered by heavy deposits of sand and sandy clay. As the marl beds were originally simply masses of shells, very loosely compacted and porous, the overlying sand has naturally sifted down into and through the marl, so that the beds as they exist now are almost everywhere full of sand grains. The extent to which the marls have been thus damaged for commercial uses is shown by the following analyses, all of which were made by A. J. Phillips at the St. Louis laboratory of the United States Geological Survey on material sampled by the writer:

Analyses of Tertiary marls from near Newbern, N. C.

\begin{tabular}{|c|c|c|c|c|c|c|c|c|c|c|c|c|c|}
\hline & 1 & 2 & 3 & 4 & 5 & 6 & 7 & 8 & 9 & 10 & 11 & 12 & 13 \\
\hline $\begin{array}{l}\mathrm{Silica}\left(\mathrm{SiO}_{2}\right) \\
\text { Alumina }\left(\mathrm{Al}_{2} \mathrm{O}_{3}\right) \\
\text { Iron oxide }\left(\mathrm{Fe}_{2} \mathrm{O}_{3}\right) \\
\text { Lime }(\mathrm{CaO}) \\
\text { Magnesia }\left(\mathrm{MgO}_{3}\right) \\
\text { Sulphur } \\
\text { Soda }\left(\mathrm{Na}_{2} \mathrm{O}\right) \\
\text { Potash }\left(\mathrm{K}_{2} \mathrm{O}\right)\end{array}$ & $\begin{array}{r}0.96 \\
.02 \\
.24 \\
52.91 \\
1.28 \\
.40 \\
.84 \\
.39\end{array}$ & $\begin{array}{r}6.80 \\
1.35 \\
.22 \\
49.62 \\
1.09 \\
.27 \\
.63 \\
.36\end{array}$ & $\begin{array}{r}9.92 \\
2.59 \\
.49 \\
46.79 \\
1.20 \\
.23 \\
.63 \\
.36\end{array}$ & \begin{tabular}{|r|}
7.98 \\
1.09 \\
.82 \\
48.01 \\
1.38 \\
.39 \\
.83 \\
.26
\end{tabular} & $\begin{array}{r}14.88 \\
1.05 \\
.21 \\
45.22 \\
1.17 \\
.21 \\
.15 \\
.24\end{array}$ & $\begin{array}{r}19.74 \\
1.17 \\
.49 \\
42.49 \\
.92 \\
.19 \\
.40 \\
.29\end{array}$ & $\begin{array}{r}23.28 \\
6.64 \\
.90 \\
35.81 \\
.93 \\
.20 \\
.92 \\
.73\end{array}$ & $\begin{array}{r}33.12 \\
1.95 \\
.31 \\
34.37 \\
1.07 \\
.20 \\
.34 \\
.36\end{array}$ & $\begin{array}{r}34.70 \\
2.98 \\
.28 \\
33.04 \\
1.09 \\
.15 \\
.32 \\
.24\end{array}$ & $\begin{array}{r}35.92 \\
1.94 \\
.58 \\
32.71 \\
1.04 \\
.20 \\
.30 \\
.49\end{array}$ & \begin{tabular}{r|}
36.98 \\
4.27 \\
1.79 \\
29.56 \\
1.21 \\
.09 \\
.40 \\
.58
\end{tabular} & $\begin{array}{r}38.82 \\
2.74 \\
1.19 \\
30.54 \\
1.04 \\
.27 \\
.28 \\
.37\end{array}$ & 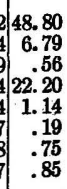 \\
\hline
\end{tabular}


These analyses show that the material can not be put to satisfactory use for either Portland cement or lime. Of the 13 samples recorded, only 1 is reasonably high grade so far as silica is concerned. As the local clays, so far as examined, were also very sandy, and as fuel in this area is by no means cheap, the problem of utilizing these marls commercially is difficult.

\section{PORTLAND CEMENT RESOURCES ÖF NORTH DAKOTA.}

Only one limestone formation of any importance-the Niobrara, of Upper Cretaceous age-is found in North Dakota, and even this is almost entirely concealed by a thick covering of drift. The Niobrara formation was recently utilized for Portland cement manufacture at Yankton, S. Dak., and it gives promise of being a future source of cement material in Nebraska and Iowa.

The physical characters and chemical composition of the Niobrara limestone are fully described on pages $257-258$. It is of peculiar valce as a Portland cement material, both because of its softness, which permits it to be easily crushed and pulverized, and because of its general freedom from magnesia and other injurious ingredients. Outcrops of the Niobrara, moreover, are commonly capped by clays of the Pierre shale, which furnish admirable materials for mixing with the chalk.

Portland cement manufacture has been attempted at only one place in North Dakota, and there the Niobrara limestone was found to be too low in lime.

\section{PORTLAND CEMENT RESOURCES OF OHIO. PORTLAND CEMENT MATERIALS.}

The geologic divisions which contain low-magnesia limestones in Ohio (see Pl. XV) are the following:

1. "Trenton" limestone (Ordovician).

2. Cincinnatian limestones and shales (Ordovician).

3. "Clinton" limestone (Silurian).

4. "Corniferous" limestone (Devonian).

5. Maxville limestone (Mississippian).

6. Pennsylvanian ("Coal Measures") limestones

7. Quaternary marls.

\section{"TRENTON" LIMESTONE.}

The "Trenton" limestone consists of shale and pure limestone, which outcrop in a narrow strip along Ohio River from the mouth of the Little Miami to a mile or two above New Richmond.

In view of the cheapness of fuel and transportation, the abundance and general excellence of material, and the ease with which it may be procured, the strips bordering Ohio River from Madison, Ind., to Maysville, Ky., seem to offer unusually promising locations for Portland cement plants. 


\section{CINCINNATIAN SHALES AND LIMESTONES.}

The Cincinnatian series in this region may be separated into three well-marked divisions: The lower division, about 250 feet thick, consists almost entirely of shale; the middle division, 200 to 250 feet thick, contains numerous layers of limestone from 3 feet to 20 feet thick; the upper division (Richmond) consists of numerous alternating beds of soft shale and limestone, generally with a heavy bed of shale at the base and top.

Analyses of Ordovician limestones, Ohio.

\begin{tabular}{|c|c|c|c|c|c|c|}
\hline & 1 & 2 & 3 & 4 & 5 & 6 \\
\hline 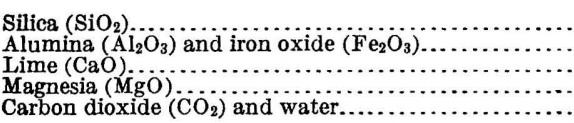 & $\begin{array}{r}23.48 \\
3.40 \\
39.93 \\
.91 \\
32.35\end{array}$ & $\begin{array}{r}10.80 \\
1.40 \\
48.50 \\
.54 \\
38.69\end{array}$ & $\begin{array}{r}7.04 \\
a .78 \\
49.28 \\
.98 \\
38.72\end{array}$ & $\begin{array}{r}12.00 \\
7.00 \\
44.41 \\
35.34\end{array}$ & $\begin{array}{r}10.10 \\
4.44 \\
46.76 \\
.72 \\
\text { n. d. }\end{array}$ & $\begin{array}{r}13.16 \\
5.90 \\
42.50 \\
1.57 \\
\text { n. d. }\end{array}$ \\
\hline
\end{tabular}

a Alumina, 2.48; iron oxide, 1.30 .

1. "Trenton" limestone, river quarries, Cincinnati. Wormley, analyst. Geol. Survey Ohio, vol. 1, pt. 1, 1873, p. 374 .

2. "Trenton" limestone, New Richmond. Idem.

3. Limestone bed in Cincinnatian series, Cincinnati. W. Simonson, analyst.

4. "Trenton" limestone, Point Pleasant. Wormley, analyst. Geol. Survey Ohio, vol. 1, pt. 1, 1873, p. 374 .

Geol. Survey No. 4, 4th ser., 1906, p. 140.

6. Limestone in Cincinnatian series, Camden, Preble County. Idem.

A long series of analyses of limestones from the Cincinnatian series, presented by Peppel in a recent report on the limestones of Ohio, shows that in few of them is the lime content high enough for use in the Portland cement industry. The selected analyses presented in the above table represent the purer beds of this group and not its normal type.

\section{"CLINTON" LIMESTONE.}

The "Clinton" limestone, exposed and quarried at many points in the southwestern quarter of Ohio, is commonly fairly low in magnesia, ranging from 80 to 95 per cent in lime carbonate and rarely going above the latter limit. Some beds are almost free from magnesium carbonate, but others carry as much as 10 per cent.

Analyses of "Clinton" limestone, Ohio.

\begin{tabular}{|c|c|c|c|c|c|c|c|c|c|}
\hline & 1 & 2 & 3 & 4 & 5 & 6 & 7 & 8 & 9 \\
\hline $\begin{array}{l}\text { Silica }\left(\mathrm{SiO}_{2}\right) \\
\text { Alumina }\left(\mathrm{Al}_{2} \mathrm{O}_{3}\right) \text { and iron oxide }\left(\mathrm{Fe}_{2} \mathrm{O}_{3}\right) . \\
\text { Lime carbonate }\left(\mathrm{CaCO}_{3}\right) \ldots \ldots \ldots \ldots \\
\text { Magnesium carbonate }\left(\mathrm{MgCO}_{3}\right) \ldots \ldots \ldots \ldots\end{array}$ & $\begin{array}{r}1.30 \\
.55 \\
90.30 \\
5.71\end{array}$ & $\begin{array}{r}2.00 \\
1.60 \\
93.00 \\
3.04\end{array}$ & $\begin{array}{r}0.07 \\
.40 \\
95.60 \\
3.93\end{array}$ & $\begin{array}{r}0.80 \\
1.20 \\
91.30 \\
6.51\end{array}$ & $\begin{array}{r}2.20 \\
2.00 \\
84.50 \\
11.16\end{array}$ & $\begin{array}{r}0.83 \\
.29 \\
96.80 \\
2.07\end{array}$ & $\begin{array}{r}0.45 \\
.26 \\
95.03 \\
4.35\end{array}$ & $\begin{array}{r}1.64 \\
.36 \\
97.09 \\
.82\end{array}$ & $\begin{array}{r}0.70 \\
.41 \\
97.14 \\
1.21\end{array}$ \\
\hline
\end{tabular}

1. Dayton, Montgomery County.

2. Adams County.

3. New Carlisle, Clark County.

4. Smith's quarry, Ludlow Falls.

5. McDonald's quarry, Xenia, Greene County.

6. New Carlisle, Clark County.

7. Piqua, Greene County.

8, 9. Osborn, Greene County.

Analyst, T. G. Wormley, Rept. Geol. Survey Ohio in 1870,1871, pp. $449-450$.

Analyst, N. W. Lord, Rept. Geol. Survey Ohio, vol. 6, 1888, pp. $728-729$. 

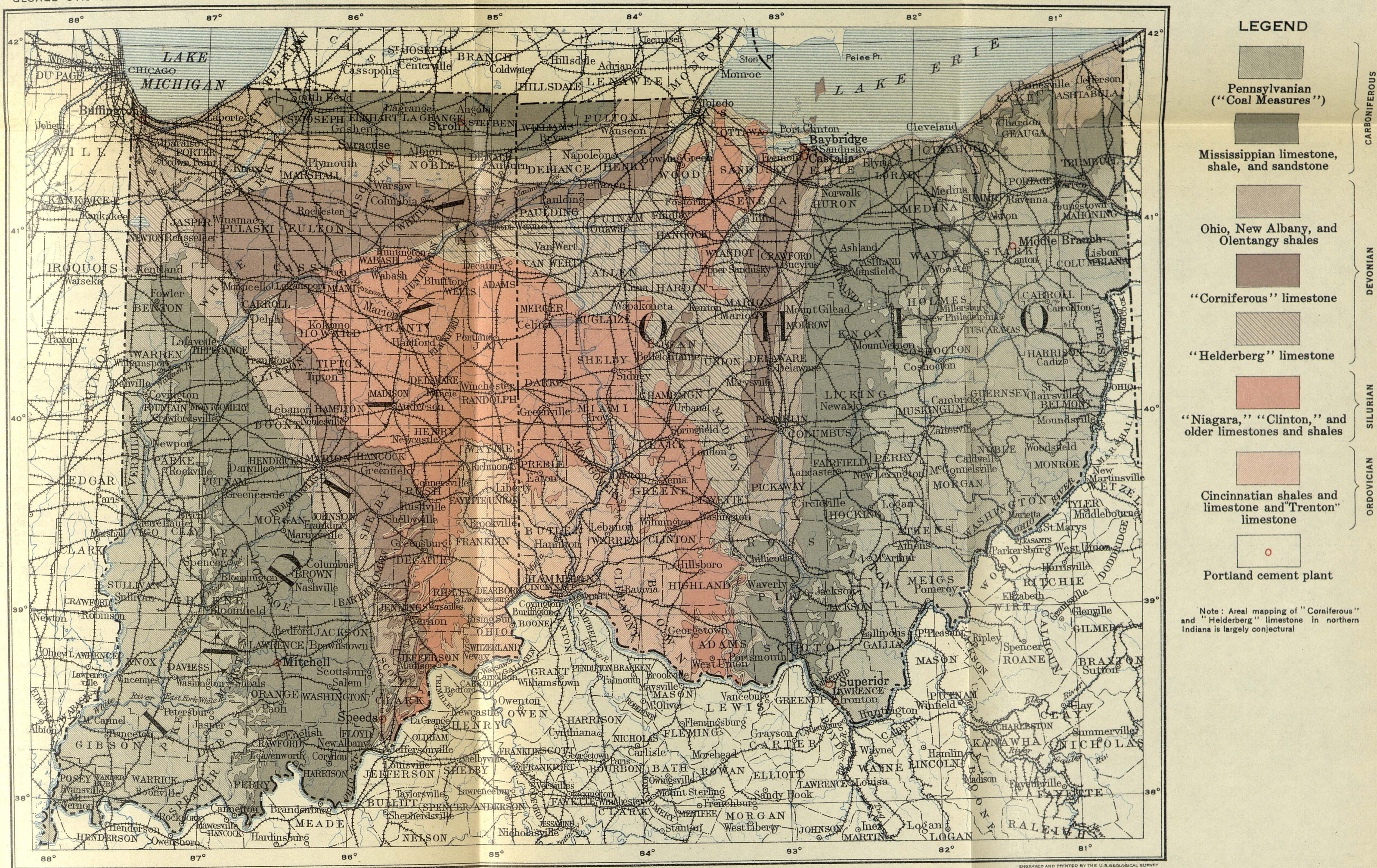

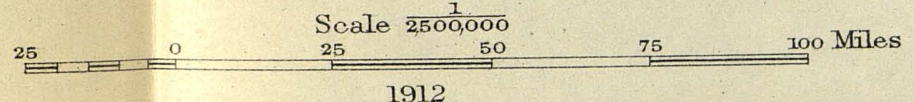





\section{"CORNIFEROUS" LIMESTONE.}

The "Corniferous" limestone, which corresponds approximately to the Onondaga limestone of New York, contains heavy beds of magnesian limestones and smaller amounts of limestones low in magnesia. The variation in this respect that may exist in a single quarry is well shown by the following analyses:

Analyses of "Corniferous" limestone from quarries in Ohio.

\begin{tabular}{|c|c|c|c|c|c|c|c|c|}
\hline . & 1 & 2 & 3 & 4 & 5 & 6 & 7 & 8 \\
\hline $\begin{array}{l}\mathrm{Silica}\left(\mathrm{SiO}_{2}\right) \\
\text { Alumina }\left(\mathrm{Al}_{2} \mathrm{O}_{3}\right) \text { and iron oxide }\left(\mathrm{Fe}_{2} \mathrm{O}_{3}\right)_{\ldots} \\
\text { Lime carbonate }(\mathrm{CaCO} \\
\text { Magnesium carbonate }(\mathrm{MgCO}\end{array}$ & $\begin{array}{r}3.20 \\
4.00 \\
88.30 \\
2.58\end{array}$ & $\begin{array}{r}4.60 \\
1.25 \\
80.40 \\
13.80\end{array}$ & $\begin{array}{r}2.92 \\
4.33 \\
84.70 \\
8.64\end{array}$ & $\begin{array}{r}1.35 \\
6.01 \\
92.00 \\
.56\end{array}$ & $\begin{array}{r}1.57 \\
3.05 \\
85.55 \\
10.39\end{array}$ & $\begin{array}{r}1.92 \\
1.85 \\
74.00 \\
21.46\end{array}$ & $\begin{array}{r}2.20 \\
1.97 \\
66.15 \\
27.97\end{array}$ & $\begin{array}{r}1.65 \\
2.65 \\
72.85 \\
22.38\end{array}$ \\
\hline & 9 & 10 & 11 & 12 & 13 & 14 & 15 & 16 \\
\hline 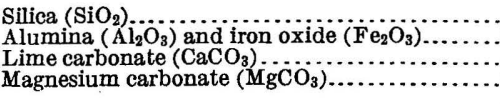 & $\begin{array}{r}0.85 \\
.27 \\
97.28 \\
2.00\end{array}$ & $\begin{array}{r}1.49 \\
.15 \\
87.10 \\
10.96\end{array}$ & $\begin{array}{r}1.05 \\
.20 \\
89.16 \\
9.48\end{array}$ & $\begin{array}{r}1.65 \\
77.14 \\
20.19\end{array}$ & $\begin{array}{r}1.00 \\
.37 \\
89.20 \\
9.64\end{array}$ & $\begin{array}{r}2.65 \\
.44 \\
77.23 \\
18.55\end{array}$ & $\begin{array}{r}1.55 \\
.18 \\
78.60 \\
19.79\end{array}$ & $\begin{array}{r}2.70 \\
3.30 \\
65.80 \\
27.95\end{array}$ \\
\hline
\end{tabular}

1-8. Different beds in a quarry at Owen station, Marion County. N. W. Lord, analyst. Geol. Survey Ohio, vol. 6,1888 , p. 769 .

9-12. Different beds in the Kelley quarries, on Kelleys Island. N. W. Lord, analyst. Idem, p. 753

13-16. Beds in the Hartshorn quarries, on the Marblehead peninsula near Sandusky. N. W. Lord and

T. G. Wormley, analysts. Idem, p. 761 .

The analyses below represent the low-magnesia beds in this formation:

Analyses of "Corniferous" limestone, Ohio.

\begin{tabular}{|c|c|c|c|c|c|c|c|c|c|c|c|}
\hline & 1 & 2 & 3 & 4 & 5 & 6 & 7 & 8 & 9 & 10 & 1i \\
\hline $\begin{array}{l}\text { Silica }\left(\mathrm{SiO}_{2}\right) \\
\text { Alumina }\left(\mathrm{Al}_{2} \mathrm{O}_{3}\right) \text { and iron oxide } \\
\left(\mathrm{Fe}_{2} \mathrm{O}_{3}\right) \ldots \ldots \\
\mathrm{Lime} \text { carbonate }(\mathrm{CaCO})_{3} \\
\text { Magnesium carbonate }(\mathrm{MgCO}\end{array}$ & $\begin{array}{r}3.20 \\
.80 \\
94.80 \\
1.21\end{array}$ & $\begin{array}{r}1.74 \\
93.21 \\
4.70\end{array}$ & $\begin{array}{r}4.90 \\
.09 \\
89.60 \\
4.41\end{array}$ & $\begin{array}{r}4.95 \\
.46 \\
90.77 \\
3.26\end{array}$ & $\begin{array}{r}5.40 \\
3.80 \\
88.40 \\
1.96\end{array}$ & $\begin{array}{r}16.06 \\
2.80 \\
72.82 \\
5.99\end{array}$ & $\begin{array}{r}25.00 \\
1.20 \\
65.80 \\
8.02\end{array}$ & $\begin{array}{r}1.41 \\
2.10 \\
93.28 \\
2.69\end{array}$ & $\begin{array}{r}3.20 \\
4.00 \\
88.30 \\
2.58\end{array}$ & $\begin{array}{r}1.35 \\
6.01 \\
92.00 \\
.56\end{array}$ & $\begin{array}{r}0.85 \\
.27 \\
97.28 \\
2.00\end{array}$ \\
\hline
\end{tabular}

1. Price quarry, Columbus, Franklin County. E. Orton, analyst. Twentieth Ann. Rept. U. S. Geol. Survey, pt. 6 (continued), 1899, p. 432.

2. Casparis quarry, Columbus, Franklin County. Chemist of Cleveland Rolling Mills, analyst. Twentieth Ann. Rept. U.S. Geol. Survey, pt. 6 (continued), 1899, p. 432.

3,4. Lilley's quarry, Columbus, Franklin County. N. W. Lord, analyst. Geol. Survey Ohio, vol. 6, 1888, p. 763.

5, 6, 7. State quarry, Columbus, Franklin County. C. C. Howard, analyst. Geol. Survey Ohio, vol. 3, 1873 , pp. 617,618 .

8. Stitt quarry, Columbus, Franklin County. C. L. Mees, analyst. Idem, p. 936.

9, 10. Owen station, Marion County. N. W. Lord, analyst. Geol. Survey Ohio, vol. 6, 1888, p. 769.

11. Kelley quarries, Kelleys Island. N. W. Lord, analyst. Idem, p. 753.

\section{MAXVILLE ("LOWER CARBONIFEROUS") LIMESTONE.}

The coal fields of Ohio are encircled by a belt of Mississippian rocks, which include a prominent limestone formation - the Maxville limestone. Most of this limestone is low in magnesia and fairly high in lime, generally ranging from 80 to 90 per cent in lime carbonate, as shown by the following analyses: 
Analyses of Maxville limestone, Ohio.

\begin{tabular}{|c|c|c|c|c|c|}
\hline & 1 & 2 & 3 & 4 & 5 \\
\hline 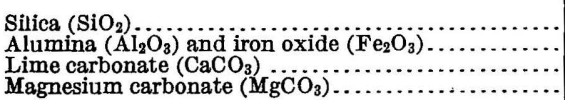 & $\begin{array}{r}3.02 \\
1.60 \\
93.08 \\
1.59\end{array}$ & $\begin{array}{r}5.91 \\
2.99 \\
89.31 \\
1.52\end{array}$ & $\begin{array}{r}9.01 \\
1.18 \\
88.71 \\
.54\end{array}$ & $\begin{array}{r}11.58 \\
2.68 \\
82.88 \\
2.23\end{array}$ & $\begin{array}{r}4.28 \\
16.09 \\
79.18 \\
1.96\end{array}$ \\
\hline
\end{tabular}

1. Glenford, Perry County.

2. Winona Furnace, Hocking County.

3, 4, 5. Webb Summit.

The analyses are taken from Rept. Geol. Survey Ohio, vol. 3, 1878, p. 934.

\section{PENNSYLVANIAN ("COAL MEASURES") LIMESTONES.}

Limestone beds occur at intervals throughout the Pennsylvanian series in Ohio as in the adjoining area of Pennsylvania. Most of these limestones are of only local importance and require no description here. One limestone, however-the Vanport ("Ferriferous") limestone member of the Allegheny formation-now furnishes cement material to four Portland cement plants in Ohio and to one just across the border in Pennsylvania. It varies in thickness from 8 to 16 feet or more. It is everywhere low in magnesia and generally carries from 80 to 90 per cent of lime carbonate. The following analyses represent its composition:

Analyses of limestone from Vanport ("Ferriferous") limestone member of Allegheny formation in Ohio.

\begin{tabular}{|c|c|c|c|c|c|c|c|c|c|c|}
\hline & 1 & 2 & 3 & 4 & 5 & 6 & 7 & 8 & 9 & 10 \\
\hline $\begin{array}{l}\text { Silica }\left(\mathrm{SiO}_{2}\right) \ldots \ldots \\
\text { Alumina }\left(\mathrm{Al}_{2} \mathrm{O}_{3}\right) \text { and iron oxide }\left(\mathrm{Fe}_{2} \mathrm{O}_{3}\right) \\
\text { Lime carbonate }(\mathrm{CaCO}) \\
\text { Magnesium carbonate }\left(\mathrm{MgCO}{ }_{3}\right)_{\ldots} \ldots \ldots \ldots\end{array}$ & $\begin{array}{r}0.60 \\
1.40 \\
97.32 \\
.45\end{array}$ & $\begin{array}{r}1.67 \\
1.36 \\
95.40 \\
1.38\end{array}$ & $\begin{array}{r}0.86 \\
\text { a1.66 } \\
96.18 \\
\text { n. d. }\end{array}$ & $\begin{array}{r}1.72 \\
b 8.22 \\
87.07 \\
\text { n. d. }\end{array}$ & $\begin{array}{c}3.24 \\
2.26 \\
93.2 \\
2.19\end{array}$ & $\begin{array}{l}2.90 \\
2.71 \\
2.02 \\
1.85\end{array}$ & $\begin{array}{r}1.00 \\
1.00 \\
94.20 \\
.76\end{array}$ & $\begin{array}{r}1.00 \\
6.80 \\
88.80 \\
1.20\end{array}$ & $\begin{array}{r}5.40 \\
2.00 \\
88.00 \\
1.51\end{array}$ & $\begin{array}{r}0.56 \\
c 1.52 \\
97.23 \\
.75\end{array}$ \\
\hline
\end{tabular}

a Alumina, 0.63 ; iron oxide, 1.03

$b$ Alumina, 1.63; iron oxide, 6.59 .

c Alumina, 1.23; iron oxide, 0.29 .

1. Eifert, Lawrence County. Twentieth Ann. Rept. U. S. Geol. Survey, pt. 6 (continued), 1899, p. 432.

2. Ironton, Lawrence County. N. W. Lord, analyst. Geol. Survey Ohio, vol. 5, 1884, p. 1109.

3, 4. Ironton, Lawrence County. C. D. Quick, analyst.

5. Lowellville, Mahoning County. N. W. Lord, analyst. Geol. Survey Ohio, vol. 5, 1884, p. 1109.

6. Holmes County. Idem.

7, 8, 9. Star Furnace, Jackson County. T. G. Wormley, analyst. Rept. Geol. Survey Ohio in 1870, 1871, p. 450 .

10. Texas Hollow. W, S. Trueblood, analyst.

\section{QUATERNARY MARLS.}

Marl deposits occur in several parts of Ohio but apparently not so oxtensively as in Indiana and Michigan. At present three plants are using marl as a Portland cement material.

\section{PORTLAND CEMENT INDUSTRY OF OHIO.}

In 1911 Ohio ranked twelfth among the States as a producer of Portland cement, its output in that year amounting to $1,451,852$ barrels. This total output was the result of the operations of five plants. Three of these, in eastern and southern Ohio, used the Vanport ("Ferriferous") limestone with shale, also of Pennsylvanian age, in their raw mixture. The other two plants, situated in central and northwestern Ohio, used a mixture of marl and clay. 
The Ohio plants using limestone are the Diamond Portland Cement Co. at Middle Branch, the Ironton Portland Cement Co. at Ironton, and the Superior Portland Cement Co. at Superior. The Alma Portland Cement Co. at Wellston, the Lehigh Portland Cement Co. at Wellston, and the York Portland Cement Co. at Portsmouth also use limestone and shale of Pennsylvanian age, but did not operate in 1910. The plants using marl and clay in 1910 were the Sandusky Portland Cement Co. at Baybridge and the Castalia Portland Cement Co. at Castalia.

Analyses of limestones and shales used in Ohio.

Limestones.

\begin{tabular}{|c|c|c|c|c|c|}
\hline & 1 & 2 & 3 & 4 & 5 \\
\hline 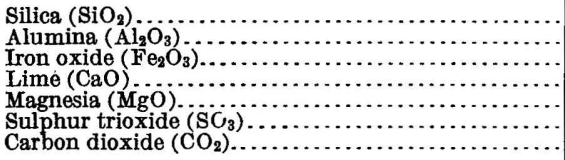 & 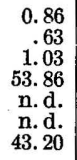 & $\begin{array}{r}3.53 \\
1.14 \\
54.45 \\
.44 \\
\text { n. d. } \\
38.74\end{array}$ & $\begin{array}{r}0.56 \\
1.23 \\
.29 \\
54.45 \\
.36 \\
\text { tr. } \\
43.17\end{array}$ & $\begin{array}{r}4.20 \\
1.61 \\
1.90 \\
50.66 \\
.73 \\
.23 \\
40.60\end{array}$ & $\begin{array}{r}1.30 \\
.73 \\
1.17 \\
53.34 \\
.75 \\
\operatorname{tr} \\
42.72\end{array}$ \\
\hline
\end{tabular}

Shales.

\begin{tabular}{|c|c|c|c|c|c|c|}
\hline & 6 & 7 & 8 & c & 10 & 11 \\
\hline 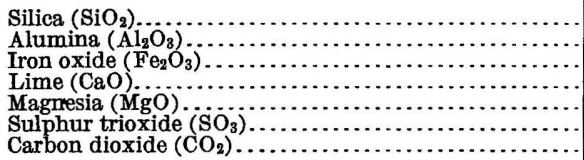 & $\begin{array}{r}60.00 \\
23.26 \\
4.32 \\
.90 \\
1.12 \\
\text { n.d. } \\
\text { n.d. }\end{array}$ & $\begin{array}{l}55.00 \\
21.79 \\
9.26 \\
\text { n.d. } \\
\text { n.d. } \\
\text { n.d. } \\
\text { n.d. }\end{array}$ & $\begin{array}{r}60.15 \\
19.78 \\
9.10 \\
.52 \\
.10 \\
\text { tr. } \\
\text { n. d. }\end{array}$ & $\begin{array}{r}62.67 \\
19.99 \\
5.46 \\
1.25 \\
.72 \\
\text { n. d. } \\
\text { n. d. }\end{array}$ & $\begin{array}{r}63.30 \\
26.00 \\
1.25 \\
1.25 \\
\text { n. d. } \\
\text { n. } d .\end{array}$ & $\begin{array}{r}69.49 \\
16.42 \\
2.29 \\
.78 \\
\text { n. d. } \\
5.43\end{array}$ \\
\hline
\end{tabular}

1, 6. Ironton Portland Cement Co. C. D. Quick, analyst.

2, 11. Alma Portland Cement Co. Twenty-first Ann. Rept. U. S. Geol. Survey, pt. 6 (continued), 1901. p. 402 .

3, 10. Lehigh Portland Cement Co. W. S. Trueblood, analyst.

4, 5, 7, 8, 9. Diamond Portland Cement Co. E. Davidson, analyst.

The plant of the Sandusky Portland Cement Co. formerly ran entirely on a mixture of marl and clay but at a later date began using limestone in part. This change was due to the impending exhaustion of its marl deposit, and it is probable that the plant can not much longer be included among the marl-using group.

Analyses of marls and clays used in Ohio.

\begin{tabular}{|c|c|c|c|c|c|}
\hline & \multicolumn{2}{|c|}{ Marls. } & \multicolumn{3}{|c|}{ Clays. } \\
\hline & 1 & 2 & 3 & 4 & 5 \\
\hline 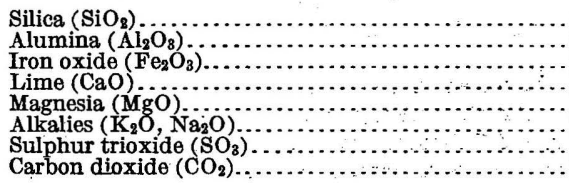 & $\begin{array}{r}1.98 \\
.97 \\
50.95 \\
.55 \\
.12 \\
.10 \\
40.03\end{array}$ & $\begin{array}{l}0.26 \\
.20 \\
52.86 \\
\text { n.d. } \\
\text { n.d. } \\
\text { n.d. } \\
\text { n.d. }\end{array}$ & $\begin{array}{r}47.45 \\
19.85 \\
17.80 \\
.09 \\
4.34 \\
1.03 \\
.57\end{array}$ & $\begin{array}{l}59.10 \\
24.01 \\
2.2 \\
2.0 \\
\text { n. d. } \\
\text { n.d. } \\
\text { n.d. }\end{array}$ & $\begin{array}{l}\text { 51. } 56 \\
14.50 \\
3.84 \\
9.8 \\
\text { n. } d . \\
\text { n.d. } \\
\text { tr. } \\
7.7\end{array}$ \\
\hline
\end{tabular}

1, 3. Buckeye Portland Cement Co. Mineral Industry, vol. 1, 1893, p. 52.

$2,4,5$. Castalia Portland Cement Co. 


\section{PORTLAND CEMENT RESOURCES OF OKLAHOMA. PORTLAND CEMENT MATERIALS. ${ }^{1}$}

Limestones of several different ages occur in Oklahoma, and most of them are probably suitable for cement materials. No complete analyses are, however, available so far as the undeveloped limestone beds of the State are concerned. (See Pl. XVI.)

\section{CAMBRIAN, ORDOVICLAN, SILURIAN, AND DEVONIAN LIMESTONES.}

A large part of the Arbuckle Mountains and of the northern foothills of the Wichita Mountains is composed of a great section of Cambrian, Ordovician, and Silurian limestones ${ }^{2}$ nearly 8,000 feet thick, containing three distinct limestone formations, separated by deposits chiefly of shale.

\section{ARBUCKLE LIMESTONE.}

The lowest limestone formation, the Arbuckle limestone, consists of limestone and dolomite of Cambrian and Ordovician age 4,000 to 6,000 feet thick. Samples from the lower part and from the top downward for 600 or 700 feet showed a very small percentage of magnesia. Beds 2,500 feet below the top contain a small amount of magnesia. Probably 2,000 feet of massive beds in the central part of the formation are dolomitic; a sample from approximately the middle of the formation yielded 29.4 per cent lime and 19.2 per cent magnesia, showing it to be nearly normal dolomite. A sample from the lower part of this dolomitic zone showed 33.1 per cent lime and 14.3 per cent magnesia.

The Arbuckle limestone outcrops over more than three-fourths of the surface of the central part of the Arbuckle Mountain district, inclosing pre-Cambrian granite and granite porphyry. Almost all the limestones of the Wichita Mountains belong to this formation, which is fine textured and generally hard.

\section{VIOLA IMESTONE.}

An Ordovician limestone, 500 to 700 feet thick, known as the Viola limestone, outcrops in a belt in the border of the Arbuckle Mountains and in small areas in the central part. It makes three small hills near Rainy Mountain Mission, in the Wichita Mountains. Chemical tests from this limestone in the Arbuckle Mountains show it to contain

\footnotetext{
1 Bull. U. S. Geol. Survey No. 243, which may be regarded as an earlier edition of the present report, contained a paper by J. A. Taff on the Portland cement resources of Indian Territory. As this paper presents the most definite knowledge yet obtainable on the subject, it is reproduced here with only a fow verbal changes.-E. C. E.

Since the above note was written a report on Portland cement materials in Oklahoma has been published by the Oklahoma Geological Survey, as noted in the bibliography on page 306.-E. F. B.

2 These limestones are described in detail in the Atoka and Tishomingo folios Nos. 79 (1902) and 98.(1903), Geol. Atlas U. S. Also in Geology of the Arbuckle and Wichita mountains: Prof. Paper U. S. Geol. Survey. No. 31, 1904.
} 


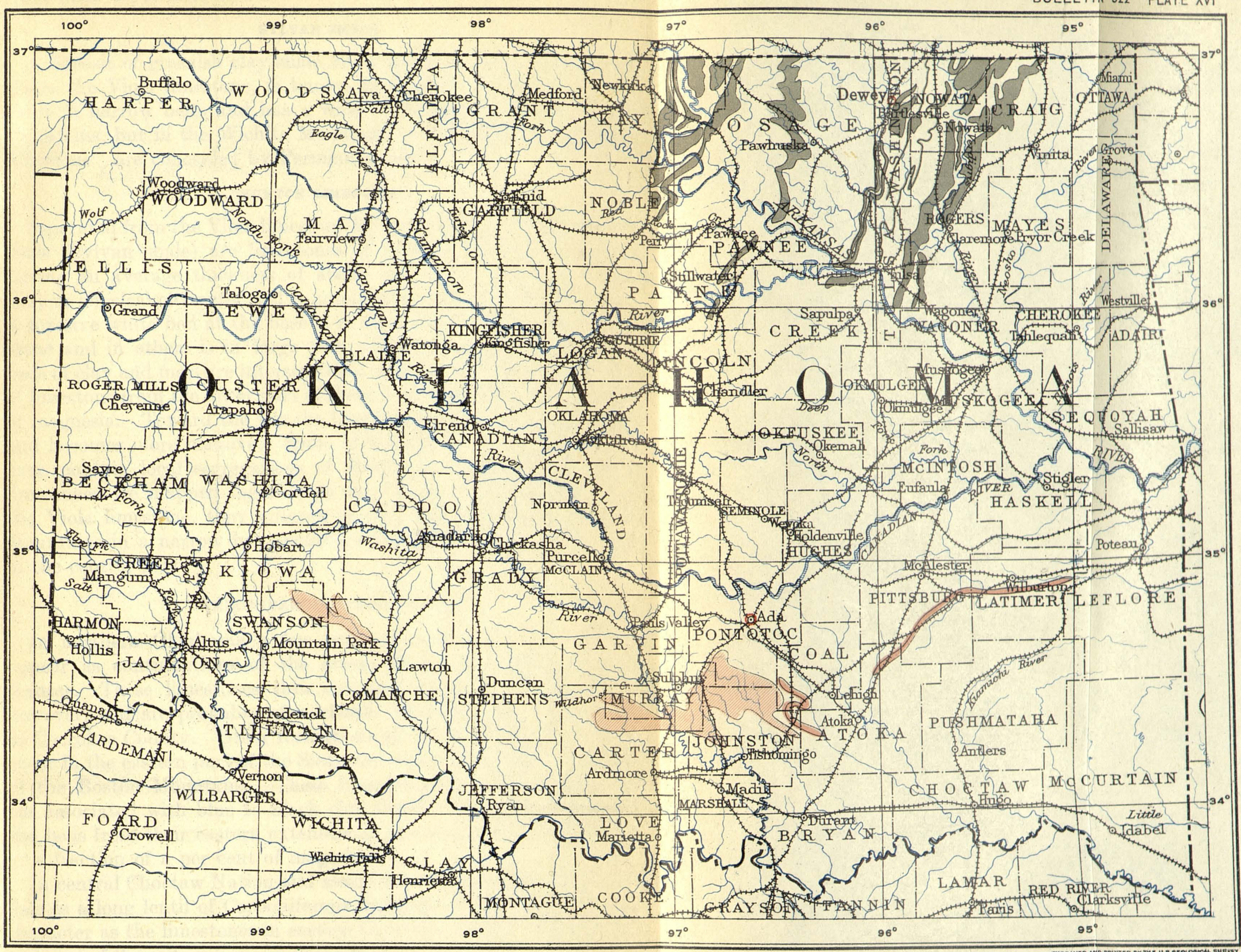

LEGEND

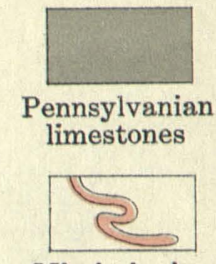

Mississippian

limestone

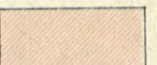

Cambrian, Ordovician and Silurian limestone

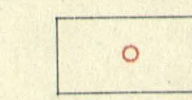

Portland cement plant

MAP OF OKLAHOMA SHOWING PRINCIPAL LIMESTONES

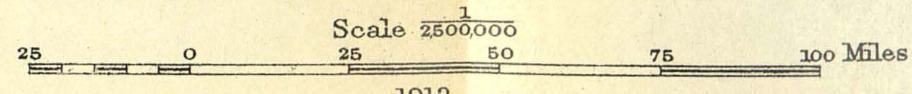



very little magnesia. It is fine textured and generally hard and contains local deposits of chert.

SYLVAN SHALE.

A deposit of greenish clay shale 50 to 300 feet in thickness, lying above the Viola limestone, is known as the Sylvan shale. It outcrops in narrow belts and has a wide distribution in the Arbuckle Mountains, but in the Wichita Mountains both it and the "Hunton limestone" are concealed by Permian deposits.

"HUNTON LIMESTONE."

Separated from the Viola limestone by about 150 to 300 feet of clay shale (Sylvan shale) are limestones of Silurian and Devonian age having an average thickness of about 200 feet. These limestones vary in physical character and in composition throughout the section. A massive white bed at the base is in some places almost pure limestone and in others is in large part silicified. In the central part beds of clay and marl are interstratified with the limestone. Samples of limestone from the lower part of these beds contain a small amount of magnesia. Toward the top the limestone is white to light yellow and becomes more massive. Some of the layers near the top, however, contain local segregations of chert. In older reports ${ }^{1}$ these limestones are mapped together as the "Hunton limestone." Like the Viola limestone, they outcrop around the borders of Arbuckle Mountains in a narrow belt, besides occurring in many small areas in the central part.

\section{CARBONIFEROUS LIMESTONES.}

In northern Oklahoma a few belts of Carboniferous limestones appear as continuations of the areas which are so important in Kansas. These limestones thin out and disappear to the south, however, and are probably of workable thickness only as far south as Cherokee County. Other formations of middle Carboniferous age occur in the eastern part of the State and extend into Arkansas north of the Boston Mountains. These limestones are thin bedded and are associated with blue to black clay shales. Analyses of some of the beds from their eastern extension in Arkansas show only a trace or a fraction of a per cent of magnesia.

In central Choctaw Nation and along the southern edge of the coal field is a long lentil of Carboniferous limestone of the same age and character as the limestones in eastern Cherokee Nation. In the central part of the exposure many of the beds are massive and the formation attains a thickness of nearly 300 feet. The eastern end of these exposures extends nearly to the Arkansas line on the north flank of 
the Ouachita Mountains, and their west end is against the Arbuckle Mountains. In physical characters this limestone is essentially the same in quality as the limestones in eastern Oklahoma and northern Arkansas.

CRETACEOUS LIMESTONES.

Cretaceous limestones occur in the southern part of the State, in several distinct formations associated with the limy clays. These limestones are mostly soft, thin bedded, and of various shades, ranging from light blue through cream to white. The lowest limestone bed is, however, massive, white, and generally homogeneous. These formations continue southward in unbroken exposures from Red River and, judged by analyses of very similar beds in Texas, are probably low in magnesia.

\section{PORTLAND CEMENT INDUSTRY IN OKIAHOMA.}

By E. F. Burchard.

The fact that the limestone formations worked so extensively for cement material in southeast Kansas are also found in Oklahoma naturally affected the development of the Portland cement industry of the latter State. Practically all Oklahoma cement manufacturers and promoters have directed their attention toward the use of Carboniferous limestones similar to those used in the Iola-Independence district of Kansas.

In 1911 Portland cement was produced by two plants in eastern Oklahoma - that of the Oklahoma Portland CementCo. at Ada and that of the Dewey Portland Cement Co. at Dewey. At the Dewey plant limestone of Pennsylvanian age is quarried $1 \frac{1}{2}$ miles east of the plant, mixed with shale from the same formation and with a small quantity of Quaternary clay. Natural gas is used both for power purposes and for burning the clinker. The Oklahoma Portland Cement Co. obtains its shale and limestone from a quarry 6 miles distant. Both materials are of Carboniferous age. Coal is used as fuel, but it is reported that it is to be supplanted by oil in the near future. A third plant is reported as being constructed at Hartshorne by the Choctaw Portland Cement Co. The rock to be utilized is of Carboniferous age, and a shale that underlies the limestone. Coal will be used as fuel.

\section{BIBIIOGRAPHY.}

Gould, C. N., and others, Preliminary report on the structural materials of Oklahoma: Bull. Oklahoma Geol. Survey No. 5, 1911, 182 pages. 


\section{PORTIAND CEMENT RESOURCES OF OREGON.}

\section{PORTLAND CEMENT MATERIALS.}

Little work has been done by the Survey on any of the nonmetalliferous mineral resources of Oregon except coal. In consequence, the data presented below on the distribution and composition of the limestones of the State are too scanty to be satisfactory. It is probable that workable limestone deposits other than those described below exist in many parts of the State. So far as known, however, the more important deposits of Oregon occur in two widely separated districts-the southwestern and the northeastern.

\section{SOUTHWESTERN OREGON.}

The limestones of southwestern Oregon are well developed at several places in Jackson and Josephine counties, where they have been used to a considerable extent for lime burning and flux. These limestones are generally of uncertain age - some are Devonian, others most likely Carboniferous, and a few certainly Cretaceous. - They occur as a series of lenses of greater or lesser size in the partly altered rocks of the district.

Several such bodies outcrop in the neighborhood of Rock Point, or Rogue River, in Jackson County, where they have been extensively exploited. A small quantity has been burned locally into lime, some has been shipped to the Portland lead smelters as flux, and a larger amount has been shipped to Portland and burned there into lime. Stone for building purposes has also been derived from this series of limestone beds.

An analysis of limestone from Rock Point, made by J. S. Phillips, follows:

$$
\text { Analysis of limestone from Rock Point, Oreg. }
$$

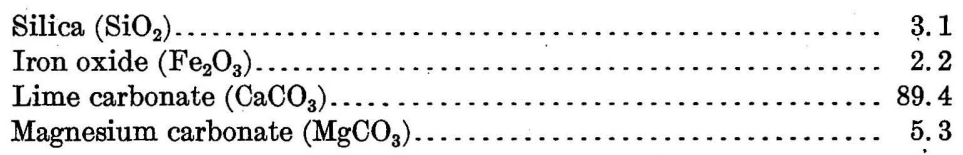

The belt of limestone lenses extends southwest from Rock Point, outcropping conspicuously on tributaries of Applegate Creek, especially Steamboat and Williams creeks, where the massive limestone contains celebrated caverns. Similar bodies occur on Sucker Creek, southeast of Waldo, near the California line. Their distribution is extremely irregular, owing to the predominance of igneous rocks. Very large deposits are said to occur near the California line, on Williams Creek, in the extreme southeastern corner of Josephine County.

\footnotetext{
1 For part of the data here given in regard to Oregon limestones the writer is indebted to Herbert Lang, The resources of the State of Oregon: State Board of Agriculture, 1892, pp. 35-37. J. S. Diller has also aided greatly by contributing data on the character and distribution of the limestones of soutbwestern Oregon.
} 
Near Roseburg, Douglas County, 4 miles from the Southern Pacific Railroad, deposits of limestone and shale have recently been investigated by private parties and the data noted below placed at the disposal of the Survey. The limestone is a dark-gray fine-grained dense rock, cut by many seams of calcite. The shale is a very hard darkgray material and is also cut by fine seams of calcite.

The raw materials are reported to be ample in quantity and of uniform composition. Coal and water power are also said to be not far distant, and the topography is favorable to the construction of a reservoir for collecting surface water from the surrounding hills. The following analyses, by W. Michaelis, jr., of the raw materials and of the clinker and ground cement are representative:

Analyses of cement materials and cement from Douglas County, Oreg.

\begin{tabular}{|c|c|c|c|c|}
\hline & $\begin{array}{l}\text { Lime- } \\
\text { st one. }\end{array}$ & Shale. & Clinker. & Cement. \\
\hline 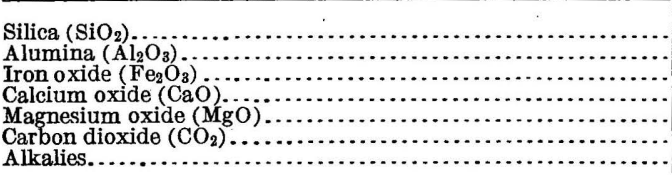 & $\begin{array}{r}2.67 \\
.55 \\
.70 \\
53.84 \\
.33 \\
41.41\end{array}$ & $\begin{array}{r}66.95 \\
14.86 \\
6.92 \\
2.43 \\
2.18 \\
4.08 \\
\end{array}$ & $\begin{array}{r}23.75 \\
5.29 \\
2.82 \\
66.66 \\
1.22 \\
.25\end{array}$ & $\begin{array}{r}23.75 \\
5.29 \\
2.82 \\
66.66 \\
1.22 \\
.25\end{array}$ \\
\hline
\end{tabular}

The composition of the limestone and shale indicates that they should be mixed in the proportions of approximately 400 pounds of the former to 100 pounds of the latter. The raw materials were ground and burned to a clinker in an experimental rotary kiln, and the clinker was ground to such a fineness that 95 per cent passed 100mesh sieve and 85 per cent passed 200-mesh sieve. The initial set began after 2 hours and set hard after 4 hours. The following tensile strengths were shown by tests made by W. Michaelis, jr.:

Tensile strength, in pounds per square inch, of trial Portland cement made from limeston and shale from near Roseburg, Oreg.

\begin{tabular}{|c|c|c|c|c|c|}
\hline \multicolumn{3}{|c|}{ Neat cement briquets. } & \multicolumn{3}{|c|}{ Briquets of 1 part cement, 3 parts sand. } \\
\hline After 24 hours. & After 7 days. & After 28 days. & After 24 hours. & After 7 days. & After 28 days. \\
\hline $\begin{array}{l}310 \\
300 \\
305 \\
295 \\
290\end{array}$ & $\begin{array}{l}650 \\
620 \\
645 \\
630 \\
635\end{array}$ & 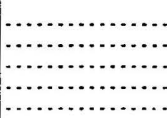 & $\begin{array}{l}115 \\
105 \\
120 \\
105 \\
125\end{array}$ & $\begin{array}{l}345 \\
365 \\
360 \\
350 \\
360\end{array}$ & 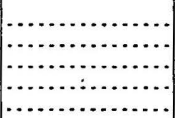 \\
\hline$a 300$ & $a 636$ & $a 810$ & $a 114$ & $a 356$ & $a 446$ \\
\hline
\end{tabular}

a Average.

An impure limestone ${ }^{1}$ having nearly the composition of a cement rock underlies a narrow area of perhaps 100 acres about a mile from

1 Newberry, S. B., Report on cement properties of Portland Cement Co., 1909, privately published. 
Marquam, Clackamas County. The rock considered to be workable ranges from 10 to 25 feet thick. The locality is about 6 miles from the Southern Pacific Railroad.

Analyses of "cement rock" near Marquam, Oreg. ${ }^{a}$

\begin{tabular}{|c|c|c|}
\hline & 1 & 2 \\
\hline 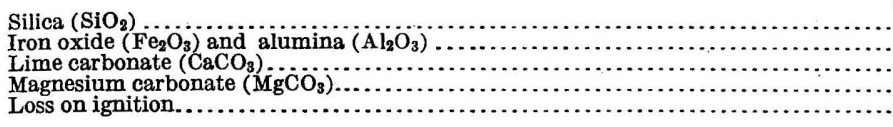 & $\begin{array}{r}46.22 \\
5.31 \\
45.60 \\
1.02 \\
1.26\end{array}$ & $\begin{array}{r}17.35 \\
6.13 \\
72.63 \\
1.27 \\
1.31\end{array}$ \\
\hline
\end{tabular}

a Analyst, R. S. Edwards, Portland, Oreg. From report on cement properties of Portland Cement Co., 1911, privately published.

1. Composite sample containing large proportion from lower strata.

2. Sample averaged from two upper strata.

Near Dallas, ${ }^{1}$ Polk County, 3.5 miles from the Southern Pacific Railroad, is a small deposit of siliceous limestone overlying basalt. The deposit is lenticular, has been drilled to depths of 20 to 80 feet, and is 1,000 to 1,500 feet wide. Chemical analysis show that it carries 15 to 33 per cent of silica, 4 to 11 per cent of iron oxide, 5 to 8 per cent of alumina, 36 to 72 per cent of carbonate of lime, and 2.25 to 9.5 per cent of carbonate of magnesia. This rock could be used for Portland-cement manufacture only by mixing it with a high-calcium stone such as that from Roseburg.

South of Rufus, ${ }^{1}$ Sherman County, on the left bank of Columbia River, 113 miles above Portland, is a deposit composed of thin limestone lenses, a foot or two thick, alternating with layers of volcanic ash. The limestone is reported to resemble travertine in physical character. A mixture of the limestone and ash would require the addition of pure limestone in order to produce Portland cement. The following analyses are of interest:

Analyses of limestone and ash from Rufus, Oreg. ${ }^{a}$

\begin{tabular}{|c|c|c|c|c|c|}
\hline & 1 & 2 & 3 & 4 & 5 \\
\hline 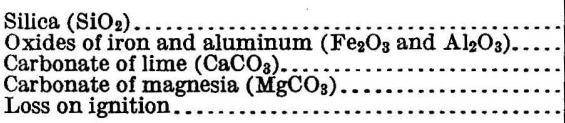 & $\begin{array}{r}17.74 \\
7.01 \\
73.93 \\
.87 \\
.42\end{array}$ & $\begin{array}{r}12.28 \\
2.44 \\
77.83 \\
8.16\end{array}$ & $\begin{array}{r}59.40 \\
16.34 \\
20.05 \\
1.81 \\
1.41\end{array}$ & $\begin{array}{r}52.84 \\
19.98 \\
18.79 \\
4.57\end{array}$ & $\begin{array}{r}31.50 \\
13.38 \\
44.24 \\
6.78 \\
-6 .\end{array}$ \\
\hline
\end{tabular}

$a$ Analyses 1 and 2 are of limestone, 3 and 4 are of volcanic ash, and 5 is of average of limestone and volcanic ash. Analyst of 1 and 3, R. S. Edwards; of 2, 4, and 5, R. K. Meade.

\section{NORTHEASTERN OREGON.}

Of the limestone deposits of northeastern Oregon the largest and most accessible seems to be on Burnt River, about 3 miles above Huntington, Baker County. The limestone beds at this point are 
associated with shales, and the entire series is upturned to give a steep dip. The river has cut through the beds, exposing a thickness of about $\mathbf{1 0 0}$ feet of limestone. This stone is remarkably pure, carrying generally less than 1 per cent of silica, alumina, and iron oxide. Its quality, quantity, and proximity to the railroad and to a series of shale beds make it worth considering as a possible source of Portland cement material.

The same series of beds outcrop in the hills to the southwest and northeast and continue into Idaho, where they form important deposits. Large limekilns are now in operation at several points on the line of outcrop.

Limestone deposits of considerable size occur in other parts of Baker County, the most important at present being extensively worked for lime about 14 miles from Baker City. Other deposits occur in Grant County, and very thick and extensive beds of blue limestone are said to cover much of Union County. In Wallowa County deposits of marbles occur, which may be of service for cement.

\section{PORTLAND CEMENT INDUSTRY IN OREGON.}

By E. F. Burchard.

Although no Portland cement plant is yet in operation in Oregon, the prospects seem good for the establishment of this industry in the near future. Early in 1912 it was reported that construction work on a plant at Oswego, near Portland, was in progress. This plant may use limestone from the vicinity of Roseburg and cement rock from near Marquam, or siliceous limestone from near Dallas, or possibly limestone and volcanic ash from $\mathrm{R}$ ufus with limestone from Roseburg.

PORTLAND CEMENT RESOURCES OF PENNSYLVANIA. PORTLAND CEMENT MATERIALS.

State at Large.

Several limestones suitable for use as Portland cement materials occur in Pennsylvania, but only one group has as yet been extensively used. For description these limestones may be conveniently grouped as:

1. Ordovician limestones (Shenandoah group).

2. Lewistown limestone (Helderberg and Cayuga); Silurian and Devonian.

3. Carboniferous limestones.

\section{ORDOVICIAN LIMESTONES.}

The Ordovician limestones, which furnish the well-known "cement rock" of the Lehigh district, occur in varying development in the counties of Northampton, Lehigh, Berks, Lebanon, Dauphin, Cumberland, Franklin, Lancaster, Center, and Blair and to a much less extent in several other counties of -southeastern Pennsylvania. (See Pl. XVII.) They belong to the Shenandoah group. Through- 
U. S. GEOLOGICAL SURVEY
EORGE OTIS SMITH, DIRECTOR

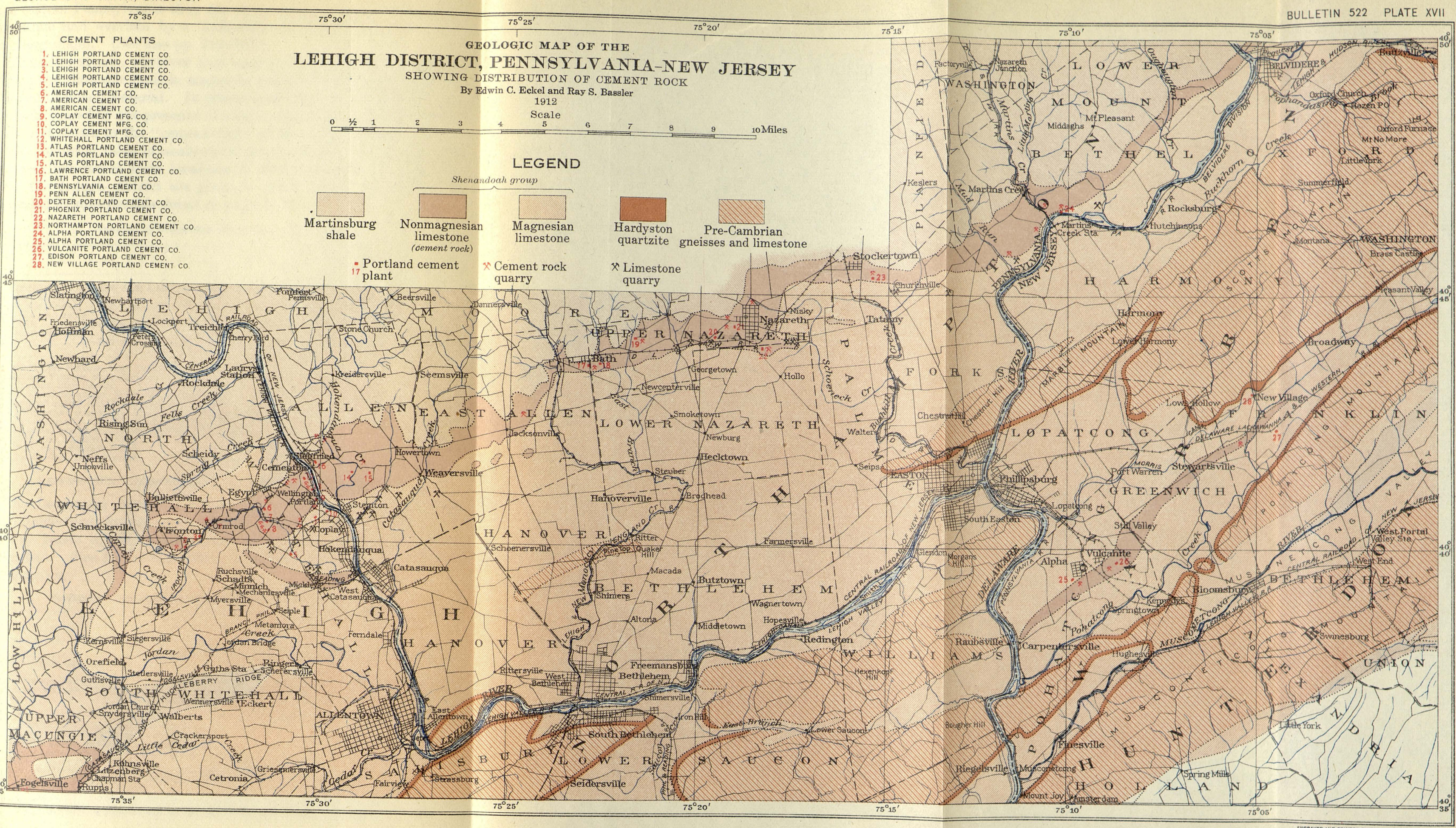



out eastern Pennsylvania they are underlain by a highly magnesian limestone and overlain by a thick series of shales and slates (Martinsburg shale). (See also pp. 314-317.)

These limestones, wherever they may occur, are almost invariably within the allowable limit in magnesia and are therefore an excellent Portland cement material. In places their value as a cement material is increased by the presence of a high percentage of clayey matter, as is well shown in the "cement rock" of the Lehigh district.

The following table of analyses shows the composition of samples of these limestones from localities in Pennsylvania. ${ }^{1}$ No analyses from the Lehigh district are given in this table as this district is discussed in considerable detail on pages 314-317.

Analyses of Ordovician limestones, Pennsylvania.

\begin{tabular}{|c|c|c|c|c|c|c|c|c|c|c|c|c|c|c|c|}
\hline & 1 & 2 & 3 & 4 & 5 & 6 & 7 & 8 & 9 & 10 & 11 & 12 & 13 & 14 & 15 \\
\hline $\begin{array}{l}\text { Silica }\left(\mathrm{SiO}_{2}\right) \\
\text { Alumina }\left(\mathrm{Al}_{2} \mathrm{O}_{3}\right) \text { and } \\
\text { iron oxide }\left(\mathrm{Fe}_{2} \mathrm{O}_{3}\right) \ldots \\
\text { Lime c a r b o n a te }\end{array}$ & $\begin{array}{r}0.91 \\
.26\end{array}$ & $\begin{array}{r}4.38 \\
.64\end{array}$ & $\begin{array}{l}5.88 \\
1.68\end{array}$ & $\begin{array}{r}3.62 \\
.19\end{array}$ & $\begin{array}{r}0.54 \\
.20\end{array}$ & $\begin{array}{r}0.39 \\
.32\end{array}$ & $\begin{array}{r}0.82 \\
.38\end{array}$ & $\begin{array}{r}0.76 \\
.43\end{array}$ & $\begin{array}{l}4.30 \\
.36\end{array}$ & $\begin{array}{r}2.51 \\
.60\end{array}$ & $\begin{array}{l}2.55 \\
\text { n.d. }\end{array}$ & $\begin{array}{r}8.41 \\
.57\end{array}$ & $\begin{array}{r}8.84 \\
.81\end{array}$ & $\begin{array}{r}0.98 \\
.26\end{array}$ & $\begin{array}{r}2.66 \\
.26\end{array}$ \\
\hline $\begin{array}{r}\left.(\mathrm{CaCO})_{3}\right) \ldots \ldots \ldots \ldots \\
\left.\mathrm{MgCO}_{8}\right) \ldots \ldots \ldots \ldots\end{array}$ & 3.87 & 2.88 & 2.25 & $\begin{array}{r}92.12 \\
4.23\end{array}$ & 1.29 & 1.17 & $\left|\begin{array}{l}97.53 \\
1.21\end{array}\right|$ & $\begin{array}{r}97.65 \\
1.13\end{array}$ & $\begin{array}{r}86.13 \\
8.86\end{array}$ & $\begin{array}{l}90.63 \\
6.17\end{array}$ & 4.54 & $\because .24$ & .96 & 1.29 & $\begin{array}{r}95.07 \\
1.04\end{array}$ \\
\hline
\end{tabular}

1. Mount Etna Furnace, Blair County.

2. Rodman Furnace, Blair County.

3, 4. Tyrone, Blair County.

5, 6, 7. Shortlidge quarry, Bellefonte, Center County.

8. Campbell quarry, near' Bellefonte, Center County.

9,10 . Rutheriord quarry, near Harrisburg, Dauphin County.

11. Cumbler quarry, near Harrisburg, Dauphin County.

12. Craighead quarry, Mount Holly, Cumberland County.

13. Mont Alto, Franklin County.

14. Williamson, Franklin County.

15. Rauchs Gap, Clinton County.

\section{LEWISTOWN LIMESTONE (HELDERBERG AND CAYUGA).}

The Lewistown limestone outcrops in central Pennsylvania and the Helderberg limestone in eastern Pennsylvania in a series of narrow bands whose distribution is too complicated to be readily described. (See Pl. XIX, p. 350.) The following analyses ${ }^{1}$ show its composition:

Analyses of Lewistown and Helderberg limestones, Pennsylvania.

\begin{tabular}{|c|c|c|c|c|c|c|c|c|c|c|c|c|c|}
\hline & 1 & 2 & 3 & 4 & 5 & 6 & 7 & 8 & 9 & 10 & 11 & 12 & 13 \\
\hline 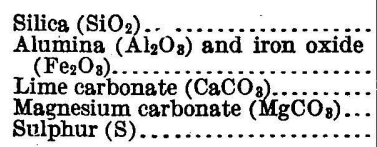 & $\begin{array}{r}2.50 \\
.84 \\
95.66 \\
1.55 \\
.10\end{array}$ & $\begin{array}{r}3.00 \\
.64 \\
95.09 \\
1.58 \\
.03\end{array}$ & $\begin{array}{r}3.02 \\
.57 \\
95.57 \\
1.52 \\
.03\end{array}$ & $\begin{array}{r}1.80 \\
.80 \\
95.25 \\
2.27 \\
.05\end{array}$ & $\begin{array}{r}1.62 \\
.65 \\
96.16 \\
1.59 \\
.07\end{array}$ & $\begin{array}{r}10.85 \\
.58 \\
84.78 \\
3.86 \\
.05\end{array}$ & $\begin{array}{r}96.14 \\
1.60 \\
.05\end{array}$ & $\begin{array}{r}5.70 \\
1.77 \\
90.90 \\
2.16 \\
.08\end{array}$ & $\begin{array}{r}2.33 \\
.70 \\
94.03 \\
1.97 \\
.06\end{array}$ & $\begin{array}{r}5.04 \\
1.14 \\
91.12 \\
1.57 \\
.03\end{array}$ & $\mid \begin{array}{r}5.30 \\
1.78 \\
89.29 \\
2.56 \\
.06\end{array}$ & $\begin{array}{r}49.03 \\
1.67 \\
77.30 \\
2.01 \\
.15\end{array}$ & $\begin{array}{r}21.68 \\
4.66 \\
70.59 \\
1.74 \\
.03\end{array}$ \\
\hline
\end{tabular}

1, 2, 3. Baker quarry, Altoona, Blair County.

4. Creswell quarry, Hollidaysburg, Blair County.

5. Manning quarry, Hollidaysburg, Blair County.

6. Loop quarry, Hollidaysburg, Blair County.

7. Sarah Furnace, Blair County.

$8,9,10$. Hudson quarry, Three Springs, Huntingdon County.

11, 12. McCarthy quarry, Saltillo, Huntingdon County.

13. Jersey Shore, Lycoming County.

1A. S. McCreath, analyst: Repts. M1, M2, M3, Second Geol. Survey Pennsylvania, 1874-1880. 
Analyses of Lewistown and Helderberg limestones, Pennsylvania-Continued.

\begin{tabular}{|c|c|c|c|c|c|c|c|c|c|c|c|c|c|}
\hline & 14 & 15 & 16 & 17 & 18 & 19 & 20 & 21 & 22 & 23 & 24 & 25 & 26 \\
\hline $\begin{array}{l}\text { Silica }\left(\mathrm{SiO}_{2}\right) \ldots \ldots \ldots \\
\text { Alumina }\left(\mathrm{Al}_{2} \mathrm{O}_{8}\right) \text { and iron oxide } \\
\left.\text { (Fe } \mathrm{F}_{2} \mathrm{O}_{3}\right) \ldots \ldots \ldots \\
\text { Lime carbonate }\left(\mathrm{CaCO}{ }_{3}\right) \\
\text { Magnesium carbonate }\left(\mathrm{MgCO}_{3}\right) \ldots \\
\text { Sulphur }(\mathrm{S}) \ldots \ldots\end{array}$ & $\begin{array}{r}15.72 \\
2.55 \\
71.73 \\
7.62 \\
\text { n.d. }\end{array}$ & $\begin{array}{l}6.53 \\
1.21 \\
89.64 \\
1.82 \\
\text { n. d. }\end{array}$ & $\begin{array}{r}2.85 \\
.70 \\
94.28 \\
1.53 \\
.06\end{array}$ & $\begin{array}{r}7.86 \\
2.11 \\
87.93 \\
1.94 \\
.23\end{array}$ & $\begin{array}{r}11.93 \\
1.36 \\
82.73 \\
2.83 \\
.70\end{array}$ & $\begin{array}{r}4.25 \\
.84 \\
93.27 \\
1.38 \\
.11\end{array}$ & $\begin{array}{r}3.92 \\
.68 \\
93.87 \\
1.31 \\
.15\end{array}$ & \begin{tabular}{|r|}
7.65 \\
.71 \\
88.82 \\
2.34 \\
.21
\end{tabular} & $\begin{array}{r}3.02 \\
.54 \\
94.28 \\
2.12 \\
.21 \\
\end{array}$ & $\begin{array}{r}4.26 \\
1.10 \\
2.20 \\
2.17 \\
.15\end{array}$ & $\begin{array}{r}20.24 \\
2.97 \\
73.43 \\
2.65 \\
\text { n. } d .\end{array}$ & $\begin{array}{r}3.61 \\
1.11 \\
90.18 \\
4.31 \\
. .25\end{array}$ & $\begin{array}{r}5.94 \\
1.26 \\
89.39 \\
3.25 \\
.27\end{array}$ \\
\hline
\end{tabular}

14, 15. Still quarry, 2 miles northeast of Montebello Narrows, Perry County.

16-17. Bossardville, Hamilton Township, Monroe County.

18-21. Van Auken quarry, Middle Smithfield Township, Monroe County.

22-23. Brown quarry, Smithfield Township, Monroe County.

45. Experiment Mills quarry, near Delaware Water Gap, Monroe County.

22-26. Poxono Island, Monroe County.

A deposit of limestone near Kings Rock, on Susquehanna River, in Lycoming County, belonging to this series is described by Uriah Cummings, ${ }^{1}$ who states that a natural cement of the following composition had been made from this rock:

Analysis of natural cement, Kings Rock, $P a$.

Silica $\left(\mathrm{SiO}_{2}\right)$ 28. 14

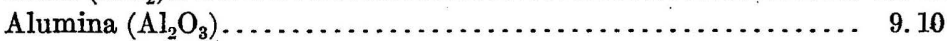

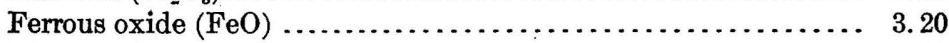

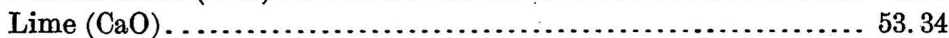

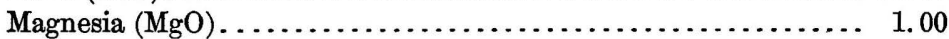

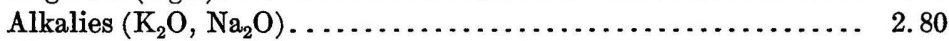

Water and loss ....................................... 2.42

Such an analysis of a natural cement would imply that the rock from which it was made was closely similar in composition to the cement rock of the Lehigh district and that the addition of 10 per cent or so of pure limestone would give a good Portland cement.

\section{CARBONIFEROUS LIMESTONES.}

Names and stratigraphic positions of Carboniferous limestones, Pennsylvania.

\begin{tabular}{|c|c|c|c|}
\hline Geologic formation or group. & Name of member. & $\begin{array}{l}\text { Thick- } \\
\text { ness. }\end{array}$ & Stratigraphic position. \\
\hline $\begin{array}{l}\text { Washington formation (of } \\
\text { Dunkard group). }\end{array}$ & \}Upper Washington limestone. & $\begin{array}{r}\text { Feet. } \\
30\end{array}$ & $\begin{array}{l}\text { At top of Washington formation, } \\
250 \text { to } 425 \text { feet above the } \\
\text { Waynesburg coal. }\end{array}$ \\
\hline Monongahela formation.. & 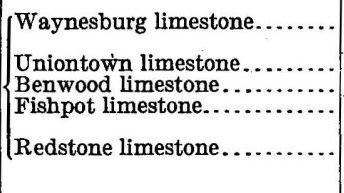 & $\begin{array}{l}73 \\
30 \\
10\end{array}$ & $\begin{array}{l}20 \text { feet below the Waynesburg } \\
\text { coal. } \\
120 \text { feet above the Pittsburgh coal. } \\
100 \text { feet or more above the Pitts- } \\
\text { burgh coal. } \\
60 \text { to } 100 \text { feet above the Pitts- } \\
\text { burgh coal. }\end{array}$ \\
\hline Conemaugh formation. & 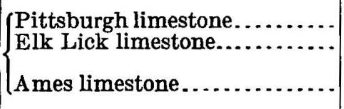 & $\begin{array}{r}12 \\
6 \\
8\end{array}$ & $\begin{array}{l}20 \text { feet below the Pittsburgh coal. } \\
\text { Between Elk Lick coal and Ames } \\
\text { limestone. }\end{array}$ \\
\hline
\end{tabular}

1 Seventeenth Ann. Rept. U. S. Geol. Survey, pt. 3 (continued), pp. 889-890. 
Names and stratigraphic positions of Carboniferous limestones, Pennsylvania-Contd.

\begin{tabular}{|c|c|c|c|}
\hline Geologic formation or group. & Name of member. & $\begin{array}{l}\text { Thick- } \\
\text { ness. }\end{array}$ & Stratigraphic position. \\
\hline Allegheny formation... & $\left\{\begin{array}{l}\text { Upper Freeport limestone...... } \\
\text { Lower Freeport limestone..... } \\
\text { Johnstown limestone........... } \\
\text { Vanport limestone............. }\end{array}\right.$ & $\begin{array}{r}\text { Feet. } \\
28 \\
5 \\
10 \\
20\end{array}$ & $\begin{array}{l}\text { Below Upper Freeport coal. } \\
\text { Below the Lower Freeport coal. } \\
\text { Below the Upper Kittanning } \\
\text { coal. the Lower Kittanning } \\
\text { Below the } \\
\text { coal. }\end{array}$ \\
\hline Pottsville formation. & $\left\{\begin{array}{l}\text { Upper Mercer limestone........ } \\
\text { Lower Mercer limestone...... }\end{array}\right.$ & $\begin{array}{l}4 \\
3\end{array}$ & \\
\hline Mauch Chunk formation.... & Greenbrier limestone........... & 30 & \\
\hline Pocono formation. & $\left\{\begin{array}{l}\text { Loyalhanna limestone } \\
\text { Benezette limestone (in Ëlk } \\
\text { County). }\end{array}\right.$ & $\begin{array}{r}60 \\
7\end{array}$ & $\begin{array}{l}200 \text { feet beneath Olean conglom- } \\
\text { erate member. Relations to } \\
\text { Loyalhanna limestone not de- } \\
\text { termined. }\end{array}$ \\
\hline
\end{tabular}

The following table ${ }^{1}$ of analyses shows the composition of the Carboniferous limestones:

Analyses of Vanport limestone member of Allegheny formation, Pennsylvania.

\begin{tabular}{|c|c|c|c|c|c|c|c|c|c|c|c|c|c|c|c|}
\hline & 1 & 2 & 3 & 4 & 5 & 6 & 7 & 8 & 9 & 10 & 11 & 12 & 13 & 14 & 15 \\
\hline 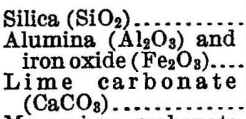 & $\begin{array}{l}2.03 \\
1.29 \\
\end{array}$ & $\begin{array}{c}0.79 \\
1.46 \\
96.01\end{array}$ & $\begin{array}{r}2.30 \\
1.38 \\
94.72\end{array}$ & $\begin{array}{r}2.11 \\
.93 \\
95.57\end{array}$ & $\begin{array}{r}2.10 \\
2.09 \\
94.18\end{array} \mid$ & $\begin{array}{l}3.42 \\
1.67 \\
93.25\end{array}$ & $\begin{array}{r}3.22 \\
1.71 \\
93.29\end{array}$ & $\begin{array}{c}2.19 \\
1.31 \\
95.23\end{array}$ & $\begin{array}{l}1.96 \\
1.05 \\
\end{array}$ & $\begin{array}{r}1.78 \\
1.53 \\
95.20\end{array}$ & $\begin{array}{r}1.11 \\
.87 \\
96.43\end{array}$ & $\begin{array}{r}1.91 \\
1.31 \\
94.39\end{array}$ & $\begin{array}{r}2.04 \\
1.31 \\
93.64\end{array}$ & $\begin{array}{r}1.30 \\
.99 \\
96.43\end{array}$ & $\begin{array}{r}1.28 \\
.78 \\
96.58\end{array}$ \\
\hline $\begin{array}{r}\text { Magnesium carbonate } \\
\left(\mathrm{MgCO}_{3}\right) \ldots \ldots \ldots \ldots \ldots . . . . . . .\end{array}$ & 0.91 & 1.50 & 1.04 & 1.42 & 1.48 & 1.74 & .97 & .41 & .93 & 1.27 & 1.20 & 1.70 & 1.82 & .91 & .83 \\
\hline & 16 & 17 & 18 & 19 & 20 & 21 & 22 & 23 & 24 & 25 & 26 & 27 . & 28 & 29 & 30 \\
\hline $\begin{array}{l}\text { Ailica }\left(\mathrm{SiO}_{2}\right) \\
\text { Alumina }\left(\mathrm{Al}_{2} \mathrm{O}_{3}\right) \text { and } \\
\text { iron oxide }\left(\mathrm{Fe}_{2} \mathrm{O}_{3}\right) \ldots \\
\text { Lime carb on ate }\end{array}$ & $\begin{array}{l}2.39 \\
2.20\end{array}$ & $\begin{array}{l}7.37 \\
2.61\end{array}$ & $\begin{array}{l}3.37 \\
1.71\end{array}$ & $\begin{array}{l}1.63 \\
1.64\end{array}$ & $\begin{array}{l}2.20 \\
1.63\end{array}$ & $\begin{array}{r}2.79 \\
.80\end{array}$ & $\begin{array}{r}1.97 \\
.63\end{array}$ & $\begin{array}{l}3.07 \\
1.56\end{array}$ & $\begin{array}{l}2.08 \\
1.19\end{array}$ & $\begin{array}{l}2.09 \\
2.03\end{array}$ & $\begin{array}{l}0.37 \\
1.00\end{array}$ & $\begin{array}{l}2.77 \\
1.82\end{array}$ & $\begin{array}{l}7.03 \\
2.32\end{array}$ & $\begin{array}{l}4.78 \\
1.29\end{array}$ & $\begin{array}{l}4.80 \\
1.59\end{array}$ \\
\hline $\begin{array}{c}\left(\mathrm{CaCO}_{8}\right) \\
\text { Magnesium carbonate } \\
\left(\mathrm{MgCO}_{3}\right) \\
\ldots\end{array}$ & 6.66 & 1.78 & \begin{tabular}{l|l}
3.81 \\
\end{tabular} & 1.63 & 1.37 & 1.73 & 1.10 & 1.46 & 1.37 & 1.59 & 1.28 & 1.54 & 1.44 & 1.57 & 1.59 \\
\hline
\end{tabular}

1, 2. Stewardson Furnace, Madison Township, Armstrong County.

3. Colwell quarry, near Mahoning Furnace, Armstrong County.

4. Reynolds quarry, near Kittarining; Armstrong County.

5. George quarry, near South Bend, Armstrong County.

6. Rhea quarry, near Greendale, Armstrong County.

7. Graff quarry, near Buffalo Mills, Armstrong County.

8. Long Run, Porter Township, Clarion County.

9. Hindman quarry, Clarion Township, Clarion County.

10. Sligo Furnace, Piney Township, Clarion County.

11. Barger quarry, Perry Township, Clarion County.

12. Bovaird quarry, near Brockwayville, Jefferson County.

13. Hanna quarry, near Sprankles Mills, Jefferson County.

14. Enty quarry, near Worthville, Jefferson County.

15. Shields quarry, near Dowling ville, Jefferson County.

16. Winslow property, near Benezette, Elk County.

17. Toby Creek, Fox Township, Elk County.

18. Brandy Camp post office, Horton Township, Elk County.

19, 20. Kane quarry, near Wilcox, Jones Township, Elk County:

21. Shinn quarry, Wampum, Lawrence County.

22. McCord quarry, Mount Jackson, Lawrence County.

23. Johnson quarry, Newcastle, Lawrence County.

24. Moffit quarry, Croton, Lawrence County.

25. Simpson quarry, Richmond, Indiana County.

26. Pine Creek Furnace quarry, Kittanning, Armstrong County.

27. Severn quarry, near Vanport, Beaver County.

28, 29. Powers quarry, near Vanport, Beaver County.

30. Tygart's quarry, near Vanport, Beaver County.

1 A. S. McCreath, analyst: Repts. M, M2, M3, Second Geol. Survey Pennsylvania, 1874-1880. 


\section{Lehigh District.}

The following description of the cement-rock deposits and cement industry in the Lehigh district is based largely upon field work by the writer during the early summer of 1903. Acknowledgments are due to the managers and chemists of cement plants in the Lehigh district, who have aided the writer greatly in this work. Use has also been made of the report by H. B. Kümmel ${ }^{1}$ on the Portland cement industry in New Jersey and the report by T. N. Dale ${ }^{2}$ on the geology of the Slatington quadrangle.

\section{LOCATION AND AREA.}

The "Lehigh district" of the engineer and cement manufacturer has been so greatly extended in recent years that the name is now hardly applicable. Originally it included merely one small area about 4 miles square, located along Lehigh River, partly in Lehigh County and partly in Northampton County, containing the villages of Egypt, Coplay, Northampton, Whitehall, and Siegfried. The cement plants which were located here at an early date secured control of most of the cement-rock deposits in the vicinity, and plants of later establishment have therefore been forced to locate farther and farther away from the original center of the district. At present the district includes parts of Berks, Lehigh, and Northampton counties, Pa., and Warren County, N. J., reaching from near Reading, Pa., at the southwest, to a few miles north of Stewartsville, N. J., at the northeast. It forms, therefore, an oblong area about 25 miles long from southwest to northeast and about 4 miles wide. Within this area 23 Portland cement plants are now in operation, and the Portland cement produced in this relatively small district amounts to about one-third the entire United States output.

\section{GEOLOGY.}

Within the "Lehigh district," as above defined, three geologic divisions occur, all of which must be considered in attempting to account for the distribution of the cement materials used there. These divisions named in descending order, are (1) Martinsburg shale; (2) Ordovician limestones, Shenandoah group, the cement rock of the district; (3) magnesian limestone of Ordovician and Cambrian age. As all these rocks dip, in general, northwestward, the Martinsburg shale occupies the northwestern portion of the district, and the cement rock and magnesian limestone outcrop in succession farther southeast.

\section{MAGNESIAN LIMESTONES.}

Underneath the cement rock lies a very thick series of light-gray to light-blue massive-bedded limestones, containing numerous beds of chert. These limestones are predominantly highly magnesian,

1 Ann. Rept. New Jersey State Geologist for 1900, 1901, pp. 9-101.

2 Slate deposits and slate industry of the United States: Bull. U. S. Geol. Survey No. 275, 1906, pp. 75-85. 
though some beds of pure nonmagnesian limestone are found in the series. The magnesian beds are, of course, valueless for Portland cement manufacture, but the pure limestone beds furnish part of the limestone used in the Lehigh district for addition to the cement rock. An excellent example of this is furnished by the quarry near the east bank of Lehigh River, just above Catasauqua. In this quarry most of the beds are highly magnesian and are therefore useful only for road metal and flux, but a few pure limestone beds occur, and the material from these low-magnesia beds is shipped to a neighboring cement mill.

Numerous analyses of the highly magnesian limestones are available, and a few typical ones have been selected for insertion here. For analyses of the purer limestone used to add to the cement rock, see page 318 .

Analyses of magnesian limestones from the Lehigh district.

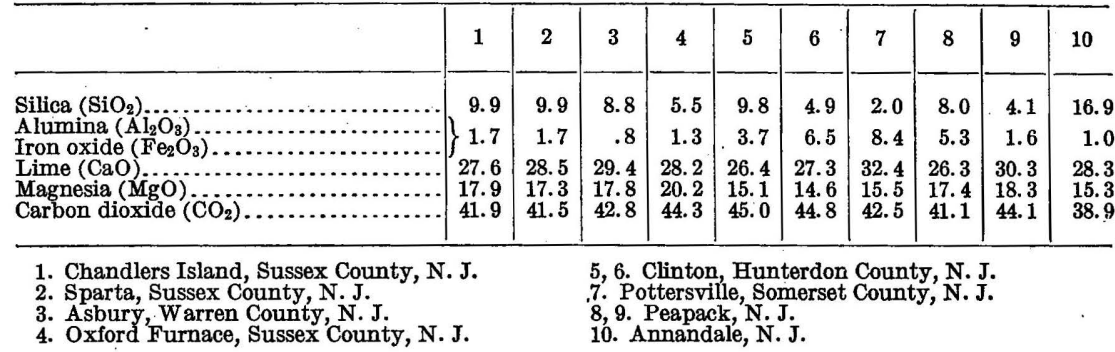

All the above analyses are from New Jersey localities, but analyses of magnesian limestones of the rest of the Lehigh district give closely similar results.

\section{ORDOVICIAN LIMESTONES.}

The Ordovician cement rocks are more or less argillaceous limestones. They vary in thickness from 150 feet in New Jersey to 250 feet or even more at Nazareth and on Lehigh River. The upper beds, near the contact with the overlying Martinsburg shale, are very shaly or slaty black limestones, carrying approximately 50 to 60 per cent of lime carbonate and 40 to 50 per cent of silica, alumina, iron, and so forth. Lower down the percentage of lime steadily increases, and that of clay decreases correspondingly, until near the base of the limestones the rock may carry from 85 to 95 per cent of lime carbonate and only 5 to 15 per cent of impurities. This change in chemical composition is accompanied by a change in the appearance and physical character of the rock, which loses its slaty fracture and blackish color as it gains in lime, until near the base of the series it is in many places a fairly massively bedded dark-gray limestone. Even so, it can generally be readily distinguished from the underlying magnesian limestone described below, for it is everywhere darker, and it nowhere contains the chert beds that are so common in the magnesian rock. 
The cement rock is nowhere nearly so high in magnesia as is the underlying limestone. It does, however, carry considerable magnesia (as compared with other Portland cement materials) throughout its thickness, few analyses showing less than 4 to 6 per cent. The following analyses ${ }^{1}$ are fairly representative of the lower, middle, and upper beds of the series. The specimens from the upper beds, near the Martinsburg shale, show considerably less lime and more clayey matter than those from the lower parts.

Analyses of Ordovician limestones (cement rock) from the Lehigh district.

\begin{tabular}{|c|c|c|c|c|c|c|c|c|c|c|}
\hline . & 1 & 2 & 3 & 4 & 5 & 6 & 7 & 8 & 9 & 10 \\
\hline $\begin{array}{l}\text { Silica }\left(\mathrm{SiO}_{2}\right) \\
\text { Alumina }\left(\mathrm{Al}_{2} \mathrm{O}_{3}\right) \\
\text { Iron oxide }\left(\mathrm{Fe}_{2} \mathrm{O}_{3}\right) \\
\text { Lime }(\mathrm{CaO}) \\
\text { Magnesia }(\mathrm{MgO}) \\
\text { Marbon dioxide }\left(\mathrm{CO}_{2}\right)\end{array}$ & $\begin{array}{r}1.86 \\
.60 \\
.51 \\
53.64 \\
.81 \\
43.03\end{array}$ & \begin{tabular}{|r|}
5.03 \\
2.06 \\
1.23 \\
49.73 \\
1.02 \\
40.19
\end{tabular} & $\begin{array}{r}8.38 \\
4.03 \\
1.32 \\
45.45 \\
1.34 \\
37.18\end{array}$ & $\begin{array}{r}11.90 \\
4.42 \\
1.70 \\
44.18 \\
1.18 \\
36.01\end{array}$ & $\begin{array}{r}11.71 \\
4.36 \\
1.62 \\
43.47 \\
1.82 \\
36.15\end{array}$ & $\begin{array}{r}11.11 \\
4.40 \\
1.91 \\
42.51 \\
2.89 \\
36.57\end{array}$ & $\begin{array}{r}17.04 \\
6.90 \\
2.13 \\
37.53 \\
2.17 \\
32.88\end{array}$ & $\begin{array}{r}22.71 \\
5.84 \\
2.13 \\
36.50 \\
1.69 \\
30.52\end{array}$ & $\begin{array}{r}19.53 \\
6.03 \\
1.70 \\
35.71 \\
3.33 \\
32.73\end{array}$ & $\begin{array}{r}24.45 \\
5.68 \\
1.57 \\
35.00 \\
2.21 \\
29.89\end{array}$ \\
\hline
\end{tabular}

The specimens whose analyses are given above were mostly from the vicinity of Belvidere, N. J., and though representative in other respects seem to have been rather lower in magnesia than the run of the limestone in the Lehigh district.

\section{MARTINSBURG SHAIE.}

The Martinsburg formation includes very thick beds of dark-gray to black shales, with local thin beds of sandstone. In certain localities, as near Slatington and Bangor, Pa., and Newton, N. J., these shales have been so altered by pressure as to become slates, the quarrying of which now supports a large roofing-slate industry.

The geographic distribution of these shales and slates in the Lehigh district can be indicated only approximately without the presentation of a geologic map of the area. They may be said to cover practically all of Northampton, Lehigh, and Berks counties north of a line passing through Martins Creek, Nazareth, Bath, Whitehall, Ironton, Guthsville, Monterey, Kutztown, Molltown, and Leesport.

The composition of the typical shales and slates of the upper part of the formation is well shown by the following analyses:

Analyses of shales and slates in upper part of Martinsburg shale in the Lehigh district.

\begin{tabular}{|c|c|c|c|c|}
\hline & 1 & 2 & 3 & 4 \\
\hline 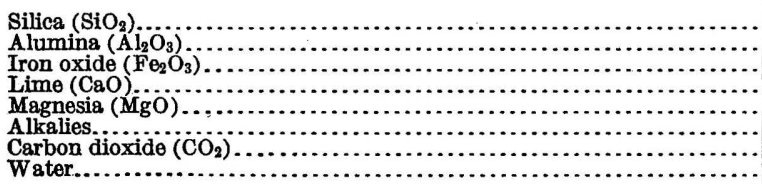 & $\begin{array}{r}68.62 \\
12.68 \\
4.20 \\
1.31 \\
1.79 \\
3.73 \\
3.00 \\
4.47\end{array}$ & $\begin{array}{r}68.00 \\
14.40 \\
5.40 \\
2.68 \\
1.51 \\
.11 \\
2.30 \\
2.70\end{array}$ & $\begin{array}{r}56.60 \\
21.00 \\
5.65 \\
3.42 \\
2.30 \\
.50 \\
2.20 \\
3.00\end{array}$ & $\begin{array}{r}\text { a } 76.22 \\
13.05 \\
2.67 \\
.93 \\
\text { n.d. } \\
\text { n.d. } \\
\text { n.d. }\end{array}$ \\
\hline
\end{tabular}

a Insoluble.

1. East Bangor, Pa. Twentieth Ann. Rept. U. S. Geol. Survey, pt. 6 (continued), 1899, p. 434.

2. One mile northwest of Colemanville, N. J. Ann. Rept. State Geologist New Jersey for 1868, p. 136.

3. Delaware Water Gap, N. J. Idem.

4. Lafayette, N. J. Ann. Rept. State Geologist New Jersey for 1900, p. 74.

1 Ann. Rept. New Jersey State Geologist for 1900, 1901, p. 95. 
As above noted, the rocks of the Lehigh district dip generally northwest, though there are numerous local exceptions to this rule. The lowest beds of the Martinsburg shale, therefore, outcrop along the southern boundary of the formation, as above outlined. These lowest beds carry much more lime and less silica, alumina, and iron than the higher beds, whose analyses are given above. They become more calcareous and form a natural transition into the underlying cement rock or Ordovician limestones.

\section{PORTLAND CEMENT INDUSTRY IN PENNSYLVANIA.}

GENERAL FEATURES.

The State of Pennsylvania is by far the largest producer of Portland cement in the country, its output during 1911 having amounted to $26,864,679$ barrels, more than one-third of the entire production of Portland cement in the United States. Until very recently Pennsylvania produced considerably over one-half of the entire annual output of the United States, but owing to the more rapid growth in other States this lead has been slowly lost.

Of the Pennsylvania total in 1911, 25,972,108 barrels came from the Lehigh district. Of the 25 plants reported by the Geological Survey as operating in Pennsylvania during 1911, 21 were located in this district. The following list of the Portland cement plants of the State will serve to show the manner in which the industry has become localized. The Lehigh district plants are named first, after which the plants elsewhere in the State are noted. In the list are included a few plants which were inactive in 1911, but which are expected to resume operations.

Lehigh district:
Allentown Portland Cement Co., Evansville.

Alpha Portland Cement Co., Martins Creek.

American Cement Co., Egypt and Lesley.

Atlas Portland Cement Co., Northampton and Coplay.

Bath Portland Cement Co., Bath.

Blanc Stainless Cement Co., Allentown.

Bonneville Portland Cement Co., Siegfried.

Central Cement Co., Egypt.

Coplay Cement Mfg. Co., Coplay.

Dexter Portland Cement Co., Nazareth.

Lawrence Portland Cement Co., Siegfried.

Lehigh Portland Cement Co., Ornarod, West Coplay and Fogelsville.

Nazareth Cement Co., Nazareth.

Lehigh district-Continued.

Northampton Portland Cement Co., Stockertown.

Penn-Allen Portland Cement Co., Nazareth.

Pennsylvania Cement Co., Bath.

Phoenix Cement Co., Nazareth.

Reliance Cement Co., Lesley.

Vindex Portland Cement Co., Molltown.

Whitehall Portland Cement Co., Cementon.

Western and southern Pennsylvania:

Crescent Portland Cement Co., Crescentdale, 1 mile south of Wampum.

Lehigh Portland Cement Co., Newcastle.

New Castle Portland Cement Co., Newcastle.

Sandusky Portland Cement Co., York.

Universal Portland Cement Co., Universal, near Pittsburgh: 
In describing the Portland cement industry of Pennsylvania, the Lehigh district will be first discrissed in the detail which its present as well as its historic importance warrants, after which the isolated plants will be briefly noticed.

\section{LEHIGH DISTRICT.}

\section{MANUFACTURING METHODS.}

\section{MATERIALS USED.}

In most of the plants of the Lehigh district the practice is to mix with a relatively large amount of the "cement rock" or argillaceous limestone a small amount of pure limestone, in order to bring the lime carbonate content up to the percentage proper for a Portland cement mixture. As above noted, all the "cement rock" is derived from the middle of the Ordovician limestone series where the beds will run from 60 to 70 per cent of lime carbonate. The pure limestone which is required to bring this material up to the necessary percentage of lime carbonate (about 75 per cent) is obtained either from the lower portion of the cement-rock series or from certain lowmagnesia beds occurring beneath it.

In plants located near Bath and Nazareth, however, the practice has been slightly different. In this particular area the cement-rock quarries generally show rock carrying from 70 to 80 per cent of lime carbonate. The mills in this vicinity, therefore, require practically no pure limestone, as the quarry rock itself is sufficiently high in lime carbonate for the purpose. Indeed, it is at times necessary for these plants to add clay or slate instead of limestone to their cement rock in order to reduce the lime carbonate to the required proportion. In general, however, it may be said that Lehigh practice is to mix a low-carbonate cement rock with a relatively small amount of pure limestone, and analyses of both these materials, as csed at various plants in the district, are given below.

Analyses of materials used in the Lehigh district.

\begin{tabular}{|c|c|c|c|c|c|c|c|c|c|c|c|}
\hline & \multicolumn{8}{|c|}{ Cement rock. } & \multicolumn{3}{|c|}{ Pure limestone. } \\
\hline & 1 & 2 & 3 & 4 & 5 & 6 & 7 & 8 & 1 & 2 & 3 \\
\hline 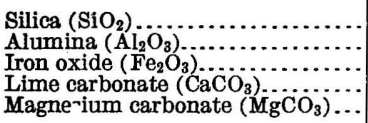 & $\begin{array}{r}15.05 \\
9.02 \\
1.27 \\
70.10 \\
3.96\end{array}$ & $\begin{array}{r}19.06 \\
4.44 \\
1.14 \\
69.24 \\
4.21\end{array}$ & $\left\{\begin{array}{r}19.08 \\
7.92 \\
67.07 \\
4.06\end{array}\right.$ & $\left\{\begin{array}{r}22.22 \\
7.24 \\
.92 \\
63.45 \\
4.56\end{array}\right.$ & $\begin{array}{r}13.80 \\
6.08 \\
76.08 \\
4.51\end{array}$ & $\begin{array}{r}9.52 \\
4.72 \\
80.71 \\
4.92\end{array}$ & $\begin{array}{r}19.62 \\
5.68 \\
69.78 \\
4.90\end{array}$ & $\begin{array}{r}14.20 \\
6.14 \\
74.30 \\
3.24\end{array}$ & $\begin{array}{r}2.14 \\
1.46 \\
94.35 \\
2.18\end{array}$ & $\begin{array}{r}3.02 \\
1.90 \\
92.05 \\
3.04\end{array}$ & $\begin{array}{r}1.98 \\
.70 \\
95.19 \\
2.03\end{array}$ \\
\hline
\end{tabular}

The cement rock is a dark-gray to black slaty limestone, breaking with an even fracture into flat pieces, which commonly have smooth glistening surfaces. As the percentage of lime carbonate in the rock 
increases - that is, as the lower beds of the formation are reachedthe color becomes a somewhat lighter gray, and the surfaces of the fragments lose their slaty appearance.

The range in composition of the cement rock as used at different plants is well shown in the above table. The nearer the material from any given quarry or part of a quarry approaches the proper Portland cement composition (say 75 to 77 per cent of lime carbonate) the less addition of pure limestone will be necessary. In by far the greater part of the district, as above noted, the cement rock is apt to run about 65 to 70 per cent of lime carbonate, therefore requiring the addition of a proportionate amount of limestone. Most of the quarries near Bath and Nazareth, however, have been opened on beds of cement rock running considerably higher in lime carbonate, some running so high ( 80 per cent or more) as to require the addition of shale or clay rather than of pure limestone.

The pure limestones that are added to the cement rock are commonly gray and break into rather cubical fragments. The fracture surfaces show a finely granular structure, quite distinct in appearance from the slaty cement rock.

In composition the limestones commonly used will carry from 90 to 96 per cent of lime carbonate, with rather less magnesium carbonate than is found in the cement rock. All the cement plants own and operate their own cement-rock quarries, but most of them are compelled to buy the pure limestone. Only very pure grades of limestone are purchased, but when a cement plant owns its limestone quarry, material running as low as 85 per cent of lime carbonate is often used.

QUARRY PRACTICE.

In most of the cement-rock quarries of the Lehigh district the rock dips from $15^{\circ}$ to $25^{\circ}$, generally northwest. At a few quarries, particularly in New Jersey, the dip is much steeper. The quarries are opened, preferably, on a side hill, and the overlying stripping, which consists of soil and weathered rock, is removed by scrapers or shoveling. The quarry of the Lawrence Cement Co. has been extended in its lower levels so as to give a tunnel through which the material is hoisted to the mill. Several other quarries have been carried straight down, until now they are narrow and deep pits, from which the material is hoisted vertically. The Bonneville Portland Cement Co. quarry is an extreme example of this type.

In quarries opened on a side hill, so as to have a long and rather low working face and a floor at the natural ground level, the rock is commonly blasted down in benches, sledged to convenient size for handling and crushing, and carried by horse carts for some distance to cars, which are hauled by cable to the mill. Occasionally the 
material is loaded at the face into small cars running on temporary tracks, hauled or pushed to a turntable, whence they are hauled to the mill by cable. Though these methods seem clumsy at first sight, they are capable of little improvement. The amount of rock used every day in a large mill necessitates very heavy blasting, and this prevents permanent tracks and cableways being laid near the working face.

At several quarries the cars or carts are loaded by steam shovels. Though the cement rock seems to be well adapted for handling by stean shovels, much sledging is necessary, and the blasting operations are interfered with.

MILL PRACTICE.

What may be considered as typical American practice in the manufacture of Portland cement from dry material owes its present success largely to the works of the Lehigh district. Prior to the commencement of Portland cement manufacture in Pennsylvania, dry processes had not been looked upon with favor. The European plants then in existence used wet processes exclusively, differing only in the amount of water that was used. A dry process can not well be used in stationary kilns, whether of dome or chamber type, for even if the mixing be done dry it will be necessary to add water in making the mixture into bricks. The natural result was that these early plants used water very liberally-almost as freely as the present marl plants of Michigan and with far more excuse for doing so. With the introduction of the rotary kiln a dry process became not only possible but advisable, and the Lehigh practice of to-day is the result.

The cement rock is crushed and dried, the first of these operations often taking place in the quarry. Large gyratory crushers are commonly used for this work, while the drying is usually done in rotary driers. The necessary amount of limestone, also previously crushed and dried, is added, and the two materials are mixed and further reduced together. Occasionally a smaller gyratory crusher, breaking to about one-half inch, is the next step in the process of reduction. Commonly, however, the mixture goes to ball mills, pulverizers or Williams mills, and then to tube mills. Some of the plants use Griffin mills, and the Atlas plant uses the Huntingdon mill. The raw mixture is ground to a fineness usually not exceeding 85 per cent through a 100-mesh sieve and often falling much lower. Compared with the practice at plants using limestone-clay mixtures, this is coarse work. It is less harmful than might be expected, however, for most of the mixture is made up of cement rock which is already naturally well mixed. The mixture is usually dampened (to prevent too much of it being blown out of the kiln) and fed to rotary kilns. 
CharaCtER AND COMPOSITION OF THE PRODUCT.

The analyses given in the following table will serve to show the composition of the product of the Lehigh district. Of the 10 analyses quoted, those numbered 1 to 8 inclusive are fairly representative. Analyses 9 and 10, on the other hand, carry very low alumina and iron oxide and correspondingly high silica.

Analyses of cements of the Lehigh district.

\begin{tabular}{|c|c|c|c|c|c|c|c|c|c|c|}
\hline & 1 & 2 & 3 & 4 & 5 & 6 & 7 & 8 & 9 & 10 \\
\hline 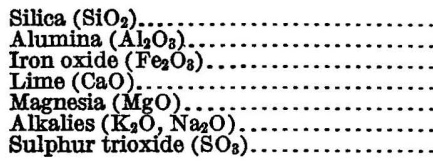 & $\begin{array}{r}21.30 \\
7.65 \\
2.85 \\
60.95 \\
2.95 \\
1.15 \\
1.81\end{array}$ & $\begin{array}{c}21.96 \\
8.29 \\
2.67 \\
60.52 \\
3.43 \\
(a) \\
1.49\end{array}$ & $\begin{array}{r}21.1 \\
8.0 \\
2.5 \\
65.6 \\
2.4 \\
(a) \\
(a)\end{array}$ & $\begin{array}{r}20.87 \\
7.60 \\
2.66 \\
63.04 \\
2.80 \\
(a) \\
1.50\end{array}$ & $\begin{array}{r}19.06 \\
7.47 \\
2.29 \\
61.23 \\
2.83 \\
1.41 \\
1.34\end{array}$ & $\begin{array}{r}21.65 \\
8.09 \\
2.93 \\
63.10 \\
2.00 \\
(a) \\
1.02\end{array}$ & $\begin{array}{r}22.68 \\
6.71 \\
2.35 \\
62.30 \\
3.41 \\
(a) \\
1.88\end{array}$ & $\begin{array}{r}21.08 \\
7.86 \\
2.48 \\
63.68 \\
2.62 \\
(a) \\
1.25\end{array}$ & $\begin{array}{r}24.23 \\
4.80 \\
1.86 \\
63.01 \\
3.20 \\
(a) \\
1.20\end{array}$ & $\begin{array}{r}24.48 \\
4.51 \\
2.68 \\
64.33 \\
2.59 \\
(a) \\
1.41\end{array}$ \\
\hline
\end{tabular}

a Not determined.

The characteristics of the Lehigh district Portland cements are best brought out by the following summary of the range and average of the constituents. In making up the average the silica, alumina, and iron oxide contents of analyses 9 and 10 have not been used, and the lime percentage of No. 3 has also been excluded. For comparison, 9 and 10 have been averaged for the first three constituents, and the results are placed in the fourth column.

Range and average of Portland cement of the Lehigh district.

\begin{tabular}{|c|c|c|c|c|}
\hline & Maximum. & Average. & Minimum. & $\begin{array}{l}\text { A verage of } \\
\text { analyses } \\
9 \text { and } 10 .\end{array}$ \\
\hline 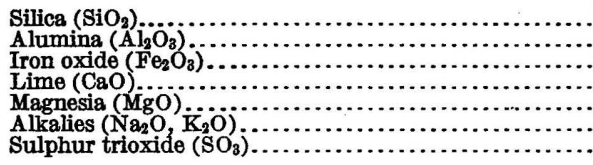 & $\begin{array}{r}22.68 \\
8.29 \\
2.93 \\
64.33 \\
3.43 \\
1.41 \\
1.88\end{array}$ & $\begin{array}{r}21.21 \\
7.71 \\
2.59 \\
62.46 \\
2.82 \\
1.28 \\
1.43\end{array}$ & $\begin{array}{r}19.06 \\
6.71 \\
2.29 \\
60.52 \\
2.00 \\
1.15 \\
1.02\end{array}$ & $\begin{array}{r}24.355 \\
4.565 \\
2.270 \\
\cdots \cdots+\cdots \\
\cdots \cdots \\
\cdots \cdots\end{array}$ \\
\hline
\end{tabular}

EXTENSION OF THE IEHIGH DISTRICT.

As noted in the earlier portion of this paper, the cement deposits have been developed from near Reading, Pa., to a few miles from Stewartsville, N. J. Most of the readily accessible cement land between these points has been taken up by the cement companies or is being held at impossible prices by the owners. Under these circumstances it seems probable that few additional plants can be profitably established in the district now developed, and that the growth of the industry will be brought about by extending the district. A few notes on the distribution of the same cement beds in adjoining 48834ㄴ -Bull, 522-13-21 
areas may therefore be of interest to those desiring to engage in the manufacture of Portland cement from materials of the Lehigh district type.

Northeast of Stewartsville, N. J., the cement beds outcrop at frequent intervals in the Kittatinny Valley all the way across New Jersey and a few miles into Orange County, N. Y: The exact locations of these deposits, with numerous analyses of the cement rocks, have been published ${ }^{1}$ and mapped very precisely.

Southwest of Reading these cement rocks outcrop in a belt that crosses Lebanon, Cumberland, and Franklin counties, Pa., passing near the towns of Lebanon, Harrisburg, Carlisle, and Chambersburg. In Maryland they occur in Washington County, and in West Virginia and Virginia they are extensively developed.

Throughout this southern extension the cement-rock series is not everywhere an argillaceous limestone, but it is commonly so and it is everywhere very low in magnesium carbonate. It is therefore probably safe to say that in southern Pennsylvania, Maryland, West Virginia, and Virginia the Ordovician limestones of this horizon are everywhere good Portland cement materials, though in some places they require pure limestone and in other places clay to bring them to a proper composition.

\section{WESTERN AND SOUTHERN PENNSYLVANIA.}

Until recently only two small Portland cement plants were in operation in western Pennsylvania. These were the planits of the Crescent Portland Cement Co. and the Clinton Iron \& Steel Co., each of which had historic interest out of proportion to its manufacturing importance.

The Portland cement plant of the Clinton Iron \& Steel Co., located at Pittsburgh, has now been permanently abandoned. It owed its interest to the fact that it was the first plant in the United States to utilize a mixture of blast-furnace slag and limestone in the manufacture of a true Portland cement, having commenced this industry several years before it was taken up by the Illinois Steel Co. at Chicago.

At present four Portland cement plants are in operation in western Pennsylvania, operated by the Universal Portland Cement Co., the Lehigh Portland Cement Co., the Newcastle Portland Cement Co., and the Crescent Portland Cement Co.

The plant of the Universal Portland Cement Co., at Universal, near Pittsburgh, utilizes a mixture of blast-furnace slag and limestone in the manufacture of a true Portland cement. At Newcastle, the plants of the Newcastle and Lehigh Portland cement companies 
use a mixture of the Carboniferous Vanport limestone member of the Allegheny formation and Carboniferous shales.

The Crescent Portland Cement Co., near Wampum, Lawrence County, is one of the oldest Portland cement plants in the United States, having gone into operation when the Saylors were the only operators in the Lehigh district. The material used here is the Vanport limestone and a shale overlying this limestone.

Analysis of Portland cement materials, Wampum, Pa.

\begin{tabular}{|c|c|c|}
\hline & Limestone. & Shale. \\
\hline $\begin{array}{l}\mathrm{Silica}\left(\mathrm{SiO}_{2}\right) \\
\text { Alumina }\left(\mathrm{Al}_{2} \mathrm{O}_{3}\right) \\
\text { Iron oxide }\left(\mathrm{Fe}_{2} \mathrm{O}_{3}\right) \\
\text { Lime }(\mathrm{CaO}) \\
\text { Magnesia }(\mathrm{Mg} \\
\text { Carbon dioxide }\left(\mathrm{CO}_{2}\right)\end{array}$ & $\begin{array}{r}5.52 \\
2.97 \\
49.66 \\
.78 \\
\text { n. d. }\end{array}$ & $\begin{array}{r}65.99 \\
21.57 \\
6.07 \\
.47 \\
.82 \\
\text { n. d. }\end{array}$ \\
\hline
\end{tabular}

At York, in southern Pennsylvania, the Sandusky Portland Cement Co. operates a small plant for the manufacture of white Portland cement. The raw materials utilized are crystalline limestone and shale low in iron.

\section{PORTLAND CEMENT RESOURCES OF RHODE ISTLAND.}

Few limestone deposits of economic importance occur in Rhode Island. At Lime Rock, Providence County, quarries have been worked, the product being used largely or entirely for lime burning. Though often referred to as dolomite the stone at Lime Rock is not a very highly magnesian rock, as is shown by the following analysis ${ }^{1}$ by J. H. Appleton of a specimen from the Harris quarry:

Analysis of limestone from Lime Rock, $R . I$.

Silica $\left(\mathrm{SiO}_{2}\right)$ 2.748

Alumina $\left(\mathrm{Al}_{2} \mathrm{O}_{3}\right)$ .309

Iron oxide $\left(\mathrm{Fe}_{2} \mathrm{O}_{3}\right)$

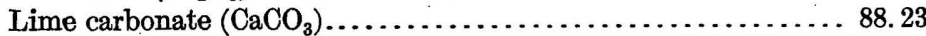

Magnesium carbonate $\left(\mathrm{MgCO}_{3}\right) \ldots \ldots \ldots \ldots \ldots \ldots \ldots \ldots \ldots \ldots .8 .80$

Moisture........................................ .04

This rock carries too much magnesia, however, to permit its use in Portiand cement manufacture under the present standards, and its amount and location with respect to fuel and märket are not particularly advantageous.

Small beds of limestone occur at other localities in the State, but none of these are of sufficient extent to be workable, whatever may be their chemical composition. 


\section{PORTIAND CEMENT RESOURCES OF SOUTH CAROLINA.}

Limestones occur at many points in South Carolina, but no good geologic map of the State is in existence and no recent report concerning them has been issued. The analyses given below are, with one exception, very old, but they will give some idea of the composition and location of the limestones.

The western part of the State contains a number of beds of metamorphosed limestone or marble that seem to be satisfactory in composition, but fuel supply, local markets, and cheap transportation are all lacking.

Analyses of metamorphic limestones, western South Carolina. ${ }^{a}$

\begin{tabular}{|c|c|c|c|c|c|c|c|}
\hline & 1 & 2 & 3 & 4 & 5 & 6 & 7 \\
\hline 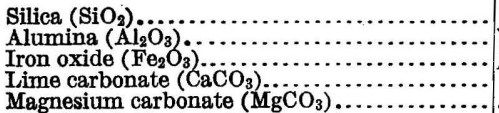 & $\begin{array}{r}25.0 \\
5.0 \\
70.0\end{array}$ & $\begin{array}{r}7.00 \\
92.00 \\
1.00\end{array}$ & $\begin{array}{r}16.0 \\
9.0 \\
75.0 \\
\text { Tr. }\end{array}$ & $\begin{array}{c}10.0 \\
4.50 \\
85.00 \\
.50\end{array}$ & $\begin{array}{r}11.0 \\
2.5 \\
86.0 \\
.5\end{array}$ & $\begin{array}{r}13.5 \\
86.0 \\
.5\end{array}$ & $\left\{\begin{array}{r}6.40 \\
3.14 \\
90.56 \\
\text { Tr. }\end{array}\right.$ \\
\hline
\end{tabular}

a Analyses by Tuomey, Rept. Geology South Carolina, 1848, pp. 262-264.

1. Brasstown Creek, Pickens district.

2. Saluda River, Laurens district.

3. Highest limestone bed, York.

4. Lower limestone bed, York.

5. Hardin's limestone bed, York.

6. Garlington's quarry, Laurens district.

7. Limestone Springs, Spartanburg.

In the coastal plain soft limestones of Tertiary age, the so-called "marls," outcrop at many points. Much of these materials would be very satisfactory for Portland cement manufacture.

Analyses of Tertiary limestones, eastern South Carolina. ${ }^{a}$

\begin{tabular}{|c|c|c|c|c|c|}
\hline & 1 & 2 & 3 & 4 & 5 \\
\hline 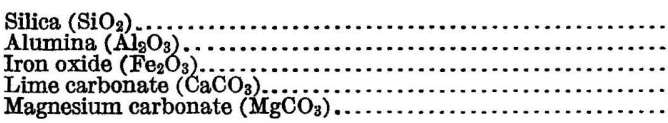 & $\begin{array}{r}12.90 \\
7.02 \\
78.52 \\
.15\end{array}$ & $\left\{\begin{array}{r}16.20 \\
\operatorname{Tr} . \\
\operatorname{Tr} . \\
76.88 \\
1.41\end{array}\right.$ & $\begin{array}{r}16.00 \\
4.75 \\
\mathrm{Tr} . \\
63.50 \\
7.00\end{array}$ & $\begin{array}{r}18.60 \\
.40 \\
\mathrm{Tr} . \\
68.00 \\
1.20\end{array}$ & $\begin{array}{r}10.20 \\
1.00 \\
\text { Tr. } \\
66.04 \\
2.56\end{array}$ \\
\hline
\end{tabular}

$a$ Analysis 1 by Crowell and Peck; analyses 2-5 by C. U. Shepard.

1. Strawberry station, Berkeley County.

3. Elwood plantation, Cooper River.

4. Goose Creek, 15 miles from Charleston.

5. Drayton Hall.

The analyses given above, though showing well the amount of free sand carried by many of these soft Tertiary limestones, hardly represent their percentages of lime carbonate. Much purer beds than these are known to occur near Charleston, but no good analyses are available 


\section{PORTLAND CEMENT RESOURCES OF SOUTH DAKOTA.}

\section{PORTLAND CEMENT MATERIALS.}

The limestone formations of South Dakota which give any promise of supporting a Portland cement industry occur in two different portions of the State. They are thus separated geographically as well as geologically into (1) the limestones of the Black Hills district and (2) the Niobrara chalk (Upper Cretaceous) of eastern South Dakota.

\section{BLACK HILLS.}

\section{STRATIGRAPHY.}

Darton has described the stratigraphy and rocks of the Black Hills district ${ }^{1}$ as follows:

The Black Hills uplift is an irregular dome-shaped anticline, embracing in its more obvious features an oval area 125 miles in length and 60 miles in breadth, with its larger dimension lying nearly northwest and southeast. It is situated in a wide area of almost horizontal beds underlying the great east-sloping plain that extends from the Rocky Mountains to the Mississippi River. It has brought above the general surface level an area of pre-Cambrian crystalline rocks about which there is upturned a nearly complete sequence of the Paleozoic and Mesozoic rocks from Cambrian to Laramie, all dipping away from the central nucleus. There are also extensive overlaps of the Tertiary deposits which underlie much of the adjoining plains area. The region is one of exceptionally fine exposures, which afford rare opportunity for a study of stratigraphic relations and variations. Many of the rocks are hard, and the streams flowing out of the central mountain area have cut canyons and gorges, in the walls of which the formations are often extensively exhibited. The structure presented locally is that of a monocline dipping toward the plains. The oldest sedimentary rocks constitute the escarpment facing the crystalline rock area, and each higher stratum passes beneath a newer one in regular succession outward toward the margin of the uplift. The sedimentary formations consist of a series of thick sheets of sandstones, limestones, and shales, all essentially conformable in structure. The overlapping areas of the Tertiary deposits extend across the edges of the older formations. The stratigraphy presents many features of similarity to the succession of rocks in the Rocky Mountains of Colorado and Wyoming, but it possesses numerous distinctive local features.

The following is a list of the formations which are exhibited in the uplift, with a generalized statement by Darton as to the thickness, characteristics, and age:

Generalized section in the Black Hills region.

\begin{tabular}{|c|c|c|}
\hline Formation. & Character. & $\begin{array}{c}\text { Average } \\
\text { thickness. }\end{array}$ \\
\hline $\begin{array}{l}\text { Upper Cretaceous: } \\
\text { Laramie (?) formation.... } \\
\text { Fox Hills sandstone....... } \\
\text { Pierre shale................ } \\
\text { Niobrara formation....... }\end{array}$ & 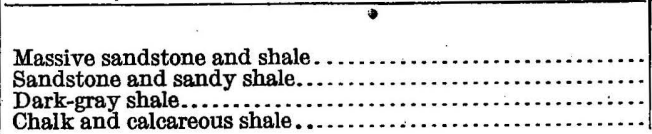 & $\begin{array}{r}\text { Feet. } \\
2,500 \\
250-500 \\
1,200 \\
225\end{array}$ \\
\hline
\end{tabular}

1 Darton, N. H., Twenty-first Ann. Rept. U. S. Geol. Survey, pt. 4, 1901, pp. 502 et seq. 
Generalized section in the Black Hills region-Continued.

\begin{tabular}{|c|c|c|}
\hline Formation. & Character. & $\begin{array}{l}\text { Average. } \\
\text { thickness. }\end{array}$ \\
\hline $\begin{array}{l}\text { Upper Cretaceous-Contd. } \\
\text { Benton group- } \\
\text { Carlile shale......... }\end{array}$ & Gray shales with thin sandstones, limestones, and concre- & $\begin{array}{l}\text { Feet. } \\
500-750\end{array}$ \\
\hline $\begin{array}{l}\text { Greenhorn limestone... } \\
\text { Graneros shale......... }\end{array}$ & 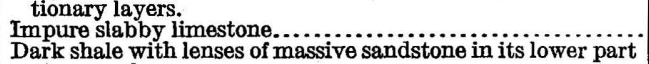 & $\begin{array}{r}50 \\
900\end{array}$ \\
\hline Dakota sandstone. & $\begin{array}{l}\text { at some places. } \\
\text { Massive buff sandstone............. }\end{array}$ & $35-150$ \\
\hline $\begin{array}{l}\text { Lower Cretaceous (?): } \\
\text { Fuson formation.... }\end{array}$ & Very fine grained sandstone and massive shales; white to & $30-100$ \\
\hline Minnewaste limestone & purpere coror. & $0-30$ \\
\hline $\begin{array}{l}\text { Lakota sandstone... } \\
\text { Jurassic (?): }\end{array}$ & Massive buff sandstone, with some intercalated shale...... & $200-350$ \\
\hline $\begin{array}{l}\text { Morrison shale ................ } \\
\text { Unkpapa sandstone....... }\end{array}$ & 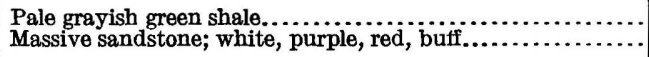 & $\begin{array}{l}0-150 \\
0-250\end{array}$ \\
\hline $\begin{array}{l}\text { Jurassic: } \\
\text { Sundance formation.... }\end{array}$ & $\begin{array}{l}\text { Dark-drab shales and buff sandstones; massive red sand- } \\
\text { stone at base. }\end{array}$ & $60-400$ \\
\hline $\begin{array}{l}\text { Triassic(?): } \\
\text { Spearfish formation.. }\end{array}$ & Red sandy shales with gypsum bed............. & $350-500$ \\
\hline $\begin{array}{l}\text { Permian: } \\
\text { Minnekahta limestone....... } \\
\text { Opeche formation }\end{array}$ & 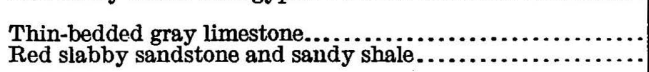 & $\begin{array}{r}30-50 \\
90-130\end{array}$ \\
\hline $\begin{array}{l}\text { Pennsylvanian-M is s i s s i } \mathrm{p}- \\
\text { pian(?): } \\
\text { Minnelusa sandstone....... }\end{array}$ & Sandstones, mainly buff and red; in greater part calcareous. & $400-450$ \\
\hline $\begin{array}{l}\text { Mississippian: } \\
\text { Pahasapa limestone.... } \\
\text { Englewood limestone... }\end{array}$ & 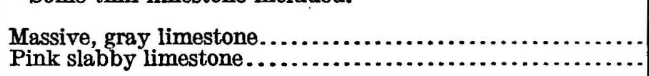 & $\begin{array}{r}250-500 \\
25\end{array}$ \\
\hline $\begin{array}{l}\text { Ordovician: } \\
\text { Whitewood limestone. }\end{array}$ & Hard, buff-colored or pink limestone................ & $0-80$ \\
\hline $\begin{array}{l}\text { Cambrian: } \\
\text { Deadwood sandstone.. }\end{array}$ & $\begin{array}{l}\text { Red-brown quartzite and sandstone, locally conglomeratic, } \\
\text { partly massive. }\end{array}$ & $4-150$ \\
\hline
\end{tabular}

Of the formations mentioned in the above table, the limestones above the Whitewood are described by Darton $^{1}$ as follows:

\section{ENGLEWOOD IIMESTONE.}

In the southern Black Hills the Deadwood formation is overlain by a series of thinbedded, pale pinkish buff limestones. On the suggestion of Mr. Jaggar, it is proposed to designate this formation the Englewood limestone, from a locality in the northern Black Hills where it is extensively exposed. It appears to extend continuously around the Black Hills, everywhere immediately underlying the Pahasapa limestone. It averages 20 to 30 feet in thickness and presents frequent outcrops in the lower slopes of the limestone escarpment and in numerous canyons. It merges rapidly into the overlying limestone, occasionally with a few feet of impure buff limestone intervening. 'It is usually sharply separated from the Deadwood formation, but only by a sudden change in the nature of the materials. [In the northern Black Hills it is in places separated from the Deadwood sandstone by the Whitewood limestone, which is of Ordovician age.] The Englewood limestone is usually fossiliferous, containing numerous corals and occasional shells. The following forms have been reported: Fenestella, Orthothetes, Leptæna, Spirifer, Chonetes logani, Reticularia peculiaris, Syringothyris carteri, and crinoids.

\section{PAHASAPA IMMESTONE.}

This prominent member, heretofore known as the gray limestone, has an extensive outcrop area in the Black Hills uplift. It constitutes much of the high wide plateau west of the central region of crystalline rocks and is most characteristically exhibited 
in the great lines of cliffs in the infacing escarpment surrounding that region. Mr. Jaggar has suggested that there be applied to it the Dakota Indian name for the Black Hills-Pahasapa. The formation consists of a thick deposit of massive gray limestone, usually outcropping in precipitous cliffs with many picturesque irregularities of form or with wide flat surfaces. Caverns are of frequent occurrence, some of them being of large size. One having several miles of galleries is known as Wind Cave, from the strong current of air which usually issues from its mouth. It is situated 8 miles north of the Hot Springs and attracts thousands of visitors. Crystal Cave, in the northern Black Hills, is also a very interesting cavern, with many large deposits of dog-tooth spar on its walls.

The most extensive exposures of the Pahasapa limestone are in the great plateau west of Custer. Here the formation begins in a line of high cliffs surmounting slopes of crystalline schists and the relatively thin sheets of Englewood limestone and Deadwood sandstone. A view of one of these cliffs is shown in figure 274. In Pennington County the plateau has a width of 10 miles of continuous limestone outcrop, constituting the most elevated area in the Black Hills excepting the small summit of Harney Peak. To the west the limestone passes beneath the sandstone of the Minnelusa formation, but it is exposed again in the arch of the steep anticline near the Wyoming-South Dakota line. Hell Canyon cuts deeply into the Pahasapa limestone, as does also the wider canyon known as Pleasant Valley. East of the crystalline rock area the limestone stands out on many conspicuous knobs, or lies on the eastern slopes of ridges due to the Deadwood quartzite, but it does not attain the high altitude which it has farther west. With decreased thickness, the more rapid dip to the east soon carries the formation below the surface in that direction, but it constitutes the walls of many of the canyons of the streams from Beaver Creek northward. French Creek has extensive cliffs of the limestone, and Spring Creek has cut a long deep canyon through it.

The thickness of the Pahasapa limestone in the central and southern Black Hills varies from about 500 feet at the northwest to 225 feet on the east and southeast. All along the eastern side of the hills it appears to have the latter thickness, with slight local variations. It does not present any noteworthy lithologic subdivisions, but its upper part is often siliceous and flinty and stained red to a greater or less extent from the overlying red beds of the Minnelusa formation. At its top there is usually a red shaly bed of slight thickness, containing oval concretions of hard silica from 6 inches to 2 feet in diameter in greater part. Fossils occur sparingly throughout the formation, including Spirifer rockymontanus, Seminula dawsoni (Athyris subtilita), Productus, and Zaphrentis, a fauna which indicates lower Carboniferous age.

\section{MINNERAHTA IMMESTONE.}

This formation, known in previous geological reports as the purple limestone, is a prominent member of the Black Hills series. It is thin, averaging less than 50 feet in thickness, but it is hard and flexible and covers moderately extensive areas of the outer slopes of the Minnelusa formation. Southwest of Hot Springs it constitutes a prominent anticlinal ridge, which extends south to Cascade Spring. It is proposed to designate this formation the Minnekahta limestone, because a distinctive geographic name is required, and the region near the hot springs, originally known as the "Minnekahta" by the Indians, is a typical locality. The springs rise through crevices in the formation just west of the town of Hot Springs, and the exposures in the vicinity show all the characteristic features which the formation presents. The prominence of the Minnekahta limestone outcrops is due largely to the fact that the overlying formation is soft red shale, which has been deeply eroded, leaving the underlying limestone bare on slopes up which the red shale originally extended. The underlying formation, the Opeche, also being soft, the limestone nearly everywhere presents an escarpment, and the many canyons which are cut through it have vertical walls of the limestone. 
The Minnekahta limestone presents more details of structure than any other formation of the Black Hills. Normally it dips outward away from the central area at from $5^{\circ}$ to $30^{\circ}$, but there are frequent variations in the amount and direction. These variations are due to the fact that the formation is a relatively hard bed of homogeneous rock lying between masses of soft, red shales, so that it was free to flex wherever pressure was exerted, the plasticity of the inclosing beds favoring local flexing and warping. Its beds are sometimes traversed by small faults and minute crumplings, but considering the large amount of deformation to which the formation has been subjected the flexures are but little broken. The formation is uniform in character throughout, being a thin-bedded, light-colored limestone containing magnesia and more or less clay as an impurity. Its thin bedding is a characteristic feature, although the thin layers are so cemented together that the formation presents a massive appearance. On weathering and through the action of frost it breaks into slabs usually 2 to 3 inches in thickness. On the western side of the Black Hills, notably in the region from east of Clifton northward, its coloring is slightly darker, varying from dove color to lead gray, and some of the beds present a seminodular structure. An increased admixture of clay is also observed in some layers. The general appearance of the formation is always slightly pinkish, with a tinge of purple, from which the term " purple limestone" originated. The thickness of the formation was measured at many points. A few representative measurements are as follows:

Thickness of Minnekahta limestone.

Spring Creek..................................... $\quad 45$

Battle Creek....................................... $\quad 40$

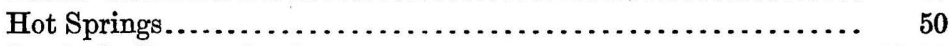

Stockade Beaver Creek............................... 28-33

Cambria well........................................ 34

This relatively uniform thickness indicates very uniform conditions of deposition during the accumulation of the red bed deposits, the Opeche formation below, and the Spearfish formation above. An analysis of a typical sample of the Minnekahta limestone is as follows:

Analysis of Minnekahta limestone.

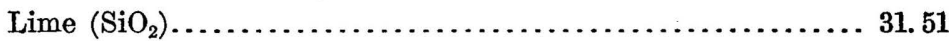

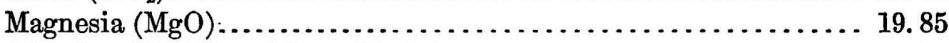

Alumina $\left(\mathrm{Al}_{2} \mathrm{O}_{3}\right)$ and iron $\left(\mathrm{Fe}_{2} \mathrm{O}_{3}\right) \ldots \ldots \ldots \ldots \ldots \ldots \ldots \ldots \ldots \ldots \ldots \ldots \ldots \ldots \ldots . .36$

Water................................................. 1.25

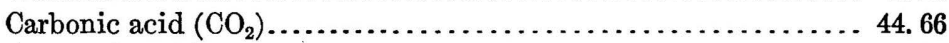

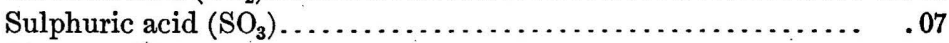

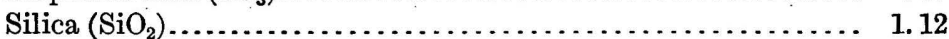

Manganese, soda, and potash.......................... None.

SOUTHEASTERN SOUTH DAKOTA.

In the eastern part of South Dakota, and more particularly in the extreme southeastern part of the State, the Niobrara chalk furnishes an excellent raw material for Portland cement manufacture. The composition and stratigraphy of these rocks have been discussed under Nebraska (pp. 257-258) and need not be taken up again here. The chalk is well exposed in numerous bluffs along Missouri River from Yankton to Chamberlain and it also outcrops in smaller isolated areas elsewhere in the district. 
PORTLAND CEMENT INDUSTRY IN SOUTH DAKOTA.

The Western Portland Cement Co., whose plant is located a few miles from Yankton, has employed the Niobrara chalk and the overlying Pierre shale as raw materials. The original plant was a wetprocess mill, with stationary kilns of the Johnson type, but these have been replaced by rotary kilns. Analyses of the raw materials follow:

Analyses of Portland cement materials, Yankton, S. Dak.

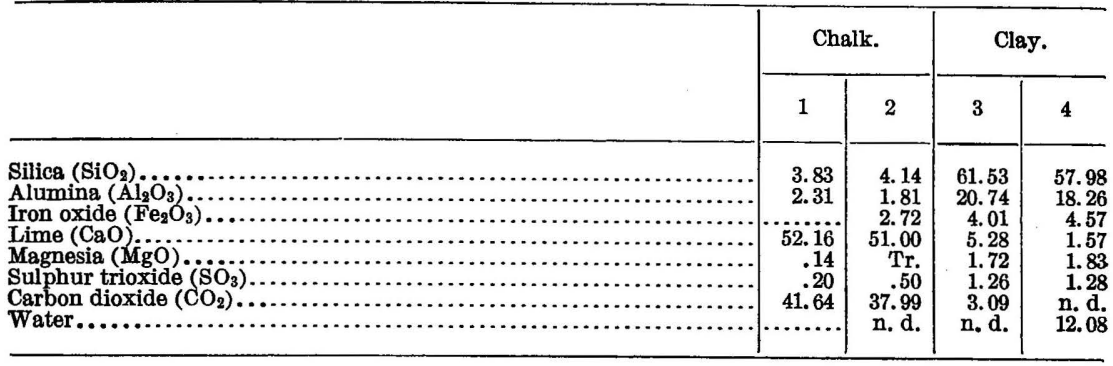

1. C. B. McVay, analyist.

2, 3. Mineral industry, vol. 1, 1893, p. 52 .

4. Mineral industry, vol. 6 , 1898, p. 97 .

The plant at Yankton was idle in 1911. For some time there has been under discussion the establishment of a plant at Chamberlain.

\section{PORTIAND CEMENT RESOURCES OF TENNESSEE.}

By E. O. ULRICH.

PORTLAND CEMENT MATERIALS.

DISTRIBUTION.

Limestones and shales that probably have the chemical composition and other properties required in the manufacture of Portland cement occur abundantly in eastern and middle Tennessee. The more promising materials and localities are confined to eastern Tennessee, where numerous large and easily quarried outcrops of nonmagnesian upper Ordovician limestones and shales alternate with generally much wider bands of dolomitic lower Ordovician limestone and Cambrian shales, sandstones, and limestones.

Very few analyses of limestones from any part of Tennessee have been published, practically the only ones being those of the phosphatic limestones of the middle part of the State. This lack of analyses is to be regretted, since the decision as to which limestones have and which have not too great a percentage of magnesia to make them available as Portland cement materials is necessarily left to the judgment of the observer. However, with exact correlations and careful comparisons with limestones of known composition it is possible to attain sufficiently reliable results. 
In east Tennessee the bands of limestone sufficiently low in magnesia to be classed as possible Portland cement materials lie mostly above the Knox dolomite.

\section{CAMBRIAN LIMESTONES.}

Limestones form but a small part of the Middle Cambrian rocks in Tennessee, and it does not seem probable that any of them have the chemical composition now deemed necessary in a Portland cement material. Certain layers of the Maryville limestone, ${ }^{1}$ are probably more promising than any other Cambrian limestone in the State. Other limestone beds, ranging in thickness from a few feet to nearly 400 feet, have been described under the names of Beaver and Rutledge limestones. Others, again, are included as calcareous members in the Nolichucky shale and the Conasauga shale.

The great bed of Knox dolomite overlies these Middle Cambrian formations. The lower half of the Knox is of Upper Cambrian age and the upper half is of Ordovician age. So far as known, the percentage of magnesia in no part of the 3,500-4,000 feet of limestone comprised in the formation is low enough for Portland cement material.

\section{ORDOVICIAN LIMESTONES.}

\section{EAST TEMNESSEE.}

EAST SIDE OF VALLEY.

The Ordovician formations of the eastern part of east Tennessee have been described in folios and other publications of the United States Geological Survey under several local names. The relations of these formations to one another are approximately as follows:

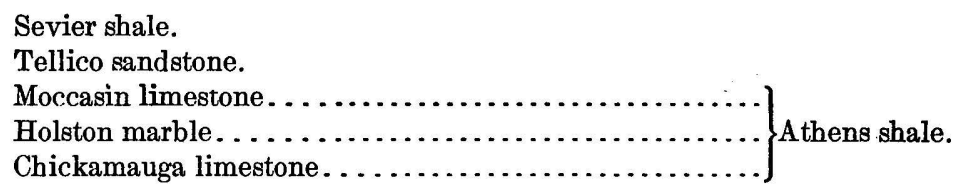

At the base is a rather persistent bed of more or less argillaceous limestone (Chickamauga), the thickness of which varies greatly, reaching in places several hundred feet. It corresponds in position, and in a considerable degree also in lithologic character, to the Ordovician limestones used for cement making in the more northern part of the Appalachian Valley. It outcrops in bands that lie approximately parallel to the margin of the valley. Near the eastern edge of the valley, where the limestone is thin and locally absent, the overlying black shale (Athens) is thicker.

In places heavy beds of red and gray marble (Holston) are associated with the Chickamauga limestone. These marbles are very

1 Folios Nos. 12, 16, 25, 27, 33, and 59, Geol. Atlas U. S., U. S. Geol. Survey, 1894-1899. 
pure limestones, being especially low in magnesia. As the outcrops are commonly close to beds of shale, some of those that for one reason or another are unfit for use as marble might be utilized in the manufacture of cement. Analyses follow:

Analyses of Ordovician marbles from Tennessee.

\begin{tabular}{|c|c|c|}
\hline . & 1 & 2 \\
\hline 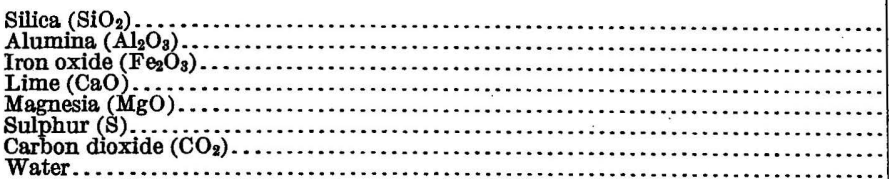 & $\begin{array}{r}0.17 \\
.04 \\
.23 \\
55.47 \\
.30 \\
43.63 \\
.21\end{array}$ & $\begin{array}{r}0.13 \\
\text { Tr. } \\
.26 \\
55.32 \\
.21 \\
.005 \\
43.51 \\
.125\end{array}$ \\
\hline
\end{tabular}

1. Knoxville, Knox County. L. G. Eakins, analyst. Bull. U. S. Geol. Survey No. 168, 1900, p. 258

2. Hawkins County. A. L. Colby, analyst. Eighteenth Ann. Rept. U. S. Geol. Survey, pt. 5 (continued), 1897, p. 983 .

Similar and in places extensive beds of crystalline and other limestones occur locally in the Sevier shale. Such limestone beds are especially well developed in the bands striking southwest from Knoxville to Athens. Thinner and more earthy beds of limestone occur, though less commonly, in the Athens shale. In the region between Holston and Clinch rivers the Chickamauga limestone is generally overlain by the Moccasin limestone, a reddish argillaceous limestone several hundred feet thick.

WEST SIDE OF VALLEY.

The Ordovician limestones of the western half of the valley are all included in the Chickamauga limestone, a great mass of rocks, aggregating from 1,200 to 2,000 feet in thickness, consisting almost entirely of limestone. Locally and in certain parts of the section, especially toward the top, the limestone becomes shaly, or it may include many thin beds of shale. Though the greater part of the formation may be classed as a pure limestone, it is nevertheless true that many layers contain considerable clayey matter and a few are siliceous and on decomposition give rise to chert. The percentage of magnesia, however, is almost everywhere low, although analyses establishing the fact are wanting. Highly argillaceous limestones, generally mottled with red, occur in the lower half of the formation, especially in the Chattanooga belt. Many localities in the western half of the valley doubtless would afford materials for a proper mixture in the same quarry.

The Chickamauga limestone contains representatives of practically all the formations into which the Ordovician rocks of middle Tennessee have been divided. The succession of the beds and of the faunas characterizing each is practically the same in the two areas, 
so that there can be little or no doubt respecting the continuity of the beds beneath the later rocks which form the intervening Cumberland Plateau.

\section{WESTERN AND MIDDLE TENWESSEE.}

STONES ,RIVER GROUP.

The nearly horizontal limestones of the Stones River group form the floor of middle Tennessee, the lowest formation outcropping at Murfreesboro. They are all essentially nonmagnesian and hence deserve mention as possible or promising materials. The Murfreesboro limestone, with an exposed thickness of 70 feet, is light blue, generally heavy bedded, in places rather earthy, and commonly very cherty. Murfreesboro is situated near the center of the area in which this limestone comes to the surface. The diameter of the area, which includes also small outliers of later formations, ranges from 12 to 14 miles.

The Pierce limestone, having a maximum thickness of scarcely 30 feet, rests on the Murfreesboro limestone and forms a narrow belt around the outcrops of that formation. It consists chiefly of thin layers of highly fossiliferous pure or somewhat argillaceous limestone interbedded with thin seams of calcareous shale.

The next formation, the Ridley limestone, 80 to 100 feet thick, consists of thick-bedded light-blue, sparsely cherty limestone. The Ridley, like the Pierce, outcrops in an irregular circular band around the Murfreesboro area. Small exposures of its upper beds occur also in Bedford and Marshall counties.

The Lebanon limestone has lithologic characters similar to those of the Pierce limestone. It is the fourth formation from the base of the Stones River group, has a thickness of 100 feet or more, and occupies a larger area than the preceding limestones. The towns of Lebanon, Lewisburg, Shelbyville, La Vergne, and Fosterville are built on this limestone. It is shown also in the bluffs of Duck River at Columbia. A considerable proportion of the bed consists of argillaceous limestone.

The Carter limestone, the uppermost division of the Stones River group, is a very light blue compact heavy-bedded limestone, 40 to 80 feet thick. It occurs in all the counties in the central basin and is more commonly burned for lime than any other of the Ordovician limestones.

LIMESTONES OF TRENTON AGE.

The limestones of Trenton age, including, from the base upward, the Hermitage, Bigby, and Catheys limestones as defined in the Columbia folio, ${ }^{1}$ form a wide but irregular belt, completely encircling the central areas of the Stones River group. 
These formations, though consisting almost entirely of limestone, still vary greatly from place to place in their lithologic characters. The Bigby limestone, for instance, is granular and phosphatic on the west side of the basin. Both of these peculiarities are lost on tracing the formation around the northern and southern sides to the eastern border, where a large part of the formation, which has, moreover, increased in thickness, consists of compact earthy limestones.

The limestones of Trenton age in the counties bordering Cumberland River are particularly promising materials. Coal was formerly boated down from eastern Kentucky mines, and these shipments might be resumed if there was sufficient reason. At present only points in the vicinity of Nashville and Carthage have access to coal brought in by railroads. At each of these places, however, there is such a variety of limestone and shales that it is scarcely to be doubted that abundant materials affording the proper mixture are available.

LEIPERS FORMATION.

Overlying the Catheys limestone is the Leipers formation, which as a rule consists of interbedded shales and thin, knotty, apparently nonmagnesian limestones. It varies considerably in composition from place to place, even in the same outcrop, and on this account is not deemed so promising as most of the underlying Ordovician limestones. The Leipers formation outcrops chiefly in the slopes of the highland rim. It is of Cincinnatian or Upper Ordovician age.

\section{SILURIAN AND DEVONIAN LIMESTONES.}

The Silurian and Devonian rocks of Tennessee embrace three limestone formations containing beds sufficiently low in magnesia to be considered available as Portland cement materials - the Clifton formation of western Tennessee (of Niagara age), the Linden formation of middle and western Tennessee (of Helderberg age), and the Hancock limestone of northeastern Tennessee (of uppermost Silurian and Devonian age). The Clifton and Linden formations outcrop chiefly along Tennessee River, and both, the Linden especially, contain interstratified beds of shale. Locally the Clifton contains beds that are more or less highly argillaceous. These argillaceous limestones occur principally in the lower part of the formation. Locally, as in the bluffs opposite Centerville, in Hickman County, they may afford material suitable for so-called natural Portland cements.

\section{MISSISSIPPIAN LIMESTONES.}

Nonmagnesian limestones occur in three Mississippian formations in Tennessee. The lowest of these is the Fort Payne formation, in which the limestones are prevailingly very siliceous and cherty and for this reason are probably not of importance in this connection. The 
principal outcrops of the Fort Payne form the barrens of the highland rim and occur in the counties immediately surrounding the central basin and in the east side of the Cumberland plateau as far north as Pickett County.

In western Tennessee the next division is the St. Louis limestone, a large outcrop of which covers the greater parts of Robertson, Montgomery, and Stewart counties and extends into adjoining counties in southwestern Kentucky. The St. Louis limestone is from 200 to 300 feet thick and consists mainly of gray and blue, thick-bedded, cherty limestone. Near its base, however, especially in Montgomery County, it commonly includes many beds of high-grade limestone, some of which are underlain by oolitic and semioolitic limestone regarded as of the same age as the Spergen limestone of Indiana. The Chester group, which normally occurs above the St. Louis limestone, is not present in western Tennessee.

In eastern Tennessee the Mississippian rocks above the Fort Payne chert are divided into the Pennington shale at the top and a limestone formation below. To the north the latter is called Newman limestone, having been traced from the Newman area in southwestern Virginia, and to the south is called Bangor limestone, being there continuous with the Bangor limestone of Alabama. The limestones in the Pennington are generally local; very little limestone appearing in the formation. The Newman limestone covers the higher points of the highland rim and forms the surface rock over a wide belt of country along the western base of the Cumberland tableland. Livingston, Sparta, Cookeville, and McMinnville are among the towns on this belt.

\section{PORTLAND CEMENT INDUSTRY.}

In 1911 Tennessee had two Portland cement plants in operationthat of the Dixie Portland Cement Co., at Richard City, near South Pittsburg, and that of the Clinchfield Portland Cement Co. at Kingsport. The former plant, which has been in operation for five years, uses a mixture of limestone and shale, both obtained from the Bangor limestone of the Mississippian.

\section{PORTLAND CEMENT RESOURCES OF TEXAS.}

Three papers are given below on Portland cement materials in Texas: The first, by J.A. Taff, is a general discussion of the limestones of the State; the second, by E. F. Burchard, and the third, by G. B. Richardson, on cement materials near Austin and near El Paso, respectively, are more detailed discussions of the resources of smaller areas. In all three certain verbal changes have been made since their earlier publication. 


\section{PORTLAND CEMENT MATERIALS.}

State at large.

By J. A. TAFF.

GEOLOGIC OCCURRENCES.

Several limestone formations occur in the Carboniferous and older Paleozoic rocks in north-central Texas and in the Trans-Pecos region, and one has been found near the base of the Tertiary in Limestone County. These limestones may prove to be adapted to the production of certain classes of cement, but their constituents have not been determined.

Of the many limestone formations in the geologic column of Texas those of widest extent and greatest purity, and therefore those best adapted for use in making Portland cement, are of Cretaceous age.

The Cretaceous of Texas occurs in a wide belt of country, extending across the central part of the State in a north-south direction from Red River to the Rio Grande. It makes the most fertile lands in the most densely populated portion of the State. The cities of Sherman, Dallas, Fort Worth, Waco, Austin, and San Antonio are built upon it. Facilities of transportation are ample, for railroads extend from the principal cities to other centers of population in the State and beyond.

Two divisions of the Cretaceous system contain limestone deposits of remarkable purity that are well adapted to the manufacture of Portland cement. These are the Austin chalk and the limestones of the Fredericksburg group (Goodland limestone to the north and Edwards limestone and Comanche Peak limestone to the south).

\section{AUSTIN CHALK.}

The Austin ehalk is in the lower part of the Gulf series (Upper Cretaceous). (See Pl. XVIII.) From Red River, near the northeast corner of the State, its outcrop bears westward, passing near Clarksville, Honeygrove, and Paris, to Sherman. From Sherman its course bears southwestward beneath Dallas, Waco, Austin, San Antonio, and numerous smaller cities. From San Antonio its course westward parallels the line of the Southern Pacific Co. to the Rio Grande near Del Rio.

The rock is a massive white friable limestone or chalk. Through several hundred feet from a horizon near the base to the top it carries from 70 to 90 per cent of carbonate of lime. Massive beds many feet thick are remarkably uniform in texture and composition. 
Analyses of Austin chalk and Taylor marl.

\begin{tabular}{|c|c|c|c|c|c|c|c|c|}
\hline & 1 & 2 & 3 & 4 & 5 & 6 & 7 & 8 \\
\hline $\begin{array}{l}\text { Silica }\left(\mathrm{SiO}_{2}\right) \text { and insoluble } \ldots \ldots \ldots \\
\text { Ferric oxide and alumina }\left(\mathrm{Fe}_{2} \mathrm{O}_{3} \text { and } \mathrm{Al}_{2} \mathrm{O}_{3}\right) \\
\text { Lime }(\mathrm{CaO})\end{array}$ & $\begin{array}{r}5.77 \\
2.14 \\
50.45\end{array}$ & $\begin{array}{r}5.94 \\
1.72 \\
48.73\end{array}$ & $\begin{array}{r}10.32 \\
6.56 \\
45.30\end{array}$ & $\begin{array}{r}11.31 \\
7.50 \\
42.61\end{array}$ & $\begin{array}{r}15.98 \\
8.47 \\
38.86\end{array}$ & $\begin{array}{l}48.02 \\
20.95 \\
14.26\end{array}$ & $\begin{array}{r}60.82 \\
21.30 \\
3.66\end{array}$ & $\begin{array}{r}23.55 \\
1.50 \\
39.32\end{array}$ \\
\hline 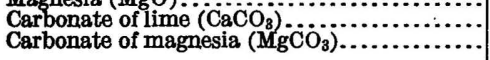 & $\begin{array}{r}90.15 \\
.58\end{array}$ & $\begin{array}{ll}3 \ldots .57 \\
86 . . .\end{array}$ & 79.75 & 76.47 & 70.60 & $\because \dddot{24.62}$ & $\dddot{6} .31$ & $\begin{array}{r}70.21 \\
.58\end{array}$ \\
\hline
\end{tabular}

1. Fresh rock from quarry, average material used in the manufacture of cement, Alamo Cement Works, 3 miles north of San Antonio, Tex.

2. Brushy Creek, Williamson County, Tex., 100 feet above base of chalk.

3. Brushy Creek, Williamson County, Tex., middle part of chalk.

4. Brushy Creek, Williamson County, Tex, upper part of chalk.

5. San Gabriel River, Williamson County, Tex., chalk marl at top of white chalk.

6. Williamson County, Tex., lower part of blue marl above the white chalk.

7. Williamson County, Tex, greensand mari, central part above blue marl.

8. Average fresh rock from quarry, Texas Portland Cement Works, 3 miles west of Dallas, Tex., lower 20 feet of white chalk.

Near Red River, east of Sherman, the chalk probably does not exceed 400 feet in thickness. It is interbedded with chalk marls but contains some thick beds of nearly pure chalk. Between Sherman and Austin the formation is approximately 600 feet thick and is generally uniform in texture and composition. From Austin southwestward the chalk probably increases in thickness, but it is broken and in part concealed by faulting.

The chalk is in contact with clay marls both above and below. It grades upward into chalk marl, which in turn is followed by limy clay, bringing into close relations all the elements essential to the production of Portland cement.

The Austin chalk is structurally, well situated for quarrying. East of Sherman it dips south and south of Sherman it dips southeast at approximately 40 feet per mile.

\section{FREDERICKSBURG GROUP.}

The limestones of the Fredericksburg group outcrop west of and generally parallel to the outcrop of the Austin chalk. To the north the group is represented by the Goodland limestone, a massive, semicrystalline white limestone 30 to 50 feet thick, which crops out in southern Oklahoma east of Ardmore. Near Ardmore the outcrop turns southward, crossing into Texas in Cooke County. From Brazos River southward the limestones gradually increase in thickness, reaching 300 feet on Colorado River. To the south the limestones of the group are represented by the Edwards limestone and the Comanche Peak limestone. The limestones of this group occur in large areas in Wise, Parker, Hood, Erath, Bosque, Hamilton, Coryell, Lampasas, Burnet, Blanco, Kendall, Comal, and Bexar counties. Still larger areas are exposed in the Edwards Plateau west of San Antonio. 


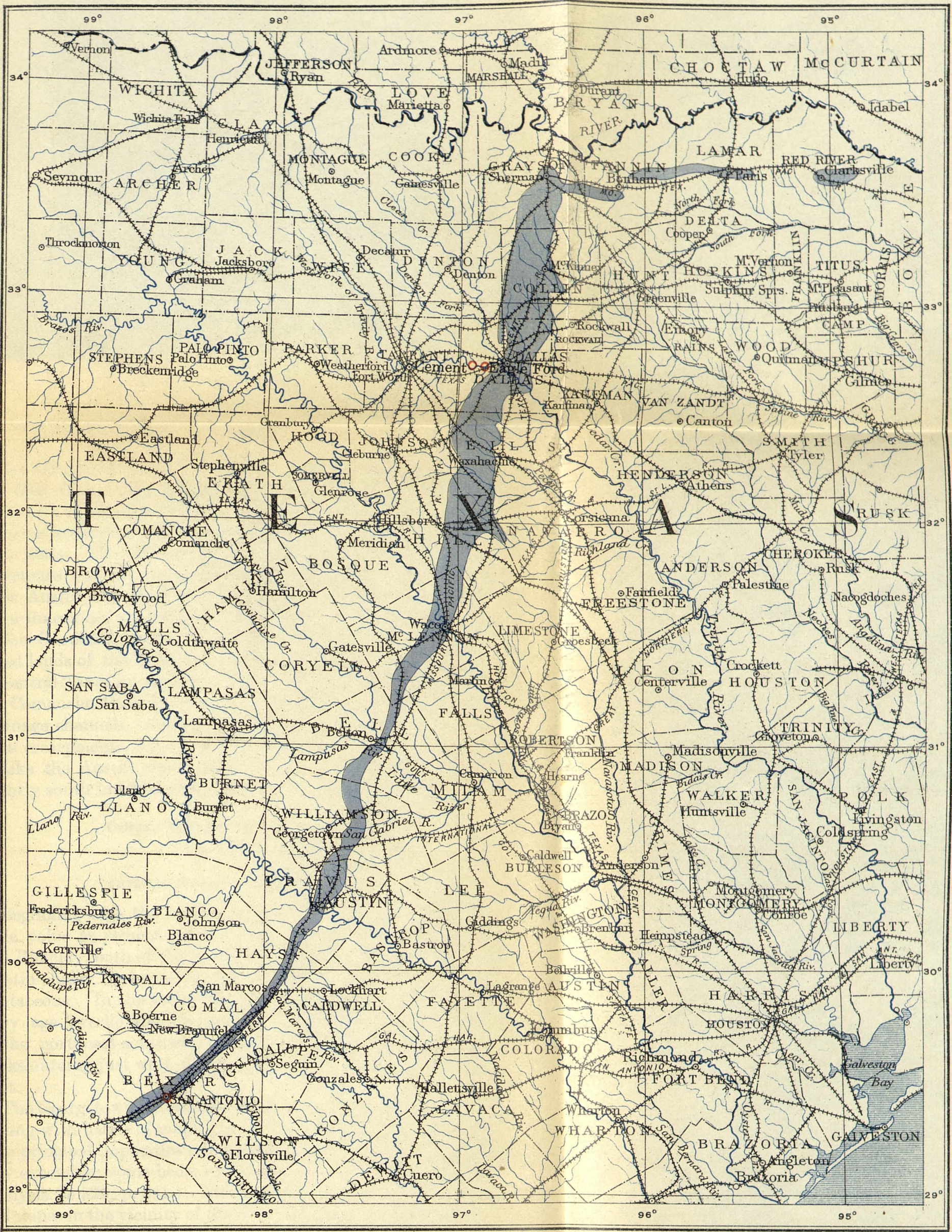

MAP OF PART OF EASTERN TEXAS

SHOWING DISTRIBUTION OF LIMESTONE.SUITABLE FOR PORTLAND CEMENT

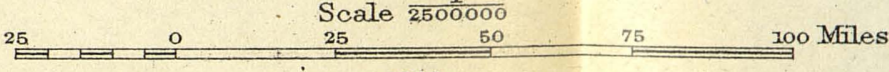



The Comanche Peak is a massive white chalky limestone nearly 100 feet thick. The Edwards limestone, the upper of the two, is composed of an alternation of thick beds of nearly pure chalk and siliceous limestone beds containing quantities of nodular and almost pure flints. The flints occur in both the chalky and the siliceous limestones but are rather more abundant in the pure limestones. Near Austin and elsewhere in the central part of the State these purer limestones are manufactured into a high grade of white lime.

The Goodland limestone caps escarpments overlooking the timbered lands of the Trinity sand in northern Texas and in Oklahoma. In central Texas its southern equivalents- the Edwards limestone and the Comanche Peak limestone-occur in a region of strongly incised drainage channels, where they cap local table-lands in the west and form escarpments, bluffs, and lowlands in the east.

Like the Austin chalk, these limestones lie almost flat, dipping slightly south in Oklahoma and slightly east and southeast in Texas.

\section{Cement material in the vicinity of Austin.}

By E. F. Burchard.

PHYSICAL CHARACTER OF CEMENT MATERIALS.

Beginning with the lowest formation the rocks considered of possible value as cement materials are the Georgetown limestone and Del Rio clay, both of the Lower Cretaceous, and the Eagle Ford clay, Austin chalk, Taylor marl, and Webberville formation of the Upper Cretaceous. In the valley of Colorado River terrace silts of Quaternary age overlie the Cretaceous unconformably. The formations strike northeast-southwest and dip gently southeast. The oldest rocks outcrop just west of Austin, the later ones overlapping from the east.

The Georgetown limestone consists of impure white limestone alternating with bands of marly clay. Its total thickness is 65 to 70 feet. The principal impurities are silica and alumina, which are not generally excessive; some beds, however, carry too much magnesia. (See analysis Se 329, p. 341.) This limestone outcrops in low bluffs and hill slopes in the vicinity of the old cement works northwest of Austin.

The Del Rio consists of greenish-blue laminated unctuous clay which weathers brown or yellow. It is rather fossiliferous, containing many seams of calcareous shells, which in places have reacted with ferrous sulphate and formed selenite crystals. This clay lies upon the Georgetown limestone. Its thickness is 80 to 100 feet, but the whole thickness rarely remains except where the clay is protected by the overlying Buda limestone. The outcrop areas of both the $48834^{\circ}-$ Bull. $522-13-22$ 
Georgetown and the Del Rio formations are narrow. As shown by the analyses (Cy 15 to Cy 25, p. 341), the Del Rio clay is generally rather low in silica as compared to the percentage of iron and alumina, and it also runs high in lime. The best sample of Del Rio clay appears to be $\mathrm{Cy} 32$.

The Eagle Ford clay is composed of laminated bituminous clays, shales, and flaggy limestone. It outcrops in narrow areas northwest of a line drawn northeast-southwest through the middle of Austin, and is commonly exposed in low bluffs below a cap of Austin chalk. The total thickness of the Eagle Ford is about 50 feet in the vicinity of Austin. The composition, as shown by analyses Se 361, 364, and 365 , approaches that of natural cement rock rather than that of true shale.

The Austim chalk is described on pages 335-336. Analyses Se 335 to 363 indicate that it runs uniformly and moderately high in lime and low in magnesia. The silica is generally in moderate amounts, not too high for the alumina and iron oxide.

Overlying the Austin chalk and occupying an outcrop area 3 to 6 miles wide east of the chalk area is more than 500 feet of calcareous joint clay or marl known as the Taylor marl. When fresh the beds consist of fine-grained, tough, unctuous blue clay, which quickly becomes laminated and changes to yellow on weathering. The material, as shown by analyses Misc. 80 and 81 , is neither a cement rock nor a good limestone, although it would not require the addition of a large proportion of limestone to bring it to the composition of a cement mixture.

Next above the Taylor marl is the Webberville formation, which is composed of clay marls with greenish glauconite grains and of black shaly clay with arenaceous layers. Analyses of clay from the Webberville are shown as Cy 26, 27, and 28. This clay is not very uniform in composition, but in places material fairly high in silica may be found (Cy 27).

The terrace silt from the south bank of Colorado River is used for making brick at two places. It is calcareous, although less so than most of the so-called shales and clays of the vicinity. Analyses Cy 30 and 31 show, respectively, a rich clay, used for making dry-pressed face brick, and a loamy clay, used for making soft-mud sand-mold brick.

It is of interest to note that at Dallas, Tex., good Portland cement is being made from the Austin chalk mixed with Eagle Ford clay, and that at San Antonio Austin chalk is also in use for natural and Portland cements. (See analyses, p: 343.) Austin, an intermediate point on the outcrop of these widespread formations, would thus appear to be favorably situated with respect to these important raw materials. 
CHEMICAL COMPOSITION.

Some years ago cement was made at Austin on a small scale in a vertical kiln from the Georgetown limestone and the Del Rio clay, rocks stratigraphically lower than the Austin chalk. An analysis of seasoned clinker from this kiln (No. 4 of the following table) corresponds closely with the average analysis of 10 samples of a mixture of 7 standard Portland cements (No. 5 of the table). In 1904 analyses and clinkering tests of limestone and clay from the properties of the Austin Portland Cement Manufacturing Co. were made at the laboratories of a large Portland cement company in the North. For purposes of comparison the following analyses are given:

Analyses of raw materials and manufactured cement from Austin, Tex. ${ }^{a}$

\begin{tabular}{|c|c|c|c|c|c|}
\hline & 1 & 2 & 3 & 4 & 5 \\
\hline 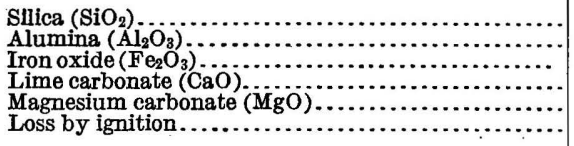 & $\begin{array}{r}5.90 \\
2.90 \\
.72 \\
49.70 \\
.20 \\
40.34\end{array}$ & $\begin{array}{r}41.68 \\
16.51 \\
2.89 \\
17.10 \\
.20 \\
19.14\end{array}$ & $\begin{array}{r}20.99 \\
8.81 \\
1.60 \\
68.31 \\
.20\end{array}$ & $\begin{array}{r}21.44 \\
8.52 \\
3.15 \\
59.44 \\
.36 \\
4.09\end{array}$ & $\begin{array}{r}22.01 \\
6.78 \\
3.21 \\
62.74 \\
2.64\end{array}$ \\
\hline
\end{tabular}

a Analyses 1-3 made at the laboratory of a working Portland cement plant. Reported by owners.

1. Georgetown limestone.

2. Del Rio clay.

3. Resulting cement.

4. Old cement clinker. Analysis made at the laboratory of the U. S. Geol. Survey, St. Louis, Mo.

5. Typical cement mixture, published for purposes of comparison.

For the kiln test the limestone (1) and clay (2) were mixed in the proportion of about 3.9 to 1 , ground wet to such fineness that practically all the mixture passed a 200-mesh sieve. The mix was dried and burned in a test kiln with gas fuel. The clinker was well sintered and dense and after being finely ground yielded a gray cement having good hardening properties. The results of some of the physical tests were as follows:

Results of physical tests on cement yielded by kiln test on mixed Georgetown limestone and Del Rio clay.

Time of set: Initial, three and one-half hours; final, seven hours.

Specific gravity: 3.12 .

Fineness: Passed 100-mesh, 99 per cent; passed 200-mesh, 88 per cent.

Tensile strength, neat: Seven days, 655 to 805 ; 28 days, 882; one year, 665 pounds per square inch.

Tensile strength, 1:3 sand: Seven days, 425 to 460 ; 28 days, 471 ; one year, 375 pounds per square inch.

To be of value for the manufacture of Portland cement shales should contain silica in the proportion of not less than twice nor more than three times the alumina plus the iron oxide; some manufacturers report best results when the ratio $\frac{\mathrm{SiO}_{2}}{\mathrm{Al}_{2} \mathrm{O}_{3}+\mathrm{Fe}_{2} \mathrm{O}_{3}}$ is betwcen 2.5 and 3 . 
Inspection of the analyses of all the clays and shales in the table on page 341 shows that in not one of the Del Rio clay samples does this ratio reach as high as 2.5 , and in some samples the ratio is less than 2. Only one out of the 20 clays (Cy 28) gives a ratio between 2.5 and 3, although two others (Cy 27 and $\mathrm{Cy} 32$ ) come close to 2.5. It is evident that these clays should be used with limestones carrying enough silica to make up for its lack in the shale. Possibly the necessary silica might be supplied from certain of the more highly siliceous beds in the Georgetown limestorie and the Austin chalk. It should be noted that analyses Se 328 and Se 329 show more than the maximum allowable limit of magnesia $(\mathrm{MgO})$, which is generally considered to be 3 per cent. The Austin chalk runs generally higher in lime than the Georgetown limestone and is uniformly low in magnesia. The Eagle Ford clay, according to the analyses, appears to be nearly a natural cement rock, which would require the addition of only a small proportion of high-calcium limestone to make a Portland cement mixture. The Taylor marl is rather high in lime and low in silica, as are most of the samples of Del Rio clay and clay from the Webberville formation. The two terrace clays give ratios much higher than the maximum limit. Se 31 shows a very high percentage of silica, but the writer is not informed as to how much of this is free silica, a very objectionable material. The proportion of alumina and iron oxide is much too low to give promise as a cement material, and the fact that it is so low suggests that a large proportion of the silica does occur in a free state. Attention should be called to the analyses $\mathrm{Cy} 32$ and $\mathrm{Cy} 27$, which seem to have been made upon the most promising clays in the whole series.

The results of a number of chemical analyses of limestone, clay, etc., from the vicinity of Austin, Tex., are given in the first table below. They were made by P. H. Bates and A. J. Phillips at the laboratories of the United States Geological Survey in St. Louis in 1908 on representative samples of material ranging generally from 20 to 50 pounds in weight, and are part of a series of tests that were planned for the promising deposits of undeveloped cement-making materials of the United States. It was planned to make kiln tests on the raw materials, to experiment with certain fuels, including lignite and producer gas, to grind the clinker, and to make the usual physical tests on the resulting cement, but lack of necessary funds prevented. The second table (p. 343) contains analyses of rocks from Dallas and San Antonio, Tex., used for making Portland cement, as well as analyses of the clinker and fresh cement made at Dallas. These data are inserted for purposes of comparison. 
Analyses of rocks from vicinity of Austin, Tex., possibly of value for making Portland cement.

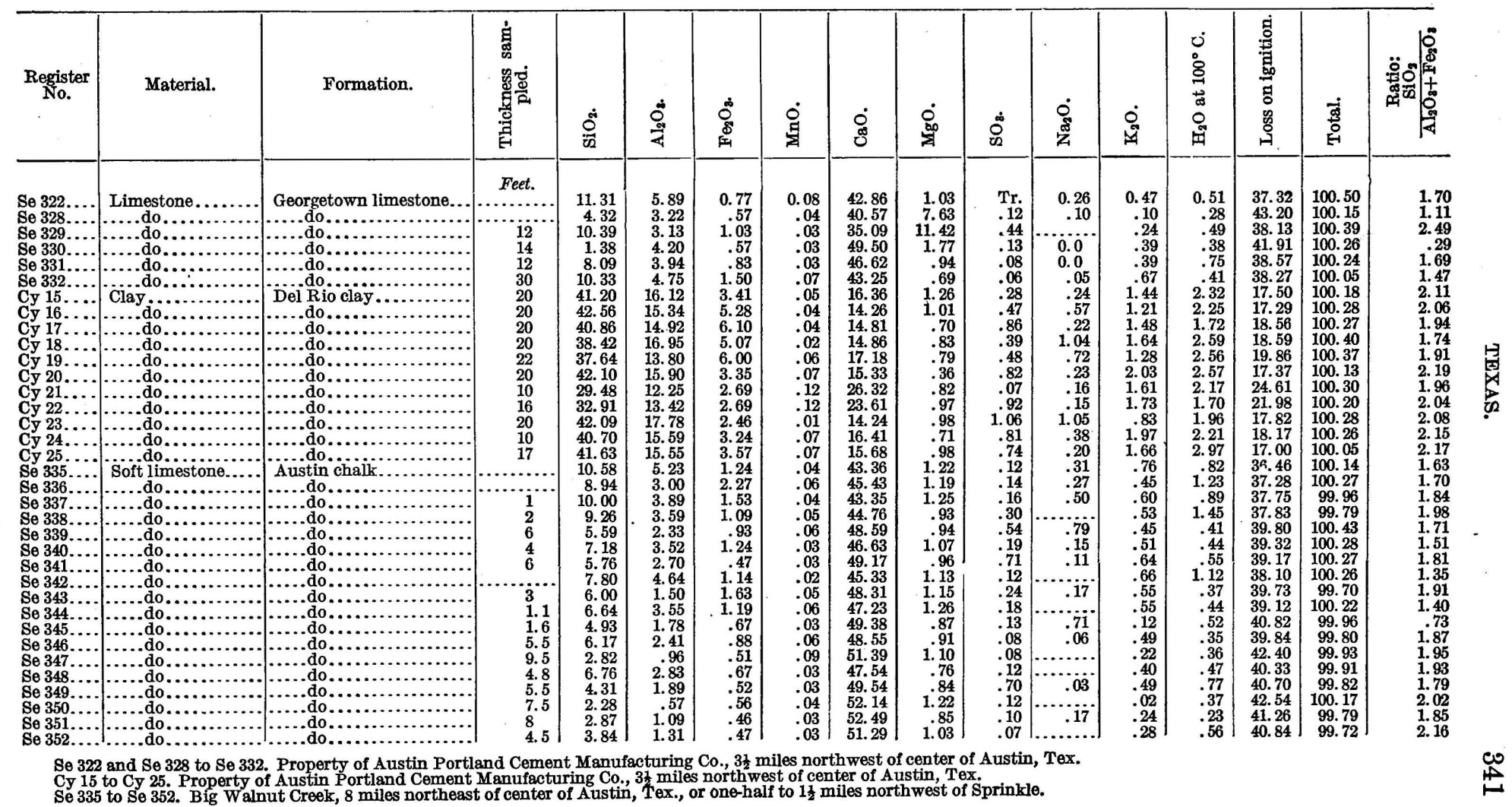


Analyses of rocks from vicinity of Austin, Tex., possibly of value for making Portland cement-Continued.

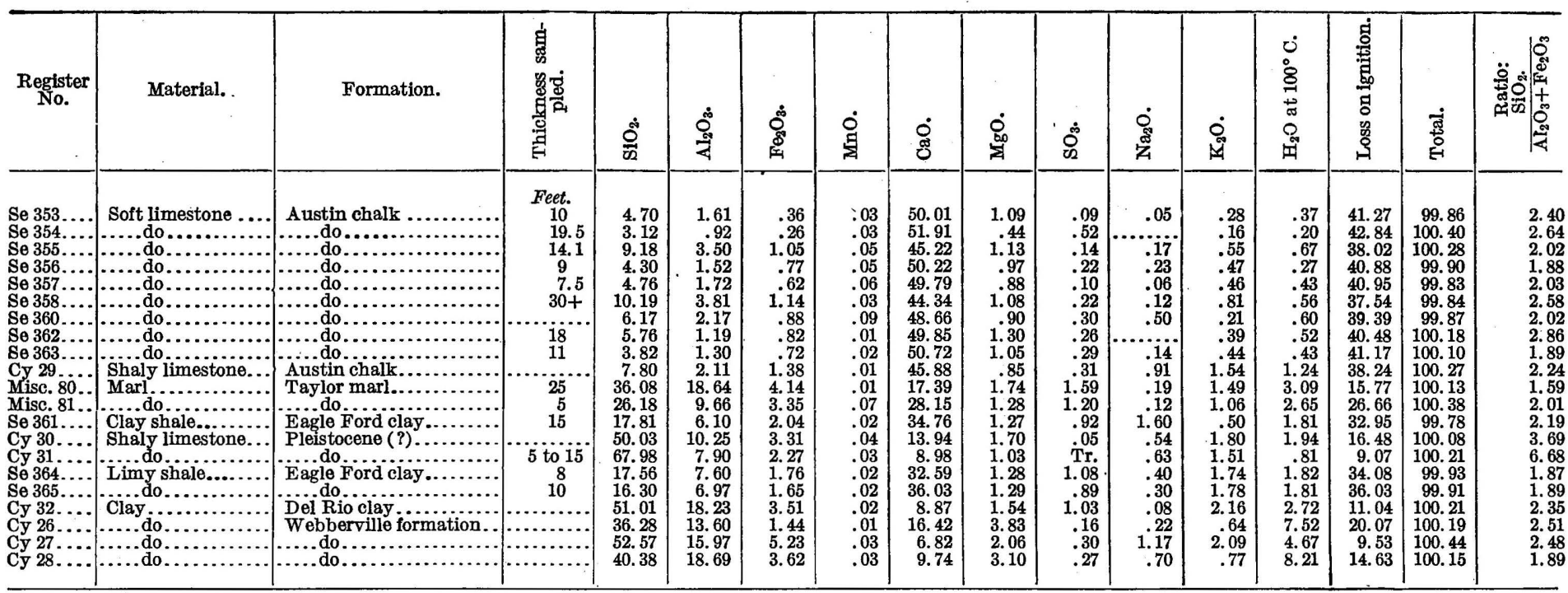

Se 353 to Se 358. Big Walnut Creek, 8 miles northeast of center of Austin, Tex., or one-half to $1 \frac{1}{2}$ miles northwest of Sprinkle.

$\mathrm{Se} 360$. Big Walnut Creek, 9 miles northeast of center of Austin, Tex.

$\mathrm{Se}$ 362. Lower 18 feet of ledge, near mouth of small creek emptying into south side of Colorado River, three-fourths mile below concrete bridge.

Se 363. Top 10 or 12 feet of ledge, near mouth of small creek emptying into south side of Colorado River, three-fourths mile below concrete bridge.

Misc. 80. East bank of Big Walnut Creek, 2 miles below Sprinkle, or $6 \frac{1}{2}$ miles northeast of Austin, Tex.

Misc. 81. Wagon road on hill just west of Little Walnut Creek, $4 \frac{1}{2}$ miles northeast of Austin, Tex., or 1 mile north of Pecan Springs.

Cy 29. Partings from top and middle of 18 -foot ledge, near mouth of small creek emptying into south side of Colorado River, three-fourths mile below concrete bridge. Cy 30. Heavy calcareous clay used in making dry-pressed brick at Butler's brickyard, south side of Colorado River, near International \& Great Northern Railroad.

Cy 31. Light loamy clay used in making sand-mold brick at Butler's brickyard, south side of Colorado River, near International \& Great Northern Railroad. $\mathrm{Se}$ 364. Eight feet of beds below middle of Eagle Ford clay, from bluff of small creek near International \& Great Northern Railroad 1 mile south of Colorado River. Se 365. Upper 10 feet of Eagle Ford clay, from bluff near International \& Great Northern Railroad, 1 mile south of Colorado River.

Cy 32. Bluff of Barton Creek, one-third mile above its mouth, sampled above and below wagon road, near bridge.

Cy. 28. Moores Branch of Onion Creek, 9 miles southeast of Austin, Tex. 
Analyses of rocks from Dallas and San Antonio, Tex., used for making Portland cement. ${ }^{a}$

\begin{tabular}{|c|c|c|c|c|c|c|c|c|c|c|c|c|c|c|c|c|}
\hline $\begin{array}{l}\text { Register } \\
\text { No. }\end{array}$ & Material. & Formation. & 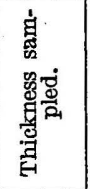 & 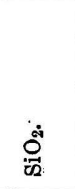 & 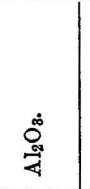 & 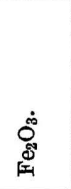 & 音 & Ö & 品 & 品 & ०ू & \%ั. & 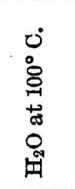 & 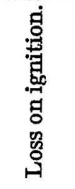 & 票 & 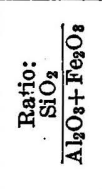 \\
\hline Se $376 \ldots .$. & Limestone (soft)....... & Austin chalk...... & $\begin{array}{r}\text { Feet. } \\
25 \\
15-20\end{array}$ & 6.54 & $\begin{array}{l}3.22 \\
4.59\end{array}$ & 2.12 & 0.04 & $\begin{array}{l}46.72 \\
44.44\end{array}$ & 0.61 & 0.55 & $\begin{array}{l}0.38 \\
74\end{array}$ & 0.59 & 0.49 & $\begin{array}{l}38.64 \\
36.80\end{array}$ & 99.90 & \\
\hline $\begin{array}{l}\text { Se } 377 \ldots . . \\
\text { D } 1 \ldots \ldots\end{array}$ & 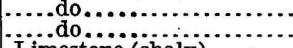 & 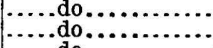 & $\begin{array}{c}15-20 \\
\ldots \ldots \ldots\end{array}$ & $\begin{array}{r}9.08 \\
3.64\end{array}$ & $\begin{array}{r}4.59 \\
2.4\end{array}$ & 2.2 & .11 & $\begin{array}{l}44.44 \\
50.92\end{array}$ & $\begin{array}{l}.62 \\
.46\end{array}$ & $\begin{array}{l}.07 \\
. .67\end{array}$ & .74 & .72 & .38 & $\begin{array}{l}36.80 \\
42.10\end{array}$ & 99.78 & $\begin{array}{l}1.33 \\
1.50\end{array}$ \\
\hline $\begin{array}{l}\mathrm{D} 2 \\
\mathrm{D} 3 \ldots \ldots\end{array}$ & $\begin{array}{l}\text { Limestone }(\text { shaly) ........... } \\
\text { Limestone (soft) } \ldots \ldots \ldots\end{array}$ & $\mid \ldots$. do............... & …...... & $\begin{array}{r}12.78 \\
3.74\end{array}$ & $\begin{array}{l}8.2 \\
2.7\end{array}$ & & $\cdots \cdots$ & $\begin{array}{l}40.22 \\
51.11\end{array}$ & .91 & $\begin{array}{l}b .68 \\
b .10\end{array}$ & $\cdots \cdots$ & $\cdots$ & $\therefore .$. & $\begin{array}{l}36.26 \\
44.70\end{array}$ & $\cdots$ & $\begin{array}{l}1.55 \\
1.36\end{array}$ \\
\hline D 4 & ..... & & & $\begin{array}{l}0.14 \\
12.70\end{array}$ & 8.5 & & $\cdots$ & $\begin{array}{l}51.11 \\
41.33\end{array}$ & $\begin{array}{l}.58 \\
.62\end{array}$ & $\begin{array}{l}0.10 \\
b .10\end{array}$ & $\ldots$ & & & $\begin{array}{l}44.70 \\
36.02\end{array}$ & & $\begin{array}{l}1.36 \\
1.48\end{array}$ \\
\hline Se $378 \ldots$ & Shale (top beds)... & Eagle Ford clay... & $8-10$ & 45.07 & 15.78 & 4. 92 & .02 & 7.98 & 1.18 & 9.71 & 08 & 1.70 & 6.51 & 6.89 & 99.84 & 2.23 \\
\hline $\begin{array}{l}\text { Se } 379 \\
\text { D } 5 . .\end{array}$ & Shale (top beds)..... & 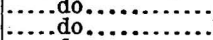 & 23 & $\begin{array}{l}56.71 \\
64.71\end{array}$ & $\begin{array}{l}19.74 \\
20.80\end{array}$ & $\begin{array}{l}5.74 \\
4.15\end{array}$ & .02 & $\begin{array}{l}1.28 \\
1.00\end{array}$ & $\begin{array}{r}1.91 \\
.31\end{array}$ & $\begin{array}{l}.25 \\
b .72\end{array}$ & .36 & 1.67 & 4.00 & $\begin{array}{l}8.62 \\
6.67\end{array}$ & 100.30 & $\begin{array}{l}2.53 \\
2.59\end{array}$ \\
\hline 6 & Shale (bottom) & .....do & ….... & 5774 & 21.49 & 7.05 & $\cdots$ & 1.66 & 2.47 & $b 1.27$ & (n...... & $\cdots$ & (n) & 8.11 & {$[\cdots \cdots \cdot$} & 2.02 \\
\hline D 7. & 1).... & $\ldots \ldots .0$ & & 60.09 & 22 & & & 2.80 & & b. 31 & & & & 12.35 & & 2.70 \\
\hline & (clinker). & & ..... & 21.82 & 11.27 & 2.59 & .06 & 62.36 & .50 & .03 & .16 & .49 & .02 & .90 & 100.20 & $\cdots$ \\
\hline SA $1 .$. & $\begin{array}{l}\text { Fresh Portland cement } \\
\text { Limestone (soft, weath- }\end{array}$ & Austin chalk. & $3-5$ & $\begin{array}{l}21.05 \\
20.09\end{array}$ & $\begin{array}{l}9.90 \\
2.40\end{array}$ & $\begin{array}{l}1.91 \\
1.20\end{array}$ & .1 & $\begin{array}{l}02.78 \\
40.82\end{array}$ & .8 & $\begin{array}{l}1.70 \\
b .07\end{array}$ & .08 & & 10 & 1.20 & & 5. \\
\hline & limestone (soft, fresh). & ......do & $3-5$ & 22.90 & 1.70 & 0.70 & & 40.77 & & b 2.10 & 2. & & & & & 9.54 \\
\hline A & $\begin{array}{l}\text { Limest } \\
. . . . \text { do }\end{array}$ & …do....... & $\underset{3-5}{20+}$ & $\begin{array}{l}16.50 \\
22.1\end{array}$ & $\begin{array}{r}6.10 ! \\
2.9\end{array}$ & 1 & & $\begin{array}{l}44.31 \\
40.82\end{array}$ & ........ & $\cdots$ & & & & & & $\begin{array}{l}2.32 \\
7.62\end{array}$ \\
\hline
\end{tabular}

a Analyses Se 376 to Se 379 and Ct 711a and Ct 711b by R. H. Bates and A. J. Phillips, U. S. Geol. Survey laboratories, St. Louis, Mo., 1908; D 1 to D 8 made at laboratory of Texas Portland Cement Co., Dallas, Tex.; SA 1 to SA 4 made at laboratory of Alamo Cement Co., San Antonio, Tex.

Se 376, Se 377, D 1 to D 4, Se 378, Se 379, D 5, D 6, D 7, from quarry of Texas Portland Cement Co., near Dallas, Tex.

Ct 711a, Ct 711b, from new mill of Texas Portland Cement Co., Dallas, Tex., March, 1908. 
ECONOMIC RELATIONS.

For the economical operation of a Portland cement plant in this vicinity operating costs must be kept as low as possible in order to compete with established plants at Dallas, San Antonio, and El Paso, Tex., and also to compete occasionally with eastern cements brought by water to Galveston and with cements imported from Germany. It is therefore probably out of the question to consider collecting the limestone and shale from separated localities, although in this way the most suitable combinations of materials might be obtained. The problem resolves itself into one of finding suitable materials adjacent to each other, and of course the more favorably situated with regard to transportation facilities the better. The most logical combinations of adjacent formations are Georgetown and Del Rio, Austin and Eagle Ford, and Austin and Taylor. If combinations of materials from any two of these formations are found, on further test, to make good Portland cement, there should be no difficulty in finding ideal manufacturing sites in the vicinity of Austin. All the materials are comparatively soft and it should be possible to grind them very finely without great expenditure of power. Petroleum is the fuel that would probably be most suitable and available in this region. The limestone, clay, and shale that have been mentioned occur in abundant quantities in the region. Their distribution is shown in detail in the Austin geologic folio. ${ }^{1}$

\section{Cement material near El Paso.}

By G. B. RiCHARDDSON.

The considerable cost of Portland cement at El Paso, Tex., owing to its distance from the nearest plant, and the fact that this rapidly growing city is the commercial center of a large area, cause the local presence of the raw materials for making cement to be a matter of importance.

GEOLOGY. ${ }^{2}$

The city of $\mathrm{El}$ Paso is situated in the Rio Grande valley, at the mouth of a narrow gap cut by the river between the Mesilla Valley and the Hueco Bolson. The Franklin Mountains lie east of the gap and the Cerro de Muleros west of it. The Franklin Mountains are composed of sedimentary and igneous rocks which range in age from Cambrian to Cretaceous. The strata dip steeply westward, and the mountains as a whole have the general characteristics of a Basin Range block, but they differ from the type by being complexly faulted internally. The Cerro de Muleros is a laccolithic mountain

1 Austin tolio (No. 76), Geol. Atlas U. S., U. S. Geol. Survey, 1902.

${ }^{2}$ See also Richardson, G. B., Reconnaissance in trans-Pecos Texas: Bull. Univ. Texas Mineral Survey No. 9, 1904. 
with a porphyry core flanked by Cretaceous sediments. This mountain also has been much faulted, especially contiguous to the pass through which the Rio Grande flows. The bolson deposits, like the flood plain of the river, consist of gravel, sand, and clay. Limestones are abundantly developed in the Franklin Mountains and both limestone and shale are present in the Cerro de Muleros and in outlying hills between the two mountains.

CLAYS.

The clay materials can be classed as bolson clay, flood-plain clay, and shale. The bolson clays are extremely irregular in their occurrence. They are locally exposed in the terraces above the river and have been found as lenses in numerous wells sunk in the Hueco Bolson. As yet none of these deposits have been developed.

Flood-plain clay occurs in several localities in the Rio Grande valley near El Paso. The material, derived from rocks that outcrop higher up in the drainage area of the river, has been brought down and deposited by the stream. In this manner deposits of clay intercalated with sand and gravel have accumulated, the mode of origin causing the deposits to be of irregular extent and composition. The beds range in thickness from a few inches to many feet, and in character from a rather pure clay to one containing large admixtures of sand. More or less organic matter also is usually present. The analysis of clay from Whites Spur, about 10 miles north of El Paso (p. 346), shows the composition of what is perhaps a typical sample of flood-plain clay. This clay is manufactured into common wirecut brick at several plants in the valley-at Vinton and Whites Spur, above El Paso, and at others below the city. The product is of fairly good grade, and several million bricks from this source are made yearly. Adobe bricks, made of sun-dried flood-plain clays, are manufactured extensively by the Mexican inhabitants of the Rio Grande valley and are used in the construction of their picturesque buildings.

The deposits of shale are more important for cement making than the flood-plain clays because of their uniform texture and general freedom from coarse particles. The blue-gray clay shale of Lower Cretaceous age is interbedded with sandstone and limestone on the flanks of the Cerro de Muleros, is well exposed in the pass along the west bank of the Rio Grande, and occurs in small areas east of the river. The composition of four samples is shown by the accompanying analyses. The figures indicate considerable variation, silica, ranging from 49.08 to 75.15 per cent, alumina from 10.90 to 20.71 per cent, and lime from 0.66 to 13.56 per cent. The analyses, except of No. 3, which contains too much silica and relatively too much aluminum and iron, show that the shale is well adapted for making 
cement. More tests are desirable to determine the extent of the different grades.

Analyses of shale, clay, and limestone from the vicinity of El Paso, Tex.

[Fusion of air-dried material. Analyst, P. H. Bates, U. S. Geol. Survey fuels and structural materials testing laboratory.]

\begin{tabular}{|c|c|c|c|c|c|c|}
\hline & 1 & 2 & 3 & 4 & 5 & 6 \\
\hline 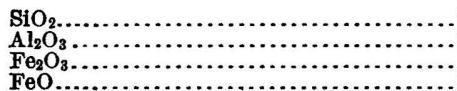 & $\begin{array}{r}49.08 \\
10.90 \\
7.74\end{array}$ & $\begin{array}{r}55.54 \\
15.72 \\
6.96\end{array}$ & $\begin{array}{r}75.15 \\
13.76 \\
2.35\end{array}$ & $\begin{array}{r}58.73 \\
20.71 \\
4.67\end{array}$ & $\begin{array}{r}64.22 \\
14.02 \\
2.16 \\
1.25\end{array}$ & $\begin{array}{r}3.22 \\
.78 \\
.28\end{array}$ \\
\hline 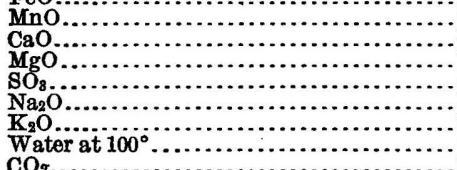 & $\begin{array}{r}13.56 \\
1.36 \\
.22 \\
.20 \\
1.26 \\
1.59\end{array}$ & $\begin{array}{r}.13 \\
4.88 \\
2.43 \\
.28 \\
.51 \\
1.64 \\
2.63\end{array}$ & $\begin{array}{l}.04 \\
.66 \\
.45 \\
.45 \\
.15 \\
.96 \\
.58\end{array}$ & $\begin{array}{r}.05 \\
2.05 \\
1.71 \\
.44 \\
.05 \\
1.70 \\
.80\end{array}$ & \multirow[t]{2}{*}{$\begin{array}{l}4.01 \\
1.84 \\
.10 \\
1.04 \\
2.19 \\
2.30 \\
1.10 \\
5.74\end{array}$} & $\begin{array}{r}.31 \\
52.36 \\
1.01 \\
.12 \\
.00 \\
.11 \\
.16\end{array}$ \\
\hline \multirow[t]{2}{*}{ 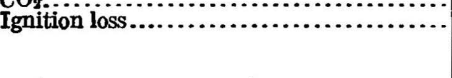 } & 14.37 & 9.25 & 5.48 & 8.91 & & 41.74 \\
\hline & 100.39 & 99.97 & 99.93 & 99.82 & 99.97 & 100.09 \\
\hline
\end{tabular}

1. Shale one-fourth mile south of Courchesne quarry.

2. Shale one-fourth mile north of Courchesne quarry.

3. Shale from El Paso Brick Co.'s property.

4. Shale from El Paso Brick Co.'s property.

5. Flood-plain clay from Whites Spur, 10 miles above El Paso

6. Limestone from Courchesne quarry.

Bricks of excellent quality are made from this shale, three grades being manufactured - pressed brick, common wire-cut brick, and fire brick. Many thousands of the first two grades are made daily, but at present only small quantities of fire brick are manufactured, their chief use being in the brick kilns. An analysis of fire clay (No. 3) shows a small content of fluxing impurities, although the high percentage of silica, 75.15 per cent, indicates only moderate refractoriness.

LIMESTONES.

The limestones of the El Paso region aggregate more than 5,000 feet in thickness and are separable into five formations-Lower Ordovician, Upper Ordovician, Silurian, Carboniferous, and Cretaceous. Without fossil evidence the different limestones can not everywhere be recognized, although each has physical properties peculiar to itself. They are all massive and are in the main gray in color, but some are whitish and others are almost black. Some are more crystalline than others and they coniain variable amounts of chert. A characteristic difference is their content of magnesia, as shown by the following analyses:

Lime and magnesia in limestones from the vicinity of El Paso, Tex.

\begin{tabular}{|c|c|c|c|c|c|}
\hline . & $\begin{array}{c}\text { Lower } \\
\text { Ordovi- } \\
\text { cian. }\end{array}$ & $\begin{array}{l}\text { Upper } \\
\text { Ordovi- } \\
\text { cian. }\end{array}$ & Silurian. & $\begin{array}{l}\text { Carbonif- } \\
\text { erous. }\end{array}$ & $\begin{array}{l}\text { Creta- } \\
\text { ceous. }\end{array}$ \\
\hline$\underset{\text { Magnesia (MgO) }}{\operatorname{Lime}(\mathrm{CaO})}$ & $\begin{array}{l}32.12 \\
16.00\end{array}$ & $\begin{array}{l}30.82 \\
18.01\end{array}$ & $\begin{array}{l}28.77 \\
18.56\end{array}$ & $\begin{array}{r}53.52 \\
.58\end{array}$ & $\begin{array}{r}52.36 \\
1.01\end{array}$ \\
\hline
\end{tabular}


The three older formations contain abundant magnesia, in quantities almost sufficient to constitute the rocks a true dolomite, but the magnesia content of the younger limestones is very small. On account of the high magnesia in the older limestones they are unfit for cement making, but those of Carboniferous and Cretaceous age are well adapted for this purpose.

The distribution of these limestones in general is distinct. The older formations outcrop along the crest and form the "backbone" of the Franklin Mountains. The Carboniferous limestone lies along the northwestern slope of this range and is particularly well developed adjacent to the Texas-New Mexico boundary line. The Cretaceous limestone outcrops along the flanks of the Cerro de Muleros and occurs also in the gorge above El Paso on both sides of the river. The greater accessibility of the Cretaceous limestone and its occurrence near the shale make it probable that this will be first used, in preference to that of Carboniferous age.

Both the magnesian and nonmagnesian limestones are burned for lime in the vicinity of El Paso. For this purpose the Ordovician limestones are quarried at the south end of the Franklin Range and the Cretaceous limestone at the pass above the city. Large quantities of the Cretaceous limestone are also quarried and crushed for use as furnace flux by the smelter in the valley 4 miles above El Paso. The rock is also extensively used for foundations and for road-making macadam.

\section{PORTLAND CEMENT INDUSTRY IN TEXAS.}

In 1911 Texas produced over 1,500,000 barrels of Portiand cement from four plants. One plant, that of the Alamo Cement Co., of San Antonio, is relatively small but has been in operation for many years. The other three plants, those of the Texas Portland Cement Co., of the Southwestern States Portland Cement Co., at Eagle Ford, and that of the Southwestern Portland Cement Co., at El Paso are large and of recent construction. All four plants use Cretaceous limestones for their raw materials. Oil is used as fuel at the plants near Dallas, coal and oil at San Antonio, and coal at El Paso.

\section{BIBLIOGRAPHY.}

Burchard, E. F., Structural materials near Austin, Tex., Bull. U. S. Geol. Survey No. 430, 1910, pp. 309-313.

Richardson, G. B., Portland cement materials near EI Paso, Tex., Bull. U. S. Geol. Survey No. 340, 1908, pp. 411-414. 


\section{PORTIAND CEMENT RESOURCES OF UTAH.}

\section{PORTLAND CEMENT MATERIALS.}

Limestones, generally low in magnesium carbonate, occur in many parts of the Wasatch Mountain area in Utah. Most of these limestones are of Carboniferous age. Many of them contain so much clayey matter as to fall below 75 per cent in lime carbonate, in which case they are to be regarded as approaching in composition the cement rock of the Lehigh district of Pennsylvania. A rock of this type would require the addition of a purer limestone to give it the proper percentage of lime for a Portland cement mixture.

In the plateau district softer limestones, of Eocene and later age, occur.

Analyses of limestones from Utah.

\begin{tabular}{|c|c|c|c|c|c|c|c|c|c|}
\hline & 1 & 2 & 3 & 4 & 5 & 6 & 7 & 8 & 9 \\
\hline 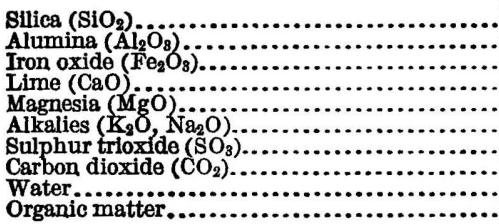 & $\begin{array}{l}0.57 \\
\text { n.d. } \\
55.20 \\
55.22 \\
\text { n. di } \\
\text { n.d. } \\
43.84 \\
\text { n.d. }\end{array}$ & $\begin{array}{r}17.19 \\
\text { n.d. } \\
43.78 \\
.91 \\
\text { n.d. } \\
\text { n.d. } \\
35.40 \\
\text { n.d. }\end{array}$ & $\begin{array}{l}\text { 4. } 33 \\
\text { n.d. } \\
.63 \\
52.34 \\
.60 \\
\text { n.d. } \\
\text { n.d. } \\
\text { 41. } 78 \\
\text { n.d. }\end{array}$ & $\left\{\begin{array}{r}2.37 \\
. .25 \\
53.09 \\
1.20 \\
\text { n.d. } \\
\text { n.d. } \\
42.88 \\
.22\end{array}\right.$ & $\begin{array}{r}27.94 \\
.35 \\
39.54 \\
.29 \\
\text { n. d. } \\
\text { n. d. } \\
31.69 \\
.25\end{array}$ & \begin{tabular}{r|}
13.61 \\
3.72 \\
43.23 \\
2.18 \\
n.d. \\
n. . \\
36.20 \\
1.17 \\
$\ldots . .$.
\end{tabular} & \begin{tabular}{r}
5.89 \\
1.09 \\
42.49 \\
8.50 \\
n.d. \\
\hdashline... \\
n.d. \\
n.d. \\
$\ldots . .$.
\end{tabular} & $\begin{array}{r}4.03 \\
.20 \\
51.33 \\
.72 \\
.63 \\
.89 \\
41.07 \\
.83 \\
.27\end{array}$ & $\left\{\begin{array}{r}19.24 \\
3.26 \\
1.09 \\
38.94 \\
2.75 \\
\text { Tr. } \\
.53 \\
29.57 \\
1.67 \\
2.96\end{array}\right.$ \\
\hline
\end{tabular}

1. Carboniferous limestone, Mammoth Peak, Tintic district. Nineteenth Ann. Rept: U.S. Geol. Survey, pt. 3, 1899, p. 625

2. Carboniferous limestone, Sioux Peak, Tintic district. Nineteenth Ann. Rept. U. S. Geol. Survey, pt. 3, 1899, p. 626 .

3. Carboniferous limestone, Eureka Peak, Tintic district. Nineteenth Ann. Rept. U. s. Geol. Survey, pt. 3,1899, p. 623 .

4. Carboniferous limestone head of Mill Canyon. B. E. Brewster, analyst. U. S. Geol. Expl. 40th Par., vol. 2, 1877, p. 376 .

5. Carboniferous limestone, Ute Peak. B. E. Brewster, analyst. Idem., p. 288,

6. Silurian (?) limestone, base of Ute Peak. B. E. Brewster, analyst. Idem., p. 411.

7. Eocene limestone, Manti. Geo. Steiger, analyst.

8. Oolitic sand, shores of Salt Lake. T. M. Chatard, anal yst. Bull. U. S. Geol. Survey No. 27, 1886, p. 69. 9. Calcareous adobe soil, Salt Lake City. L. G. Eakins, analyst. Bull. U. S. Geol. Survey No. 64, 1890, p. 51 .

In addition to the limestones just mentioned, an interesting material has newly been discovered to be of value in the manufacture of Portland cement. ${ }^{1}$ It occurs in the form of marl underlain by clay. This deposit lies in the abandoned bed of the northern portion of the old Salt Lake basin. It is a homogeneous, unstratified, grayish, fine-grained soft marl. At the surface the material is, in midsummer, fairly dry to the depth of 1 foot or more, but becomes damp below, and at the base salty water seeps in and fills holes where the underlying clay is excavated. The clay underlying the loam ranges from light gray through yellow to bluish in color, and is also fine grained. The deposit referred to lies 5.6 miles northwest of Brigham. The nearest remnant of Salt Lake is a small lake known as Boxelder Lake, a marshy tract which lies a short distance south of

1 Burchard, E. F., The cement industry in the United States in 1910: Mineral Resources U. S. for 1910. U. S. Geol. Survey, pt. 2, 1911, pp. 525-526. 
the marl deposit. The marl is 4 to 10 feet deep, and the clay has been tested to a depth of 18 feet. The marl runs generally between 1 and 3 per cent of magnesium oxide, between 40 and 46 per cent of calcium oxide, between 7 and 12 per cent of silica, and between 1 and 3.5 per cent of alumina plus iron oxide. There has been found as high as 4.5 per cent of sodium chloride (common salt) in the marl, and the wet material carries as high as 32.29 per cent moisture. The clay carries 48 to 50 per cent of silica, 16.5 to 18.6 per cent of alumina plus iron oxide, about 7.6 per cent of lime oxide, 2.5 to 2.8 per cent of magnesium oxide, 2.7 to 2.9 per cent of potassium oxide, 1.3 to 5 per cent of sodium oxide, and about 2.25 per cent of sodium chloride. In a wet condition the clay contains as much as 40 per cent of moisture.

\section{PORTLAND CEMENT INDUSTRY.}

During 1911 the output of Portland cement in Utah amounted to 662,849 barrels. This was produced by three plants.

The oldest company in the State is the Portland Cement Co. of Utah, which has its mill in Salt Lake City, but which obtains its raw materials from Parleys Canyon, several miles southeast of the city. Two different types of limestones are obtained here-one a cement rock high in clayey matter, the other a relatively pure limestone. These are mixed in proper proportion for Portland cement.

Analyses of Portland cement materials used in Salt Lake City, Utah.

\begin{tabular}{|c|c|c|c|c|}
\hline \multirow{2}{*}{ 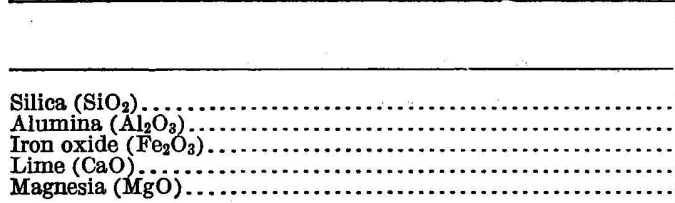 } & \multicolumn{2}{|c|}{ High-lime rock. } & \multicolumn{2}{|c|}{ Low-lime rock. } \\
\hline & $\left.\begin{array}{r}4.70 \\
1.73 \\
1.42 \\
50.96 \\
.58\end{array}\right\}$ & $\begin{array}{c}6.8 \\
3.0 \\
50.3 \\
.36\end{array}$ & $\left\{\begin{array}{r}18.90 \\
7.05 \\
2.85 \\
36.74 \\
2.70\end{array}\right.$ & $\begin{array}{r}21.2 \\
8.0 \\
35.2 \\
1.8\end{array}$ \\
\hline
\end{tabular}

The second cement plant put into operation in Utah is at Devils Slide, near Ogden, and is owned by the Union Portland Cement Co. This plant uses high calcium and low calcium limestones and shale.

The newest plant is that of the Ogden Portland Cement Co., at

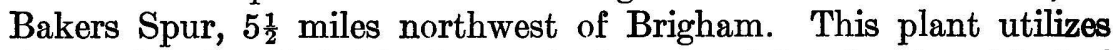
the marl and underlying clay at the bottom of the abandoned bed of the northern part of Great Salt Lake.

\section{PORTLAND CEMENT RESOURCES OF VERMONT.}

Vermont, unlike the other New England States, contains extensive and important deposits of nonmagnesian limestones and marbles, which are worked at present for building stone and lime burning.

The limestones quarried in Vermont fall into two distinct groups. The first group contains the crystalline limestones (marbles), worked extensively in the vicinity of Rutland, West Rutland, Dorset, and 
Brandon. The material obtained in this area is well known commercially as the "Vermont marble." The second group includes those quarried in northwestern Vermont, principally near Swanton, Highgate Springs, Winooski, and Leicester Junction. These limestones are mostly of Ordovician age (Chazy and Trenton), are not markedly crystalline, and commonly range in color from dark gray or blue to almost black.

Both types-the marbles and the black limestones-are generally very low in magnesia, as may be seen from the analyses below:

Analyses of limestone from Vermont.

\begin{tabular}{|c|c|c|c|c|c|c|c|c|c|}
\hline . & 1 & 2 & 3 & 4 & 5 & 6 & 7 & 8 & 9 \\
\hline 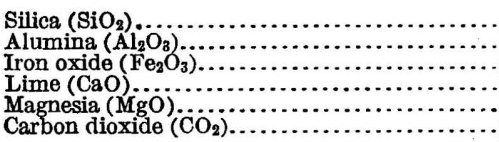 & $\left\{\begin{array}{r}0.35 \\
.20 \\
55.00 \\
.25 \\
44.02\end{array}\right.$ & $\left\{\begin{array}{r}0.63 \\
.05 \\
53.93 \\
1.47 \\
43.96\end{array}\right.$ & $\begin{array}{r}0.63 \\
.05 \\
.34 \\
55.09 \\
.37 \\
43.68\end{array}$ & $\left\{\begin{array}{c}0.40 \\
.10 \\
55.83 \\
\operatorname{Tr} . \\
43.65\end{array}\right.$ & $\begin{array}{r}0.28 \\
.30 \\
55.27 \\
.28 \\
43.82\end{array}$ & $\begin{array}{r}0.40 \\
.20 \\
55.26 \\
.15 \\
43.66\end{array}$ & $\begin{array}{r}0.70 \\
.15 \\
55.50 \\
\mathrm{Tr} \\
43.65\end{array}$ & $\left\{\begin{array}{r}0.22 \\
55.15 \\
.57 \\
44.00\end{array}\right.$ & $\begin{array}{r}0.62 \\
54.95 \\
.59 \\
43.80\end{array}$ \\
\hline
\end{tabular}

1, 2. Proctor, Rutland County. Seventeenth Ann. Rept. U. S. Geol. Survey, pt. 3 (continued), 1896, p. 809. 3. Columbian Marble Co., Proctor. Penfield, analyst. Twentieth Ann. Rept. U. S. Geol. Survey, pt. 6 (continued), 1899, p. 447.

4. Felton Quarry, Highgate Springs. S. P. Sharples, analyst. Twentieth Ann. Rept. U. S. Geol. Survey, pt. 6 (continued), 1899, p. 456.

5,6,7. Vermont Marble Co., West Rutland. Seventeenth Ann. Rept. U. S. Geol. Survey, pt. 3 (continued), 1896, p. 808 .

8, 9. Vermont Marble Co., West Rutland. J. N. Harris, analyst. Seventeenth Ann. Rept. U. S. Geol. Survey, pt. 3 (continued), 1896, p. 808.

So far as composition is concerned, both the marbles and the ordinary limestones are well suited for Portland cement materials. Fuel, however, is expensive; good local markets for cement and cement products are lacking; and satisfactory clays are rather difficult to obtain. Commercial conditions, therefore, seem to rule these otherwise excellent Vermont limestones out of consideration. If conditions were different, a flourishing Portland cement industry might be established, as a cement plant could utilize the enormous waste from the marble quarries.

\section{PORTLAND CEMENT RESOURCES OF VIRGINIA.}

\section{PORTLAND CEMENT MATERIALS.}

\section{DISTRIBUTION.}

From a geologic point of view, the promising sources of Portland cement material in Virginia, named in descending geologic order, are:

1. Tertiary shell beds or "marls."

2. Greenbrier and Newman limestones (Mississippian age).

3. Lewistown limestone (Devonian and Silurian age).

4. Ordovician limestones (Trenton and Stones River age).

The last three divisions (see Pl. XIX) occur in western Virginia, in the Great Valley and in the foothills of the Allegheny ridges. The 


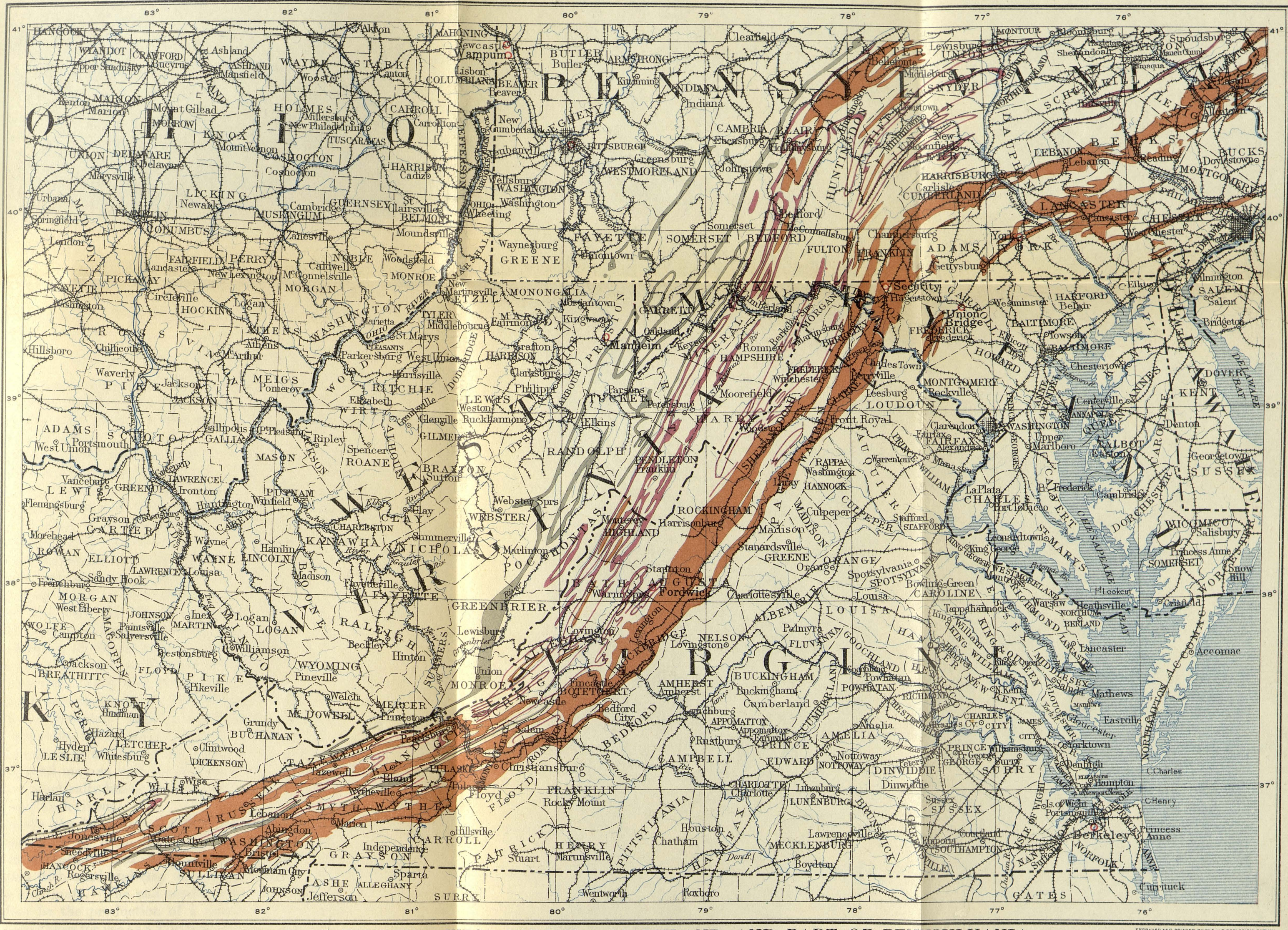

MAP OF VIRGINIA, WEST VIRGINIA, MARYLAND, AND PART OF PENNSYLVANIA SHOWING DISTRIBUTION OF LIMESTONES

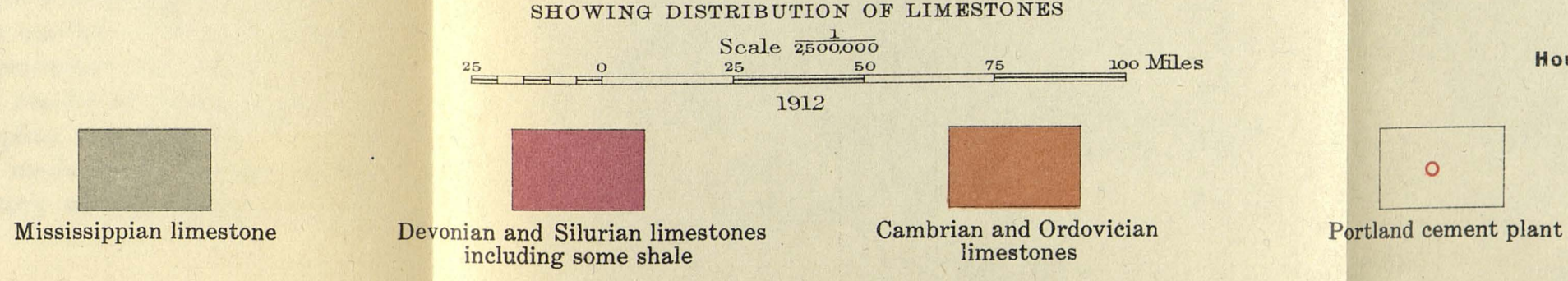



Tertiary shell beds, which are probably the most important, occur in tidewater Virginia.

\section{TERTIARY SHELL BEDS OR "MARLS."}

In the eastern counties of Virginia certain Tertiary formations carry beds of so-called marl, which are of great importance in connection with the probable development of the Portland cement industry in Virginia.

The Tertiary shell beds or "marls" of Virginia are not the same materials which have long been known as marl in the Portland cement industry of New York, Ohio, Indiana, Michigan, and Canada, nor are they limy shales of the type which the older geologists called marls. In order to distinguish the Tertiary materials from these other "marls," they will be alluded to in the present report as "shell beds," a term which is precise and descriptive and which does not carry with it implications of identity with the other types of "marl."

Shell beds occur in both the Eocene and Miocene series of the Tertiary, but only the Miocene shell beds need be considered as possible sources of Portland cement material. The Miocene shell beds outcrop in all the counties of the coastal plain in Virginia, being best exposed, however, in Nansemond, Isle of Wight, Surry, York, and Gloucester. They owe their great importance as cement materials not to any superiority in their composition but entirely to their location on tidewater. Indeed, the composition of most of them is hardly attractive to the cement manufacturer, and such of them as do not outcrop on or near deep water and within easy reach of a coalcarrying road may as well be dismissed from consideration at once. This fact practically limits development to the beds lying on or near James and York rivers.

Originally the beds were made up of masses of shells of various mollusks; some of them contained considerable clay at the time of their deposition, and since deposition many have become so infiltrated with sand and clay as to show relatively low percentages of lime carbonate. The end result of such changes in composition will often be the production of a mixture of sand, clay, and shells utterly worthless for use as a Portland cement material.

Of course it is not at all difficult to get a small sample of almost any desired composition from one part or another of these shell beds. The following analyses, however, really represent the range in composition of the better beds and are the results of careful sampling through the entire thickness. The sampling was done by $\mathrm{H}$. Drew and E. C. Eckel, and the analyses were made by the Lehigh Valley Testing Laboratory and in the laboratory of the Alpha Portland Cement Co. 
Analyses of Miocene shell beds, Virginia.

\begin{tabular}{|c|c|c|c|c|c|c|c|c|c|c|c|}
\hline & 1 & 2 & 3 & 4 & 5 & 6 & 7 & 8 & 9 & 10 & $\begin{array}{c}\text { Aver- } \\
\text { age. }\end{array}$ \\
\hline $\begin{array}{l}\text { Silica }\left(\mathrm{SiO}_{3}\right) \\
\text { Alumina }\left(\mathrm{Al}_{2} \mathrm{O}_{3}\right) \\
\text { Iron oxide }\left(\mathrm{Fe}_{2} \mathrm{O}_{3}\right) \\
\text { Lime carbonate }(\mathrm{CaO}) \\
\text { Magnesium carbonate }(\mathrm{MgO})\end{array}$ & $\begin{array}{r}12.42 \\
3.70 \\
6.16 \\
74.00 \\
\text { Tr. }\end{array}$ & $\begin{array}{c}21.08 \\
5.29 \\
3.63 \\
67.64 \\
\text { Tr. }\end{array}$ & $\begin{array}{r}11.44 \\
1.52 \\
3.79 \\
81.25 \\
.96\end{array}$ & $\begin{array}{r}14.54 \\
5.07 \\
7.25 \\
70.91 \\
\text { Tr. }\end{array}$ & $\begin{array}{r}10.03 \\
1.47 \\
2.67 \\
84.78 \\
.99\end{array}$ & $\begin{array}{r}16.52 \\
1.75 \\
3.46 \\
76.48 \\
1.01\end{array}$ & $\begin{array}{r}5.26 \\
3.13 \\
3.63 \\
86.71 \\
\text { Tr. }\end{array}$ & $\begin{array}{r}8.00 \\
1.91 \\
4.71 \\
83.99 \\
\text { Tr. }\end{array}$ & $\begin{array}{r}9.74 \\
.92 \\
2.47 \\
85.73 \\
1.07\end{array}$ & \begin{tabular}{|}
5.14 \\
2.08 \\
3.26 \\
88.53 \\
Tr.
\end{tabular} & $\begin{array}{r}11.42 \\
2.68 \\
4.10 \\
80.00 \\
1.01\end{array}$ \\
\hline
\end{tabular}

The above series of analyses shows certain peculiarities. The magnesia is very low but steady, at about one-half of 1 per cent. The lime runs only a little higher than is needed in a Portland cement mixture, so that the addition of very little clay is required. In the argillaceous constituents, however, the balance is different from that of normal clayey limestones. The silica, for example, is low compared to the total of alumina and iron oxide. Most striking of all, the iron oxide is much in excess of the alumina. These peculiarities of composition in the more clayey shell beds involve difficulties in manufacture, and it is therefore highly desirable to use the purer shell beds. Careful exploration has shown that such purer beds are scarce, and it is this fact which sets a maximum limit to the possibilities of cement development in the Coastal Plain region of Virginia.

The cement plant of the Norfolk Portland Cement Co. is now using the Tertiary shell beds and associated clays. (See p. 359.)

\section{GREENBRIER AND NEWMAN LIMESTONES (MISSISSIPPIAN AGE).}

Position of the deposits. - Throughout western Virginia the Mississippian series consists largely of limestone. In West Virginia and Maryland this limestone is called the Greenbrier limestone, and the same name is applicable throughout the greater portion of its extent in Virginia. In southwestern Virginia, however, the term Newman limestone is applied to a heavy limestone occupying approximately the same stratigraphic position as the Greenbrier farther north, and the two limestones agree closely in composition as well as in stratigraphic position.

The Mississippian limestones outcrop, in spite of their thickness, only as rather narrow strips in several of the counties of southwestern Virginia. The most favorable localities, so far as the possibilities of cement manufacture are concerned, are in the vicinity of Cumberland Gap, Tenn., where the limestone beds are accessible to two railroads and are within a few miles of the important Middlesboro coal district of Kentucky. The following data were gathered during an examination of the cement possibilities of the district by the writer, in the course of work for the United States Geological Survey.

The rocks of the Cumberland Gap district include Silurian, Devonian, and Carboniferous formations, dipping mostly $15^{\circ}$ to $35^{\circ} \mathrm{NW}$. 
The section exposed, from above downward, may be generalized as follows:

Carboniferous:

Geologic section near Cumberland Gap, Tenn.

Pennsylvanian-

Pottsville group-

Shales and sandstones with coal beds.

Thickness

in feet.

Lee conglomerate (massive sandstone and conglomerate)... 1, 000-1, 100

Mississippian-

Pennington shale (greenish shales and thin sandstone)........ $50-150$

Devonian:

Newman limestone (heavy-bedded blue and gray limestone)... $\quad 250-400$

Grainger shale (gray to greenish shales) ................... $50-125$

Silurian:

Chattanooga shale (black carbonaceous shales)............... $150-300$

Clinton formation (shales and sandstones, with beds of red hema-

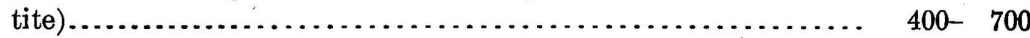

Of the formations above listed, the topmost shales and sandstones outcrop only in the area northwest of Cumberland Mountain, the crest and northwest flank of this mountain being formed by the massive Lee conglomerate. Underlying the conglomerate, near the top of the southeastern flank of the mountain, is a relatively thin bed of Pennington shale. Below this and generally forming the middle part of the slope are heavy beds of Newman limestone. The Grainger and Chattanooga shales outcrop on the lower slopes of the mountain and in Poor Valley at its foot; the Clinton formation commonly makes up the Poor Valley Ridge just southeast of Poor Valley.

Available limestone.-The Newman limestone shows 250 to 400 feet of heary-bedded blue to gray limestones. Cherty beds occur at several horizons, but the mass of the rock is fairly pure and low enough in magnesia to furnish a satisfactory Portland cement material.

Analyses of Newman limestone near Cumberland Gap, Tenn.

\begin{tabular}{|c|c|c|c|c|c|c|c|c|c|c|}
\hline & 1 & 2 & 3 & 4 & 5 & 6 & 7 & 8 & 9 & 10 \\
\hline Silica & 1.40 & 1.86 & 5.05 & 4.20 & 2.00 & 2.80 & 1.32 & 4.12 & 0.74 & \\
\hline $\begin{array}{l}\text { Alum } \\
\text { Iron 0 }\end{array}$ & 1.00 & .96 & 1.86 & 1.50 & 1.00 & .90 & 1.23 & .42 & .24 & .4 \\
\hline $\left.\mathrm{CaCO}_{3}\right)$ & 94.57 & 94.85 & 90.05 & 89.54 & 94.57 & 91.72 & 95.62 & 87.10 & 95.50 & 90.90 \\
\hline 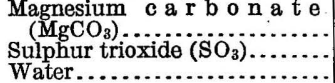 & $\begin{array}{l}3.03 \\
\text { n.d. }\end{array}$ & $\begin{array}{l}2.33 \\
\text { n. d. }\end{array}$ & $\begin{array}{l}3.04 \\
\text { n.d. }\end{array}$ & $\begin{array}{l}4.76 \\
\text { n. d. }\end{array}$ & $\begin{array}{l}2.50 \\
\text { n.d. }\end{array}$ & $\begin{array}{l}4.58 \\
\text { n.d. }\end{array}$ & $\begin{array}{r}1.32 \\
.51\end{array}$ & $\begin{array}{l}3.30 \\
\text { n.d. } \\
2.21\end{array}$ & $\begin{array}{l}2.79 \\
\text { n. d. } \\
.44\end{array}$ & $\begin{array}{c}1.46 \\
\text { n.d. } \\
1.28\end{array}$ \\
\hline
\end{tabular}

1-6. Analyses by W. Rosenfeld, chemist of Virginia Iron, Coal \& Coke Co.

7. Analysis by L. F. Barnes.

8-10. Analyses by J. Sanderson, chemist of Watts Iron and Steel Co.

The shales required for cement can be obtained from four different geologic formations-the topmost part of the Carboniferous, the Pennington shale, the Grainger shale, and the Chattanooga shale. $48834^{\circ}-$ Bull. $522-13-23$ 
Each of these formations is well exposed in this vicinity. The latter three outcrop along the southeast flank of Cumberland Mountain and the topmost shales of the Pennsylvanian outcrop in the Middlesboro basin northwest of that ridge. The shales will be briefly described in geologic order.

The Chattanooga shale (Devonian) is in this district 150 to 400 feet thick. It consists of brittle black carbonaceous shales or slates, many of which contain small percentages of pyrite. Some beds contain too much sulphur to be entirely satisfactory as cement material, but the mass of the formation is good enough, so far as sulphur is concerned. Few beds are sandy, and the silica percentage of many of them falls so low that $\frac{\text { silica }}{\text { aluminatiron oxide }}=2.25$. Material with this silica-alumina ratio can be used in cement manufacture, but the shales next to be considered would seem more satisfactory.

The Grainger shale, lying above the Chattanooga shale and below the Newman limestone, varies from 50 to 125 feet in thickness. It is composed of gray to greenish shales, siliceous enough on analysis, but with no coarse sandy beds. For this reason this shale is probably the most satisfactory as a cement material.

Analysis of Grainger shale, Cumberland Gap, Tenn.

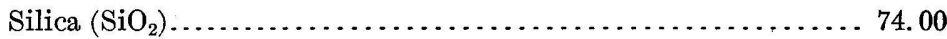

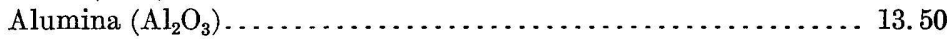

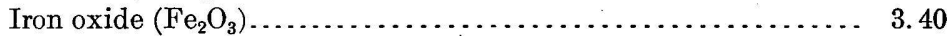

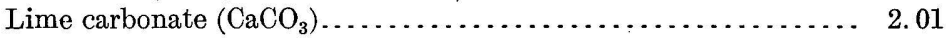

Magnesium carbonate $\left(\mathrm{MgCO}_{3}\right) \ldots \ldots \ldots \ldots \ldots \ldots \ldots \ldots \ldots \ldots \ldots \ldots \ldots \ldots \ldots$

The above analysis was made in 1904 by J. G. Harding, of Wellston, Ohio, on a sample of shale taken a few feet below the limestone in the Morrison quarry. It is obviously very satisfactory for use in Portland cement manufacture, owing to its composition giving the following ratio:

$$
\frac{\text { Silica }}{\text { Alumina + iron oxide }}=\frac{74.00}{16.90}=4.38
$$

The Pennington shale, which overlies the limestone, is here from 50 to 150 feet thick. It consists of greenish shales alternating with thin layers of sandstone. Though it is probable that by careful grinding this material could be utilized for cement manufacture, it is not regarded as so satisfactory as the Grainger shale, which underlies the Newman limestone.

In the "Coal Measures" of the Middlesboro district, immediately west of Cumberland Mountain, shale beds occur at many localities. At the Harkness Brick Works, 8 miles northwest of Cumberland Gap, some of these Carboniferous shales have been utilized. Analyses of these shales, by A. H. Phillips, follow: 
Analyses of Carboniferous shales used at Harkness Brick Works, Virginia.

\begin{tabular}{|c|c|c|}
\hline . & 1 & 2 \\
\hline 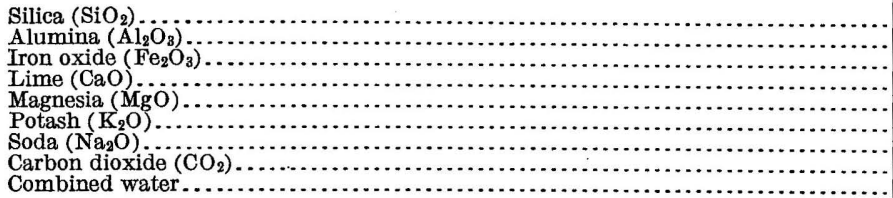 & $\begin{array}{r}61.14 \\
19.35 \\
5.89 \\
.93 \\
1.87 \\
3.07 \\
1.54 \\
5.86\end{array}$ & $\begin{array}{r}56.21 \\
27.00 \\
2.74 \\
.13 \\
.77 \\
3.46 \\
1.58 \\
7.67\end{array}$ \\
\hline
\end{tabular}

Analyses of Mississippian limestones (Greenbrier and Newman) from a number of other localities in southwestern Virginia are presented in the following table:

Analyses of Greenbrier and Newman limestones, Virginia.

\begin{tabular}{|c|c|c|c|c|c|c|c|c|c|c|}
\hline & 1 & 2 & 3 & 4 & 5 & 6 & 7 & 8 & 9 & 10 \\
\hline $\begin{array}{l}\text { Silica }\left(\mathrm{SiO}_{2}\right) \\
\text { Alumina }\left(\mathrm{Al}_{2} \mathrm{O}_{3}\right) \text { and iron oxide }\left(\mathrm{Fe}_{2} \mathrm{O}_{3}\right) \\
\text { Lime }(\mathrm{CaOO}) \ldots \ldots \ldots \ldots \ldots \ldots\end{array}$ & $\begin{array}{r}8.24 \\
1.04 \\
48.52 \\
1.87\end{array}$ & $\begin{array}{r}8.42 \\
1.00 \\
48.56 \\
1.32\end{array}$ & $\begin{array}{r}4.46 \\
1.56 \\
51.22 \\
.51\end{array}$ & $\begin{array}{r}15.10 \\
1.46 \\
43.84 \\
2.07\end{array}$ & $\begin{array}{r}5.28 \\
1.56 \\
51.02 \\
.60\end{array}$ & $\begin{array}{r}7.72 \\
.68 \\
50.20 \\
.89\end{array}$ & $\begin{array}{r}10.40 \\
.72 \\
48.64 \\
.86\end{array}$ & $\begin{array}{r}8.56 \\
1.00 \\
49.24 \\
.88\end{array}$ & $\begin{array}{r}7.22 \\
.41 \\
50.96 \\
.65\end{array}$ & $\begin{array}{r}15.82 \\
3.40 \\
43.98 \\
.47\end{array}$ \\
\hline
\end{tabular}

1-4. Greenbrier limestone, Lurich, Giles County. J. H. Gibboney, analyst. Bull. Virginia Geol. Survey No. 2A, 1909, pp. 276-278.

5. Greenbrier limestone, northern part of Wythe County. Idem, p. 278.

6-7. Newman limestone, near Mendota, Washington County, Idem, p. 280.

8. Newman limestone, Horton Summit, Scott County. Idem, p. 280.

9. Newman limestone, Big Stone Gap, Lee County. Idem, p. 281.

10. Newman limestone, Ollinger Gap, Lee County. Idem, p. 281.

\section{LEWISTOWN LIMESTONE.}

The Lewistown limestone appears in the foothills of the Allegheny ranges on the west side of the Great Valley throughout the entire extent of the latter in Virginia. At Fordwick the Virginia Portland Cement Co. has for a number of years used the Lewistown limestone as its principal raw material in cement manufacture. Farther southwest in Virginia limestones of approximately the same age as the Lewistown have been described and mapped as the Hancock limestone.

This series of limestones is exceedingly variable not only from place to place along the strike of the rocks but most notably from bed to bed in the same locality. It is therefore very difficult to make satisfactory general statements as to composition. In a very general way it may be said that the lower beds of the formation are generally shaly limestones, in. many localities approximating natural cement rocks in composition. The beds higher in the formation are commonly less shaly, but in this upper portion of the series many cherty layers are interbedded with the pure limestones. Magnesia seems, unfortunately, to be confined to no particular portion of the formation. With all this the series carries some very satisfactory 
cement materials, and where it outcrops along the line of a coalhauling railroad it is certainly worthy of consideration and of close examination.

Of the analyses in the following table Nos. 1 'and 2 represent the composition of the purer beds of the Lewistown and Nos. 3 and 4 apparently that of cherty beds.

Analyses of Lewistown limestone, Virginia.

\begin{tabular}{|c|c|c|c|c|}
\hline & 1 & 2 & 3 & 4 \\
\hline $\begin{array}{l}\text { Silica }\left(\mathrm{SiO}_{2}\right)_{1} \\
\text { Alumina }\left(\mathrm{Al}_{2} \mathrm{O}_{3}\right) \text { and iron oxide }\left(\mathrm{Fe}_{2} \mathrm{O}_{3}\right) \ldots \ldots \\
\text { Lime }(\mathrm{CaO}) \ldots \ldots \\
\text { Magnesia }(\mathrm{MgO})\end{array}$ & $\begin{array}{r}5.76 \\
.52 \\
50.88 \\
1.12\end{array}$ & $\begin{array}{r}0.43 \\
.76 \\
54.55 \\
.63\end{array}$ & $\begin{array}{r}19.32 \\
1.00 \\
44.50 \\
.05\end{array}$ & $\begin{array}{r}14.68 \\
1.26 \\
43.96 \\
2.09\end{array}$ \\
\hline
\end{tabular}

1. Seven Fountains, Massanutten Mountain. J. H. Gibboney, analyst. Bull. Virginia Geol. Survey No. 2A, 1909 , p. 263.

2. Craigsville. C. Catlett, analyst. Bull. U. S. Geol. Survey No. 225, 1904, p. 461.

3. Covington. J. H. Gibboney, analyst. Bull. Virginia Geol. Survey No. 2A, 1909, p. 267.

4. Warm Springs. Idem, p. 265.

ORDOVICIAN LIMESTONES (TRENTON AND STONES RIVER AGE).

The Ordovician limestones of Virginia, because of their attractive composition and because they outcrop in the most thickly settled section of the western part of the State, have been discussed extensively as possible sources of cement material. The Tertiary shell beds, however, are nearer to the market, and the Greenbrier and Lewistown limestones are nearer to the fuel supply, thus heavily handicapping the Ordovician limestones in any competition for northern or western markets.

It is impossible to discuss in detail, in the space allowable, the rather complicated stratigraphy and geographic distribution of the Ordovician limestones in Virginia. Only a summary of the facts bearing on the possible utilization of these limestones for Portland cement can be given.

The great series of limestones which occupies most of the valley between the Blue Ridge and the Allegheny range has for convenience been termed the Shenandoah limestone. From a very early date, however, it was known that this limestone series contained representatives of several geologic formations and that in age the limestones covered the period from early Cambrian well into Ordovician. Careful work by a number of geologists has resulted in the subdivision of the Shenandoah group into several formations. The details of the subdivision and the names applied to the units vary in different parts of the valley. Certain broad statements, however, are sufficiently close to the truth to be serviceable throughout the State as aids in the search for low-magnesia limestones.

The basal portion of the Shenandoah group, or in a general way the Cambrian part of the group, in most places carries too much magnesia 
to be fit for use in Portland cement manufacture. In places lowmagnesia limestones are found in the lower part of the Shenandoah group, but such are very exceptional and can not be discussed satisfactorily here.

The upper part of the Shenandoah group, however, is markedly different. The upper limestones, corresponding in a general way to the Ordovician portion of the group, are commonly sufficiently low in magnesium carbonate to be worth considering as possible sources of Portland cement material. These upper limestones are principally of Trenton and Stone River age. In different parts of Virginia they are subdivided and named differently, but for present purposes they can be considered together under the general term of Ordovician limestones.

The Ordovician limestones are best exposed, in general, along the western side of the Shenandoah Valley and its southern continuations. (See Pl. XIX.) In most localities they are overlain, or are flanked on the west, by a heavy series of shales called in the northern and western portion of the valley the Martinsburg shale.

The following table contains a number of analyses of Ordovician limestones from Virginia localities. This table could have been extended indefinitely, but it is believed that the analyses given will suffice to illustrate the range in composition of the limestones:

Analyses of Ordovician limestones, Virginia.

\begin{tabular}{|c|c|c|c|c|c|c|c|c|c|c|c|c|c|c|c|}
\hline & 1 & 2 & 3 & 4 & 5 & 6 & 7 & 8 & 9 & 10 & 11 & 12 & 13 & 14 & 15 \\
\hline $\begin{array}{l}\text { Silica }\left(\mathrm{SiO}_{2}\right) \ldots \ldots . \\
\text { Alumina }\left(\mathrm{Al}_{2} \mathrm{O}_{3}\right) \text { and } \\
\text { iron oxide }\left(\mathrm{Fe}_{2} \mathrm{O}_{3}\right) \\
\text { Lime carbonate }(\mathrm{CaO})\end{array}$ & $\left|\begin{array}{r}0.36 \\
.08 \\
99.01\end{array}\right|$ & $\begin{array}{r}3.11 \\
.64 \\
94.82\end{array}$ & $\begin{array}{r}9.10 \\
1.32 \\
86.82\end{array}$ & $\begin{array}{r}8.06 \\
1.14 \\
87.68\end{array}$ & $\begin{array}{r}10.04 \\
1.46 \\
86.57\end{array}$ & $\begin{array}{r}14.88 \\
2.38 \\
80.36\end{array}$ & $\left|\begin{array}{c}2.54 \\
1.24 \\
94.88\end{array}\right|$ & $\begin{array}{r}1.80 \\
.22 \\
97.32\end{array}$ & $\begin{array}{r}1.62 \\
.72 \\
960.71 \\
\end{array}$ & $\begin{array}{r}8.42 \\
3.66 \\
84.14 \\
\end{array}$ & $\begin{array}{r}11.68 \\
1.52 \\
85.86\end{array}$ & $\begin{array}{r}20.48 \\
2.04 \\
76.36\end{array}$ & $\begin{array}{r}6.14 \\
.94 \\
89.82\end{array}$ & $\begin{array}{r}2.04 \\
.50 \\
96.07\end{array}$ & $\begin{array}{r}8.56 \\
1.68 \\
89.48\end{array}$ \\
\hline $\begin{array}{r}\text { Magnesium carbonate } \\
\text { (MgO)............................ }\end{array}$ & .45 & 1.53 & 2.71 & 1.61 & 1.54 & 2.18 & 1.03 & $\begin{array}{l}.15 \\
\end{array}$ & $\begin{array}{l}.90 \\
\end{array}$ & 1.41 & 1.94 & 1.06 & 3.30 & 2.78 & .17 \\
\hline
\end{tabular}

1. Upper part Stones River limestone, Strasburg. J. H. Gibboney, analyst. Bull. Virginia Geol. Survey No. 2 A, 1909 , p. 55 .

2. Upper part Stones River limestone, Riverton. Idem.

3. Upper part Stones River limestone, Harrisonburg. Idem.

4. Stones River limestone, Mount Horeb Church. Idem.

5. Lower part Chambersburg limestone, Woodstock. Idem, p. 60.

6. Upper part Chambersburg limestone, Woodstock. Idem, p. 61.

7. Murat limestone, Murat. Idem, p. 107.

8. Murat limestone, near Lexington. Idem, p. 109.

9. Murat limestone, Eagle Mountain. Idem, p. 109.

10. Argillaceous limestone, Gate City. Idem, p. 166.

11. Chickamauga limestone, Tazewell. Idem, p. 169.

12. Argillaceous limestone, Tazewell. Idem, p. 169.

13. Chickamauga limestone, Pearisburg. Idem, p. 172.

14. Chickamauga limestone, Tazewell. Idem, p. 175.

15. Chickamauga limestone, Ben Hur. Idem, p. 183.

The table shows that the Ordovician limestones in Virginia, as elsewhere in the eastern United States, include both pure highcarbonate rocks and shaly limestones or cement rocks of the type used in the Lehigh district of Pennsylvania and New Jersey. The Virginia cement rocks seem to tend to show a bad ratio between the silica and the alumina and iron oxide, but this may not persist 
throughout the State. No criticism can be made of the highcarbonate limestones, and the overlying shales are almost everywhere suitable for mixture with these overlimed rocks.

\section{PORTLAND CEMENT INDUSTRY IN VIRGINIA.}

At present Virginia has only two plants engaged in the manufacture of Portland cement, and to the writer it seems probable that whatever future development may take place in. the cement industry of the State will be along lines not considered in previous publications on this subject. The tendency in discussions of the cement possibilities of Virginia has been to assume that the excellent limestone resources of the valley of Virginia are alone sufficient to justify cement developments in that portion of the State. Unfortunately for this theory, Virginia itself does not furnish an important cement market, and the only justification for cement manufacture within its borders is that it possesses sites having advantages in fuel or transportation over competitive sites in adjoining States. To justify the erection of a cement plant a site should not only furnish a satisfactory limestone supply, but should have reasonably cheap coal for power and kilns and should offer transportation rates which will enable the output to be shipped to large markets and sold there in competition with the product of plants of other localities. Such favorable sites there may be in Virginia, but they are not in the valley areas which have commonly been considered possible centers of cement manufacture. This matter is emphasized here because in Bulletin 243 of the United States Geological Survey, which may be regarded as a first edition of the present report, the more abundant data available as to the limestones of the valley of Virginia caused them to receive undue attention as compared with other and now more promising formations.

The two Portland cement plants at present in operation in Virginia are widely separated as to location and use very different raw materials.

The plant of the Virginia Portland Cement Co. is at Fordwick, near Craigsville, on the line of the Chesapeake \& Ohio Railway. The raw materials used are from the Lewistown limestone and the Devonian shale. Analyses ${ }^{1}$ follow:

Analyses of cement materials used at Fordwick, near Craigsville, Va.

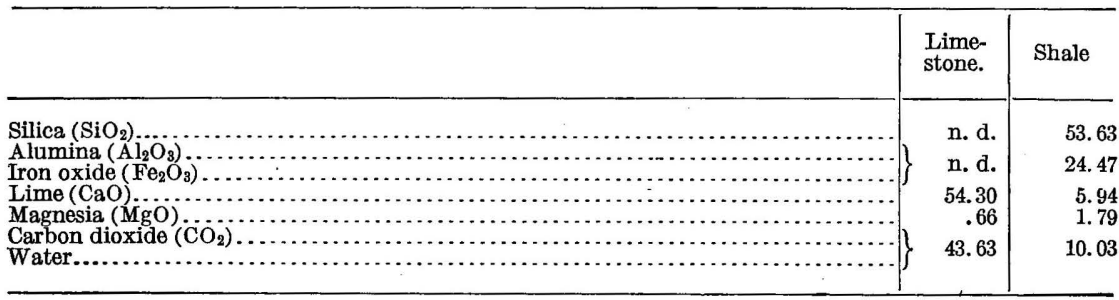

1 Vredenburgh, W., The cement industry, 1900, p. 133. 
The Norfolk Portland Cement Co., a subsidiary of the American Cement Co., has recently put into operation a plant at South Norfolk, or Berkeley. The raw materials used are derived from the Tertiary shell beds along and near James River and from the sedimentary clays that at several places overlie these shell beds. Analyses follow:

Analyses of raw materials used near Norfolk, Va.

\begin{tabular}{|c|c|c|c|c|c|c|}
\hline & \multicolumn{3}{|c|}{ Shell beds. } & \multicolumn{3}{|c|}{ Clays. } \\
\hline & 1 & 2 & 3 & 1 & 2 & 3 \\
\hline 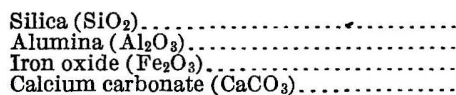 & $\begin{array}{r}5.14 \\
2.08 \\
3.26 \\
88.53\end{array}$ & $\begin{array}{r}5.26 \\
3.13 \\
3.63 \\
86.71\end{array}$ & $\begin{array}{r}10.03 \\
1.47 \\
2.67 \\
84.78\end{array}$ & $\begin{array}{r}67.67 \\
16.99 \\
4.44 \\
\ldots . . .\end{array}$ & $\begin{array}{r}65.39 \\
18.43 \\
5.13 \\
-\ldots \ldots\end{array}$ & $\begin{array}{r}68.67 \\
17.92 \\
3.44 \\
.6 .\end{array}$ \\
\hline $\begin{array}{l}\text { Lime }(\mathrm{CaO}) \\
\text { Magnesium carbonate }\left(\mathrm{MgCO}_{3}\right) \ldots\end{array}$ & Tr & $\mathrm{Tr}$ & 99 & .54 & 17 & n. d. \\
\hline Magnesia (MgO) & & & & $\because 48$ & .44 & n. \\
\hline
\end{tabular}

BIBLIOGRAPHY.

The following list contains references to the more important papers and reports dealing with the cement materials and cement industry of Virginia.

Bassler, R. S.; Cement materials of the Valley of Virginia: Bull. U. S. Geol. Survey No. 260,1905 , pp. 531-544.

Portland cement resources of Virginia: Bull. U. S. Geol. Survey No. 243, 1905, pp. 312-322.

- Cement resources of Virginia west of the Blue Ridge: Bull. Virginia Geol. Survey No. 2A, 1909, 309 pp.

Catrett, Charles, Cement resources of the Valley of Virginia: Bull. U. S. Geol. Survey No. 225,1904 , pp. $457-461$.

Eckel, E. C., Cement resources of the Cumberland Gap district, Tennessee-Virginia: Bull. U. S. Geol. Survey No. 285, 1906, pp. 374-376.

Vredenburgh, W., The Virginia Portland Cement Co.'s works, Craigsville, Va.: The Cement Industry, 1900, pp. 132-141.

\section{PORTLAND CEMENT RESOURCES OF WASHINGTON.}

\section{PORTLAND CEMENT MATERIALS. ${ }^{1}$}

Washington shares with adjoining portions of British Coulmbia the distinction of having the only large deposits of limestone located on deep water along the entire Pacific coast of the United States and Canada, and this fact may become of importance in relation to the future development of the cement industry.

Limestone, the principal ingredient necessary in the manufacture of cement, is found only in the northern counties of the State from Puget Sound to the Idaho boundary; that is, in San Juan, Whatcom, Snohomish, Skagit, King, Okanogan, Ferry, and Stevens counties. Clays occur much more widely, but only those near the limestones will be discussed.

1 Reprinted, with a few verbal changes, from Landes, Henry, Cement resources of Washington: Bull. U. S. Geol. Survey No. 285, 1906, pp. 377-383. 


\section{SAN JUAN COUNTY.}

In San Juan County the only deposits of limestones and clays worth considering are at tidewater on San Juan and Orcas islands. The principal deposits on San Juan Island are at Roche Harbor, where the largest lime works on the Pacific coast are located, and are the property of the Tacoma \& Roche Harbor Lime Co., whose lime has an established reputation because of its purity. The limestone has been rendered entirely crystalline by metamorphism, and any fossils which it may have contained have been destroyed. It is one of a series of metamorphic rocks which have been greatly contorted and faulted. Its geologic age has not been accurately determined, but it is without doubt older than the Cretaceous rocks which form the bulk of the small neighboring islands a few miles to the north.

At Roche Harbor the limestone occurs as two large ledges, with a strike a little east of north. In outcrop they extend from north to south about one-half mile and from east to west about 1,000 feet. The height of the limestone above tidewater averages 200 feet; its depth below the ocean level has not been determined. The fact that the limestone is much broken and that but little stripping is required makes it possible to quarry the stone and deliver it to the crusher at a minimum expense. The quarry at this place has been in operation since 1882, and the manufacture of lime amounts to about 300,000 barrels per year. The limestone varies but little in composition and is very uniform in character.

Large deposits of glacial sediments adjacent to the limestones contain extensive beds of clays interstratified with sands. Some of the clay beds are at least 40 feet thick and have been so thoroughly washed as to be uncommonly free from gritty ingredients. In case the clays do not afford enough silica for use in cement manufacture it may be easily obtained from the quartzites and slates that are near at hand as members of the metamorphic series of which the limestone is a part.

Analyses of limestone, clay, slate, and quartzite from Roche Harbor, Wash.

\begin{tabular}{|c|c|c|c|c|c|c|c|c|}
\hline & \multicolumn{3}{|c|}{ Limestone. } & \multicolumn{2}{|c|}{ Clay. } & \multirow{2}{*}{ Slate. } & \multicolumn{2}{|c|}{ Quartzite. } \\
\hline & 1 & 2 & 3 & 4 & 5 & & 7 & 8 \\
\hline 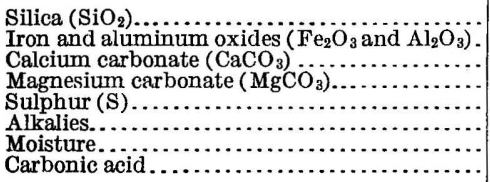 & \begin{tabular}{r|}
0.44 \\
1.13 \\
98.21 \\
$\cdots \cdots$ \\
$\cdots \cdots$ \\
$\cdots$
\end{tabular} & $\begin{array}{r}0.27 \\
.21 \\
99.06 \\
.46 \\
\ldots . . .\end{array}$ & $\begin{array}{r}0.20 \\
.30 \\
98.57 \\
1.02 \\
\ldots \ldots . . \\
\ldots \ldots . .\end{array}$ & \begin{tabular}{|r|}
55.81 \\
26.28 \\
4.34 \\
3.39 \\
Tr. \\
3.98 \\
6.11
\end{tabular} & $\begin{array}{r}56.35 \\
24.62 \\
3.66 \\
2.58 \\
.31 \\
3.94 \\
7.52\end{array}$ & $\begin{array}{l}78.0 \\
6.98 \\
6.45 \\
1.56 \\
\operatorname{Tr} \\
1.56 \\
.30 \\
5.15\end{array}$ & $\begin{array}{r}72.32 \\
10.11 \\
7.75 \\
2.24 \\
.07 \\
1.11 \\
.45 \\
5.01\end{array}$ & $\begin{array}{r}84.84 \\
6.78 \\
3.63 \\
.80 \\
\text { Tr. } \\
\text { Tr. } \\
\hdashline . .41\end{array}$ \\
\hline
\end{tabular}

No. 1, made in 1888, by Moss Bay Hematite \& Iron Co. (Ltd.), Workington, England.

No. 2, made in 1893, by Puget Sound Reduction Co,, Everett, Wash.

No. 3 , made in 1902 , by C. F. McKenna, New York City.

Nos. 5 to 8 ,made by F. C. Newton, Seattle, Wash. 
A cement plant built at Roche Harbor could be so arranged that the limestone at least might be transported to the mills by a gravity system. The final product could also be transported in the same manner to warehouses on the wharf. The harbor is well protected and the water is sufficiently deep for ocean-going vessels to enter and depart at any tide.

On the northwest shore of Orcas Island several outcrops of limestone are very similar in character and occurrence to those described at Roche Harbor but are of smaller extent. At several points quicklime has been made from time to time and the conditions for cement making are favorable. The limestone ledges lie far enough above the water level to make a gravity method feasible at all stages of cement making from the quarry to the warehouse on the wharf. The water is very deep, and large vessels may come very close inshore. As at Roche Harbor the limestone is entirely crystalline, and with its neighboring metamorphic rocks has suffered extreme folding, faulting, and other dislocations. Along the adjacent shores, conveniently near the outcrops of limestone, shales and beds of clay afford materials suitable for cement manufacture. Below are some analyses of limestones, shales, and clays from this location on Orcas Island, made by A. H. Cederberg.

Analyses of limestone, shale, and clay from Orcas Island, Wash.

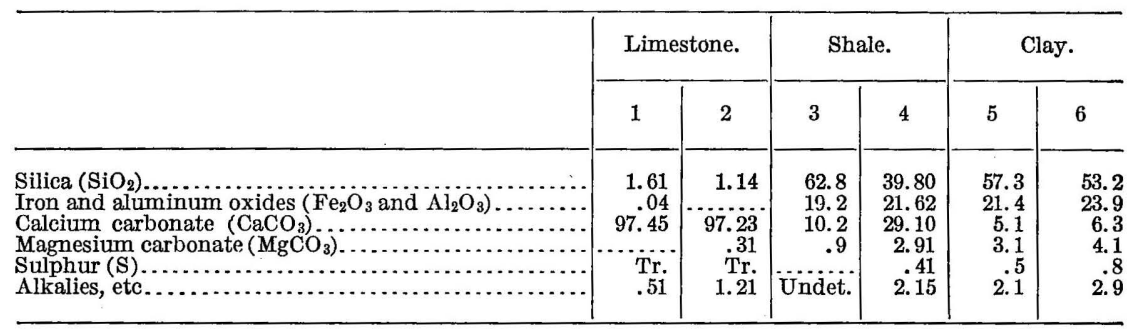

WHATCOM COUNTY.

In the vicinity of Kendall, on the line of the Bellingham Bay \& British Columbia Railroad, a number of deposits of limestone and clay afford proper materials for cement manufacture. The outcrops of limestone immediately south of the railway do not indicate large bodies, but north of the railway, about 3 miles from Kendall, a large ledge of this rock presents a vertical face or cliff that may be seen for a distance of 2 or 3 miles. The limestone is entirely crystalline and all traces of fossils have been eliminated. This limestone, like the limestones of San Juan County, is part of an extensive metamorphic series which has been greatly folded and crushed. As a result of the breaking up of the original bed of limestone and of extensive erosion the rock occurs in fragments and not in one continuous body. The amount of limestone here could be determined readily by means of 
the diamond drill, and this should be done before a cement plant is installed.

A few miles west of the limestone deposits and along the railroad track there are beds of glacial clay, one of which was explored by drilling to a depth of 50 feet. The clay is advantageously located and may be loaded on cars at a very small cost.

Analyses of limestone, clay, and slate from Kendall, Wash.

\begin{tabular}{|c|c|c|c|c|c|c|}
\hline & \multicolumn{2}{|c|}{ Limestone. } & \multicolumn{2}{|c|}{ Clay. } & \multicolumn{2}{|c|}{ Slate. } \\
\hline & 1 & 2 & 3 & 4 & 5 & 6 \\
\hline 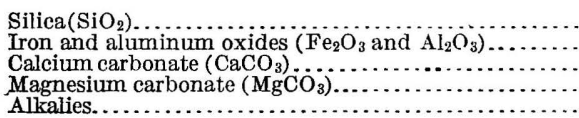 & $\begin{array}{r}1.52 \\
.35 \\
97.48 \\
1.26\end{array}$ & $\begin{array}{r}1.37 \\
.42 \\
98.72 \\
.26\end{array}$ & $\begin{array}{r}61.27 \\
25.30 \\
2.96 \\
4.68\end{array}$ & $\begin{array}{r}57.06 \\
26.80 \\
10.62 \\
1.13 \\
2.56\end{array}$ & $\begin{array}{r}66.01 \\
17.65 \\
8.01 \\
3.15\end{array}$ & $\begin{array}{r}72.69 \\
22.19 \\
2.16 \\
2.47\end{array}$ \\
\hline
\end{tabular}

Nos. 1 and 3 made by D. W. Riedle, Montavilla, Oreg.

Nos. $2,4,5$, and 6 made by $\mathrm{A}$. H. Cederberg.

\section{SNOHOMISH COUNTY.}

Limestone occurs in a number of places in the eastern half of Snohomish County, but only at a point 3 miles east of Granite Falls, on the Northern Pacific Railway, has the rock been quarried to any extent. This stone is crystalline and is a member of an extensive metamorphic series extending in a broad belt north and south. The adjacent rocks are chiefly slates and schists. A quarry has been opened by the side of the railway track, and the stone is loaded directly on to the cars. The quarry has been in operation for several years, and the principal sales of rock have been made to the smelter and paper mill at Everett. A limekiln having a capacity of 100 barrels per day is in operation. The property is owned by the Canyon Lime and Cement Co. Some investigations have been made as to the possibilities for a cement factory, but no active work has yet been done.

The following analyses were made by A. H. Cederberg:

Analyses of limestone, calcareous slate, and clay near Granite Falls, Wash.

\begin{tabular}{|c|c|c|c|}
\hline . & $\begin{array}{l}\text { Lime- } \\
\text { stone. }\end{array}$ & $\begin{array}{l}\text { Calcare- } \\
\text { ous slate. }\end{array}$ & Clay. \\
\hline 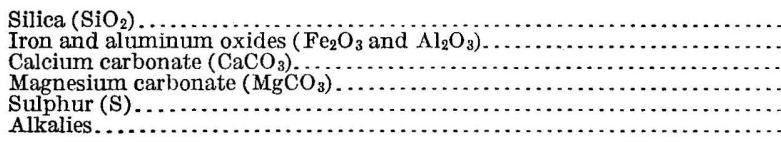 & $\begin{array}{r}0.2 \\
1.4 \\
98.1 \\
\operatorname{Tr} .\end{array}$ & \begin{tabular}{r|}
22.1 \\
10.6 \\
59.6 \\
1.8 \\
$\operatorname{Tr}_{1.4}$ \\
1.4
\end{tabular} & $\begin{array}{l}61.6 \\
25.4 \\
7.2 \\
2.3 \\
1.6 \\
2.94\end{array}$ \\
\hline
\end{tabular}


KING COUNTY.

The metamorphic rocks, occurring in Whatcom, Skagit, and Snohomish counties continue into King County. In the vicinity of Snoqualmie Pass and at several points along the line of the Great Northern Railway, notably in the region about Baring, outcrops of crystalline limestone have been found, but very little work has been done looking to the development of any of the deposits, and there is little information at hand concerning them.

So far as clay is concerned King County is particularly favored. Clays of excellent quality occur abundantly in the western part of the county, chiefly in connection with the Tertiary coal measures. At Renton, Taylor, and Kummer thick beds of shale are found interstratified with seams of coal. At all these points clay is mined for use in the manufacture of ornamental and paving bricks, terra cotta, sewer pipe, etc. Known deposits of limestones and clays are too widely separated to make the manufacture of cement profitable, but further prospecting may reveal the presence of desirable beds of clay within or adjacent to the limestone areas.

\section{OKANOGAN COUNTY.}

In many parts of northern Okanogan County crystalline limestone has been discovered in conjunction with slate, metamorphic sandstone, and conglomerate. The largest limestone areas are west and northwest of Riverside, where conspicuous cliffs of this rock have an areal distribution of several square miles. On the eastern slope of Palmer Mountain several bold outcrops of light-gray limestone are only partly crystalline. Because of the difficulties in the way of transportation and the sparseness of population nothing has been done toward utilizing the limestone, but it is safe to assume that the neighboring argillaceous rocks could be used with the limestone in the manufacture of cement whenever a sufficient demand arises.

FERRY COUNTY.

The geologic formations of Ferry County are mainly metamorphic rocks represented by limestones, slates, and quartzites, with many granite intrusions. Here and there small areas of sandstones and shales indicate the existence of lakes in Tertiary times. The largest limestone area is in the form of a long, narrow belt which extends north and south across the country and which lies at the western foot of the granite divide separating Columbia and Kettle rivers from the streams to the west. A few miles west of Republic, at a large outcrop of a very compact and hard bluish limestone, a limekiln is in 
operation and a high grade of quicklime is manufactured. Clay and impure limestone occur close at hand and may be utilized in cement manufacture.

The following analyses were made by $\mathrm{A} . \mathrm{H}$. Cederberg:

Analyses of crystalline limestone, impure limestone, and clay from Ferry County, Wash.

\begin{tabular}{|c|c|c|c|}
\hline & $\begin{array}{c}\text { Crystal- } \\
\text { linelime- } \\
\text { stone. }\end{array}$ & $\begin{array}{c}\text { Impure } \\
\text { lime- } \\
\text { stone. }\end{array}$ & Clay. \\
\hline 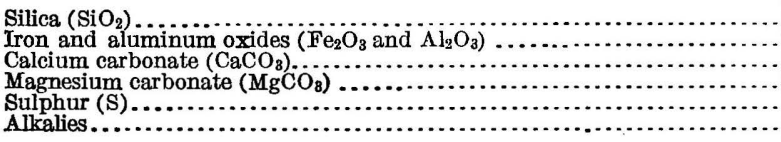 & 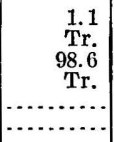 & \begin{tabular}{r|}
18.9 \\
7.2 \\
66.1 \\
4.5 \\
$\operatorname{Tr}$ \\
2.1
\end{tabular} & $\begin{array}{r}60.13 \\
29.10 \\
8.98 \\
1.36 \\
.75 \\
.29\end{array}$ \\
\hline
\end{tabular}

STEVENS COUNTY.

Stevens County contains very large deposits of materials necessary for cement manufacture, the only drawback being the high cost of fuel, which is subject to a long transportation charge. The rocks of the county are chiefly metamorphic in character, consisting mainly of limestone or marble, slate, and quartzite. These have been greatly disturbed by folding as well as by intrusions of granite, basalt, and other igneous rocks. At most places the limestones are entirely crystalline and at several places yield marble of excellent quality. The fossils they may have contained have been wholly destroyed except near Springdale, where the semicrystalline limestone contains coral remains which indicate its Paleozoic, probably Carboniferous, age. Though these rocks are ordinarily known as limestones, many of them are really dolomites, and careful field work must be done and many analyses made in order to locate the true limestones and determine their extent.

Analyses of limestone and clay from Box Canyon, Wash.

\begin{tabular}{|c|c|c|}
\hline . & $\begin{array}{l}\text { Lime- } \\
\text { stone. }\end{array}$ & Clay. \\
\hline 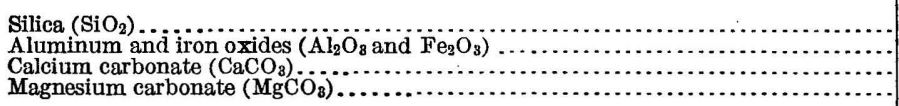 & $\begin{array}{l}1.60 \\
\text { Tr. } \\
98.50 \\
\text { Tr. }\end{array}$ & $\begin{array}{r}64.1 \\
22.30 \\
1.69 \\
\text { Tr. }\end{array}$ \\
\hline
\end{tabular}

In the vicinity of Colville, on the Spokane Falls \& Northern Railway, some limestones occur that are free from magnesium carbonate in harmful amounts. One such is 15 miles northeast of Colville, whero the Jefferson Marble, Mining \& Milling Co. has opened a quarry and established marble works. The limestone outcrops cover a broad area, and extensive beds of glacial clays are conveniently 
near. The limestone or marble exhibits many varieties of colors, from clear white through yellow, brown, and dark blue to black. The stone is fine grained and compact. Analyses of two varieties of marble, made by Prof. S. Shedd, of Pullman, are as follows:

Analyses of white and pink marble from quarry 15 miles northeast of Colville, Wash.

\begin{tabular}{|c|c|c|}
\hline & White. & Pink. \\
\hline $\begin{array}{l}\text { Silica }\left(\mathrm{SiO}_{2}\right) \\
\text { Iron } \\
\text { Alumina } \\
\text { Lime }\left(\mathrm{CaO} \mathrm{O}_{2}\right) \\
\text { Magnesia }\left(\mathrm{MgO}_{2}\right)_{\mathrm{M}} \\
\text { Marbon dioxide }\left(\mathrm{CO}_{2}\right) \\
\text { Cam }\end{array}$ & $\begin{array}{r}0.87 \\
\text { None. } \\
\text { None. } \\
55.16 \\
.21 \\
43.77\end{array}$ & $\begin{array}{r}3.49 \\
.24 \\
\text { None } \\
51.54 \\
1.11 \\
42.46\end{array}$ \\
\hline
\end{tabular}

The property of the Keystone Marble Co. lies near the locality last described, $8 \frac{1}{2}$ miles east of Bossburg, a station on the Spokane Falls \& Northern Railway. The marble outcrops over a considerable area and presents ample conveniences for quarrying. The stone exhibits great diversity in color, but on the whole approaches a pure calcium carbonate. Interstratified with the beds of marble are slates and quartzites. Analyses of two varieties of marble, made by Prof. S. Shedd, of Pullman, are as follows:

Analyses of white and gray marble from quarry $8 \frac{1}{2}$ miles east of Bossburg, Wash.

\begin{tabular}{|c|c|c|}
\hline & White. & Gray. \\
\hline $\begin{array}{l}\text { Silica }\left(\mathrm{SiO}_{2}\right) \\
\text { Iron }\end{array}$ & $\begin{array}{c}0.98 \\
\text { Tr. }\end{array}$ & $\begin{array}{l}0.82 \\
\text { Tr. }\end{array}$ \\
\hline (1) & & \\
\hline $\operatorname{Lime}\left(\mathrm{CaO}_{2}\right) \ldots \ldots \ldots \ldots \ldots \ldots$ & 53.96 & 54.81 \\
\hline $\begin{array}{l}\text { Magnesia }\left(\mathrm{MgO}_{2}\right) \\
\text { Carbon dioxide }\left(\mathrm{CO}_{2}\right)\end{array}$ & $\begin{array}{r}1.25 \\
43.76\end{array}$ & 43.56 \\
\hline
\end{tabular}

In the vicinity of Ryan, a small station on the Spokane Falls \& Northern Railway, marble outcrops in conspicuous bluffs on both sides of Columbia River, in an advantageous position for economical quarrying. The marble is fine grained, mostly light gray, and unusually hard. An analysis made by Prof. S. Shedd, of Pullman, is as follows:

Analysis of marble from Ryan, Wash.

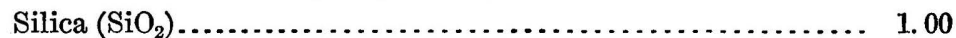

Iron and alumina..................................... None.

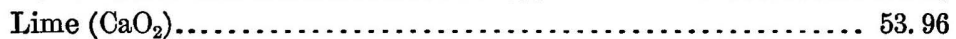

Magnesia $\left(\mathrm{MgO}_{2}\right) \ldots \ldots \ldots \ldots \ldots \ldots \ldots \ldots \ldots \ldots \ldots \ldots \ldots \ldots \ldots \ldots \ldots \ldots \ldots, 1.60$

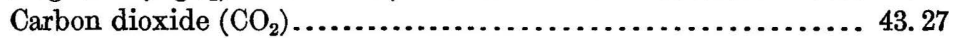

Besides the clay represented in the slates occurring in proximity to the limestones, there are many places in Stevens County where clays exist in large amounts. Some of them are of glacial origin, and 
others are residual from granites. As a type of the latter the clays in the vicinity of Clayton may be mentioned. Numerous drill holes show that the clay beds cover several thousand acres. There can be little question that both limestones and clays may be had in close relationship and at points convenient for transportation, so that in time Stevens County may become an important producer of cement.

PORTLAND CEMENT INDUSTRY OF WASHINGTON.

The State of Washington produced nearly 1,000,000 barrels of Portland cement in 1911. Three Portland cement plants-those of the Washington Portland Cement Co. and of the Superior Portland Cement Co., both at Concrete, Skagit County, and that of the Inland Portland Cement Co. at Metaline Falls, Stevens County-are at present operating in Washington. The first two plants utilize practically the same types of raw material, the mixture being made up of a metamorphic, highly crystalline limestone and a recent sedimentary clay. Analyses of these raw materials, as used at the plant of the Washington Portland Cement Co., are given below:

Analyses of limestone and clay from the property of the Washington Portland Cement Co., Concrete, Wash.

\begin{tabular}{|c|c|c|c|c|}
\hline & \multicolumn{2}{|c|}{ Limestone. } & \multicolumn{2}{|c|}{ Clay. } \\
\hline & 1 & 2 & 3 & 4 \\
\hline 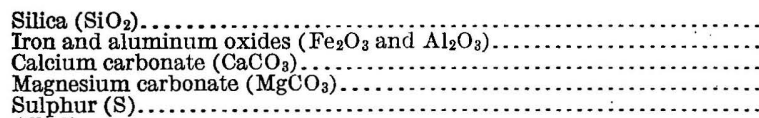 & $\begin{array}{r}0.80 \\
.70 \\
98.14 \\
.65\end{array}$ & $\begin{array}{r}3.41 \\
1.78 \\
92.50 \\
2.30\end{array}$ & $\begin{array}{r}58.75 \\
25.94 \\
4.66 \\
4.47\end{array}$ & $\begin{array}{r}55.90 \\
25.50 \\
4.90 \\
2.83 \\
.51\end{array}$ \\
\hline 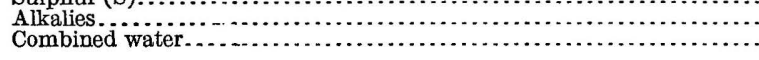 & & & $\begin{array}{ll}7.38 \\
4.60\end{array}$ & $\begin{array}{l}3.91 \\
6.45\end{array}$ \\
\hline
\end{tabular}

Nos. 1 and 3 made by Prof. C. W. Johnson, Seattle, Wash.

Nos. 2 and 4 made by F. C. Newton, Seattle, Wash.

Limestone, shale, and clay are utilized at the plant of the Inland Portland Cement Co. The limestone is reported to contain from 87 to 91 per cent calcium carbonate, from 3 to 3.5 per cent magnesium carbonate, and from 2 to 4.5 per cent alumina, iron oxide, and silica. Calcite carrying 97.5 per cent calcium carbonate is available 3 miles north of Metaline Falls. Two shales and one terrace clay are also available within a few miles of the site. Neither shale alone is satisfactory, but an appropriate mixture of the two is reported to effect a composition whereby any desired percentage of silica may be secured in the finished cement, irrespective of the lime content. The shale from Sullivan Creek runs rather high in lime carbonate and low in silica, and the shale from Sand Creek runs high in silica and comparatively low in alumina, iron oxide, and calcium carbonate. These calcareous shales are in general dark blue or black in color and are finely cleavable, the planes of lamination being distinct and close 
together. In places greenish shales were noted, which may be chloritic. The Inland Portland Cement Co., of Allentown, Pa., has kindly furnished the following analyses made by it of the shales in the vicinity of Metaline Falls:

Analyses of shales from Sullivan Creek, Metaline Falls, Wash.

\begin{tabular}{|c|c|c|c|c|c|}
\hline & 1 & 2 & 3 & 4 & 5 \\
\hline 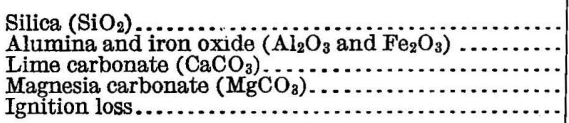 & $\begin{array}{r}25.72 \\
15.72 \\
53.02 \\
3.66 \\
25.64\end{array}$ & $\begin{array}{r}15.62 \\
9.82 \\
68.66 \\
4.81 \\
32.82\end{array}$ & $\begin{array}{r}37.40 \\
25.14 \\
29.71 \\
2.93 \\
16.20\end{array}$ & $\begin{array}{r}20.32 \\
12.20 \\
62.11 \\
3.66 \\
29.66\end{array}$ & $\begin{array}{r}32.22 \\
20.52 \\
39.11 \\
3.87 \\
20.34\end{array}$ \\
\hline
\end{tabular}

Analyses of shales from Sand Creek, 5 miles south of Metaline Falls.

\begin{tabular}{|c|c|c|c|c|c|}
\hline & 1 & 2 & 3 & 4 & 5 \\
\hline 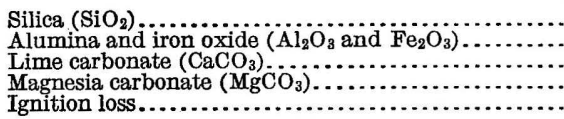 & $\begin{array}{r}71.00 \\
13.20 \\
5.95 \\
6.61 \\
6.40\end{array}$ & $\begin{array}{r}81.16 \\
11.06 \\
1.41 \\
2.70 \\
2.04\end{array}$ & $\begin{array}{r}78.00 \\
11.24 \\
2.19 \\
3.41 \\
3.80\end{array}$ & $\begin{array}{r}65.72 \\
17.84 \\
4.37 \\
3.80 \\
7.44\end{array}$ & $\begin{array}{r}66.50 \\
13.32 \\
8.12 \\
8.71 \\
8.42\end{array}$ \\
\hline
\end{tabular}

Oil is used as fuel in the two western plants, and coal is used in the plant of the Inland Portland Cement Co., which is in the extreme eastern part of the State.

\section{PORTIAND CEMENT RESOURCES OF WEST VIRGINIA.}

Though West Virginia itself furnishes no large market for Portland cement, some of its excellent limestones are very advantageously situated for making cement for shipment outside the State. Some of this advantage lies in proximity to transportation routes, but the more important part of it arises from the abundant fuel that is available in certain portions of the State.

\section{PORTLAND CEMENT MATERIALS.}

\section{DISTRIBUTION.}

Four geologic divisions in West Virginia afford limestones which are worth considering as possible Portland cement materials. (See Pl. XIX, p. 350.) These divisions, named in descending geologic order, are as follows:

1. Pennsylvanian ("Coal Measures") limestones.

2. Greenbrier limestone (Mississippian or "Lower Carboniferous" age).

3. Lewistown limestone (Devonian and Silurian age).

4. Ordovician limestones (Trenton and Stones River age).

The Greenbrier and the Ordovician limestones are by far the most important so far as the possibility of their utilization in Portland cement manufacture is concerned. 


\section{PENNSYLVANIAN LIMESTONES.}

A number of more or less persistent beds of limestone are normally low enough in magnesium carbonate to be considered available for use as Portland cement materials in the Pennsylvanian of West Virginia. Few of them are very pure, commonly ranging only from 80 to 90 per cent of lime carbonate and 5 to 15 per cent or more of silica, alumina, and iron oxide. Individual beds are ordinarily not very thick and rarely outcrop in such a manner as to admit of cheap open quarrying. As against these disadvantages must be set the proximity of developed coal fields, which gives the limestones, when considered as possible bases for the establishment of a Portland cement industry, advantages which must be carefully weighed.

The following table contains analyses of a number of Pennsylvanian limestones from West Virginia localities:

Analyses of Pennsylvaniun limestones, West Virginia.

\begin{tabular}{|c|c|c|c|c|c|c|c|c|c|c|c|}
\hline & 1 & 2 & 3 & 4 & 5 & 0 & 7 & 8 & 9 & 10 & 11 \\
\hline Silica $\left(\mathrm{SiO}_{2}\right)$ & 10.24 & 10.88 & 13.28 & 32.04 & 0.92 & 10.33 & 1.53 & 1.60 & 7.20 & 1.76 & 5.96 \\
\hline $\begin{array}{l}\text { Alumina }\left(\mathrm{Al}_{2} \mathrm{O}_{3}\right) \\
\text { Iron oxide }\left(\mathrm{Fe}_{2} \mathrm{O}_{3}\right)\end{array}$ & 3.52 & 1.92 & 1.68 & 7.00 & .96 & .90 & .96 & 1.60 & 2.00 & .80 & 2.28 \\
\hline 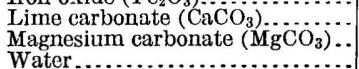 & $\begin{array}{r}81.40 \\
3.32 \\
1.24\end{array}$ & $\begin{array}{c}86.80 \\
\text { Tr. } \\
.60\end{array}$ & $\begin{array}{r}84.40 \\
\text { Tr. } \\
.64\end{array}$ & $\begin{array}{r}56.48 \\
2.48 \\
2.00\end{array}$ & $\begin{array}{r}95.52 \\
1.88 \\
\end{array}$ & {$\left[\begin{array}{r}{[85.75]} \\
{[2.26]}\end{array}\right]$} & {$\left[\begin{array}{r}{[95.10]} \\
{[1.95]}\end{array}\right]$} & $\begin{array}{c}96.20 \\
\text { Tr. }\end{array}$ & $\begin{array}{c}89.72 \\
\text { Tr. }\end{array}$ & $\begin{array}{r}83.92 \\
2.80 \\
72\end{array}$ & $\begin{array}{r}86.70 \\
5.32\end{array}$ \\
\hline Water................................... & 1.24 & .60 & .64 & 2.00 & .76 & .05 & $.10^{\circ}$ & .60 & 1.08 & .72 & 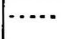 \\
\hline
\end{tabular}

1. Two and one-half miles southeast of Kingwood. Rogers, W. B., Geology of the Virginias, 1884, p. 400. 2, 3. Tenmile Creek, 1 mile from mouth, Kanawha County. Idem, p. 524.

4. Hughes Creek, Kanawha County. Idem, p. 400.

5. Clarksburg. Idem, p. 401.

6, 7. Moundsville Narrows, 12 miles below Wheeler. Bull. U. S. Geol. Survey No. 9, 1884, p. 17.

8, 9, 10. Twomile Creek, Kanawha County. Rogers, W. B., Geology of the Virginias, 1884, p. 525.

11. Scotts Run, Monongalia County. Rept. West Virginia Geol. Survey, vol. 3, 1906, p. 529.

\section{GREENBRIER LIMESTONE.}

The Greenbrier (Mississippian or "Lower Carboniferous") limestone covers large areas in West Virginia. (See Pl. XIX.) This is owing in part to the great thickness of the formation, which reaches its maximum development in its type area in Greenbrier County. At Manheim, on Cheat River, east of Grafton, this limestone furnishes the raw material for the only Portland cement plant in West Virginia - that of the Buckhorn Portland Cement Co.

Throughout its extent in West Virginia the Greenbrier consists almost entirely of very pure nonmagnesian limestone, though some shaly or magnesian beds occur. In the vicinity of Fort Spring, for example, the senior writer found that the basal portion of the formation was appreciably higher in both silica and magnesium carbonate than the upper portion, and that the oolitic beds, which are almost uniformly of exceedingly high-grade stone, occur several hundred feet above the base of the limestone. 
Because of its thickness, its generally favorable composition, and its situation with respect to fuel supplies and transportation routes, the Greenbrier limestone is a very promising source of Portland cement material.

The following table contains a number of analyses of Greenbrier limestone from West Virginia:

Analyses of Greenbrier limestone, West Virginia.

\begin{tabular}{|c|c|c|c|c|c|c|c|c|c|c|c|c|}
\hline & 1 & 2 & 3 & 4 & 5 & 6 & 7 & 8 & 9 & 10 & 12 & 13 \\
\hline $\begin{array}{l}\text { Silica }\left(\mathrm{SiO}_{2}\right) \\
\mathrm{Alumina}\left(\mathrm{Al}_{2} \mathrm{O}_{3}\right) \text { and iron oxide } \\
\left(\mathrm{Fe}_{2} \mathrm{O}_{3}\right) \\
\left.\text { Lime carbonate }(\mathrm{CaCO})_{3}\right) \\
\text { Magnesium carbonate }\left(\mathrm{MgCO}{ }_{3}\right)\end{array}$ & $\begin{array}{r}0.97 \\
1.46 \\
96.46 \\
1.11\end{array}$ & $\begin{array}{r}19.87 \\
4.09 \\
74.56 \\
1.95\end{array}$ & $\begin{array}{c}6.20 \\
1.20 \\
89.92 \\
\text { Tr. }\end{array}$ & $\begin{array}{r}1.88 \\
.56 \\
95.92 \\
\text { Tr. }\end{array}$ & $\begin{array}{r}6.04 \\
.88 \\
89.44 \\
2.80\end{array}$ & $\begin{array}{r}0.40 \\
.48 \\
98.20 \\
\text { n. d. }\end{array}$ & $\begin{array}{r}5.80 \\
1.16 \\
89.76 \\
2.32\end{array}$ & \begin{tabular}{r|r}
27.00 & 7 \\
$: 88$ & 2 \\
67.40 & 88 \\
2.32 & $\mathrm{n}$
\end{tabular} & \begin{tabular}{r|r}
7.24 & 6 \\
2.52 & 1 \\
88. 32 & 88 \\
n.d. & 3
\end{tabular} & \begin{tabular}{l|r}
6.00 & 26.96 \\
1.52 & 1.60 \\
38.52 & 64.0 \\
3.24 & 6.7
\end{tabular} & \begin{tabular}{|c|c|}
6 & n.d. \\
0 & n.d. \\
01.96 \\
6 & 3.51
\end{tabular} & $\begin{array}{r}3.52 \\
1.04 \\
92.78 \\
2.01\end{array}$ \\
\hline & 14 & 15 & 16 & 17 & 18 & 19 & 20 & 21 & 22 & 23 & 24 & 25 \\
\hline $\begin{array}{l}\text { Silica }\left(\mathrm{SiO}_{2}\right) \\
\text { Alumina }\left(\mathrm{Al}_{2} \mathrm{O}_{3}\right) \text { and iron oxide } \\
\left(\mathrm{Fe}_{2} \mathrm{O}_{3}\right) \\
\text { Lime carbonate }(\mathrm{CaCO})_{3} \\
\text { Magnesium carbonate }\left(\mathrm{MgCO}{ }_{3}\right) \ldots\end{array}$ & $\mid \begin{array}{r}12.86 \\
2.69 \\
81.10 \\
2.54\end{array}$ & \begin{tabular}{r|}
1.38 \\
.46 \\
96.23 \\
1.84
\end{tabular} & $\begin{array}{r}6.85 \\
1.51 \\
89.39 \\
1.99\end{array}$ & $\begin{array}{r}4.74 \\
.58 \\
92.53 \\
2.15\end{array}$ & $\begin{array}{r}6.86 \\
2.43 \\
89.16 \\
1.93\end{array}$ & $\begin{array}{r}4.97 \\
2.82 \\
87.93 \\
4.00\end{array}$ & \begin{tabular}{r|}
0.89 \\
.61 \\
97.73 \\
1.44
\end{tabular} & \begin{tabular}{|r|}
3.74 \\
1.31 \\
92.88 \\
2.79
\end{tabular} & \begin{tabular}{r|r}
4 & 12.64 \\
1 & 6.77 \\
8 & 78.28 \\
9 & 1.51
\end{tabular} & \begin{tabular}{|r|r|}
34 & 8.28 \\
77 & 3.26 \\
38 & 86.84 \\
51 & 2.11
\end{tabular} & $\begin{array}{r}3.31 \\
1.78 \\
94.98 \\
1.38\end{array}$ & $\begin{array}{r}2.47 \\
1.63 \\
96.13 \\
.49\end{array}$ \\
\hline
\end{tabular}

1. Huddleston quarry, Snowflake, Greenbrier County. J. B. Britton, analyst. "Twentieth Ann. Rept. U. S. Geol. Survey, pt. 6 (continued), 1899, p. 460.

2. Shavers Mountain, Randolph County. E. Whitfield, analyst. Bull. U. S. Geol. Survey No. 27, $1886, p, 74$.

3. Near Red Sulphur Springs, Monroe County. Rogers, Geology of the Virginias, p. 396.

4. Near Union, Monroe County. Idem, p. 397.

5. Two miles south of Kingwood, Preston County. Idem, p. 398.

6. Muddy Creek Mountain, near Blue Sulphur Springs. Idem, p. 396.

7, 8. Cheat River, below Gum Camp Run, Preston County. Idem, p. 397.

9. East side Laurel Hill, Monongalia County. Idem.

10. Front ridge, opposite Petersburg, Tucker County. Idem, p. 398

11. East side Briery Mountain, Preston County. Idem.

12. West of Glen Lyn, Va., in Mercer County, W. Va. Sample by E. C. Eckel. Analyzed by Lehigh Valley Testing Laboratory.

13-16. Two miles east of Fort Spring, Greenbrier County. Sample by E. C. Eckel. Analyzed by Lehigh Valley Testing Laboratory.

17. Hendricks, Tucker County. J. C. Drydon, analyst. Rept. West Virginia Geol. Survey, vol. 3, 1906, p. 521.

18. Hendricks, Tucker County. G. P. Maury, analyst. Idem.

19, 20. Frazier quarry, Fort Spring, Greenbrier County. Idem, p. 525

21. Lewisburg, Greenbrier County. Idem.

22-25. Morgantown, Monongalia County. Idem, p. 527.

\section{LEWISTOWN LIMESTONE.}

Owing to the small areas of outcrop of the Lewistown limestone in West Virginia, as compared to the areas covered by the Greenbrier and Ordovician limestones, the Lewistown is ordinarily of slight importance as a possible cement material. At a few places, however, its location gives it advantages which render it worthy of serious consideration. In Mercer and Monroe counties limestone of this age, which there is included in the Giles formation, is exposed along the lines of the great coal-carrying. railroads very near the coal fields, and such points are worth examining with care.

The following table contains a few analyses of Lewistown limestone from points in West Virginia. Nos. 1 and 2 are of pure Lewistown limestone from one of the northern counties, and Nos. 3 and 4 are of $48834^{\circ}-$ Bull. $522-13-24$ 
limestone from the Giles formation in Mercer County. Nos. 3 and 4, it may be noted, represent cement rocks much like those of the Lehigh district. The pure limestone needed to mix with them is found at the same locality in the Greenbrier limestone (analysis 12, p. 369).

Analyses of Devonian and Silurian limestones, West Virginia.

\begin{tabular}{|c|c|c|c|c|c|}
\hline . & 1 & 2 & 3 & 4 & 5 \\
\hline 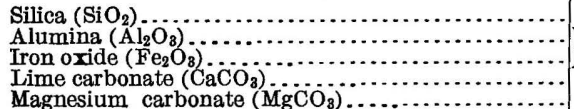 & $\begin{array}{r}1.85 \\
1.45 \\
93.89 \\
1.32\end{array}$ & $\begin{array}{r}0.49 \\
.40 \\
98.94 \\
.68\end{array}$ & $\begin{array}{r}16.10 \\
4.06 \\
1.81 \\
71.23 \\
4.95\end{array}$ & $\begin{array}{r}19.89 \\
4.42 \\
1.81 \\
66.59 \\
5.50\end{array}$ & $\begin{array}{r}4.96 \\
.76 \\
92.44 \\
1.40\end{array}$ \\
\hline
\end{tabular}

1. Lewistown limestone, Standard Lime Co. quarry, Keyser, Mineral County. F. F. Grout, analyst. Rept. West Virginia Geol. Survey, vol. 3, 1906, p. 518.

2. Lewistown limestone, Keyes quarry, Keyser, Mineral County. Idem.

3, 4. Limestone in Giles formation west of Glen Lyn, Va., in Mercer County, W. Va. Sampled by E. C. Eckel, analyzed by Lehigh Valley Testing Laboratory.

5. Lewistown limestone, Pattersons Creek, near Hampshire Furnace. Quoted by Rogers, W. B., Geology of the Virginias, 1884, p. 395.

\section{ORDOVICIAN LIMESTONES.}

The only large area of Ordovician limestones in West Virginia occupies much of Jefferson and Berkeley counties, in the extreme northeastern angle of the State. (See Pl. XIX.) Most of the other areas are not commercially available, though one belt of Ordovician limestone in Mercer County, crossing the lines of the Norfolk \& Western Railway and the Virginian Railway, may be worthy of consideration.

The Ordovician limestones of Jefferson and Berkeley counties are a portion of the great Shenandoah group of limestones occupying the valley between the Blue Ridge and the Allegheny Mountains. The Shenandoah group has been already discussed (see pp. 203-204), and it is only necessary to add that in West Virginia the limestones at the top of the Shenandoah group are well developed; that they carry heavy beds of low-magnesia limestones, and that they far outweigh in commercial importance, both-present and prospective, the remainder of the group.

Analyses of Ordovician limestones, West Virginia.

\begin{tabular}{|c|c|c|c|c|c|c|c|}
\hline . & 1 & 2 & 3 & 4 & 5 & 6 & 7 \\
\hline 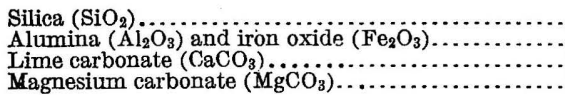 & $\begin{array}{r}1.18 \\
1.60 \\
92.27 \\
3.18\end{array}$ & $\begin{array}{r}0.02 \\
.75 \\
98.21 \\
.86\end{array}$ & $\begin{array}{r}0.12 \\
1.01 \\
95.55 \\
2.44\end{array}$ & $\begin{array}{r}3.81 \\
2.00 \\
89.91 \\
3.18\end{array}$ & $\begin{array}{r}0.50 \\
.69 \\
95.44 \\
2.51\end{array}$ & $\begin{array}{r}1.14 \\
.81 \\
95.18 \\
3.47\end{array}$ & $\begin{array}{r}0.60 \\
.46 \\
97.17 \\
1.26\end{array}$ \\
\hline
\end{tabular}

1, 2. Keller Lime Co., Engels. F. F. Grout, analyst. Rept. West Virginia Geol. Survey, vol. 3, 1906, p. 336 .

3. Standard Lime \& Stone Co., Bakerton. Idem, p. 337

4. Standard Lime \& Stone Co., Kearneysville. Idem, p. 337.

5. Baker Bros. Quarry, Martinsburg. Idem, p. 338.

6. Martinsburg Limestone Co., Martinsburg. Idem, p. 338.

7. Kline Quarry, Bunker Hill.' Idem, p. 340 . 


\section{PORTLAND CEMENT INDUSTRY OF WEST VIRGINIA.}

At present only one Portland cement plant is in operation in West Virginia. The plant of the Alpha Portland Cement Co., on Cheat River, at Manheim, near Grafton, formerly known as the Buckhorn mill, uses Greenbrier limestone, Mississippian shales, and Quaternary clays from deposits on the river flats. Analyses ${ }^{1}$ of all these materials follow:

Analy'ses of cement materials, Manheim, W. Va.

\begin{tabular}{|c|c|c|c|c|c|}
\hline & \multicolumn{3}{|c|}{ Limestone. } & \multirow{2}{*}{ Shale. } & \multirow{2}{*}{ Clay. } \\
\hline & Lower. & Middle. & Upper. & & \\
\hline 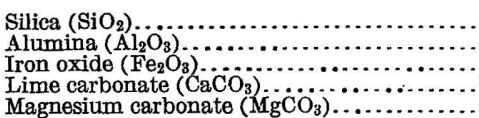 & $\begin{array}{r}23.40-20.20 \\
9.10-8.80 \\
60.31-68.89 \\
\text { Tr. }\end{array}$ & $\begin{array}{r}18.60-13.08 \\
7.60-6.12 \\
72.27-80.09 \\
\text { Tr. }-.61\end{array}$ & $\begin{array}{r}8.84-2.92 \\
5.04-1.82 \\
85.00-94.00 \\
.72-1.10\end{array}$ & $\begin{array}{r}62.74 \\
19.40 \\
.38 \\
1.41\end{array}$ & $\begin{array}{r}68.16 \\
16.18 \\
.42 \\
1.04\end{array}$ \\
\hline
\end{tabular}

From inspection of the above analyses it will be seen that the necessary composition for the raw cement mix could be obtained in several ways. The procedure actually followed is to combine different grades of limestone.

\section{PORTLAND CEMENT RESOURCES OF WISCONSIN.}

\section{PORTLAND CEMENT MATERIALS.}

\section{ORDOVICIAN AND SILURIAN LIMESTONES.}

Although the Ordovician and Silurian deposits in Wisconsin contain heavy and widely distributed beds of limestone, the chances for obtaining a well-located limestone sufficiently low in magnesia to be serviceable seem to be very poor. Of the numerous analyses of Wisconsin limestones examined only three show less than 30 per cent of magnesium carbonate. So far as known, the only fairly thick and extensive bodies of low-magnesia limestone in Wisconsin occur in the lead region in the upper part of the Platteville limestone.

In the söuthwestern part of the State a generally thin and rather locally developed bed of relatively pure limestone forms the top of the Platteville. The "glass rock," as this bed is called, is probably better developed at Mineral Point and Platteville, Wis., than anywhere else in the lead district. At these localities it is filled with a highly characteristic fauna of late Stones River age. The rocks deposited upon it are the Decorah shale and the Galena dolomite.

Farther east, as at Beloit, and thence northward to Escanaba, Mich., the "glass rock" is not represented in the sections. The "upper buff" and "blue," however, occur continuously east and north of 
Janesville and Beloit, Wis., but are wanting, at least locally, in the lead region.

Grant ${ }^{1}$ has described this particular limestone as follows:

The "glass rock" belongs near the top of the Trenton [Platteville] limestone. This term has been applied to a number of varieties of limestone in this general horizon. It may be said that the name is used for very fine grained, compact, and hard beds of limestone which occur near the top of the Trenton [Platteville]. This is about as accurate a general definition of the term as can be given. There is, however, one particular phase of this rock which may be called the typical glass rock and which is apparently the rock to which the name was first applied. This is a very fine grained, very compact limestone, which breaks with a conchoidal fracture, and which when fresh is of a light-brown or chocolate color. On exposure to the air, however, this color changes to a bluish gray. This phase of the glass rock is found in many places throughout the western two-thirds of the lead and zinc district. It usually occurs in thin beds, and in some places, especially at Platteville, is an important building material, the normal school building at this place and one of the high school buildings being constructed almost entirely of this rock. The fact that it does not occur in thicker beds prevents its universal use as a building stone. Very frequently this glass rock is packed full of fossils. It is a comparatively pure limestone, containing only a small amount of magnesia, the chief impurities being silica and clay.

The composition of this rock is shown by the following analyses: Analyses of Platteville limestone, Wisconsin.

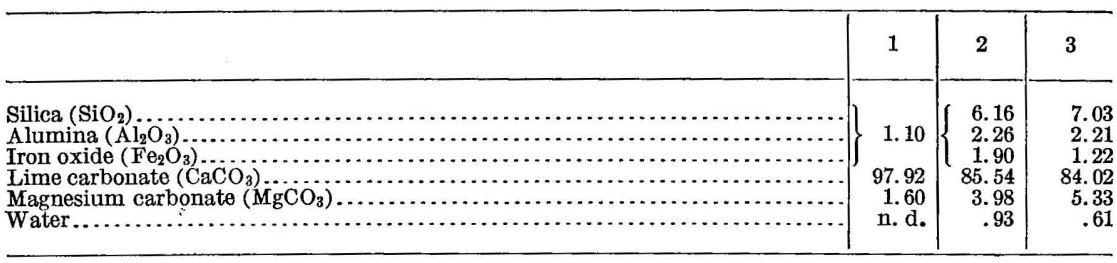

1. Near Benton, on Fever River. Geol. Wisconsin, vol. 2, 1877, pp. 560-561.

2. Mineral Point. Idem, pp. 560-561.

3. Bristol, Dane County. Idem, pp. 560-561.

Limestone, shale, and loess clay that occur near Dubuque, Iowa, and that are possibly suitable for the manufacture of Portland cement have already been described (pp. 174-179). As the southwestern part of Wisconsin adjoins Dubuque County, and as the same geologic conditions prevail on both sides of the river, the descriptions of the Iowa materials are of interest in this connection. Two geologic sections of Ordovician rocks in southwest Wisconsin, not heretofore given, are as follows:

Section of Ordovician formations (Platteville to Galena) near Potosi station, Wis.

1. Limestone, fine grained, thin bedded (Galena).................... 12

2. Shale, including 2 feet 4 inches of interbedded limestone, total....... $\quad 7 \quad 10$

3. Limestone, fine grained, thin bedded......................... $3 \quad 6$

4. Limestone, even grained, medium bedded........................ 3

5. Limestone, crystalline, thin bedded............................ 12

6. Limestone, fine grained, thin, wavy bedded (partly concealed) ........ 18

1 Grant, U.S., Lead and zinc deposits of Wisconsin: Bull. Wisconsin Geol. and Nat. Hist. Survey No. 9, 1903 , p. 26. 
Section of Ordovician formations (Platteville to Galena) near McCartney, Wis.

1. Limestone, subcrystalline, with carbonaceous shale partings (Galena)... Ft. in

2. Shale, calcareous, including 6 inches of thin limestone partings, total..... 3

3. Shale, blue............................................. 2

Concealed.............................................. 5

4. Limestone, bluish, crystalline, thin bedded...................... 5

Concealed................................................. 10

5. Limestone, fine grained, thin bedded ..................... 7

Concealed................................................ 13

6. Limestone, heavy bedded, buff to blue, probably magnesian........... 6

Analyses of the shale beds, exclusive of the limestone bands, comprising No. 2 of the section at Potosi station and Nos. 2 and 3 at McCartney, are published on page 177 of this bulletin. ${ }^{1}$

\section{QUATERNARY SHELL MARLS.}

Wisconsin, like Michigan, Ohio, New York, and other States north of the glacial limits, contains many lakes, some of which contain deposits of marl. Little attention has yet been paid to these deposits, and practically nothing can be said as to their occurrence and character. One noteworthy feature, however, should be borne in mind. As already shown, almost all the limestone deposits of the State are highly magnesian, and as the marls are derived from local limestones Wisconsin marls probably carry larger percentages of magnesia than marls occurring in areas of pure limestones. This seems to be indicated by the following analysis:

Analysis of shell marl, Wisconsin.

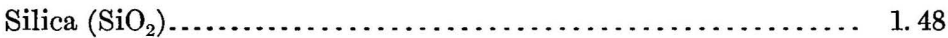

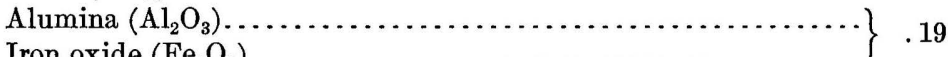

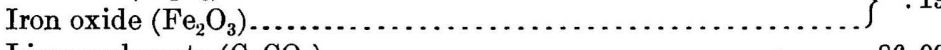

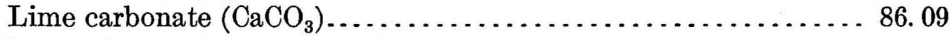

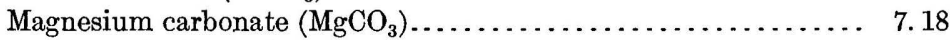

Sulphur trioxide $\left(\mathrm{SO}_{3}\right) \ldots \ldots \ldots \ldots \ldots \ldots \ldots \ldots \ldots \ldots \ldots \ldots \ldots, .44$

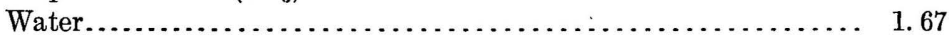

Organic matter............................................ 952

Sections 17, 18, 19, and 20; town of Pierce, T. 24, R. 25, Kewaunee County. G. Bode, analyst. Geology of Wisconsin, vol. 2, 1877, p. 239.

\section{PORTLAND CEMENT RESOURCES OF WYOMING.}

Limestones are extensively distributed throughout Wyoming, but little attention has yet been paid to their economic value. The first detailed discussion of the cement possibilities of the State was published in 1907 by S. H. Ball, ${ }^{2}$ who made a very careful examination of two groups of limestone and shale areas tributary, respectively, to

\footnotetext{
1 See also Grant, U. S., and Burchard, E. F., Lancaster-Míneral Point folio (No. 145) Geol. Atlas U. S., U. S. Geol. Survey, 1907, pp. 4-5.

2 Ball, S. H., Portland cement materials in eastern Wyoming: Bull. U. S. Geol. Survey No. 315, 1907, pp. 232-244.
} 
Newcastle and Cheyenne. His results, which are distinctly interesting, may be summarized best by presenting tables of analyses of the limestones and shales and noting the most important features of each.

Analyses of limestones, Wyoming.

\begin{tabular}{|c|c|c|c|c|c|}
\hline & 1 & 2 & 3 & 4 & 5 \\
\hline 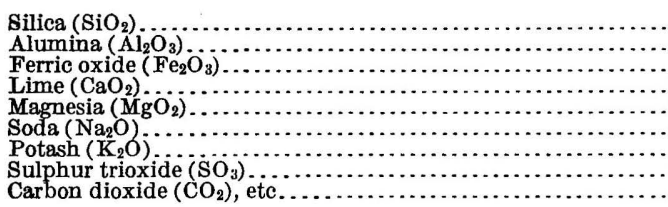 & $\begin{array}{r}18.10 \\
6.26 \\
.80 \\
37.57 \\
.76 \\
2.14 \\
.92 \\
.27 \\
31.58\end{array}$ & $\begin{array}{r}1.08 \\
.33 \\
.77 \\
53.40 \\
.57 \\
.36 \\
.16 \\
.12 \\
42.92\end{array}$ & $\begin{array}{r}1.42 \\
.68 \\
.40 \\
52.85 \\
.72 \\
.76 \\
.30 \\
.12 \\
42.78\end{array}$ & $\begin{array}{r}6.44 \\
1.46 \\
2.32 \\
45.00 \\
2.65 \\
.66 \\
.07 \\
30.71\end{array}$ & $\begin{array}{r}10.52 \\
.46 \\
1.55 \\
43.30 \\
3.53 \\
.05 \\
.70 \\
.06 \\
39.22\end{array}$ \\
\hline
\end{tabular}

Of the above limestones the first three are from the Newcastle district and the others from the vicinity of Cheyenne. The interesting "cement rock" shown in analysis 1 was found $2 \frac{1}{2}$ miles southeast of Newcastle in an outcrop 40 feet thick, which Ball states could probably be worked with a steam shovel. Nos. 2 and 3 are purer limestones from about 5 miles southeast of Newcastle, where a 40-foot bed covers a large area of outcrop. Nos. 4 and 5 are from Iron Mountain, 40 miles from Cheyenne. No. 4 is exposed to a thickness of 60 feet or more and is a thin-bedded, readily quarried rock. No. 5 is harder and less satisfactorily situated and is about 40 feet thick. All the analyses represent the average of a series of samples taken across the full thickness of the beds.

As regards shales, the following analyses cover the ground of the report:

Analyses of shales, Wyoming.

\begin{tabular}{|c|c|c|c|c|c|c|c|}
\hline & 1 & 2 & 3 & 4 & 5 & 6 & 7 \\
\hline 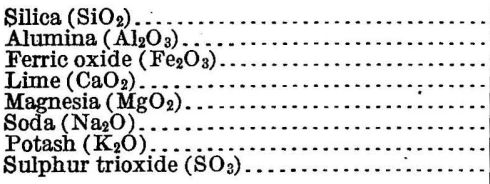 & $\begin{array}{r}45.78 \\
12.92 \\
3.96 \\
.56 \\
.73 \\
.64 \\
.50 \\
.42\end{array}$ & $\begin{array}{r}67.55 \\
17.58 \\
.47 \\
.36 \\
.74 \\
.21 \\
.79 \\
.50\end{array}$ & $\begin{array}{r}58.82 \\
16.43 \\
4.47 \\
.54 \\
1.68 \\
.33 \\
2.18 \\
1.32\end{array}$ & $\begin{array}{r}68.30 \\
14.65 \\
.37 \\
1.18 \\
1.03 \\
.30 \\
.39 \\
.09\end{array}$ & $\begin{array}{r}60.66 \\
2.13 \\
1.21 \\
1.59 \\
1.54 \\
.53 \\
2.16 \\
.43\end{array}$ & $\begin{array}{r}63.60 \\
14.66 \\
7.44 \\
.78 \\
.46 \\
.37 \\
1.79 \\
.53\end{array}$ & $\begin{array}{r}62.34 \\
21.98 \\
7.92 \\
1.28 \\
.73 \\
.19 \\
1.71 \\
.36\end{array}$ \\
\hline
\end{tabular}

The first five of the above analyses are of shales from near Newcastle; Nos. 6 and 7 are from the Cheyenne district. Nos. 2, 4, and 5 are unusually low in iron. No. 3 , which is by far the most satisfactory of the Newcastle analyses, was taken from a 40-foot outcrop located $2 \frac{1}{2}$ miles southeast of Newcastle. The two Cheyenne samples would be good enough for mixture with ordinary limestones, but the limestones of the Cheyenne district are of somewhat uncommon character and would apparently require the addition of a highly ferruginous shale.

The two regions have very unequal possibilities as cement producers. The three limestones of the Newcastle district can be 
handled together, like a Lehigh Valley mix, without adding of shale. The two limestones of the Cheyenne district are highly siliceous and of doubtful value. Added to this is a fuel advantage for Newcastle, for there coal can be obtained from the mines at Cambria, only 8 miles away, whereas coal at the Cheyenne localities would cost $\$ 4.50$ to $\$ 5.50$ per ton.

The following analyses of limestones from Wyoming may also prove serviceable:

Analyses of limestones, Wyoming. ${ }^{a}$

\begin{tabular}{|c|c|c|c|c|c|c|c|c|c|}
\hline . & 1 & 2 & 3 & 4 & 5 & 6 & 7 & 8 & 9 \\
\hline 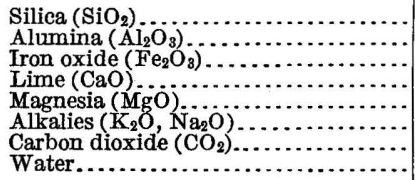 & $\begin{array}{r}2.02 \\
.57 \\
54.06 \\
.34 \\
\text { n. d. } \\
42.85 \\
.42\end{array}$ & $\begin{array}{r}22.22 \\
.21 \\
43.24 \\
.15 \\
\text { n. d. } \\
33.94 \\
.14\end{array}$ & $\left\{\begin{array}{r}31.28 \\
1.83 \\
34.22 \\
.11 \\
.51 \\
26.79 \\
4.64\end{array}\right.$ & $\begin{array}{r}31.45 \\
1.58 \\
.21 \\
34.18 \\
.08 \\
.61 \\
2.68 \\
4.64\end{array}$ & $\begin{array}{r}23.49 \\
6.17 \\
2.16 \\
33.79 \\
.62 \\
.38 \\
27.08 \\
6.27\end{array}$ & $\begin{array}{r}23.47 \\
6.27 \\
23.20 \\
33.83 \\
.74 \\
.38 \\
27.03 \\
6.20\end{array}$ & $\begin{array}{r}6.49 \\
54.16 \\
.15 \\
\text { n. d. } \\
43.68\end{array}$ & $\begin{array}{r}1.52 \\
54.18 \\
.15 \\
\text { n. d. } \\
43.69\end{array}$ & $\begin{array}{r}0.43 \\
.10 \\
.12 \\
55.34 \\
.21 \\
\text { n. } .2 . \\
43.73 \\
.05\end{array}$ \\
\hline
\end{tabular}

a Analyses 1-8 by B. E. Brewster, Rept. U. S. Geol. Expl. 40th par., vol. 2, 1877, pp. —; analysis 9 from Ann. Rept. Territorial Geologist for Wyoming for 1888-89, 1890, p. 79 .

1. Vermilion Creek Canyon. "Upper Coal Measures."

2. Near Red Buttes. Jurassic?.

3,4. Turtle Bluffs, north side of Henrys Fork. Eocene.

5,6. Green River City. Eocene.

7,8 . Five miles south of Cheyenne. Pliocene.

9. Three miles east of Laramie. Carboniferous.

\section{BIBLIOGRAPHY.}

By E. F. Burchard.

For the convenience of the reader a summary. of papers on cement materials, cement, and concrete, published by the United States Geological Survey, by other Government bureaus, by State geological surveys, and by certain nonofficial organizations is given below, although some of these papers have been mentioned in the bibliographies of cement materials by States.

\section{PUBLICATIONS BY THE UNITED STATES GEOLOGICAL SURVEY.}

The following list summarizes the principal publications on cement and concrete materials by the United States Geological Survey. These Survey publications, except those to which a price is affixed, can be obtained free by applying to the Director, United States Geological Survey, Washington, D. C. The priced publications may be purchased from the Superintendent of Documents, Government Printing Office, Washington, D. C. Publications of which the edition is exhausted can not be obtained even from the Superintendent of Documents, though they can be consulted at most public libraries. The Survey does not distribute any other than its own publications.

Adams, G. I., and others, Stratigraphy and paleontology of the upper Carboniferous rocks of the Kansas section: Bull. 211, 1903, $123 \mathrm{pp} .20 \mathrm{c}$.

Economic geology of the Iola quadrangle, Kansas: Bull. 238, 1904, 80 pp. 
BaLL, S. H., Portland cement materials in eastern Wyoming: Bull. 315, 1907, pp. 232-244. 50c.

Bassler, R. S., Cement materials of the Valley of Virginia: Bull. 260, 1905, pp. 531-544. 40c.

BAstik, E. S., The lime industry of Knox County, Me.: Bull. 285, 1906, pp. 393-400. Edition exhausted.

Clays of the Penobscot Bay region, Maine: Bull. 285, 1906, pp. 428-431. Edition exhausted.

Branner, J. C., Clays of Arkansas: Bull. 351, 1908, 247 pp.

Burchard, E. F., Portland cement materials near Dubuque, Iowa: Bull. 315, 1907, pp. 225-231. 50c.

Concrete materials produced in the Chicago district: Bull. 340, 1908, pp. 383-410. 30c.

- Structural materials available in the vicinity of Austin, Tex.: Bull. 430, 1910, pp. 292-316.

Cement: Mineral Resources U. S. for 1910, pt. 2, 1911, pp. 69-535. 75c.

Cement: Mineral Resources U. S. for 1911, pt. 2, 1912, pp. 485-519.

Catrett, C., Cement resources of the Valley of Virginia: Bull. 225, 1904, pp. 457-461. $35 \mathrm{c}$.

Clapp, F. G., Limestones of southwestern Pennsylvania: Bull. 249, 1905, 52 pp.

Crider, A. F., Cement resources of northeast Mississippi: Bull. 260, 1905, pp. 510521. $40 \mathrm{c}$.

- Geology and mineral resources of Mississippi: Bull. 283, 1906, $99 \mathrm{pp}$.

Darton, N. H., Geology and.water resources of the northern portion of the Black Hills and adjoining regions in South Dakota and Wyoming: Prof. Paper 65, 1909, $104 \mathrm{pp}$.

- Structural materials in parts of Oregon and Washington: Bull. 387, 1909, $36 \mathrm{pp}$.

_ Cement materials in Republican Valley, Nebraska: Bull. 430, 1910, pp. 381-387.

- and Siebenthal, C. E., Geology and mineral resources of the Laramie Basin, Wyoming: Bull. 364, 1908, 81 pp.

Duryee, E., Tests of cement materials from Gila River, Arizona: Water-Supply Paper 33, 1900, pp. 82-90. 15c.

- Cement investigations in Arizona: Bull. 213, 1903, pp. 372-380. 25c.

Eckex, E. C., The materials and manufacture of Portland cement: Senate Doc. 19, 58th Cong., 1st sess., 1903, pp. 2-11.

Cement-rock deposits of the Lehigh district: Bull. 225, 1904, pp. 448-450. $35 \mathrm{c}$.

Cement materials and cement industries of the United States: Bull. 243, 1905, 395 pp. Edition exhausted.

- The American cement industry: Bull. 260, 1905, pp. 496-505. 40c.

- Portland cement resources of New York: Bull. 260, 1905, pp. 522-530. 40c. Cement resources of the Cumberland Gap district, Tennessee-Virginia: Bull. 285, 1906, pp. 374-376. Edition exhausted.

—Cement: Mineral Resources U. S. for 1908, pt. 2, 1909, pp. 441-453. 80c.

and CrIDer, A. F., Geology and cement resources of the Tombigbee River district, Mississippi-Alabama: Senate Doc. 165, 58th Cong., 3d sess., 1905, 21 pp.

Fenneman, N. M., Geology and mineral resources of the St. Louis quadrangle, Missouri-Illinois: Bull. 438, 1911, 73 pp.

Humphrey, R. L., The effects of the San Francisco earthquake and fire on various structures and structural materials: Bull. 324, 1907, pp. 14-61. 50c.

- Organization, equipment, and operation of the structural-materials testing laboratories at St. Louis, Mo.: Bull. 329, 1908, 85 pp. 20 c. 
HumpHRey, R. L., Portland cement mortars and their constituent materials: Results of tests, 1905 to 1907: Bull. 331, 1908, 130 pp. 25c.

The strength of concrete beams; results of tests made at the structural-materials testing laboratories: Bull. 344, 1908, 59 pp. $10 \mathrm{c}$.

The fire-resistive properties of various building materials: Bull. 370, 1909, 99 pp. 30c.

LANDES, H., Cement resources of Washington: Bull. 285, 1906, pp. 377-383. Edition exhausted.

LipPincotт, J. B., Manufacture of Portland cement in southern California: WaterSupply Paper 60, 1902, pp. 135-137. 15c.

Martin, G. C., The Niobrara limestone of northern Colorado as a possible source of Portland cement material: Bull. 380, 1909, pp. 314-326.

Pepperberg, L. J., Cement material near Havre, Mont.: Bull. 380, 1909, pp. 327336.

Richardson, G. B., Portland cement materials near El Paso, Tex.: Bull. 340, 1908, pp. 411-414. 30c.

Ries, HeIn rich, Clays of Illinois: Prof. Paper 11, 1903, pp. 94-97. 40c.

Russeli, I. C., The Portland cement industry in Michigan: Twenty-second Ann. Rept., pt. 3, 1902, pp. 620-686. \$2.

Schrader, F. C., Geology of the Independence (Kans.) folio (No. 159), Geol. Atlas U. S., 1907. $25 \mathrm{c}$.

- and HA worth, E., Economic geology of the Independence quadrangle, Kansas: Bull. 296, 1906, 74 pp.

Sewell, J. S., The effects of the San Francisco earthquake on buildings, engineering structures, and structural materials: Bull. 324, 1907, pp. 62-130. 50c.

Siebenthal, C. E., The Bedford oolitic limestone (Indiana): Nineteenth Ainn. Rept., pt. 6, continued, 1898, pp. 292-296.

Sмттн, E. A., The Portland cement materials of central and southern Alabama: Senate Doc. 19, 58th Cong., 1st sess., 1903, pp. 12-23. Cement resources of Alabama: Bull. 225, 1904, pp. 424-447. 35c.

TAFr, J. A., Chalk of southwestern Arkansas, with notes on its adaptability to the manufacture of hydraulic cements: Twenty-second Ann. Rept., pt. 3, 1902, pp. 687-742. $\$ 2$.

UdDen, J. A., Oolitic limestone industry at Bedford and Bloomington, Ind.: Bull. 430, 1910, pp. 335-345.

\section{PUBLICATIONS BY MISCELLANEOUS GOVERNMENT BUREAUS.}

Cox, Auvin J., Volcanic tuff as a construction and a cement material: Philippine Jour. Sci., Bureau Sci., Manila, P. I., November, 1908, pp. 391-406.

- Philippine raw cement materials: Philippine Jour. Sci., Bureau Sci., Manila, P. I., May, 1909, pp. 211-229.

Humphrey, R. L., and Losse, L. H., The strength of reenforced-concrete beamsresults of 333 beams: Tech. Paper Bur. Standards No. 2, 1912, 200 pp.

Office of Public Roads, The construction of concrete fence posts: Farmers' Bull. No. 403, U. S. Dept. Agr., 1910, 31 pp.

Use of concrete on the farm: Farmers' Bull. No. 461, U. S. Dept. Agr., 1911, $23 \mathrm{pp}$.

PAGE, L. W., Oil-mixed Portland cement concrete: Bull. Office Pub. Roads No. 46, U. S. Dept. Agr., 1912, 28 pp.

Reibling, W. C., and Reyes, F. D., Physical and chemical properties of Portland cement: Philippine Jour. Sci., Bureau Sci., Manila, P. I., December, 1910, pp. 367-417, June, 1911, pp. 207-251.

United States Government, Specification for Portland cement: Circ. Bur. Standards No. 33, 1912, 28 pp. 
WIG, R. J., The effect of high-pressure steam on the crushing strength of Portland cement mortar and concrete: Tech. Paper Bur. Standards No. 5, 1912, 25 pp.

Wig, R. J., and Bates, P. H., Tests of the absorptive and permeable properties of Portland cement mortars and concretes, together with tests of damp-proofing and waterproofing compounds and materials: Tech. Paper Bur. Standards No. 3, $1912,127 \mathrm{pp}$.

Wormley, P. L., jr., Cement mortars and concrete-preparation and use for farm purposes. Farmers' Bull. No. 235, U. S. Dept. Agr., 1905, 32 pp.

\section{PUBLICATIONS BY STATE GEOLOGICAL SURVEYS.}

Investigations of cement materials have been made by certain of the State geological surveys, and many detailed reports have been published on important local deposits. The surveys of the following States have made special studies of local cement resources: Alabama, Arkansas, California, Georgia, Illinois, Indiana, Iowa, Maryland, Michigan, Mississippi, Missouri, New Jersey, New York, North Dakota, Ohio, Oklahoma, South Dakota, Vermont, Virginia, Wash_ ington, and West Virginia. Certain other States have done a little work on their cement materials.

The most important of the State reports are listed below:

Alabama: Smith, E. A., and Ries, Heinrich, Preliminary report on the clays of Alabama: Bull. Alabama Geol. Survey No. 6, 1900, 220 pp.

Smith, E. A., and Eckel, E. C., The cement resources of Alabama, and the materials and manufacture of Portland cement: Bull. Alabama Geol. Survey No. 8, 1904, 93 pp.

Arkansas: Branner, J. C., On the manufacture of Portland cement: Ann. Rept. Arkansas Geol. Survey for 1888, vol. 2, pp. 291-302.

Hopkins, T. C., Marbles and other limestones (of Arkansas): Ann. Rept. Arkansas Geol. Survey for 1890, 1893, vol. 4, 443 pp.

California: Aubury, Lewrs E., The structural and industrial materials of Cali- fornia: Bull. California State Min. Bur. No. 38, 1906, pp. 171-189.

Georgia: LADD, G. E., Clays of Georgia: Bull. Georgia Geol. Survey No. 6, 1898, $204 \mathrm{pp}$.

Maynard, T. Poole, Limestones and cement materials of North Georgia: Bull. Georgia Geol. Survey No. 27, 1912, 293 pp.

McCallie, S. W., Marbles of Georgia: Bull. Georgia Geol. Survey No. 1, 2d ed., $1907,126 \mathrm{pp}$.

Illinois: BURCHARD, E. F., Concrete materials produced in the Chicago district: Bull. Illinois Geol. Survey No. 8, 1907, pp. 345-372.

CADY, G. H., Cement-making materials in the vicinity of La Salle: Bull. Illinois Geol. Survey No. 8, 1907, pp. 127-134.

Bleininger, A. V., Lines, E. F., and Layman, F. E., Portland cement resources of Illinois: Bull. Illinois Geol. Survey No. 17, 1912.

Indiana: Blatchley, W. S., and Ashley, G. H., Portland cement; The lakes of northern Indiana and their associated marl deposits; Oolite and oolitic stone for Portland cement manufacture: Twenty-fifth Ann. Rept. Indiana Dept. Geology and Nat. Res., 1901, pp. 1-330.

Blatchley, W. S., Oolite and oolitic stone for Portland cement manufacture: Twenty-fifth Ann. Rept. Indiana Dept. Geology and Nat. Res., 1901, pp. 322-330.

Hopkins, T. C., and Siebenthal, C. E., The Bedford white limestone of Indiana: Twenty-first Ann. Rept. Indiana Dept. Geology and Nat. Res., 1897, pp. 291-427. 
Iowa: Eckex, C. E., and BAIN, H. F., Cement and cement materials of Iowa: Iowa Geol. Survey, vol. 15, 1904, pp. 33-124.

Beyer, S. W., Supplementary report on Portland cement materials in Iowa: Bull. Iowa Geol. Survey No. 3, 1906, 36 pp.

Beyer, S. W., and Williams, I. A., The materials and manufacture of Portland cement: Iowa Geol. Survey, vol. 17, 1906, pp. 29-89.

Kansas: HAworTH, E., Mineral resources of Kansas, 1897.

Kentucky: GaRDNER, J. H., Report of progress for 1904-05: Kentucky Geol. Survey, 1906, pp. 18-20.

Maryland: Ries, HeINRICH, Report on the clays of Maryland: Repts. Maryland Geol. Survey, vol. 4, 1902, pp. 203-505.

Martin, G. C., Geology and mineral resources of Garrett County, Md.: Repts. Maryland Geol. Survey, Garrett County, 1902, pp. 55-229.

O'Harra, C. C., and others, Geology and mineral resources of Allegany County: Repts. Maryland Geol. Survey, Allegany County, 1900, pp. 57-192.

Mathews, E. B., and Grasty, J. S., The limestones of Maryland with special reference to their use in the manufacture of lime and cement: Maryland Geol. Survey, vol. 8, pt. 3, 1910, pp. 225-484, 14 pl., map.

Michigan: Ries, Heinrich, Clays and shales of Michigan: Michigan Geol. Survey, vol. 8 , pt. 1, 1900, pp. 1-67.

LATHBURY, B. B., The development of marl and clay properties for the manufacture of Portland cement: Michigan Geol. Survey, vol. 8, pt. 3, 1903, pp. 191-198.

HALE, D. J., and others, Marl (bog lime) and its application to the manufacture of Portland cement: Michigan Geol. Survey, vol. 8, pt. 3, 1903, 386 pp.

Mississippi: Crider, A. F., Cement and Portland cement materials of Mississippi: Bull. Mississippi State Geol. Survey No. 1, 1907.

Missouri: BueHler, A. H., Lime and cement resources of Missouri: Missouri Geol. Survey, vol. 6, 2d ser., 1907, $255 \mathrm{pp}$.

New Jersey: Kümmet, H. B., Report on Portland cement industry: Ann. Rept. New Jersey Geol. Survey for year 1900, pp. 9-101.

KüMmex, H. B., The chemical composition of the white crystalline limestones of Sussex and Warren Counties: Ann. Rept. New Jersey State Geologist for 1905, pp. 173-192.

RIEs, HeInRICH, and others, The clays and clay industry of New Jersey: Final Rept. New Jersey State Geologist, vol. 6, 1904, 548 pp.

New York: Ries, HeinRICH, Clays of New York: Bull. New York State Mus. No. $35,1900,455 \mathrm{pp}$.

ECKEx, E. C., The quarry industry in southeastern New York: Twentieth Ann. Rept. New York State Mus., 1902, pp. 141-176.

Ries, Heinrich, Lime and cement industries of New York: Bull. New York State Mus. No. 44, 1903, pp. 640-848.

North Dakota: BarRy, J. G., and Melsted, V. J., Geology of northeastern North Dakota, with special reference to cement materials: Fifth Bien. Rept. North Dakota Geol. Survey, 1908, pp. 115-225.

Ohio: Bleininger, A. V., Manufacture of hydraulic cements: Bull. Ohio Geol. Survey No. 3, 4th ser., 1904.

Orton, E., jr., and Peppex, S. V., The limestone resources and the lime industry in Ohio: Bull. Ohio Geol. Surviey No. 4, 4th ser., 1906.

Oklahoma: GouLd, C. N., NELSON, GAYLORD, and others, Structural materials in Oklahoma: Bull. Oklahoma Geol. Survey No. 5, 1911.

South Dakota: TodD, J. E., Cements and clays; Mineral resources of South Dakota: Bull. South Dakota Geol. Survey No. 3, 1902, pp. 98-109.

O'HARRA, C. C., and others, The cement resources of the Black Hills: Bull. 8, South Dakota School of Mines, 1908, $55 \mathrm{pp}$. 
Tennessee: Gordon, C. H., Cement resources and possibilities in Tennessee; Resources of Tennessee, vol. 1, No. 2: Tennessee State Geol. Survey, August, 1911, p. 58.

Virginia: BAssler, R. S., and Eckel, E. C., Cement resources of Virginia west of the Blue Ridge: Bull. Virginia Geol. Survey No. II-A, 1909, 309 pp.

Washington: SHEDD, SolON, Clays of Washington: Bull. State Coll. Washington, 1910, $339 \mathrm{pp}$.

West Virginia: Grimsley, G. P., Cement industry and cement resources in West Virginia: West Virginia Geol. Survey, vol. 3, 1905, pp. 423-555.

\section{NONOFFICIAL PUBLICATIONS.}

By organizations.-Series of monthly and special bulletins of the Association of American Portland Cement Manufacturers: Percy $\mathrm{H}$. Wilson, secretary, Land Title Building, Philadelphia, Pa.

Series of Annual Proceedings of the National Association of Cement Users: Richard L. Pumphrey, president, Harrison Building, Philadelphia, Pa.

Miscellaneous articles.-Hundreds of articles have been published on cement, covering a wide range of special subjects, such as the industry at home and abroad, effect of alkalies and sea water, machinery, manufacturing, materials, mills, new problems, testing, etc., and on concrete aggregates, blocks and tile, construction and practice, use in mines, roads, sea water, absorption and permeability, testing, and waterproofing. The following are a very few of the more interesting and valuable papers that have appeared recently either in papers devoted wholly to cement and concrete, in general engineering papers, or in the publications of engineering societies:

Bates, P. H., Review of the present status of iron-ore cement: Adv. Paper Nát. Assoc. Cement Users, March, 1912.

Brown, H. E., Marine or iron-ore cements: Adv. Paper Nat. Assoc. Cement Users, March, 1912.

Cement Age, The addition of slag to Portland cement. October, 1911, pp. 144-145.

- The present status of iron-ore cements. April, 1912, pp. 194-196.

Eckel, E. C., Ferrite cements and ferro-Portlands: Eng. News, August 3, 1911, pp. 157-158.

Edwards, G. E., Concrete shaft work in mines: Min. World, March 11, 1911, p. 535.

FAY, A H., Shaft of Detroit Salt Co.: Eng. and Min. Jour., March 18, 1911, pp. $565-569$.

Goldbeck, A. T., The expansion and contraction of concrete while hardening: Proc. Am. Soc. Testing Materials, 1911, pp. 563-571.

HAGAR, EDW. M., The utilization of blast-furnace waste: Cement, May 19, 1911, pp. 1-5; Iron Age, June 8, 1911, p. 1397; Canadian Eng., June 15, 1911, p. 843; Min. Sci., July 13, 1911, p. 35; Min. and Eng. World, July 15, 1911, p. 105; Met. and Chem. Eng., August, 1911, p. 407; Eng. Rec., August 5, 1911, p. 167.

Harrison, A. H., The waterproofing of tunnels: Cement, March, 1911, pp. 431-434.

Kempster, J. H., Portland cement as a by-product: Jour. Ind. and Eng. Chem., January, 1911, pp. 34-36.

Ieandis, W. S., Some problems of the cement industry: Cement, May, 1911, pp. 17-25. (See also Jour. Am. Soc. Mech. Eng., April, 1911.) 
McKenna, C. F., The evolution of Portland cement processes: Met. and Chem. Eng., April, 1911, pp. 182-187.

Maynard, T. P., Portland cement and coal resources of the Southern States: Proc. Am. Min. Cong., vol. 14, 1911, pp. 208-213.

PAGE, L. W., Some of the properties of oil-mixed Portland cement mortar and concrete: Proc. Am. Soc. Civil Eng., September, 1911, pp. 994-1009; reprint in Eng. News, October 12, 1911, p. 440; abstract in Canadian Eng., October 12, 1911, pp. 428, 440; also in Eng. Record, October 14, 1911, p. 445.

RICE, G. S., Some special uses of concrete in mining: Cement, January, 1911, pp. 342-347. See also Min. World, May 20, 1911, p. 1027; Cement Record, April, 1911, p. 167; Coal Trade Bull., June 1, 1911, p. 33; Min. and Sci. Press, May 27, 1911, p. 725; Coal and Coke Operator, June 8, 1911, p. 357.

Sснотт, Отто, American cement mill machinery: Cement Age, August, 1911, pp. $54-59$.

TAYLOR, W. P., The importance and cost of cement testing: Cement and Eng. News. April, 1911, pp. 148-149.

Wenzel, E., Reinforced concrete in mines (Germany): Min. World, March 25, 1911, p. 645 . 



\section{INDEX.}

A. Page.

Abbot, Maine, limestone at, analysis of ...... 195 Abrigo limestone, analyses of.............. 91 Acknowledgments to those aiding.......... 15 Ada, Okla., Portland cement plant at...... 306 Agricultural College, Miss., clay at, analysis of.......................... 244 limestone at, analyses of............. 232 Alabama, cement in, analyses of. .......... 89 cement in, bibliography of............. $\quad 89$ production of. .................. $37-38,88$ cement industry in ................... 88-89 cement materials of................. 68-87 clays and shales of. ............ 72-74,77-85 analyses of....................... 76,87

fuel in . . . . . . . . . . . . . . . . . . . . . 68,88 geologic map of.................... 68

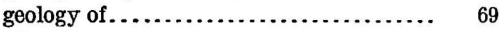
labor in............................. 88

limestones of . . . . . . . . . . . . $69-72,77-85$ analyses of................. 51,75,86-87,89 markets in.......................... 88

Alabama Portland Cement Co., cement of, analyses of.

limestones used by .................... analyses of. plant of.

Albany, Ga., limestone at, analysis of Albright, Mont., limestone at, ana]ysis of.... Alcorn County, Miss., limestone of......... 23 limestone of, analysis of

Aldrich, Mo, shale at, analysis of . Alkali waste, analyses of. ................. 55 nature of . . ....................... 54-55

Allegheny Grove, Md., limestone at, analysis

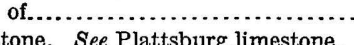

Allen limestone. See Plattsburg limestone. Allentown, Pa., Portland cement plant at... Allentown Portland Cement Co., plant of.... Alma, Kans., limestone at, analysis of....... Alma Portland Cement Co., materials in..... materials in, analyses of

Alpena, Mich., cement materials at, analyses of.................... 211, 214, 216

Portland cement plants at.......... 223, 224 Alpena Portland Cement Co., plant of....... 224 Alpha, N. J., Portland cement plant at...... 270 Alpha Portland Cement Co. (N. J.), plant of. 270 Alpha Portland Cement Co. (Pa.), plant of. . . 317 Alpha Portland Cement Co. (W. Va.), materials of.

Alsen, N. Y., limestone near, analysis of.....

Portland cement plant at.

Alsen American Portland Cement Co., materials of.
Page.

, Pa., limestone at, analysis of ...... $3 I 1$

Alumina in limestone, occurrence of........ 46

American Portland Cement Co., plant of..... 317

Amsterdam, N. Y., limestone at, analyses of. 275

American Cement Co., cement of, analysis of. . $\quad 290$ materials of....................... 289-290 analyses of ................... 290

Andover, N. J., limestone at, analysis of..... 270

Anna, Ill., limestone at, analysis of......... 143 Annandale, N. J., limestone at, analyses of. . 263,

Annona chalk, analyses of . . . . . . . . . . . . 112-113 distribution and character of . . ...... 102-106 sections of .......................... 103, 104

Antrim shale, analysis of . . . ........... 217 distribution and character of .......... 217

Apalachicola group, limestone of, analysis of. 130 Arbuckle limestone, distribution and character of...

Asbury, N. J., limestone at, analysis of..... 315 Archimedeslimestone. See Pitkin limestone. Argillaceous limestones. See Cement rock.

Arizona, cement in, bibliography of........ 91 production of . . . . . . . . . . . . . . . . . cement industry in ................... 91 cement material in . ................ 68, 60-91 clays and shales of, analyses of......... $\quad 90$ limetones of ....................... $90-91$ analyses of . .................... 90

Arkansas, cement in, bibliography of....... 116 production of. . . . . . . . . . . . . cement industry in .................. 115 cement material in. . . . . . . . . . . . . 68, 92-115 chalky beds of . ....................68, 101 analyses of . . . . . . . . . . . . . . . . 112-113 sections of ........ 103, 104, 106, 107, 110, 111 clays and shales of. . . . . . . . . . . . . . . 113-115 analyses of . . .................. 114-115 fuel of ............................ 68 geologic map of ................... 100 limestones of . . . ............... 51, 68,92-113 analyses of . ...... 94,96, 97,99-100, 112-113 sections of ........ 103, 104, 106, 107,110,111

marl in, section of . . . . ................ 104 Arkansas City, Kans., limestone at, analysis of ....................... 184 Asbury, N. J., limestone near, analysis of... . 263 Ashley, G. H., and Blatchley, W. S., on Indiana marls............... 155-157

Aspdin, Joseph, invention of . . . . . . . . . . . . 24-26 invention of, contemporary notices of... . 25-26 technical value of................ 24-25 Aspen, Colo., limestone at, analyses of...... 127 Athens, Maine, limestone at, analyses of..... 195 Atlantic \& Gulf Portland Cement Co., plant of $\quad 89$ 
Atlas Portland Cement Co. (Mo.), materials of 25 materials of, analyses of .............. 252

Atlas Portland Cement Co. (Pa.), plant of... 317

Attalia, Ala., limestone at............... $\quad 72$

Austin, Tex., cement made at............ 339 cement made at, analysis of........... $\quad 339$

cement material near................ 337-344 analyses of..................... 341-343

Austin chalk, analyses of............ 336,341-343 distribution and character of. . 335-336, 338, 340

\section{B.}

Baird, Cal., limestone at, analysis of......... Bakers Spur, Utah, Portland cement plant

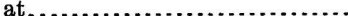

Bakerton, W. Va., limestone at, analysis of.

Ball, S. H., on Wyoming

370

373-374

Bangor, Ala., limestone at................. $\quad 72$

Bangor limestones, analyses of............ 132 distribution and character of. . . 72,130,132, 334

Barrellville, Md., limestone at, analyses of. 198, 199

Barrett, Mo., shale at, analysis of .......... 250

Bartold Valley, Mo., limestone at, analysis of. 250

Bass Lake, Ind., marl of, analysis of....... 157

Bastin, E. S., on Maine.................. 193,194

Bath, Pa., Portland cement plant at....... 317

Bath Portland Cement Co., plant of........ 317

Baybridge, Ohio, Portland cement plant at. 303

Bay City, Mich., shale of, analyses of....... 220

Bayou Chicot limestones, distribution and character of.............................

Bayport, Mich., limestone at...............

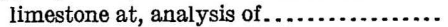

Bayport limestones, distribution and character of.

Bay Spring, Miss., limestone near..........

Bear Creek, Miss., cement materials at, analyses of .

Beattie, Kans., limestone at, analysis of....

Beaver Run, N. J., limestone near, analysis

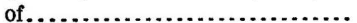

Becraft limestones, analyses of..............

Bedford, Ind., limestone at, analysis of..... Portland cement plant at...............

Beekmantown limestones, analyses of...... distribution and character of ...........

Belknap, Ill., limestone at, analysis of....... Bellefonte, Pa., limestone at, analyses of.....

Bellevue, Mich., limestone at............... limestone at, analyses of . ........... 208, 212

Portland cement plant at.............. $\quad 223$

Belmont Bluff, Ala., limestone at, analysis of. $\quad 86$

Belvidere, N. J., limestone at or near, analyses of . ...................... 263, 265

Benezett, Pa., limestone near, analysis of.... 313 Ben Hur, Va., limestone at, analysis of..... $\quad 357$ Benton, Ala., limestone at, analysis of....... 87 Benton, Ark., clay at, analyses of......... 115 Benton group, distribution and character of.. 257 Bergen, N. Y., marl at, analysis of......... 283 Berkeley, Va., Portland cement plant at..... 359 Bexar, clays at.......................... 74

Bibbville, Ala., clay at.................. 74 clay at, analysis of ................. 76

Bibliography........................ 375-381 See also particular States.
Bigby limestone, distribution and character of ....................... 332-333

Big Creek, Ind., limestone at, analysis of.... 155 Big Stone Gap, Va., limestone at, analysis of.. 355 Big Walnut Creek, Tex., cement material at, analyses of.................. 342

Billings, Mo., shale at, analysis of ........ 251

Birmingham, shales near, analyses of....... 76

Bisbee district, Ariz., limestones of, analyses of . ......................... 91

Black Hills, S. Dak., geology of .......... 325

limestones of . . . . . . . ................ 326-328

analyses of ..................... 328

See also South Dakota.

Blanc Stainless Cement Co., plant of....... 317

Blast-furnace slag, analysis of . ............ 55

nature of ........................... 55

Blast-furnace slag and limestone, production from....................... 42-43

Blatchley, W. S., and Ashley, G. H., on Indiana marls................... 155-157

Bloomington, Ind., limestone at, analysis of.. $\quad 155$

Blount Springs, Ala., limestone at......... 72

limestone at, analysis of.............. 75

Bluffport, Ala., limestone at............. 80

limestone at, analysis of ............. 86

Bodea Creek, Miss., limestone on........... 228

Bonner Brand Portland Cement Co., materials of . . ...................... 187

Bonner Springs, Kans., Portland cement plant at.................... 187

Bonneville Portland Cement Co., plant of.... 317

Boone formation, chert in ................ 97-99

limestone of, analyses of........... 97, 99-100 distribution and character of..... 92,96-100

Booneville, Miss., limestone at............ $\quad 235$

Boonville, Mo., clay at, analysis of ........ 251 shale at, analysis of................... 251

Bossardville, $\mathrm{Pa}$., limestone at, analysis of... 312

Bossburg, Wash., limestone near.......... $\quad 365$ limestone near, analyses of............ 365

Bowler, Mont., limestone at, analyses of..... 255

Box Canyon, Wash., limestone at, analyses of. 364

Branchville, N. J., limestone near, analysis of. 264

Brandon, Miss., limestone near ........... 241-242

limestone near, analyses of........... 242

Brandy Camp, Pa., limestone at, analysis of. 313

Branner, J. C., on Arkansas clays........... 113

Brasstown Creek, S. C., limestone at, analysis of ....................... 324

Bridger, Mont., limestone at, analysis of..... 255

Briery Mountain, W. Va., limestone near, analysis of.................... 369

Bristol, Wis., limestone at, analysis of...... 372

Brock Mountain, Cal., limestone at, analysis of......................... 120

Brockwayville, Pa., limestone at, analysis of. 313 Bronson, Mich., marl at, analysis of......... 214

Portland cement plant at............. 224

shale near, analyses of. ............... 218, 219

Brush Creek, Ark., limestone at, analysis of.. 100

Brushy Creek, Tex., limestone at, analyses of. $\quad 337$

Bryan, Ohio, clay of, analysis of........... 222

Buckeye Portland Cement Co., materials of, analyses of ................. 303

Buckeystown, Md., limestone at, analysis of.. 204

Buffalo Mills, Pa., limestone at, analysis of.. 313 
Buffington, Ind., Portland cement plant at.. 157 Bunker Hill, W. Va., limestone at, analysis of ............................ 370

Burchard, E. F., acknowledgment to ...... 15, 67 on Dubuque district, Iowa........... 174-179 on Kansas cement industry ........... 185-187 on Nebraska cement industry........... 259 on vicinity of Austin, Tex............ 337-344

Burchard, E. F., and Weller, Stuart, on Illinois.

Burlington limestone, analysis of. distribution and character of 167-168

Burt Portland Cement Co., materials of..... 223

Burton, Wis., limestone at, analysis of...... 372

Byram, Miss., limestone near............. 240

limestone near, analysis of............. 240

section near. 240-241

C.

Cable, Mont., limes'nne at, analysis of....... Cahaba, Alk., limest ne at, analysis of....... Calcis quarry, Ala., limestone of. limestone of, analysis of .......

Caledonia, N. Y., cement materials at, analyses of................ 283, 294

Portland cement plant at................ 294

California, cement of, analyses of......... 121,123 cement in, bibliography of............ 123-124 production of.................... 37-38,120 cement industry in ................... 120-123 cement materials in .............68,116-120 clay, and shales of. 118 analyses of $\ldots \ldots \ldots \ldots \ldots \ldots \ldots 118,122,123$ fuel in . . . . . . . . . . . . . . . geologic map of..................... 116 limestones of ....................68,116-120 analyses of ...........49,117-120,122,123 travertine in ....................... 118, 121 analyses of ................. 119,121,122

California Portland Cement Co., materials of. 122 plant of ........................... 120,122

Cambrian limestones, analysis of........... 253 distribution and character of....... 72, 204, 330 See also particular Cambrian formations.

Cambrian shales, analyses of ............... 76 distribution and character of........... 72-73

Cambridge, Kans., limestone at, analysis of.. 184 Camden, Ohio, limestone at, analysis of ..... 300 Canaan, Conn., limestone at, analyses of..... 129 Canastota, N. Y., marl at, analysis of ....... 283

Cape Fear River, N. C., limestone at, analysis of..........................

Cape Girardeau Portland Cement Co., plant of............ 252,253

Carboniferous limestones, analyses of..... 167-172, 312-313,348 distribution and character of.......... 166-172, 173, 256-258, 305-306, 313, 346-347 See also particular Carboniferousformations.

Carboniferous shales, analyses of. ...... 114, 199, 355 distribution and character of .. 113-114, 354-355

Carpentersville, N. J., limestone near, analysis of.

Carter limestone, distribution and character of

Carthage, Maine, limestone at, analyses of ..

$48834^{\circ}-$ Bull. 522-13-25
Page.

Carthage, Mo., limestone at, analysis of..... 250

Carthage, N. Mex., cement material at...... 271

Carthage Landing, N. Y., cement at, analysis of........................... 285

cement making at...................... 285

Cascade Hollow, Iowa, section at......... 167-168

Castalia, Ohio, Portland cement plant at.... 303

Castalia Portland Cement Co., materials of.. $\quad 303$ materials of, analyses of ............... 303

Catheys limestone, distribution and character of..................... 332-333

Catskill, N. Y., limestone at, analysis of..... 281

Catskill Cement Co., cement of, analysis of. . $\quad 290$ materials of......................... 290 analyses of ........................ 290

Cavetown, Md., limestone at, analysis of.... 204

Cayuga group, limestones of, analyses of..... 203 limestones of, distribution and character of .......................... 202-203

Cayuga Lake Cement Co., cement materials of ........................... 291

cement materials of, analyses of........... 291

Cedartown, Ga., limestone at, analysis of.... 132

Cedar Valley limestone, analyses of......... 164 distribution and character of.......... 163-165

Cement, classification of ................... 16-18 See also particular sorts of cement.

Cements, ancient, nature of................. 18-19

Cement, Cal., Portland cement plant at...... 121 CementCity, Mich., Portland cement plantat. 223 Cement City, Mo., Portland cement plant at. $\quad 253$ Cement materials, chemical composition of.. 65 cost of ............................... $59-60$ deposits of, valuation of.............. 63-65 excavation of.......................... 57-59 milling of............................ $\quad 320$

mixture of, analyses of ................. 65 physical character of................... 66 quarrying of........................ 319-320 supply of.......................... 66 See also Portland cement; Limestone; Clay; Iron-bearing material; Marl; etc.

Cementon, Pa., Portland cement plant at.... $\quad 317$

Cement rock, analyses of.................... $\quad 49$ distribution and character of ........... 47-49 See also Lehigh district; particular States.

Cement rock and limestone, production from. 42-43 Centerville, N. J., limestone at; analysis of... $\quad 270$ Central Portland Cement Co., plant of...... 317

Chain Lake, Ind., marl of, analyses of........ 157

Chalk, analyses of........................ 51 distribution and character of ............. 50-51 distribution of, by States.............. 68 See also particular States.

Chalk Bluff, Ala., clay at.................. 74 clay at, analysis of.................... 76

Chambersburg limestone, analyses of....... 204 distribution and character of........... 204 Chandlers Island, N. J., limestone at, analyses of.......................... 262,315

Changewater, N. J., limestone at, analysis of . 263 Charleston, Ill., limestone at, analysis of.... 141 Charlton, Md., limestone at, analysis of...... 204 Chattanooga shale, distribution and character of............................ 354 
Chazy, N. Y., limestone at, analysis of....... $\quad 273$

Chazy limestone, analyses of............... $\quad 273$ distribution and character of .......... 272-773

Cheat River, W. Va., limestone on, analysis of 369

Chelsea, Mich., clay of, analysis of.......... 222 Portland cement plant at............. 224

Cheltenham, Mo., shale at, analysis of...... 251

Cheshire, Mass., limestone at, analysis of..... 207

Chester group, analyses of.................. 190 distribution and character of ......... 154, 190

Chewsville, Md., limestone at, analysis of.... 204

Cheyenne, Wyo., cement materials near, analyses of ................. 374, 375

Chicago Portland Cement Co., materials of... 151 materials of, analyses of ............... 151 quarry of, section in ................... 151

Chickamauga limestone, analyses of....... 75,132 distribution and character of ......... 69-71, 131-132, 330, 331-332

Chickasaw County, Miss., limestone of....... 233 limestone of, analyses of.............. 233

Cincinnati, Ohio, limestone at, analyses of... 300

Cincinnatian series, analyses of.......... 189, 300 distribution and character of....... 153,189, 300

Claiborne, Ala., limestone near............. 84

Clarksville, Ark., clay at, analysis of........ 114

Clarksburg, W. Va., limestone at, analysis of. 368

Clay, composition of..................... 56 cost of, at mill......................... $59-60$ excavation of........................ 57-59

varieties of.

56

See also particular States.

Clay and marl, production from............ 42-43

Clay (or shale) and limestone, production from.......................... 42-43

Clear Creek, Ind., limestone at, analysis of... 55

Clifton, Mo., clay at, analysis of........... 251

Clifton limestone, distribution and character

Cliftonville, Miss., limestone at.

Clinchfield Portland Cement Co., material of

Clinton, Maine, limestone at, analysis of....

Clinton, Mo., shale at, analysis of............

Clinton, N. J., limestone at and near, analyses of........................... 263,315

Clinton, N. Y., limestone at............... 276 limestone at, analysis of............... 280

Clinton age, limestones of, analyses of........ 278 limestones of, distribution and character

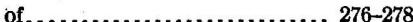

section of.......................... 277

Clinton limestone, analyses of............ $\quad 300$ distribution and character of............. $\quad 300$

Coal, cement kiln, analyses of............... 61 cement kiln, preparation of.............. 61-62

use of ...................... 60

Coal measures. See Pennsylvanian.

Cobleskill, N. Y., limestone at, analysis of... 280

Cockeysville marble, distribution and character of. ......................

Coffeyville, Kans., slate at, analysis of.......

Coldwater, Mich., marl at, analyses of....... Portland cement plant at

shale near, analyses of................ 218,219

Coldwater shale, analyses of.
Coldwater shale, distribution and character of ............................. 217

Colemanville, N. J.; limestone at, analysis of. 316 Coleville, N. J., limestone at, analysis of..... $\quad 266$ Collinsville, N. Y., limestone at, analysis of.. $\quad 275$ Colorado, cement in, bibliography of......... 128 cement in, production of................ 37-38 cement industry in................... 128 cement material in................ 68, 124-127 clays and shales of, analyses of.......... 127 fuel in............................... 68 limestones of ..................... 37, 124-127 analyses of .................. 49,126,127

Colorado Portland Cement Co., materials of.. 128 Colton, Cal., Portland cement plants at.... 121,122 Columbia, N. J., limestone at, analyses of.. 263, 264 Columbia,. . Y. Y., limestone at, analysis of. ... 280

Columbus, Ohio, limestone at, analyses of.... 301

Colville, Wash., limestone near........... 364-365 limestone near, analyses of............. 365

Comanche Peak limestone, distribution and character of .................. 336-337

Compton, Ala., limestone at................. 72 limestone at, analysis of .............. 75

Concreto, Colo., Portland cement plant at... 128 Concreto shale. See Lane shale.

Condra, G. E., on Nebraska............... 258-259

Connecticut, cement materials in ...... 68, 128-129 limestones of .................... 68,128-129 analyses of ...................... 129

Conococheague limestone, analyses of........ . 204 distribution and character of ........... , 204

Continental, Mo., Portland cement plant at.. 252 Continental Portland Cement Co., materials of . ......................... 252-253

Contra Costa County, Cal., travertine of...... 118 travertine of, analyses of............... 119 Coochie Brake limestone, distribution and character of..................., 192

Cooley Lake, Ind., marl of, analysis of....... 157 Coolidge, Kans., limestone at, analysis of.... 185

Cooper River, S. C., limestone at, analyses of. $\quad 324$

Coosada, Ala., clay near................... . 74 clay near, analysis of................. . 76

Coplay, Pa., Portland cement plant at....... 317

Coplay Cement Manufacturing Co., plant of.. : 317

Corinth, Md., shales near, analyses of....... 199

Corinth, Miss., limestone at............... 236

limestone at, analysis of ............... 236

Corniferous limestone, analyses of.......... $\quad 301$ distribution and character of............ 301

Corriganville, Md., clays and shales at, analyses of........................... 202

limestone at, analyses of. ............ 202, 203

Cottonwood Canyon, Nev., limestone at, analysis of.....................

Cottonwood Falls, Kans., limestone at, analysis of................... 182

Cottonwood Falls limestone, analysis of....... 182 distribution and character of......... 181-182

Covington, Va., limestone at, analysis of..... 356

Cowell, Cal., cement plant at............... 122 materials at, analyses of................. 122

Cowell Portland Cement Co., materials of.... 122 materials of, analyses of................ 122 
Crabtree, Md., limestone at, analysis of.......

Craigsville, Va., cement materials at or near, analyses of.

356,358 Portland cement plant at............... 358

Crapo Lake, Mich., marl at, analysis of..... 214

Crawford, Miss., limestone near............ 232 limestone near, analysis of............ 232

Crescent Portland Cement Co., materials of.. $\quad 323$ materials of, analyses of ................ $\quad 323$ plant of.

Crescentdale, Pa., Portland cement plant at. $\quad 317$

Cretaceous chalks, analyses of........ 112, 160, 185 distribution and character of. 101-112,160,184-185 sections of......... 103, 104, 106, 107, 110, 111, 160 See also Selma chalk.

Cretaceous clays, analyses of.............. 76, 87 distribution and character of....... 73-74,77,81 See also Selma chalk.

Cretaceous limestones, distribution and character of.................. 306,346-347

Crider, A. F., on Mississippi.............. 225-245

Croton, N. Y., cement making at......... 284-285

Croton, $\mathrm{Pa}$., limestone at, analysis of....... 313

Crystalline limestones, analyses of......... 75, 133 distribution and character of....... 72, 130,133

Cumberland, Md., limestone at, analyses of. 202, 203

Cumberland Gap, Tenn., limestone near.. 352-354 limestone at, analysis of............... $\quad 353$ section near.......................... 353

shale near............................. 354

analysis of....................... 354

Cummings, Uriah, on cement rock......... 312

Cypress Pond, Miss., limestone at, analysis of. $\quad 226$

\section{D.}

Dallas, Oreg., limestone at limestone at, analysis of............... 309

Dallas, Tex., cement material at and near, analyses of . . ...............51,336, 343

Danbury, Conn., limestone at, analysis of... 129

Darton, N. H., on Nebraska........... 256, 257-258 on South Dakota..................... 325-328

Davenport, Cal., cement plant at............ 122 materials at, analyses of............... 123

Dawson, Md., limestone at, analysis of...... 203

Dayton, Ohio, limestone at, analysis of...... 300

Deciper area, Ark., chalk of .............. 110-112 chalk of, analyses of................... 113 section of......................... 111

Decorah shale, analysis of................. 162

Deep Lake, Ind., marl of, analysis of........ $\quad 157$

Deepwater, Mo., shale at, analysis of ....... 251

De Kalb, Iowa, limestone at, analysis of .... $\quad 172$

Delaware, cement resources of............ 68,129

Delaware Valley, limestones of........... 267-268 limestones of, analyses of........... 267, 268

Delaware Water Gap, N. J., limestone at and near, analyses of ..........266, 312,316

Del Rio clay, analyses of ............. 339,341,342 distribution and character of........... 337,340

Demopolis, Ala., cement from, analyses of.. 89 Portland cement plant at.............. 89 limestone at and near................ 80,81 analyses of ................. $51,86,87,89$

Denieville, Ark., limestone at, analysis of... 100
Page.

Des Moines, Iowa, clay at, analysis of........ 170 Portland cement plant at............... $\quad 179$

Des Moines group, analyses of ........... 170,171 distribution and character of.......... 170-171

Devils Backbone, Md., section of........... 201

Devils Slide, Utah, Portland cement plant at. $\quad \mathbf{3 4 9}$

Devonian limestones, analyses of.. 163, 164, 236, 253 distribution and character of.......... 162-165, $173,225-236,333$

section of

225

See also Helderberg limestones.

Devonian shales, analyses of. distribution and character of............. 248 Dewart Lake, Ind., marl of, analyses of...... 157 Dewey, Okla., Portland cement plant at.... 306 Dewey Portland Cement Co., materials of... 306 Dexter, Me., limestone at, analyses of........ 195 Dexter Portland Cement Co., plant of....... 317 Diamond Portland Cement Co., materials of. $\quad 303$ materials of, analyses of ................ 303

Dickinson, $111 .$, materials at.............. 151-152 materials at, analyses of................ 152

Portland cement plant at............... 151

Diller, J. S., on Shasta County, Cal ....... 119-120 Dixfield, Maine, limestone at, analyses of... 195 Dixie Portland Cement Co., materials of.... 334 Dixon, Ill., Portland cement plant at........ 152 Dobyville, Ark., section at................ 110 Dover, Maine, limestone at, analysis of...... 195 Dowlingville, Pa., limestone near, analysis of. $\quad 313$ Drakes Pond, N. J., limestone near, analyses of ........................... 265, 266

Drayton Hall, S. C., limestone at, analysis of........................... 324

Dresden, N. Y., limestone at, analysis of .... 282 Drewry, Ala., limestone at.............. $\quad 85$ Driftless Area, clay and loess of, analyses of.. 178 Drum limestone, distribution and character of........................... 186

Dubuque, Iowa, cement materials near.... 174-178 literature on......................... 179 manufacturing sites near............. 178-179

Dundee, Mich., limestone near............. 209 limestone near, analysis of............. 209

Dundee limestone, analyses of............ 208-210 distribution and character of......... 208-210 sections of......................... 208-210

\section{E.}

Eagle Ford, Tex., Portland cement plant at. $\quad \mathbf{3 4 7}$ Eagle Ford clay, analyses of .............. 342-343 distribution and character of.......... 337-340 Eagle Mountain, Va., limestone at, analysis of........................... 357

Earlham, Iowa, limestone at, analysis of.... 172 section at.......................... 171-172 East Bangor, $\mathrm{Pa}$., limestone at, analysis of.. $\quad 316$ East Helena, Mont., limestone at, analyses of............................

Eastside Laurel Hill, W. Va., limestone at, analysis of.......................

Eden shale, distribution and character of.... 189

Edgewood, Ala., clay near................. 74 clay near, analysis of ................ $\quad 76$ Edison Portland Cement Co., plant of....... 270 

Page.
Edwards limestone, distribution and char-
acter of..................... $336-337$ 336-337

Egypt, Pa., Portland cement plant at...... 317 Egyptian Portland Cement Co., plant of.... 224 Eifert, Ohio, limestone at, analysis of...... 302 Elk Portland Cement Co., materials of..... 223 Elk Rapids, Mich., Portland cement plant at. $\quad 223$ Elbrook formation, analyses of............. 204 distribution and character of.......... 204 Eldorado, Kans., limestone at, analysis of... 184 Elm Point, Mo., clay at, analysis of........ 251

El Paso, Tex., cement material near....... 344-347 geology near........................ 344-345 clays and shales of.................. 345-346 analyses of ..................... 346

limestones of . .................... 346-347 analyses of ....................... 346

Portland cement plant at............. 347

Empire Portland Cement Co., cement of, analysis of..................... 295

materials of...................... 294-295

analysis of...................... 295

Englewood limestone, distribution and character of..

Epes, Ala., limestone at and near........... limestone at and near, analyses of

Escabrosa limestone, analysis of.

Eureka Peak, Utah, limestone at, analysis of Evansville, Pa., Portland cement plant at.. Evergreen, Ala., limestone near.

limestone near, analysis of..............

$$
\text { F. }
$$

Fairplay, Colo., limestone at, analysis of..... Farmington, Maine, limestone at, analysis of. Farmington Hill, Me., limestone at, analysis of.

Farmington, Mich, clay of, analysis of

Fenton, Mich., clay of, analysis of........... marl at, analyses of.................. 214 Portland cement plant at............ 223-224

Ferry County, Wash., cement material of.. 363-364 cement material of, analyses of.......... 364

Florida, cement materials in.......... 68,129-130 fuel of ............................ 130 geologic map of..................... 68 limestones of..................... 68,129-130 analyses of...................... 130

Flushing, Mich., shale of, analyses of....... 220

Fogelsville, Pa., Portland cement plant at... $\quad 317$

Fontana, Kans., limestone at, analysis of.... 182

Fordwick, Va., cement materials at........ 355, 358 cement materials at, analyses of........ 358 Portland cement plant at............... 358

Fort Dodge,Iowa, cement made at, analysis of. $\quad 170$ clay at, analysis of.................... 170

Fort Payne formation, distribution and character of...................... 333-334

Fort Smith, Ark., clay at, analyses of........ 114

Fort Spring, W. Va., limestone at, analyses of 369

Fort Worth, Fla., limestone at, analysis of. . 130

Fossick quarries, Ala., limestone of......... 71-72 limestone of, analysis of................

Fossil Hill, Mo., limestone at, analysis of...

Foster, Mo., shale at, analysis of.............

F'ourmile Lake, Mich., analysis of...........
Frederick, Md., limestone at, analysis of Pase.

Fredericksburg group, distribution and character of.................... 336-337

Fremonts Pass, Nev., limestone at, analysis of ........................... 259

Fuels, supply of, importance of............ 66 supply of, by States.................. 67-68 use of, in cement manufacture.......... $60-62$

\section{G.}

Gadsden, Ala., clay at, analysis of.......... 76

Gainestown, Ala., limestone near.......... 84

Gainesville, Ala., limestone at and near...... 79-80 limestone at and near, analyses of ....... 86

Galena, Kans., limestones of................ 180 limestones of, analysis of............... 181

Galena dolomite, analyses of .............. 162 distribution and character of............ 177

Garnett, Kans., limestone at, analyses of.. 182-183

Gate City, Ala., limestone at................ $\quad 70$ limestone at, analysis of............... 75

Gate City, Va., limestone at, analysis of..... 357 Geological Survey, United States, publica-

tions of................... 375-377

Geological surveys, State, publications of.. 378-380

Georgetown limestone, analyses of ........ 339,341 distribution and character of............ 337

Georgia, cement in, bibliography of......... 134 cement in, production of ............... 37-38 cement industry in ................... 133-134 cement material in...............68,130-133 fuel of.............................. 68 geologic map of....................... 68 limestones of . . . . . . . . .

analyses of .................... 132,133 marls of ........................ 130,133

German-American Portland Cement Co., materials of....................... 151 materials of, analyses of ................ Geyserville, Cal., limestone near............ 119 limestone near, analysis of............. $\quad 119$

Gila River, Ariz., limestones on, analyses of.. 90-91 Giles formation, analysis of............... $\quad 370$ distribution and character of............ 369 Gillmore, Q. A., on Portland cement......... 284 Glass rock. See Platteville limestone.

Glen Allen, Ala., clay near, analysis of...... 76

Glendon, Ala., limestone near.............. 84

Glens Falls, N. Y., limestone at............ $\quad 274$ limestone at, analyses of .............. 275 Portland cement plant at.............. 292

Glens Falls Portland Cement Co., cement of, analysis of.................... 293

materials of $\ldots \ldots \ldots \ldots \ldots \ldots \ldots \ldots \ldots . . .292$

analyses of...................... 293

Glenwood Springs, Cal., limestone at, analysis of......................... 127

Glen Lyn, W.Va., limestone at, analyses of. 369,370 Golden State Portland Cement Co., materials of............................. 123

Goodland limestone, distribution and character of...................... 336

Goose Creek, S. C., limestone at, analysis of. . 324 Government publications on cement, list of. $375-378$ Grainger shale, analysis of ................ 354 distribution and character of............ $\quad 354$ 
Page.

Grand Gulf clay, analyses of.............. 240

distribution and character of .......... 240

Grand Peak, Nev., limestone at, analysis of. 259

Grand Rapids group, distribution and character of.

Granite Falls, Wash., cement materials near. 362 cement materials near, analyses of...... 362

Grant, U. S., on Wisconsin............... 372

Grayling Lake, Mich., analysis of........... 214

Great Cacapon, Md., clays and shales of, analyses of......................

limestone at, analysis of. ............. 202

Greeley, Kans., limestone at, analyses of .. 182-183

Greenbrier limestone, analyses of. . 198, 199, 355, 369

distribution and character of... . . . . . . . 196-198,

352, 368-369

section of.

198

Greendale, Pa., limestone at, analysis of.... 313

Greenhorn limestone, distribution and character of. .

Green River City, Wyo., limestone at, analysis of.

Grimes, Md, limestone at, analysis of ......

Grinding, improvements in.................

Guide Rock, Nebr., limestone near, analysis

of. ........................

Guilford, Maine, limestone at, analysis of .... Guntown, Miss., limestone at...............

Gypsum, use of, as retarder.

\section{H.}

Hagerstown, Md., limestone at, analyses of. . Hainesburg, N.J., limestone near, analysis of Hamburg, N.J., limestone at and near, analyses of ..................... 262,269

Hamilton, Ala., clay near............... 74 clay near, analysis of. ................ $\quad 76$

Hancock, Md., limestone at, analysis of...... 203

Hannibal, Mo., cement materials at, analyses of. 250,251

Portland cement plant at

Hardyston quartzite, distribution and character of.

Harmony, Maine, limestone at, analysis of.

Harrisburg, Pa., limestone at, analysis of....

Harrisonburg, Va., limestone at, analysis of..

Harrodsburg limestone, distribution and character of....................

Havre, Mont., limestone near.............. limestone near, analyses of.............. shale near, analysis of.

Hawarden, Iowa, chalk at, analysis of ......

Haworth, E., on Kansas......... 180-182,184,185

Hayt Corners, N. Y., limestone at, analysis of. 282

Hayward, Ky., limestone at, analysis of..... 191

Helderberg Cement Co., materials of........ 293 materials of, analyses of . . ............

Helderberg group, analyses of . . . . . . . 280, 281 distribution and character of. . . . . . . . 278-281

Helderberg limestone, analyses of. . . . . . . 202, 280 distribution and character of . . . . . . . . 199-202 sections of........................ 201,202

Helena, Mont., limestone near, analyses of. . . 253

Hendricks, W. Va., limestone at, analysis of. 369
Hermitage limestone, distribution and char

Pange. acter of. . .................... 332-333

Highbridge limestone, distribution and character of.

188

Hilgard, E. W., on Mississippi............. 243

Highgate Springs, Vt., limestone at, analysis of........................... 350

Hill Creek, Ark., limestone at, analysis of.... 96

Hitchcock, C. H., on Maine analyses....... 195

Hog Lake, Ind., marl of, analysis of........ 157

Hollidaysburg, Pa., limestone at, analyses of. 311

Hollister, Cal., limestone near............. 118

limestone near, analysis of............ 118

Holston marble, distribution and character

of. ....................... 330-331

Hope, N. J., limestone near, analyses of... 265, 270

Horton, Kans., limestone at, analysis of..... 182

Horton Summit, Va., limestone at, analysis of........................... 355

Houghton Lake, Ind., marl of, analysis of. .. 157

Houston, Miss. , clay near. . . . . . . . . . . . . . 244

Howes Cave, N. Y., limestones of.......... 293

limestones of, analyses of............ 280,293

Portland cement plant at.............. 293

Hudson, N. Y., cement materials at, analyses of......................... 294

Portland cement plants at and near . . . 294, 295 map showing...................... 274

Hudson Portland Cement Co., materials of. . 294 materials of, analyses of............... 294

Hudson River district, N. Y., early manufacture of cement.............. $\quad 27$

limestones of. ................... 274, 280-281 analyses of. . . . . . . . . . . . . . . . . 281,294

sections in .......................... 281

Hughes Creek, W. Va., limestone on, analysis of ....................... 368

Hulls, Ala., clay at, analysis of........... 76

Humansville, Mo., shale at, analysis of..... 250

Humboldt, Iowa, limestone at, analysis of... 169

Humboldt, Kans., limestone at, analysis of. . 182

Hunter Valley, Ind., limestone at, analysis of.......................... 155

Huntington, Oreg., limestone at. ......... 309-310

Hunton limestone, distribution and charac-

ter of......................... 305

Huntsville, Mo., shale at, analysis of......... 251

Huntsburg, N. J., limestone near, analysis of. $\quad 265$ Huron Portland Cement Co., materials of..... 223 Hydraulic cements, nature of............ 16-18 Hydraulic limes, nature of............... 16

\section{I.}

Idaho, cement material in .......... 68, 135-140 cement material in, analyses of ..... 136, 138, 139 clays of. .......................... 139 analyses of...................... 138 fuel in......................... 68 limestones of. ................. 68, 135-140 analyses of ................... 136, 138, 139

Ilasco, Mo., cement materials at........... 252 cement materials at, analyses of........ 252 Portland cement plant at.............. $\quad 252$

Illinois, cement in, bibliography of ........ 153 cement in, production of............... 37-38 
Page.

Illinols, cement industry in

$151-152$

cement material in

clays and shales of.

analyses of.

$68,140-150$

fuel of

148-151

limestones of.................... 68, 140-150

analyses of ............... 141,144-148, 151

Independence, Kans., limestone at, analysis

of ................... 182

Portland cement plant at.............. 186

Indiana, cement in, bibliography of....... 158-159

cement in, production of............ 37-38, 157

cement industry in ................. 157-158

cement material in ................ 68, 153-157

clays and shales of.................. 153-154

analyses of ...................... 158

fuel of .............................. 168

geologic map of....................... $\quad 300$

lakes in, containing marl............... 156

limestones of................... 68, 153-157

analyses of.................... 155, 158

marls of...................... 68, 155-157

analyses of..................... 157

Industry, Maine, limestone at, analysis of.... 195

Ingham Mills, N. Y., limestone at, analyses

of ............................

Inland Portland Cement $\mathrm{Co}$., materials of......

Iola, Kans., cement making at.............. 186

limestone at........................ 186

analyses of ..................... 186

limestone at, analysis of ............... 182

Portland cement plants at............. 186

shale at and near, analyses of.......... 184, 186

Iola limestone, distribution and character of. 183, 186

Iola Portland Cement Co., materials of........ 186

Ionia, Mich., clay near, analysis of........... 221

Iowa, cementin, bibliography of ........... $\quad 179$

cementin, production of................ 37-38

cement material in...............68, 159-178

chalk of ............................ 159, 160

analyses of....................... 160

section of 160

clays and shales of................... $\quad 159$ analyses of............ 162,165, 170, 177, 178

fuel in.......................... 68, 173-174

geologic map of...................... 160

limestones of.................... 159, 160,161 analyses of..... 160,162-164, 167-172, 176, 177

manufacturing sites in............... 178-179

markets of............................. 174

marls of............................... 159

Iowa City, Iowa, limestone at, analysis of.... 164

Iowa Portland Cement Co., materials of.... 179

Iron-bearing materials, use of, in cement manufacture.

Iron in limestone, effect of.................. 46 occurrence of....... 46

Ironton, Ohio, limestone at, analyses of...... 302 Portland cement plant at............. 303

Ironton Portland Cement Co., materials of.. 303 analyses of......................... 303

Islesboro, Maine, limestone near........... 195 limestone near, analysis of............ 195

Izard limestone, analysis of............... 94 distribution and character of............ 92-94
J.

Page.

Jackson, Mich., clay near, analyses of....... 221 marl at, analysis of ................... 214

Jacksonburg, N. J.; limestone at, analysis of. 264

Jacksonburg limestone, analyses of....... 264-265 distribution and character of .......... 263-265 section of.......................... 263-264

Jacque Mount, Colo., limestone at, analysis of 122 James Creek, Miss., limestone at ........... $\quad 229$

James Lake, Ind., marl of, analysis of....... 157

Jamesville, N. Y., limestone at, analysis of... $\quad 280$

Jamul, Cal., limestone at................ 116-117

limestone at, analysis of .............. $\quad 117$

Jefferson City, Mo., clay at, analysis of....... 251

Jefferson limestone, analysis of........... 253

Jersey Shore, Pa., limestone at, analysis of... $\quad 311$

Jetmore, Kans., limestone at, analysis of.... $\quad 185$

Johnsville, Mo., limestone at, analysis of..... 205

Joplin, Mo., shale at, analysis of............ 250

Jordan, N. Y., cement and cement materials at, analyses of.

marl at analysis of

Portland cement plant at................. 280

Jordans Ferry, Ala., limestone at, analysis of. $\quad 86$

\section{K.}

Kalamazoo, Mich., early manufacture of cement at.

Kankakee Marsh, Ind., marl of, analysis of.. $\quad 157$

Kansas, cement in, bibliography of .......... 187 cements in, production of........... 37-38, 185 cement industry in . .................. 185-187 cement material in ................ 68, 180-185 clays and shales of.................. 183-184 analyses of.................. 184, 186, 187 fuel of ..................... 68, 185-186, 187 geologic map of...................... 180 limestones of..................... 68, 180-187 analyses of..................... 181-187

Kansas City, Mo., clay at, analysis of........ 251 Kansas City Portland Cement Co., materials of......................... 252-253

Kearneysville, W. Va., limestone at, analysis of........................... 370

Keedysville, Md., limestone at, analysis of .. 204 Kelleys Island, Ohio, limestone at, analyses of. 301

Kemper County, Miss., limestone of........ 228-229 limestone at, analyses of.............. 228,229

Kenansville, N. C., limestone at, analysis of . 298 Kendall, Wash., cement material of. . ..... 361-362 cement material of, analyses of.......... $\quad 362$

Kennett, Cal., limestone at................ 120 limestone at, analysis of ................ 120

Kentucky, cement in, production of......... 37-38 cement industry in................... 191 cement material in . ................... 187-191

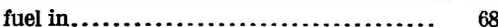
geologic map of...................... 188 limestones of . ..................... 187-191

analyses of . .................... 188-191

Kern County, Cal., limestones of. . ....... 117-118

Keyser, W. Va., limestone at, analysis of .... $\quad 370$ Key West, Fla., limestone at, analyses of.... 130

Kiln fuels, relative importance of ........... 60-61

Kimmswick limestones, analyses of......... $\quad 247$ distribution and character of ........... 217 
Page.

Kinderbrook group, analyses of............. 167

distribution and character of ........... .166

King County, Wash., cement material of.... 363

Kingsport, Tenn., Portland cement plant at. 334

Kings Rock, Pa., limestone at, analysis of... $\quad 312$

Kingston, N. Y., cement making at........ 284

Kingston, N. C., limestone near, analysis of.. 298

Kingwood, W. Va., limestone at, analyses of. .......................... 368, 369

Kittanning, $\mathrm{Pa}$., limestone at, analysis of.... 313

Kittatinny limestones, analyses of......... 262-263 distribution and character of. ......... 261-262

Knickerbocker Portland Cement Co., matorial of.

Knobstone group, distribution and character of. ............................

Knox dolomite, distribution and character of. Knoxville, Tenn., limestone at, analysis of... Kosmosdale, Ky., Portland cement plant at. Kosmos Portland Cement Co., materials of. .

\section{I.}

Lafayette, N. J., limestone at and near, analyses of ................ 264, 265, 266, 316

Lafferty Creek, Ark., limestone at, analysis of. $\quad 94$

Lake Champlain, limestone near....... 272, 273-274

Lakenan, Mo., shale at, analysis of. ........ 251

Lane, Kans., limestone at, analyses of . . ... 182-183

Lane shale, analysis of.................. 187 distribution and character of.............. 183

Lansing, Kans., limestone at, analysis of.... 182

Lansing, N. Y., limestone at, analysis of..... 282

Laramie, Wyo., limestone at, analysis of .... 375

La Salle, Ill., materials near............... 151

materials near, analyses of............. 151

Portland cement plant near............. 151

sections at and near................... 141,143

Lawrence, Kans., limestone at, analysis of... 182

Lawrence Portland Cement Co., plant of.... 317

Lebanon, N. J., limestone near, analysis of... 263

Lebanon limestone, distribution and character of........................ 332

Lee County, Miss., limestone of............ 233-234 limestone of, analyses of............... $\quad 234$

Leeds, Ala., Por'land cement plant at........ 89

Le Gore, Md., limestone at, analysis of....... 204

Legrand, Iowa, limestone at, analyses of..... 167

Lehigh district, $\mathrm{Pa}$.,

cement in, production of............. 37-39

cement industry in ............... 27-28,38-39

cement material in ................. 314-316

cement rock of................ 48-49,314-316

analyses of . .................. 49,315,316

clays and shales of................. 316-317

analyses of....................... 316

extent of . . . . . . . . . .

geologic map of..................... $\quad 310$

geology of .......................... 314

limestone of . . ................ 48-49,314-316 analyses of................. 49,315,316

See also Pennsylvania; New Jersey.

Lehigh Portland Cement Co. (Ind.), materials of .............................

materials of, analyses of................

Lehigh Portland Cement Co. (Iowa), materials of.
Lehigh Portland Cement Co. (Ohto), materials of........................ 303 materials of, analyses of................ 303 Lehigh Portland Cement Co. (Pa.), materials of.................. 157,322-323 materials of, analyses of.................. 158 plant of.............................. $\quad 317$

Leipers formation, distribution and character of..

Lemars, Iowa, chalk at, analysis of........... $\quad 160$

Leroy, N. Y., limestone at, analyses of........ 279

Lesley, Pa., Portland cement plant at....... 317

Lesley, R. W., on natural cement industry... 23

Leverett, Frank, on Sibley quarries....... 209-210

Lewisburg, W. Va., limestone at, analysis of. $\quad 369$

Lewiston, N. Y., section at................. 277

Lewiston limestone, analyses of.... 311, 312,356,370 distribution and character of........... 311-312, $355-356,369-370$

Lexington, Mo., shale at, analysis of........ 251

Lexington, Va., limestone at, analysis of .... 357

Lexington limestone, distribution and character of...

Leyden, N. Y., limestone at and near, analyses of:

188

Lime Creek shale, anailysis of ............. 275 distribution and character of............... 165 section of.............................. 165

Lime Lake, Ind., marl of, analysis of........ 157

Lime Lake, Mick., marl at, analysis of....... 214

Lime Point, Idaho, clays at................ $\quad 139$ limestones of ....................... 136-140 analyses of ...................... 138, 139

Lime Rock, R. T., limestone at, analysis of.. $\quad 323$

Limespur, Mont., limestone at, analyses of .. $\quad 255$

Limestone, chemical composition of......... 44-46 cost of............................... 59-60 deposits of, valuation of............... $63-65$ distribution of, by States............... 68 excavation of......................... 57-59 effect of heat on...................... 47 impurities in........................ 44-46 origin of .............................. 43 physical character of .................. 46-47 varieties of ..........................42,43-44 used in cement manufacture...... 42,47-55

See also Cement rock; Limestones (pure hard); Chalk; Marl; Shell deposits; Alkali waste; particular States.

Limestones (soft). See Chalk.

Limestones (pure hard), analyses of......... $\quad 50$

use of ............................... 49

Limestone and blast-furnace slag, production

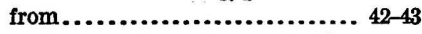

Limestone and cement rock, production from........................ 42-43 Limestone and clay or shale, production from. 42-43 Lincoln, N. J., limestone at, analyses of..... 270 Linden limestones, distribution and character of............................. 333

Linwood, Md., limestone at, analysis of...... 205

Littlo Rock, Ark., clay at............... 113-114 clay at, analyses of................... 114 Lime sulphate, use of, as retarder.........62-63 Little Eagle Lake, Ind., marl of, analysis of. 157 Little Wills Valley, Ala., clays of............ 73 clays of, analyses of.................. 76 
Livermore Falls, Maine, limestone at, analysis of.............................

Livingston, Ala., section at.

Livingston, Mont., limestone at, analyses of.

Lockport, N. Y., limestone at, analyses of... section near.

Long Run, $\mathrm{Pa}$., limestone at, analysis of....

Longview, Ala., limestone at................ limestone at, analysis of................

Loon Lake, Ind., marl of, analysis of........

Lort, A. B., on Idaho materials............ 138-139

Los Angeles County, Cal., limestones of...... 117 limestones of, analysis of............. 117

Louisiana, cement materials of ........... 191-192 fuel in.............................. 68 limestones of........................ 191-192 analyses of ...................... 192

Louisiana, Mo., section at................ $\quad 249$ shale at............................. 248 analysis of....................... 248

Louisville Cement Co., materials of........... Lowellville, Ohio, limestone at, analysis of.. Lowndes County, Miss. See Noxubee County.

Low Point, N. Y., cement making at........ Lowville, N. Y., limestone at, analysis of.... Ludington, Mich., marl at, analysis of........ Ludlow Falls, Ohio, limestone at, analysis of. Lumber River, N. C., limestone at, analysis of.............................

Lupton, Mich., marl at, analyses of.......... Lurich, Va., limestone at, analysis of........

M.

Mabelvale, Ark., clay at, analysis of.

McCallie, S, W , on Georgia limestones.......

McCartney, Wis., section near.

McFarland, Kans, limestone at, analysis of

Maclay, W. W., on cement strength.........

Macon, Miss., limestone at and near.......... limestone at and near, analyses of ...... 230,231

Madison limestone, analysis of............. $\quad 253$

Magnesia in limestone, allowable limit of.... $\quad 45$ occurrence of......................... 44-45

Mahoning Furnace, Pa., limestone at, analysis of......................... 313

Maine, cement material in............ 68, 192-195 clays and shales of.................... 193 analyses of $\ldots \ldots \ldots \ldots \ldots \ldots \ldots \ldots \ldots .193$

limestones of....................... 192-195

analyses of ...................193, 195

Mammoth Peak, Utah, limestone at, analysis of............................ 348

Manack, Ala., limestone near............... 81-82 limestone at, analysis of.............. 87

Manchester, Ohio, limestone at, analysis of.. $\quad 300$

Manheim, W. Va., cement materials at, analyses of

368,371

Manistee Junction, Ala., clay at........... 83 clay at, analyses of ................ 87

Manitou Lake, Ind., marl of, analysis of..... $\quad 157$ Manlius limestone, analyses of .......... 268, 281 Manor, Tex., cement material at, analysis of. 342 Manti, Utah, limestone at, analysis of...... 348 Marble City, Ark., limestone at, analysis of. $\quad 97$ Marblehead, Ill., limestone at, analysis of...
Marengo Portland Cement Co., cement mate rials of......................... 294 cement materials of analyses of......... 294

Markets, contiguous, importance of.......... 64,66 Marksboro, N. J., limestone at, analysis of.. 270 Marlbrook marl, chalk of, analyses of........ 113 chalk of, distribution and character of. . 101,

106-112

sections of.................. 107,110, 111

Marl, analyses of......... 52, 214-215, 283, 352,359 bibliography of..................... 52 cost of, at mill...................... $59-60$

definition of.......................... 51-52

depositions and occurrence of........... 51-52 deposits of, description of............ 155-157, 212-215, 283, 351-352

distribution of, by States.............. 68

See also Tertiary shell beds; Quatenary shell beds; particular States.

Marls and clays, production from.......... 42-43

Marquam, Oreg., cement rock at......... 308-309 cement rock at, analyses of............ 309

Marquette Cement Co., materials of........ 151-152 materials of, analyses of ............. 152

Marshalls, Ala., clay at, analysis of ......... 87 limestone at.......................... 84-85

Martin, G. C., on Niobrara limestone....... 125

Martin limestone, analysis of.............. 91

Martins, Ala., limestone at............... $\quad 81$ limestone at, analysis of............... $\quad 87$

Martinsburg, W. Va., limestone at, analyses of ........................ $\quad 370$

Martinsburg shale, analyses of........... 266,316 distribution and character of....... 266,316-312

Martins Creek, Pa., Portland cement plant at....................... $\quad 317$

Maryland, cement in, bibliography of - . ... 207 cement in, production of............. 37-38 cement industry in .................. 205 cement material in.................. 196-205 clays and shales of................... 197, 202 analyses of ................. 199, 202, 206 fuel of $. . \ldots \ldots \ldots \ldots \ldots \ldots \ldots \ldots \ldots \ldots, \quad 68$ geologic map of...................... $\quad 350$ limestones of ..... 196-205 analyses of.............. 198-199, 202-206

Maryville limestone, distribution and character of........................

Mason City, Iowa, limestone at, analysis of. Portland cement plants at.............. 179

Massachusetts, cement industry in......... 207 cement material in .................... 207 limestones of ......................... 2077 analyses of....................... 207

Massanutten Mountain, Va., limestone at, analysis of ................... 356

Mather, W. W., on natural cement industry. 22-23 Maxinkuckee Lake, Ind., marl of, analyses of 157 Maxville limestone, analyses of............ 302 distribution and character of........... 301

Maysville formation, distribution and character of ...................... 189

Menard, Ill., limestone at, analysis of...... 143 Mendota, Va., limestone near, analysis of.... $\quad 355$ Metaline Falls, Wash., limestone near..... 366-367 limestone near, analysis of............ $\quad 367$ 
Page. cement in, production of............ 37-38,223 cement industry in ............... 27, 223-224 cement material in . .................. 208-222 clays and shales of.................... 216-222. analyses of . . ................... 216-222

fuel of................................ 68

geologic maps of .................... 208, 210

limestones of . ...................... 208-212 analyses of...................... 208-212

marl of ............................... 212-215 analyses of. ..................... 214-215

Michigan formation, distribution and character of........................

Michigan Portland Cement Co., materials of.. Middle Branch, Ohio, Portland cement plant

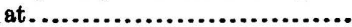

Milbury, Ohio, clay of, analysis of..........

Mill Canyon, Utah, limestone at, analysis of. . Mill Creek, Ark., limestone at, analysis of...

Mills Lake, Mich., marl at, analysis of...... Milltown, Ind., limestone at, analysis of.....

Milton, N. Dak., limestone at, analysis of...

Mineral Point, Wis., limestone at, analysis of.

Minnekahta limestone, analyses of.

distribution and character of . .......... 327-328

Minnesota, cement materials of............. 224

Mississippi, cement in, bibliography of...... 245 cement material in . ..............68, 225-245 chalk in ........................... 226-237 analyses of........... 226, 228-233, 235, 236 clays and shales of................. 240,244-245 analyses of............... 226, 240, 244-245 geologic map of.

limestones of....................... 225-243 analyses of.... 226, 228-233, 235, 236, 239-243

marls of ........................... 239-240 analyses of.................... 239,240

Mississippian limestones, analyses of........ $\quad 75$, $143,155,181,190,226,250,253$

distribution and character of ........... 69, 71-72, 141-143, 153-154, 180-181, 189-190, 226, 248-250, 253, 333-334

section of ........................... 142

See also particular Mississippian formations.

Mississippian shales, analyses of ....... 76, 226, 250 distribution and character of ....... 73, 154,249

Missouri, cement in, production of....... 37-38, 252 cement industry in.................. 252-253 cement material in . ..............68,246-251 clays and shales of.................. 248-251 analyses of................ 248, 250, 251 fuel of............................... 68 geologic map of..................... 246 limestones of .................... $68,247-251$ analyses of............. 247, 250, 251, 252

Missouri group, analysis of............... 172 distribution and character of ........... 171-172 section of .......................... 171-172

Mitchell, Ind., materials at, analyses of ...... 158

Mitchell County, Towa, limestone at, analyses of............................

Mitchell limestone, distribution and character of...............................
Mohawkian limestones, analyses of . ....... 275,276 distribution and character of.......... 273-276 Mohawk Valley, N. Y., limestone of......... 274 Moline, Kans., limestone at, analysis of...... 182 Molltown, Pa., Portland cement plant at.... 317 Monroe Corners, N. J., limestone at, analyses of.......................... 264,270

Monroe County, Miss., limestone of........... 233 Montague, N. J., limestone at, analyses of.... 268, 270 Mont Alto, Pa., limestone at, analysis of.... 311 Montana, cement in, production of......... 37-38 cement industry in.................... 257 cement material in...............68, 253-256 clays and shales of, analyses of.......... 254 fuel in................................. 68 limestones of......................... 253-254 analyses of.................... 253-255

Montebello Narrows, Pa., limestone at, analysis of ......................... 312

Montezuma, Ga., limestone at, analysis of..... 133

Montezuma, N. Y., cement at, analysis of..... 288 cement at, materials for, analyses of....... 288 cement making at..................... 287-288 marl at, analysis of .................. 283

Moore Lake, Ind., marl of, analysis of........ 157 Morgantown, W. Va., limestone at, analysis of........................... 369

Morrison, Colo., limestone at, analysis of..... 127 Mosherville, Mich., marl at, analyses of....... 214 Portland cement plant at.............. 224 Moundsville Narrows, W. Va., limestone at, analysis of......................

Mount Etna Furnace, Pa., limestone at, analysis of..................... 311

Mount Holly, Pa., limestone at, analysis of.. 311 Mount Horeb Church, Va., limestone at, analysis of.................... 357

Mount Jackson, Pa., limestone at, analysis of. 313

Mount Savage, $\mathrm{Ky}$., limestone at, analysis of. 191 Mount Silverheels, Colo., limestone at, analysis of.

Muddy Creek Mountain, W. Va., limestone on, analysis of.................. 369

Mud Lake, Ind., marl of, analysis of......... 157

Mumford, N. Y., marl at, analysis of........ 283

Murat, Va., limestone at, analysis of........ 357

Murphreesboro limestone, distribution and character of................... 332

Murphy, N. C., limestone at and near, analyses of.

Myrtle Grove, N. J., limestone near, analysis of..............................

N.

Naco limestone, analysis of............... 91

Nancy, Miss., limestone near............... 243 limestone near, analysis of............. 243

Napa Junction, Cal., cement plant at........ 121 materials at, analyses of............... 122

Natural cement, analysis of................ 21 maximum production of................ 24 nature of. . .........................16-17 prices of, chart showing............... 34 production of, chart showing............ 32 
Natural cement industry, establishment of, in different States. .............. 23

history of, in Europe................ 19-20

in America..................... 20-24

Nauvoo, $\mathrm{ml}$., limestone at, analysis of ........ 143

Nazareth, Pa., Portland cement plants at... $\quad 317$

Nazareth Portland Cement Co., plant of..... 317

Nebraska, cement industry in............. $\quad 259$

cement material in . ....................68, 256

clays and shales of................... 208-259

limestones of . . . . . .

analyses of....................... 258

Negro Mountain, Md., limestone near, analy-

sis of ..........................

Neodesha, Kans., limestone at..............

limestone at analyses of.

Portland Cement Co. materials of...... 187

shale at, analyses of................. 184, 187

Nevada, cement materials in.............. $\quad 259$

limestones of.

analyses of.......................

New Petna Portland Cement Co., materials

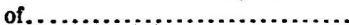

Newago, Mich., Portland cement plant at...

Newago Portland Cement Co., materials of. .

Newbern, N. C., limestone at, analysis of... marls near, analyses of.

New Bronson Portland Cement Co., materials

$$
\text { of............................. }
$$

New Carlisle, Ohio, limestone at, analyses of.

Newcastle, Colo., Portland-cement plant at...

Newcastle, $\mathrm{Pa}$., limestone at, analysis of.....

Portland cement plant at...............

Newcastle, Wyo., cement materials near, analyses of.

Newcastle Portland Cement Co. (Colo.), plant of..........................

New Castle Portland Cement Co. (Pa.), materials of....................... $322-323$

plant of............................ 317

New Hampton, N.J., limestone at, analysis of . 263

New Jersey, cement in, bibliography of..... 270-271 cement in, production of............. 37-38, 270 cement industry in.................... 270 cement material in...............68, 260-270 clays and shales of..................... 266 analyses of $. . . . . . \ldots \ldots \ldots \ldots \ldots \ldots \ldots . .266$ geologic map of....................... 310 geologic structure in................ 266-267 limestones of ............. 68, 260-265, $267-270$ analyses of............... 262-265, 267-270

marls of

analyses of .......................... 270

Newman limestone, analyses of.......... 353, 355 distribution and character of...... 334, 352-353

New Mexico, cement material in............ 271

New Richmond, Ohio, limestone at, analysis

of ......................... 300

New Sharon, Maine, limestone at, analyses of. 195 Newton, N. J., limestone near, analyses of... 262, $263,265,266,270$

New Village, N. I., Portland-cement plant at. $\quad 270$ New Windsor, Md., limestone at, analysis of.. $\quad 205$ New York, cement in, analyses of........ 285-286, $288,290,292,293,295$

cement in, bibliography of.............. 296 production of................... 37-38, 289
Page.

New York, cement industry in........... 27, 29, 283 cement material in ...................68,271 clays and shales of, analyses of......... 287, $288,290,291-295$

fuel of.............................68, 273 geologic maps of................ 272, 274, 276 limestones of ........................ 272-283 analyses of ..................... 273, 275, 276, 278-283, 287, 288, 290, 291-295

marls of .............................. 283 analyses of ..................... 283, 295 natural cement in .................... 21-23

New York, central, limestone of........... $\quad 280$ limestone of, analyses of ............... $\quad 280$

New York, northern, limestones of. ......... 273-275 limestones of, analysis of............... 275

New York, western, limestones of........ 279-280 limestones of, analysis of.............. 279 natural cement in .................... 20-22

Nez Perce County, Idaho, limestones of...... 135-136 limestones of, analyses of............. 136

Niobrara limestone, analyses of ........... 126, 258 distribution and character of............ 124,

$257-258,299,328$

Norborne, Mo., clay at, analysis of.......... 251

Norfolk Portland Cement Co., materials of... 359 Norridgewock, Maine, limestone at, analysis of........................... 195

Norris, Md., limestone at, analysis of....... 205 North Adams, Mass., limestone at, analysis of. $\quad 207$ Northampton, $\mathrm{Pa}$., Portland cement plant at. $\quad 317$ Northampton Portland Cement Co., plant of. 317

North Carolina, cement material in........ 68, 297 fuel of .............................. 68 limestones of ..................... 68, 297-299 analyses of..................... 297, 298

marl of............................. 297-299 analyses of....................... 298

North Dakota, cement materials of .......... 68,299 limestones of ........................... 68 analysis of ........................... 51

North Judson Marsh, Ind., marl of, analysis of ............................. 157

North Park, Colo., limestone at, analysis of. . 127 Notre Dame Lake, Ind., marl of, analysis of.. 157 Noxubee and Lowndes counties, Miss., limestones of..................... 229-232 limestone of, analyses of............. 229-232

\section{O.}

Ogden Portland Cement Co., materials of.... 349

Oglesby, Ill., materials at................. 151 materials at, analyses of.............. 151 Portland cement plant at.............. 151 quarry at, section in................... 151

O'Harra, C. C., on Maryland.............. 199-202 Ohio, cement in, production of.......... 37-38, 302 cement industry in.................. 302-303 cement material in ................ 68, 299-302 clays and shales of.................... 300 analyses of ..................... 222, 303 fuel of ............................. 68 geologic map of...................... 300 limestones of...................... $68,299-302$ analyses of ..................... 300-303 marls of ............................. 68,302 analyses of ..................... 303 
Page.

okanogan County, Wash., cement material of 363

Oklahoma, cement in, bibliography of...... 306 cement in, production of........... 37-38, 306 cement industry in .................... 306 cement material in . . . ............ 68, 304-306 clays and shales of................... 305

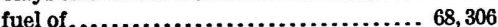
geologic map of...................... 304 limestones of $\ldots \ldots \ldots \ldots \ldots \ldots \ldots \ldots$ 304-306

Oklahoma Portland Cement Co., materials of.......................... 306

Okolona, Ark., chalk at and near. . ....... 109-110 chalk at and near, analyses of........... 113

Okolona, Miss., limestone at, analyses of..... 233

Oktibbeha County, Miss., limestone of..... 232-233 limestone of, analyses of ............. 232-233 Ollinger Gap, Va., limestone at, analysis of.. 355

Omega Portland Cement Co., materials of.. 223-224 Onondaga limestones, analyses of..... 279, 280, 281 distribution and character of........... 278-281

Orange County, Cal., limestones of.......... 117 limestones of, analyses of.............. 117

Orcas Island, W ash., cement materials at.... 361 cement materials at, analyses of ........ 361

Ordovician limestones, analyses of .......... 141, $162,247,311,316,331,357,370$ distribution and character of... $140,161,173,204$, $310-311,315-316,330-333,356-358,370,371-373$ section of. ............... 141,161-162,372-373 See also particular Ordovician formations.

Ordovician shales, analyses of. ............ 76, 248 distribution and character of. ..... 69, 72-73, 248 See also Martinsburg shale.

Oregon, cement in, analysis of............. 308 cement industry in ................... 310 cement material in. . . . . . . . . . . . 68, 307-310 clays and shales of . . .................. 308 analyses of . ................... 308

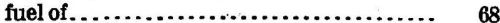

limestones of . ................68, 307-310 analyses of ..................... 308

Oriskany Falls, N. Y., limestone at, analysis of

Ormrod, Pa., Portland cement plant at....

Oro Grande, Cal., cement plant at......... 123

Osage group, analyses of................... 168 distribution and character of. . ........ 167-168 section of . ......................... 167-168

Osborn, Miss., limestone near, analysis of..... 232

Osborn, Ohio, limestone at, analysis of...... 300

Oskaloosa, Iowa, limestone at, analysis of.... 109

Ottumwa, Iowa, clay at, analysis of. ........ 170

limestone at, analysis of.............. 169

section at........................... 169

Ottawa, Kans., limestone at, analyses of... 182-183

Oven Bluff, Ala., limestone near. ........... 83-84 limestone near, analyses of.............. 87

Owen, Ohio, limestone at, analyses of....... 301

Oxanna, Ala., clay at, analysis of........... 76

Oxford Furnace, N. J., limestone at, analyses of..................... 263,315

P.

Pacific Portland Cement Co., cement of, analysis of . .....................

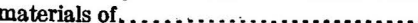

Pahasapa limestone, distribution and char-

acter of.................... 326-327

Parker, -, "Roman" cement of............. 19-20

Pattenburg, N. J., limestone near, analysis of. 264

Pattersons Creek, W.Va., limestone at, analy-

sis of......................... $\quad 370$

Peapeck, N. J., limestone at, analyses of.... 263,315

Pea Ridge, Ky., limestone at, analysis of..... 191

Pearlsburg, Va., limestone at, analysis of. . . . . 357

Peerless Portland Cement Co., materials of. 223-224

Pegram, Ala., clay at, analysis of. .......... $\quad 76$

Pella, Iowa, limestone at, analysis of.......... 169

Peninsular Portland Cement Co., materials of. 223

Penn-Allen Portland Cement Co., plant of.... 317

Pennington shale, distribution and charac-

ter of.................. 334, 353, 354

Pennsylvania, cement in, analyses of...... 321 cement in, production of........... 37-38,317 cement industry in ................ 27,317 cement material in . . . ............68,310-317 clays and shales of. ................. 316-317 analyses of...................... 316,323

fuel of............................. 68

geologic maps of. ................... 310,350

limestones of . . . . . . . . . . . . . analyses of............ 311-313, $315,316,323$ manufacturing methods in............. 318

Pennsylvania Portland Cement Co., plant of. 317 Pennsylvanian limestones, analyses of...... 144, $182,183,191,251,258,259,302,368$ distribution and character of......... 143-144, $181-183,191,250-251,257-258,271,302,368$ section of.

See also particular Pennsylvanian formations.

Pennsylvanian shales, analyses of . .... 76, 184,251 distribution and character of....... 73, 183-184 Penters Bluff, Ark., limestone of . . . . . . . . . . 92-95 Penville, N. J., limestone at, analysis of..... 263 Perkinsville, N. Y., marl at, analysis of...... 283 Permian limestones, analyses of ........... 184 distribution and character of............. 184

Petersburg, W. Va., limestone near, analysis of............................. 369

Peters Valley, N. J., limestone at, analyses of......................... 268,270

Phillips, Me., limestone at, analyses of...... 195 Phillipsburg, N. J., limestone at, analysis of. 263 Phoenix Portland Cement Co., plant of..... 317 Piedmont Portland Cement Co., materials of........................ 133,134

Pierce, Wis., shell marl near, analysis of.... 373 Pierce limestone, distribution and character of ....................... 332 Pierre shale, distribution and character of. 258-259 Pinckney, Mich., clay near, analysis of....... 221 Pine Valley; Nev., limestone at, analysis of.. $\quad 259$ Piqua, Ohio, limestone at, analysis of....... $\quad 300$ Piqua limestone. See Stanton limestone.

Pinesburg, Md., limestone at, analysis of..... 204 Pitkin limestone distribution and character of ..........................92,100-101

Plain, Miss., limestone near................ 241 limestone near, analysis of. ............. 241

Plants, location of...................... 66 Platteville limestone, analyses of..... 162,176, 372 
Plattevlle limestone, distrlbution and character of ............ 175-176, 224, 371-373 section of.................. 175, 177,372-373 shale from, analyses of................ 177

Plattin limestone, analyses of ............ 247 distribution and character of............ 247

Plattsburg limestone, analysis of............ 187 distribution and character of........... 183,186

Pleasant Lake, Mich., marl at, analysis of... 214

Plummer Lake, Mich., marl at, analysis of... 214

Point Pleasant, Ohio, limestone at, analysis of 300

Polk Bayou, Ark., limestone at, analyses of. . 94,

Polk Bayou limestone, analyses of.......... 96 distribution and character of.......... 92,94-95

Pond Mountain, Ark., limestone at, analysis of.......................... 100

Portage River, Mich., limestone at, analysis of 212

Porters Creek clay, analyses of............. 245 distribution and character of....... 229, 244-245

Portland, Colo., Portland cement plant at... 128

Portland, Ga., Portland cement plant at.. 133-134

Portland cement, composition of....... 17-18,40,41 composition of. See also particular States.

definition of .............................. exports of . $35-36$

imports of ............................ 35

invention of......................... 24-26

manufacture of ..................... 17,40

American modifications in.......... 28-30

fluxes used in.................... 62

fuels used in...................... 60-62

materials used in. See Cement materials.

methods of . ................... 318-320

plants for, distribution of, map show-

ing...........................

locating of ..................... 66

retarders used in ..................6.

nature of ........................... 17-18,40

predecessors of........................ 18

prices of .............................. 33-35

chart showing................... 34

production of..................... 31-33,36-39

by commercial districts............ 37-38

by States......................... 36-37

by raw materials used ..............42-43

chart showing...................... 32

Portland Cement Co., materials of.......... 349

Portland cement industry, geographic distribution of ...................... 36-39

growth of, in Europe................ 26-27

in United States.................. 30-31

history of.................... 27-31, 283-289

statistics of......................... 31-39

Portland cement plants, distribution of, map showing .......................

See also particular States.

Portland cement resources, by States...... 67-381

Portland Point, N. Y., limestone at, analyses of..............................

Portland cement plant at................ 291

Portsmouth,Ohio, Portland cement plantat. . 303

Potomac, M.d., limestone at, analyses of... 202, 203 section at............................ 202

Potosi, Wis., section near.................. 372
Page.

Pottersville, N.J., limestone at, analyses of. 263,315

Poughkeepsie, N. Y., limestone near....... 275-276 limestone near, analysis of............. 276 distribution of, map showing........ 276 Poxono Island, Pa., limestone at, analysis of. 312 Prairie Rock, Miss., limestone near....... 231-232 limestone near, analysis of............. 231 Pratts Ferry, Ala., limestone at............ $\quad 70$ Prentiss County, Miss., limestone of....... 235-236 Proctor, Vt., limestone at, analysis of........ 350 Prospect, N. Y., limestone at, analysis of.... 275 Prospect Hill, Mo., Portland cement plant at. 252 shale at, analysis of.................... 251 Prosser, C. S., on Nebraska.............. 256-257

Puzzolan cements, nature of............... 18

Puzzolan cements, ancient, nature of........ 18-19 Pyramid Lake, Nev., limestone near, analyses of.

\section{Q.}

Quaternary shell beds, analysis of distribution and character of .............. 373 Queen Creek Ariz., limestone at, analyses of. $\quad 91$ Quilby Creek, Miss., limestone on.......... 228 Quincy, Ill., limestone at, analyses of....... 143 Quincy, Mich., Portland cement plant at.... 223

R.

Ransome patents, nature of................. Rathbun, Iowa, limestone at, analysis of.... Rauchs Gap, Pa., limestone at, analysis of... Rawlins, Md., limestone at, analysis of...... Rayborns Lick, La., limestone at, analysis of $\ldots . . . . . . . . . . . . . . . .192$ Red Buttes, Wyo., limestone near, analysis of............................ 375 Red Clay, Ga., limestone at, analysis of...... 131 Red Cloud, Nebr., limestone near, analysis of. 258 Red Hill, Miss., limestone near............. $\quad 243$ limestone near, analysis of............. 243 Red Sulphur Springs, W. Va., limestone near, analysis of.................... 369

Reid, J. A., on Nevada................... $\quad 259$

Reliance Portland Cement Co., plant of...... 317

Renfrew, Mass., limestone at, analysis of..... 207

Republic, Wash., limestone at............. 363-364

Rhode Island, cement materials in.......... 323 limestones of....................... 68, 323 analyses of....................... 323

Rhodes Mill, Ark., limestone at, analysis of. . $\quad 97$ Richard City, Tenn., Portland cement plant at........................... 334

Richardson, G. B., on Texas............. 344-347

Richmond, Pa., limestone at, analysis of.... 313 Richmond formation, distribution and character of ...................... 189

Ridgwood, Ark., clay at, analysis of......... 115 Ridley limestone, distribution and character of...........................

Rising Fawn, Ga., limestone at, analysis of.. 132 River Junction, Fla., limestone at, analysis of........................... 130

Riverside, Ariz., limestone at, analysis of.... Riverside, Cal., cement plant at.............. Riverside Portland Cement Co., materials of. Riverton, Nebr., limestone at, analysis of...

\section{.} . 政

92 .

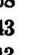

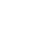

9

7

(n)

23

97

34

47

13

\section{9}

\section{5}


Page.

Riverton, Va., limestone at, analysis of...... 357

Roche Harbor, Wash., cement materials at. 360-361 cement materials at, analysis of ........ $\quad 360$

Rochester, N. Y., section at................ $\quad 277$

Rockland, Maine, limestone near. ........ 193-194 limestone near, analyses of ............ 194

Rockmart, Ga., cement plant at ......... 133-134 clay at, analyses of.................. 134 limestone at, analysis of............. 132,134

Rock Point, Oreg., limestone at, analysis of. . 307

Rockport, Maine, limestone near ........ 193-194 limestone near, analysis of............. 194

Rock Run, Ala., clay near............... 72 clay near, analyses of................ 76

Rock Springs, Ala., limestone at........... 70 limestone at, analysis of............. 75

Rocky Comfort area, Ark., chalk of... 101, 102-103 chalk of, analyses of ............... 112

Rocky Point, N. C., limestone near, analysis of............

Rodman Furnace, $\mathrm{Pa}$. , limestone at, analysis of..............................

Roes Bluff, Ala., limestone at............... limestone at, analysis of................

Rogers, Ark., limestone at, analysis of......

"Roman" cement, invention of........... 19-20

Romona, Ind., limestone at, analysis of...... $\quad 155$

Rondout, N. Y., limestone at, analysis of.... 281

Rondout limestone, analysis of............ 268

Roseburg, Oreg., cement at, analysis of...... 308 cement materials at.................. 308 analyses of ...................... 308

Rosendale region, N. Y., natural cement of. 22-23 Rosiclare, Ill., limestone at, analyses of..... 143 Rotary kiln, invention and effect of ......... 29-30 Rotten limestone. See Selma chalk.

Round Mountain, Ark., clay at, analysis of. .

Round Top, Md., limestone at, analysis of...

Rufus, Oreg., limestone at.................... limestone at, analyses of................ volcanic ash at.

Rumford Falls, Maine, limestone at, analysis of ...........................

Runyan Lake, Mich., marl at, analysis of....

Russell, I. C., on cement.................... on Idaho $\ldots$ on Michigan....................... 209-223

Ryan, Wash., limestone at............... 365 limestone at, analysis of............... 365

S.

Sabbath, Colo., limestone near, analysis of... Sabetha, Kans., limestone at, analysis of..... Saginaw, Mich., clay and shale from, analyses of ....... 219,222

Saginaw formation, distribution and character of........................ 219-220

shales of, analyses of.................219,220

St. Clair limestone, analyses of............... distribution and character af.......... 92, 94-96

St. Clair Springs, Ark., limestone at, analyses

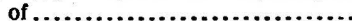

Ste. Genevieve, Mo., shale at, analysis of.....

Ste. Genevieve limestone, distribution and character of.....................

St. Joe, Ark., limestone at, analysis of........
Page.

St. Joe limestone member, analyses of....... 97 distribution and character of............ 96-97

St. Louis, Mo., clay at, analysis of.......... 251 limestone at, analyses of.............. 250

St. Louis limestone, analyses of........... 169, 190 distribution and character of....... 168, 190, 334 section of............................ 169

St. Louis Portland Cement Co., materials of. 252

St. Stephens, Ala., clay near, analyses of.... $\quad 87$ limestone at.......................... 83 analysis of........................ 87

St. Stephens limestone, analyses of......... 86-87 distribution and character of....... 77, 82-85, 88 section of............................. 82

Salem, Ind., limestone at, analysis of........ 155 Saline Landing area, chalk of.......... 101,104-106 chalk of, analyses of................. 112-113

Saltillo, Pa., limestone at, analysis of....... 311

Salt Lake City, Utah, limestone at, analyses

of............................. 348, 349

Portland cement plant at.............. $\quad 349$

Saluda River, S. C., limestone at, analysis of. $\quad 324$

San Andreas limestone, distribution and character of.

271

San Antonio, Tex., limestone at and near, analyses of................51,336,343

San Benito County, Cal., limestones of...... 118

limestones of, analyses of.............. 118

San Carlos, Ariz., limestone at, analyses of... . 91

Sand Creek, Wash., limestone at............ 366-367 limestone at, analysis of............... 367

San Diego County, Cal., limestones of...... 116-117 limestones of, analysis of................ 117 Sand Mountain, Ga., limestone at, analysis of. 132 Sandusky, Ohio, limestone at, analysis of.... 301

Sandusky Portland Cement Co. (Ill.), materials of..................... 152

Sandusky Portland Cement $\mathrm{Ca}$ (Ind.), cement of, analysis of........... 158

materials of........................... 157

materials of, analyses of................ 158

Sandusky Portland Cement Co. (Ohio) materials of..................... 303

Sandusky Portland Cement Co. (Pa.), materials of .................... 317,323

San Fernando, Cal., shell limestone at, analyses of......................... 117

San Gabriel River, Tex., limestone at, analysis of........................... 336

San Juan County, Wash., cement materials in........................... 360-361

cement materials in, analyses of...... 360,361

Santa Cruz County, Cal., cement material at. . 118

cement material at, analyses of......... 118

Santa Cruz Portland Cement Co., cement of, analysis of................... 123

materials of.......................... 122-123

analyses of....................... 123

Saplington, Mont., limestone at, analyses of.. $\quad 255$

Sarah Furnace, Pa., limestone at, analysis of. $\quad 311$

Saratoga, Ark., chalk from, analysis of...... 112 section near......................... 107

Saratoga chalk member, analyses of........ 113

distribution and character of....... 101, 106-112

190
96 $\begin{array}{r}\text { sections of ..................... 107,110,111 } \\ \text { Sarepta, N. J., limestone at, analysis of...... }\end{array}$ 
Scooba, Miss., chalk at, analysis of.......... 238 clay at, analysis of................... 245

Scope of report......................... $\quad 15$

Scotts Run, W. Va., limestone on, analysis of. $\quad 368$ Searls Gulch, Colo., limestone at, analysis of. . 127 Security, Md.,cement material at, analyses of. 206 Portland cement plant at............. 205

Security Cement \& Lime Co., materials of .. 205-206 materials of, analyses of................. 206

Selma chalk, analyses of.................. 86-87 clays of........................... 244

analyses of........................ 244 distribution and character of. . 77-82, 88, 226-237 sections of ........................... $\quad 227$

Seville, Fla., limestone at, analysis of....... 130

Shales. See Clays and shales.

Shale (or clay) and limestone, production from........................ 42-43

Sharpsburg, Md., limestone at, analysis of... 204 Shasta County, Cal., limestones of.......... 119-120 limestones of, analyses of ............ 120

Shavers Mountain, W. Va., limestone at, analysis of....

Shelby, Ala limestone at .

limestone at, analysis of. ................

Shell beds. See Tertiary shell beds; Quaternary shell beds.

Shell Bluff, Ga., limestone at, analysis of.... 133

Shells, analyses of . ....................... 53,54

bibliography of....................... 54 deposits of ......................... 53

Sherman, Tex., limestone near............ 336

Short Creek, Kans., limestone at, analysis of. 181

Shenandoah group, limestones of, analyses of ......................... 204,311

limestones of, distribution and character of........... 203-204,310-311, 356-357

Shiloh, N. J., limestone at, analyses of....... $\quad 270$

Shuqualak, Miss., limestone at............. 229 limestone at, analysis of.............. 229

Siegfried, Pa., Portland cement plant at... 317

Silica in limestone, effect of.................. $\quad 45$ occurrence of........................45-46

Silurian limestones, analyses of ........... 267, 268 distribution and character of . ..... 267-268, 333

Silverdale, Kans., limestone at, analysis of.. 184 Silver Lake, Ind., marl of, analysis of ....... 157 Sioux Peak, Utah, limestone at, analysis of.. $\quad 348$

Slates, analyses of........................ 57 nature of ............................ 56-57

Sligo Furnace, $\mathrm{Pa}$., limeston $\theta$ at, analysis of.. . $\quad 313$ Smeaton, _- early experiments of . . . . Smith, E. A., on Alabama............... 68-89 Smith, W. A., on cement making in New York...................... 287-288

Smith Landing, N. Y., cement plant at...... 290 Smiths Basin, N.Y.,limestone at, analyses of 275 Snake River, Idaho, limestones near....... 135-140 limestones near, analyses of. ...... 136, 138, 139

Snowflake, W. Va., limestone at, analysis of. 369 Snohomish County, Wash coment mater of. ........................... cement materials of, analyses of..........

Solano County, Cal., travertine of............ travertine of, analyses of.................

Sonoma County, Cal., limestones of.......... limestones of, analysis of................
South Bend, Pa., limestone at, analysis of .. 313 South Bethlehem, N. Y., limestone at, analysis of................... 280

South Carolina, cement materials in....... 68, 324

limestones of......................6 68, 324 analyses of.................... 324

South Chicago, Ill., Portland cement plant at 152

South Dakota, cement in, production of. .... 37-38 cement industry in .................. 329 cement material in . .............. 68, $325-328$

limestones of . .................. 68,326-328 analyses of . . . . . . . . . . . . . section in......................... $\quad 325$

Southern States Portland Cement Co., materials of . . . . . . . . . . . 133-134

materials of, analyses of.............. 134

South Norfolk, Va., Portland cement plant at................... 359

South Rondout, N. Y., cement at, analyses of. $\quad 286$ cement making at.................... 29, 285 materials for, analyses of .......... 287

South Thomaston, Maine, limestone at, analysis of........................

Southwestern States Portland Cement Co., materials of................... 347

Sparta, N. J., limestone at, analyses of ..... 262,315 Spartanburg, S. C., limestone at, analysis of. 324 Spechts Ferry, Pa., limestone at, analyses of. 162 section at.......................... 161-162 Speeds, Ind., Portland cement plant at...... $\quad 157$ Spencer, Ind., limestone near, analyses of ... $\quad 155$ Spergen limestone, analyses of............. 190 distribution and character of......... 154, 190 Spocari, Ala., Portland cement plant at..... 88 Sprankle Mills, Pa., limestone at, analysis of.. $\quad 313$ Springdale, N. J., limestone at, analysis of... 265 Spring Mills, Md., limestone at, analysis of.. 205 Springtown, N. J., limestone at, analysis of.. $\quad 263$ Springville; Ala., limestone near........... 72 Springville, Md., limestone at, analysis of.... 205 Sprinkle, Tex., chalk at, analyses of....... 341-342 Standard Portland Cement Co. (Ala.), plant

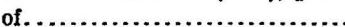

Standard Portland Cement Co. (Cal.), materials of ........................ 121

analyses of .......................... 122

Stanton limestone, analyses of............. 183

distribution and character of........... 183 Star Canyon, Nev., limestone at, analysis of. $\quad 259$ Star Furnace, Ohio, limestone at, analysis of. 302 Starkville, Miss., clays at and near, analyses of. . ........................ 244, 245

limestone at and near, analyses of....... 232 Sterrett, Ala., limestone near.............. 71 Stevens County, Wash., cement materials of 364-366 cement materials of, analyses of ....... 364,365 Stewardson Furnace, Pa., limestone at, analysis of.................... 313

Stillwater, N: J., limestone near, analysis of . $\quad 264$ Stinesville, Ind., limestone at, analysis of.... 155 Stockbridge, Mich., clay near, analyses of .... 221 Stockertown, Pa., Portland cement plant at.. $\quad 317$ Stones River group, distribution and character of .............................
Stones River limestone, analyses of

distribution and character of............. Strasburg, Va., limestone at., analysis of..... . . 政

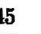
.

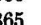
, . 155 317 
Page.

Strawberry, S. C., limestone at, analysis of . . 324

Stroh, Ind., materials at, analyses of. ...... materials at, cement from, analysis of...

Strong, Maine, limestone at, analysis of ...... Strong City, Kans., limestone at, analysis of. .

Sucker Creek, Oreg., limestone on...........

Sugar Creek, Ill., limestone at, analysis of....

Sugarloaf, Colo., limestone at, analysis of.....

Suisun, Cal., cement plant at.............. materials at, analyses of ...............

Sullivan Creek, Wash., limestone at...... . . 366-367 limestone at, analysis of.............. 367

Superior, Nebr., limestone near, analysis of. . 258 Superior, Ohio, Portland cement plant at.... 303 Superior Portland Cement Co., materials of. . 303 Swain Mountain, Ark., limestone of.........

Swartswood, N. J., limestone at or near, analyses of.

Sylvan shale, distribution and character of... Sylvarena, Miss., limestone near............ Syracuse, Ind., materials at, analyses of ..... materials at, cement from, analyses of.... Syracuse Lake, Ind., marl of, analysis of....

T.

Taff, J. A., on Arkansas 101

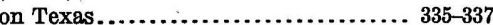

Talladega County, Ala., marbles of, analyses of ...........................

Tate, Ga., limestone at, analyses of..........

aylor marl, analyses of ................. 342 distribution and character of. . ....... 338, 340

Tazewell, Va., limestone at, analyses of..... 357

Technology of Portland cement, American modifications in.

$28-31$

Tehachapi, Cal., limestone at............ 117-118

Temple, Maine, limestone at, analysis of..... 195

Tenabo Peak, Nev., limestone at, analysis of. $\quad 259$

Tenmile Creek, W. Va., limestone on, analysis of ........................ 368

Tennessee, cement in, production of ........ 37-38 cement industry in ................. $\quad 334$ cement material in...............68,329-334 geologic map of .................... 188 limestones of....................68,329-334 analyses of...................... 331

Tertiary clays, analyses of............. 87,115 distribution and character of..... 82-85,113-114

Tertiary limestones, analyses of.......... 133, 259 distribution and character of............ 133 See also Vicksburg limestone.

Tertiary shell beds, analyses of .......... 352,359 distribution and character of.......... 351-352

Texas, cement in, analyses of............. 339 cement in, bibliography of............. 347 production of. . ............... 37-38,347 cement industry in.................. 347 cement material in.............. 68,334-338 clays and shales of . ................ 345-346 analyses of.............. 339,341-343,345 geologic map of. ...................... 336 limestones of............. 68,335-338,346-347 analyses of.......... 51,336, 339, 341-343, 346

'Texas, Md., limestone at..................... 205 limestone at, analysis of
Texas Hollow, Ohio, limestone at; analysis of Page. Texas Portland Cement Co., material of..... 347 Thebes, limestone at, analyses of........... 152 Thomaston, Maine, limestone at, analysis of . 194 Three Springs, Pa., limestone at, analysis of. . 311 Tidewater Portland Cement Co., materials of. 206 materials of, analyses of................ 206 Tippecanoe Lake, Ind., marl of, analyses of. . 157 Toby Creek, Pa., limestone at, analysis of...: 313 Tomahawk Creek, Ark., limestone at, analy-

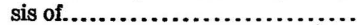

Tomstown limestone, analyses of........... distribution and character of . - .

Tonto dam site, Ariz., cement materials at, analyses of..................... 90

Tracy, Iowa, limestone at, analysis of....... 169

Transportation, importance of............65,66

Traverse formation, clays and shales of...... 216 clays and shales of, analyses of.......... 216 distribution and character of.......... 210-211 limestones of, analyses of.............. 211

Travertine, analyses of.............. 119,121,122 use of, for cement material........ 118,121,122

Trenton, Ga., limestone at and near........ 131 limestone at and near, analysis of....... 132

Trenton, Mich., limestone at.............. 209 limestone at, analysis of.............. 210 section near........................... 210

Trenton limestone, distribution and character of....................... $\quad 399$

Trident, Mont., limestone at, analysis of . . . . . 255

Tristates, N. J., limestone at ............ 2C7-268 limestone at, analyses of .............. 268

Trussville, Ala., limestone near............ 72 limestone near, analysis of............ $\quad 75$

Tully limestone, analyses of.............. 282 distribution and character of ......... 281-282

Tupelo, Miss., limestone at and near...... 234-235 limestone at and near, analyses of....... 235 section at............................. 234

Turner, Maine, limestone at, analysis of .... 195 Turtle Bluffs, Wyo., limestone at, analysis of. $\quad 375$ Tuscaloosa formation, clays of, analyses of... 76 clays of, distribution and character of... . 73-74 Twomile Creek, W. Va., limestone on, analysis of ....................... 368 Tyrone, Iowa, limestone at, analysis of..... 311 U.

Ullin, Ill., limestone at, analysis of....... 143

Ulrich, E. O., on Arkansas.............. 98, 99 on Kentucky ....................... 188 on Minnesota........................ 224 on Tennessee. . . . . .................. 329-334

Union, Maine, limestone at, analysis of ...... 194

Union, W. Va., limestone near, analysis of... $\quad 369$ Union Bridge, Md., cement materials at. .. . . 205-206 cement materials at, analyses of ......... 206 Portland cement plant at............... 205

Union City, Mich., marl at, analyses of ...... 215 Portland cement plant at.............. . 224 shale near .......................... $\quad 217$ analyses of ....................... 218 Union Portland Cement Co., materials of .... 349 Union Sand \& Materials Co., plants of... 252,253 Uniontown, Ala., clay near, analysis of ....... 87 
Page.

niontown, Ala., limestone at. limestone at, analyses of.

United Kansas Portland Cement Co., materials of...................... 186, 187 materials of, analyses of .............. 187

United States Cement Co., materials of...... 157

United States Portland Cement Co. (Colo.), materials of ....................

United States Portland Cement Co. (Kans.), materials of.

Universal, $\mathrm{Pa}$, Portland cement plant at

Universal Portland Cement Co. (IIl.), materials of.

Universal Portland Cement Co. (Ind.), materials of ....

Universal Portland Cement Co. (Pa.), materials of ...................... 317,322

Utah, cement in, production of........ 37-38, 349 cement industry in................... 349 cement material in. . . . . . . . . . . . 68, 348-349 clay of.............................. $\quad 348$ fuel in........................... 68

limestones of . . ................ 68,348-349 analyses of . . ................ 49,348,349

marl of ......................... 348-349

Ute Peak, Utah, limestone at, analyses of.... 348

\section{V.}

Valley Head, Ala., clay near.............. clay near, analyses of..................

Valley Park, Mo., limestone at, analysis of. . Valley Wells, Mo., limestone at, analysis of. .

Vance, Ala., limestone at. limestone at, analysis of. limestone at, analyses of. ............ 86,87

Vanport, Pa., limestone near, analyses of.... 313

Vanport limestone, analyses of............ 302 distribution and character of.......... 302

Varnells, Ga., limestone at, analysis of....... 130

Vermilion Creek, Wyo., limestone at, analysis of........................... 375

Vermont, cement materials in . . ...... 68, 349-350 limestones of. ...................... 349-350 analyses of ....................... $\quad 350$

Vicksburg, Miss., clay near................ 240 clay near, analyses of.................. 240 limestone at. ....................... 237-238 analyses of...................... 239 marl at, analyses of.................. 239 section at.................... 237-238, 239

Vicksburg group, distribution and character of. ........................ 129-130

Vicksburg limestone, analyses of . . . . . . . . . 239-243 distribution and character of.......... 237-243 sections of. ............. 237-238, 239, 240-241

Victor, Ark., limestone at, analysis of....... 99 Vigus, Mo., limestone at, analysis of........ 250 Vilas, Kans., limestone at, analysis of....... 183 Vilas shale, distribution and character of..... 183 Vindex Portland Cement Co., plant of....... 317 Viola limestone, distribution and character of .......................... 304-305

Virginia, cement in, bibliography of. ...... 359 coment in, production of................. 37-38
Page.

Virginia, cement industry in . . . . . . . . . . 358-359 cement material in. ............ 68,350-358

clays and shales of................. 354-355 analyses of.................... 355,358 geologic map of.................... $\quad 350$ limestones of . ..................... 350-358 analyses of............... 353,355-358 marls of ............................ $351-352$ analyses of..................... 352,359 Virginia Portland Cement Co., materials of.. $\quad 358$ materials of, analysis of............. 358 Vulcanite, N. J., Portland cement plant at.. 270 Vulcanite Portland Cement Co., mill of...... 270

\section{W.}

Wabash Portland Cement Co., cement of, analysis of ............... 158

materials of. ........................ 157 analyses of................... 158

Wahalak, Miss., limestone near............ 229

limestone near, analysis of............ 229

Wallkill, N. Y., Portland Cement Co., history of.

Wallpack Center, N. J., limestone at, analysis of.......................... 267

Wallpack Ridge, N. J., limestone at, analysis of........................... 268

Wampum, Pa., early manufacture of cement at........................... 27

limestone at, analysis of.............. $\quad 313$

Wapsipinicon limestone, analyses of........ 163 distribution and character of............ 163

Warm Springs, Va., limestone at, analysis of. $\quad 356$

Warners, N. Y., cement making at.... 283-284, 291 cement of, analysis of.................. 292 marl at, analyses of . . . . . . . . . . . . . . . 283, 292 Portland cement plant at................ 291 section at............................ 291

Warners Portland Cement Co., plant of.... 288-289 Warrior Mountain, Md., clays and shales of, analyses of.................... 202 limestone at, analysis of............... 202 Washington, cement in, production of... 37-38, 366 cement industry in ................. 366-367 cement material in . . . . . . . . . . 68, 359-366 clays and shales of................. 360-364 analyses of............... 360, 362, 364, 367

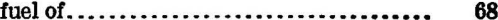
limestones of. . . . . . . . . . . . . . . . 68, 360-366 analyses of.............. 360-362,364,365

Washington area, Ark., chalk of. .......... 107-109 analyses of ........................... 113 Waterloo, N. Y., limestone at, analysis of.... 279 Waverly, Iowa, limestone at, analysis of...... 164 Wayland, N. Y., cement and cement materials at, analyses of......... 283, 295 Portland cement plants at............. 294, 295 WaylandPortland Cement Co., materials of.. 295 materials of, analyses of................ 295

Webberville formation, analyses of .......... 348 distribution and character of. ......... 338,340

Weller, Stuart, and Burchard, E. F., on

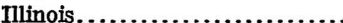

Wellston, Ohio, Portland cement plants at... West Coplay, Pa., Portland cement plant at.. 317 Westernport, Md., limestone at, analysis of. . $\quad 199$ 
Page.

Western Portland Cement Co., materials of.. $\quad 329$ Western States Portland Cement Co., materials of $\ldots \ldots \ldots \ldots \ldots \ldots \ldots \ldots, 186,187$

Westfield, Iowa, chalk at, analysis of........ 160

West Point, Miss., clay of, analysis of........ 244

West Rutland, Vt., limestone at, analyses of. $\quad 350$

West Stockbridge, Mass., limestone at, analysis of....................... 207

West Virginia, cement in, production of...... 37-38 cement industry in .................... 371 cement material in ...............68,367-370 clays and shales of, analyses of .......... 371 geologic map of........................ 350 limestones of.....................68,367-370 analyses of ..................... 368-370

West Waterville, Me., limestone at, analyses of............................ $\quad 195$

Wetzell, Mich., marl at, analyses of......... 215

Whatcom County, Wash., cement material of........................... 361-362 cement material of, analyses of......... 362

White, Canvass, cement invented by ........ 20-21

White Bluff, Ala., limestone at............ 81 limestone at, analysis of ............... 87

Whitecliffs area, Ark., chalk of........ 101,103-104 chalk of, analyses of................. 51,112 sections of ..................... 103,104

Whitecliffs chalk. See Annona chalk.

Whitecliffs Landing, Ark., Portland cement plant at. section at.

Whitehall, N. Y. , limestone near, analysis of . Whitehall Portland Cement Co., plant of....

White Pigeon, Mich., marl at, analysis of...

White Rock, Mich., shale near, analysis of... 219

Wilbarger Creek, Tex., cement material at, analyses of

Wilbur, N. Y., limestone at, analysis of..... Wilcox, Pa., limestone near, analysis of....... Willard, N. Y., limestone at, analysis of..... Williams Creek, Oreg., limestone on.......... Williamson, $\mathrm{Pa}$., limestone at, analysis of.... Williamsport, Md., limestone at, analysis of.. Williamsville, N. Y., limestone at, analysis of. Willsboro Point, N. Y., limestone at.......... limestone at, analyses of

Wilmington, N. C., limestone at and near, analyses of

Wilson formation, distribution and character of.

$48834^{\circ}-$ Bull. $522-13-26$
Winchester, Kans., limestone at, analysis of Winchester limestone, distribution and character of.................... 188, 189

Winfield, Kans., limestone at, analysis of ... 184 Winnemucca Lake, Nev., limestone at, analysis of.......................... 259

Winnfield, La., limestone at, analysis of..... 192

Winnfield limestone, analysis of............ 192

distribution and character of............ 191-192

Winslow, Maine, limestone at, analyses of ... 195

Wisconsin, cement material in............. 68,371

limestones of .......................68,371 analyses of........................ 372

section in............................ 372

shell marl in....................... 373 analysis of..................... 373

Wolverine Portland Cement Co., materials of............................. 223

Woodstock, Ala., clay near................. 74

clay near, analyses of ................. 76

Woodstock, Mich., marl at, analyses of...... 215

Woodstock, Va., limestone at, analyses of.... 357

Worthville, Pa., limestone at, analysis of ... $\quad 313$

Wright, Benjamin, on White's cement....... 20,21

Wyandotte, Mich., clay of, analysis of....... 222

Portland cement plant at.............. 223

Wyandotte Portland Cement Co., materials

of............................. 223

Wyoming, cement material in......... 68,373-375

clays and shales of..................... 374 analyses of........................ 374

fuel of............................. 68, 375

limestones of................... 68,373-375 analyses of..................... 374, 375

$\mathrm{X}$.

Xenia, Ohio, limestone at, analysis of ........ $\quad 300$

Y.

Yankton, S. Dak., limestone at, analyses of. 51, 329

Portland cement plant at.............. 329

Yates Center, Kans., limestone at, analysis of. 182

Yellow Creek, Miss., section on.............. 225

Yocemento, Kans., Portland cement plant at. 187

York, Pa., Portland cement plant at....... $\quad 317$

York, S. C., limestone at, analyses of....... 324

York Portland Cement Co., materials of..... $\quad 303$

\section{Z.}

Zukey Lake, Mich., marl at, analyses of..... 






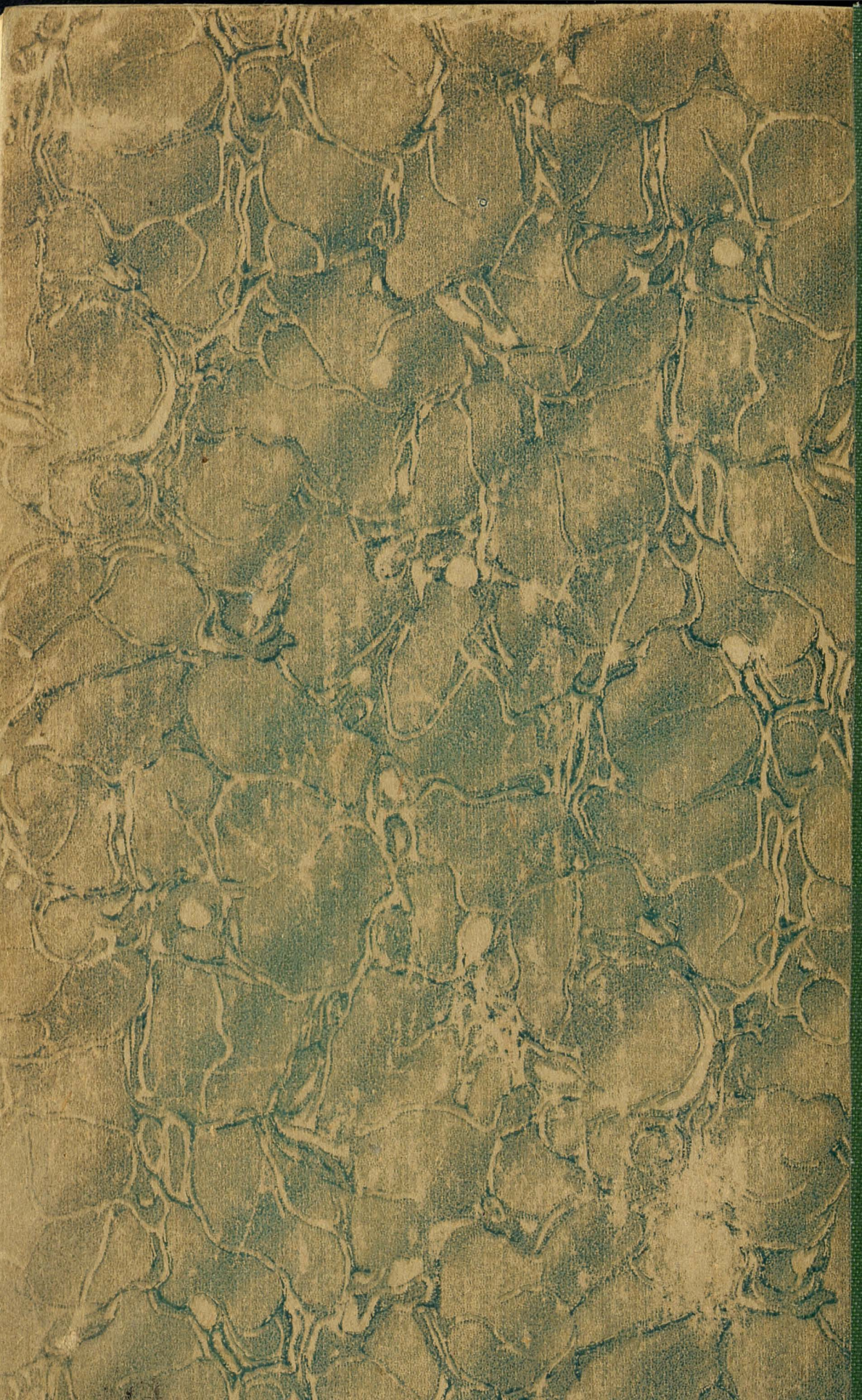

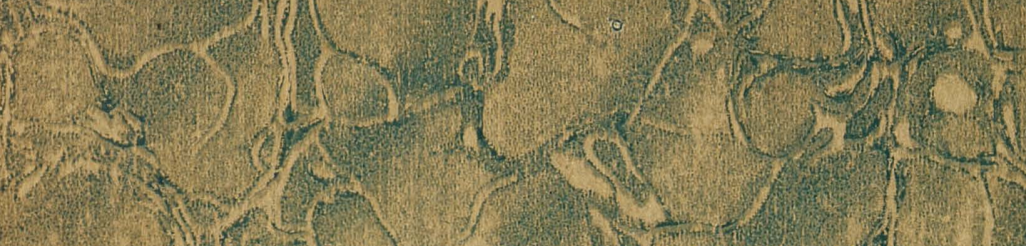

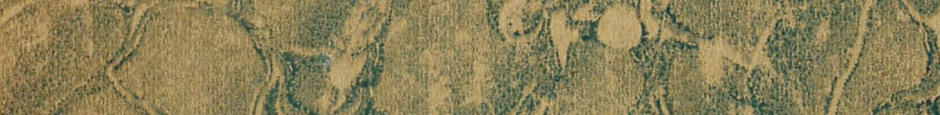

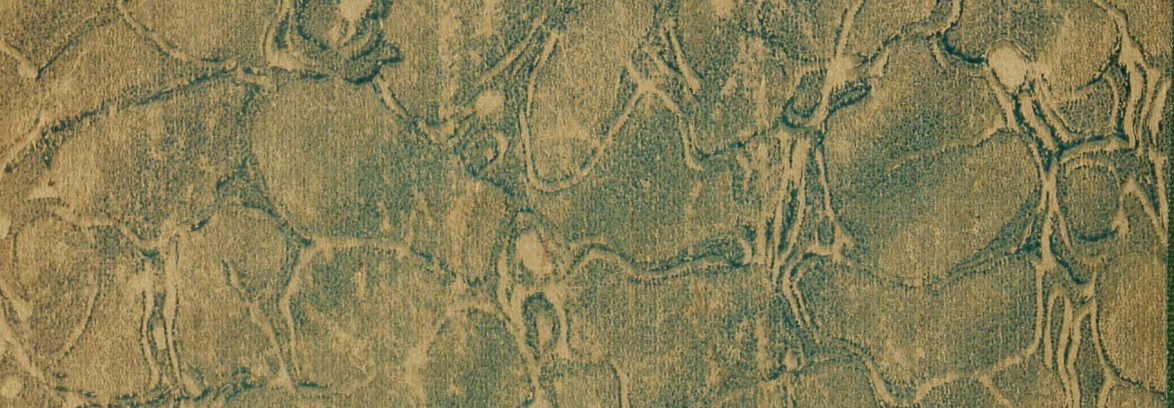

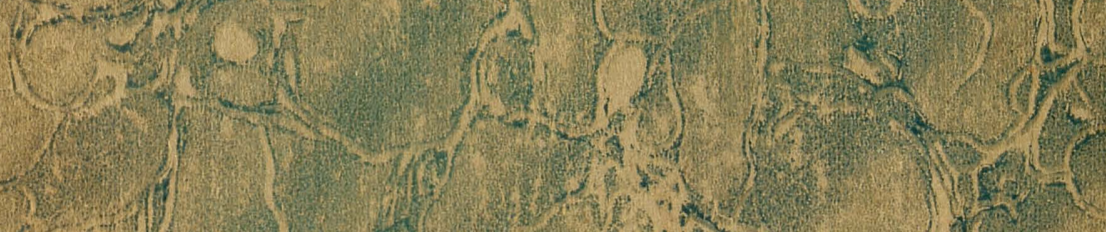

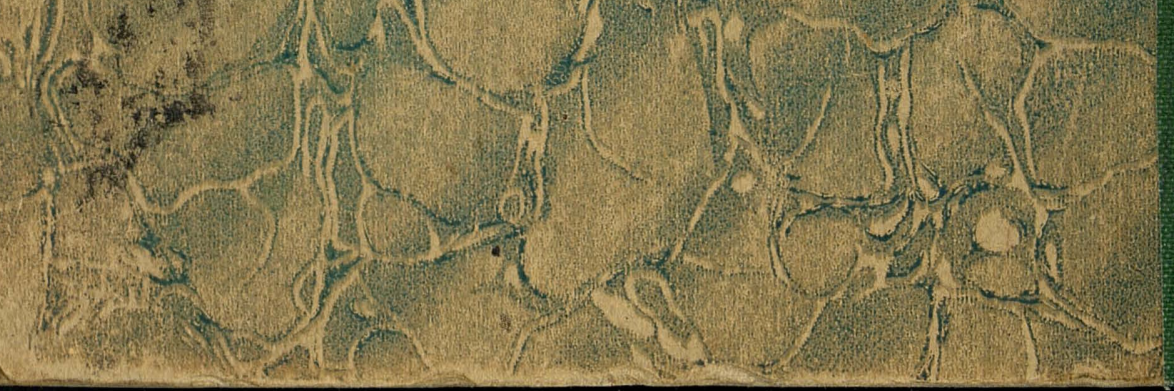

